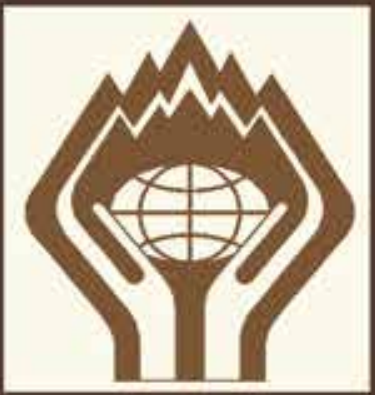

УСТОЙЧИВОЕ

ISSN 1998-4502

e-ISSN 2499-975X

РАЗВИТИЕ

ГОРНЫХ ТЕРРИТОРИЙ

НАУЧнЫЙ ЖУРНАл Sustainable Development of Mountain Territories

Земля - ппанета не простая A. де Сент-Oкзиопери
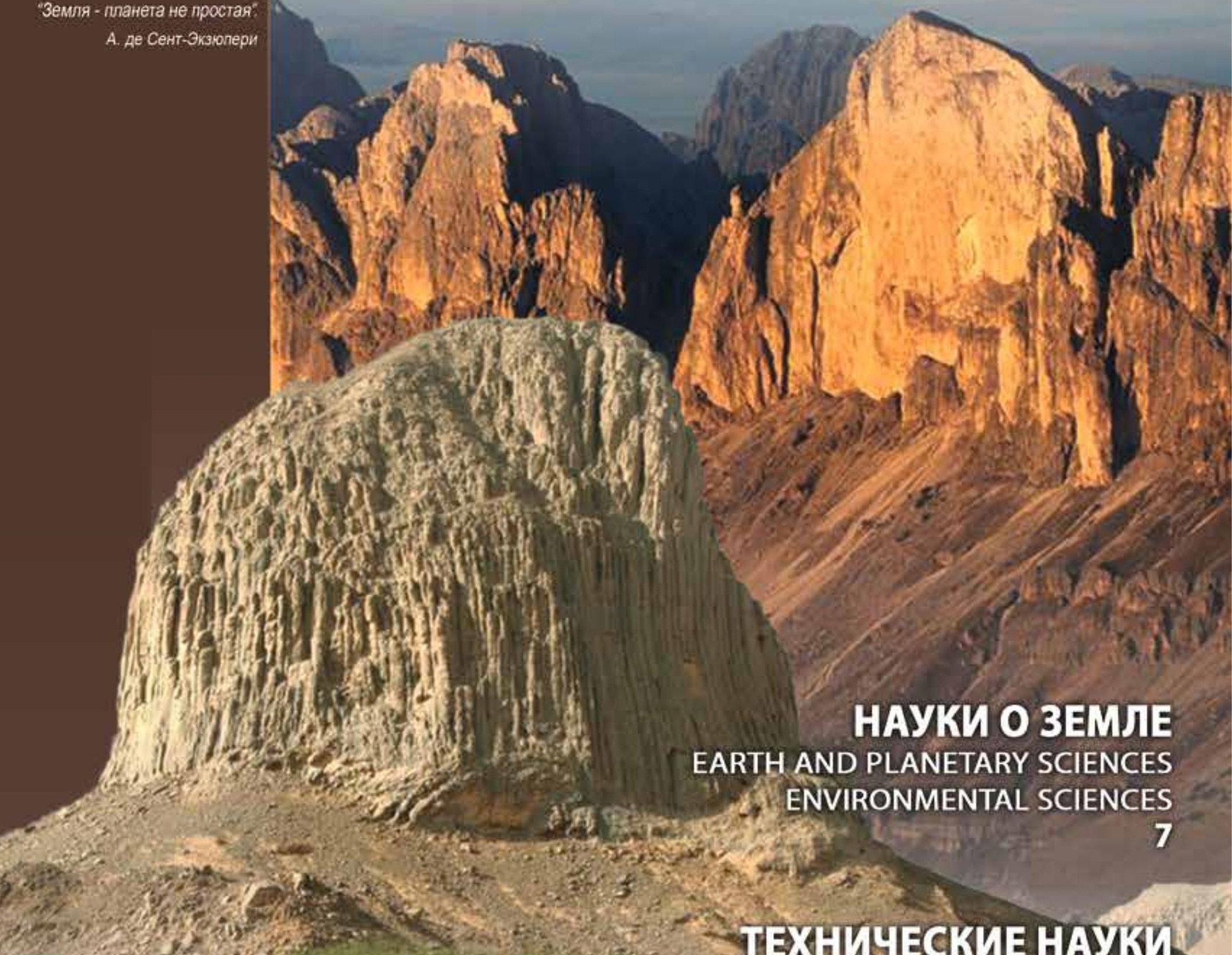

НАУКИ О ЗЕМЛЕ EARTH AND PLANETARY SCIENCES 4. ENVIRONMENTAL SCIENCES 


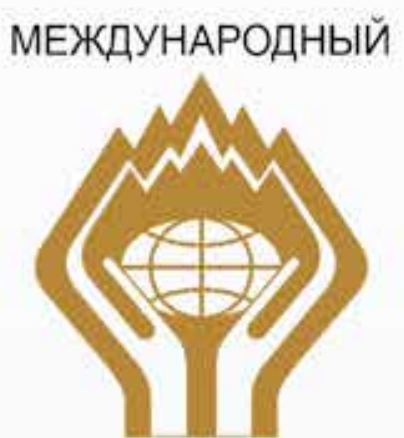

\section{НАУЧНЫЙ ЖУРНАЛ "УСТОЙЧИВОЕ РАЗВИТИЕ ГОРНЫХ ТЕРРИТОРИЙ"}

Журнал входит в Перечень изданий, рекомендованных Высшей аттестационной комиссией (ВАК)

Журнал включен в международную реферативную базу данных и систему цитирования Scopus

\section{Адрес редакции, учредителя, издателя: \\ 362021, РСО-Алания,}

г. Владикавказ, ул. Николаева, 44,

Северо-Кавказский горно-

металлургический институт

(государственный технологический университет)

редакция журнала «Устойчивое развитие горных территорий».

Тел.: 8(8672) 40-75-75, 8(918) 707-39-25 $8(8672)$ 40-72-28

Адрес в Интернете: http://www.naukagor.ru E-mail: editor@naukagor.ru

Ответственность за содержание статей несут авторы.

Редакция не имеет возможности возвращать присылаемые материалы. За сведения в рекламных материалах редакция ответственности не несет.

Перепечатка допускается только с разрешения редакции

и с обязательной ссылкой на журнал «Устойчивое развитие горных территорий».

Журнал зарегистрирован в Федеральной службе по надзору за соблюдением законодательства в сфере массовых коммуникаций и охраны культурного наследия.

Свидетельство о регистрации

ПИ №ФС77-27831 от 19.04.2007 г. Издается с 2009 г.

Редактор МИСИКОВА И.А.

Технический перевод ПЕЙКАРОВА Н.И. Компьютерный дизайн и верстка ПРОВОТОРОВА Н.М.

Тираж 500 экз. Заказ №283

Подписано в печать: 30.03.2018 г Дата фактического выхода: 31.03.2018 r

Отпечатано в типограсии ИП Могилевский Е.С. 344064, г. Ростов-на-Дону, ул. 2-й Пятилетки 23У.

(c) «Устойчивое развитие горных территорий», 2018
УЧРЕДИТЕЛЬ:

СЕВЕРО-КАВКАЗСКИЙ ГОРНО-МЕТАЛЛУРГИЧЕСКИЙ ИНСТИТУТ (ГОСУДАРСТВЕННЫЙ ТЕХНОЛОГИЧЕСКИЙ УНИВЕРСИТЕТ)

РЕДАКЦИОННАЯ КОЛЛЕГИЯ

Главный редактор - Дмитрак Юрий Витальевич - доктор технических наук, профессор, и.о. ректора Северо-Кавказского горно-металлургического института (государственного технологического университета) (Владикавказ, Россия)

\section{ЗАМЕСТИТЕЛИ ГЛАВНОГО РЕДАКТОРА}

Темираев Р.Б. - доктор сельско-хозяйственных наук, профессор, первый заместитель главного редактора, проректор по научной работе и инновационной деятельности Северо-Кавказского горно-металлургического института (государственного технологического университета (Владикавказ, Россия).

Гуня А.Н. - доктор географических наук, профессор, руководитель горной группы МАВ-6 программы ЮНЕСКО «Человек и биосфера» в Институте географии Российской академии наук, старший научный сотрудник ИГ РАН (Москва, Россия). Клюев Р. - доктор технических наук, профессор, заведующий кафедрой «Электроснабжение промышпенных предприятий» Северо-Кавказского горно-металлургического института (государственного технологического университета), ответственный за выпуск номеров журнала (Владикавказ, Россия).

Хосаев Х.C. - доктор технических наук, профессор, заместитель начальника Управления внешних связей и устойчивого развития Северо-Кавказского горно-металлургического института (государственного технологического университета), ответственный за выпуск номеров журнала (Владикавказ, Россия).

ОТВЕТСТВЕННЫЕ СЕКРЕТАРИ (по направлениям):

Науки о Земле - Хацаева Ф.М. - кандидат географических наук, доцент, декан фракультета географии и геоэкологии, заведующий кафедрой «Геоэкология и землеустройство» Северо-Осетинского государственного университета им. К.Л. Хетагурова, Председатель отделения Русского географического общества в Республике Северная Осетия-Алания (Владикавказ, Россия)

Экология - Гриднев Е.А. - кандидат технических наук, доцент кафедры «Экология и техносферная безопасность» Северо-Кавказского горно-металлургического института (государственного технологического университета) (Владикавказ Россия).

Экономические науки - Галачиева С.В. - доктор экономических наук, профессор, заведующий кафедрой экономической теории Северо-Кавказского горно-металлургического института (государственного технологического университета) (Владикавказ, Россия).

Технические науки - Лолаев А.Б - доктор технических наук, заведующий кафедрой «Автомобильные дороги и аэродромы» Северо-Кавказского горно-металлургического института (государственного технологического университета) (Владикавказ, Россия); Хетагуров В.Н. - доктор технических наук, профессор кафедры «Технологические машины и оборудование» Северо-Кавказского горно-металлургического института (государственного технологического университета) (Владикавказ, Россия)

\section{РЕДАКТОРЫ:}

Караев Ю.И. - директор Международного инновационного научно-технологического центра «Устойчивое развитие горных территорий» (МИНТЦ «Горы») Северо-Кавказского горно-металлургического института (государственного технологического университета) (Владикавказ, Россия).

Мисикова И.А. - начальник редакционно-издательского отдела Северо-Кавказского горно-металлургического института (государственного технологического университета) (Владикавказ, Россия).

\section{РЕДАКЦИОННЫЙ СОВЕТ:}

Председатель редакционного совета:

Котляков В.М. - доктор географических наук, академик РАН, Почётный президент Русского географического общества, председатель экспертного совета Национальной премии «Хрустальный компас», член Межправительственной группь экспертов по проблеме изменения климата (Москва, Россия).

\section{СОПРЕДСЕДАТЕЛИ РЕДАКЦИОННОГО СОВЕТА:}

Вейнгартнер Р. - доктор наук, профессор Университета г. Берн (Швейцария), заведующий кафедрой гидрологии Географического института Университета г. Берн. Руководитель Международной Исследовательской Инициативы (MRI) (г. Берн, Швейцария)

Дзасохов А.С. - доктор политических наук, заместитель председателя Комиссии Российской Федерации по делам ЮНЕ СКО (Москва, Россия)

Кавалла Р. - кандидат технических наук, профессор, директор института обработки металлов давлением Фрайбергской Горной Академии (Германия)

Пучков Л.А. - доктор технических наук, профессор, член корр. РАН, профессор кафедры «Безопасность и экология горного производства» Горного института Национального исследовательского технологического университета «Московский институт стали и сплавов» (Москва, Россия)

\section{СОСТАВ РЕДАКЦИОННОГО СОВЕТА:}

Айдаралиев А.А. - доктор медицинских наук, академик Национальной Академии наук Республики Кыргызстан, Председатель попечительского Совета УНПК «Международный университет Кыргызстана» (Бишкек, Кыргызская Республика). Бабаян Г.А. - кандидат физико-математических наук, заведующий отделом мониторинга и инноваций Института геологических наук Национальной Академии наук Армении (Ереван, Республика Армения)

Баденков Ю.П. - кандидат геолого-минералогических наук, ведущий научный сотрудник Института географии РАН, научный руководитель горной группы МАВ-6 программы ЮНЕСКО «Человек и биосфера» в Институте географии РАН (Москва, Россия)

Большаков В.Н. - доктор биологических наук, профессор, академик Российской академии наук Советник РАН, гпавный научный сотрудник, заведующий лабораторией эволюционной экологии Института экологии растений и животных УрО РАН (Москва-Екатеринбург, Россия)

Вагин В.С. - доктор экономических наук, профессор, директор Института международного образования Южно-Российского государственного политехнического университета (Новочеркасского политехнического института) (Новочеркасск, Россия)

Викторов С.Д. - доктор технических наук, профессор, заместитель директора по научной работе Института проблем комплексного освоения недр РАН (Москва, Россия).

Глазырина И.П. - доктор экономических наук, кандидат физико-математических наук, профессор, заведующая кафедрой «Прикладная информатика и математика» Забайкальского государственного университета (Чита, Россия).

Голик В.И. - доктор технических наук, профессор; профессор кафедры «Технология разработки месторождений» Северо-Кавказского горно-металлургического института (государственного технологического университета) (Владикавказ, Россия)

Гроппен В.О. - доктор технических наук, профессор, заведующий кафедрой «Автоматизированная обработка информации» Северо-Кавказского горно-металлургического института (государственного технологического университета) (Владикавказ, Россия).

Залиханов М.Ч. - доктор географических наук, профессор, академик РАН, Главный научный сотрудник Высокогорного геофизического института Росгидромета (Нальчик, Россия)

Кондратьев Ю.И. - доктор технических наук, профессор Северо-Кавказского горно-металлургического института (государственного технологического университета) (Владикавказ, Россия)

Лурье П.М. - доктор географических наук, профессор, ведущий метеоролог Северо-Кавказского управления по гидрометеорологии и мониторингу окружающей среды (Ростов-на-Дону, Россия)

Матвеева Л.Г. - доктор экономических наук, профессор, заведующая кафедрой «Информационная экономика» экономического факультета Южного федерального университета (Ростов-на-Дону, Россия).

Минцаев М.Ш. - доктор технических наук, профессор, проректор по научной работе и инновациям Грозненского государственного нефтяного технического университет им. акад. М.Д. Миллионщикова (Грозный, Россия)

Прхалова М. - программный специалист отдела «Экология и науки о Земле» Секретариата ЮНЕСКО, (Париж, Франция) Ревякин В.С. - доктор географических наук, профессор кафедры «Общая география» Национального исследовательского Томского государственного университета, руководитель региональной группы «Алтай-Саяны» в составе сети горных центров мира, (Алтай, Россия)

Сысоев Н.И. - доктор технических наук, профессор кафедры «Нефтегазовая техника и технологиии» Южно-Российского государственного политехнического университета (НПИ) имени М.И. Платова, (Новочеркасск, Россия). Штадельбауэр Й. - доктор философских наук, профессор Фрайбургского университета (Германия). 


\section{EDITORIAL TEAM}

Chief Editor - Yuri V. Dmitrak - Professor, Acting Rector of the North Caucasian Institute of Mining and Metallurgy(State Technological University) (Vladikavkaz, Russia).

\section{DEPUTY CHIEF EDITORS:}

First Deputy Chief Editor - Rustem B. Temiraev - Doctor of Agricultural Science, Professor, Head of Publication Finalizing Team, Vice Rector for Research and Innovation, North Caucasian Institute of Mining and Metallurgy (State Technological University) (Vladikavkaz, Russia).

Alexey N. Gunya - Dr. Sci. in Geography, Professor, Head of Mountain Group MAB-6 aided by UNESCO "Man and Biosphere" Program, Institute of Geography, Russian Academy of Science, Senior Research Associate of IG RAS (Moscow, Russia).

Roman V. Klyuev - Doctor of Technical Science, Professor, Head of Department of Power Supply of Industrial Enterprises, North Caucasian Institute of Mining and Metallurgy (State Technological University) (Vladikavkaz, Russia).

Hazbi S. Hosaev - Doctor of Technical Science, Professor, Deputy Director of Centre for International Cooperation, External Relations and Sustainable Development, North Caucasian Institute of Mining and Metallurgy (State Technological University) (Vladikavkaz, Russia).

\section{EXECUTIVE EDITORS (by areas of activity):}

Earth Sciences - Fatima M. Khatsaeva - Cand Sc. in Geography, Associate Professor, Dean of Faculty of Geography and Geoecology, Head of Department Geoecology and Land Management Department of North Ossetian State University, Chairman of North Ossetian Department of Russian Geographical Society (Vladikavkaz, Russia)

Ecology - Yevgeny A. Gridnev - Cand. Sc. (Engineering), Associate Professor of Department of Ecology and Technosphere Safety, North Caucasian Institute of Mining and Metallurgy (State Technological University) (Vladikavkaz, Russia).

Economic Sciences - Svetlana B. Galachieva - Doctor of Economics, Professor, Head of Department of Economic Theory, North Caucasian Institute of Mining and Metallurgy (State Technological University) (Vladikavkaz, Russia)

Engineering Sciences - Alan B. Lolaev - Doctor in Technical Science, Professor, Head of Department of Automobile Roads and Aerodromes, North Caucasian Institute of Mining and Metallurgy (State Technological University) (Vladikavkaz, Russia).

Valery N. Hetagurov - Doctor of Technical Science, Professor of Department of Technological Science and Equipment, North Caucasian Institute of Mining and Metallurgy (State Technological University) (Vladikavkaz, Russia).

\section{EDITORS:}

Yuri I. Karaev - Director of International Innovation Scientific Technological Centre Sustainable Development of Mountain Territories, North Caucasian Institute of Mining and Metallurgy (State Technological University) (Vladikavkaz, Russia).

Indira A. Misikova - Head of Editorial Department, North Caucasian Institute of Mining and Metallurgy (State Technological University) (Vladikavkaz, Russia).

\section{EDITORIAL BOARD:}

\section{Chairman:}

Vladimir M. Kotlyakov - Dr. Sci. in Geography, Member of Russian Academy of Science, Honorary President of Russian Geographical Society, Chairman of Expert Board of Crystal Compass National Award, Member of Intergovernmental Panel on Climate Change (Moscow, Russia).

\section{CO-CHAIRS}

Rolf Weingartner - Doctor of Science, Professor of University of Bern (Switzerland), Head of Department of Hydrology, Institute of Geography, University of Bern. Supervisor of International Research Initiative (MRI) (Bern, Switzerland).

Alexander S. Dzasokhov - Doctor of Political Science, Deputy Chairman of Russian Commission for UNESCO (Moscow, Russia). Rudolf Kawalla - Doctor of Technical Science, Professor, Director of Institute of Metal Processing Pressure, Freiberg University of Mining and Technology (Germany).

Lev A. Puchkov - Doctor in Technical Science, Professor, Corresponding Member of Russian Academy of Science, Member of Academy of Natural Sciences, Member of International Academy of Higher Education, Professor of Department of Safety and Ecology of Mining Industry, College of Mining, National University of Science and Technology MISiS (Moscow, Russia).

\section{MEMBERS OF EDITORIAL BOARD:}

Asylbek A. Aidaraliev - Dr. habil. in Medicine, Member of National academy of Science of Kyrgyz Republic, Head of UNESCO Department of Sustainable Mountain Development and Chairman of Supervisory Board of Educational Research and Production Complex «International University of Kyrgyzstan» (Bishkek, Kyrgyz Republic).

Hector A. Babayan - Cand. Sc. (Physics and Mathematics), Head of Department of Monitoring and Innovation, Institute of Geological Sciences, National Academy of Science, Republic of Armenia (Yerevan, Republic of Armenia)

Yuri P. Badenkov - Cand. Sc. in Geology and Mineralogy, Leading Research Associate of Institute of Geography of Russian Academy of Science, Scientific Supervisor of Mountain Group MAB-6, Man and Biosphere Program by UNESCO, Institute of Geography of RAS (Moscow, Russia).

Yuri N. Bolshakov - Dr. Sci. in Biology, Professor, Member of Russian Academy of Science, Adviser to RAS, Senior Research Associate, Head of Laboratory of Evolutionary Ecology, Institute of Plant and Animal Ecology, Ural Department of Russian Academy of Science (Moscow-Yekaterinburg, Russia).

Vladimir S. Vagin - Doctor of Economics, Professor, Director of Institute of International Education, South Russian State Polytechnic University (Novocherkassk Polytechnic Institute) (Novocherkassk, Russia)

Sergey D. Viktorov - Doctor in Technical Science, Professor, Deputy Director for Research Institute of Comprehensive Exploitation of Subsoil, Russian Academy of Science (Moscow, Russia).

Irina P. Glazyrina - Doctor in Economics, Cand. Sc. in Physics and Mathematics, Head of Department of Applied Mathematics and Informatics, Trans-Baikal State University (Chita, Russia)

Golik V. I. - Doctor of Technical Sciences, Professor, Professor of the Department "Development of mineral deposits", NorthCaucasian Institute of Mining and Metallurgy (State Technological University) (Vladikavkaz, Russia).

Vitaly O. Groppen - Doctor in Technical Science, Professor, Head of Department of Automated Processing of Information, North Caucasian Institute of Mining and Metallurgy (State Technological University) (Vladikavkaz, Russia).

Mikhail Ch. Zalikhanov - Dr. Sci. in Geography, Professor, Member of Russian Academy of Science, Senior Research Associate, High-Mountain Geophysical Institute of Federal Service for Hydrometeorology and Environmental Monitoring of Russia (Nalchik, Russia).

Yuri I. Kondratyev - Doctor Technical Science, Professor, North Caucasian Institute of Mining and Metallurgy (State Technological University) (Vladikavkaz, Russia).

Pyotr M. Lur'e - Dr. Sci. in Geography, Professor, Leading Meteorologist, North Caucasian Department of Hydrometeorology and Environmental Monitoring (Rostov-on-Don, Russia).

Lyudmila G. Matveeva - Doctor in Economics, Head of Department of Information Economy, Faculty of Economics, South Federal University (Rostov-on-Don, Russia).

Magomed Sh. Mintsaev - Doctor in Technical Science, Professor, Vice Rector for Research and Innovation, Acad. M. D. Millionshchikov Grozny State Oil Technical University (Grozny, Russia).

Marie Prchalova - Programme Specialist, Division of Ecological and Earth Sciences, UNESCO Secretariat.

Viktor S. Revyakin - Dr. Sci. in Geography, Professor of Department of General Geography, National Research Tomsk State University, Head of Altai-Sayans Regional Group of World Mountain Centers Network, Member of Russian Academy of Natural Sciences and Russian Ecological Academy (Barnaul, Russia).

Nikolay I. Sysoev - Doctor in Technical Science, Professor of Department of Petroleum Engineering and Technology, South Russian State Polytechnic University (Novocherkassk Polytechnic Institute) (Novocherkassk, Russia).

Jorg Stadelbauer - Dr. Phil., Professor of University of Freiburg (Germany).

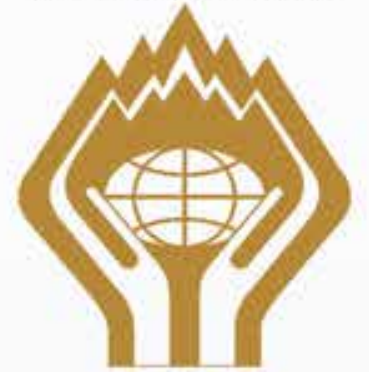

SCIENTIFIC JOURNAL

"SUSTAINABLE DEVELOPMENT OF MOUNTAIN TERRITORIES"

The journal is included in the List of publications recommended by Supreme

Attestation Commission (VAK)

The journal is included in the International Reference Database and Scopus citation System

Address of the editorial office, founder, publisher:

44 Nikolaev Street, Vladikavkaz, RNO-Alania, 362021 NORTH CAUCASIAN INSTITUTE OF MINING AND METALLURGY

(STATE TECHNOLOGICAL UNIVERSITY)

Editorial Office of the journal "Sustainable

Development of Mountain Territories". Tel.: +7 (8672) 40-75-75, $+7(918) 707-39-25$, +7 (8672) 40-72-28.

Internet address: http://www.naukagor.ru E-mail: editor@naukagor.ru

Authors are responsible for the content of the articles.

Editorial staff is not in the position to return the submitted materials.

Editorial staff is not responsible for the information in promotional materials. Reprinting is allowed only with the permission of the editorial office and reference to the journal

«Sustainable Development of Mountain Territories» is required

The journal is registered in the Federal Service for Media Law Compliance and Cultural Heritage Protection.

Registration Certificate PI No FS 77-27831 From April, 192007

Published since 2009 Is free Editor MISIKOVA I.A.

Technical translation

PEYKAROVA N.I.

Computer design and make-up PROVOTOROVA N.M.

Covering -500 copies Order No 283

Signed to print: 30.03 .2018

Date of actual release: 31.03.2018

Printed by IE E.S. Mogilevsky, $23 \mathrm{U} 2$ Pyatiletki st.

344064, Rostov-on-Don 


\section{СОДЕРЖАНИЕ}

\section{НАУКИ О ЗЕМЛЕ}

Орлова Н.С., Каменецкий Е.С..

ВЕРИФИКАЦИЯ МОДЕЛИ ГОРНЫХ ОБВАЛОВ НА

ОСНОВЕ КОНТИНУАЛЬНОГО ПОДХОДА

Bilichenko I.N., Danko L.V.

APPLICATION OF LANDSCAPE ECOLOGY

METHODS IN THE STUDY

OF GEOSYSTEMS OF BAIKALIAN SIBERIA

Гудкова Н.К., Горбунова Т.Л., Любимцев А.Л. ИДЕНТИФИКАЦИЯ ЭКОЛОГИЧЕСКИХ РИСКОВ, СВЯЗАННЫХ С РАЗВИТИЕМ РЕКРЕАЦИОННОТУРИСТИЧЕСКИХ РЕГИОНОВ ЧЕРНОМОРСКОГО ПОБЕРЕЖЬЯ КАВКАЗА НА ПРИМЕРЕ КОМПЛЕКСНОЙ ОЦЕНКИ ЭКОСИСТЕМЫ ГОРНОЙ РЕКИ ЛАУРА

Забураева Х. Ш., Заурбеков Ш.Ш., Таймасханов Х.Э.

ОПТИМИЗАЦИЯ ЗЕМЛЕПОЛЬЗОВАНИЯ

В ГОРНЫХ РЕГИОНАХ

CЕВЕРО-ВОСТОЧНОГО КАВКАЗА

Косолапов А.Е., Косолапова Н.А., Матвеева Л.Г., Чернова О.А.

РАЦИОНАЛЬНОСТЬ ИСПОЛЬЗОВАНИЯ

ВОДНЫХ РЕСУРСОВ В ЭКОНОМИКЕ ГОРНЫХ

ТЕРРИТОРИЙ СЕВЕРНОГО КАВКАЗА

Nwizug-bee Leyii Kluivert

HEAVY OIL DEPOSITS AND COMPOSITIONAL ANALYSIS OF SOME BITUMINOUS OIL SAND SAMPLES OF SOUTH WESTERN NIGERIA

Дега Н.С., Онищенко В.В, Петропавловский Б.С ВЛИЯНИЕ ТЕХНОГЕННОЙ ТРАНСФОРМАЦИИ ВОЗДУШНОЙ СРЕДЫ НА УСТОЙЧИВОСТЬ ХВОЙНЫХ ЛЕСОВ КАРАЧАЕВО-ЧЕРКЕСИИ

Червяцова О.Я., Потапов С.С., Филиппова К.А., Дбар P.C.

НЕКОТОРЫЕ ОСОБЕННОСТИ

ГИДРОХИМИЧЕСКОГО РЕЖИМА

НОВОАФОНСКОЙ ПЕЩЕРЫ (ЗАПАДНЫЙ

КАВКАЗ) В КОНТЕКСТЕ СОВРЕМЕННОГО

МИНЕРАЛООБРАЗОВАНИЯ

И УСЛОВИЙ ПИТАНИЯ КАРСТОВЫХ ВОД
7 Matthias Schmidt

DYNAMIC PROCESSES AND DEVELOPMENTS

IN THE CENTRAL KARAKORAM

Le Jeune, Christine $M$.

7 A COMPARATIVE ANALYSIS OF TWO MOUNTAIN RESEARCH COMMUNITIES:

INTERDISCIPLINARY AND INTERNATIONAL

AGENDAS

14 ТЕХНИЧЕСКИЕ НАУКИ

Борщевский С.В., Моргун В.С., Тотев Л., Чжун Чан ОСНОВА УСТОЙЧИВОГО РАЗВИТИЯ

РСО-АЛАНИЯ -

ГОРНОДОБЫВАЮЩАЯ ОТРАСЛЬ

Tran Viet Anh., Klyuev R.V., Bosikov I.I., Tsidaev B.S.

23 ESTIMATION OF THE RELIABILITY

OF THE VENTILATION CONTROL

SYSTEM AT THE MINING SITES

Дребенштедт К., Голик В. И., Дмитрак Ю. В.

ПЕРСПЕКТИВЫ ДИВЕРСИФИКАЦИИ

35 ТЕХНОЛОГИИ ДОБЫЧИ МЕТАЛЛОВ

В РСО-АЛАНИЯ

Евдокимов С.И., Ли И, Герасименко Т.Е. УСТОЙЧИВОЕ РАЗВИТИЕ ГОРНЫХ ТЕРРИТОРИЙ:

48 ИНВЕСТИЦИОННАЯ ПРИВЛЕКАТЕЛЬНОСТЬ ТЕХНОГЕННЫХ ЗАПАСОВ ЗОЛОТА

Грязев М.В., Качурин Н.М, Стась Г.В. ВОЗДЕЙСТВИЕ СТОКОВ С ПОРОДНЫХ ОТВАЛОВ

63 ШАХТ УГОЛЬНОГО БАССЕЙНА НА ПОЧВЫ ПРИЛЕГАЮЩИХ ТЕРРИТОРИЙ

ОБОЗРЕНИЕ

69 Габараев О.З., Соколова Е.А., Баликоева М.И. ОСОБЕННОСТИ

PЕАЛИЗАЦИИ ПРОЕКТА ERASMUS+

В ГОРНЫХ ВУЗАХ

ИНФОРМАЦИЯ ДЛЯ АВТОРОВ

ПОДПИСКА 


\section{CONTENTS}

\section{EARTH AND PLANETARY SCIENCES ENVIRONMENTAL SCIENCES}

Orlova N.S., Kamenetskiy E.S. VERIFICATION OF ROCK FALLS MODEL USING THE CONTINUUM APPROACH

Bilichenko I.N., Danko L.V. APPLICATION OF LANDSCAPE ECOLOGY METHODS IN THE STUDY

OF GEOSYSTEMS OF BAIKALIAN SIBERIA

Gudkova N.K., Gorbunova T.L., Lubimtsev A.L. THE IDENTIFICATION OF THE ECOLOGICAL RISKS CONCERNING THE RECREATION - TOURIST REGIONS DEVELOPMENT OF THE CAUCASIAN BLACK SEA SHORE USING THE COMPLEX ESTIMATION OF THE MOUNTAIN RIVER LAURA ECOSYSTEM

Zaburaeva Kh.Sh., Zaurbekov Sh.Sh.,

Taimaskhanov Kh.E.

LAND USE OPTIMIZATION IN MOUNTAINOUS REGIONS OF THE NORTHEAST CAUCASUS

Kosolapov A.E., Kosolapova N.A., Matveeva L.G., Chernova O.A.

EFFICIENCY OF WATER RESOURCE USE IN ECONOMICS OF THE NORTH CAUCASUS MOUNTAIN TERRITORIES

Nwizug-bee Leyii Kluivert HEAVY OIL DEPOSITS AND COMPOSITIONAL ANALYSIS OF SOME BITUMINOUS OIL SAND SAMPLES OF SOUTH WESTERN NIGERIA

Dega N.S., Onischenko V.V., Petropavlovskiy B.S. AIR MEDIUM TECHNOGENIC TRANSFORMATION AFFECT ON THE CONIFEROUS FORESTS OF KARACHAI-CHEKESSIA

Cherviatsova O.Ya., Potapov S.S., Fillipova K.A., Dbar R.S.

SOME FEATURES OF THE HYDROCHEMICAL REGIME OF THE NOVOAFONSKAYA CAVE (WESTERN CAUCASUS) IN THE CONTEXT OF THE MINERAL FORMATION AND THE GENESIS OF KARST WATER
Matthias Schmidt

7 DYNAMIC PROCESSES AND DEVELOPMENTS IN THE CENTRAL KARAKORAM

Le Jeune, Christine $M$.

7 A COMPARATIVE ANALYSIS OF TWO MOUNTAIN RESEARCH COMMUNITIES:

INTERDISCIPLINARY AND INTERNATIONAL AGENDAS

14 ENGINEERING

Borschevski S. V., Morkun V.S., Totev Lyuben, Chyun Chan THE BASIS OF THE SUSTAINABLE DEVELOPMENT OF NORTH OSSETIA-ALANIA - MININGINDUSTRY

Tran Viet Anh., Klyuev R.V., Bosikov I.I.,

Tsidaev B.S.

ESTIMATION OF THE RELIABILITY

OF THE VENTILATION CONTROL

SYSTEM AT THE MINING SITES

Golik V.I., Dmitrak Yu.V., Drebenshtedt K. THE PROSPECTS OF DIVERSIFICATION OF TECHNOLOGY OF EXTRACTION OF METALS IN RSO-ALANIYA

48 Evdokimov S.I., Li I., Gerasimenko T.E. SUSTAINABLE DEVELOPMENT OF MOUNTAIN TERRITORIES: INVESTMENT INTERESTS OF TECHNOGENIC GOLD STOCKS

63 Griyzev M.V., Kachurin N.M., Stas G.V. INFLUENCING SLUDGE LIQUOR FROM WASTE DUMPS OF MOSCOW COAL BASIN MINES UPON SOILS OF ADJACENT TERRITORIES

Gabaraev O.Z., Sokolova E.A., Balikoeva M.I. ERASMUS + PROJECTIMPLEMENTATIONIN MINING UNIVERSITIES INFORMATION FOR AUTHORS

MAGAZINE SUBSCRIPTION

SUBSCRIPTION 157 

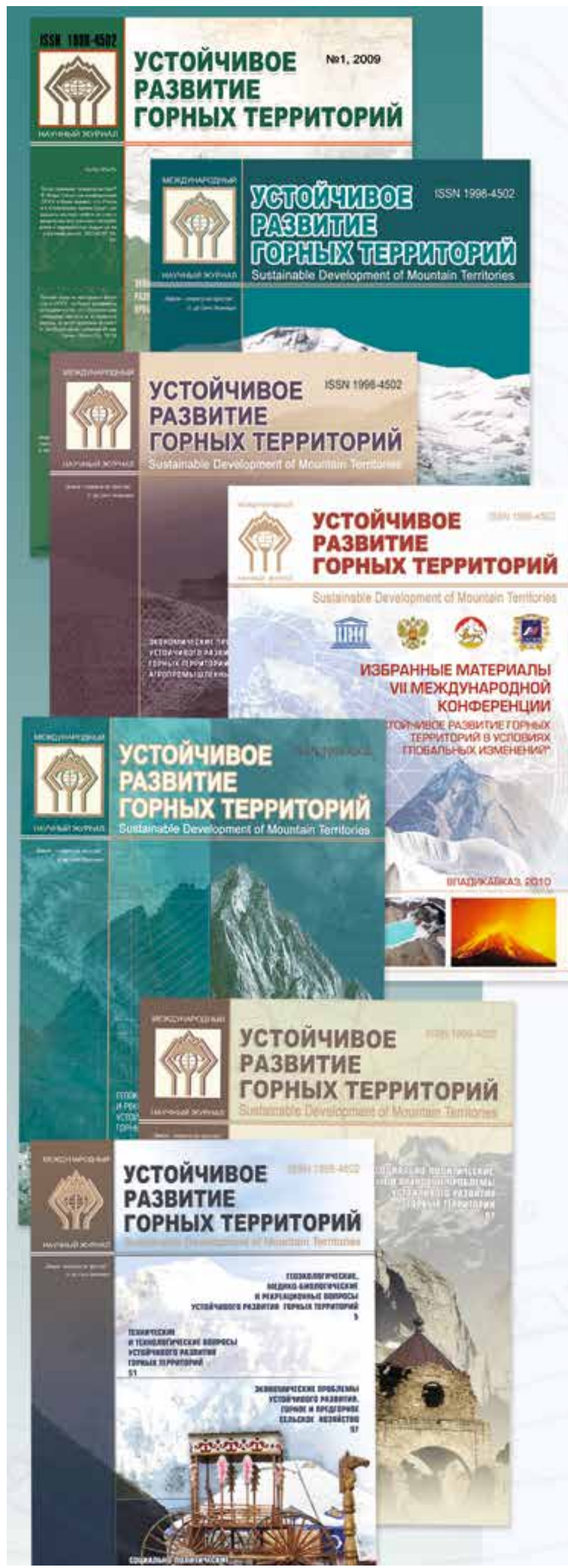

Уважаемые коллеги!
В соответствии с Заключением Президиума ВАК Минобрнауки РФ от 19.12.2014 г. №47/307 с 2015 года статьи для публикации в журнале «Устойчивое развитие горных территорий» принимаются по следующим отраслям и группам наук:

25.00.00 Науки о Земле (вся отрасль наук о Земле);

05.00.00 Технические науки (три группы из отрасли):

05.05.00 Транспортное, горное и строительное машиностроение,

05.13.00 Информатика, вычислительная техника и управление, 05.14.00 Энергетика;

08.00.00 Экономические науки.

В соответствии с градацией наук, принятой в международных системах цитирования Scopus и Web of Science, статьи для публикации в журнале «Устойчивое развитие горных территорий» принимаются по следующим отраслям и группам наук:

1. Технические науки;

2. Науки о Земле и планетарные науки;

3. Наука об окружающей среде.

В связи с тем, что журнал «Устойчивое развитие горных территорий» входит в «Перечень российских рецензируемых научных журналов, в которых должны публиковаться основные научные результаты диссертаций на соискание ученых степеней доктора и кандидата наук», и количество статей, поступающих в редакцию, резко возросло, просьба:

- максимально четко выполнять требования к авторам; сразу же, вместе с текстом статьи направлять все необходимые сопроводительные материалы, не дожидаясь, пока с Вами свяжутся сотрудники редакции;

- не выходить за рамки обозначенного допустимого объема;

- четко выполнять все требования, предъявляемые к рисункам, диаграммам, фотографиям и прочему, присылать их в регламентируемом формате.

Напоминаем, что редакция не возвращает авторам присланные материалы равно как на бумажных, так и на электронных носителях.

Сообщаем также, что количество журналов, в рекламных целях рассылавшихся ранее бесплатно, значительно сокращено, в связи с чем информируем, что подписка на журнал продолжается. Те, кто не успел подписаться на 1 полугодие 2018 года в отделениях Роспечати, могут сделать это в самой редакции (подробности стоимости и условий подписки в разделе «Подписка. Реклама» журнала).

Редакция также осуществляет услуги по изготовлению и размещению рекламных материалов на страницах журнала (обложка, цветные вклейки, черно-белые вставки). Вы можете прорекламировать продукцию, разработанную в ваших лабораториях и научных центрах, предложить запатентованное вами оборудование, приборы, новые технологии, сделать предложение о сотрудничестве, предложить услуги научного либо прикладного характера, попытаться привлечь инвестиции под ваши проекты, проанонсировать монографию, т.е. на правах рекламы разместить любую необходимую для вас информацию.

Сделав заявку и прислав текст и примерный вид вашей предполагаемой рекламы, Вы, связавшись с нами по телефонам редакции 8 (8672) 40-73-60, +7(918)707-39-25, обговариваете все детали. Получив от нас счет за выполненную работу, оплачиваете его, а копию платежного получения присылаете на электронный адрес редакции.

Всегда рады сотрудничеству. 


\section{НАУКИ О ЗЕМЛЕ}

\section{EARTH AND PLANETARY SCIENCES}

\section{ENVIRONIMENTAL SCIENCES}

Крупные катастрофы, уюе разорившие и продолжающие разорять современный мир, происходят от нежелания человека считаться с законами природы,

от нежелания понять, что голод нельзя утолить, опустошая землю.

Жан ДОРСТ

\section{ВЕРИФИКАЦИЯ МОДЕЛИ ГОРНЫХ ОБВАЛОВ НА ОСНОВЕ КОНТИНУАЛЬНОГО ПОДХОДА}

1,2Орлова Н.С., *

${ }^{1}$ Каменецкий Е.C.

\section{Введение}

Обвал - это обрушение как отдельных глыб и блоков, так и более крупных объёмов твёрдых и относительно твёрдых горных пород из обнажений, расположенных на горном склоне или из крутой, почти отвесной верхней части склона, сопровождающееся их скатыванием, опрокидыванием и раскалыванием [1].

Важность изучения подобных явлений определяется целым рядом причин, среди которых опасность для жизнедеятельности человека на соответствующих территориях; распространённость, увеличивающаяся в связи с освоением горных и предгорных территорий; неожиданность их возникновения; участие в формировании и изменении рельефа местности и т. п. В настоящее время актуальной задачей является оценка размеров зон поражения при обвалах массы горных пород.

Для исследования обвальных процессов применяются различные методы, среди которых важную роль играет математическое и компьютерное моделирование [2-9], в особенности для тех случаев, когда реальные наблюдения и создание экспериментальных установок оказываются затруднительными.

На сегодняшний день для описания горных обвалов используются, в основном, дискретные модели. Дискретные модели могут описывать движение потока вещества либо в виде движения группы отдельных не соударяющихся друг с другом частиц, каждая из которых без сопротивления проходит сквозь другую (соседнюю) частицу, либо в виде группы упруго соударяющихся друг с другом частиц [3-7]. Они позволяют моделировать ограниченное количество движущихся обломков. Увеличение количества моделируемых обломков требует достаточно мощных вычислительных ресурсов, т.к. необходимо рассматривать движение каждого обломка в отдельности. Известны также и континуальные модели обвалов [8; 9], в которых движущаяся масса вещества представляется в виде сплошной среды, характеризующейся неразрывным полем значений физических параметров. Но эти модели не учитывают процесс ожижения потока об-

\footnotetext{
${ }^{1}$ Южный математический институт-филиал Владикавказского научного центра Российской академии наук, г. Владикавказ, Россия

${ }^{2}$ Финансовый университет при Правительстве РФ, г. Владикавказ, Россия

*e-mail: norlova.umi.vnc@gmail.com
}

УДК: 551.4 .013

DOI: 10.21171/1998-4502-2018-

$10-1-7-13$

Исследовалось движение обвалов горной массы по склону, сопряженному с горизонтальным участком. Осуществлялось теоретическое исследование движения горной массы с использованием двухжидкостной модели на основе континуального подхода и кинетической теории гранулярного газа. Проведена верификация модели движения горной массы с использованием результатов экспериментов, полученных на лабораторной установке. Представлены сравнительные данные по дальности пробега обвальной массы в зависимости от крутизны склона в экспериментах и расчетах, полученных с использованием двухжидкостной модели и модели на основе метода дискретного элемента.

КЛЮЧЕВЫЕ СЛОВА:

математическое моделирование, обвал, метод дискретных элементов, континуальный подход, кинетическая теория гранулярного газа, OpenFOAM, дальность пробега.

Статья поступила в редакцию 08.07.2017 
вальных горных пород, движущихся по склону. Под ожижением понимается изменение объемной плотности обломков по толщине слоя, которая может меняться во время его движения. Несмотря на достаточно большое количество известных зарубежных и отечественных научных работ, отсутствует математическая модель обвалов, которая бы учитывала ожижение обломков, вызванное их хаотическим движением.

В работе [10] исследовалась математическая модель движения обломков горных пород с использованием континуального подхода, когда движение потока вещества представляется в виде сплошной среды. В модели учитывается ожижение потока обвальных горных пород в процессе их движения по склону. Моделирование ожижения потока обвальных горных пород осуществляется с использованием кинетической теории гранулярных газов, которая учитывает хаотическое движение обломков (вследствие их столкновений друг с другом и с поверхностью склона) как в плотном, так и в разреженном состоянии. Таким образом, кинетическая теория гранулярных газов дает возможность учесть влияние столкновений обломков друг с другом и со склоном на движение обвалов. Ранее такой подход не использовался для описания обвалов.

Следует отметить, что в работе [10] представлены результаты моделирования движения обвалов в двумерном приближении. Было проведено сравнение полученных результатов расчетов с результатами других известных моделей [5; 11], которые описывают реальные наблюдения. Полученные размеры зоны поражения в среднем совпадают с результатами, которые рассчитаны по упрощенным динамическим моделям и получены при обработке данных наблюдений.

В данной работе представлены результаты трехмерного моделирования движения обвалов с использованием модели на основе континуального подхода с учетом ожижения потока обвальных горных пород. Верификация модели осуществлялась с использованием результатов экспериментов, проведенных в лабораторных условиях [12].

Полученные результаты сравнивались также с расчетами движения обломков горных пород при обвале, полученными с использованием модели, в основе которой лежит метод дискретных элементов (МДЭ) [13]. В этом случае вычисления осуществлялись с использованием свободного открытого программного кода LIGGGHTS [14], в котором реализован МДЭ. В расчетах использованы монодисперсные сферические частицы диаметром 5 мм, что примерно соответствует среднемассовому размеру частиц в экспериментах.

На рис. 1 представлено положение частиц доломита после обрушения, полученное при визуализа- ции результатов расчета с использованием метода дискретных элементов. Использовалось значение массы доломита $m=3$ кг, угла склона $\beta=35$ градусов, высоты, на которой располагался материал, $h=$ 50 см. Размеры расчетной области соответствовали размерам экспериментальной установки. Дальность пробега материала определялась так же как и в экспериментальных исследованиях путем проведения границы, разделяющей сплошную часть материала от части, в которой материал разрежен (рис.1).

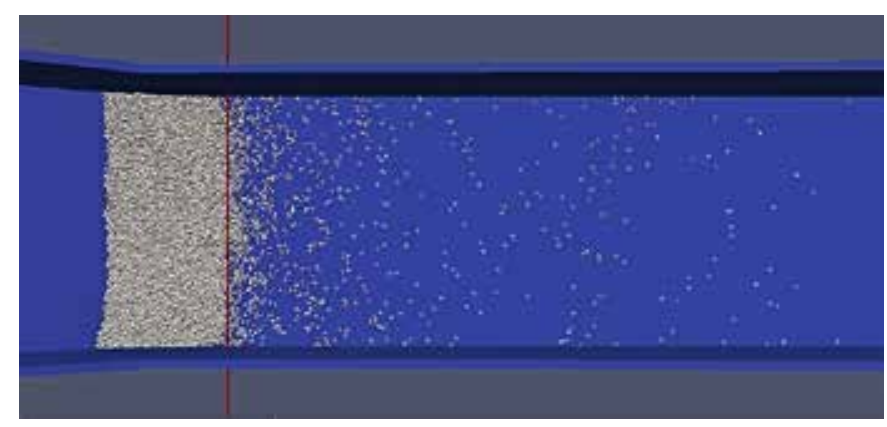

Pис. 1. Результаты эксперимента. Вид сверху /

Fig. 1. Experimental results. The view from the top

\section{Материал и методы исследования}

Для моделирования движения обвалов на основе континуального подхода и кинетической теории гранулярного газа использовался пакет для численного моделирования задач гидроаэромеханики OpenFOAM. Для описания движения обвала с учетом ожижения использовался решатель twoPhaseEulerFoam. В решателе twoPhaseEulerFoam реализована двухжидкостная модель кипящего (ожиженного) слоя на основе континуального подхода (подхода Эйлера), при котором движение слоя рассматривается как движение двух взаимодействующих континуумов, связанных с газом и частицами. Основные уравнения двухжидкостной модели - уравнения неразрывности и уравнения количества движения для обеих фаз [15-18]:

$$
\frac{\partial}{\partial t}\left(\alpha_{\varphi} \rho_{\varphi}\right)+\nabla \cdot\left(\alpha_{\varphi} \rho_{\varphi} \bar{U}_{\varphi}\right)=0
$$

$\frac{\partial}{\partial t}\left(\alpha_{\varphi} \rho_{\varphi} \bar{U}_{\varphi}\right)+\nabla \cdot\left(\alpha_{\varphi} \rho_{\varphi} \bar{U}_{\varphi} \bar{U}_{\varphi}\right)+\nabla \cdot\left(\alpha_{\varphi} \bar{R}_{\varphi, e f f}\right)=$ $=-\alpha_{\varphi} \nabla P+\alpha_{\varphi} \rho_{\varphi} \bar{g}+\bar{M}_{\varphi}$

Индекс $\alpha_{\varphi}$ означает принадлежность к фазе (твердой «a» или газовой «b», обе фазы считаются несжимаемыми); $\alpha_{\varphi}$ - объемная доля соответствующей фазы; $\underline{\rho}_{\varphi}-$ плотность фазы; $\bar{U}_{\varphi}-$ вектор скорости фазы; $\vec{R}_{\varphi, e f f}-$ тензор эффективных напряжений; $P$ давление газовой фазы; $\bar{g}-$ ускорение свободного падения; $\bar{M} \varphi$ - член, моделирующий обмен импульсом между фазами. Выражения для коэффициентов и членов, входящих в уравнения (1-2), подробно описаны в литературе [15-17].

Для учета эффектов, обусловленных взаимодей- 
ствием частиц друг с другом, используется кинетическая теория (по аналогии с кинетической теорией газа), с помощью которой можно выразить эффективные напряжения, возникающие в дисперсной фазе за счет движения частиц и за счет столкновений частиц друг с другом. По аналогии с термодинамической температурой, вводится гранулярная температура $\Theta$, как средняя энергия флуктуаций скорости частиц (обломков). Уравнение для расчета гранулярной температуры представлено в работе [16].

Задача решалась в трехмерном приближении. Использовались следующие начальные условия:

$$
\bar{U}_{a}=0 ; \bar{U}_{b}=0 ; P=0 ; \alpha_{a}=0,6 ; \theta=0 .
$$

На рис. 2 схематически представлена область расчетов и граничные условия задачи. Рассматривалась область, состоящая из склона, сопряженного с горизонтальным участком. Расчеты проводили при разном значении угла склона к горизонтальной поверхности $\left(\beta_{1}=35\right.$ градусов, $\beta_{2}=46$ градусов и $\beta_{3}=53$ градуса).

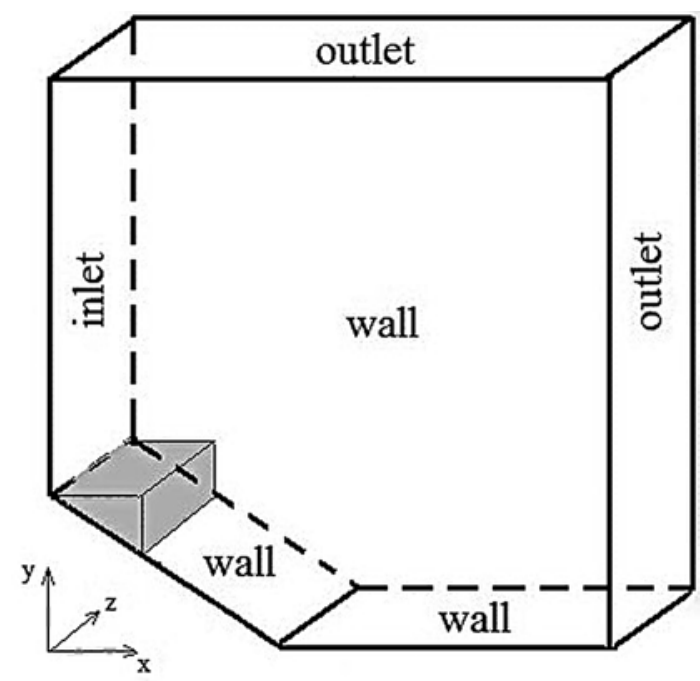

Рис. 2. Область расчетов /

Fig. 2. The calculation area

Размеры вычислительной области: высота $H=3$ м, длина горизонтального участка $L=1,5$ м, ширина $r=0,45$ м, высота, на которой располагалась обвальная масса в начальный момент времени, $h=0,5$ м. Движение обвала рассчитывалось в среднем за 40 - 60 с. Это позволило рассмотреть движение обвальной массы по склону и горизонтальной поверхности до момента, когда она остановится. При этом использовался шаг по времени, равный 0,005 с. Шаг по пространству равен 0,05 м. Проводилось распараллеливание расчетов на 4 ядрах. Время расчета одного варианта составляло примерно 30 минут.

В верхней части склона в начальный момент времени располагалась обвальная масса в виде треугольной призмы, объемом примерно 0,0023 м². Обвальная масса представлялась как совокупность твердых частиц сферической формы. Диаметр частиц (облом- ков) принимался одинаковым и равным 5 мм, что примерно соответствует среднемассовому размеру частиц в экспериментах [12].

Важно отметить, что в рамках континуального подхода необходимо учитывать отношение размера вычислительной ячейки (пространственного шага) к размеру (диаметру) частиц, т.к. континуальный подход основан на гипотезе сплошности среды. Согласно этой гипотезе масса среды (континуума) распределена в объеме непрерывно и, в общем, неравномерно. Основной динамической характеристикой среды является плотность (объемная доля) распределения массы по объему. Гипотеза сплошности среды означает, что всякий малый элемент объема среды считается все-таки настолько большим, что содержит еще очень большое число частиц $[19 ; 20]$. Под малым элементом объема в данном случае подразумевается размер вычислительной ячейки.

Далее представлены: граничные условия на входной левой границе (inlet):

$$
\bar{U}_{a}=0 ; \bar{U}_{b}=0 ; \frac{\partial P}{\partial n}=0 ; \alpha_{a}=0 ; \frac{\partial \theta}{\partial n}=0
$$

граничные условия на верхней и правой свободных границах (outlet):

$\frac{\partial \bar{U}_{a}}{\partial n}=0 ; \frac{\partial \bar{U}_{b}}{\partial n}=0 ; \frac{\partial P}{\partial n}=0 ; \frac{\partial \alpha_{a}}{\partial n}=0 ; \frac{\partial \theta}{\partial n}=0$

а также граничные условия (условия прилипания) на стенках (wall):

$$
\bar{U}_{a}=0 ; \bar{U}_{b}=0 ; \frac{\partial P}{\partial n}=0 ; \frac{\partial \alpha_{a}}{\partial n}=0 ; \frac{\partial \theta}{\partial n}=0 .
$$

Следует отметить, что для боковых поверхностей (рис. 2) использовались граничные условия на стенках, то есть условия прилипания.

Было проведено исследование влияния граничного условия на стенках на результаты расчетов [21]. Получено, что в качестве граничного условия на стенках предпочтительно использовать условие прилипания или условие слабого проскальзывания (при значениях коэффициента проскальзывания в пределах от 0,1 до 0,4). Результаты расчетов, полученные при условии прилипания, практически не отличаются от результатов расчетов, полученных при слабом проскальзывании, и хорошо соответствуют результатам расчетов по упрощенным динамическим моделям и результатам обработки данных наблюдений. Поэтому в данной работе в качестве граничного условия на стенках установки для скорости обвальной массы используется условие прилипания.

\section{Полученные результаты и их обсуждение}

На рис. 3 представлены результаты расчетов распределения объемной доли частиц $\alpha_{a}$ после обрушения горной породы для случая, когда угол склона к го- 


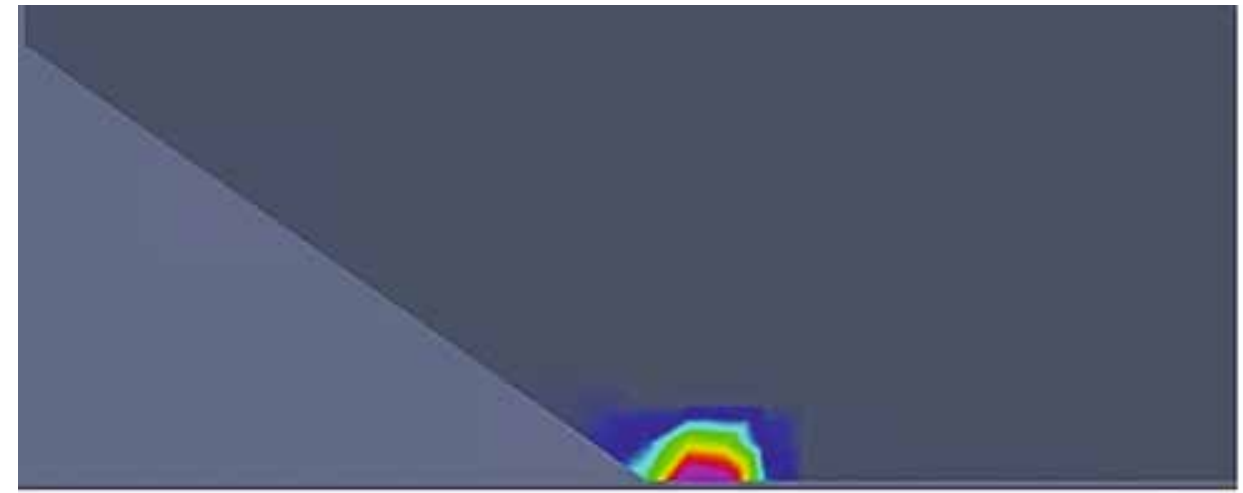

a)
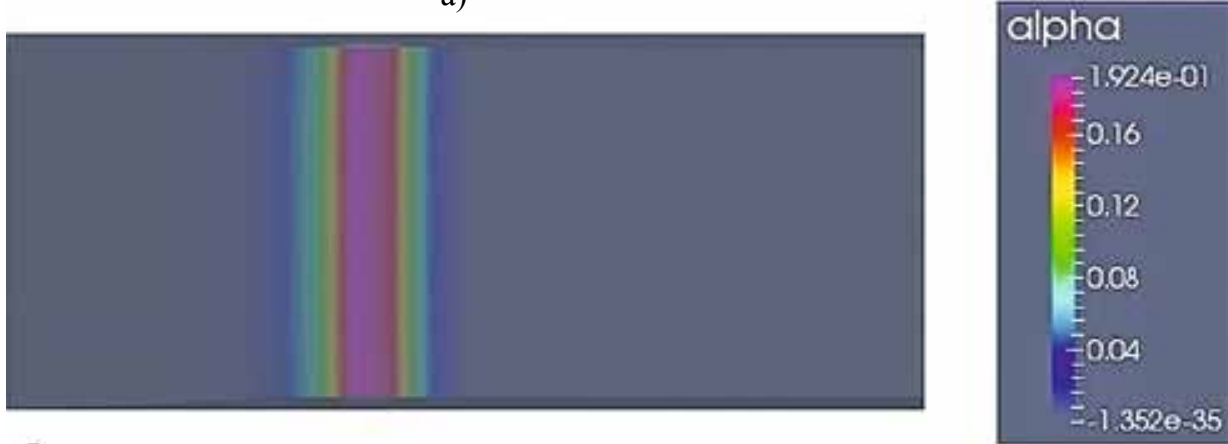

$-$

б)

Рис. 3. Результаты моделирования с использованием двухжидкостной модели /

Fig. 3. The simulation results using the two-fluid model

ризонтальной поверхности равен 35 градусов. Модель основана на континуальном подходе, поэтому обвальная масса визуализируется в виде сплошной среды с непрерывно распределенной объемной долей частиц.

Дальность пробега массы на горизонтальном участке определялась следующим образом. Расчетная область разбивалась на несколько продольных сечений (построенных в направлении оси z) вдоль горизонтального участка в направлении оси $x$. В каждом сечении были построены кривые распределения объемной доли частиц $\alpha_{a}$ вдоль оси $x$.

На рис. 4 представлены кривые распределения объемной доли частиц вдоль оси $x$ в продольном сечении при $z=22,5$ см, что соответствует середине ширины $r$ расчетной области. Кривая 1 на рис. 4 соответствует распределению объемной доли частиц при значении угла склона $\beta_{1}=35$ градусов, кривая 2 - распределению при значении $\beta_{2}=46$ градусов, кривая 3 - распределению при $\beta_{3}=53$ градуса. Следует отметить, что кривые распределения $\alpha_{a}$, построенные в других продольных сечениях при разных значени$я \mathrm{x} z$, незначительно отличаются от кривых, представленных на рис. 4.

В работе [20] представлены результаты одномерного (в вертикальном направлении) моделирования динамики виброкипящего слоя, которые были получены с использованием моделей на основе континуального подхода и кинетической теории гранулярного газа. Нижняя граница слоя определялась с исполь- зованием значения объемной доли частиц $\alpha_{a}=0,05$. В данной работе граница, разделяющая сплошную часть материала от части, в которой материал разрежен, также определялась с использованием значения $\alpha_{a}=0,05$.

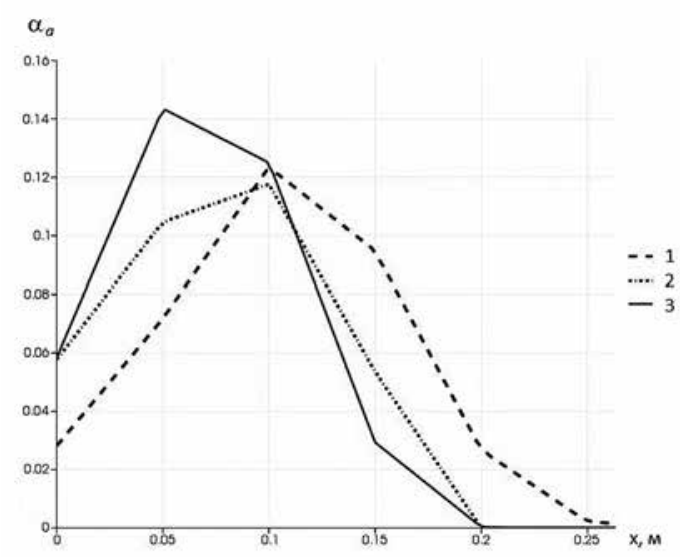

Puc. 4. Распределение объемной доли частиц в цеентре при разных значениях угла склона /

Fig. 4. The distribution of the volume fraction of particles in the center at different values of the slope angle

Из рис. 4 видно, что с увеличением значения угла склона $\beta$ увеличивается дальность пробега массы вдоль горизонтального участка. Дальность пробега массы составила $l_{p}=13,8$ см при $\beta_{1}=35$ градусов; $l_{p}=5,3$ см при $\beta_{2}^{p}=46$ градусов и $l_{p}=18,3$ см при $\beta_{3}^{p}=53$ градуса. 
На рис. 5 представлено сравнение результатов экспериментов (кривая 1) с результатами расчетов, полученными с использованием модели на основе метода дискретного элемента (кривая 2), и результатами расчетов, полученными с использованием двухжидкостной модели на основе континуального подхода и кинетической теории гранулярного газа (кривая 3). Приведена зависимость дальности пробега массы от угла склона при ее начальном расположении на высоте $h=50 \mathrm{~cm}$.

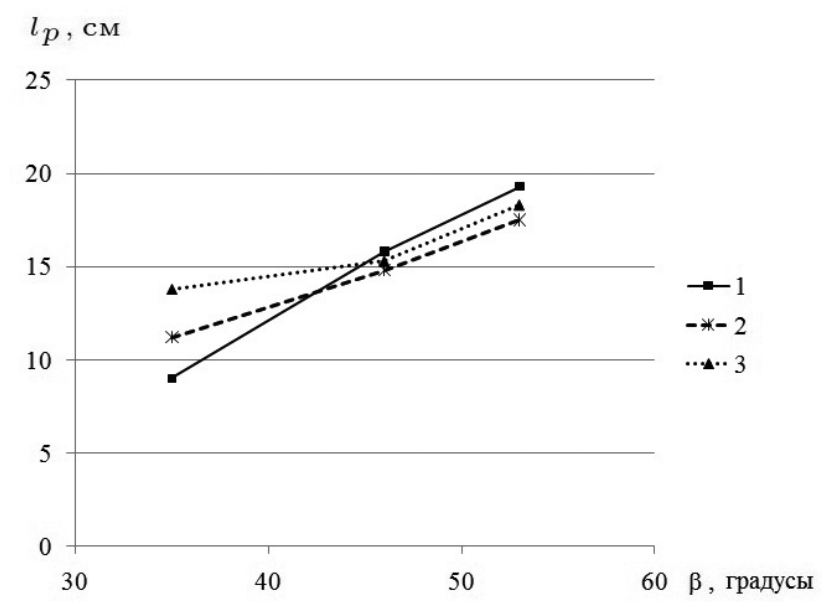

Puc. 5. Зависимость дальности пробега материала от угла склона. Сравнение результатов экспериментов с результатами расчетов /

Fig. 5. The dependence of the material run distance from the slope angle. Comparison of experimental results with the results of calculations

В целом, результаты расчетов удовлетворительно описывают эксперимент. Дальность пробега возрастает практически линейно с увеличением угла склона. При малых значениях угла склона $\left(\beta_{1}=35\right.$ градусов) наблюдается завышение результатов расчетов по сравнению с экспериментальными данными, особенно в случае использования двухжидкостной модели. Возможно, что для моделирования движения обвалов при малых значениях угла склона обе модели нуждаются в доработке.

В остальных случаях (когда $\beta_{2}=46$ градусов и $\beta_{3}=53$ градуса) расчетные значения несколько ниже экспериментальных. В этих случаях экспериментальным данным лучше соответствуют расчеты, полученные с использованием двухжидкостной модели. Кроме того, затраты машинного времени на выполнение расчетов с использованием двухжидкостной модели примерно в четыре раза меньше, чем в случае использования модели на основе дискретного элемента. При этом распараллеливание вычислений в обоих случаях проводилось на четырех ядрах (частота процессора также была примерно одинаковая).

Небольшое расхождение результатов расчетов и экспериментов можно объяснить как недостаточной точностью определения дальности пробега массы и в экспериментах и при обработке результатов расчетов, так и тем, что при проведении расчетов использовались сферические частицы одного размера. В действительности, в экспериментах частицы доломита имеют неправильную форму, и их размеры варьируются от 3 до 6 мм.

\section{Заключение}

По результатам проведенных исследований можно сделать вывод о том, что двухжидкостную модель на основе континуального подхода и кинетической теории гранулярного газа можно использовать для описания движения обвалов горных пород и оценки области поражения при обвалах. Модель позволяет получить расчеты примерно в четыре раза быстрее по сравнению с моделью на основе метода дискретных элементов. Это является существенным при моделировании реальных горных обвалов.

Работа выполнена при поддержске гранта РФФИ № 16-35-00147.

6. Rammer W., Brauner M., Dorren L.K.A., Berger F., Lexer M.J. Evaluation of a 3-D rockfall module within a forest patch model // Natural Hazards ahd Earth system Sciences. 2010. No. 10. Pp. 669-711.

7. Hungr O. A model for the runout analysis of rapid flow slides, debris flows and avalanches // Canadian Geotechnical Journal. 1995. Vol. 32. no. 4. Рp. 610-623.

8. Божинский А.Н., Назаров А.Н. Динамика двухфазного селевого потока // Вестник Московского университета. Серия 5. География. 1999. N 5. С. 15-20.

9. Fangqiang Wei, Hu Kaiheng, Jose Luis Lopez, Cui Peng. Method and its application of the momentum model for debris flow risk zoning // Chinese Science Bulletin. 2003. No. 48(6). Pp. 594-598. 
10. Орлова Н.С., Волик М.В. Математическое моделирование движения обвалов с использованием континуального подхода // Известия вузов. Северо-Кавказский регион. Естественные науки. 2016. N3. С. 20-24.

11. Nilsen M. Modelling of rockfall runout range. Employing empirical and dynamical methods // Master Thesis in Geosciences Discipline: Environmental geology and geohazards. Department of Geosciences, Faculty of Mathematics and Natural Sciences, University of Oslo, 2008. 96 p.

12. Кусраев А.Г., Минасян Д.Г., Орлова Н.С., Пантилеев Д.Г., Хубежты Ш.С. Верификация модели обвалов, использующей метод дискретного элемента // Геология и геофизика Юга России. 2016. N4. C. 83-93.

13. Pöschel T. Computational Granular dynamics models and algorithms. Berlin Heidelberg New York, Springer. 2005. $322 \mathrm{p}$.

14. LIGGGHTS Open Source Discrete Element Method Particle Simulation Code. http://www.liggghts.com

15. Henrik Rusche. Computational Fluid Dynamics of Dispersed Two-Phase Flows at High Phase Fractions // Thesis submitted for the degree of Doctor of Philosophy of the University of London and Diploma of Imperial College. 2002. 343 p.
16. Berend van Wachem. Derivation, Implementation, and Validation of Computer Simulation Models for Gas-Solid Fluidized Beds // Dissertation at Delft University of Technology, 2000. 222 p.

17. Каменецкий Е.С., Орлова Н.С., Волик М.В., Минасян Д.Г. Исследование динамики кипящего гранулированного слоя с использованием пакета OpenFoam // Известия вузов. Северо-Кавказский регион. Естественные науки. 2014. N5. C. $37-42$.

18. Gidaspow D. Multiphase flow and fluidization: Continuum and kinetic theory descriptions. Boston: Academic Press Inc., 1994. $211 \mathrm{p}$.

19. Волков К.Н., Емельянов В.Н. Течения газа с частицами. Москва: Физматлит, 2008. 600 с.

20. Орлова Н.С. Разработка и исследование математических моделей виброкипящего слоя. Deutschland, Saarbrucken: LAPLAMBERT Academic Publishing, 2013. $173 \mathrm{c}$.

21. Орлова Н.С., Волик М.В. Исследование влияния граничных условий на результаты моделирования движения обвалов // Процессы в геосредах. 2017. N4. С. 693-699.

\section{СВЕДЕНИЯ ОБ АВТОРАХ / Information about authors:}

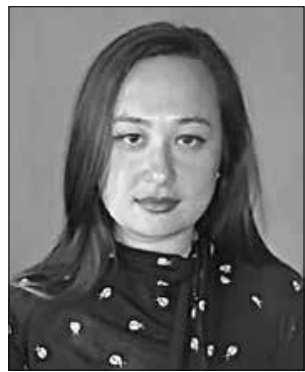

ситета при Правительстве РФ.

ОРЛОВА Наталья Сергеевна - кандидат технических наук, старший научный сотрудник отдела математического моделирования Южного математического институтафилиала Владикавказского научного центра Российской Академии наук (ЮМИ ВНЦ РАН); старший преподаватель кафедры «Математика и информатика» Финансового универ362027, г. Владикавказ, Россия

Тел.: +7(928) 859-65-49 (моб.), +7 (8672)53-11-20 (сл.). e-mail: norlova.umi.vnc@gmail.com

ORLOVA Natalya Sergeevna - Candidate of Technical Sciences. Vladikavkaz Scientific Center of the Russian Academy of Sciences, Department of Mathematical Modeling, Senior Researcher; Financial University under the Government of RF, Department of Mathematics and Informatics, Senior Lecturer

362027, Vladikavkaz, Russia.

Tel.: +7(928) 859-65-49 (mobile), +7(8672) 53-11-20 (office).

e-mail:norlova.umi.vnc@gmail.com

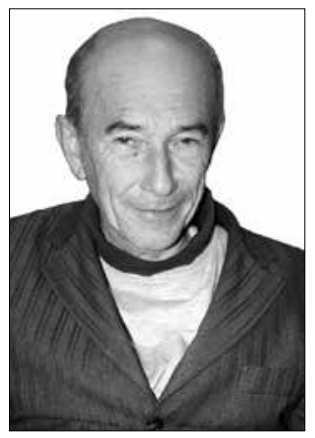

КАМЕНЕЦКИЙ Евгений Самойлович - доктор физ.-мат. наук, доцент; главный научный сотрудник.

Южный математический институт-филиал Владикавказского научного центра Российской Академии наук

362027, РСО-Алания,

г. Владикавказ, Россия

Тел.: +7(8672)53-11-20

E-mail: esk@smath.ru

KAMENETSKY Evgeny Samoylovich - Doctor of Physical and Mathematical Sciences, associate professor; chief researcher. Southern Mathematical Institute - branch of Vladikavkaz Scientific Center of Russian Academy of Sciences

362027, RNO-Alania, Vladikavkaz, Russia

Tel: +7 (8672)53-11-20

E-mail:esk@smath.ru

\section{VERIFICATION OF ROCK FALLS MODEL USING THE CONTINUUM APPROACH}

${ }^{1,2}$ N.S. Orlova,*

${ }^{1}$ E.S. Kamenetskiy

${ }^{1}$ Southern Mathematical Institute-branch of the Vladikavkaz Scientific Center of the Russian Academy of Sciences (YUMI Russian Academy of Sciences), Vladikavkaz, Russia

${ }^{2}$ Financial University under the government of the Russian Federation, Vladikavkaz, Russia

DOI: $10.21177 / 1998-4502-2018-10-1-7-13$

An actual problem is the assessment of the affected areas size in the case of rock mass crashes at the present time.
To study the rock fall processes, various methods are used, among which an important role is played by the mathemati- 
cal and computer modeling. The rock fall movement of the slope which is associated with the horizontal section was investigated in the paper. The theoretical investigation was performed using two-fluid model based on the continuum approach and kinetic theory of granular gas. At the continuum approach the moving mass of a substance is represented as a continuous medium characterized by the inseparable field of the physical parameters values. To describe the fluidization of the mass of rock fall in the course of its motion, the kinetic theory of granulated gas was used, which takes into account the chaotic motion of debris both in the dense and in the rarefied state.Fluidization means a change in the density of the layer which can change during its movement. Verification of the model was carried out using the results of the experiments obtained on the laboratory equipment. The comparison between the experiment results and calculations, performed using two-fluid model and discrete element method were presented. The numerical calculations of the affected area of rock fall performed for various values of the slope angle to horizontal surface satisfactorily describe the experiments. The affected area increases almost linearly with an increase in the slope angle. The experimental data is corresponding to the calculations obtained using the two-fluid model at relatively large values of the slope angle better than the calculations obtained using the discrete element method. In addition, the computer time spent on computations using the two-fluid model is about four times less than in the case of using the discrete element method.Based on the results of the study, it can be concluded that the two-fluid model based on the continuum approach and the kinetic theory of granulated gas can be used to describe the motion of the rock fall and to estimate the affected area.

Keywords: continuum approach, rock fall, affected area, granular gas, fluidization.

References: 1. Lomtadze V.D. Engineering geology. Engineering geodynamics. Leningrad. Nedra. 1977. 479 p. (in Russian).

2. Manzella I., Labiouse V. Empirical and analytical analyses of laboratory granular flows to investigate rock avalanche propagation. Landslides. 2013. No. 10. Pp. 23-36.

3. Mikhailov V.O. Classification of numerical mathematical models of mudflow and slope processes. Engineering geology. 2011. No. 3. Pp. 56-63(in Russian).

4. Mikhailov V.O. Three-dimensional mathematical model of avalanche processes. Bulletin of Moscow University. Series 5. Geography. 2011. No. 4. Pp. 53-58 (in Russian).

5. Luuk K.A. Dorren A review of rock fall mechanics and modeling approaches. Progress in Physical Geography. 2003. vol. 27. No. 1. Pp. 69-87.

6. Rammer W., Brauner M., Dorren L.K.A., Berger F., Lexer M.J. Evaluation of a 3-D rock fall module within a forest patch model. Natural Hazards and Earth system Sciences. 2010. No. 10. Pp. 669-711.
7. Hungr O. A model for the runout analysis of rapid flow slides, debris flows and avalanches. Canadian Geotechnical Journal. 1995. V. 32. No. 4. Pp. 610-623.

8. Bozhinski A.N., Nazarov A.N. Dynamics of two-phase mudflow. Bulletin of Moscow University. Series 5. Geography. 1999. No. 5. Pp. 15-20 (in Russian).

9. FangqiangWei, HuKaiheng, JoseLuisLopez, CuiPeng. Method and its application of the momentum model for debris flow risk zoning. Chinese Science Bulletin. 2003. No.48(6). Pp. 594-598.

10. Orlova N.S., Volik M.V. Mathematical modeling of the motion of rock fall using the continuum approach. Proceedings of the Universities. North Caucasus region. Natural sciences. 2016. No. 3. Pp. 20-24 (in Russian).

11. Nilsen M. Modelling of rock fall run out range. Employing empirical and dynamical methods. Master Thesis in Geosciences Discipline: Environmental geology and geohazards. Department of Geosciences, Faculty of Mathematics and Natural Sciences, University of Oslo. 2008. 96 p.

12. Kusraev A.G., Minasyan D.G., Orlova N.S., Pantileev D.G., HubezhtySh.S. Verification of the model of rock fall using the discrete element method. Geology and geophysics of the South of Russia. 2016. No. 4. Pp. 83-93 (in Russian).

13. Pöschel T. Computational Granular dynamics models and algorithms. Berlin Heidelberg New York, Springer. 2005. $322 \mathrm{p}$.

14. LIGGGHTS Open Source Discrete Element Method Particle Simulation Code. http://www.liggghts.com

15. Henrik Rusche. Computational Fluid Dynamics of Dispersed Two-Phase Flows at High Phase Fractions. Thesis submitted for the degree of Doctor of Philosophy of the University of London and Diploma of Imperial College. 2002. $343 \mathrm{p}$.

16. Berend van Wachem. Derivation, Implementation, and Validation of Computer Simulation Models for Gas-Solid Fluidized Beds. Dissertation at Delft University of Technology. 2000. 222 p.

17. Kamenetskiy E.S., Orlova N.S., Volik M.V., Minasyan D.G. The study of the dynamics of fluidized granular layer using the package Open Foam. Proceedings of the Universities. North Caucasus region. Natural Sciences. 2014. No. 5. Pp. 37-42 (in Russian).

18. Gidaspow D. Multiphase flow and fluidization: Continuum and kinetic theory descriptions. Boston: Academic Press Inc. 1994. 211 p.

19. Volkov K.N., Emelyanov V.N. Gas flows with particles. Moscow, Fizmatlit. 2008, 600 p. (in Russian).

20. Orlova N.S. Development and research of mathematical models of the vibrated fluidized layer. Deutschland, Saarbrucken: LAPLAMBERT Academic Publishing. 2013. 173 p. (in Russian). 
${ }^{1}$ Irina N. Bilichenko, ${ }^{*}$ ${ }^{1}$ Lidia V. Danko

\section{APPLICATION OF LANDSCAPE ECOLOGY METHODS IN THE STUDY OF GEOSYSTEMS OF BAIKALIAN SIBERIA}

УДК: 911.2

DOI: 10.21177/1998-4502-201810 -1-14-22

For the typical regional geosystems of the Baikalian region, this study of spatial landscape heterogeneity was carried out at the level of elementary territorial units, $i$. e. facies. Our investigation into the spatial-coenotic changes of the mountain taiga and subtaiga forests and steppe geosystems of the Southern Baikal Region and the Western Baikal Region allowed us to establish the dependence of the spatial landscape heterogeneity on the variability of the hydrothermal conditions and litomorphic nature of habitats. A useful starting point for landscape heterogeneity research has been to explore landscape as groups of plant communities or ecosystems forming ecological units (patches) which have distinguishable structural, functional, morphological, and disturbance regimes. We identified dominant and edificatory species of vegetation as well as peculiarities in their spatial distribution in the key sites. The complexity of the landscape structure is enhanced by the mixed character of the successiondynamical states of geosystems arising as a consequence of different impacts. The application of a structural dynamic approach to the analysis of the spatial landscape heterogeneity in our study made it possible to show the order of changes of the facies due to the variability in ecological conditions in the form of models, namely, factoringdynamic models. These models will support us in understanding and integrating information on spatial and temporal heterogeneity of the current and prognostic geosystems needed to provide the main functions of the geosystems. These are the resource, environment-forming, environmentprotective and social functions. We studied this landscape structure as a set of the geosystems existing in different dynamical states as a result of their directed transformation under spatial and temporal changes in natural conditions and under anthropogenic impact. Landscape structure analysis was made of the middle-scale landscape profiles using the comparative-geographical method, since the landscape topographic profile and spatial combination of the facies within it reflect the main structural and dynamic features of the territorial landscape structure with regard to regional nature characteristics.

\section{KEYWORDS:}

Landscape Ecology, Spatial heterogeneity, Geosystems, Structural-dynamic Analysis, Mountain taiga and sub-taiga forests, Mountain steppe, Baikalian Siberia.

$\overline{\text { Article received 01.11.2017 }}$

\section{Introduction}

Landscape Ecology should continue to refine knowledge of when spatial heterogeneity is fundamentally important, and focus on forecasting future landscape [1]. A landscape with structure and pattern implies that it has spatial heterogeneity, or an uneven, non-random distribution of objects across the landscape [2]. Landscape patterns result from complex relationships among multiple factors, many of which are well known. Heterogeneity is a key element of landscape ecology which separates this discipline from other branches of ecology [3-6]. However, forecasting the future landscape remains a challenging task in which the suite of drivers of landscape patterns and their interactions must be considered. Understanding the relative importance of different factors (and their roles at multiple scales) in producing landscape patterns is another important challenge [1].

A useful starting point for landscape heterogeneity research has been to explore landscape as groups of plant communities or ecosystems forming ecological units (patches) which have distinguishable structural, functional, morphological, and disturbance regimes [7]. Since some plant species have a higher sensitivity to change in the ecological habitat conditions, the presence of such species in plant communities is indicative of short-term fluctuations in the landscape structure. The reasons for phytocenotic changes are associated with both natural and anthropogenic changes in heat and moisture conditions, either individually or in combination.

Landscapes of the Baikal Siberia are a unique environment and valuable natural resources. According to the landscape-ecological regionalization of the Russian Federation, the territory under investigation is incorporated in the Pre-Sayan province of the subtaiga zone of the Middle-Siberian sector [8]. Landscapes of the Baikal Siberia are situated at the interface between the southern Siberian dark taiga, the eastern Siberian Light-coniferous and Mongolian-Daurian forest steppe [9]. Territorially, mountain-taiga forests are dominant, but the peculiarities of the natural conditions of the region are the cause of the wide diversity of landscapes systems or geosystems, with a high degree of spatial contrast. The altitudinalzonal differentiation of the geosystems reflect the optimal, limited and reduced conditions of the vegetation habitat of the taiga forests and steppe. The local differences in the landscape-ecological conditions, the distribution of atmospheric precipitation and especially heat predetermine the uniqueness of the landscape. Additionally there is a high degree of contrast in the territorial landscape structure with the co-existence of the steppe, meadow-bog, sub-taiga, mountain-taiga, sub-golets and golets vegetation communities. The complexity of the landscape structure is enhanced by the mixed character of the succession-dynamical states of geosystems arising as a consequence of different impacts.

In this research, the Western and Southern Baikal Regions were selected as the study sites. A small-scale landscape pattern of these three major vegetation types, namely the southern Siberian dark taiga, the eastern Siberian Light-coniferous and the Mongolian Daurian forest steppe was found depending on the site characteristics. The objective of this study was to analysis the spatial variability of elementary landscape units or elementary geosystems, such as facies, and their connection with different factors using structural-dynamic methods. The present

${ }^{1}$ The V.B. Sochava Institute of Geography SB RAS, Irkutsk, Russia

*E-mail: irinabilnik@mail.ru 


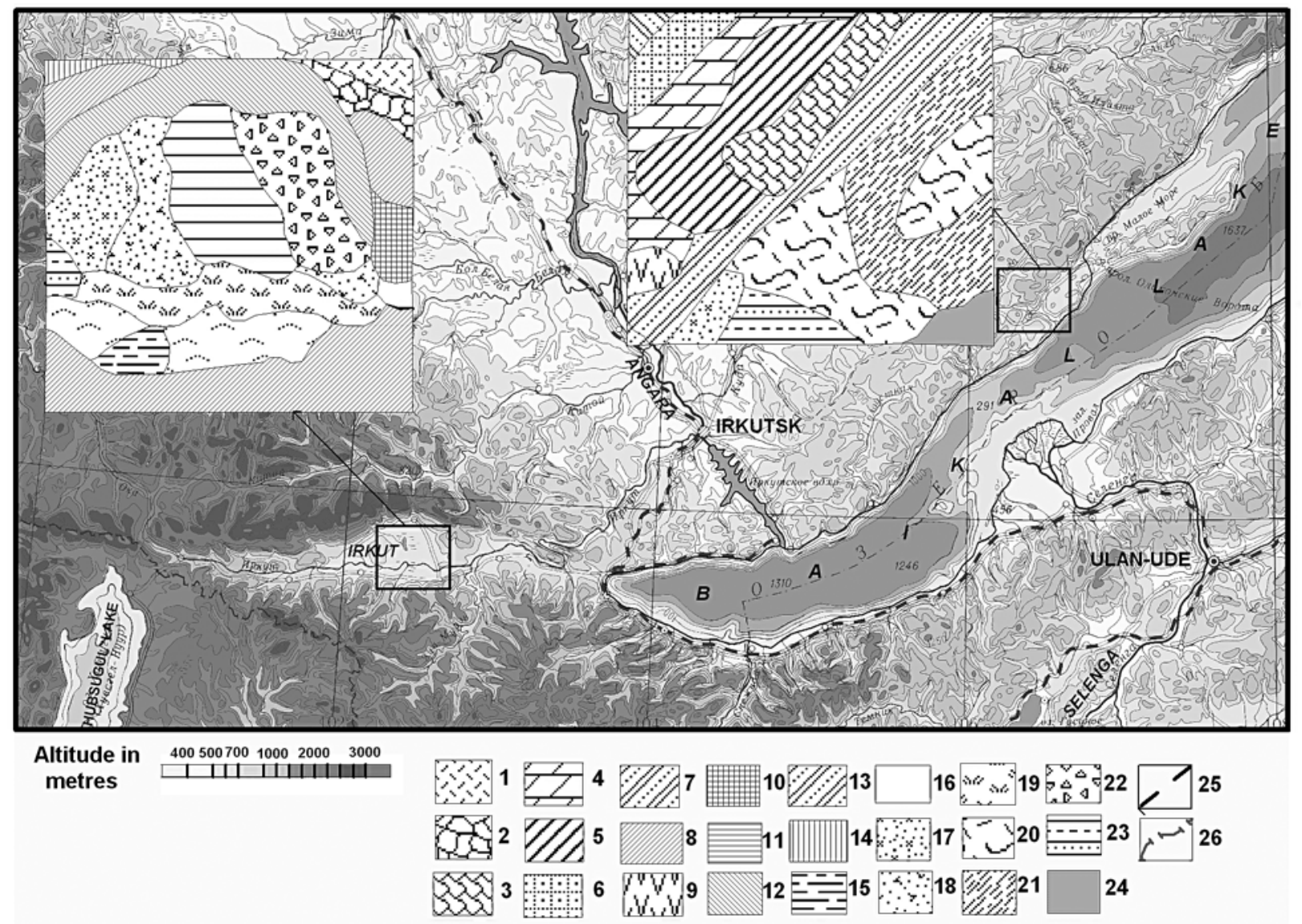

Fig. 1. The study areas location within the Southern (A) and Western (B) Baikal Region and fragments of landscape map, which was created by Mikheev, Ryashin (1977) [10]

issue focuses on investigating landscape heterogeneity and the interactions of multiple driving forces producing landscape structure and pattern.

\section{Study area}

The Preol'khon landscapes, which are located in the centre the Western Baikal Region, and Tunkinskie Goltsy Range and Khamar-Daban Range landscapes located in the Southern Baikal Region are the focus of this study (Fig. 1). The character of the natural conditions in the southern and western part of the Baikal Region, including mountain relief, climate variations, and diversity in vegetation and soil cover, are the cause of this landscape heterogeneity.

Northern-Asian Golets and Taiga Geosystems: Golets and sub-golets Baikal-Dzhugdzur and Easten-Sayan: I . Golets tundra: 1 - lichen flattened surface, 2 - slopes talus with lichen cover and sparse cedar dwarft cover; II. Sub-golets shrubs and open larch woodland: 3 - leveled surface and slopes open larch woodland with cedar. Mountain-taiga Baikal-Dzhugdzur: III - Mountain-taiga larch forest of limited development: 4 - slopes larch forest with pine, 5 - slopes larch forest with cedar and mixed undergrowth, 6 - valley yernik; IV. Mountain-taiga larch forest of optimal development: 7 - slopes larch forest shrubby undergrowth with the dominated Rhodendron dauricum, 8 - slopes larch forest with pine and forbs, 9 - valley of meadows with gramineous (sometime steepificated) cover, 10 - piedmont birch-larch up- land with shrubby undergrowth and herbaceous cover, 11 - valley swampy meadows, 12 - bottoms of depressions larch forest with pine and forbs. Mountain-taiga Southern-Sibirian: V. Mountain-taiga dark-coniferous forest of limited development: 13 - gently sloping forest from cedar and fir with fruticulose - small herbaceous and true moss cover, 14 - slopes sedar forest with spruce, larch and small herbaceous - true moss cover; VI. Mountain-taiga pine forest: 15 - slopes pine forest with shrubby undergrowth and herbaceous cover, $16-$ slopes herbaceous steepificated with Rhodendron dauricum. VII. Submountain-taiga pine forest: 17 - plain pine forest with Rhodendron dauricum bushes, 18 - bottoms of depressions pine forest with Rhodendron dauricum bushes, 19 - valley poplar-pine forest and osier-bed plain meadow. Central-Asian steppe geosistems: Mountain Easten-Zabzikalskie: 20 - bottoms of depressions gramineous steppe (feather and wheat grass), 21 - terrace low-bunchgrass steppe, 22 - bottoms of depressions fescue, and cobresia and shortgrass medow-steppe with frozen, 23 - valley carex-gramineous swampy of solonetzic meadows. 24 - Aquatory of the Baikal Lake. 25 - Federal highway. 26 - National boundaries.

Climate is believed to be the binding natural factor of landscape dynamics. The extreme continental climate of the Baikal Region is formed as a result of changes in atmospheric circulation in warm and cold periods. The 
climate around Lake Baikal (455 m a.s.1.) is continental with large seasonal variations in precipitation and temperature $[11 ; 12]$. January and July represent the coldest and warmest months respectively, and these clearly show the annual temperature range which indicates the severity of seasonality in the region. In July, temperatures in the intermountain depressions can reach $35^{\circ} \mathrm{C}$, dropping in January below $-40^{\circ} \mathrm{C}$ in the mountains. The surrounding Lake Baikal mountain ridges are 1700 to $2500 \mathrm{~m}$ high and annually they receive over $700 \mathrm{~mm}$ precipitation. The intermountainous depressions and coastal plains (500-700 $\mathrm{m}$ a.s.1.) experience a drier climate with average annual precipitation $250-300 \mathrm{~mm} /$ year or even less [12]. The maximum atmospheric precipitation occurs during summer in June to August. The effect of rather low precipitation on the forest vegetation at lower elevations is compensated for by low summer temperatures of 14 to $16^{\circ} \mathrm{C}$ in July, and by low evaporation. The total solar radiation is maximal for Siberia, and $20 \%$ larger compared with other areas at the same latitudes. The local barometric maximum occurs in summer, when repeated air streams from lake to land increases, and a breeze with high-valley circulation develops. Lake Baikal substantially exerts these pressures on coast landscapes from season to season, because it has a huge water body and significant longitudinal extension of this water area. During warm periods, air temperatures on the coast are lower, and in autumn and winter they are higher compared to the average for other areas in the Baikal Region.

The nonfrost vegetation period continues for about 4-4.5 months on the coast and 2-3 months in the mountains, since the climatic conditions are not uniform (Table). The humidification conditions vary from insufficient moistening for the Preol'khon landscapes to excessively

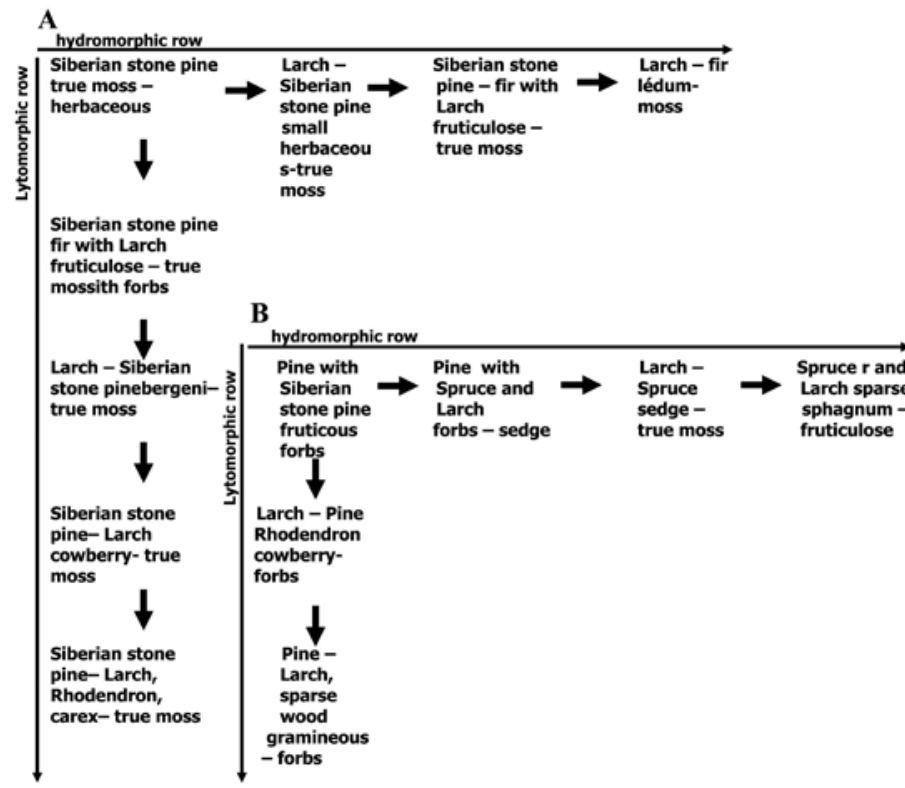

Fig.2. Watershed-sloping rows of facies: $A$-sub-mountain-plain Larch-Siberian stone pine-taiga landscape, Hamar-Daban mountain Range (cryo-humid conditions); B-sub-mountain Pine-Larch subtaiga landscape, Tunkinskie Goltsy Range(cryo-subhumid conditions) moist in the Khamar-Daban Range. As a result, moisture conditions are favourable for supporting a wide spread of taiga dominated by the boreal summer-green (e.g. larch - Larix, birch - Betula, poplar, aspen - Populus), evergreen (e.g. Siberian stone pine - Pinus sibirica or cedar, spruce - Picea, fir-Abies) and eurythermic (e.g. Scots pine - Pinus sylvestris) broadleaved and coniferous arboreal taxa. Dark-coniferous (dark-needles) forests of cedar, fir, spruce and pine grow in the most humid sites. Light-coniferous (light-needles) forests dominated by larch, pine and birch occur in relatively dry sites of the lower mountain belt. Steppes' associations with grasses and Artemisia species, and light open forests with the dominant Scots pine and larch are widely spread in the Preol'khon landscapes. The dominant positions in the structure of plant communities of steppes are occupied by representatives of] the grass family, depending on the growth period, water availability in different seasons, and the character of anthropogenic influences. These consist of Festuca lenensis, Poa attenuama, Koeleria cristata, and Agropypon cristatum. The most characteristic representatives of the grasses are Potentilla tanacetifolia, and Heteropappas altaicus. Shrubby sub-alpine associations represented by shrubby pine - Pinus pumila, alder Alnus fruticosa (Duschem fruticosa) and birch - Betula middendorfii, cover the upper parts of the northern slopes above $1300-1800 \mathrm{~m}$ and the southern slopes at 2000 $2200 \mathrm{~m}$

\section{Methods}

According to landscape ecology theory, landscape structure is determined by the composition, the configuration, and the proportion of different patches across the landscape, while function refers to how elements in the landscape interact based on their life cycle events [3]. Pattern is the term for the contents and internal order of a heterogeneous area of land [7]. We studied this landscape structure as a set of the geosystems existing in different dynamical states as a result of their directed transformation under spatial and temporal changes in natural conditions and under anthropogenic impact [13; 14].

Natural complexity can be best explored using spatial analysis tools based on the concepts of geosystems dynamics as a process continuum which can be partly decomposed into elements or patches. Geosystems, a term coined by the Russian geographer V.B. Sochava in 1963 [15], represent a special class of open and dynamic systems, hierarchically organized into an elementary area of the terrestrial surface and at regional, and planetary levels. This definition is applicable across scales and adaptable to different systems both terrestrial and aquatic, and also to natural human-dominated systems. The geosystems paradigm directs the following:

(1) The study of the spatial and temporal regularities of landscape structure and states of both natural and human-dominated geosystems;

(2) analysis disturbances and successions for assess- 
Climatic characteristics for the Western and Southern Baikal Region according to dates from the weather station for the study area in 1960-2000

\begin{tabular}{|c|c|c|c|c|c|c|}
\hline Meteostation & $\begin{array}{c}\text { Alti- } \\
\text { tude } \\
(\mathbf{m})\end{array}$ & $\begin{array}{c}\text { Average } \\
\text { temperature of } \\
\text { January } \\
\left({ }^{\circ} \mathbf{C}\right)\end{array}$ & $\begin{array}{c}\text { Average } \\
\text { temperature } \\
\text { of July } \\
\left({ }^{\circ} \mathbf{C}\right)\end{array}$ & $\begin{array}{c}\text { Annual } \\
\text { precipitation } \\
\text { sum } \\
(\mathbf{m m})\end{array}$ & $\begin{array}{c}\text { Average } \\
\text { summer } \\
\text { precipitate } \\
\text { on (mm) }\end{array}$ & $\begin{array}{c}\text { Average winter } \\
\text { precipitation } \\
(\mathbf{m m})\end{array}$ \\
\hline \multicolumn{7}{|c|}{ Southern Baikal Region } \\
\hline Hamar-Daban & 1442 & -17.9 & 12.7 & 1442 & 1210 & 232 \\
\hline Arshan & 892 & -19.0 & 16.0 & 570 & 530 & 40 \\
\hline Tunka & 722 & -25.0 & 15.0 & 412 & 381 & 31 \\
\hline Mondi & 1303 & -21.0 & 14,4 & 300 & 285 & 15 \\
\hline \multicolumn{7}{|c|}{ Western Baikal Region } \\
\hline Sarma & 464 & $-17,7$ & 12,2 & 205 & 165 & 40 \\
\hline Khuzhir & 460 & -18.0 & 11,1 & 200 & 175 & 25 \\
\hline Bol. Goloustnoye & 488 & $-17,4$ & 15,0 & 250 & 185 & 65 \\
\hline
\end{tabular}

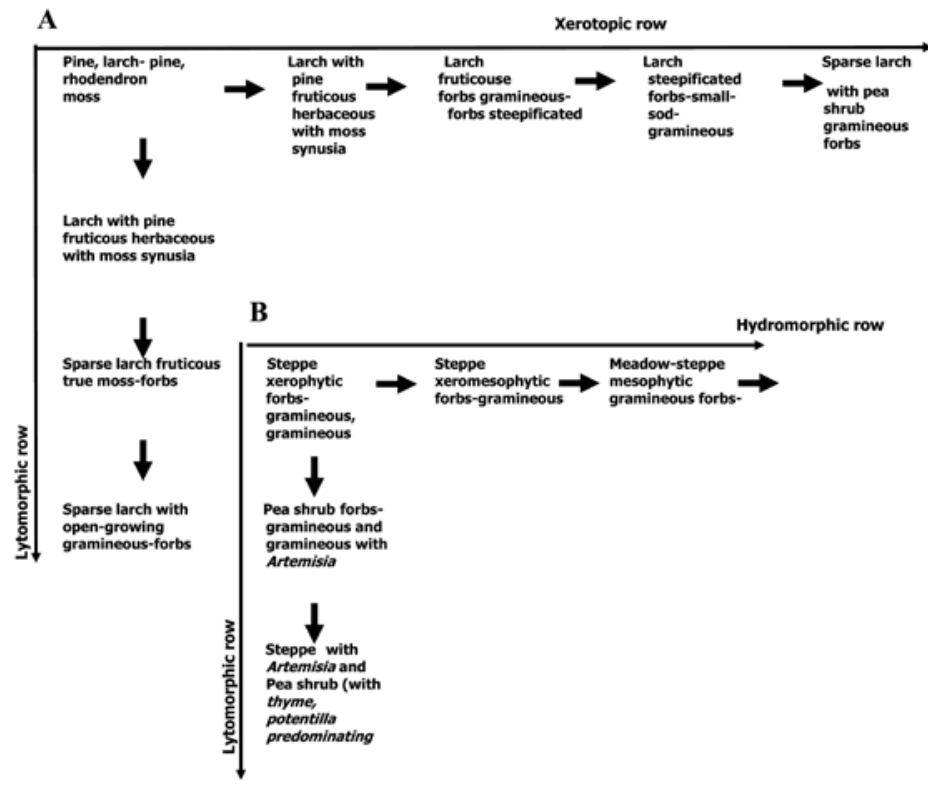

Fig. 3. Watershed-sloping rows of facies: A - sub-mountain PineLarch sub-taiga landscape of the Preol'khon area (cryo-semiarid conditions); $B$-sub-mountain steppe landscape of the Preol'khon area (cryo-subarid conditions)

ing and forecasting the development of geosystems with regard to their spontaneous and antropogenic dynamics and the natural regimes corresponding to them;

(3) the quest for rational techniques for quantitative assessment of geosystems states and landscape-forming processes;

(4) The systems analysis of spatial links at the elementary, regional and planetary levels and their interactions;

(5) The analysis of the socio-economic factors and their roles as the environment changes.

The structural-dynamics approach to understanding the spatial-and-temporal heterogeneity of geosystems is basic, and it has been employed since the early 1970's as a means of studying not only the morphological signs of its components, but also dynamic communications between them [16]. The geosystems dynamics as result- ing interaction between components and anthropogenic influence on nature is considered as a change within a certain invariant structure. The invariant structure of the geosystem is governed by a specific community of properties and processes, such as incoming heat, moisture, migration characteristics and other landscape-forming processes and landscape phenomena. Thereby, an invariant structure is a geosystem pattern which represents spatial heterogeneity in at least one landscape-forming factor or driver. Thus, each spatial unit, or patch, in the concrete spatial scale, (eg. landscape facies), which is representative of one invariant structure can possibly be considered as a step, or element, in a factored-dynamic series (eg.lithomorphic, hydromorphic, etc.) [17] or in patch dynamics [2], Each of the factored-dynamic series characterises refraction of the ecological conditions and processes in landscape facies, as a result of increasing or decreasing the effect of one of the local factors. Therefore, structural-dynamic analysis allows definition of the typological "kernel" of landscape structure of a concrete territory, and it also reveals all possible transformations of structure under the influence of local factors.

Analysis of vegetation heterogeneity is frequently used to examine the spatial variability of landscape or geosystems units. Vegetation dynamics serves as a reliable indicator of dynamic transformations of geosystems, because it is a function of the interaction of the main landscape-forming factors [13; 18]. Vegetation composition was chosen as a key criterion for structuraldynamic analysis because vegetation controls many processes in the functioning of ecosystems and geosystems, and it constitutes a "critical component" for them [19; 20]. Therefore, when determining the dynamic connections of geosystems, due consideration must primarily be given to the species composition and to the cenotic structure of plant communities. Furthermore, it is necessary to take into account the landscape-ecological (ecotopic) 
characteristics. Changes in the structure of plant communities, and also successions in florocenotic composition have indicative significance.

The location of the geosystems under investigation was chosen due to altitudinal-zonal variations of landscape-ecological conditions, and in compliance with the principles of landscape profiling, since geosystems' altitudinal differentiation can be regarded as a regional landscape model. Diversity and contrast of landscape structure were also considered. The field explorations within key plots were carried out during 2003-2007 for the Western Baikal Region, and 2007-2009 for the Southern Baikal Region. These explorations included a detailed landscape-geobotanical survey of typical landscape facies of the territory in order to study their structure, with due regard to the space inhomogeneity of the hydrothermal conditions and also anthropogenic disturbance. Releves consisting of about 320 homogenous plots of $100 \mathrm{~m}^{2}$ were made according to the catena method, which entails a number of locations connected according to topoecological profile, with various landscape-ecological conditions. Furthermore, structural heterogeneity of the topography, including watersheds, slopes, ravines and terraces, was taken into consideration because the boundaries of landscape facies generally correspond to the boundaries of elementary land forms, and this is especially true for mountain conditions. The floristic composition of tree and herbaceous-subshrub layers was described and the ecotope was characterized (land forms, humidification degree and soil properties) on releves for biogeocenoses as elementary patches of the landscape facies.

Specific tasks included the study of the morphological structure of the geosystems, the properties of landscape components (geological basement, relief, mezzoand microclimate) and an estimation of anthropogenic disturbance. A combination of field explorations with GIS-technology involving remote sensing and mapping was used to examine landscape structure. This procedure implies the possibility of switching from a local to a regional level of analysis, and it also allows making a distinction between the regional and local features landscape structure.

\section{Results and discussion}

Our investigations into the spatial-coenotic changes of mountain taiga, sub-taiga and steppe vegetation within the study areas made it possible to identify the spatial variability features for typical regional and local geosystems. We identified dominant and edificatory species of tree, shrub and herbaceous-subshrub layers of vegetation of the typical facies, and peculiarities of it spatial heterogeneity in the key plots.

Landscape structure analysis was made of the middle-scale landscape profiles using the comparative-geographical method, since the landscape topographic profile and spatial combination of the facies within it reflect the main structural and dynamic features of the territorial landscape structure with regard to regional nature characteristics. Geosystems of two middle-scale landscape profiles were investigated in the Southern Baikal Region, where the first profile occupies the northern macroslope of the Hamar-Daban Range and the second is the southern macroslope of the Tunkinskie Goltsy Range which includes medium-and low mountain belts and piedmonts. In the Western Baikal region, one middle-scale profile was examined in the piedmont of the Primorsky Range and Preol'khon plateau.

Firstly comparative analysis of the key plots has helped us to determine changes in the biogeocenoses' vegetation species composition as elementary landscape facies patches. This depended on their ecotop characteristics and the characteristics of the neighborhood and boundaries.

The vegetation of the Southern Baikal Region primarily consists of dark-coniferous forests with Pinus sibirica, Abies sibirica and Larix sibirica in the upper mountain belt, and light-coniferous (also called subtaiga) forests with Pinus sylvestris, Larix sibirica and Betula in the lower mountain belt and piedmonts. Within the study area, there is a gradient between the geosystems of the Hamar-Daban Range, which are relatively close to the southern Siberian dark taiga, and the geosystems of the Tunkinskie Goltsy Range, which are closer to the eastern Siberian light taiga. There is increased precipitation in the Hamar-Daban Range affording better growth conditions for the dark taiga, since Pinus sibirica and Abies sibirica have greater water demands than tree species in the light taiga. In general, although Pinus sibirica needs a better water supply than Picea obovata, therefore requiring high precipitation, soil water content, air humidity, and high snow cover in winter time, Picea obovata is less sensitive to water-logging but more sensitive to late spring and summer frosts and to rapid temperature changes.

Vegetation of the Tunkinskie Goltsy Range depends to a greater degree on altitude. The piedmont and low mountain belt are stocked with light coniferous forests dominated by Larix sibirica and Pinus sylvestris, with the inclusion of Betula and also Pinus sibirica which is concentrated on sites with optimal water-supply. Forests with Larix sibirica dominate the mountain taiga of the Tunkinskie Goltsy Range. In the forests of the taiga mountain Tunkinskie Goltsy Range, Larix sibirica increases on the steepest slopes, and simultaneously Rhododendron aureum appears in the undergrowth, while Carex and Gramineae increase in the ground cover.

The light-coniferous forests of the mountain-taiga and sub-taiga types are the prevaling primordial vegetation in the Western Baikal Region. The piedmonts of the Primorsky Range and Preol'khon plateau are distinguished by the complexity and contrast of vegetation cover due to the formation of a taiga forest-steppe borderline [21] Within the study area, the borderline between light conif- 
erous taiga forests and steppe is neither a single abrupt forest line, nor a continuous transition similar to the forest-steppe stage between the zonal taiga and the zonal steppe. Here, it is an aspect-dependent vegetation mosaic, where forests mainly cover the northern and eastern slopes, whereas steppe vegetation occupies slopes with southern and western aspects which are more sun-exposed and face the Lake Baikal aquatory.

The vegetation cover of the investigated part of the Primorsky Range piedmont is composed of pine-larch and larch forest, including open woodland. It also includes Daurian Rhododendron, Duschekia fruticosa, Cotoneaster melanocarpus, and Spiraea media with true moss-sedge, forbs-sedge and, more rarely, steppified forbs ground cover. In felled and burned-out areas, there are secondary birch and aspen shrubs forests. Both natural and antropogenic forest fires and other disturbances lead to the creation of a secondary mixed coniferous and mixed light-coniferous-birch forest, which often includes aspen.

The sun-exposed slopes of the Preol'khon plateau and parts of the Primorsky Range piedmont are too dry and stony even for Larix Sibirica. On these slopes, the temperature increases and air humidity decreases with reduced of distance from the aquatory of Lake Baikal, and they are covered with gramineous grass and gramineousforbs vegetation. The steppe slopes are characterised by sparse vegetation of shortgrasses and short herbs, and projecting coverage of $30-60 \%$ of the ground depends on soil thickness and water supply. Nevertheless, the upper parts of the most southern slopes are covered by sparse larch and larch open woodland with shrub undergrowth of Daurian rhododendron and Cotoneaster melanocarpus, and Carex and steppified forbs occupy the ground cover. Steppe facies with a prevalence of xerophytes and Artemisia frigida predominate on the steepest southern slopes, and also on the slopes surrounding Baikal and near human settlements.

In the second step, similar biogeocenoses were grouped into landscape facies according to the composition of the dominant and edificatory species of tree, shrub and herbaceous-subshrub vegetation layers with equivalent ecotope properties. It was detected that moisture and heat condition variation leads to changes in facies structure, however the effects geomorphologic processes such as gravity-slope, water erosion and avalanche are also important. Characteristics of the underlying surface controls the complexity and contrast of the facies and their area, form and occurrence frequency.

Our investigations showed that the landscape structure of the study areas is characterized by a combination of facies which can be described by general dynamical correlations such as the facies of a lytomorphic row and a hydromorphic or xerotopic row, as presented in Fig. 2 and 3. The sequence of facies within these rows reflects changes in their vegetation structure in concordance with changes in ecological conditions. The spatial variability in composition and the relationship of the main tree and herb species indicate local differences in the patterns of water supply, and also the enhancement of the lithomorpic character of conditions for facies (Figuries 2 and 3).

The position of the facies on the axis of the xerotopic row corresponds to the water requirements of the coenoses that form this facies, i. e. their position shows a decrease in demand for water or a resistance to water deficiency of each subsequent facies compared with the previous one. The position of facies along the axis of the hydromorphic row demonstrates an inverse relationship. Facies in the lithomorphic row have closer dependence between the vegetation composition and both the degree stoniness of the surface and soil, and the soil thickness of several facies formed under similar microclimatic conditions, but under different geological and geomorphologic conditions.

Thus, dark-coniferous taiga forests with cedar, fir, spruce and pine grow on the most humid sites, while light-coniferous taiga forests dominated by larch, pine and birch occur on relatively dry sites in the lower mountain belt. With increasing moisture, larch has wider distribution, but it is replaced by spruce under waterlogged conditions. But larch also dominates on steeper and rocky slopes with drier condition, while humidity increase results in

\section{Conclusion}

In summary, we can conclude that spatial heterogeneity of the investigated geosystems' structure in the Southern and Western Baikal regions are determined by a complexity of local landscape-ecological characteristics and anthropogenic impacts. The existence of mosaics of vegetation cover on the studied territory is evidence of the varied and dynamic structure of these geosystems.

Our investigations into the spatial-coenotic changes of vegetation cover of the taiga, sub-taiga and steppe geosystems of the Southern and Western Baikal regions allowed us to establish the dependence of spatial landscape heterogeneity on the variability of landscape-ecological conditions at the biogecoenose and landscape facies level. The changes in species composition and the abundance of plants correspond to the "refraction" of the landscape-ecological conditions due to the increasing influence of such driving forces as stoniness and the steepening slopes of the underlying surface, as well as the degree of moisture.

Our studies show the efficacy of the structural-dynamic approach applied to the analysis of landscape heterogeneity. This approach was especially beneficial in presenting the modification order of the facies under the influence of important local factors, such as in the factored-dynamic series model.

Construction of a factored-dynamic model of geosystems for the landscape heterogeneity study of the Southern and Western Baikal regions has helped us to charac- 
terise the typological structure of geosystems and the formative principles of spatial distribution of the elementary morphological units. It also allows assessment of the peculiarities and sequences of possible dynamic changes in the structure of both local and regional geosystems under given environmental changes. This includes zonal and altitudinal differentiation of the environment and also the morphological peculiarities of separate geosystems and the specificity of relief and lithology. These models will support understanding and integrating information on

\section{REFERENCES:}

1. Tuner, M.G. Landscape Ecology: What Is the State of the Science? Annual Review of Ecology, Evolution, and Systematic. 2005, no 36, pp. 319-344.

2. Forman, R.T.T. Land Mosaics: The Ecology of Landscapes and Regions. Cambridge University Press, Cambridge, UK, 1995, $632 \mathrm{p}$.

3. Tuner, M.G., Gardner, R.H. (eds.). Quantitative Methods in Landscape Ecology. Springer-Verlag, New York, NY, USA, 1991, 619 p.

4. Sanderson, J., Harris, L.D. (eds.). Landscape Ecology: A Top-Down Approach. Lewis Publishers, Boca Raton, Florida, USA, 2000, $246 \mathrm{p}$.

5. Tuner, M.G., Gardner, R.H., O'Neill, R.V. Landscape Ecology in Theory and Practice. Springer-Verlag, New York, NY, USA, 2001, $401 \mathrm{p}$.

6. Wu, J. Cross-disciplinarity, landscape ecology, and sustainability science. Landscape Ecology. 2006, no. 21, pp. 1-4.

7. Forman R.T.T., Godron M. Landscape Ecology. John Wiley, New York, 1986, 619 p.

8. Isachenko A.G. Landscape regionalization of Russia at the basis for regional ecologo-geographical analysis. Izvestiya Russkogo geograficheskogo obshchestva [News of the Russian Geographical Society]. 1996, V. 128, no. 5, pp. 12-24. (in Russian)

9. Batuev A.R., Bogdanov V.N., Korytny L.M., Plyusnin V.M., Beshentsev A.N., Dorjgotov D. Ecological atlas of the Baikal basin: cartographic innovation. Geografiya i prirodnye resursy [Geography and natural resources]. 2015, V. 36, no. 1, pp. 5-16. (in Russian)

10. Mikheev V.S., Ryashin V.A. Physical-geographical regionalization: Insert map of a scale 1:8 000 000. In: The landscape in the South of the east Siberia: the 1:1 500000 Map. Moscow, GUGK, 1977. (in Russian)

11. Alpat'ev A.M., Arkhangel'skii A.M., Podoplelov N.Y., Stepanov A.Y. Fizicheskaya geografii SSSR (Arkticheskaya chast') [Physical geography of the USSR (Asiatic part)]. Vysshaya Shkola, Moscow, 1976, 286 p. (in Russian)

12. Galaziy G.I., (ed.). Bajkal'skij atlas [Baikal Atlas]. Federal Agency for Geodesy and Cartography of Russia. Nauka, Moscow, 1993, 160 p. (in Russian)

13. Sochava V.B. Vvedenie v teoriyu o geosistemah [An introduction to the Theory of Geosystems]. Nauka, Novosibirsk, 1978, 318 p. (in Russian)

14. Isachenko A.G. Methodology of landscape study and landscape-geographical scientific method. Izvestiya Russkogo geograficheskogo obshchestva [News of the Russian Geographical Society]. 2016, V. 148, no. 1, pp. 15-30. (in Russian) the spatial and temporal heterogeneity of the current and prognostigated geosystems needed to provide the main functions of the geosystems. These function comprise resources, environment-forming, environment-protective and also social functions. The presented results of this landscape-ecological investigation of taiga, sub-taiga and steppe geosystems into key plots of the Southern and Western Baikal regions will enable quantification of the tendencies occasioning regional changes in the mountain landscapes throughout Baikalian Siberia.

15. Sochava V.B. Definition of the some notions and terms of physiography. Doklady Instituta geografii Sibiri i Dal'nego Vostoka [Reports of the Institute of Geography of Siberia and the Far East]. 1963, no. 3, pp. 3-10. (in Russian)

16. Sochava V.B. Geographie und Okologoe. In Petermanns Geographische Mutteilungen, 1972, no. 5, pp. 89-98. (in German)

17. Mikheev V.S. Landshaftnyj sintez v geograficheskih znaniyah [Landscape Synthesis of the geographical knowledge]. Nauka, Novosibirsk, 2001, 216 p.

18. Nikolayev V.A. Memory of landscape. Vestnik Moskovskogo universiteta. Seriya 5 Geografiya [Bulletin of Moscow University. Series 5: Geography].1986, no. 1, pp. 17-21. (in Russian)

19. Mikheev V.S. Landshaftno-geograficheskoe obespechenie kompleksnyh problem Sibiri [Landscape-Geographical Provision of Comprehensive Problems of Siberia]. Novosibirsk, Nauka, 1987, 207 p.

20. Plyusnin V.M. Ecological safety of Siberia. Sibirskij ehkologicheskij zhurnal [Contemporary Problems of Ecology]. 2014, V. 7, no. 6, pp. 597-603.

21. Sizykh A.P., Voronin V.I. Soil-geobotanical profiling in studies on communities of the forest-extrazonal steppe junction and zonal forest-steppe (the Baikal region). Journal of ecology. 2013, V. 44, no. 2, pp. 93-99. 


\section{INFORMATION ABOUT AUTHORS / Сведения об авторах:}

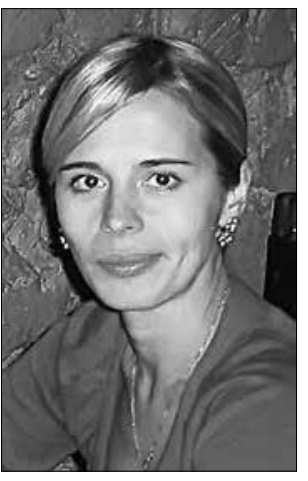

Irina Nikolaevna BILICHENKO - Candidate of Geographical Sciences, researcher.

Institute of Geography after V.B. Sochava, Siberian branch of the Russian Academy of Sciences, Irkutsk, Russia.

Tel.: +7(3952)42-77-97 (work); $+7(914) 880-56-07$ (mobile)

E-mail: irinabilnik@mail.ru

БИЛИЧЕНКО Ирина Николаевна, научный сотрудник, кандидат геогра-

фических наук.

Институт географии им. В.Б. Сочавы СО РАН,

2. Иркутск, Россия

Тел.: +7(3952)42-77-97(служ.); +7(914)880-56-07 (моб.)

E-mail: irinabilnik@mail.ru

\section{ПРИМЕНЕНИЕ МЕТОДОВ ЛАНДШАФТНОЙ ЭКОЛОГИИ В ИЗУЧЕНИИ ГЕОСИСТЕМ БАЙКАЛЬСКОЙ СИБИРИ}

\author{
Биличенко И.Н., * \\ Данько Л.В. \\ Институт географии им. В.Б. Сочавы СО РАН, Иркутск, Россия \\ e-mail: irinabilnik@mail.ru
}

DOI: $10.21177 / 1998-4502-2018-10-1-14-22$

Для типичных региональных геосистем Байкальского региона это исследование пространственной неоднородности ландшафта проводилось на уровне элементарных территориальных единиц, фаций. Проведенное исследование пространственно-ценотических изменений горно-таежных, подтаежных и степных геосистем Южно-Байкальского и Западно-Байкальского региона позволило установить зависимость пространственной неоднородности ландшафта от изменчивости гидротермальных и литоморфных условий. Отправной точкой при исследовании неоднородности ландшафта было изучение ландшафтов как групп растительных сообществ или экосистем, образующих экологические единицы, которые обладают различимыми структурными, функциональными, морфологическими и нарушенными режимами. Были определены доминирующие виды растительности, а также особенности их пространственного распределения на ключевых участках. Сложность ландшафтной структуры усиливается смешанным характером сукцессионно-динамических состояний геосистем, возникающих в результате различных воздействий. Применение структурно-динамического подхода к анализу пространственной неоднородности в нашем исследовании позволило показать порядок изменений фаций из-за изменчивости экологических условий в виде моделей, а именно факторально-динамических рядов. Эти модели помогут в понимании и интеграции информации о пространственной и временной неоднородности существующих и прогнозируемых геосистем, необходимых для обеспечения основных функций геосистем. Это ресурсная, средообразующая, средозащитная и социальная функции. Мы изучали ландшафтную структуру, как совокупность геосистем, находящихся в разных динамических

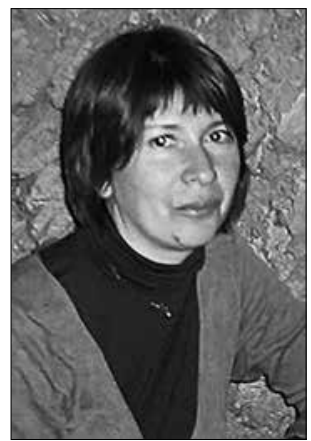

Lydia Veniaminovna DANKO Candidate of Geographical Sciences.

Institute of Geography after V.B. Sochava, Siberian branch of the Russian Academy of Sciences, Irkutsk, Russia.

ДАНЬКО Лидия Вениаминовна, кандидат географических наук

Институт географии им. В.Б. Сочавы СО РАН, г.Иркутск, Россия состояниях и испытывающих трансформацию под влиянием природных условий и антропогенных воздействий. Анализ ландшафтной структуры проводился с использованием среднемасштабных ландшафтных профилей с использованием сравнительно-географического метода, поскольку ландшафтный топографический профиль и пространственное сочетание фаций внутри него отражают основные структурные и динамические особенности территориальной структуры ландшафта в соответствии с региональными характеристиками.

Ключевые слова: ландшафтная экология, пространственная неоднородность, геосистемы, структурно-динамический анализ, горно-таежные и подтаежные леса, горная степь, Байкальская Сибирь.

\section{Литература}

1. Tuner M.G. Landscape Ecology: What Is the State of the Science? // Annual Review of Ecology, Evolution, and Systematic. 2005. No 36. Pp. 319-344.

2. Forman, R.T.T. Land Mosaics: The Ecology of Landscapes and Regions. Cambridge University Press. Cambridge, UK. 1995. $632 \mathrm{p}$.

3. Tuner, M.G., Gardner, R.H. (eds.). Quantitative Methods in Landscape Ecology. Springer-Verlag. New York, NY, USA. $1991.619 \mathrm{p}$.

4. Sanderson, J., Harris, L.D. (eds.). Landscape Ecology: A Top-Down Approach. Lewis Publishers, Boca Raton, Florida, USA. 2000. 246 p.

5. Tuner M.G., Gardner R.H., O'Neill R.V. Landscape Ecology in Theory and Practice. Springer-Verlag, New York, NY, USA. 2001. 401 p.

6. Wu J. Cross-disciplinarity, landscape ecology, and sustainability science // Landscape Ecology. 2006. No. 21. Pp. 1-4. 
7. Forman R.T.T., Godron M. Landscape Ecology. John Wiley, New York. 1986. 619 p.

8. Исаченко А.Г. Ландшафтное районирование России как основа для регионального эколого-географического анализа // Известия Русского географического общества. 1996. T. 128. N 5. C. 12.

9. Батуев А.Р., Бешенцев А.Н., Богданов В.Н., Доржготов Д., Корытный Л.М., Плюснин В.М. Экологический атлас бассейна озера Байкал: картографическая инновация // География и природные ресурсы. 2015. N 1. С. 5-16.

10. Михеев В.С., Ряшин В.А. Ландшафты юга Восточной Сибири: Карта масштаба 1 : 500000 / Общ. ред. В.Б. Сочавы. М.: ГУГК, 1977.

11. Алпатьев А.М., Архангельский А.М., Подоплелов Н.Ю., Степанов А.Ю. Физическая география СССР (арктическая часть). Москва: Высшая школа, 1976. 360 с.

12. Байкальский атлас. Федеральное агентство геодезии и картографии России / ред. Галазий Г.И. Москва: Наука, 1993, 160 c.

13. Сочава В.Б. Введение в учение о геосистемах. Новосибирск: Наука, 1978. 320 с.

14. Исаченко А.Г. Методология ландшафтоведения и ландшафтно-географический научный метод // Известия русского географического общества. 2016. Т. 148. N 1. C. $15-30$.
15. Сочава В.Б. Определение некоторых понятий и терминов физической географии // Доклады Института географии Сибири и Дальнего Востока. 1963. N3. C. $3-10$.

16. Sochava V.B. Geographie und Okologoe // In Petermanns Geographische Mutteilungen. 1972. No. 5. Pp. 89-98. (in German)

17. Михеев В.С. Ландшафтный синтез в географических знаниях. Новосибирск: Наука. 2001. 216 с.

18. Николаев В.А. Память ландшафта // Вестник Московского университета. Серия 5: География. 2013. N 1. C. $17-21$.

19. Михеев В.С. Ландшафтно-географическое обеспечение комплексных проблем Сибири. - Новосибирск: Наука, 1987. 207 с.

20. Плюснин В.М. Экологическая безопасность Сибири // Сибирский экологический журнал. 2014. Т. 21. N 6. C. $807-815$.

21. Sizykh A.P., Voronin V.I. Soil-geobotanical profiling in studies on communities of the forest-extrazonal steppe junction and zonal forest-steppe (the Baikal region) // Journal of ecology. 2013. V. 44. No. 2. Pp. 93

Статья поступила в редаки̧ию 01.11.2017 


\section{ИДЕНТИФИКАЦИЯ ЭКОЛОГИЧЕСКИХ РИСКОВ, СВЯЗАННЫХ С РАЗВИТИЕМ РЕКРЕАЦИОННО-ТУРИСТИЧЕСКИХ РЕГИОНОВ ЧЕРНОМОРСКОГО ПОБЕРЕЖЬЯ КАВКАЗА НА ПРИМЕРЕ КОМПЛЕКСНОЙ ОЦЕНКИ ЭКОСИСТЕМЫ ГОРНОЙ РЕКИ ЛАУРА}

${ }_{1}^{1}$ Гудкова Н.К., 1Горбунова Т.Л., * Любимцев А.Л.

\section{Введение}

На современном этапе комплексного изучения горных рек Сочинского региона назрела необходимость идентификации экологических рисков, связанных с развитием рекреационно-туристских регионов черноморского побережья Кавказа. Как отмечает Баденков Ю.П. [1], на современном этапе необходимы междисциплинарные исследования по изучению проблем горных территорий с участием всех заинтересованных сторон и специалистов. Только такой подход может обеспечить платформу для устойчивого развития горных регионов.

Сотрудниками Сочинского филиала ФГБНУ «ИПТС» РАН совместно со специалистами ФГБУ «СЦГМС ЧАМ» Росгидромета в рамках государственного задания по разработке эффективной системы экологических индикаторов был инициирован проект исследования биоразнообразия рек черноморского побережья Кавказа на территории Большого Сочи. Исследования проводились с октября 2016 года по сентябрь 2017 года включительно. Наряду с физико-химическими и гидрохимическими показателями качества воды, определяемыми лабораторией ФГБУ «СЦГМС ЧАМ», определялись биологические индексы, отражающие состояние биоценозов рек.

Определение гидрохимических показателей производится в рамках выполнения государственного задания на выполнение государственных работ по основным видам деятельности ФГБУ «СЦГМС ЧАМ». В программу наблюдений включено определение основных физико-химических параметров воды, а также ряда загрязняющих веществ, в числе которых нефтепродукты, биогенные элементы, взвешенные вещества, тяжелые металлы, органические вещества (по БПК и ХПК) и ряд других.

Гидробиологическая оценка состояния рек на территории Большого Сочи государственной программой наблюдений Росгидромета не предусмотрена. Однако биологические индикаторы в отличие от гидрохимических показателей способны дать ответ на вопрос о развитии сообщества гидробионтов и аддитивном влиянии на него факторов изменения среды обитания в течение времени. Они могут помочь в обнаружении и идентификации экологических проблем на ранних стадиях [2]. После проведения в городе Сочи XXII Олимпийских зимних игр и ХІ Паралимпийских зимних игр 2014 года, исследования по изучению долгосрочного влияния развития горных курортов Красной Поляны на биологические сообщества природных водоемов этого района не проводились. Поэтому невозможно предоставить научно-обоснованное заключение об изменениях структуры биологических сообществ рек под влиянием антропогенной нагрузки от строительства и эксплуатации олимпийской инфраструктуры. Некоторые ученые обращают внимание на возможность вторичного загрязнения среды малых рек в зонах интенсивного

\footnotetext{
${ }^{1}$ Филиал ФГБНУ «Институт природно-технических систем» в г. Сочи, Россия

${ }^{2}$ Специализированный центр по гидрометеорологии и мониторингу окружающей среды Черного и Азовского морей»

* e-mail: tatianashaw@mail.ru
}

УДК: 574.633

DOI: 10.21171/1998-4502-201810-1-23-34

Комплексное исследование р. Лаура позволило идентифицировать экологические риски для экосистемы горной реки, обусловленные интенсивной антропогенной деятельностью на территории олимпийского строительства и развития горного курорта. Определено, что на изменение состояния гидробиоценозов реки влияют такие факторы, как изменение водного режима водоема, активизации опасных геологических процессов, загрязнение поверхностных и подземных вод недостаточно очищенными стоками. Использование биологических индикаторов макрозообентоса сделало возможным не только анализировать отдельные загрязняющие вещества в воде, но и выявить аддитивное влияние всех факторов на сообщества живых организмов природного водоема. Выявлено, что обезвоживание реки в летний период, связанное с интенсивным забором воды для нужд курорта, 6 комплексе с повышением температуры воды препятствует естественному процессу самоочищения водоема и ведет к эфтрофикации горной реки, изменению состава биологических сообществ и статуса ее трофности.

КЛЮЧЕВЫЕ СЛОВА:

экологические риски, гидрологический режим, опасные экзогенные процессы, гидрохимические показатели, эфтрофикация, биоиндикация, макрозообентос, видовое разнообразие.

Статья поступила в редакцию 30.10.2017 
развития туризма, которое вызывается процессами декомпозиции попадающих в воду загрязнителей. Это способствует появлению в горных водоемах не свойственных им организмов, устойчивых к антропогенному загрязнению [3].

Научная новизна данной работы состоит в том, что она является началом первого после зимней Олимпиады 2014 года комплексного исследования водоемов горного кластера города-курорта Сочи, ставящее целью определить и проанализировать экологические опасности и риски для природных водоемов при освоении горных территорий Кавказа, а также проследить динамику долгосрочных изменений речных биоценозов в этих районах. Особую важность такое исследование приобретает в связи с планами дальнейшего развития горных территорий Кавказского государственного природного биосферного заповедника, так как оно позволит идентифицировать и, возможно, предотвратить, неоправданные риски для биологических сообществ этого уникального региона Кавказа.

В качестве объекта исследования была выбрана река Лаура (правый приток реки Мзымты) по ряду причин, которые будут рассмотрены ниже.

\section{Описание исследуемого объекта и антропогенной нагрузки}

Река Лаура берёт свое начало на южных склонах хребта Ассара на территории Кавказского заповедника, впадает в р. Мзымта в 50 км выше ее устья.

Согласно данным государственного водного реестра, Ачипсе - правый приток реки Лаура [4], которая, в свою очередь, является правым притоком реки Мзымты. Однако в более ранних источниках Ачипсе упоминается как приток реки Мзымты, а Лаура как приток Ачипсе [5;6].

Название реки имеет два толкования. Согласно первому, в переводе с адыгского оно означает «козья вода». Согласно второй версии, река получила название от племени Ахчипсоу, проживавшего по её берегам [7].

В реку впадают многочисленные горные ручьи. Рельеф русла - горный, особенно в верховьях, где многочисленны водопады.

В нижнем течении реки ранее располагался рабочий посёлок Сланцевый Рудник. В настоящее время река Лаура протекает в зоне функционирования крупных рекреационных объектов и популярных туристических маршрутов горного кластера г. Бол. Сочи.

В нижнем течении реки Лаура в ее левобережной пойме на отрезке между точкой слияния с р. Ачипсе и впадением Лауры в р. Мзымту в 2008 году был открыт Горно-туристический центр ПАО «Газпром». При подготовке к зимним Олимпийским играм 2014 года инфраструктура горно-туристического центра значительно расширилась, плато хребта Псехако и левобережные склоны долины реки были оборудованы горнолыжными подъемниками и трассами, включая биатлонный и лыжный комплексы, построено множество гостиничных, ресторанных, развлекательных и других объектов инфраструктуры, соединенных между собой разветвленной транспортной сетью.

На правом берегу реки, на территории Кавказского государственного природного биосферного заповедника, расположен эко-комплекс «Лаура», который включает в себя целый ряд антропогенных объектов: вольерный комплекс диких животных, конюшню, дома для сотрудников заповедника на кордоне Лауpa, гостевые домики, парк приключений, кафе, баню, стоянку для автотранспорта и другие объекты инфраструктуры.

Вдоль правого берега р. Лауры проложена автомобильная дорога, ведущая к эко-комплексу «Лаура» и на хребет Псехако, к сооружениям Горно-туристического центра ПАО "Газпром". Все эти объекты, как показало исследование, в совокупности оказывают значительную антропогенную нагрузку на долину р. Лаура. Кроме того, русло реки на этом участке зарегулировано габионами, что затрудняет процессы ее самоочищения.

\section{Геологическая характеристика водосборного бассейна р. Лауры}

В геологическом строении территории, по которой протекает река Лаура, принимают участие мезо-кайнозойские породы геосинклинальной формации, среди которых выделяются: песчано-глинистая (глинисто-сланцевая аспидная) формация нижней и средней юры, терригенно-карбонатная (флишевая) формация верхней юры, мела и частично палеогена.

Четвертичные отложения на рассматриваемой территории имеют весьма широкое распространение и разнообразные условия залегания. Среди них следует выделить делювиально-пролювиальные, пролювиальные и аллювиальные отложения в переуглублениях речной долины, характеризующиеся различной водоносностью.

В долине реки, в районе кордона Лаура, в семидесятые годы прошлого века было разведано Ачипсинское месторождение подземных пресных вод, которое до строительства горно-туристского комплекса являлось резервным для обеспечения питьевого водоснабжения горных поселков Красная Поляна и Эсто-Садок. В настоящее время из данного месторождения производится водоснабжение только горно-туристского комплекса ПАО "Газпром"", который оборудовал в долине реки небольшой водозабор для собственных нужд. Остальная территория Ачипсинского месторождения подземных пресных вод застроена коттеджами и отелями, принадлежащими ПАО "Газпром" и фактически утрачена, как резерв высококачественной питьевой воды для нужд этого горного района.

Геологической особенностью региона является 
наличие геохимических аномалий тяжелых металлов. На территории водосборного бассейна р. Лауры выявлены локальные геохимические аномалии меди и цинка в поверхностном слое почвы от 0 до 30 см и в грунтах на глубине от 30 см до 1,0 м.

В период интенсивного строительства рекреационных и олимпийских объектов выявлена активизация экзогенных геологических процессов (ЭГП), наиболее опасными из которых являются оползни, сели, осыпи и эрозия.

Оползни широко распространены в этом районе в связи с особенностями геологического строения и наличием склонов значительной крутизны (более 15-30). Другими важным фактором возникновения оползней являются переувлажнение пород атмосферными осадками и подземными водами. В этих условиях интенсивная строительная деятельность в долине реки Лаура, сопровождающаяся вырубкой леса, подрезкой склонов при прокладке дорог и складированием строительных грунтов вызвала резкую активизацию эрозионных, оползневых и селевых процессов в долине реки.

Сели находятся в сложном взаимоотношении с другими типами ЭГП (оползнями, обвалами, осыпями, эрозией и др.), которые подготавливают и доставляют в русло водотока твердую составляющую, а в некоторых случаях играют решающую роль в формировании жидкой составляющей селей. Прямое влияние на образование селей оказывают геоморфологические факторы: уклоны тальвегов, крутизна склонов, морфология долин. Участки долины, сложенные скальными породами, являются источниками осыпей, обвалов и селей [8].

Эрозия является одним из основных факторов денудации. Основную роль играет линейный поверхностный сток, формирующийся за счет атмосферного и верхового подземного питания. Особенно опасно уничтожение растительности на склонах, где активизация опасных экзогенных процессов может приводить к катастрофическим последствиям. Под покровом растительности эрозия почв протекает малозаметно, но при нарушении растительного покрова она может проявиться катастрофически, превращаясь в бедствие. Боковой эрозии и, особенно, эрозии берегов, в большинстве случаев подвержена высокая пойма реки и первые надпойменные террасы. Именно эти участки в последнее десятилетие наиболее активно осваиваются человеком, что сопровождается усилением проявления опасных геологических процессов. Решающим фактором, способствующим катастрофическому развитию плоскостной эрозии, является строительная деятельность, которая зачастую осуществляется без осуществления необходимых природоохранных мероприятий.

Следует отметить, что после 2010 гг. в районе курортов Красной поляны произошло резкое увеличе- ние селевой активности, вызванное уничтожением растительного покрова и активизацией эрозионных процессов на склонах, вследствие активных работ по строительству и расширению спортивных и рекреационно-туристских объектов. В результате селевые и другие опасные геологические процессы активизировались даже там, где они ранее морфологически не проявлялись или были малозначительными [9].

Кроме того, массовое изъятие гравийно-галечного материала из русел р. Лауры в период интенсивного строительства рекреационных и олимпийских объектов (с 2007 по 2014 годы) привело к изменению режима реки, провоцировало активизацию опасных экзогенных геологических процессов и, как следствие, значительному увеличению мутности воды и ее загрязнению.

Возросшее содержание взвешенных веществ и подвижных форм тяжелых металлов, поступающих в водоем вследствие активизации экзогенных геологических процессов, повышает риски негативного влияния этих факторов на экосистему реки.

\section{Гидрология и гидрохимия р. Лаура}

Река относится к горному типу, характеризуется сильным течением, большими продольными уклонами и частыми изменениями уровня и расхода воды, связанными с количеством атмосферных осадков. Температурный и кислородный режимы этого водоема также типичны для рек горного типа: температура в течение года колеблется от 8 до $15^{\circ} \mathrm{C}$, а содержание растворенного кислорода не опускается ниже 8 мг/л [10].

По данным ФГБУ «СЦГМС ЧАМ» р. Лаура относится к категории малых рек. Тип питания смешанный (дождевые паводки и снеготаяние). По характеру питания и распределения стока во времени, река относится к 5-й зоне прибрежной полосы Черноморского побережья. Для реки характерна средняя и низкая водность, преобладает зимний сток. Долина реки трапецеидальная, шириной 130-180 м; склоны крутые 45-60, сильно расчленены. Высота водораздельных хребтов до 2,5 км. Склоны сложены скальными породами, покрыты слоем элювиально-делювиальных суглинков толщиной $0,2-0,5 \mathrm{M}$, на которых сформированы горно-лесные дерново-карбонатные почвы. Склоны покрыты смешанным лесом высотой до 15-20 м и кустарником. Пойма правобережная, шириной до 130 м, густо поросшая подлеском. Русло извилистое, галечно-булыжное, деформирующееся, местами с сильно выраженной косоструйностью. Берега крутые 1-1,5 м. Река не пересыхает и не перемерзает.

Как было отмечено выше, нижнее течение реки Лаура располагается в зоне функционирования крупных олимпийских и туристических объектов, инфраструктура которых значительно расширилась при подготовке к зимним Олимпийским играм 2014 года. 
Если до начала олимпийского строительства пункт гидрологических и гидрохимических наблюдений «Кордон Лаура», входящий в состав сети государственной службы наблюдений Росгидромета и находящийся в 2,4 км выше впадения реки в р. Мзымту, рассматривался как фоновый, то к настоящему времени такой подход едва ли оправдан - на реку Лаура оказывается значительная антропогенная нагрузка, связанная с освоением новых территорий на водосборных площадях.

Опыт сочинских природоохранных организаций и результаты комплексных исследований рек прибрежной полосы Черного моря в районе г. Бол. Сочи показывают, что одной из основных проблем, с которой приходится сталкиваться в регионе, является эвтрофикация природных водоемов, которая возникает в результате попадания в водоемы неочищенных или недостаточно очищенных хозяйственно-бытовых и ливневых стоков с территорий населенных пунктов, предприятий и автомагистралей $[11 ; 12]$.

Это также справедливо и для оценки антропогенной нагрузки на природные водотоки бассейна реки Мзымты, протекающих по территории, затронутой олимпийским строительством, так как в настоящее время данные объекты используются для целей рекреационного туризма, который является основным видом деятельности в населенных пунктах горного кластера г. Бол. Сочи.

Гидрохимическая оценка состояния реки Мзымта и ее притоков, в том числе рек Лаура и Бешенка, на протяжении олимпийского строительства осуществлялось несколькими организациями: ФГУ «Кубаньмониторингвод» и НИИ прикладной и экспериментальной экологии Кубанского госагроуниверситета в 2010 году, отдельно ФГУ «Кубаньмониторингвод» - с 2009 по 2015 гг. ФГБУ «СЦГМС ЧАМ» на постоянной основе осуществляет регулярные гидрохимические наблюдения на реках Мзымта и Лаура.

По результатам наблюдений данных организаций в годы олимпийского строительства в реке Мзымта наблюдались значительные превышения ПДК по содержанию нефтепродуктов, ряда тяжелых металлов (железа, ртути, кадмия, меди, цинка), трудноокисляемых (по ХПК) и легкоокисляемых (по БПК) органических веществ, а также высокое содержание взвешенных веществ, значительно превышающее среднестатистические показатели более ранних лет.

Нормативами ПДК для рыбохозяйственных водоемов установлено, что повышение содержания взвешенных веществ в природном водоеме на 0.25 мг/л по отношению к фону может вызывать негативные последствия для живых организмов. Кроме того, различными авторами было доказано, что антропогенное повышение концентрации мелкодисперсной взвеси в водоеме, продолжающееся более часа, может привести к значительным потерям в его биоце- нозах, преимущественно влияя на малоподвижные формы бентоса и перифитона и водофильтрующие организмы. При этом повышенное содержание взвешенных веществ оказывает влияние на гидробионты, не только ухудшая физические свойства водной среды, что приводит к снижению интенсивности питания, дыхания и подвижности живых организмов, но и увеличивая токсичные свойства других загрязнителей, таких как подвижные формы металлов [13; 14$]$.

После проведения в 2014 году Олимпийских игр нагрузка на реки, связанная с интенсивным строительством в горном кластере, должна была существенно снизиться. Тем не менее, на развитие биоценозов уникальных природных водоемов Кавказа продолжают оказывать влияние эксплуатация возведенных спортивных и рекреационно-курортных объектов, ливневые и хозбытовые стоки с территорий значительно разросшихся прилегающих населенных пунктов. По данным гидрохимических наблюдений ФГБУ «СЦГМС ЧАМ» в 2014 и 2015 годах качество поверхностных вод реки Лаура было охарактеризовано как «слабо загрязненная», класс чистоты - 2, что свидетельствует о продолжающемся после олимпийского строительства воздействии внешних факторов [14].

В 2010 году ФГУ «Кубаньмониторингвод» и НИИ прикладной и экспериментальной экологии Кубанского ГАУ включили биологические исследования в комплексную программу изучения влияния техногенного воздействия на малые реки на территории олимпийского строительства, в том числе по р. Лаура. Авторы пришли к выводу, что наиболее информативным показателем экологического состояния реки является сапробный индекс Пантле и Букка и биотический индекс Вудивиса, что подтверждается и нашими исследованиями. По данным вышеуказанной работы определено, что река Лаура по индексу сапробности соответствует пограничному состоянию между олиго- и $\beta$-мезосапробной зоной. Значения индекса принимали минимальные значения, соответствующие чистому водоему, в ноябре (1.34), а максимальные (2.06), характеризующие умеренно загрязненные водоемы, в сентябре. Средний показатель индекса Вудивиса для реки Лаура был равен 8, что относит ее к чистым водотокам [10]. Других данных гидробиологических исследований реки Лаура для оценки влияния на нее развития курортов обнаружить не удалось.

По мнению специалистов, исследовавших воздействие строительных и берегоукрепительных работ бассейна р. Терек на состав речных биоценозов, процесс восстановления биологических сообществ в горных реках после воздействия техногенных факторов проходит очень медленно и может занять годы [16].

В тех случаях, когда антропогенная нагрузка на горные водоемы продолжается или повторяется в течение длительного времени, биологические со- 
общества не имеют возможности восстанавливаться в своем прежнем виде и вынужденно приспосабливаются к загрязнению среды: исчезают эндемичные виды, характерные для чистых олигосапробных водоемов, и появляются устойчивые к загрязнению группы гидробионтов. Поэтому чрезвычайно важно определить и изучить экологические риски, связанные с освоением горных кластеров туристической индустрии, которые могут привести к практически необратимой деградации природных сообществ в долгосрочной перспективе.

\section{Материалы и методы}

В данном исследовании показатели индекса сапробности и оценка биологического разнообразия сообществ макрозообентоса и перифитона р. Лаура было использовано в качестве основных показателей экологического состояния водоема на данном участке. Результаты биологического анализа сравнивались с гидрохимическими и геоэкологическими критериями оценки исследуемого участка реки для определения возможных причин трансформации речных биоценозов и определения основных экологических рисков для горного водоема.

Отбор и гидрохимические исследования проб воды проводились в соответствии с действующими аттестованными методиками измерений РД 52.24., разработанными ФГБУ «ГХИ» Росгидромета [17]. Отбор производился в пункте наблюдений «Кордон Лаура» сети государственной службы наблюдений Росгидромета.

Сбор биологического материала макрозообентоса осуществлялся в том же месте в соответствии с общепринятыми методами, утвержденными Гидрометеослужбой РФ [18]. Кроме того, в летний период были отобраны пробы в 1 км выше по течению р. Лаура от пункта наблюдений «Кордон Лаура», для определения состояния биологических сообществ вне влияния туристических объектов комплекса «Газпром». Пробы фиксировались 75\%-м раствором этилового спирта.
При камеральной обработке гидробионты распределялись по систематическим группам, определялись по видам и пересчитывались на 1 квадратный метр поверхности дна водоема [19; 20].

В качестве экспресс метода оценки биологических сообществ использовался индекс Вудивиса, который определялся на основе выделенных групп организмов. Уровень эфтрофикации реки определялся по значениям сапробного индекса по Пантле и Букку. Для определения индивидуального сапробного индекса эндемичных и суб-эндемичных для рек Кавказа ручейников использовались данные научной работы Якимова и др. [21]. Кроме того, были рассчитаны индекс относительного видового разнообразия Шеннона, индексы выравненности по Пиелу [22].

\section{Результаты и обсуждение}

Видовой состав макрозообентоса реки Лаура отличается сравнительно небольшим видовым разнообразием. В пробах за время исследования идентифицировалось от 8 (март) до 19 (июль) видов гидробионтов. Наименьшая средняя численность организмов в пробах отмечалась в марте $(29,4$ на м²). Численность гидробионтов значительно возрастала в летние месяцы (до 138,3 на м²), начиная с конца апреля, после схода снежных покровов на территориях, прилегающих к месту отбора проб. В среднем 72,2\% обнаруженных в пробах видов относятся к группам реофильных ручейников, веснянок и поденок. Однако, анализ процентного соотношения численности гидробионтов устойчивых к органическому загрязнению (с индивидуальным сапробным индексом 2 или выше) показал, что относительное количество таких организмов в пробах стабильно возрастает с марта по июль (рис. 1).

Кроме того, на рис. 2 отражена зависимость изменения доли организмов, устойчивых к эфтрофикации в связи с сезонным повышением температуры воды в летние месяцы: с июня по август. В сентябре их доля в пробах снижается. Содержание растворенного кисло-

Процентная доля организмов, толерантных к органическому загрязнению /

The percentage share of tolerant to pollution organisms
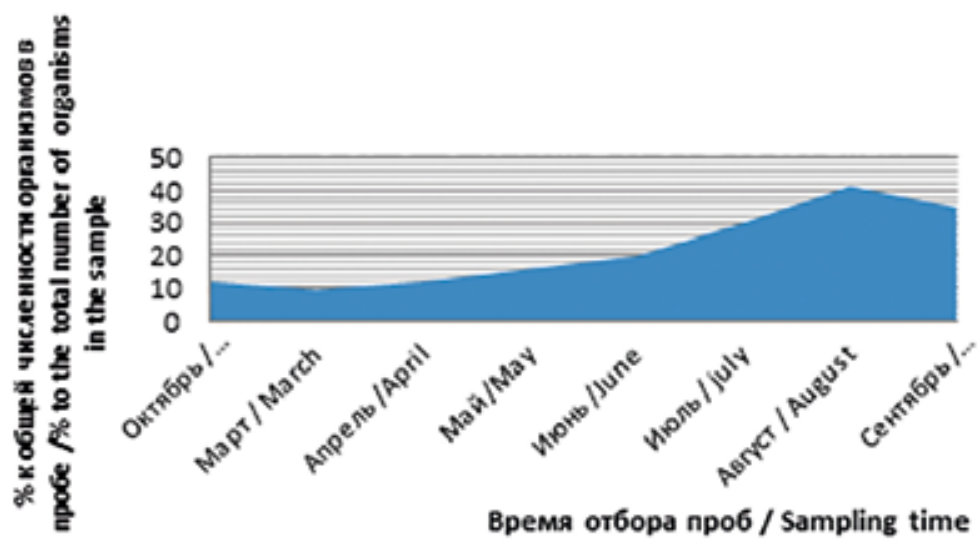

口 $\%$ толерантных к загрязнению форм / \% tolerant to pollution forms

Pис. 1. Прочентная доля организмов макрозообентоса р. Лаура, толерантных к органическому загрязнению среды /

Fig. 1. The percentage share of macrozoobenthos organisms in the Laura river, tolerant to organic pollution 


\section{Изменение доли толерантных к органическому загрязнению форм в зависимости от изменения температуры воды / \\ Changing in the tolerant to pollution percentage share depending on water temperature fluctuation}

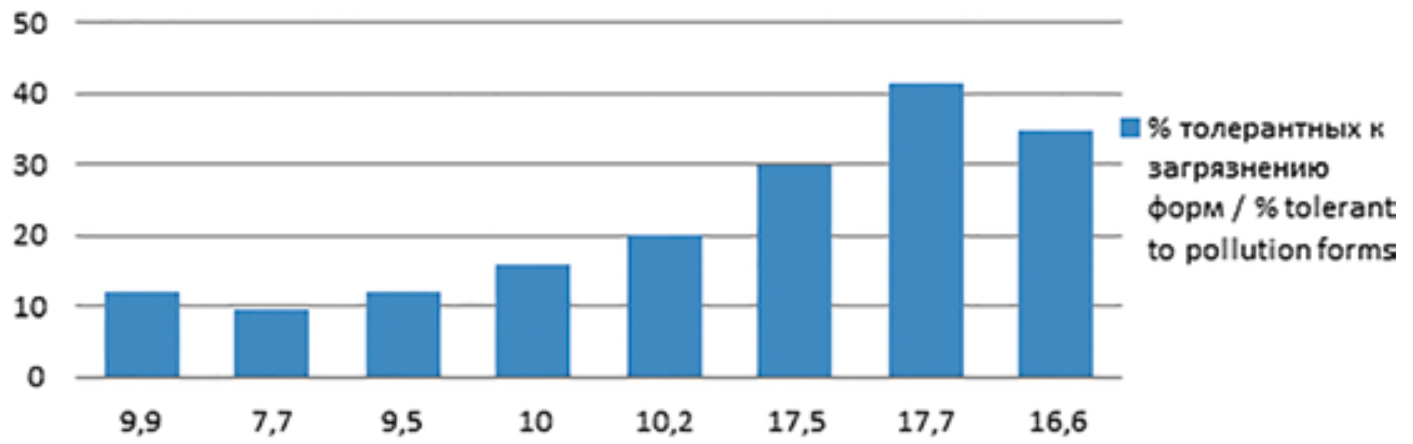

Puc. 2. Изменение процентной доли организмов макрозообентоса р. Лаура, толерантных к органическому загрязнению среды в зависимости от колебаний температуры воды /

Fig. 2. Changing in the percentage share of macrozoobenthos organisms of Laura river, tolerant to organic pollution, depending on water temperature fluctuations

рода оставалось стабильным в течение всего периода исследований, и не принимало значений ниже $7,9{ }^{\circ} \mathrm{C}$ за счет гидрологических особенностей горной реки. Это обеспечивает эффективное окисление поступающей в водоем органики и способствует процессу самоочищения.

Среднее значение индекса Вудивиса за период исследования было 7.6, что соответствует чистому водоему. Однако показатели индекса Вудивиса использовались только для экспресс оценки качества водной среды, так как он не достаточно чувствителен к незначительным изменениям в биоценозах. Данные анализа сапробности показывают, что уровень эфтрофикации реки Лаура находится в пограничной зоне между олигосапробной (чистой) и $\beta$-мезосапробной (умеренно загрязненной) зоной. Его среднее значение за время исследования было 1,44. Минимальные значения наблюдались в октябре $(1,18)$, а максимальные - в июле $(2,0)$. Наблюдалось повышение индекса сапробности до 1,57 в марте, что вероятно связано с интенсивным таянием снега и загрязненными смывами с дорог и производственных участков в реку. Значения индекса сапробности повышались, начиная с апреля по июльавгуст (1,2-2), показано на рис. 3 . В сентябре наблюдалось незначительное снижение индекса сапробности.

Предположительно, это связано с уменьшением водности реки и ограничением ее разбавляющей способности, повышением температуры воды, а также с увеличением объемов попадающих в реку примесей, вызванным проведением туристического сезона на территории, прилегающей к реке и увеличению транспортного потока. Необходимо отметить, что в марте при повышении индекса сапробности в пробах наблюдалось повышенное содержание легкоокисляемых органических веществ (по БПК5) (1,7 мг/л) по сравнению с пробами, отобранными в октябре, апреле и июле - 0,7; 1,4 и 0,9 мг/л соответственно. Повы- шенное значение БПК5 наблюдалось также в июне $-1,6 \mathrm{мг/л.}$

Это практически полностью соответствует данным исследований 2010 года, периоду времени, когда в районе реки велось интенсивное строительство, и нагрузка определялась работами по освоению территории. По данным сапробного анализа, биоценозы реки Лаура в настоящее время не показывают признаков восстановления до уровня, соответствующего олигосапробному горному водоему. Как описывается выше, в пробах биоты, наряду с гидробионтами - индикаторами чистой воды, были обнаружены организмы устойчивые к органическому загрязнению. При этом следует обратить внимание на то, что анализ сапробности чувствителен прежде всего к эфтрофикации водоема, а не к повышенному содержанию в воде некоторых тяжелых металлов.

Выводы предыдущих исследований и многолетних наблюдений ФГБУ «СЦГМС ЧАМ» указывают на то, что высокое содержание (более 1 ПДК) ряда тяжелых металлов характерно для всех горных рек Черноморского побережья Кавказа и обусловлено естественными аномалиями горных пород молодых гор Кавказа. Это свидетельствует об отсутствии связи между загрязнением и антропогенным воздействием на качество речных вод. Река Лаура в данном случае не является исключением. Загрязнение такими металлами, как медь и цинк является для данного водного объекта характерным или устойчивым.

Однако увеличение индекса сапробности, которое фиксировалось как в 2010 году, так и нашими исследованиями, говорит о влиянии, связанном с повышением уровня эфтрофикации реки. Это в большей степени зависит от интенсивной эксплуатации рекреационно-туристических и жилых объектов, попадания в реку неочищенных или недостаточно очищенных хозяйственно-бытовых стоков и поверхностных 


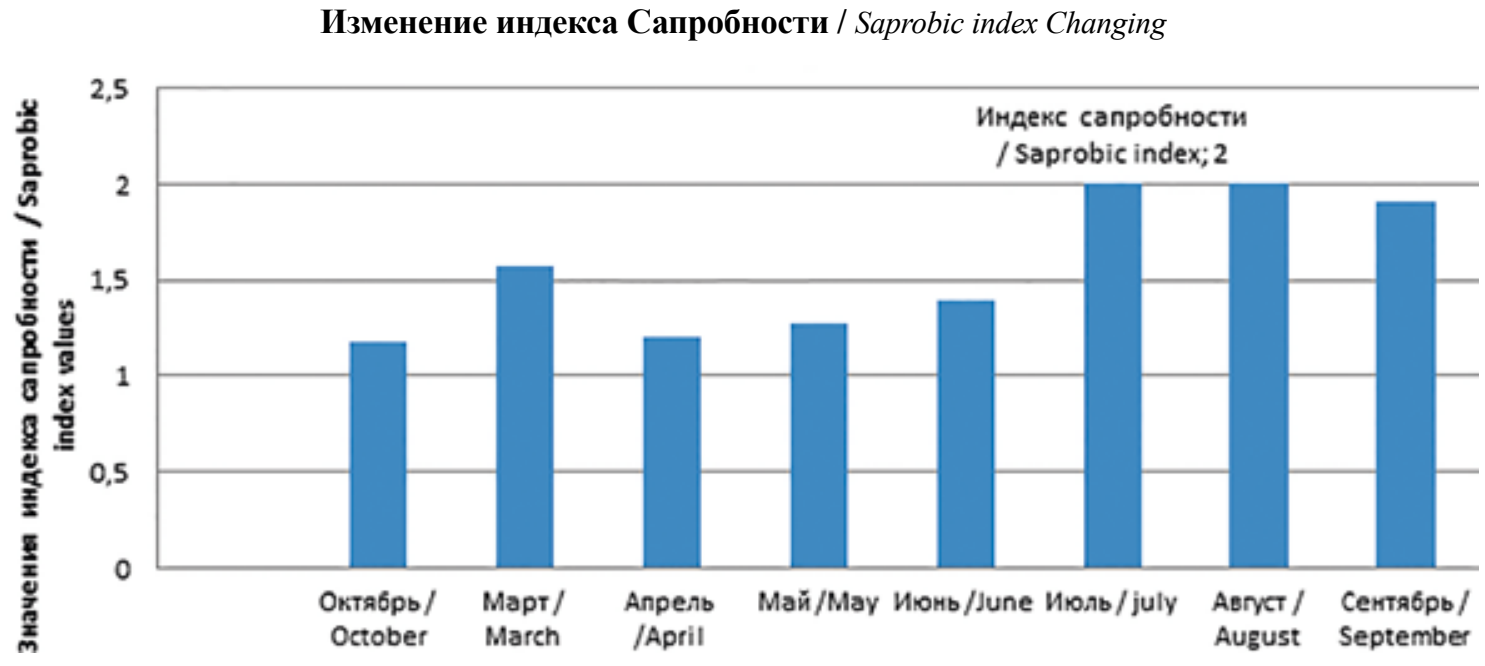

Puc. 3. Изменение значений индекса Сапробности в пробах реки Лаура /

Fig. 3. Changing of Saprobic index values in Laura river samples

стоков с водосборных площадей, включая ливневую канализацию автодороги, пролегающей вдоль реки.

Между тем стоит отметить, что результаты гидрохимических наблюдений ФГБУ «СЦГМС ЧАМ», проводимых в основные гидрологические фазы, не свидетельствуют о наличии в водах р.Лаура повышенного и высокого содержания биогенных элементов азотной и фосфорной группы, что свидетельствует об эфтрофикации реки преимущественно за счет поступления органических веществ.

Для определения относительного обилия видов гидробионтов реки Лаура определялся индекс Шеннона, а для оценки выравненности видового состава биологического сообщества - индекс выравненности Пиелу. Определено, что в течение данных исследований индекс Шеннона варьировался от 2 - в октябре до 2,78 - в августе. Отмечено, что, если значения индекса Шеннона изменялись незначительно с октября по май (от 2 до 2.13), то в июне наблюдалось резкое повышение этого параметра (рис. 4).
Такое изменение относительного видового разнообразия в водоеме согласуется с изменением его статуса по оценке сапробного индекса. Горная река, постепенно переходит из олигосапробной зоны, характеризующейся относительно небольшим видовым богатством, переходит в зону $\beta$-мезосапробности, характеризующуюся увеличением трофности водоема, интенсивными окислительными процессам и большим обилием видов.

Пробы из р.Лаура, отобранные в 1 км выше по течению от пункта наблюдений «Кордон Лаура», характеризовались как олигосапробные (средний индекс сапробности - 1,28. Средний индеек Вудивиса в этих пробах был 9,5, относящий эти участки к очень чистым водоемам. Значения индекса Шеннона за исследуемый период изменялись незначительно $(2,49-2,62)$.

Индекс Шеннона не отражает индикаторной значимости отдельных организмов и их чувствительности к определенным факторам изменения среды и указывает только на изменения структуры биоцено-

Индекс Шеннона / Shannon index

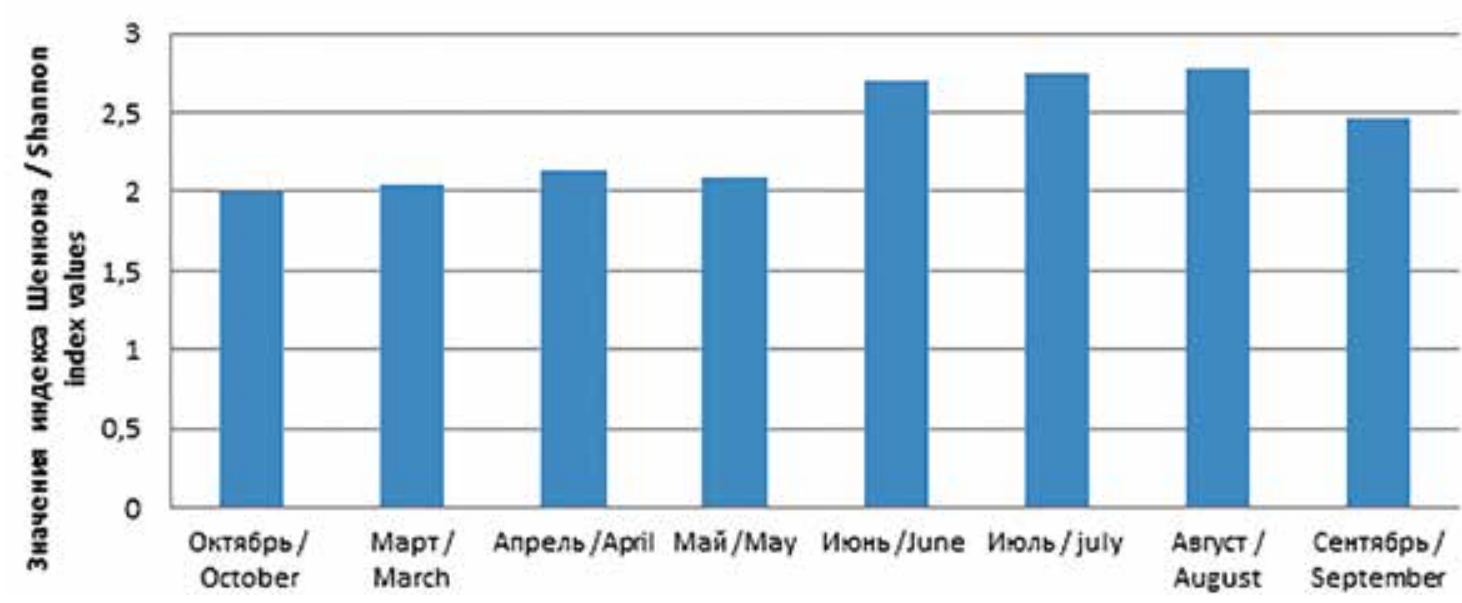

Pис. 4. Изменение значений индекса Шеннона /

Fig. 4. Changes in Shannon index values 
за. Значения выравненности видового состава практически не изменялись в ходе исследования на обеих станциях, характеризуя сравнительно стабильные биоценозы, приспособившиеся к изменениям внешних факторов.

\section{Заключение}

Река Лаура, находясь в зоне бурного развития горно-курортной индустрии, имеет важное рекреационное значение. При гидрохимической оценке качества воды реки Мзымта створ на реке Лаура рассматривается как фоновый. Кроме того, этот водоток является одним из притоков реки Мзымта - основного источника водоснабжения Адлерского района г. Сочи.

Выявлено, что фауна макрозообентоса реки в основном представлена реофильными организмами олигосапробной зоны, характерными для чистых горных водоемов: личинками ручейников, веснянок и поденок. Однако наряду с такими организмами в пробах были обнаружены организмы толерантные к органическому загрязнению и характерные для $\beta$-мезосапробной зоны. Определено, что статус реки определяется в пограничном отрезке между олигосапробным и $\beta$-мезосапробным участком, что подтверждается предыдущими исследованиями, выполненными в 2010 г. Ранее предполагалось, что на биологические сообщества реки оказывает влияние строительство крупных олимпийских объектов и аномально высокое содержание некоторых тяжелых металлов в водах горных рек черноморского побережья Кавказа. Однако, исходя из принципа сапробного анализа и биотического индекса Вудивиса, эти определения нацелены главным образом на определение эфтрофирующего влияния на водоем. Анализ данных индекса Шеннона также указывает на стабильную трансформацию биологических сообществ реки от олигосапробного водоема, с относительно бедным видовым и численным составом, к мезосапробному, характеризующемуся большим видовым разнообразием, интенсивными окислительными и самоочищающими процессами. Никаких индикаторов токсобности, таких как резкое снижение численности организмов, их угнетение, нарушение процессов жизнедеятельности, в пробах не выявлено. Это указывает на то, что основными причинами изменений биоценоза типичной горной реки является интенсивная эксплуатация рекреационно-туристических объектов без принятия необходимых мер по обеспечению соответствующей очистки хозяйственно-бытовых стоков, загрязненных ливневых стоков с автодорог и прилегающих освоенных территорий, экологическибезопасной утилизации бытовых отходов в районах водосбора горной реки.

Следует отметить, что биоценозы чистых горных водоемов очень чувствительны к органическому загрязнению и эфтрофикации и обладают невысокой способностью к самоочищению. Поэтому для со- хранения их статуса будет оправдано введение более жесткого экологического контроля на хозяйственных объектах, расположенных в зонах водосбора таких водоемов и оценке состояния самих рек. Такой контроль должен быть комплексным и включать в себя как химический анализ воды, донных отложений и биоты, так и интегральные биологические методы $[23 ; 24]$.

На примере комплексной оценки горной реки Лаура можно идентифицировать основные экологические риски, связанные с развитием рекреационно-туристских регионов черноморского побережья Кавказа:

-возросшее за период реализации олимпийского проекта техногенное воздействие на геологическую среду региона провоцирует активизацию уже существующих оползней, селей, эрозии и т.д., что повышает риски безопасности жизнедеятельности человека и экосистемы в целом;

- массовое изъятие гравийно-галечного материала для строительства рекреационно-туристских объектов из русел горных рек привело к изменению режима этих рек и активизации опасных экзогенных процессов;

- в результате активизации опасных геологических процессов на склонах горных рек происходит уничтожение природного ландшафта, загрязнение поверхностных и подземных вод, деградация почв, уничтожение мест обитания флоры и фауны;

- наличие в почво-грунтах района локальных геохимических аномалий может привести к переносу загрязняющих веществ в результате активизации оползневых, селевых и эрозионных процессов в водные экосистемы горных рек и их загрязнению;

- повышение уровня органического загрязнения реки неочищенными или недостаточно очищенными хозяйственно-бытовыми стоками в комплексе с возросшим содержанием мелкодисперсных взвешенных веществ, поступающих в водоем вследствие активизации экзогенных геологических процессов, и повышенного содержания ионов подвижных форм тяжелых металлов при естественных аномалиях, свойственных этому горному району, создает риски аддитивного увеличения степени негативного влияния этих факторов на сообщества гидробионтов;

- обезвоживание реки в летний период, связанное с интенсивным забором воды для нужд интенсивно развивающегося курорта, препятствует естественному процессу самоочищения водоема и достаточному разбавлению поступающих в него загрязненных стоков. Это ведет к постепенной эфтрофикации горной реки, изменению состава биологических сообществ и статуса ее трофности;

- изменение состава биологических сообществ реки, вызванных ее эфтрофикацией, изменением физико-химических свойств воды и водного режима создает риск снижения рыбохозяйственного и рекре- 
ационного значения не только самой р. Лаура, но и p. Мзымта, являющейся одним из важнейших водных объектов Сочинского региона и ресурсом чистой питьевой воды для города-курорта.

По результатам проведенных исследований сделан вывод о необходимости расширения программы мониторинга по рекам Лаура, Мзымта и их основных притоков и включения в нее исследований

\section{ЛИТЕРАТУРА:}

1. Баденков Ю.П. К вопросу о государственной политике развития горных регионов России. Нужен ли России федеральный горный закон? // Устойчивое развитие горных территорий, 2017. Том 9. N 2(32). С.111-119.

2. OECD report. Key environmental indicators // Conference OECD (France, Paris, 28-29 April, 2008). France: Paris. 2008.

3. Алборов И. Д., Тедеева Ф.Г., Гриднев Е.А, Хасдан В. Геоэкологические аспекты загрязнения водозаборов населенных пунктов республики Северная Осетия-Алания в зоне пассивной деятельности горного производства // Устойчивое развитие горных территорий. 2017. Том 8. N 3. С. 195-204. DOI: 10.21177/1998-4502-2016-8- 3-195-203.

4. Государственный водный реестр. Река Ачипсе. 2007. [электронный ресурс] Режим доступа: http://water-rf.ru, свободный (дата обращения 17.09.2017.

5. Воронов Ю.Н. Древности Сочи и его окрестностей. Краснодар: Краснодарское книжное издательство, 1979. $128 \mathrm{c.}$

6. Академия наук СССР. Геоморфология. Москва: Наука, 1973. С. 71.

7. Твердый А.В. Топонимический словарь Кавказа. Краснодар; Краснодарское книжное издательство, 2006. 432 с.

8. Гудкова Н.К., Оноприенко М.Г. Об активизации опасных геодинамических процессов в результате увеличения техногенной нагрузки при строительстве в Сочинском регионе // Экологический вестник Северного Кавказа. 2011. Том 7., No 3. C. 37-40.

9. Гудкова Н.К. Мониторинг геологической среды олимпийских объектов в Сочи // Системы контроля окружающей среды. 2016. N 3(23). С.130-133.

10. Результаты гидрохимических и гидробиологических наблюдений за состоянием поверхностных вод рек, расположенных в зоне строительства олимпийского комплекса г. Сочи за 2010 год. 2011. [электронный ресурс]. Режим доступа: URLhttp://voda.mnr.gov.ru/activities/detail.php?ID=6021, свободный, (дата обращения 02.06.17.).

11. EU Water Framework directive, European Parliament and Council [Электронный pecypc]. Official Journal OJL 327, 22 December, 2000. - Режим доступа: www.ec.europa.eu/ environment/water/water-framework/, свободный (Дата обращения 15.08 2017).

12. Горбунова Т.Л. Биоиндикация в системе мониторинга состояния водной среды на территориях рекреационно-курортной специализации // Успехи современной науки. 2017. T. 9. N 3. C. 89-93.

13. Harding, J., Quinn, J., Hickey, C. Effect of mining and production forestry /J.Harding, J.Quinn, C.Hickey // New Zealand stream invertebrates: ecology and implications for management. New Zealand, Christchurch, 2000. P. 230-259. фактически фоновых участков рек, расположенных выше площадей с интенсивной антропогенной активностью. Мониторинг должен включать в себя анализ всех биотических и абиотических факторов, влияющих на качество окружающей среды, а также интегральные методы оценки состояния водных экосистем.

14. Горбунова Т.Л. Анализ токсичности сточных вод участка открытой разработки и обогащения железо-титанового концентрата // Актуальные проблемы гуманитарных и естественных наук. 2017. N 6-1. С. 7-16.

15. Ежегодник качества поверхностных вод Российской Федерации. 2014 и 2015. [Электронный ресурс]. Режим доступа: www.gidrohim.com, свободный (дата обращения 25.08.2017)

16. Olomukoro J.O., Dirisu A. Macroinvertebrate Community and Pollution Tolerance Index in Edion and Omodo Rivers in Derived Savannah Wetlands in Southern Nigeria // Jordan Journal of Biological Sciences. 2014, Vol. 7:1. P. 19-24.

17. РД 52.24.309-2011. Организация и проведение режимных наблюдений за состоянием и загрязнением поверхностных вод суши. - Взамен Р 52.24.309-2004; введ. 1 июня 2012. Ростов-на-Дону: Гидрометеоиздат. 2011. 26 с.

18. Абакумов В.А. Руководство по методам гидробиологического анализа поверхностных вод и донных отложений // Государственный комитет СССР по гидрометеорологии и контролю природной среды. Л.: Гидрометеоиздат, 1983. $240 \mathrm{c}$.

19. Определитель пресноводных беспозвоночных России и сопредельных территорий: в 6-ти т. / ред. С.Я. Цалолихин. СПб.: Наука, 1997-2000.

20. Bennett H. H., Mullen M. W., Stewart P. M., Sawyer J. A. Development of an Invertebrate Community Index for an Alabama Coastal Plain Watershed // Journal of the American Water Resources Association. 2004. No 40:1. 43-51.

21. Якимов А. В., Сарахова М.А., Львов В.Д., Шахмурзов M.М., Черчесова С.К., Шибзухова 3.С. Ручейники (Trichoptera) Кабардино-Балкарии (Центральный Кавказ) как индикаторы качества речных вод // Современные проблемы науки и образования. 2013. N 6. URL: http://www.science-education. $\mathrm{ru} / 113-10892$.

22. Crowley D., Staines A., Collins C., Bracken J., Bruen M., Fry J., Hrymak V., Malone D., Magette B., Ryan M., Thunhurst C. Health and environmental effects of landfilling and incineration of Waste - A Literature Review -Dublin: Dublin institute of technology, 2003, Report 3 [электронный ресурс] Режим доступа http://arrow.dit.ie/schfsehrep/3, свободный (дата обращения 25.08.2017). P. 284.

23. Stark J. D. SQMCI: a biotic index for freshwater macroinvertebrate coded abundance data // New Zealand journal of marine and freshwater research. 1998. Vol. 32. P. 55-66.

24. Chessman B.C., Trayler R.V., Davis J.A Family and species level biotic indices for macroinvertebrates of wetlands on the Swan Coastal Plain // Western Australia. Marine and Freshwater Research. 2002. No 53. P.919-930. 


\section{БЛАГОДАРНОСТИ / Gratitudes:}

Авторы выражают благодарность коллективу лаборатории СЦГМС ЧАМ за содействие в отборе проб на исследуемых участках и своевременное проведение гидрохимических анализов / The authors express their gratitude to the laboratory staff of the Specialized center for Hydrometeorology and environmental monitoring of the Black and Azov seas for assistance in sampling at the sites under study and timely production of hydrochemical analyses.

\section{КРИТЕРИИ АВТОРСТВА / Contribution:}

Гудкова Н. К. - собрала и проанализировала геологическую информацию и данные по реке Лаура, определила и описала риски, связанные с антропогенной нагрузкой и опасными геологическими процессами; Горбунова Т. Л. - провела гидробиологический отбор проб макрозообентоса, их камеральную обработку и расчет биоиндикаторных показателей; Любимцев А. Л. - организовал отбор и анализ гидрохимических проб, собрал и проанализировал архивный материал по химическому составу воды исследуемого объекта / Gudkova $\mathbf{N}$. K. - collected and analyzed geological information and data on the Laura river, identified and described risks associated with anthropogenic pressure and hazardous geological processes; Gorbunova T. L. - conducted hydro-biological sampling of macrozoobenthos, their identification treatment and calculation of bioindication parameters; Lubimtsev $\boldsymbol{A}$. L. - organized the collection and analysis of hydro-chemical samples, collected and analyzed archival material on the chemical composition of the water from the studied object.

Все авторы принимали равное участие в написании рукописи и несут ответственность за плагиат / All authors took equal part in writing the manuscript and are responsible for plagiarism .

\section{КОНФЛИКТ ИНТЕРЕСОВ / Conflict of interest:}

Авторы заявляют об отсутствии конфликта интересов / The authors declare no conflict of interest.

\section{СВЕДЕНИЯ ОБ АВТОРАХ / Information about authors:}

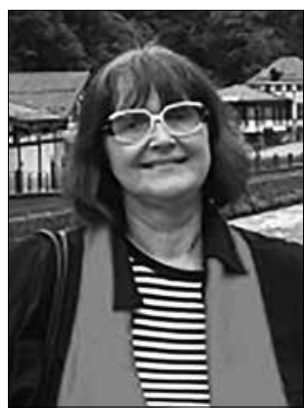

ГУДКОВА Наталья Константиновна - кандидат геолого-минералогических наук, старший научный сотрудник лаборатории экономики природопользования и экологии. Филиал Института природно-технических систем в г. Сочи, руководитель секции геологии и минералогии Сочинского городского отделения Русского географического общества.

Курортный проспект 99/18, Сочи, Россия

Тел.: +7 (918)204-36-12.

e-mail:n.k.gud@yandex.ru

Natalia Konstantinovna GUDKOVA - Candidate of Geological and Mineralogical Sciences, head researcher of the Laboratory of Economy of Ecology and Environmental Management, branch of Institute of Natural and Technical Systems in Sochi, leader of the Geology and Mineralogy Section of Sochi branch of the Russian Geographic Society.

Research interests-Geology, Geo-ecology, sustainable development of tourist regions.

Author of over 80 scientific publications.

Kurortny prospect 99/18, Sochi, Russia

Tel.: + 7 (918) 204-36-12

e-mail:n.k.gud@yandex.ru

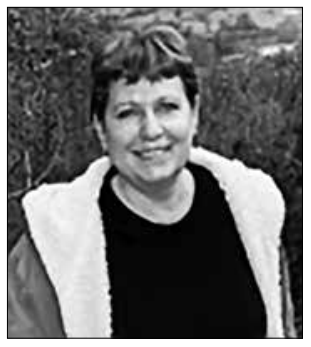

ГОРБУНОВА Татьяна Львовна - гидробиолог, научный сотрудник лаборатории экономики природопользования и экологии, филиал Института природно-технических систем в г. Сочи, действительный член Сочинского городского отделения Русского географического общества, секция экологии.

Курортный проспект 99/18, Сочи, Россия

Тел.: +7 (988)284-15-70

e-mail: tatianashaw@mail.ru

Tatiana Lvovna GORBUNOVA - researcher of the Laboratory of Economy of Ecology and Environmental Management, branch of Institute of Natural and Technical Systems in Sochi, current member of Sochi branch of the Russian Geographic Society, ecological section.

Research interests: hydro-biology, bio-indication of water environment, sanitary toxicology, hydro-biological monitoring of water bodies.

Author of 7 scientific publications.

Tel.: + 7 (988)284-15-70

Kurortny prospect 99/18, Sochi, Russia

e-mail: tatianashaw@mail.ru 
ЛЮБИМЦЕВ Андрей Львович - химик-аналитик, начальник лаборатории.

Специализированный центр по гидрометеорологии и мониторингу окружающей среды Черного и Азовского морей. Севастопольская 25, г. Сочи, Россия

Тел.: +7 (918) 606-29-56

e-mail: lab.pogoda@yandex.ru

Andrey Lvovich LUBIMTSEV - head of the Laboratory of Specialised Center of Hydrometeorology and Monitoring of the Black and Azov Seas Environment.

Research interests: hydrochemistry and organization of water environment monitoring, environmental quality control.

25 Sevastopolskaya st. Sochi, Russia,

Tel.:+7 (918) 606-29-56

e-mail:lab.pogoda@yandex.ru

\title{
THE IDENTIFICATION OF THE ECOLOGICAL RISKS CONCERNING THE RECREATION - TOURIST REGIONS DEVELOPMENT OF THE CAUCASIAN BLACK SEA SHORE USING THE COMPLEX ESTIMATION OF THE MOUNTAIN RIVER LAURA ECOSYSTEM
}

\author{
${ }^{1}$ Gudkova N.K. \\ 'Gorbunova T.L.* \\ ${ }^{2}$ Lubimtsev A.L. \\ ${ }^{1}$ Branch of Institute of Natural and Technical Systems in Sochi, Russia \\ ${ }^{2}$ Specialised Center of Hydrometeorology and Monitoring of the Black and Azov Seas Environment, Sochi, Russia, \\ *e-mail: tatianashaw@mail.ru
}

\section{DOI: $10.21177 / 1998-4502-2018-10-1-23-34$}

The goal is to identify ecological risks, associated with development of recreational and tourism objects in the mount cluster of Sochi. The anthropogenic, geological, hydrological, hydro chemical aspects which represent danger for the resort as well as for unique ecosystems of the mount river Laura were studied.

Methods. During 2016-2017 the complex research of the Laura river were conducted within the framework of which the analysis of exogenous geological processes and studying of hydro-chemical and hydro-biological parameters of ecological situation of the water body were carried out. The examinations of water were carried out in accordance with methods approved by the Hydro-meteorological Service of the Russian Federation. For evaluation of biological communities conditions the saprobical method and analysis of biological diversity were used.

Results. The research indicated that intensive anthropogenic influence on the geological environment of the region provokes activation of the dangerous geological processes increasing the risks for humans health and safety as well as for the natural communities of the river Laura. It was determined that during summer months in the hydro biocenoses of the Laura river due to the complex "Gazprom" influence on zone share tolerant to the organic pollution of macrozoobenthic organisms significantly increases. Resulting from the river dewatering and increasing anthropogenic pressure, the status of the river on this area was changed from oligosaprobical to $\beta$-mezosaprobical. The increase in the river pollution level by domestic wastewater combined with the raised fine-grained suspended solids content and excessive metal ions concentrations due to the natural geochemical anomalies creates risks of additive influence of these factors on the mountain river biocoenoses in the region. It was revealed that the Laura river above the resort complex ter- ritory where there is practically no anthropogenic pressure during the whole investigation period was characterized as a clean, oligosaprobic waterway.

Conclusion. A comprehensive study of the Laura mountain river allowed identification of the environmental risks for the river ecosystem. It was revealed in the course of the research that the changes in the water body hydro biocenoses composition creates the risks of decreasing the fishery and recreational value not only of the Laura river but also of the Mzymta river, the inflow of which it is. The authors recommend the expansion of the monitoring program of these rivers which should include the study of the actual referencing areas and a comprehensive analysis of all biotic and abiotic factors affecting the ecological status of water bodies.

Keywords: ecological risks, hydrological regime, dangerous exogenous processes, hydro chemical parameters, euphtrophication, bio indication, macrozoobenthos, species diversity.

\section{References}

1. Badenkov Y.P. On the state policy of the mountain regions development in Russia. Dose Russia need a federal mountain law? Sustainable development of mountain territories. 2017. Vol 9. No.2 (32). Pp. 111-119.

2. OECD report. Key environmental indicators. Conference OECD.(France, Paris, 28-29 April, 2008. France: Paris.

3. Alborov I.D., Tedeeva F.G., Gridnev E.A., Khasdan V. Geoecological aspects of water-reservoir contamination in the North Ossetian - Alania localities in the air of the passive mining activity. Sustainable development of mountain territories. 2017 Vol 8. No.3 (32). Pp. 195-204. DOI: 10.21177/1998-4502-2016-8-3-195-203.

4. State water register. The river Achipse. 2007. (Electronic version) Access mode: http://water-rf.ru, free (Request date 17.09.2017). 
5. Voronov U. N. Antiquities of Sochi and its surroundings. Krasnodar: Krasnodarskiy publishing house. 1979. 128 p.

6. USSR Academy of Sciences. Geomorphology. Moscow: Nauka, 1973. 71p.

7. Tvyordyi A.V. Toponymic dictionary of Caucasus. Krasnodar: Krasnodarskiy publishing house, 2006, 432 p.

8. Gudkova N.K., Onoprienko M.G. On activization of dangerous geodynamic processes due to technogenic load increase during building in Sochi region. Ecological bulletin of the North Caucasus. 2011. Vol. 7, No. 3. Pp. 37-40.

9. Gudkova N.K. Monitoring of the geological medium of the Olympic objects in Sochi. Environment control systems. 2016. No 3(23). Pp. 130-133.

10. The results of hydrochemical and hydrobiological observations of the rivers surface waters state in the building zone of Sochi Olympic complex in 2010-2011 (electronic version) Access mode: URLhttp://voda.mnr.gov.ru/activities/ detail.php?ID=6021, free (request date 02.06.2017).

11. EU Water Framework directive, European Parliament and Council [electronic version]. Official Journal OJL 327, 22 December, 2000. Access mode: www.ec.europa.eu/ environment/water/water-framework/. Free (Request date 18.08.2017).

12. Gorbunova T.L. Bio-indication in the monitoring system of water on the recreation-resort territories. Advances of modern science. 2017. Vol. 9. No. 3. Pp.89-93.

13. Harding J., Quinn J., Hickey C. Effect of mining and production forestry. New Zealand stream invertebrates: ecology and implications for management. New Zealand, Christchurch, 2000. P. 230-259.

14. Gorbunova T.L. Analysis of sewage waters toxicity of the open mining and ferrum - titanium concentrate enrichment. Actual problems of humanitarian and natural sciences. 2017. No.6-1. Pp. 7-16.

15. Annual of the surface waters quality of Russian Federation in 2014-2015. [electronic version] . Access mode: $w w w$. gidrohim.com, (request date 25.08.2017).

16. Olomukoro J. O., Dirisu A. Macroinvertebrate Community and Pollution Tolerance Index in Edion and Omodo Rivers in Derived Savannah Wetlands in Southern Nigeria.
Jordan Journal of Biological Sciences. 2014, Vol. 7:1. Pp. 19-24.

17. RD 52.24.309.-2011. Organization and observations of the state and contamination of the land surface waters. Instead of R 52.24.309-2004; from 1 June 2012. Rostov-onDon: Hydrometeoizdat. 2011. 26 p.

18. Abakumov V.A. Manual on hydro biological analysis methods of the surface waters and bottom residues. State committee of USSR on hydrometeorology and environment control. Leningrad: Hydrometeoizdat, 1983. 240 p.

19. Determinant of freshwater invertebrates in Russia and adjacent territories: in 6 vol. / edit. S.Ya. Tsalolikhin. $S P b: N A U K A, 1997-2000$.

20. Bennett H. H., Mullen M.W., Stewart P.M., Sawyer J. A Development of an Invertebrate Community Index for an Alabama Coastal Plain Watershed. Journal of the American Water Resources Association. 2004. No 40:1. Pp. 43-51.

21. Yakimov A.V.. Sarakhova M.A., Lvov V.D., Shakhmurzov M.M., Cherchesova S.K., Shibzukhova Z.S. Trichoptera of Kabardino-Balcaria (Central Caucasus) as indicators of river waters quality. Modern problems of science and education. 2013. No.6. URL: http://www.scienceeducation.ru/113-10892.

22. Crowley D., Staines A., Collins C., Bracken J., Bruen V., Fry J., Hrymak V., Malone D., Magette B., Ryan M., Thunhurst C. Health and environmental effects of landfilling and incineration of Waste - A Literature Review. Dublin: Dublin institute of technology, 2003, Report 3 [Electronic version]. Access mode: http://arrow.dit.ie/schfsehrep/3, free (request date 25.08.2017). P. 284.

23. Stark J.D. SQMCI: a biotic index for freshwater macroinvertebrate coded abundance data. New Zealand journal of marine and freshwater research. 1998. Vol. 32. Pp. 55-66.

24. Chessman B.C., Trayler R.V., Davis J.A. Family and species level biotic indices for macroinvertebrates of wetlands on the Swan Coastal Plain. Western Australia. Marine and Freshwater Research. 2002. No. 53. Pp. 919-930.

Статья поступила в редакияию 30.10.2017 


\section{ОПТИМИЗАЦИЯ ЗЕМЛЕПОЛЬЗОВАНИЯ В ГОРНЫХ РЕГИОНАХ СЕВЕРО-ВОСТОЧНОГО КАВКАЗА}

1,23абураева X. Ш., *

1,2Заурбеков Ш. Ш.,

1,2Таймасханов X. Э.

Введение. Земельные ресурсы - стратегический фактор социальноэкономического развития любого государства. Выполняя роль средства производства, пространственного базиса размещения населения и производительных сил, а также важнейших экологических функций, земля выступает в качестве абсолютно ограниченного ресурса, который невозможно воспроизводить. Данное обстоятельство, в свою очередь, определяет необходимость поиска научно-обоснованных, экономически эффективных и экологически безопасных подходов к использованию земельного фонда как на государственном, так и на региональном и муниципальном уровнях.

Кавказ в целом подобно другим горным регионам мира сталкивается с глобальными вызовами, обусловленными изменением климата, геополитической напряженностью, социально-экономическими, экологическими процессами. Регионы на северо-востоке Кавказа издавна заселялись различными этносами - носителями уникальной глубокой самобытной культуры. В геоэкологическом отношении Чечня, Дагестан и Ингушетия относятся к привлекательным регионам России ввиду значительного биотического и ландшафтного разнообразия, большого количества редких и отнесенных к исчезающим видов флоры и фауны, эндемичных видов и уникальных природных комплексов, что создает предпосылки для широкого спектра землепользования. В условиях горных регионов Кавказа земельные ресурсы и землепользование - определяющие устойчивого существования их народов на протяжении многих веков.

Объект исследования - горные регионы Северо-Восточного Кавказа.

Цель - эколого-географический анализ проблем и предпосылок оптимизации землепользования в регионах Северо-Восточного Кавказа.

\section{Материалы и методы исследования}

Для реализации поставленной цели был собран и проанализирован значительный объем научной литературы, фондового и картографического материала, включая материалы региональных министерств и ведомств, функционирующих на территории Чечни, Дагестана и Ингушетии (Министерство сельского хозяйства, комитет по статистике, Министерство лесного хозяйства и др.). В ходе исследования применялись методы сравнительно-географического анализа, статистический и картографический методы. Для выделения объекта исследования применялся бассейновый подход, на основе которого обоснована естественная граница исследуемых регионов в составе единого водосборного бассейна - Северо-Восточного Кавказа.

Итоговая карта-схема рекомендуемых приоритетных направлений развития исследуемых регионов разработана путем наложения серии карт (распространения сельскохозяйственных угодий, использования пахотных угодий, геоэкологического каркаса, туристско-рекреационного потенциала), отражающих фактические условия и особенности землепользования. Они выполнены в программе Corel Draw.

Результаты и обсуждение. Концепция сбалансированного землеполь-

\footnotetext{
${ }^{1}$ Грозненский государственный нефтяной технический университет им. акад. М.Д. Миллионщикова, г. Грозный, Россия.

${ }^{2}$ Комплексный научно-исследовательский институт им. Х.И. Ибрагимова Российской академии наук, г. Грозный, Россия,

*E-mail: zaburaeva@inbox.ru
}

УДК: 332.3 (631+379.85) DOI: $10.21177 / 1998-4502-2018-10-$ 1-35-47

В статье обоснована концепция сбалансированного землепользования. Показана роль правового регулирования землепользования. Приведены зарубежные подходы к разработке оптимизационной модели землепользования. Предложен алгоритм оптимизации землепользования в регионах Северо-Восточного Кавказа. На основании анализа проблем и с учетом выявленных благоприятных предпосылок сбалансированного землепользования 6 регионах Северо-Восточного Кавказа предложены пути оптимизации землепользования c картографической визуализацией на муниципальном уровне

\section{КЛЮЧЕВЫЕ СЛОВА:}

сбалансированное землепользование, горные регионы, урбогеосистемы, оптимизация, устойчивое развитue

Статья поступила в редакцию 25.07.2017 
зования ориентирована на обеспечение рационального использования и охраны земельных ресурсов, воспроизводство продуктивного потенциала сельскохозяйственных земель и повышение благосостояния людей [1]. Ее реализация возможна лишь посредством планирования землепользования в контексте концепции устойчивого развития [2].

Речь идет об обеспечении экологизации землепользования, базирующейся на нормативно-правовых основах [3]. В России порядок использования природных ресурсов и в целом экологические отношения, охрана окружающей среды регламентируются как основным законом государства - Конституцией РФ, так и международными договорами, специальными законодательными актами, указами Президента РФ. Источниками экологического права выступают также нормативные правовые акты федеральных органов исполнительной власти, субъектов РФ и органов местного самоуправления. Общие принципы регулирования отношений в сфере охраны окружающей среды и рационального природопользования на федеральном и региональном уровне закреплены в Конституции РФ (ст. 72). В настоящее время основным законодательным актом экологического права в РФ выступает Федеральный закон «Об охране окружающей среды», принятый в 2002 г.

Важнейший инструмент правового регулирования землепользования - земельный кодекс РФ, в соответствии с которым земля должна охраняться как основа жизни и деятельности человека, природный объект и средство производства. Земельное законодательство в регионах Северо-Восточного Кавказа базируется на Конституции РФ, Земельном кодексе РФ и иных нормативно-правовых актах федерального (законы «Об обороте земель сельскохозяйственного назначения», «Об особо охраняемых природных территориях», «О землеустройстве» и др.) и регионального (Конституции Чечни, Дагестана, Ингушетии, законы Чечни и Ингушетии «О земельных отношениях», закон Дагестана «О земле» и др.) уровня (рис. 1).

Система управления устойчивым землепользованием помимо нормативно-правовых инструментов должна включать эколого-экономические (экологизация сельскохозяйственного производства, сбалансированное соотношение между использованием и охраной земельных ресурсов и др.) и социальные (экологическое образование, воспитание и др.) [4]. Некоторые авторы в оптимизации землепользования видят наибольший эффект в мотивации личного и публичного землепользования посредством экономического инструментария фискальной политики - налогообложения и штрафов [5]. В целом модернизация горных территорий и их устойчивое развитие должны быть ориентированы на экономический рост при условии обеспечения социальной эффективности и экологической безопасности [6]. В ряде регионов России (на
Алтае, в Дагестане) уже наметились тенденции модернизации некоторых горных районов посредством развития туризма и современных IT-технологий [7].

При оптимизации системы землепользования необходимо учитывать существующую структуру земельного фонда регионов. Дискуссии относительно оптимального баланса между формами использования земель в науке идут с давних пор (В.В. Докучаев, Д.Л. Арманд, А.Г. Исаченко, Н.Ф. Реймерс и др.) и весьма далеки от единой позиции. При определении оптимальной структуры землепользования следует учитывать ряд факторов: специфика ландшафтной структуры, развития региона, урожайность на единицу площади и др. Экологические нормы соотношения структуры землепользования наиболее детально проработаны для степной зоны (В.В. Докучаев, Н.Ф Реймерс, А.А. Молчанов, Н.И. Парфенова и др.). Исследуемые регионы Северо-Восточного Кавказа расположены в нескольких природных зонах - начиная от засушливой полупустынной зоны и заканчивая зоной альпийских лугов и ледников.

В соответствии с действующим законодательством Российской Федерации структура землепользования определяется категориями земель, выделяемыми по целевому назначению. Согласно концепции сбалансированного землепользования структура землепользования должна включать использование (земли сельскохозяйственного назначения, поселений, промышленности, транспорта и иного назначения), охрану (особо охраняемые природные территории) и воспроизводство (земли лесного, водного фонда, запаса). Несмотря на территориальную общность и аграрную специализацию экономики регионы Северо-Восточного Кавказа отличаются по структуре землепользования (рис. 2-4). Так, доля земель сельскохозяйственного назначения варьирует в пределах 41,6-86,4\%, а запаса - от 0 до $22,7 \%$. Данная структура резко отличается и от общего фона по стране, где преобладают земли лесного фонда (рис. 5).

В таком ключе в стране в целом в блок «Использование» входит около 1/4 её территории. В Чечне, Ингушетии и Дагестане этот показатель превышен в 2,9; 1,8 и 3,6 раза соответственно. По мнению Л.М. Бурлаковой [8], разрабатывавшей экологические нормативы для Алтайского края, для аграрноориентированного региона оптимальным является наличие не менее $68 \%$ сельхозугодий. В условиях Северо-Восточного Кавказа такой высокий показатель, на наш взгляд, может спровоцировать усиление почворазрушающих процессов (в первую очередь эрозии и засоления).

Наша позиция близка к расчетам Н.Ф. Реймерса. С учетом региональной специфики исследуемых субъектов (рельефа, развития экономики и др.), экологических параметров, предложенных предыдущими исследователями, полагаем, что в целом по регионам доля «используемых» земель должна быть в пре- 


\begin{tabular}{|c|c|}
\hline & ІОЛЬЗОВАНИЕ / LAND USE \\
\hline $\begin{array}{l}\text { Федеральные законы, } \\
\text { нормативы, акты / Federal laws, } \\
\text { standards, acts: } \\
\text { 1. Земельный кодекс (2001) / } \\
\text { Land соде (2001). } \\
\text { 2. Конституция (1993) / } \\
\text { Constitution (1993). } \\
\text { 3. Закон «Об обороте земель } \\
\text { сельскохозяйственного } \\
\text { назначения» (2002) / Law «About } \\
\text { land turnover of agricultural } \\
\text { purposee» (2002) } \\
\text { 4. Закон «Об охране } \\
\text { окружающей среды» (2002) / } \\
\text { Environment protection act (2002) } \\
\text { 5. Закон «Об особо охраняемых } \\
\text { природных территориях» (1995) } \\
\text { / Law «On specially protected } \\
\text { natural territories» (1995) } \\
\text { 6. Закон «O землеустройстве» } \\
\text { (2001) / Law «About Land } \\
\text { Management» (2001) } \\
\text { 7. Градостроительный кодекс } \\
\text { (2004) / Urban Development } \\
\text { Code (2004) }\end{array}$ & 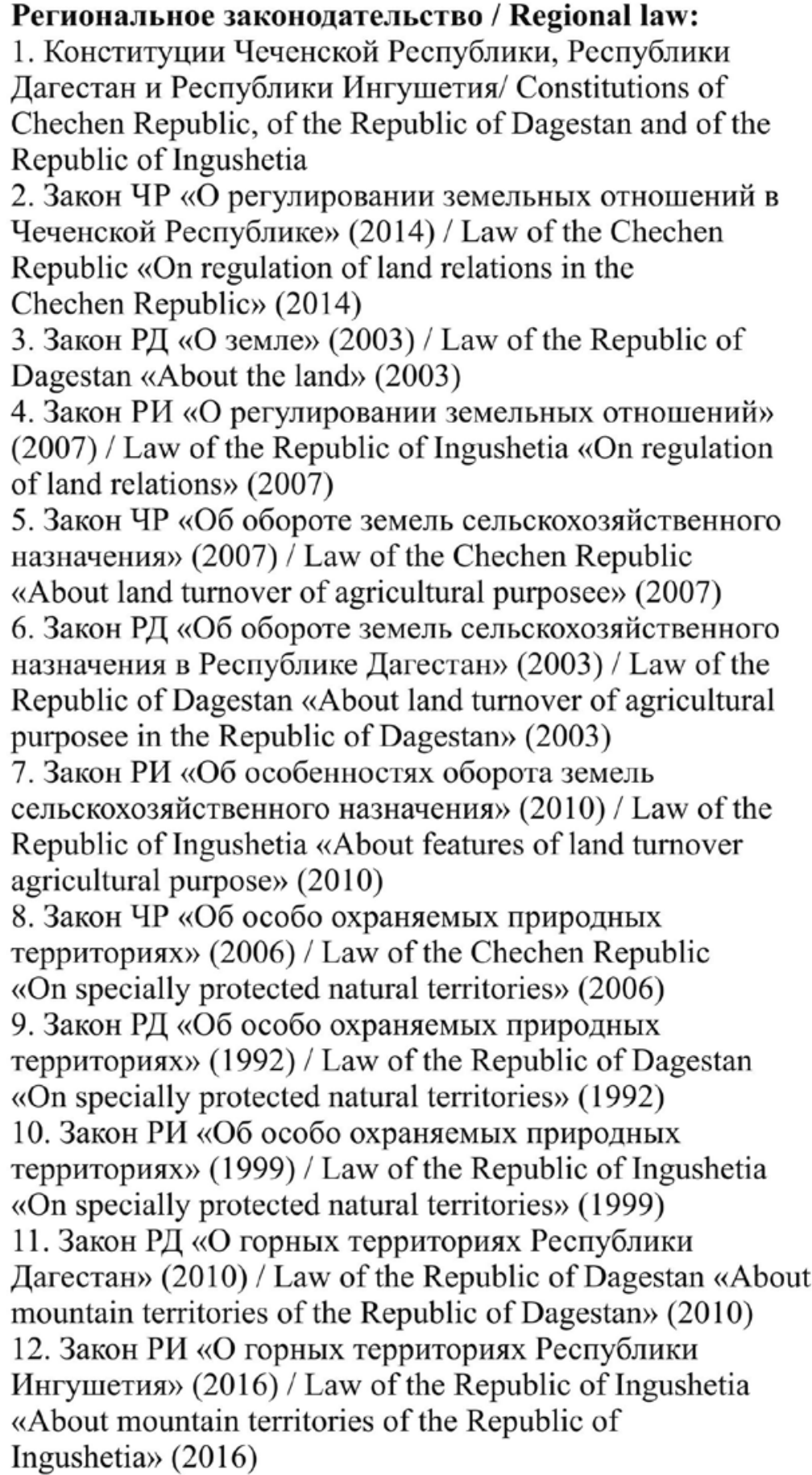 \\
\hline
\end{tabular}

Примечание: ЧР - Чеченская Республика, РД - Республика Дагестан, РИ - Республика Ингушетия / Note: ЧР - Chechen Republic, РД - Republic of Dagestan, РИ - Republic of Ingushetia

Pис. 1. Правовые основы регулирования землепользования в регионах Северо-Восточного Кавказа /

Fig. 1. Legal bases of regulation of land use in regions of the Northeast Caucasus 


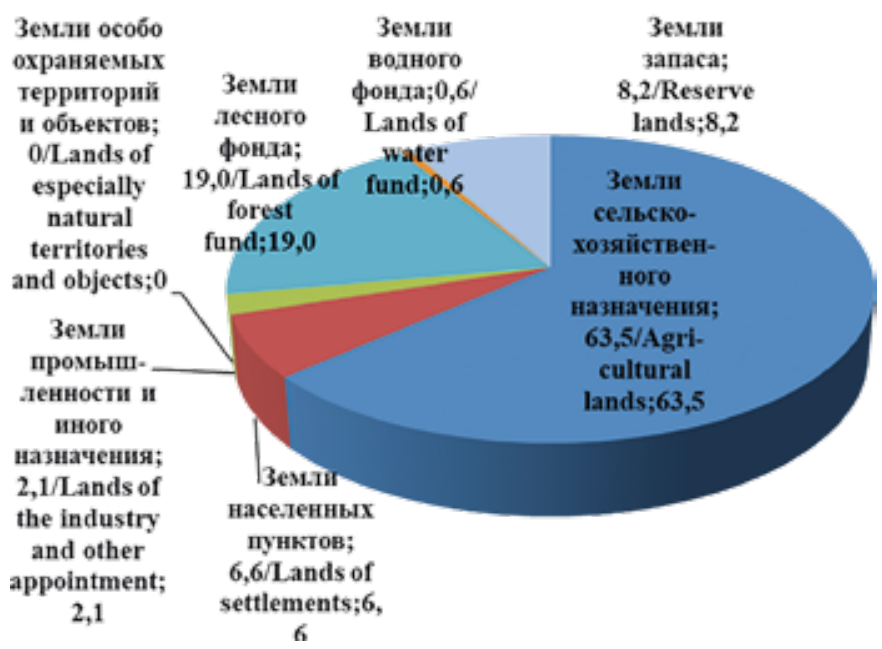

Puc. 2. Структура земельного фонда Чеченской Республики /

Fig. 2. Land fund structure of Chechen Republic

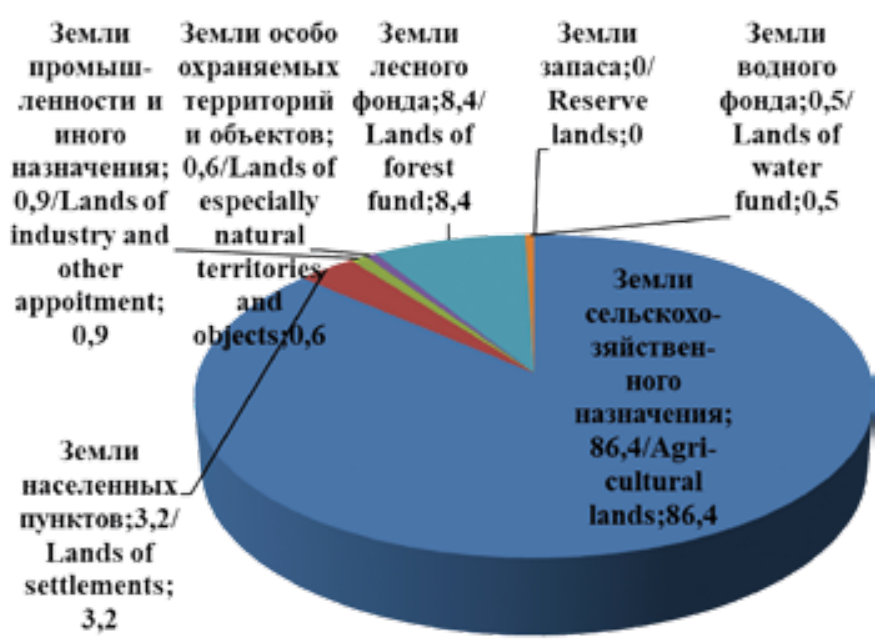

Рис. 4. Структура земельного фонда Республики Дагестан /

Fig. 4. Land fund structure of Republic of Dagestan

делах 30-40\%, а остальная часть должна включать категории, отнесенные к охране и воспроизводству (земли особо охраняемых природных территорий, запаса, водного и лесного фонда). Внутри субъекта с учетом ландшафтной зоны данное соотношение будет отличаться.

Важную роль в обеспечении сбалансированности и в целом устойчивого развития играют земли особо охраняемых природных территорий. В регионах Северо-Восточного Кавказа на их долю приходится от $11,8 \%$ в Дагестане до $19,6 \%$ в Чечне и $20,9 \%$ в Ингушетии. Однако в действительности они включены в другие категории и в соответствующей категории земель либо не отражаются, либо учтена их незначительная доля ввиду того, что организованы без изъятия у землепользователей. В данной ситуа-

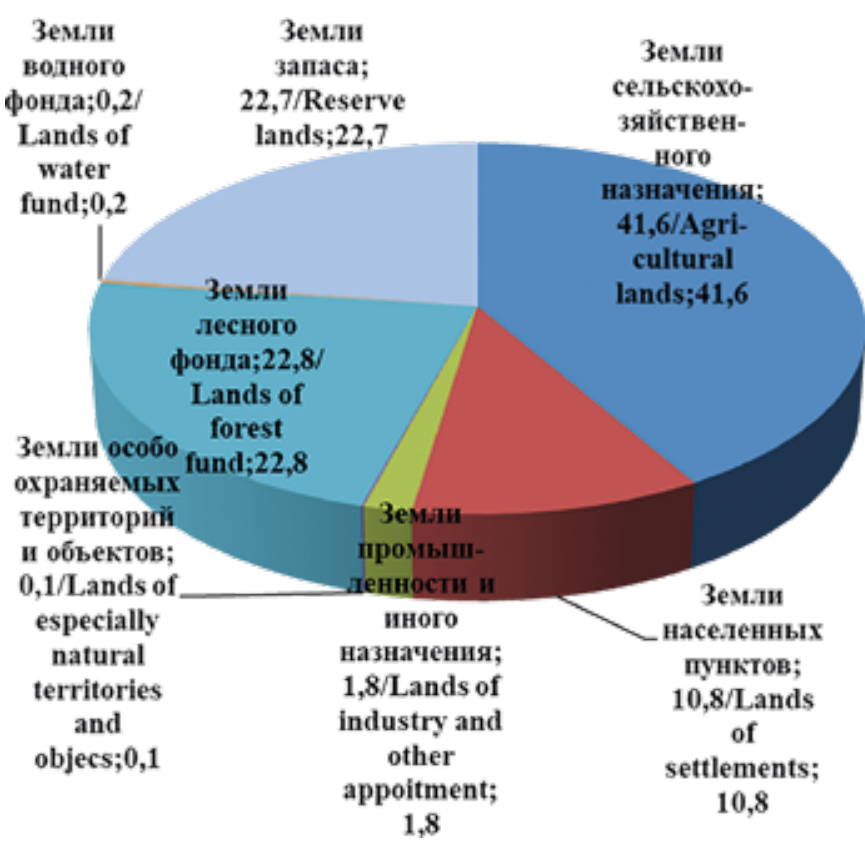

Рис. 3. Структура земельного фонда Республики Ингушетия /

Fig. 3. Land fund structure of Republic of Ingushetia

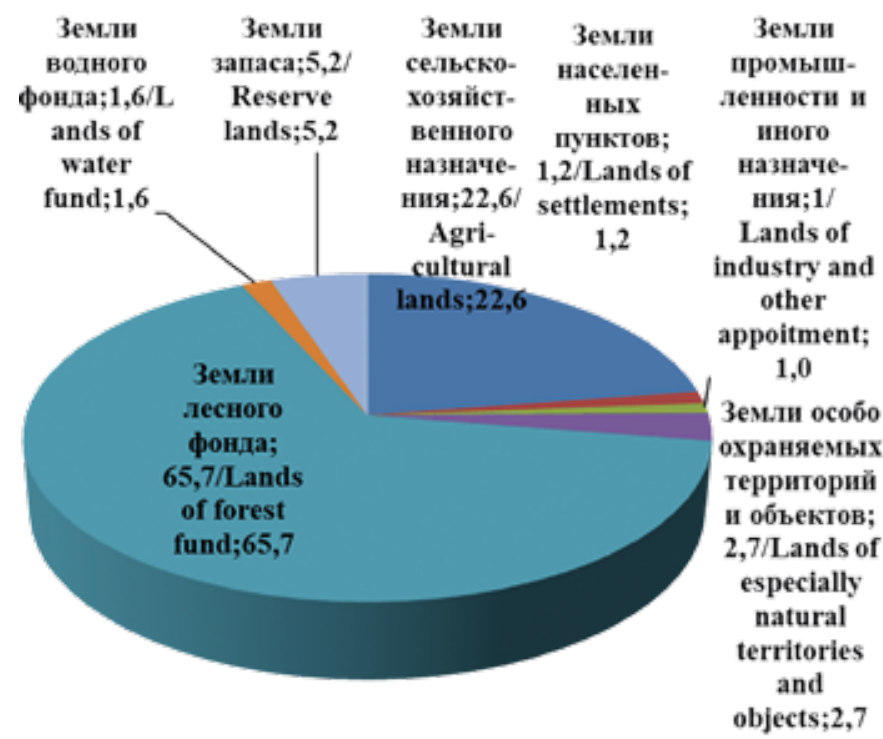

Puс. 5. Структура земельного фонда Российской Федерации / Fig. 5. Land fund structure of Russian Federation

ции сложно объективно оценить фактическое землепользование. Важен учет и структура земель особо охраняемых природных территорий, формирующих данную категорию. На Северо-Восточном Кавказе отсутствуют национальные парки, а в Чечне и заповедники. В общей доле таких земель доминируют государственные природные заказники федерального и регионального уровней.

В комплексных исследованиях горных территорий для устойчивого развития выделяют три важнейших концептуальных подхода, основанных на покомпонентном анализе и синтезе природы, хозяйства и населения горной территории, обособлении ведущей проблемы (проблемно-ориентированный подход) и глубоком анализе социальных процессов (социально-ориентированный подход) [9]. 
Как показывает мировая практика в развитии горных стран приоритетными остаются индустриальное, аграрное и рекреационное направления. Первые два из них с геоэкологических подходов наименее привлекательны ввиду уязвимости и чувствительности горных геосистем к антропогенным воздействиям. В ряде европейских горных стран рекреационная деятельность выступает в качестве наиболее оптимальной и высокодоходной отрасли экономики, в том числе развитие симбиоза аграрной и туристской сфер деятельности [10;11]. Конечно же в условиях регионов Северо-Восточного Кавказа с учетом их аграрной направленности отказ от развития данного сектора экономики не представляется возможным и необходимым. Традиционные виды землепользования следует развивать и модернизировать, при этом необходимы инновационные научно-обоснованные подходы к планированию развития горных регионов [12].

Универсальных моделей по оптимизации землепользования, которые могли бы применяться повсеместно, не существует. Они должны разрабатываться с учетом региональных особенностей и могут включать различные этапы. Некоторые авторы считают, что оптимизационная модель на начальном этапе предполагает обработку статистических данных с целью прогноза спроса на пахотные земли, земли застройки и исходя из этого строится региональная модель землепользования [13]. Модели развития горных территорий должны быть адаптированы к конкретным географически условиям местности и учитывать устои, традиции природопользования (землепользования) коренных этносов [14].

Полагаем, что алгоритм оценки и оптимизации землепользования должен включать три этапа (рис. 6). На начальном этапе необходима мониторинговая оценка земель - комплексные непрерывные наблюдения за качественным состоянием земель (бонитировка почв, развитие деградационных процессов). Процесс разработки стратегического плана управления земельными ресурсами в условиях аграрноориентированной территории предполагает выявление проблем землепользования [15]. Данная оценка включает также сведения о правовом режиме земель и контроль за выполнением землепользователями природоохранных мероприятий.

На следующем этапе необходимы анализ динамики этих процессов и оценка потенциала (земельноресурсного, человеческого, минерально-сырьевого, биоразнообразия), способного обеспечить сбалансированное землепользование. Заключительный этап оптимизации землепользования в регионах $\mathrm{Ce}$ веро-Восточного Кавказа предполагает разработку приоритетных направлений с учетом результатов, полученных на предыдущих этапах с обеспечением сохранения и воспроизводства природно-ресурсного потенциала, био- и этнокультурного разнообразия.
Важная роль отводится оценке последствий развития данных направлений и в последующем их учету в развитии и прогнозировании землепользования.

Учитывая аграрную направленность экономики горных регионов Северо-Восточного Кавказа (в контексте устойчивого развития), а также сложившиеся давние традиции, устои и нынешние реалии и тенденции мирового развития в исследуемых регионах, следует развивать три направления: агропромышленный комплекс, систему особо охраняемых природных территорий и туристско-рекреационную деятельность (рис. 7). Однако условия ведения сельскохозяйственного производства здесь существенно отличаются от равнинных целым рядом характерных особенностей, накладывающих свой отпечаток на уровень экологически безопасного и экономически эффективного функционирования агроэкосистем (вертикальная поясность почвенного и растительного покрова, сильная расчлененность рельефа, мелкоконтурность землепользования и др.).

При оптимизации использования сельскохозяйственных земель важная роль отводится их защите от загрязнителей, в частности, химических [16], а также борьбе с деградацией земель (водной и ветровой эрозией, засолением, дегумификацией и др.). Здесь имеется значительный потенциал (земельно-ресурсный, человеческий, биоклиматический) для развития агропромышленного комплекса [17].

Для реализации вышеуказанных целей требуется ряд условий, включая следующие:

Внедрение адаптивных форм землепользования.

Полнота использования пахотных земель.

Подготовка высококвалифицированных кадров землеустроителей, агрономов и др.

Кооперация растениеводческой и животноводческой отраслей.

Обновление и расширение материально-технической базы.

Межрегиональное сотрудничество с учетом разделения труда (преобладание растениеводства в Чечне и Ингушетии, а в Дагестане - животноводства, рыболовства).

С учетом природно-климатических и почвенногеоморфологических условий в ряде районов нами рекомендуется приоритетное развитие земледелия, а в других - животноводства. Зона земледелия включает районы (преимущественно в степной зоне), в которых сельскохозяйственные угодья представлены в основном пахотными угодьями (Малгобекский, Сунженский, Грозненский, Хасавюртовский, Бабаюртовский и др.). Здесь сосредоточены черноземные, лугово-каштановые, каштановые и другие разновидности почв.

Росту урожайности и валового сбора сельскохозяйственной продукции в исследуемых регионах будет способствовать и вовлечение в оборот неис- 


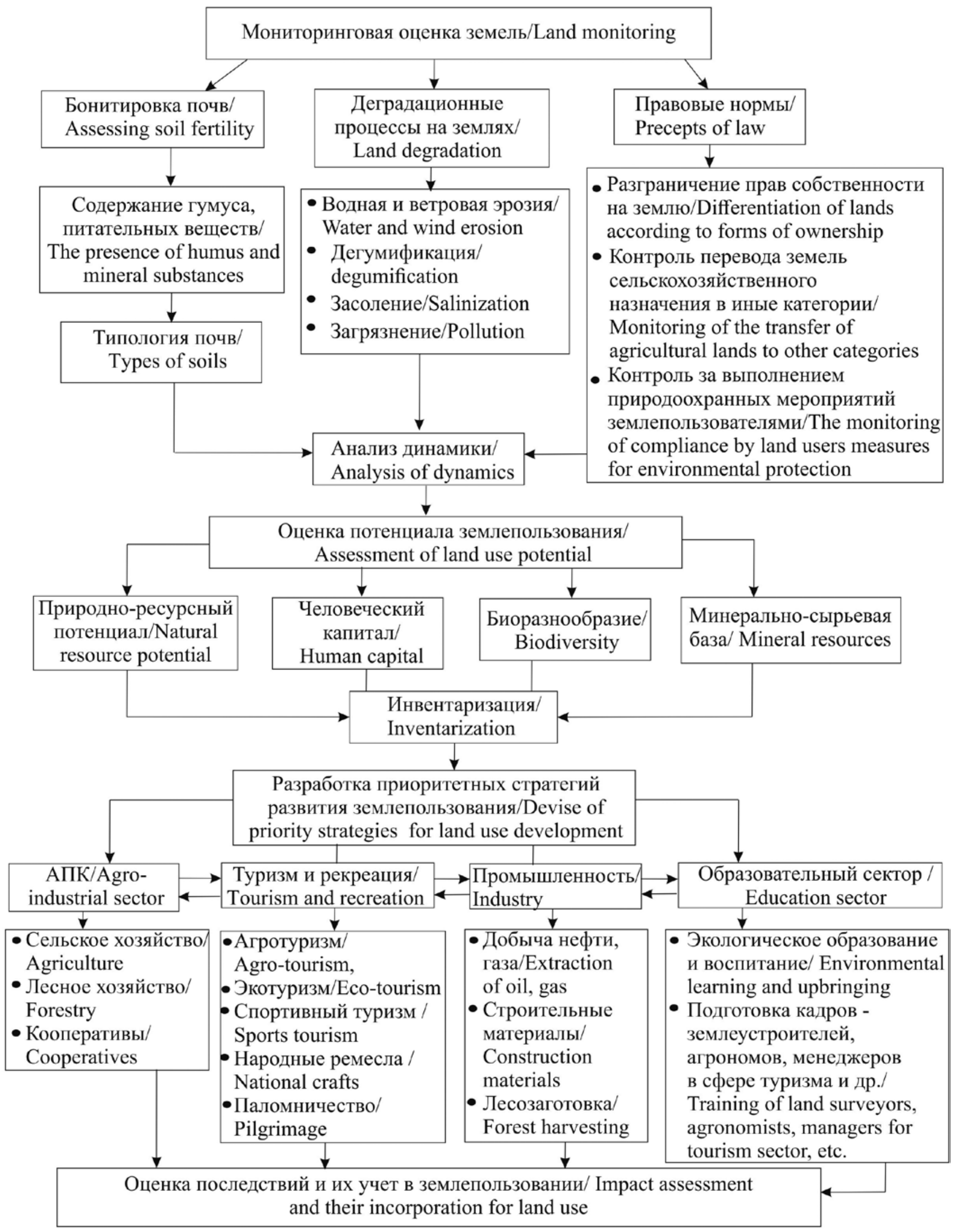

Puc. 6. Алгоритм оченки и оптимизации землепользования /

Fig. 6. Algorithm of an assessment and optimization of land use 


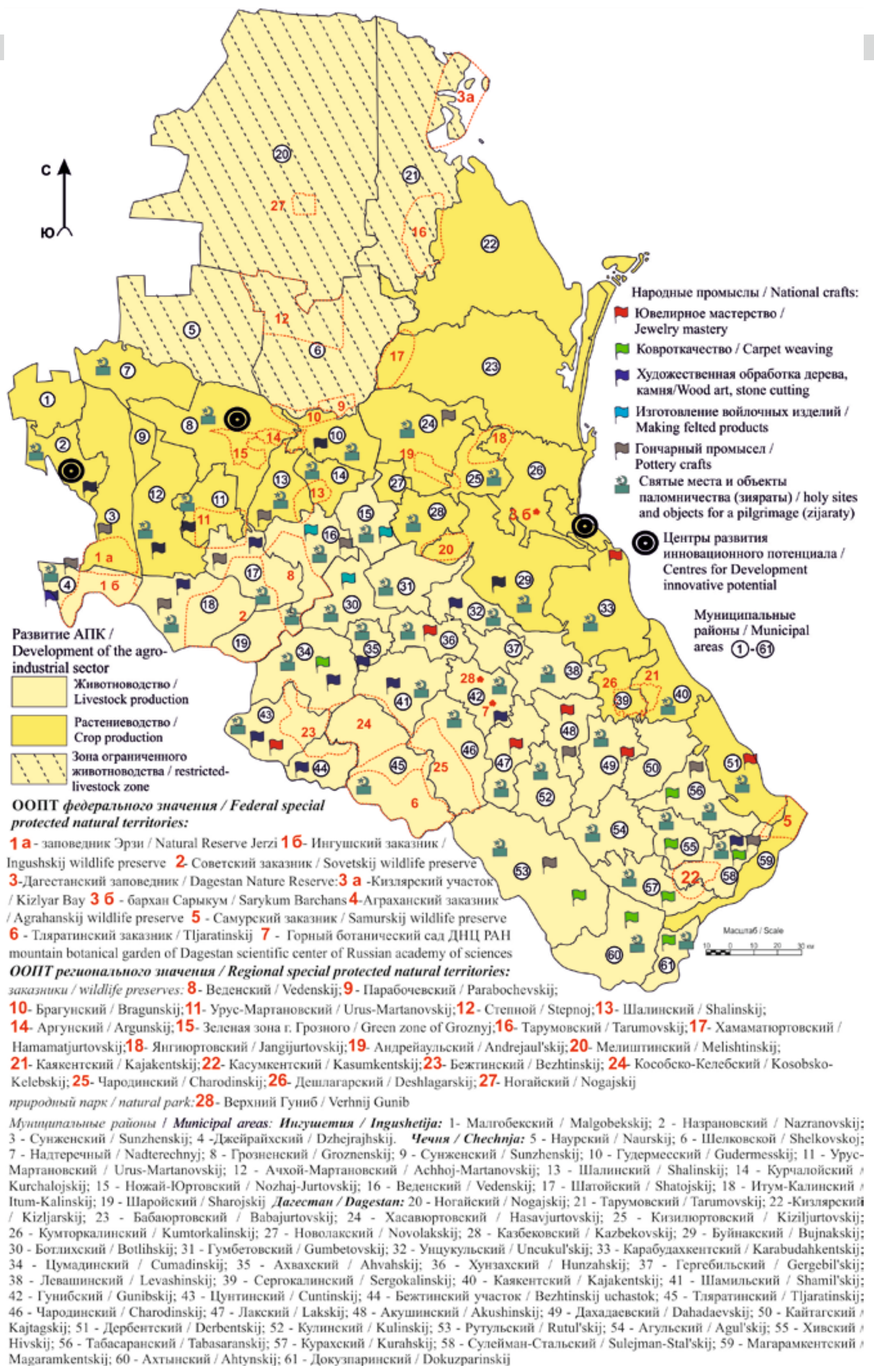

Pис. 7. Рекомендуемые направления землепользования в регионах Северо-Восточного Кавказа I

Fig. 7. The recommended directions of land use in regions of the Northeast Caucasus 
пользуемой пашни, в т. ч. пашни под минами (Чечня), достаточное внесение минеральных и органических удобрений. Доля неиспользуемой пашни в ряде районов достигает 20-40\% (Урус-Мартановский, Шалинский, Назрановский, Кумторкалинский и др.).

В низменной и горной частях наиболее перспективно развитие животноводства. При этом в первой оно должно иметь щадящие формы, поскольку здесь получили развитие процессы опустынивания и в целом данная зона уязвима в геоэкологическом отношении. В пределах Чечни - это территория Наурского и Шелковского районов, в а Дагестане - Ногайский и Тарумовский районы. Рекомендация приоритетного направления АПК не исключает возможности использования данных земель в иных целях. Например, в ряде горных районов благоприятные условия для возделывания экологически чистого картофеля, зернобобовых культур. Однако это имеет крайне фрагментарный характер.

В числе факторов, лимитирующих сбалансированное землепользование на Северо-Восточном Кавказе: деградационные процессы на землях (водная и ветровая эрозия почв, засоление, дегумификация и др.) и сосредоточение свыше половины всех пахотных угодий в острозасушливой зоне. Все это в совокупности с другими причинами не позволяет вовлекать в оборот все балансовые площади сельскохозяйственных земель. Среди регионов Северо-Восточного Кавказа более полно пахотные угодья используются в Ингушетии (70\%) и в Дагестане (68\%). В Чечне используется лишь половина пашни (52\%).

Сбалансированное землепользование не сводится чисто к аграрному (земледелие) и включает наряду с безопасным сельскохозяйственным производством, все аспекты рациональной и экономически эффективной структуры землепользования, создание наилучших и безопасных условий для различных форм жизнедеятельности населения, как ныне живущих, так и будущих поколений.

Другое перспективное направление развития регионов Северо-Восточного Кавказа - туристско-рекреационная сфера. Данный потенциал представлен сохранившимися до наших дней видами народного промысла (ювелирная обработка металлов, насечка металлом по дереву, гончарное дело, ковроткачество и др.), объектами паломничества и культурно-историческим наследием (склепы, башенные строения и др.).

Северо-Восточный Кавказ издавна населяют десятки этносов, сохранивших уникальные традиции и культурно-нравственный облик. Традиционные народные промыслы, сложившиеся на Северо-Восточном Кавказе еще в эпоху средневековья и получившие известность далеко за его пределами, не только свидетели древней и долгой истории народов Северо-Восточного Кавказа, часть их культурного наследия, но и огромный потенциал устойчивого развития.
Изучение территориальной организации промыслов позволяет наметить пути их сохранения и дальнейшего развития в период формирования туристско-рекреационной индустрии Северо-Восточного Кавказа.

Значительная доля данного потенциала сосредоточена в горных и высокогорных районах, где сохранились и продолжают передаваться из поколения в поколение семейные секреты мастеров ювелирного, гончарного и другого ремесла, во многом благодаря сохранившейся внутриобщинной замкнутости и целостности [18]. Высочайшее искусство исполнения воплощается в женских украшениях, предметах сервировки стола, письменных приборах, различных видах оружия (мечей, луков, ножей, шлемов).

Безусловно, ассортимент продуктов, в частности, ювелирного мастерства с момента зарождения претерпел значительные изменения. Если в средние века ремесло кузнецов во многом подразумевало кольчуги, мечи и сабли, то к настоящему времени наиболее актуальны ювелирные украшения, холодное декоративного оружие, вышивки золотом и серебром и т.д. Ювелирное мастерство сохранилось в Дахадаевском (с. Кубачи), Хунзахском (с. Гоцатль), Лакском (с. Кумух) и других районах. Ковроткачеством занимаются мастера Ахтынского (с. Ахты), Докузпаринского (с. Микрах), Табасаранского (с. Хучни, Аркит) и ряда других районов. Мастеров гончарного ремесла можно найти в равнинной части - в Хасавюртовском районе (с. Сулевкент), в горной - в Шатойском (с. Шатой), Джейрахском (с. Ляжги), Сулейман-Стальском (с. Испик) и других районах. Изготовление войлочных изделий встречается реже и по нашим данным сохранилось лишь в Ботлихском (с. Рахата), Веденском (с. Ведено) и Ножай-Юртовском (с. Симсир) районах.

Памятники истории и культуры распространены повсеместно, хотя имеют дифференцированный характер по типу рельефа. На равнине они преимущественно представлены памятниками воинам ВОВ, домами, в которых жили знаменитости, обелисками, курганными группами, а в горной части - сторожевыми, оборонительными, сигнальными башнями, барельефами, надземные склепами, святилищами и др.

Для эффективного функционирования и развития туристско-рекреационной сферы необходимо обеспечить: разработку межрегиональных программ развития туризма (в т. ч. создание туристических маршрутов); создание благоприятного инвестиционного климата; создание инфраструктуры; подготовку высококвалифицированных менеджеров в сфере туризма; выделение экономических зон на территории Чечни, Ингушетии и Дагестана, характеризующихся наличием туристско-рекреационного потенциала (памятников истории и культуры, объектов для паломничества и др.).

Сохранению этногенетического разнообразия 
Северо-Восточного Кавказа будет способствовать сохранение и обогащение этногенетического потенциала Чечни, Дагестана и Ингушетии; формирование межрегионального и межэтнического интереса к культуре и традициям этносов, населяющих Северо-Восточный Кавказ; проведение этнокультурных фестивалей, ярмарок народных промыслов; формирование межэтнической толерантности и устранение барьеров (административных, экономических и др.) для межрегионального сотрудничества в сфере услуг, торговли и пр.

Система особо охраняемых природных территорий (ООПТ) призвана обеспечить «сбалансированность» антропогенного воздействия и способствовать устойчивому развитию регионов. Велика роль системы ООПТ в сохранении биоразнообразия и обеспечении устойчивого (сбалансированного) развития [19; 20]. ООПТ Северо-Восточного Кавказа не являются системой, т.к. представлены разрозненными участками охраняемых территорий различных категорий. В целом на Северо-Восточном Кавказе на их долю приходится около 15\% (1016 тыс. га) территории.

Важная роль в обеспечении сбалансированного землепользования и в целом устойчивого развития регионов Северо-Восточного Кавказа отводится формированию на этой территории геоэкологического каркаса. Он должен обеспечить организацию путей миграции животных и ликвидацию административных барьеров в организации сети ООПТ.

В высокогорной части на базе заповедников и заказников Чечни, Ингушетии и Дагестана, имеющих федеральный и региональный статус, видится целесообразным организация трансграничного биосферного заповедника с целью сохранения уникального биологического разнообразия этой зоны. Реализация этого проекта требует разработку научных основ для устойчивого функционирования формируемого заповедника путем межрегиональной координации, а в последующем - функциональное зонирование территории данного биосферного заповедника с выделением зон абсолютного заповедования и территорий для развития научно-познавательного туризма.

Оптимизация землепользования должна осуществляться как на региональном, так и на муниципальном уровне. Особого внимания заслуживают урбогеосистемы - центры развития инновационного потенциала. В последние годы с целью анализа структуры и эффективности землепользования широко применяются методы дистанционного зондирования, позволяющие проследить и динамику землепользования [21].

Крупные урбогеосистемы Северо-Восточного Кавказа следует развивать как по традиционным направлениям (промышленность, туризм, оптовый/розничный оборот товаров потребления), так и путем внедрения в науку, образование и производственную сферу инновационных технологий [22]. В Махачкале, Грозном и Назрани сосредоточены основные образовательные учреждения, научно-исследовательские базы, положительное сальдо миграции, естественный прирост населения. Здесь имеются благоприятные предпосылки для развития и наращивания инновационного потенциала. Однако реализация этих задач потребует достаточных затрат, как в плане инвестиций, так и по времени реализации. Формирование и использование инновационных ресурсов (материальных, финансовых, интеллектуальных) позволят повысить уровень социально-экономического развития городов, роста благосостояния населения и обеспечить экологическую безопасность урбогеосистем.

\section{Выводы}

Оптимизация землепользования - важнейшая стратегическая задача в условиях регионов СевероВосточного Кавказа с быстро растущим населением. С учетом дифференциации физико-географических, природно-климатических условий и природно-ресурсного, биоклиматического, этногенетического, рекреационного, инновационного потенциалов в исследуемых регионах в качестве приоритетных выделены: развитие агропромышленного комплекса, системы особо охраняемых природных территорий и туристско-рекреационной сферы.

Устойчивое (неистощительное) развитие земледелия перспективно в равнинных районах с наиболее плодородными почвами, целинными землями при научно-обоснованном подходе к его организации. Для животноводства благоприятные условия имеются в горных и отчасти низменных районах.

Северо-Восточный Кавказ издавна населяют десятки этносов, сохранивших уникальные традиции и культурно-нравственный облик. Традиционные народные промыслы - не только свидетели древней и длительной истории народов Северо-Восточного Кавказа, часть их культурного наследия, но и огромный потенциал устойчивого развития. Значительная его доля сосредоточена в горных и высокогорных районах, где сохранились и продолжают передаваться из поколения в поколение семейные секреты мастеров ювелирного, гончарного дела и др. Следует наметить пути сохранения народных промыслов и их дальнейшего развития в период формирования туристско-рекреационной индустрии Северо-Восточного Кавказа.

В исследуемых регионах преобладает сельское население, тем не менее в стратегическом планировании их развития особое внимание следует уделять крупным геосистемам, поскольку здесь сосредоточена основная доля образовательных и научно-исследовательских учреждений и значителен трудовой потенциал. Такие крупные города как Грозный, Махачкала и Назрань следует развивать как по традиционным направлениям (промышленность, туризм, оптовый/розничный оборот товаров потребления), 
так и путем внедрения в науку, образование и производственную сферу инновационных технологий.

Оптимизация землепользования предполагает формирование на территории Северо-Восточного Кавказа геоэкологического каркаса, обеспечивающего беспрепятственную миграцию животных и ликвидацию административных барьеров в организации системы особо охраняемых природных территорий.
Эта система призвана обеспечить экологическое равновесие при интенсивном хозяйственном использовании земель. Туристско-рекреационный потенциал регионов Северо-Восточного Кавказа позволяет развивать здесь различные виды туризма, в частности, научно-познавательный, аграрный, этнографический, спортивно-оздоровительный, экстремальный, а также паломничество к святым местам (зияраты).

\section{КРИТЕРИИ АВТОРСТВА / Contribution:}

Забураева Х.Ш. - проанализировала и обобщила данные, разработала алгоритм оценки и оптимизации землепользования, написала рукопись и несет ответственность за плагиат; Заурбеков Ш.Ш., Таймасханов Х.Э. - участвовали в анализе правовых основ землепользования / Zaburaeva Kh. Sh. - analyzed and summarized the data, developed the algorithm of an assessment and optimization of land use, wrote the manuscript and responsible for plagiaris; Zaurbekov Sh. Sh., Taymaskhanov Kh.E. - participated in the analysis of the legal basis of land use.

\section{КОНФЛИКТ ИНТЕРЕСОВ / Conflict of interest:}

Авторы заявляют об отсутствии конфликта интересов / The authors declare no conflict of interest.

\section{ЛИТЕРАТУРА:}

1. Забураева Х. Ш. Проблемы и предпосылки сбалансированного землепользования в Чеченской Республике: монография. Калининград: Страж Балтики, 2010. 211 с.

2. Paul De Wit, Willy H. Verheye. Land use planning for Sustainable Development. Land use, land cover and soil sciences. 2009. Vol. III. P. 33-60.

3. John R. Nolon. Compendium of land use laws for Sustainable Development. Cambridge University. 2006. 442 p.

4. Польшакова Н.В. Системное управление переходом к устойчивому землепользованию // Научный альманах. 2016. N 2-1 (16). C. 306-309. DOI: 10.17117/ na.2016.02.01.306.

5. Киреева Е.Е. Эколого-экономическая эффективность управления землепользованием // Вестник ВСГУТУ. 2015. N 2. C. $94-101$.

6. Гуня А.Н. Модернизация и устойчивое развитие горных территорий // Устойчивое развитие горных территорий. 2016. Т. 8. N 4. С. 281-288.

7. Баденков Ю.П., Дунец А.Н., Мудуев Ш.С., Мухаббатов Х.М. Модернизация и развитие горных районов: советский и российский опыт // Устойчивое развитие горных территорий. 2016. Т. 8. N 4. С. 323-337.

8. Бурлакова Л.М. Стратегическое управление земельными ресурсами в системе управления устойчивым развитием аграрного природопользования // Вестник Алтайского государственного аграрного университета. 2007. N 10 (36). С. 5-9.

9. Гуня А.Н. Социально-ориентированные концепции и подходы в исследовании горных территорий Кавказа и обеспечении устойчивого развития // Устойчивое развитие горных территорий. 2015. N 3 (25). С. 15-22.

10. Rural tourism in France - supplementary activities on the farm. URL: http://vranicarajac.wordpress.com/2012/05/16/ rural-tourism-in-france-supplementary-activities-on-the-farm/ (дата обращения: 18.06.2017).

11. Rural tourism in Italy. URL: http:/www.italianreflections.com/2010/04/rural-tourism-in-italy.html (дата обращения: 18.06.2017).
12. Sustainable Development in Mountain Regions: Southeastern Europe / Editor Georgi Zhelezov. Switzerland: Springer, 2016. $404 \mathrm{p}$.

13. Wenbo Chen, Gerrit J. Carsjens. A spatial optimization model for sustainable land use at regional level in China: a case study for Poyang lake region // Sustainability. 2015. Vol. 7. P. 35-55.

14. Бурдзиева О.Г., Чотчаев Х.О., Маммадли Т.Я. Модель поддерживаемого развития горных территорий Северного Кавказа // Устойчивое развитие горных территорий. 2016. Т.8. N 4. С. 348-359.

15. Шарабарина С.Н. Стратегическое управление в целях оптимизации землепользования аграрно-ориентированной территории // Международный журнал прикладных и фундаментальных исследований. 2013. N 5. C. $70-73$.

16. Vink A.P.A. Land use in advancing agriculture. Springer-Verlag. Berlin Heidelberg. New York. 1975. 383 p.

17. Краснов Е.В., Забураева Х.Ш. Горная Чечня и сопредельные территории Северо-Восточного Кавказа: потенциал устойчивого землепользования // Устойчивое развитие горных территорий. 2012. N 3 (13). С. 158-163.

18. Магомедов А.Д. Этнолингвистические аспекты изучения народных промыслов и ремесел Дагестана // Вестник института языка, литературы и искусства им. Г. Цадасы. 2013. N 3. С. 34-51.

19. Онищенко В.В., Тамбиев Б.Н., Узденова Ф.М. К вопросу преобразования государственных заповедников в устойчивом развитии Северного Кавказа // Устойчивое развитие горных территорий. 2015. N 2(24). С. 27-32.

20. Бердюгин К.И., Большаков В.Н. О стратегии и тактике сохранения биоразнообразия горных регионов как необходимого условия устойчивого развития // Устойчивое развитие горных территорий. 2010. N 3 (5). С. 31-38.

21. Tadesse W., Coleman T. L., Tsegaye T.D. Improvement of land use and land cover classification of an urban area using image segmentation from Landsat ETM+data. In: Proceedings 
of the $30^{\text {th }}$ International symposium on remote sensing of the environment, 10-14 Nov. 2003, Hondulu, Hawaii.

22. Забураева Х. Ш., Краснов Е. В. Анализ трансформа- ции урбогеосистем Северо-Восточного Кавказа с использованием ГИС-технологий // Вестник КрасГАУ. 2016. N 10. C. $88-94$.

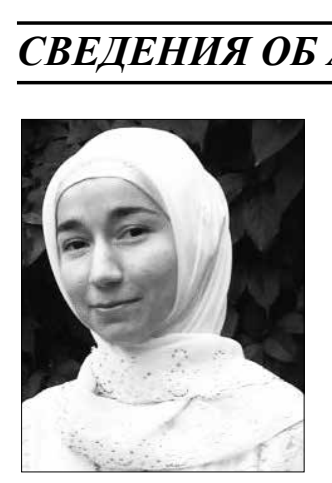
Комплексного научно-исследовательского института им. Х.И. Ибрагимова Российской академии наук, г. Грозный, Россия.

Область научных интересов: геоэкология, природопользование, медицинская экология.

Автор более 80 научных публикаций, включая 4 монографии.

Тел. +7 (966) 724-84-4,

E-mail: zaburaeva@inbox.ru

Khava Shahidovna ZABURAEVA - Candidate of Geographical Sciences, Associate Professor of the Department of Ecology and Nature Management, Grozny State Petroleum Institute named after M.D. Millionshikov, Grozny, Russia; Senior researcher of the laboratory of Geology and Geoecology, Complex Institute named after Kh.I. Ibragimov of the Russian Academy of Sciences, Grozny, Russia.

Research interests: Geoecology, Nature management, medical Ecology.

Author of more than 80 scientific publications, including 4 monographs.

Tel.: +7 (966) 724-84-4, E-mail: zaburaeva@inbox.ru
ЗАУРБЕКОВ Шарпутди Шамсутдинович - доктор географических наук, профессор, заведующий кафедрой экологии и природопользования Грозненского государственного нефтяного технического университета им. акад. М.Д. Миллионщикова, г. Грозный, Россия; заведующий лабораторией геологии и геоэкологии Комплексного научноисследовательского института им. Х.И. Ибрагимова Российской академии наук, г. Грозный, Россия.

Область научных интересов: геология, геоэкология, экология.

Автор более 140 научных публикаций, включая 6 монографий.

г. Грозный, Россия

Тел. +7(8712) 22-36-07,

Sharputdi Shamsutdinovich ZAURBEKOV - Doctor of Geographical Sciences, Professor, Head of the Department of Ecology and Nature Management, Grozny State Petroleum Institute named after M.D. Millionshikov, Grozny, Russia; Head of the laboratory of Geology and Geoecology, Complex Institute named after Kh.I. Ibragimov of the Russian Academy of Sciences, Grozny, Russia.

Research interests: Geology, Geoecology, Ecology.

Author of more than 140 scientific publications, including 6 monographs.

Tel.: +7(8712) 22-36-07

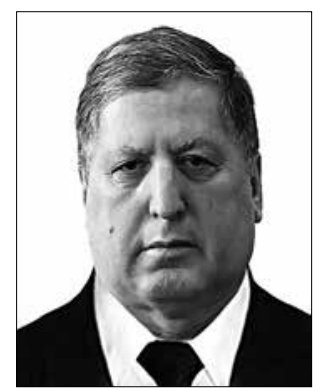

ТАЙМАСХАНОВ Хасан Элимсултанович - доктор экономических наук, профессор, ректор Грозненского государственного нефтяного технического университета им. акад. М.Д. Миллионщикова, г. Грозный, Россия; главный научный сотрудник лаборатории экономических исследований Комплексного научно-исследовательского института им. Х.И. Ибрагимова Российской академии наук, г. Грозный, Россия.

Область научных интересов: региональная экономика, экономика агропромышленного комплекса, проблемы социально-экономического развития в условиях рыночной экономики.

Автор более 170 научных публикаций, включая 25 монографий.

г. Грозный, Россия.

Тел. +7(8712) 22-36-07

Khasan Elimsultanovich TAIMASKHANOV - Doctor of Economics, Professor, Rector, Grozny State Petroleum Institute named after M.D. Millionshikov, Grozny, Russia; Chief researcher of laboratory of economic researches, Complex Institute named after Kh.I. Ibragimov of the Russian Academy of Sciences, Grozny, Russia.

Research interests: Regional economy, agricultural economy, socio-economic problems in conditions of market economy.

Author of more than 170 scientific publications, including 25 monographs.

Tel.: +7(8712) 22-36-07 


\title{
LAND USE OPTIMIZATION IN MOUNTAINOUS REGIONS OF THE NORTHEAST CAUCASUS
}

\author{
${ }^{1,2}$ Kh.Sh. Zaburaeva* \\ ${ }^{1,2}$ Sh.Sh. Zaurbekov \\ ${ }^{1,2}$ Kh.E. Taimaskhanov \\ ${ }^{1}$ Grozny State Petroleum Institute named after M.D. Millionshikov, Grozny, Russia. \\ ${ }^{2}$ Kh.I. Ibragimov Complex Institute of the Russian Academy of Sciences, Grozny, Russia.
}

\section{DOI: $10.21177 / 1998-4502-2018-10-1-35-47$}

The purpose of the article is to analyze the problems and pre-conditions of land use optimization in mountain regions of the Northeast Caucasus. To achieve this goal the authors have applied the comparative-geographical analysis, statistical and cartographic methods.

Results and discussion. The article proves that the concept of balanced land utilization is a combination of rational use and protection of land resources and reproduction of productive capacity of agricultural lands. The algorithm of land use optimization in the regions of Northeast Caucasus includes a number of serial stages: monitoring assessment of land fund condition, enclosing the analysis of dynamics of these processes, the quantitative and quality standard of potential of the steady (balanced) land use and development of the optimum directions of land use on condition of preservation of natural and resource potential, biological and ethnocultural diversity. Consequence assessment of the development of the specified directions and their subsequent consideration in development and forecasting of land use is important.

Optimization of land use has to be carried out both on regional and municipal levels. In addition, special attention should be paid to urban geological systems as centers for development of innovative potential. Large urban geological systems (Grozny, Makhachkala, Nazran) should be developed trough the improvement of traditional directions (industry, tourism, wholesale/retail commodity circulation) as well as through integration of innovation technologies in science, education and production sphere.

Conclusions. During the research the authors have revealed both positive (natural and resource, ethnogenetic, innovative potential, etc.) and negative (land degradation processes, poorly developed infrastructure, etc.) aspects for balanced land use in the regions of Northeast Caucasus. Agroindustrial complex, the system of natural protected areas, tourism and recreation activities are the most recommended as the priority direction of development. Natural-climatic and soil-geomorphological conditions in a plain (steppe zone) mainly promote agriculture development, and in a mountain part - livestock production. In the Northeast Caucasus an important part is assigned to the formation of geoecological framework in order to ensure ecological balance in the intensive economic use of lands. Tourist and recreational capacity of this territory allows to develop here scientific and cognitive, sports, extreme, ethnographic, rural and other types of tourism.

Keywords: balanced land use, mountain regions, urban geological system, optimization, sustainable development.

\section{References}

1. Zaburaeva Kh.S. Problems and preconditions for balanced land use in the Chechen Republic: monograph. Kaliningrad: Straj Baltiki. 2010. P. 211 (in Russian).
2. Paul De Wit, Willy H. Verheye. Land use planning for Sustainable Development. Land use, land cover and soil sciences. 2009. Vol. 3. Pp. 33-60.

3. John R. Nolon. Compendium of land use laws for Sustainable Development. Cambridge University. 2006. P. 442.

4. Polshakova N.V. System management of transition to sustainable land utilization. Scientific almanac. 2016. No. 2-1 (16). Pp. 306-309 (in Russian). DOI: 10.17117/ na.2016.02.01.306.

5. Kireeva E E. Environmental and economic effectiveness of land use management. Bulletin of East Siberia State University of Technology and Management. 2015. No. 2. Pp. 94-101 (in Russian).

6. Gunya A.N. Modernization and sustainable development of mountain territories. Sustainable Development of Mountain Territories. 2016. Vol. 8, No. 4. Pp. 281-288 (in Russian).

7. Badenkov Yu.P. Dunets A.N., Muduev Sh.S., H.M. Muhabbatov Modernization and development of mountain regions: the Soviet and Russian experience. Sustainable Development of Mountain Territories. 2016.Vol. 8, No. 4. Pp. 323-337 (in Russian).

8. Burlakova L.M. Strategic management of land resources in the system of sustainable development management of agricultural use. Bulletin of Altai State Agrarian University. 2007. No. 10 (36). Pp. 5-9 (in Russian).

9. Gunya A.N. Socially-oriented concepts and approaches in the study of mountain territories of the Caucasus and ensuring sustainable development. Sustainable Development of Mountain Territories. 2015. Vol. 7, No. 3 (25). Pp. 15-22 (in Russian).

10. Rural tourism in France - supplementary activities on the farm. URL: http://vranicarajac.wordpress. com/2012/05/16/rural-tourism-in-france-supplementary-activities-on-the-farm/ (accessed date: 18.06.2017).

11. Rural tourism in Italy. URL: http://www.italianreflections.com/2010/04/rural-tourism-in-italy.html (accessed date: 18.06.2017).

12. Sustainable Development in Mountain Regions: Southeastern Europe. Edited by Georgi Zhelezov. Switzerland: Springer. 2016. P. 404.

13. Wenbo C., Gerrit J. Carsjens. A spatial optimization model for sustainable land use at regional level in China: a case study for Poyang lake region. Sustainability. 2015. Vol. 7. Pp. 35-55.

14. Burdzieva O.G., Chotchaev H.O., Mammadli T.Y. Model of the North Caucasus mountain territories supported development. Sustainable Development of Mountain Territories. 2016. Vol. 8, No. 4. Pp. 348-359 (in Russian).

15. Sharabarina S.N. Strategic management for the land 
use optimization of agricultural-oriented territory. International Journal of Applied and Fundamental Research. 2013. No. 5. Pp. 70-73 (in Russian).

16. Vink A.P.A. Land use in advancing agriculture. Springer-Verlag, Berlin, Heidelberg, New York. 1975. P. 383.

17. Krasnov E.V., Zaburaeva H.Sh. Mountain Chechnya and adjacent areas of North-Eastern Caucasus: the potential of sustainable land management. Sustainable Development of Mountain Territories. 2012. Vol. 4, No. 3 (13). Pp. 158-163 (in Russian).

18. Magomedov, A.D. Ethno-linguistic aspects of the study of folk arts and crafts of Dagestan. Bulletin of $G$. Tsadasa Institute of Language, Literature and Art. 2013. No. 3. Pp. 34-51 (in Russian).

19. Onishchenko V.V., Tambiev B.N., Uzdenova F.M. On the issue of transformation of state reserves in sustainable development of the North Caucasus. Sustainable Development of Mountain Territories. 2015. No. 2 (24). Pp. 27-32 (in Russian).
20. Berdyugin K.I., Bolshakov V.N. Strategy and tactics of mountain regions biodiversity conservation as a necessary condition for sustainable development. Sustainable Development of Mountain Territories. 2010. No. 3 (5). Pp. 31-38 (in Russian).

21. Tadesse W., Coleman T.L., Tsegaye T.D. Improvement of land use and land cover classification of an urban area using image segmentation from Landsat ETM+data. Proceedings of the 30th International symposium on remote sensing of the environment, 10-14 Nov. 2003.Hondulu, Hawaii.

22. Zaburaeva H.S., Krasnov E.V. Analysis of transformation of arbogastes North-Eastern Caucasus with the use of GIS-technologies. Bulletin of Krasnoyarsk State Agrarian University. 2016. No. 10. Pp. 88-94 (in Russian).

Article received 25.07.2017 
${ }^{1}$ Косолапов А.Е., ${ }^{2}$ Косолапова Н.А., 2Матвеева Л.Г., * гЧернова О.А.

\section{РАЦИОНАЛЬНОСТЬ ИСПОЛЬЗОВАНИЯ ВОДНЫХ РЕСУРСОВ В ЭКОНОМИКЕ ГОРНЫХ ТЕРРИТОРИЙ СЕВЕРНОГО КАВКАЗА}

\section{УДК: 556.55}

\section{DOI: $10.21177 / 1998-4502-2018$} 1-10-48-62

Проведен ретроспективный анализ водопользования в республиках Северного Кавказа с позиции рационального использования природных ресурсов горных территорий. Выявлены тенденции изменения показателей водообеспеченности, нагрузки на водные ресурсы и водоемкости валового регионального продукта в данных регионах. На основе анализа сложившейся структуры земельного фонда и уровня водообеспеченности горных территорий СКФО исследована динамика состояния и рациональности использования их водных ресурсов.

Результаты проведенного анализа могут послужить основой для выработки практических рекомендаций по повышению рациональности водопотребления в горных республиках Северного Кавказа.

\section{КЛЮЧЕВЫЕ СЛОВА:} пользование ресурсами, устойчивость, сохранение водных ресурсов, водопользование, рациональное водопотребление

Статья поступила в редакцию 28.11.2017

\section{Введение}

Проблема рациональности использования водных ресурсов как одного из системообразующих факторов жизнедеятельности актуальна для всех регионов Российской Федерации. Это объясняется необходимостью достижения гармонизации взаимодействия экологической, экономической и социальной сфер, обеспечения эффективного ресурсообеспечения регионального хозяйства с целью выхода регионов на траекторию устойчивого роста. В современных условиях реализация принципов экологически ориентированного устойчивого развития территорий является одним из ключевых условий сохранения здоровья населения и формирования эколого-ориентированных экономических интересов. Исторически существующие региональные различия в природно-климатических, социально-экономических и других характеристиках горных республик Северного Кавказа являются причиной высокой конкуренции в сфере ресурсообеспеченности. В данном контексте уровень природоохранной деятельности становится одним из значимых факторов конкурентоспособности горных территорий, обязательным условием их успешного социально-эколого-экономического развития.

Интенсивное и наступательное развитие индустрии приводит к необходимости разработки научно-обоснованных подходов к оценке рациональности использования природных, в частности водных, ресурсов горных регионов, «сильно уязвимых к внешнему воздействию природно-территориальных комплексов» [1]. В этой связи для повышения значимости экологической составляющей в стратегических документах развития горных республик необходимо реализовывать комплексный подход к оценке рациональности использования водных ресурсов на основе учета следующих групп показателей: водообеспеченности, нагрузки на водные ресурсы, водоемкости, качества водных ресурсов.

Эволюция подходов к исследованию проблемы рационального водопользования. Сопряженность вопросов распределения водных ресурсов и уровня развития территории, выражаемого в показателе ВРП, в последние годы находит все большее отражение в научных публикациях. В своих исследованиях российские и зарубежные ученые, занимающиеся решением задачи согласования потребностей региона в водных ресурсах с возможностью их удовлетворения [2; 3], отмечают необходимость целеориентированности водообеспечения региональной хозяйственной системы как основного условия сохранения целостности и устойчивости ее развития. Большое число работ посвящено вопросам рационального использования водных ресурсов как с позиций экономической целесообразности, так и достижения наибольшего уровня согласования интересов отдельных водопользователей [4-8]. В ряде исследований [9-15] проводится оценка водных ресурсов как фактора реализации стратегических планов развития региона, а также эффективности их использования в отраслевом аспекте [16; 17]. При этом ряд исследователей отмечают, что рациональность распределения водных ресурсов должна оцениваться с позиций обеспечения роста ВРП на основе интенсивных факторов. Этой же точки зрения придерживаются и авторы настоящей статьи.

В публикации Керимова И.А. и др. отмечается, что «горные территории

${ }^{1}$ Российский информационно-аналитический и научно-исследовательский водохозяйственный центр, Ростов-на-Дону, Россия,

${ }^{2}$ Южный федеральный университет, Российский информационно-аналитический и научно-исследовательский водохозяйственный центр, Ростов-на-Дону, Россия,

*e-mail: matveeva_lg@mail.ru 
характеризуются высоким уровнем ландшафтного и биологического разнообразия. Здесь сосредоточены основные запасы питьевой воды, минерально-сырьевых, рекреационных и гидроэнергетических ресурсов, которые являются основой развития экономики» $[18$, c.211]. Вместе с тем эти и ряд других авторов отмечают высокую динамичность и чувствительность горных ландшафтов к внешним воздействиям, в силу чего горные ландшафты отнесены к очень ранимым и уязвимым экосистемам и их исследование является приоритетным направлением в XXI веке [19]. В данном контексте представляют методологический и практический интерес публикации ученых, посвященные оценке использования водных ресурсов в различных регионах с учетом влияющих на водопотребление климатических и других факторов [20-23]. В числе основных факторов, определяющих объемы проектируемого водопотребления, большинство авторов выделяют изменяющиеся погодные и климатические условия, определяющие влажность почвы [24; 25], возможности комплексного использования подземных и поверхностных вод [26]. Соответственно большое число работ содержит разработку экономико-математических моделей оптимального управления водными ресурсами, в которых сочетаются климатические и социально-экономические сценарии [27-29], а также достижение коалиционного компромисса на основе ценового регулирования и стимулирования к внедрению водосберегающих технологий стимулирования [30-34].

Цель данного исследования состоит в анализе уровня использования ограниченных водных ресурсов в горных республиках Северного Кавказа с позиций рациональности водопотребления для оценки возможностей повышения эффективности водообеспечения с целью достижения устойчивого развития этих регионов в стратегической перспективе.

Материалы и методы исследования

Материалами для написания статьи послужили результаты исследований, проводимых авторами по состоянию, оценке и рациональному использованию природно-ресурсного (водного) потенциала горных территорий Северного Кавказа, а также материалы мониторинга водных объектов, статистические и литературные источники по данной тематике.

Авторская гипотеза состоит в том, что рациональность использования водных ресурсов отражается, в первую очередь, в показателях водоемкости валового регионального продукта. При этом снижение водоемкости ВРП при наличии тенденции роста объемов последнего означает, что в региональном хозяйстве используются ресурсосберегающие инновационные технологии, обеспечивающие социально-экономические развитие региона за счет интенсивных, а не экстенсивных факторов, что имеет важнейшее значение в современных императивах неоиндустриализации национальной экономики.

Для подтверждения данной гипотезы, а также для исследования уровня рациональности водопотребления в горных республиках Северного Кавказа в исследовании проведен анализ показателей нагрузки на водные ресурсы, водоообеспеченности и водоемкости ВРП.

\section{Полученные результаты и их обсуждение}

Нагрузка на водные ресурсы и водообеспеченность горных территорий. Несмотря на огромный потенциал водохозяйственных систем рассматриваемых горных территорий, вопросы рационального использования природных ресурсов, в том числе водных, имеют для этих субъектов особое значение, учитывая то обстоятельство, что в данных регионах наблюдается «высокий» и «критически высокий» уровень нагрузки на водные ресурсы, что наглядно демонстрируют данные, приведенные в табл. 1 .

Результаты исследования показали, что «высокую», «очень высокую» и «критически высокую» нагрузку на средние многолетние местные водные ресурсы испытывают все горные регионы, кроме Чеченской Республики (рис.1). «Низкая» и «очень низкая» водообеспеченность (табл. 2) суммарными водными ресурсами (тыс.м³/год на чел.) в средние по водности годы отмечается в Республике Ингушетия (3.94 тыс.м³/год на чел.). При наступлении маловодных лет и периодов водообеспеченность суммарными водными ресурсами изменяется до уровня «очень низкая» в Республике Ингушетия.

В расчете на средние многолетние местные водные ресурсы «катастрофически низкий», «очень низкий» и «низкий» уровни водообеспеченности имеют место во всех горных регионах, кроме Карачаево-Черкесской Республики и РСО-Алания. При наступлении маловодных периодов все горные территории, кроме Карачаево-Черкесской Республики, имеют «катастрофически низкий», «очень низкий» и «низкий» уровни водообеспеченности.

Таким образом, наименее водообеспеченным регионом является Республика Ингушетия, где в средние по водности годы отмечается «низкий» и «очень низкий» уровни водоосбеспеченности, а в маловодные годы водообеспеченность изменяется до уровня «очень низкой» и «катастрофически низкой». Это подтверждается также средними показателями обеспеченности этих регионов водными ресурсами: по данным за 2015 г. этот показатель составляет 2,892 тыс. м $^{3} /$ год на человека - почти в 11 раз ниже среднероссийского значения $\left(31,71\right.$ тыс. $\mathrm{M}^{3} /$ год на человека) и почти в 2,5 раза ниже, чем в наиболее обеспеченной водными ресурсами Республике Карачаево-Черкессия $(13,681$ тыс. м³/год на человека) [16]. Ситуация в данной сфере в рассматриваемых республиках 
Нагрузка на водные ресурсы (\%) в горных республиках СКФО ${ }^{1}$ /

Pressure on water resources (\%) in mountain republics $N C F D^{l}$

\begin{tabular}{|c|c|c|c|c|c|c|}
\hline \multirow[b]{2}{*}{$\begin{array}{c}\text { Субъекты РФ / } \\
R F \text { constituent territory }\end{array}$} & \multicolumn{2}{|c|}{$\begin{array}{c}\text { Нагрузка на суммарные водные } \\
\text { ресурсы, \% / } \\
\text { He load on the total water resources \% }\end{array}$} & \multicolumn{4}{|c|}{$\begin{array}{c}\text { Нагрузка на местные водные ресурсы, \% / } \\
\text { The burden on local water resources, \% }\end{array}$} \\
\hline & $\begin{array}{c}\text { на средние } \\
\text { многолет- } \\
\text { ние / on the } \\
\text { long-term } \\
\text { average }\end{array}$ & $\begin{array}{c}\text { характеристика } \\
\text { уровня нагрузки } \\
\text { / characteristics of the } \\
\text { load level }\end{array}$ & $\begin{array}{c}\text { на средние } \\
\text { многолетние } \\
\text { / on the long- } \\
\text { term average }\end{array}$ & $\begin{array}{c}\text { характерис- } \\
\text { тика уровня } \\
\text { нагрузки / } \\
\text { characteristics of } \\
\text { the load level }\end{array}$ & $\begin{array}{c}\text { за малово- } \\
\text { дный период / } \\
\text { for the low- } \\
\text { water period }\end{array}$ & \begin{tabular}{|} 
характерис- \\
тика уровня \\
нагрузки / \\
characteristics \\
of the load level
\end{tabular} \\
\hline $\begin{array}{c}\text { Кабардино-Балкарская } \\
\text { Республика / } \\
\text { Kabardian-Balkar Republic }\end{array}$ & 13.49 & умеренная / moderate & 34.67 & $\begin{array}{c}\text { высокая / } \\
\text { high }\end{array}$ & 61.91 & $\begin{array}{l}\text { критически } \\
\text { высокая / } \\
\text { critically high }\end{array}$ \\
\hline $\begin{array}{l}\text { Карачаево-Черкесская } \\
\text { Республика / Karachai- } \\
\text { Circassian Republic }\end{array}$ & 46.89 & $\begin{array}{c}\text { очень высокая / } \\
\text { very high }\end{array}$ & 46.89 & $\begin{array}{c}\text { очень высо- } \\
\text { кая / } \\
\text { very high }\end{array}$ & 52.69 & \begin{tabular}{|c|} 
очень высо- \\
кая / \\
very high \\
\end{tabular} \\
\hline $\begin{array}{l}\text { РеспубликаДагестан / } \\
\text { Republic of Daghestan }\end{array}$ & 16.80 & умеренная / moderate & 43.96 & $\begin{array}{c}\text { очень высо- } \\
\text { кая / } \\
\text { very high }\end{array}$ & 54.95 & \begin{tabular}{|c|} 
очень высо- \\
кая / \\
very high
\end{tabular} \\
\hline $\begin{array}{c}\text { Республика Ингушетия / } \\
\text { Republic of Ingushetia }\end{array}$ & 7.99 & низкая / low & 24.64 & $\begin{array}{c}\text { высокая / } \\
\text { high }\end{array}$ & 35.71 & $\begin{array}{c}\text { высокая / } \\
\text { high }\end{array}$ \\
\hline $\begin{array}{c}\text { Республика Северная } \\
\text { Осетия-Алания / Republic } \\
\text { of North Osetia-Alania }\end{array}$ & 14.18 & умеренная / moderate & 27.99 & $\begin{array}{c}\text { высокая / } \\
\text { high }\end{array}$ & 32.17 & $\begin{array}{c}\text { высокая / } \\
\text { high }\end{array}$ \\
\hline $\begin{array}{c}\text { Чеченская Республика / } \\
\text { Chechen Republic }\end{array}$ & 2.72 & низкая / low & 13.54 & $\begin{array}{l}\text { умеренная / } \\
\text { moderate }\end{array}$ & 18.05 & $\begin{array}{c}\text { умеренная / } \\
\text { moderate }\end{array}$ \\
\hline
\end{tabular}

${ }^{1}$ Составлено авторами по материалам форм 2-ТП-водхоз, размещена в АИС ГВР, АИС ГМВО.

${ }^{I}$ Drawn up by the authors the materials of the forms 2-TP-Vodkhoz, placed in GWR AIS, AIS GMVO.

обостряется тем, что на фоне отмеченной низкой воодообеспеченности общие потери воды при транспортировке в горных территориях СКФО составляют более $25 \%$, что является самым большим значением данного показателя среди всех федеральных округов РФ.

Обеспеченность водными ресурсами становится сдерживающим фактором устойчивого развития горных территорий, для нивелирования которого необходимо регулирование водопотребления, а также привлечение дополнительных источников водных ресурсов.

Значимость решения проблемы рационального использования водных ресурсов в горных регионах СКФО усиливается с учетом их преимущественно сельскохозяйственной специализации при относительно большой продолжительности маловодного периода по сравнению с другими регионами России (рис. 2). Так, в период маловодья, по оценкам экспертов, объем водных ресурсов в горных республиках Северного Кавказа может снижаться на $30-40 \%$, а в некоторых случаях составлять только $19 \%$ от их значения в средний по водности год (рис. 3).
При этом удельный вес земель сельскохозяйственного назначения в структуре земельного фонда горных республик превышает $50 \%$, тогда как земли водного фонда не превышают 1\% (табл. 3).

Эти верифицируемые реальной практикой факты делают актуальным взаимоувязанное исследование проблематики водообеспечения регионального хозяйства и динамики показателей социально-экономического развития горных регионов СКФО.

Показатель водоемкости валового регионального продукта в горных республиках СКФО. Анализируя уровень водоемкости ВРП в федеральных округах, можно отметить, что наибольшее его значение характерно именно для регионов СКФО (рис. 4, 5). При этом, даже несмотря на наличие ярко выраженной тенденции снижения данного показателя за последние 5 лет (более чем в 3 раза), он остается в два раза выше, чем в остальных субъектах РФ. 
Таблица 2 / Table 2

Водообеспеченность водными ресурсами по горным республикам СКФО (тыс.м³/год на чел.) ${ }^{\mathbf{1}} /$ Water availability for water resources in the mountain republics of the $N C F D^{2}$ (ths. cbm / year per person) ${ }^{1}$

\begin{tabular}{|c|c|c|c|c|c|c|}
\hline \multirow{2}{*}{$\begin{array}{c}\text { Субъекты РФ / } \\
\text { RF constituent territory }\end{array}$} & \multicolumn{2}{|c|}{$\begin{array}{c}\text { Водообеспеченность суммар- } \\
\text { ными водными ресурсами, } \\
\text { тыс.м³/год на чел. / } \\
\text { Water availability by total water } \\
\text { resources, ths. cbm /year per } \\
\text { person }\end{array}$} & \multicolumn{4}{|c|}{$\begin{array}{l}\text { Водообеспеченность местными водными ресурсами, } \\
\text { тыс.м³/год на чел. / } \\
\text { Water availability by local water resources, ths. cbm / year } \\
\text { per person }\end{array}$} \\
\hline & $\begin{array}{l}\text { средними } \\
\text { много- } \\
\text { летними } \\
\text { / average } \\
\text { perennial }\end{array}$ & $\begin{array}{l}\text { характери- } \\
\text { стика водо- } \\
\text { обеспеченности / } \\
\text { characterization of } \\
\text { water availability }\end{array}$ & $\begin{array}{l}\text { средними } \\
\text { много- } \\
\text { летними } \\
\text { / average } \\
\text { perennial }\end{array}$ & $\begin{array}{l}\text { характеристи- } \\
\text { ка водообе- } \\
\text { спеченности / } \\
\text { characterization } \\
\text { of water } \\
\text { availability }\end{array}$ & $\begin{array}{l}\text { за малово- } \\
\text { дный пери- } \\
\text { од / for the } \\
\text { low-water } \\
\text { period }\end{array}$ & $\begin{array}{l}\text { характеристи- } \\
\text { ка водообе- } \\
\text { спеченности / } \\
\text { characterization } \\
\text { of water } \\
\text { availability }\end{array}$ \\
\hline $\begin{array}{c}\text { Кабардино-Балкарская } \\
\text { Республика / } \\
\text { Kabardian-Balkar Republic }\end{array}$ & 8.47 & $\begin{array}{l}\text { средняя / } \\
\text { mean }\end{array}$ & 3.19 & $\begin{array}{l}\text { низкая / } \\
\text { low }\end{array}$ & 1.71 & $\begin{array}{c}\text { очень низкая / } \\
\text { very low }\end{array}$ \\
\hline $\begin{array}{c}\text { Карачаево-Черкесская } \\
\text { Республика / } \\
\text { Karachai-Circassian Republic }\end{array}$ & 12.23 & $\begin{array}{l}\text { высокая / } \\
\text { high }\end{array}$ & 12.23 & $\begin{array}{c}\text { высокая / } \\
\text { high }\end{array}$ & 10.75 & $\begin{array}{c}\text { высокая / } \\
\text { high }\end{array}$ \\
\hline $\begin{array}{l}\text { Республика Дагестан / } \\
\text { Republic of Daghestan }\end{array}$ & 7.04 & $\begin{array}{l}\text { средняя / } \\
\text { mean }\end{array}$ & 2.54 & $\begin{array}{l}\text { низкая / } \\
\text { low }\end{array}$ & 1.98 & $\begin{array}{c}\text { очень низкая / } \\
\text { very low }\end{array}$ \\
\hline $\begin{array}{c}\text { Республика Ингушетия / } \\
\text { Republic of Ingushetia }\end{array}$ & 3.94 & $\begin{array}{l}\text { низкая / } \\
\text { low }\end{array}$ & 1.25 & $\begin{array}{c}\text { очень низкая / } \\
\text { very low }\end{array}$ & 0.85 & $\begin{array}{c}\text { катастрофи- } \\
\text { чески низкая / } \\
\text { disastrously low }\end{array}$ \\
\hline $\begin{array}{c}\text { Республика Северная } \\
\text { Осетия-Алания / Republic of } \\
\text { North Osetia-Alania }\end{array}$ & 10.53 & $\begin{array}{l}\text { высокая / } \\
\text { high }\end{array}$ & 5.21 & $\begin{array}{l}\text { средняя / } \\
\text { mean }\end{array}$ & 4.50 & $\begin{array}{c}\text { низкая / } \\
\text { low }\end{array}$ \\
\hline
\end{tabular}

${ }^{1}$ Составлено авторами по материалам форм 2-ТП-водхоз, размещена в АИС ГВР, АИС ГМВО /

${ }^{2}$ Drawn up by the authors the materials of the forms 2-TP-Vodkhoz, placed in GWR AIS, AIS GMVO.

Показатели структуры земельного фонда республик СКФО

таблица 3 / Table 3

Indicesofavailable land structure in the NCFD republics ${ }^{2}$

\begin{tabular}{|c|c|c|}
\hline $\begin{array}{c}\text { Субъекты РФ / } \\
R F \text { constituent territory }\end{array}$ & $\begin{array}{c}\text { Удельный вес земель сельскохо- } \\
\text { зяйственного фонда в структуре } \\
\text { земельного фонда, \% } \\
\text { Specific weight of agriculturall ands in } \\
\text { available land structure,\% }\end{array}$ & $\begin{array}{c}\text { Удельный вес земель водного } \\
\text { фонда в структуре земельно- } \\
\text { го фонда, \% } \\
\text { Specific weight of water reserves } \\
\text { in available land structure,\% }\end{array}$ \\
\hline $\begin{array}{c}\text { Кабардино-Балкарская Республика / } \\
\text { Kabardian-Balkar Republic }\end{array}$ & 86,43 & 0,53 \\
\hline $\begin{array}{c}\text { Карачаево-Черкесская Республика / } \\
\text { Karachai-Circassian Republic }\end{array}$ & 41,59 & 0,16 \\
\hline $\begin{array}{l}\text { Республика Дагестан / } \\
\text { Republic of Daghestan }\end{array}$ & 58,06 & 0,22 \\
\hline $\begin{array}{c}\text { Республика Ингушетия / } \\
\text { Republic of Ingushetia }\end{array}$ & 57,22 & 0,71 \\
\hline $\begin{array}{c}\text { Республика Северная Осетия- Алания / } \\
\text { Republic of North Osetia-Alania }\end{array}$ & 52,42 & 0,31 \\
\hline $\begin{array}{c}\text { Чеченская Республика / } \\
\text { Chechen Republic } \\
\end{array}$ & 63,5 & 0,56 \\
\hline
\end{tabular}

${ }^{2}$ Официальный сайт Министерства природы и экологии РФ. URL: http://www.mnr.gov.ru/gosdoklad-eco-2015/skfo.html (дата обращения 15.11.2017) /

${ }^{2}$ Official website of the Ministry of nature and environment. URL: http://www.mnr.gov.ru/gosdoklad-eco-2015/skfo.html (accessed 15.11.2017). 

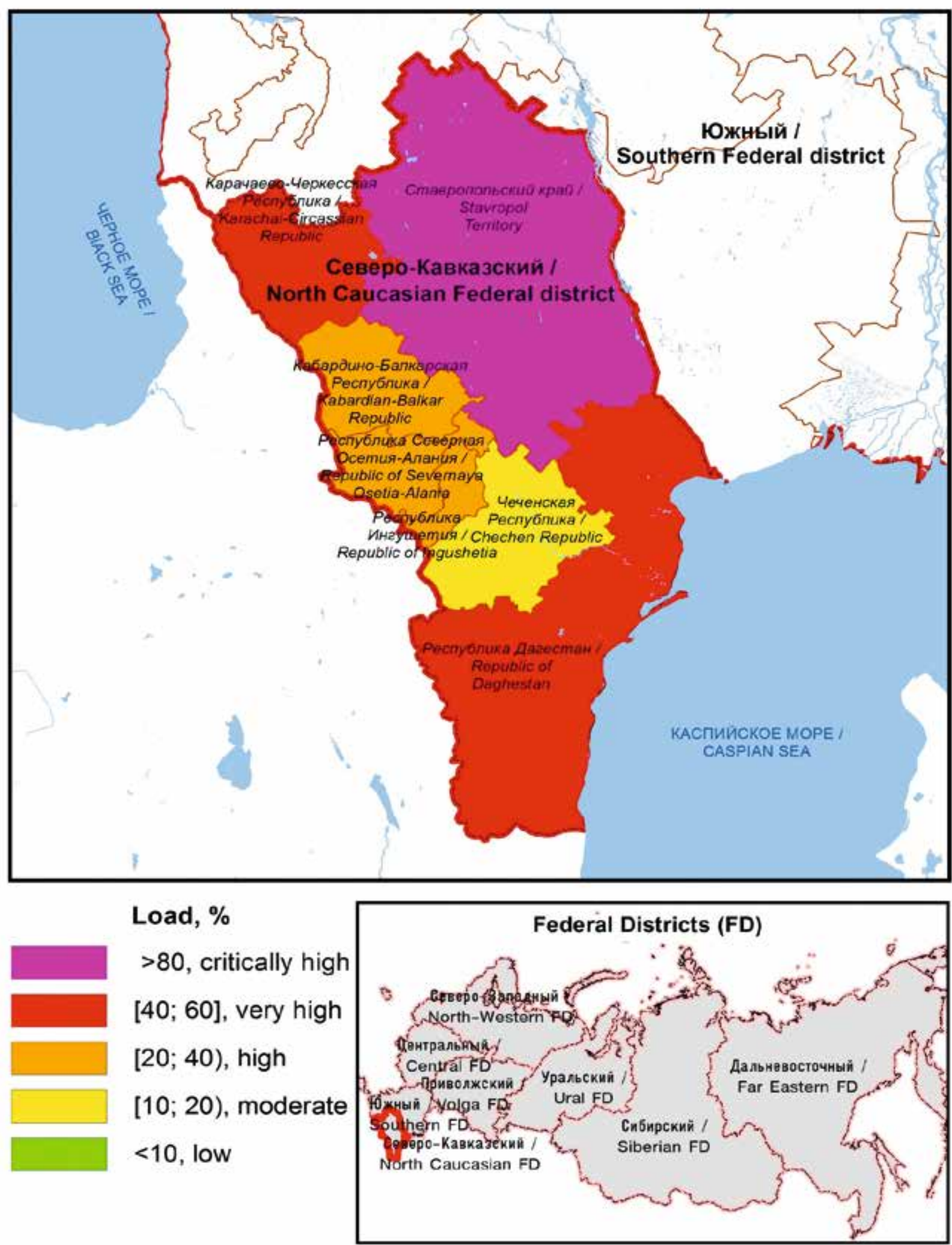

Pис. 1. Дифференцииачия нагрузки на средние многолетние местные водные ресурсы в горных республиках Северного Кавказа ${ }^{1}(\%)$ /

Fig. 1. Differentiation of load on average of many years local water resources in mountain republics of the North Caucasus ${ }^{1}(\%)$ 


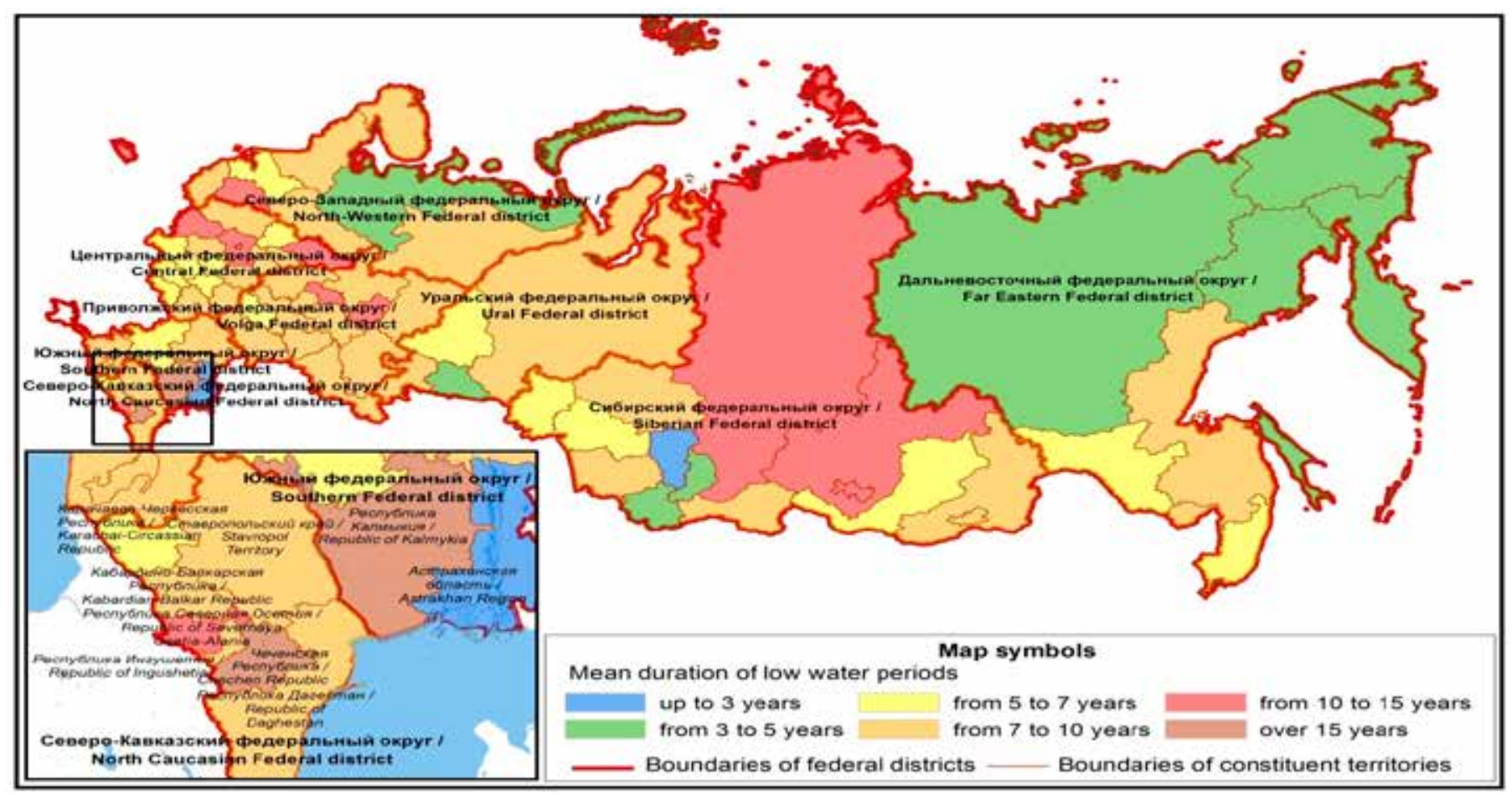

Puc. 2. Средняя продолжительность маловодных периодов в регионах России ${ }^{1}$ /

Fig. 2. Mean duration of low water periods in regions of Russia ${ }^{l}$

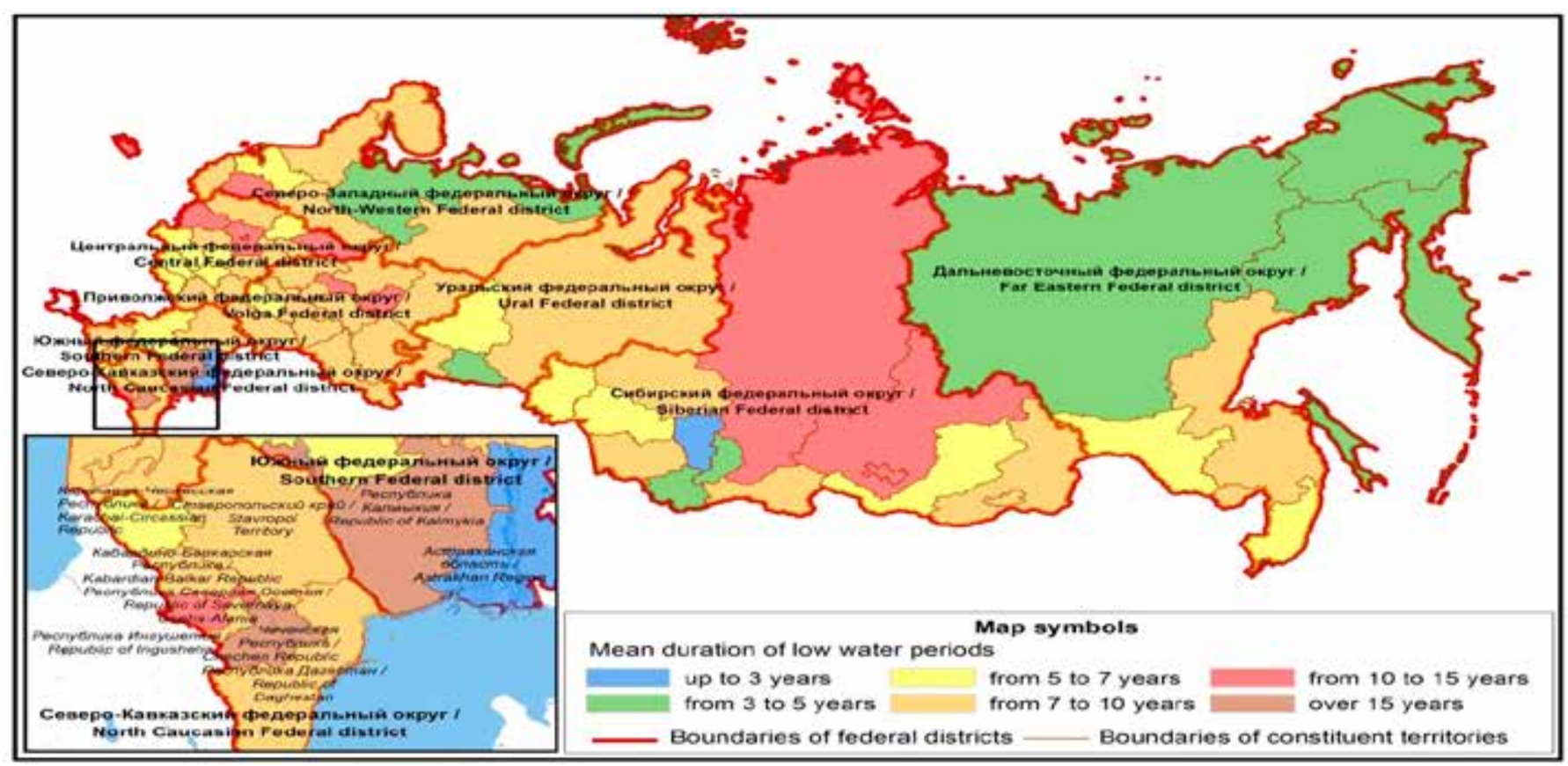

Рис. 3. Водные ресурсы маловодных периодов (в долях от среднемноголетнего значения) ${ }^{2}$

Fig. 3. Water resources of low water periods (in portions of average of many years in of low water periods) ${ }^{2}$

\footnotetext{
${ }^{1,2}$ Составлено авторами / Drawn up by the authors.
} 


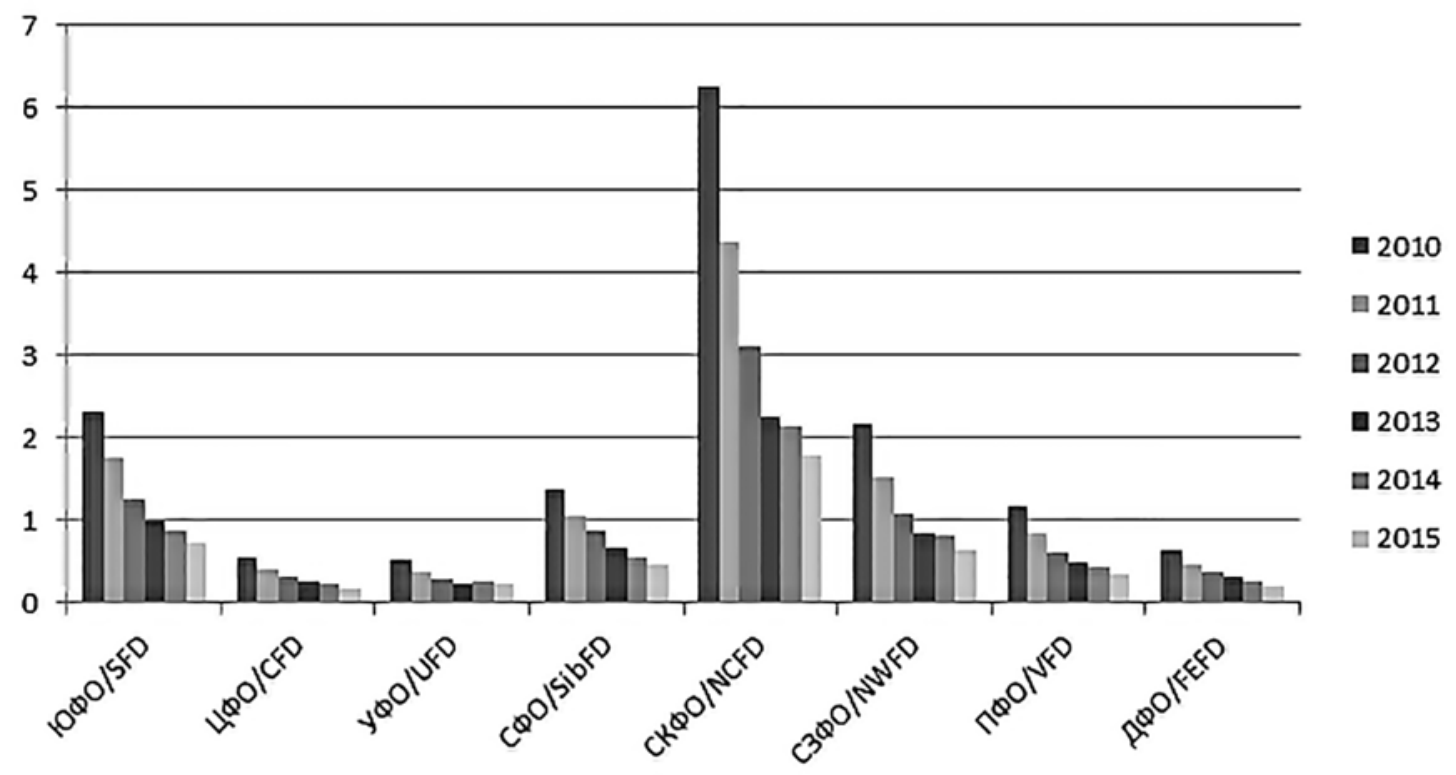

Pис. 4. Изменение показателей водоемкости ВРП в федеральных округах, $\mathrm{m}^{3} / \mathrm{p}^{1}$ / Fig. 4. Change in water capacity indices of the GRP in federal districts, cbm/rouble ${ }^{1}$

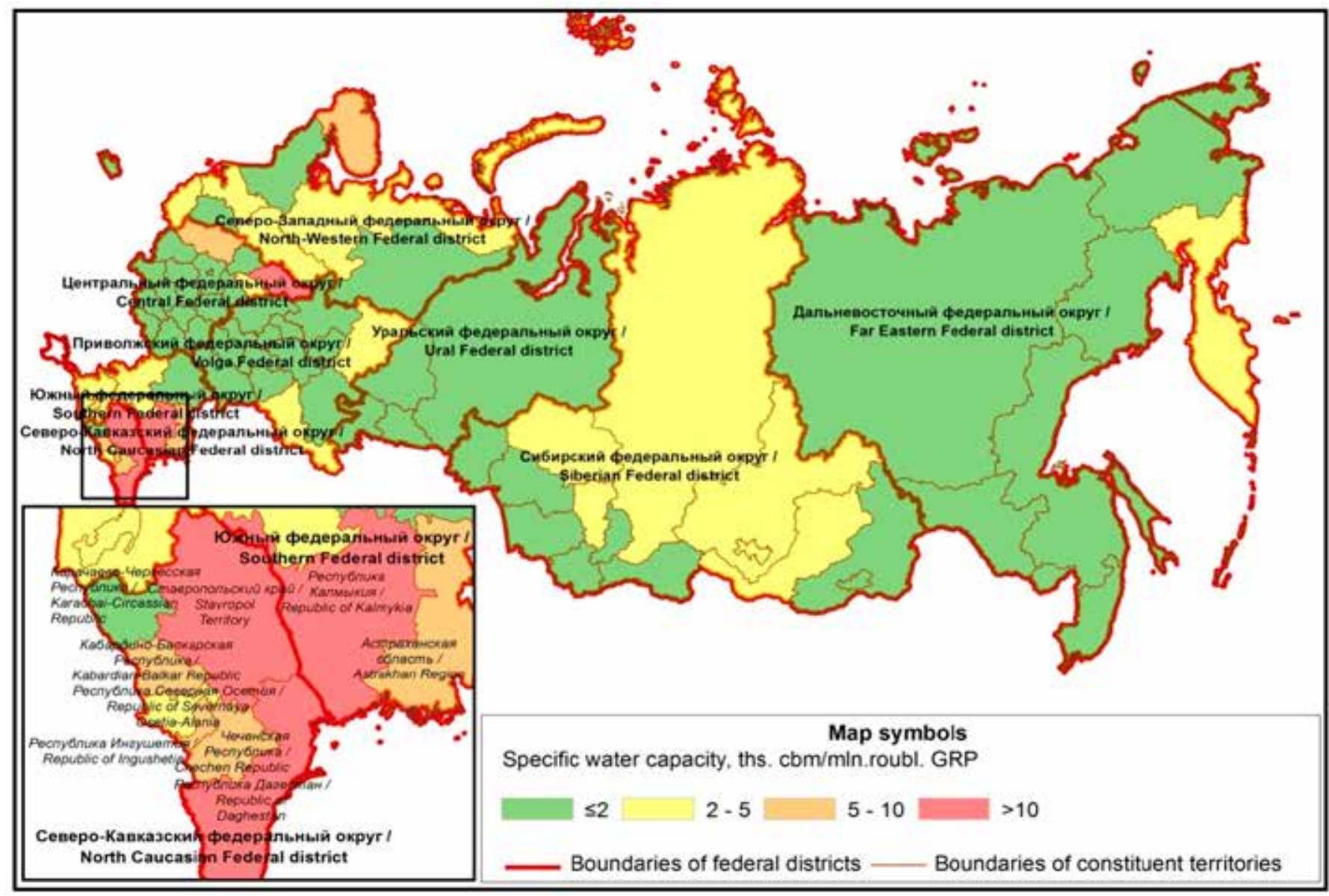

Puc. 5. Удельная водоемкость ВРП в России /

Fig. 5. GRP specific water capacity in Russia ${ }^{2}$

\footnotetext{
${ }^{1}$ Рассчитано по источнику: Регионы России. Социально-экономические показатели. 2016. Стат. сб. / Росстат. - М., 2016, - 1326 с. / Calculated by source: Regions of Russia. Socio-economic indicators. 2016. Statistical compilation / Rosstat. Moscow, 2016. - 1326 p.

${ }^{2}$ Составлено авторами / Drawn up by the authors.
} 
Бассейновые управления и отделы управления водными ресурсами на территории СКФО/

Таблица 4 / Table 4

/ Basin administrations and departments of water resources management in the NCFD territory

\begin{tabular}{|c|c|}
\hline Субъекты РФ / RF constituent territory & $\begin{array}{c}\text { Бассейновое управление / } \\
\text { Basin administration }\end{array}$ \\
\cline { 1 - 1 } Кабардино-Балкарская Республика / Kabardian-Balkar Republic & $\begin{array}{c}\text { Кубанское БВУ / } \\
\text { Kuban'Basin Water Administration (BWA) }\end{array}$ \\
\cline { 1 - 1 } Карачаево-Черкесская Республика / Karachai-Circassian Republic & Западно-Каспийское БВУ / \\
\cline { 1 - 2 } Республика Дагестан / Republic of Daghestan & Western-Caspian BWA \\
\cline { 1 - 2 } Республика Ингушетия / Republic of Ingushetia & \\
\cline { 1 - 2 } Республика Северная Осетия-Алания / Republic of North Osetia-Alania & \\
\cline { 1 - 2 } Чеченская Республика / Chechen Republic & \\
\hline
\end{tabular}

Водные ресурсы горных регионов СКФО находятся в ведении двух водных бассейновых управлений, представленных в табл. 4.

Для анализа факторов, оказавших влияние на изменение водоемкости ВРП, была использована факторная модель вида: $B_{\mathrm{e}}=V_{\text {св }} / В P П$, где $B_{\mathrm{e}}-$ водоемкость ВРП, $V_{\text {св }}$ - объем потребления свежей воды.

Динамика уровня водоемкости ВРП горных регионов СКФО отражена на рис. 5.

Результаты проведенного анализа позволили сделать вывод, что по уровню потребления свежей воды анализируемый макрорегион занимает среднее значение среди всех субъектов РФ. Следует также отметить, что в целом в макрорегионе высоких значениях водоемкости ВРП Карачаево-Черкесская Респу- блика, водные ресурсы которой находятся в ведении Кубанского БВУ, стабильно имеет довольно низкие значения данного показателя (менее $1 \mathrm{~m}^{3} /$ тыс. руб). Также значительно снизились за последние пять лет (менее 1 м 3 тыс. руб) показатели водоемкости ВРП в Республике Ингушетия и Республике Северная Осетия-Алания, где в последние годы отмечается активное развитие предприятий сферы АПК (данное противоречие между ростом масштабов производства отраслей сферы АПК и одновременным снижением водоемкости ВРП может объясняться разными причинами, в том числе использованием инновационных, ресурсосберегающих технологий).

Сведения об уровне потребления свежей воды в горных регионах СКФО представлены на рисунке 6.

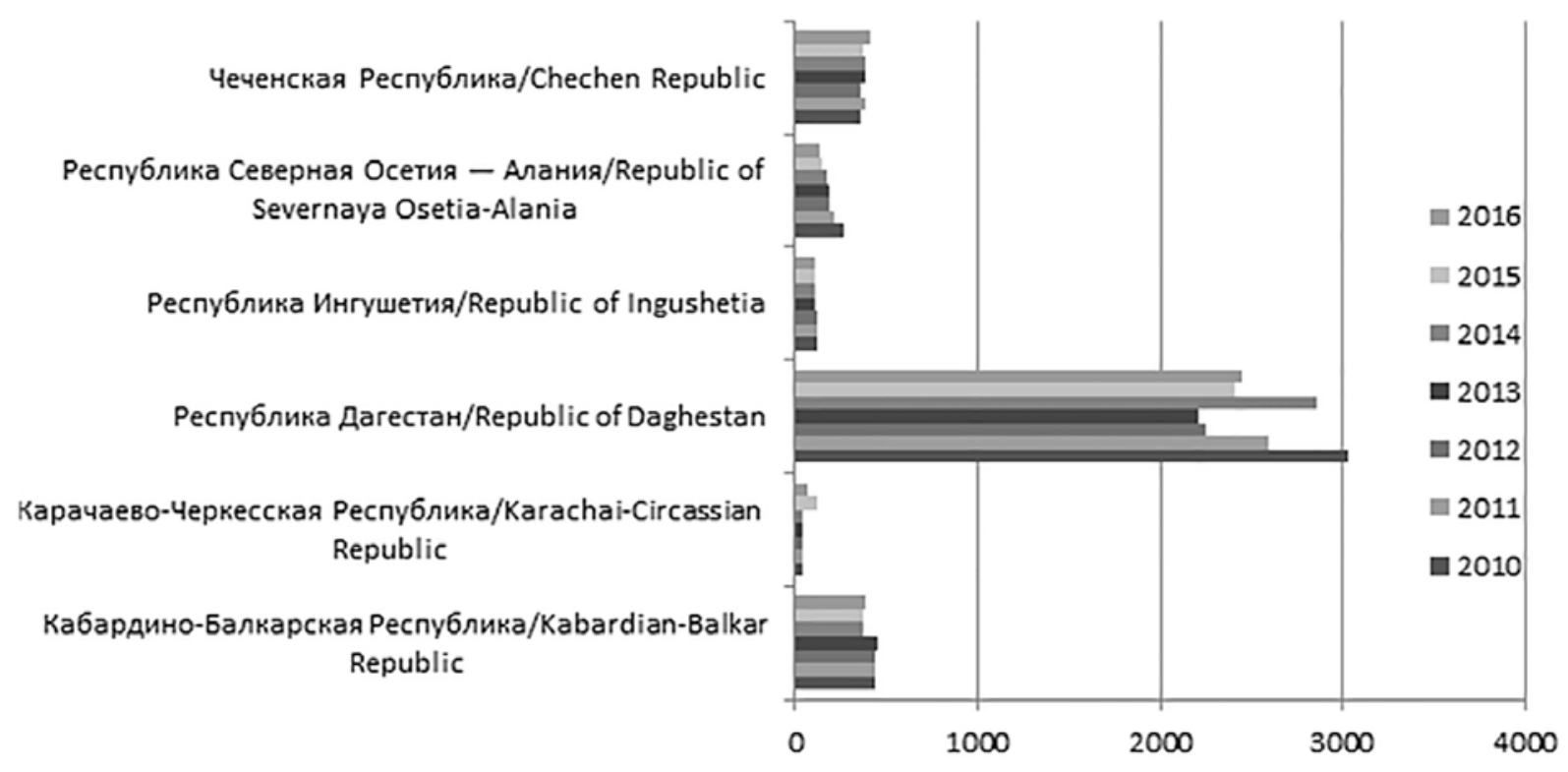

Puc. 6. Динамика уровня потребления свежей воды в регионах СКФО, $\left(\mathrm{m}^{3}\right)^{1} /$

Fig. 6. Dynamics of fresh water use level in NCFD regions, $\left(m^{3}\right)^{l}$

\footnotetext{
${ }^{1}$ Рассчитано по источнику: Регионы России. Социально-экономические показатели. 2016. Стат. сб. / Росстат. - М., 2016, - 1326 с. /

${ }^{1}$ Calculated by source: Regions of Russia. Socio-economic indicators. 2016. Statistical compilation / Rosstat. Moscow, $2016 .-1326$ p.
} 


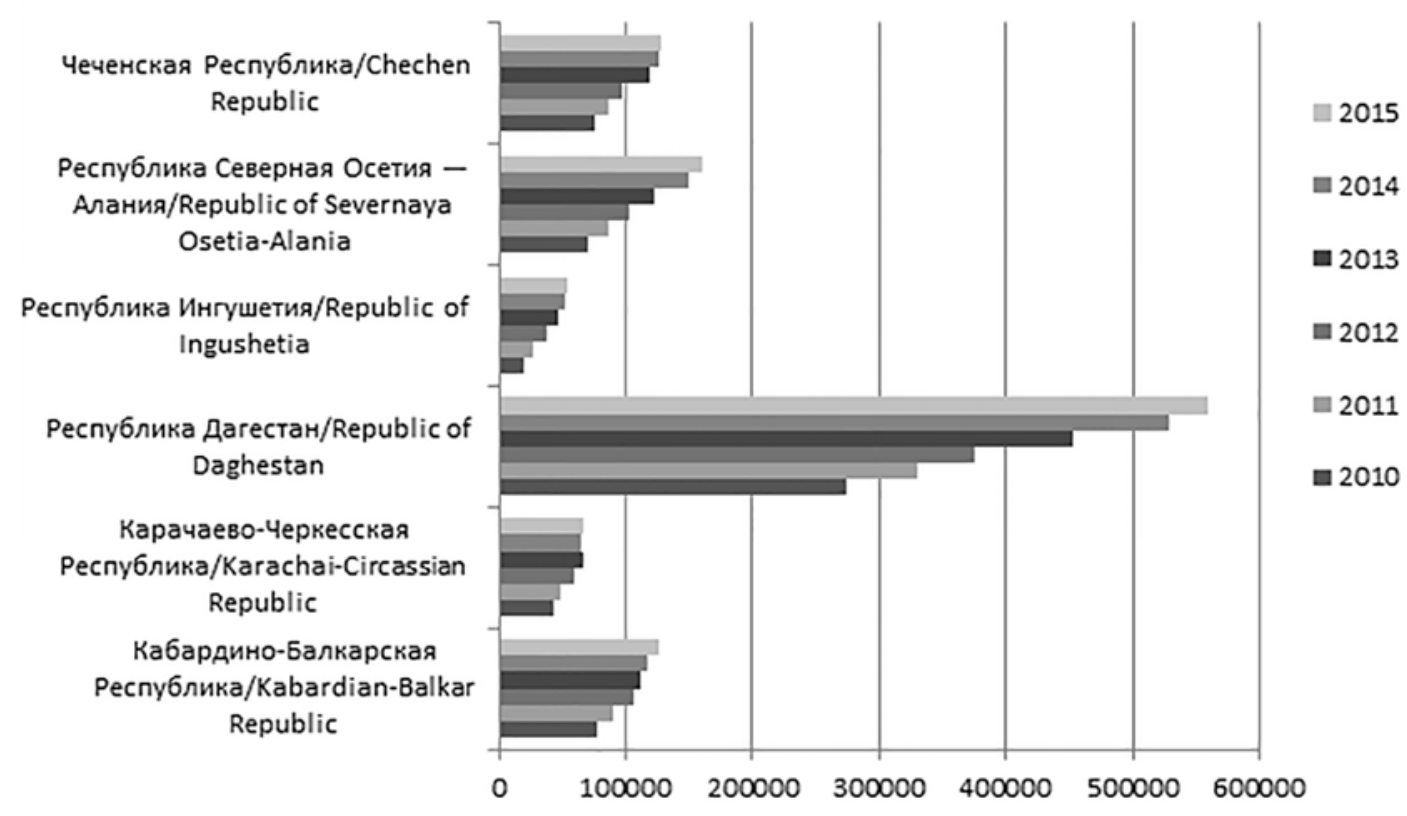

Pис. 7. Динамика ВРП в горных регионах СКФО, млн. руб. ${ }^{1} /$

Fig. 7. Dynamics of GRP in NCFD mountain regions $8, \mathrm{mln}^{\text {. rouble }}{ }^{l}$

Динамика показателя водоемкости ВРП в горных регионах. Следующим логическим этапом исследования является выявление тенденций изменения показателя водоемокости ВРП. При этом, поскольку показатель уровня водоемкости изменяется достаточно равномерно в ограниченных пределах, это позволяет использовать эмпирическое правило Стерджеса для определения оптимального количества интервалов, на которые разбивается наблюдаемый диапазон случайной величины при построении гистограммы. Принимая во внимание, что в рамках данного исследования анализировалась довольно большая совокупность показателей, а их распределение близко к нормальному, можно говорить о достаточной степени достоверности полученных результатов.

Согласно полученным расчетам можно выделить границы интервалов, определяющих наивысший и наиболее низкий уровень водоемкости ВРП в горных республиках Северного Кавказа за рассматриваемый период. Данные показатели являются относительными, характеризуя уровень водоемкости ВРП (высокий или низкий) по сравнению с показателями водоемкости рассматриваемых регионов в конкретном году. То есть, принимая во внимание общую тенденцию снижения водоемкости ВРП, седьмая группа (высокий уровень водоемкости) в 2015 году образована значениями порядка 5,3 м³/тыс. руб., что для 2010 года являлось достаточно низким значением.

Результаты расчета количества интервалов и распределение численности полученных величин уровня водоемкости ВРП приведены в табл. 5.
К первой группе горных регионов относится Чеченская республика с относительно постоянным достаточно низким уровнем водоемкости ВРП. Одновременно отметим, что для данной республики характерны более высокие темпы роста ВРП по сравнению с другими горными республиками СКФО, за исключением Республики Дагестан. Одновременно для остальных горных республик характерно снижение водоемкости ВРП, причем для Республики Дагестан такой переход является скачкообразным при самых высоких и относительно стабильных темпах роста ВРП. Это позволяет сделать вывод о том, что наиболее рациональное водопотребление (с позиций ориентации водных ресурсов на решение стратегических задач развития регионального хозяйства) характерно для Республики Дагестан.

\section{Заключение}

Результаты проведенной оценки уровня рациональности водопотребления региональным хозяйством горных республик Северного Кавказа позволяет разработать конкретные мероприятия по повышению эффективности использования водных ресурсов в рамках стратегий социально-экономического развития рассматриваемых регионов. Сделан вывод, что в регионах с тенденцией к снижению показателя водоемкости на фоне роста ВРП применяются водосберегающие инновационные технологии, обеспечивающие социально-экономическое развитие за счет интенсивных, а не экстенсивных факторов. Это, в частности, Республика Дагестан, что позволяет говорить о высоком уровне рациональности водопотребления в этом субъекте РФ.

\footnotetext{
${ }^{1}$ Рассчитано по источнику: Регионы России. Социально-экономические показатели. 2016. Стат. сб. / Росстат. - М., 2016, - 1326 с.

${ }^{l}$ Calculated by source: Regions of Russia. Socio-economic indicators. 2016. Statistical compilation / Rosstat. Moscow, 2016. -1326 p.
} 
Таблица 5 / Table 5

Результаты расчета интервальных значений показателей водоемкости ВРП в горных республиках Северного Кавказа в соответствии с правилом Стерджеса /

Results of interval values computation for GRP water capacity in dices in mountain republics of the North Caucasusac cording to Sturges'rule

\begin{tabular}{|c|c|c|c|c|c|c|c|}
\hline \multicolumn{2}{|c|}{$\begin{array}{c}\text { Интервальная разница/ } \\
\text { Interval difference }\end{array}$} & 1,89473536 & 1,47743127 & 1,13570754 & 1,01987544 & 0,9607237 & 0,71298933 \\
\hline \multirow{7}{*}{ 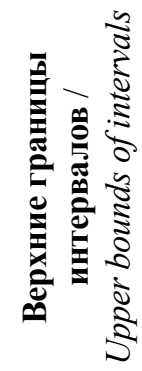 } & 1 & 2,02497182 & 1,58321951 & 1,22777915 & 1,0926644 & 1,0249131 & 0,76380529 \\
\hline & 2 & 3,91970718 & 3,06065078 & 2,3634867 & 2,11253985 & 1,9856368 & 1,47679462 \\
\hline & 3 & 5,81444254 & 4,53808206 & 3,49919424 & 3,13241529 & 2,9463605 & 2,18978395 \\
\hline & 4 & 7,70917790 & 6,01551334 & 4,63490179 & 4,15229074 & 3,9070843 & 2,90277329 \\
\hline & 5 & 9,60391326 & 7,49294462 & 5,77060934 & 5,17216618 & 4,867808 & 3,61576262 \\
\hline & 6 & 11,4986486 & 8,97037590 & 6,90631689 & 6,19204162 & 5,8285317 & 4,32875195 \\
\hline & 7 & 13,3933839 & 10,4478071 & 8,04202443 & 7,21191707 & 6,7892554 & 5,04174128 \\
\hline
\end{tabular}

Как видно, по характеру изменения уровня водоемкости ВРП можно выделить три группы горных регионов (табл. 6).

Группировка горных регионов СКФО по характеру изменения уровня водоемкости ВРП /

Grouping of the mountainous regions of the NCFD by the nature of the change in the level of the reservoir of GRP

\begin{tabular}{|c|c|c|}
\hline $\begin{array}{l}\text { Характер изменения водоем- } \\
\text { кости ВРП / The nature of the } \\
\text { change in the reservoir of GRP }\end{array}$ & Регионы / Regions & $\begin{array}{c}\text { Направление изменения водоемкости ВРП } \\
\text { (групп) / The direction of the change in the water } \\
\text { capacity of GRP (groups) }\end{array}$ \\
\hline $\begin{array}{c}\text { Относительно постоянный } \\
\text { уровень водоемкости ВРП / } \\
\text { The relatively constant level of } \\
\text { the reservoir of GRP }\end{array}$ & $\begin{array}{l}\text { Чеченская Республика / } \\
\text { Chechen Republic }\end{array}$ & $\begin{array}{c}\text { Достаточно низкий уровень водоемкости ВРП / } \\
\text { A sufficiently low level of the reservoir of GRP } \\
\text { Уровень водоемкости региона за весь рассматривае- } \\
\text { мый период не превышал } 4 \text { м }^{3} / \text { тыс.руб., } \\
\text { ак } 2015 \text { г. - } 1,6 \mathrm{~m}^{3} / \text { тыс.руб / } \\
\text { The level of the region's water capacity for the whole } \\
\text { period under review did not exceed } 4 \text { cbm/ths. rouble, } \\
\text { and by } 2015 \text { - } 1.6 \text { cbm/ths. rouble }\end{array}$ \\
\hline \multirow[t]{2}{*}{$\begin{array}{c}\text { Снижение уровня водоемкости } \\
\text { ВРП / } \\
\text { Reduction of the level of the } \\
\text { reservoir of GRP }\end{array}$} & $\begin{array}{c}\text { Республика Северная } \\
\text { Осетия-Алания / } \\
\text { Republic of North Osetia-Alania, } \\
\text { Кабардино-Балкарская республи- } \\
\text { ка / Kabardian-Balkar Republic, } \\
\text { Республика Ингушетия / } \\
\text { Republic of Ingushetia }\end{array}$ & $\begin{array}{c}\text { Переход в «соседние» группы (неболее } 2 \text { переходов) } \\
\text { / The transition to "neighboring" groups (no more than } \\
2 \text { transitions) }\end{array}$ \\
\hline & $\begin{array}{l}\text { Республика Дагестан / } \\
\text { Republic of Daghestan }\end{array}$ & $\begin{array}{c}\text { «Скачкообразный» переход в группы (не более 2) / } \\
\text { "Jump" transition in groups (no more than 2) }\end{array}$ \\
\hline
\end{tabular}

Обосновано, что для успешного управления рациональным использованием водных ресурсов горных территорий СКФО и регулирования уровня нагрузки на их водные ресурсы необходимо проведение регулярного мониторинга водопотребления и коррекции типологизации регионов в зависимости от склады- вающихся тенденций изменения показателей водопользования, что будет способствовать выходу территорий на траекторию устойчивого экологически ориентированного социально-экономического роста. 


\section{ЛИТЕРАТУРА:}

1. Ализаде Э.К., Тарихазер С.А., Кучинская И.Я., Гулиева С.Ю. Ландшафтно-геоморфологическая оценка рекреационного потенциала горных геосистем (на примере азербайджанской части Большого Кавказа) // Устойчивое развитие горных территорий. 2017. Т.9. N2 (32). С.130140. DOI: 10.21177/1998-4502-2017-9-2-130-140

2. Данилов-Данильян В.И., Пряжинская В.Г. Экономические и территориальные аспекты управления водохозяйственным комплексом России. Москва: РАСХН, 2013.311 с.

3. Левит-Гуревич Л.К., Пряжинская В.Г., Хранович И.Л., Ярошевский Д.М. Проблемы при составлении схем комплексного использования и охраны водных объектов // Водное хозяйство России. 2010. N6. С.4-16.

4. Беляев С.Д., Мерзликина Ю.Б., Прохорова Н.Б. Предложения по переходу к побассейновой системе управления водными ресурсами // Водное хозяйство России. 2014. N5. C. $10-28$.

5. Пряжинская В.Г. Решение водохозяйственных проблем с использованием математических моделей // Известия Кабардино-Балкарского научного центра РАН. 2011. N1(39). C.307-310.

6. Фролов Д. П., Стратулат И.В., Бабкин М.М., Соловьева И.А. Секторно-сбалансированное развитие экономики региона: постановка проблемы // Современные проблемы науки и образования. 2015. N1. С. 468-469.

7. Шикломанов И.А., Бабкин В. И., Балонишникова Ж. А. Водные ресурсы, их использование и водообеспеченность в России: современные и перспективные оценки // Водные ресурсы. 2011. Том 38. N 2. C. 131-141.

8. Zhang D., Guo P. Integrated agriculture water management optimization model for water saving potential analysis // Agricultural Water Management. 2016. Vol. 170. Pp. 5-19. DOI: 10.1016/J.AGWAT.2015.11.004.

9. Благодаткин А.В. Смирнова В.М., Макеев И.С. Методические указания. Метод комплексной оценки степени загрязненности поверхностных вод по гидрохимическим показателям. Определение удельного комбинаторного индекса загрязненности воды (УКИЗВ) и класса качества воды. Н.Новгород, 2015. 19 с.

10. Дружинин А.Г. Юг России в меняющемся геостратегическом контексте: важнейшие структурные компоненты и тренды (взгляд географа-обществоведа) // Научная мысль Кавказа. 2014. N3. С. 58-66.

11. Киселева Н.Н., Орлянская А.А., Сулиманов А.Р. Адаптивное управление социально-экономическим развитием сельских территорий регионов СКФО. Москва: Академия Естествознания. 2013. 136 с.

12. Колесников Ю.С. Региональная политика модернизации экономики российского Кавказа: проблемы и стратегии // Terra Economicus. 2012. Т.10. N3. Ч.3. С. 5-10

13. Фридман Ю.А., Речко Г.Н., Логинова Е.Ю. Инновационное развитие сырьевых отраслей как драйвер роста конкурентоспособности региона: концепция исследования // Региональная экономика. Юг России. 2014. N1. (3). С. $14-19$.

14. Боярко Г.Ю., Цибульникова М.Р., Вазим А.А. Актуальные вопросы экономики природопользования. Томск: STT, 2017. $122 \mathrm{c}$.
15. Корпачев В.П. Водные ресурсы и основы водного хозяйства. Санкт-Петербург: Лань, 2012. 318 с.

16. Lin X., Sha J., Yan J. Exploring the Impacts of Water Resources on Economic Development in Beijing-Tianjin-Hebei Region // ERSA conference. European Regional Science Association. URL: http://www-sre.wu.ac.at/ersa/ersaconfs/ersa15/ e150825aFinal00723.pdf (дата обращения 20.10.2017).

17. Niua G., Li Y.P., Huangb G.H., Liu J., Fanb Y.R. Crop planning and water resource allocation for sustainable development of an irrigation region in China under multiple uncertainties // Agricultural Water Management. 2016. Vol. 166. Pp. 53-69. DOI:10.1016/j.agwat.2015.12.011.

18. Керимов И.А., Даукаев А.А., Гайрабеков У.Т., Даукаев Асл. А. Природно-рекреационный потенциал горной части Чеченской Республики как фактор устойчивого развития региона // Устойчивое развитие горных территорий. 2017. T.9. N3 (33). C.211-218. DOI: 10.21177/1998-45022017-9 -3-211-218.

19. Xu C.-Y., Singh V.P. Review on Regional Water Resources Assessment Models under Stationary and Changing Climate // Water Resources Management. 2004. Vol. 18. Issue 6. Pp. 591-612. DOI: 10.1007/s11269-004-9130-0.

20. Loukas A., Mylopoulos N., Vasiliades L. A Modeling System for the Evaluation of Water Resources Management Strategies in Thessaly, Greece // Water Resources Management. 2007. Vol. 21. Issue 10. Pp. 1673-1702. DOI: 10.1007/ s11269-006-9120-5.

21. Torregrosa T., Sevilla M., Montaño B., López-Vico $\mathrm{V}$. The Integrated Management of Water Resources in Marina Baja (Alicante, Spain). A Simultaneous Equation Model // Water Resources Management. 2010. Vol. 24. Issue 14. Pp. 3799-3815. DOI: 10.1007/s11269-010-9634-8.

22. Molina J.L Aróstegui J.L., Benavente J., Varela C., Hera A., Geta J.A. Aquifers Over exploitation in SE Spain: A Proposal for the Integrated Analysis of Water Management // Water Resources Management. 2009. Vol. 23. Issue 13. Pp. 2737-2760. DOI: 10.1007/s11269-009-9406-5.

23. Calizayar A., Meixner O., Bengtsson L., Berndtsson R. Multi-criteria Decision Analysis (MCDA) for Integrated Water Resources Management (IWRM) in the Lake Poopo Basin, Bolivia // Water Resources Management. 2010. Vol. 24. Issue 10. Pp. 2267-2289. DOI: 10.1007/s11269-009-9551-x.

24. Maneta M.P., Torres M., Wallender W.W., Vosti S., Kirby M., Baissoi L.H., Rodrigues L.N. Water demand and flows in the São Francisco River Basin (Brazil) with increased irrigation // Agricultural Water Management. Vol. 96, Issue 8. 2009. Pp. 1191-1200. DOI: 10.1016/j.agwat.2009.03.008.

25. Souza J., Saad João C., Sánchez-Román R., Rodríguez-Sinobas L. No-till and direct seeding agriculture in irrigated bean: Effect of incorporating crop residues on soil water availability and retention, and yield // Agricultural Water Management. Vol. 170.2016. Pp. 158-166. DOI: 10.1016/j. agwat.2016.01.002.

26. Amisigo B. A., McCluskey A., Swanson R. Modeling Impact of Climate Change on Water Resources and Agriculture Demand in the Volta Basin and other Basin Systems in Ghana // Sustainability. 2015. Vol.7. Pp. 1-19.

27. Ponce R., Blanco M., Giupponi C. Climate Change, 
Water Scarcity in Agriculture and the Country-Level Economic Impacts. A Multimarket Analysis // Serie Working Paper. 2014. No 2. 30 p. URL: http://repositorio.udd.cl/bitstream/ handle/11447/20/wp02.pdf (дата обращения 20.10.2017).

28. Ponce R., Parrado R. Climate Change, Water Scarcity on Agriculture and the Economy-Wide: impacts in the LAC Region // Serie Working Paper. № 16, 2015. 25 p. URL: http://repositorio.udd.cl/bitstream/handle/11447/110/wp16. pdf?sequence=1 (дата обращения 20.10.2017).

29. Barthel R., Reichenau T., Krimly T., Dabbert S., Schneider K., Mauser W. Integrated Modeling of Global Change Impacts on Agriculture and Groundwater Resources // Water Resources Management. Volume 26, Issue 7, 2012. Pp. 1929-1951. DOI: 10.1007/s11269-012-0001-9.

30. Habibi Davijani M., Banihabib M.E., Nadjafzadeh Anvar A. et al. Multi-Objective Optimization Model for the Allocation of Water Resources in Arid Regions Based on the Maximization of Socioeconomic Efficiency // Water Resourc- es Management. 2016. No 30 (3). Pp. 927-946. DOI: 10.1007/ s11269-015-1200-y.

31. Chen Z., Wang H. \& Qi X. Pricing and Water Resource Allocation Scheme for the South-to-North Water Diversion Project in China // Water Resources Management. 2013. No 5. Pp. 1457-1472. DOI: 10.1007/s11269-012-0248-1.

32. Esmaeili, A. \& Vazirzadeh, S. Water Pricing for Agricultural Production in the South of Iran // Water Resources Management. 2009. No 23. Pp. 957-964. DOI: 10.1007/ s11269-008-9308-y.

33. Aidam $P$. The impact of water-pricing policy on the demand for water resources by farmers in Ghana // Agricultural Water Management. 2015. No 158. Pp. 10-16. DOI: 10.1016/j. agwat.2015.04.007.

34. Mo Li, Ping Guo, Singh V., Yang G. An uncertaintybased framework for agricultural water-land resources allocation and risk evaluation // Agricultural Water Management. 2016. No 177. Pp. 10-23.

\section{БЛАГОДАРНОСТЬ / Gratitude:}

Статья реализуется за счет средств внутреннего гранта ЮФУ ВнГр-07/2017-13 в рамках проекта «Формирование системы поддержки принятия решений по управлению ресурсным обеспечением стратегического развития регионов Юга России» базовой части Госзадания Минобрнауки РФ / The article is implemented at the expense of the internal grant of Southern Federal University BнГp-07/2017-13 in the framework of the project "Formation of a decision support system for the management of resources for the strategic development of the South of Russia" of the basic part of the state Assignment of the Ministry of education and science.

\section{СВЕДЕНИЯ ОБ АВТОРАХ / Information about authors:}

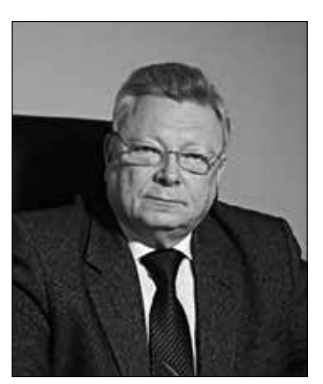

КОСОЛАПОВ Алексей Евгеньевич - доктор технических наук, профессор; директор.

Российский информационноаналитический и научно-исследовательский водохозяйственный центр, г. Ростов-на-Дону, Россия e-mail:akosol@mail.ru Тел.:+7(8632)64-46-87,

Alexey Evgenievich KOSOLAPOV - Doctor of Technical Sciences, Professor; Director.

Russian Information-Analytical and Research Water Management Center, Rostov-on-Don, Russia

e-mail:akosol@mail.ru

Тел.:+7(8632)64-46-87,

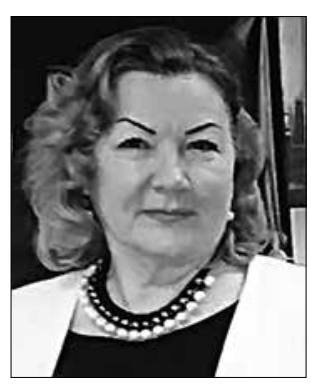

МАТВЕЕВА Людмила Григорьевна - доктор экономических наук, профессор, профессор кафедры информационной экономикиЮжного федерального университета; главный научный сотрудник Российского информационно-аналитического и научно-исследовательского водохозяйственного центра, г. Ростов-наДону, Россия

e-mail: matveeva_lg@mail.ru

Тел.: +7(8632)64-46-87,

Lyidmila Grigorievna MATVEEVA - Doctor of Economics, Professor, Professor of Information Economics department, Southern Federal University; Chief Researcher, Russian Information-Analytical and Research Water Management Center, Rostov-on-Don, Russia e-mail:matveevalg@mail.ru

Тел.: +7(8632)64-46-87, 


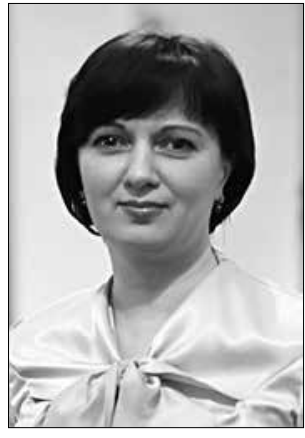

Тел.: +7(8632)64-46-87

\section{ЧЕРНОВА Ольга Анатольев-}

на - доктор экономических наук, доцент, профессор кафедры информационной экономики Южного федерального университета; ведущий научный сотрудник Российского информационно-аналитического и научно-исследовательского водохозяйственного центра, г. Ростов-наДону, Россия

e-mail: chernova.olga71@yandex.ru

Olga Anatolievna CHERNOVA - Doctor of Economics, Associated Professor, Professor of Information Economics Department, Southern Federal University; chief researcher, Russian Information-Analytical and Research Water Management Center, Rostov-on-Don, Russia

e-mail: chernova.olga71@yandex.ru

Тел.: +7(8632)64-46-87

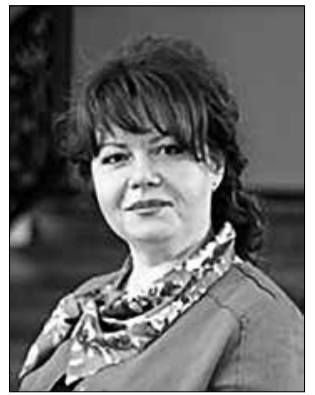

КОСОЛАПОВА

Наталья

Алексеевна - доктор экономических наук, доцент, профессор кафедры экономической кибернетики Южного федерального университета; старший научный сотрудник Российского информационно-аналитического и научно-исследовательского водохозяйственного центра, г. Ростов-на-Дону, Россия

e-mail: nakosolapova@sfedu.ru

Тел.: +7(8632)64-46-87

Natalia Alekseevna KOSOLAPOVA - Doctor of Economics, Associate Professor, Professor of Economic Cybernetics Department Southern Federal University; Senior Researcher, Russian Information-Analytical and Research Water Management Center, Rostov-onDon, Russia

e-mail:nakosolapova@sfedu.ru

Тел.: +7(8632)64-46-87

\section{EFFICIENCY OF WATER RESOURCE USE IN ECONOMICS OF THE NORTH CAUCASUS MOUNTAIN TERRITORIES}

${ }^{1}$ Kosolapov A. E.,

${ }^{2}$ Kosolapova N. A.,

${ }^{2}$ Matveeva L.G.,*

${ }^{2}$ Chernova O.A.

${ }^{I}$ Russian Information-Analytic and Research Water Economy Centre, Rostov-on-Don, Russia

${ }^{2}$ Southern Federal University, Russian Information-Analytic and Research Water Economy Centre, Rostov-on-Don, Russia,

*e-mail: matveevalg@mail.ru

\section{DOI: $10.21177 / 1998-4502-2018-10-1-48-62$}

Competiveness enhancement of the North Caucasus mountain territories against the background of high water capacity in the regional production and simultaneous lower level of water supple call forth urgency for carrying out a comprehensive analysis of water use efficiency in the examined regions and this is the objective of the present research. The authors think that from the position of development stability in the mountain territories, water use efficiency should be assessed together with socioeconomic indices of these regions. This will make it possible to raise harmonization level of their ecological, economical and social spheres.

Materials and research methods. Assessment of water resource use efficiency is carried out from the position of the system-synergetic approach using the following groups of indices: loadings on water resources, water supple, water capacity, water resource quality.

The results received and their discussion. The research results indicated that in spite of a significant potential of water economy systems in the mountain territories they were notable for the high and critically high levels of loading on water resources. All the mountain regions, except the Karachi-Circassian Republic and the Republic Severnaya Osetia-Alania, have "catastrophically low", "very low" and "low" water supply levels. This is an impeding factor for their steady development and mares the task of enhancing water use efficiency important. Significance of solving this problem increases taking into consideration primarily agricultural specialization of the North Caucasus republics in addition to that arable land intensity in their availavle land structure exceeds $50 \%$ and low water period lasts for 10 years, on the average. The authors' hypothesis is that efficiency of water resource use is primarily reflected in water capacity indices of the Gross Regional Product (GRP). Analysis of this index for the considered regions showed that they had its highest level among all the RF constitutional territories. At the same time, under the trend of growing the GRP, reducing in its water capacity is observed. This means that in the corresponding regions resource saving technologies are used and these assure the socio-economical development at the expense of intensive rather that extensive factors. The highest indices of the GRP growth rate are typical for the Republic of Dagestan that allows to say about the high level of water use efficiency for this region.

Conclusion. Regular monitoring of water use efficiency indices mares it possible to develop definite measures within the frame of strategies for the steady social and economical development of the mountain territories.

Keywords: resource use, stability, water resource conservation, water use, efficient water use.

\section{References}

1. Alizade Je.K., Tarihazer S.A., Kuchinskaja I.Ja., Gulieva S.Ju. Landscape-geomorphologic evaluation of recreational potential of mountain geosystems (on an example of Azerbaijan part of greater Caucasus). Sustainable development of mountain territories. 2017. vol. 9, no 2 (32). Pp. 130-140. (in Russian) DOI: $10.21177 / 1998-4502-2017-9-2-130-140$

2. Danilov-Danil'jan V.I., Prjazhinskaja V.G. The economic and territorial aspects of water management complex of Russia. Moscow. 2013. 311 p. (in Russian) 
3. Levit-Gurevich L.K., Prjazhinskaja V.G., Hranovich I.L., Jaroshevskij D.M. Problems in the preparation of schemes of complex use and protection of water objects . Russia's water sector. 2010. No 6. Pp. 4-16. (in Russian)

4. Beljaev S.D., Merzlikina Ju.B., Prohorova N.B. Proposals for the transition to Obasanjo the water resources management system. Russia's water sector. 2014. No 5. Pp. 10-28 (in Russian).

5. Prjazhinskaja V.G. The solution of water management problems using mathematical models. Proceedings of the Kabardino-Balkar scientific centre of the RAS. 2011. No 1(39). Pp. 307-310 (in Russian).

6. Frolov D. P., Stratulat I.V., Babkin M.M., Solov'eva I.A. A sector-balanced development of regional economy: the problem. Modern problems of science and education [Sovremennye problemy nauki i obrazovanija], 2015, no 1. (in Russian), pp. 468-469. (in Russian)

7. Shiklomanov I.A., Babkin V. I., Balonishnikova Zh. A. Water resources, their use and water availability in Russia: current and perspective assessment. Water resources. 2011. Vol 38, no 2. Pp. 131-141. (in Russian)

8. Zhang D., Guo P. Integrated agriculture water management optimization model for water saving potential analysis. Agricultural Water Management. 2016. vol. 170. Pp. 5-19. DOI: 10.1016/J.AGWAT.2015.11.004.

9. Blagodatkin A.V. Smirnova V.M., Makeev I.S. Methodical instructions. The method of complex assessment of the degree of contamination of surface water by hydrochemical indicators. Determination of the specific combinatorial index of water pollution, and water quality. N. Novgorod. 2015. 19 p. (in Russian)

10. Druzhinin A.G. The South of Russia in the changing geo-strategic context: the critical structural components and trends (glance geographer-social scientist). Scientific thought of Caucasus. 2014. No 3. Pp. 58-66. (in Russian)

11. Kiseleva N.N., Orljanskaja A.A., Sulimanov A.R. Adaptive management of socio-economic development of rural territories of the North Caucasus Federal district regions. Moscow. Akademija Estestvoznanija. 2013. 136 p. (in Russian)

12. Kolesnikov Ju.S. Regional economic modernization policy of the Russian Caucasus: problems and strategies. Terra Economicus. 2012. Vol.10, no 3. Pp. 5-10. (in Russian)

13. Fridman Ju.A., Rechko G.N., Loginova E.Ju. Innovative development of primary industries as the driver of growth of regional competitiveness: concept studies. Regional economy. The South of Russia. 2014. No 1(3). Pp. 14-19. (in Russian)

14. Bojarko G.Ju., Cibul'nikova M.R., Vazim A.A. Current issues of environmental Economics. Tomsk: STT. 2017. 122 p. (in Russian)

15. Korpachev V.P. Water and basis of water management. Sankt-Peterburg: Lan'. 2012.318 p. (in Russian)

16. Lin X., Sha J., Yan J. Exploring the Impacts of Water Resources on Economic Development in Beijing-Tianjin-Hebei Region. ERSA conference. European Regional Science Association. Available at: http://www-sre.wu.ac.at/ ersa/ersaconfs/ersa15/e150825aFinal00723.pdf (accessed 20.10.2017).

17. Niua G., Li Y.P., Huangb G.H., Liu J., Fanb Y.R. Crop planning and water resource allocation for sustainable devel- opment of an irrigation region in China under multiple uncertainties. Agricultural Water Management, 2016, vol. 166 , pp. 53-69. DOI:10.1016/j.agwat.2015.12.011.

18. Kerimov I.A., Daukaev A.A., Gajrabekov U.T., Daukae Asl. A. Natural-recreational potential of the mountainous part of the Chechen Republic as factor of sustainable development of the region. Sustainable development of mountain territories. 2017. Vol. 9, no 3 (33). Pp. 211-218. DOI: 10.21177/1998-4502-2017-9 -3-211-218. (in Russian)

19. Xu C.-Y., Singh V.P. Review on Regional Water Resources Assessment Models under Stationary and Changing Climate. Water Resources Management, 2004, vol. 18 (6), pp. 591-612. DOI: 10.1007/s11269-004-9130-0.

20. Loukas A., Mylopoulos N., Vasiliades L. A Modeling System for the Evaluation of Water Resources Management Strategies in Thessaly, Greece. Water Resources Management. 2007. Vol. 21 (10). Pp.1673-1702. DOI: 10.1007/ s11269-006-9120-5.

21. Torregrosa T., Sevilla M., Montaño B., López-Vico V. The Integrated Management of Water Resources in Marina Baja (Alicante, Spain). A Simultaneous Equation Model. Water Resources Management. 2010. Vol. 24 (14). Pp. 3799 3815. DOI: $10.1007 / \mathrm{s} 11269-010-9634-8$.

22. Molina J.L Aróstegui J.L., Benavente J., Varela C., Hera A., Geta J.A. Aquifers Over exploitation in SE Spain: A Proposal for the Integrated Analysis of Water Management. Water Resources Management. 2009. Vol. 23 (13). Pp. $2737-$ 2760. DOI: 10.1007/s11269-009-9406-5.

23. Calizayar A., Meixner O., Bengtsson L., Berndtsson R. Multi-criteria Decision Analysis (MCDA) for Integrated Water Resources Management (IWRM) in the Lake Poopo Basin, Bolivia. Water Resources Management. 2010. Vol. 24 (10). Pp. 2267-2289. DOI: 10.1007/s11269-009-9551-x.

24. Maneta M.P., Torres M., Wallender W.W., Vosti S., Kirby M., Baissoi L.H., Rodrigues L.N. Water demand and flows in the São Francisco River Basin (Brazil) with increased irrigation. Agricultural Water Management. 2009. Vol. 96 (8). Pp. 1191-1200. DOI: 10.1016/j.agwat.2009.03.008.

25. Souza J., Saad João C., Sánchez-Román R., Rodríguez-Sinobas L. No-till and direct seeding agriculture in irrigated bean: Effect of incorporating crop residues on soil water availability and retention, and yield. Agricultural Water Management. Vol. 170. 2016. Pp. 158-166. DOI: 10.1016/j. agwat.2016.01.002.

26. Amisigo B. A., McCluskey A., Swanson R. (2015). Modeling Impact of Climate Change on Water Resources and Agriculture Demand in the Volta Basin and other Basin Systems in Ghana. Sustainability. 2015. Vol. 7. Pp. 1-19.

27. Ponce R., Blanco M., Giupponi C. Climate Change, Water Scarcity in Agriculture and the Country-Level Economic Impacts. A Multimarket Analysis. Serie Working Paper. 2014. No 2. 30 p. Available at: http://repositorio.udd.cl/ bitstream/handle/11447/20/wp02.pdf (accessed 20.10.2017).

28. Ponce R., Parrado R. Climate Change, Water Scarcity on Agriculture and the Economy-Wide: impacts in the LAC Region. Serie Working Paper. 2015. no 16, 25 p. Available at: http://repositorio.udd.cl/bitstream/handle/11447/110/wp16. pdf? sequence $=1$ (accessed 20.10.2017).

29. Barthel R., Reichenau T., Krimly T., Dabbert S., Schneider K., Mauser W. Integrated Modeling of Global 
Change Impacts on Agriculture and Groundwater Resources. Water Resources Management. 2012. Vol. 26 (7). Pp. 1929-1951. DOI: 10.1007/s11269-012-0001-9.

30. Habibi Davijani M., Banihabib M.E., Nadjafzadeh Anvar A. et al. Multi-Objective Optimization Model for the Allocation of Water Resources in Arid Regions Based on the Maximization of Socioeconomic Efficiency. Water Resources Management. 2016. No 30 (3). Pp. 927-946. DOI: 10.1007/s11269-015-1200-y.

31. Chen, Z., Wang, H. \& Qi, X. Pricing and Water Resource Allocation Scheme for the South-to-North Water Diversion Project in China. Water Resources Management. 2013. No 5. Pp. 1457-1472. DOI: 10.1007/s11269-0120248-1.
32. Esmaeili, A. \& Vazirzadeh, S. Water Pricing for Agricultural Production in the South of Iran. Water Resources Management. 2009. No 23. Pp. 957-964. DOI: 10.1007/ s11269-008-9308-y.

33. Aidam P. The impact of water-pricing policy on the demand for water resources by farmers in Ghana. Agricultural Water Management. 2015. No 158. Pp. 10-16. DOI: 10.1016/j.agwat.2015.04.007.

34. Mo Li, Ping Guo, Singh V., Yang G. An uncertainty-based framework for agricultural water-land resources allocation and risk evaluation. Agricultural Water Management.2016. No 177. Pp. 10-23. 


\section{HEAVY OIL DEPOSITS AND COMPOSITIONAL ANALYSIS OF SOME BITUMINOUS OIL SAND SAMPLES OF SOUTH WESTERN NIGERIA}

\section{Bitumen occurrences}

\section{Introduction}

1.1 Surface occurrences: Extensive bituminous seepages and sediments impregnated with tarry oil (oil sands) define a narrow band about $5-8 \mathrm{Km}$ wide between latitude $6^{\circ} 37^{\prime} \mathrm{N}$ and $6048^{\prime} \mathrm{N}$, stretching from just east of Ijebu-Ode town, in Ogun State to the banks of Siluko river at Ofosu village in Edo State, with approximate distance of $110 \mathrm{Km}$. They occur in two different forms:

- As seepages in farmlands, seen mostly on hot sunny days, from the underlying sandstone reservoir,

- As surface and near surface impregnated sediments exposed along road cuts, cliff faces, riverbanks and at the break of slope [1 - 3].

With the exception of road - cuts, most of these outcrops and seepages occur in geographic positions not easily accessible. An example is in deeply incised valleys underneath cover of lush vegetation. These sediments are cretaceous (Maastrichtian) in age and abort on basement complex rocks over the Okitipupa structure. They form the oldest outcropping sediments within the Benin basin. These hydrocarbon shows were a source of attraction to early explorationist, and between 1907 and 1966, oil exploration activities were focused within the marginal and coastal area of the Benin basin [4-6].

1.2 Subsurface occurrences: Subsurface occurrences of bituminous sands and heavy oil are from flows and shows in abandoned wells drilled in the onshore, costal and near offshore areas of the Benin basin. Most of these wells penetrated horizons with highly viscous hydrocarbons in relatively shallow depths. Two major horizons generally referred to as Horizons $X$ and $Y$ have been encountered within the shallow levels [7-9].

2. Top lateritic soils: Thickness, a function of topography and degree of lateritization, ranges from $1.5 \mathrm{~m}$ to $8 \mathrm{~m}$. Lateral variations occur due to the original in-situ material. Usually, thick vegetation cover with a rich darkish loamy soil 0.0 $-0.65 \mathrm{~m}$ is observed. Where the top loamy soil is absent, the lateritic soil is composed of lateritized clay, sand and pebbles. The colour ranges from grey to yellow, brown and reddish brown. In a typical vertical distribution indicated below, the thickness of the colour band is controlled by the degree of lateritization, advanced stages thick column of reddish to reddish - brown soils. A typical soil profile is:

-Thin darkish loamy soil cover

- Light grey - brownish with patches of whitish to yellowish clay/sand.

- Fine medium grained sands and clays with pebble mixtures. Clays confer some degree of plasticity. Pebbles are sub-angular to sub-rounded. Average diameter $0.003 \mathrm{~m}-0.01 \mathrm{~m}[10-12]$.

3. Upper shales and limestone: The upper shales and limestone, age Maastrichtian - Palaeocene, have thickness ranges from $3 \mathrm{~m}$ in up dip boreholes to 55 $\mathrm{m}$ in down dip boreholes. In a borehole, $\mathrm{BH}-10$, located about I Km south of the bitumen outcrop belt, it attains a thickness of $50 \mathrm{~m}$. It is composed of marine clays, sandy clays, silty clay, clayey sand, shale, limestone, calcareous sands and clay stones. Predominantly lithofacies are sandy clays and silty clays. Others occur as thin beds. The shales are grey to dark - grey - black, may be soft and plas-

\footnotetext{
${ }^{1}$ Department of Petroleum Engineering, Rivers State University of Science and Technology, Port Harcourt, Rivers State, Nigeria
}

${ }^{1}$ Nwizug-bee Leyii Kluivert

\section{УДК: 622.276 .66}

DOI: 10.21177/1998-4502-2018-10-

\section{$1-63-68$}

Compositional analysis of some bituminous oil sand samples and heavy oil deposits of South Western Nigeria are presented in this research work. An in-depth study of bituminous occurrences, top lateritic soils, upper shales and limestone, upper bituminous sediments (Horizon X), lower bituminous sediments (Horizon $Y$ ) is considered.

\section{КЛЮЧЕВЫЕ СЛОВА:}

bituminous oil, oil sand, compositional analysis, heavy oil, tar belt, sediments. Minerals, percentage by weight, Horizon $X$, Horizon Y. 
tic. Clay stones are fairly compact and hard. Shales are thinly laminated. Lignite streaks and pyrite are common. Whitish crystalline limestone to greyish sandy limestone occur as thin beds, size $0.008 \mathrm{~m}$, becoming thicker eastwards [13-15].

4. Upper bituminous sediments (Horizon $X)$ : This sequence is composed of fine to medium grained sands with interbeds $1-2 \mathrm{~m}$ thick of sandy - clay or clayey sands, clay, shale and loose sands devoid of bitumen. Lignite streaks and framebold pyrite occur in the fine grained sediments. Shell fragments of macrofossils and cast of pelecypods occurs. The outcrop sections around camp Loda are known to contain inoceramus foraminifers and dinoflagellates. Oil sand thickness varies from $9 \mathrm{~m}$ to $22 \mathrm{~m}$, with an average of $15 \mathrm{~m}$ [16 - 18].

5. Lower bituminous sediments (Horizon Y): It is composed of fine to medium grained sands, with thin interbeds, having a maximum thickness of $2 \mathrm{~m}$, with grey - sandy clays and dark - grey shales. Shales are fossiliferous, containing abundant shell fragments of bivalves, lignite streaks and nodules of pyrite. An oil water con- tact separates the oil sands from the clean water bearing sands below. In some boreholes, the bitumen in the sands flows.

The depth to the top of this sand body ranges from $0.2 \mathrm{~m}$, near the outcrop areas to $83 \mathrm{~m}$, in more southern areas. East - West variation of depth to top of sand increases eastwards. The thickness of the Y Horizon varies widely from $3 \mathrm{~m}$ (East) to $22.6 \mathrm{~m}$ (West). Within an average thickness of $12-16 \mathrm{~m}$ (Western half), decreasing in the South - East direction. The horizon thus significantly becomes irregular and inconsistent. In the sediment basement rock contact areas, the clayey units are generally absent $[19-22]$.

6. Compositional analysis of bituminous oil sand samples: Bituminous oil sand samples were collected from various locations across the tar belt, grouped into three (3) and analyzed. Percentage by weight of bitumen, mineral matter and water were determined. The results are presented in table 1, 2 and 3 while figure 1,2 and 3 present graphical illustrations of these parameters.

Compositional analysis of group 1 bituminous oil sand

\begin{tabular}{|c|c|c|c|c|}
\hline Sample № & Location & $\begin{array}{c}\mathrm{Wt} \% \\
\text { Bitumen }\end{array}$ & $\begin{array}{c}\mathrm{Wt} \% \\
\text { Mineral Matter }\end{array}$ & $\begin{array}{c}\text { Wt\% } \\
\text { Water }\end{array}$ \\
\hline 1 & Yegbata (C1) & 20 & 82 & 0.9 \\
\hline 2 & Yegbata (C2) & 19 & 80 & 0.8 \\
\hline 3 & Igorisa(Left 1) Pit 1 & 17 & 83 & 0.7 \\
\hline 4 & Igorisa(Left 2) Pit 2 & 7 & 90 & 1.8 \\
\hline 5 & Yegbata (Right 1) Pit1 & 14 & 82 & 1.3 \\
\hline 6 & Yegbata (Right 2) Pit2 & 15 & 81 & 1.0 \\
\hline
\end{tabular}

Table 2

Compositional analysis of group 2 bituminous oil sand

\begin{tabular}{|c|c|c|c|c|}
\hline Sample № & Location & $\begin{array}{c}\mathrm{Wt} \% \\
\text { Bitumen }\end{array}$ & $\begin{array}{c}\mathrm{Wt} \% \\
\text { Mineral Matter }\end{array}$ & $\begin{array}{c}\text { Wt } \% \\
\text { Water }\end{array}$ \\
\hline 2 & Sogbon(Pit 1) & 12 & 85 & 5.4 \\
\hline 3 & Iju-Oke(Pit1) & 8 & 90 & 4.6 \\
\hline 4 & Iju-Oke(Pit2) & 5 & 82 & 5.2 \\
\hline 5 & Oke- Idebi & 11 & 50 & 6.3 \\
\hline 6
\end{tabular}

Compositional analysis of group 3 bituminous oil sand

\begin{tabular}{|c|c|c|c|c|}
\hline Sample № & Location & $\begin{array}{c}\text { Wt\% } \\
\text { Bitumen }\end{array}$ & $\begin{array}{c}\text { Wt\% } \\
\text { Mineral Matter }\end{array}$ & $\begin{array}{c}\text { Wt\% } \\
\text { Water }\end{array}$ \\
\hline 1 & Sogbon (Pit 2) & 3.5 & 95 & 4.5 \\
\hline 2 & Ladan (Pit 1) & 19.8 & 78 & 5.3 \\
\hline 3 & Ladawo (Pit 1) & 17.2 & 80 & 5.2 \\
\hline 4 & Ladawo (Well 2) & 18.3 & 79 & 5.1 \\
\hline
\end{tabular}




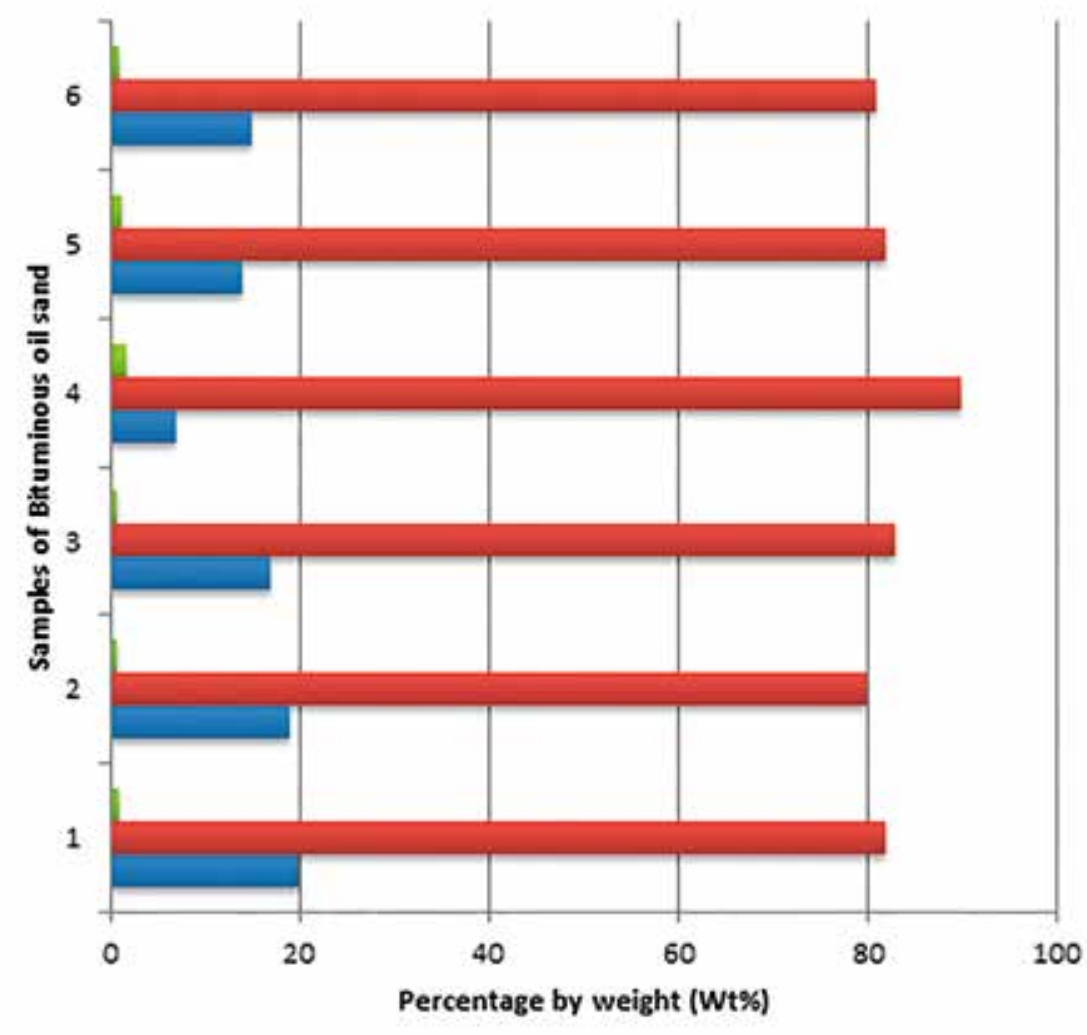

I Wt\% Water

wt\% Mineral Matter

wts Bitumen

Fig. 1. Graphical analysis of group 1 bituminous oil sand

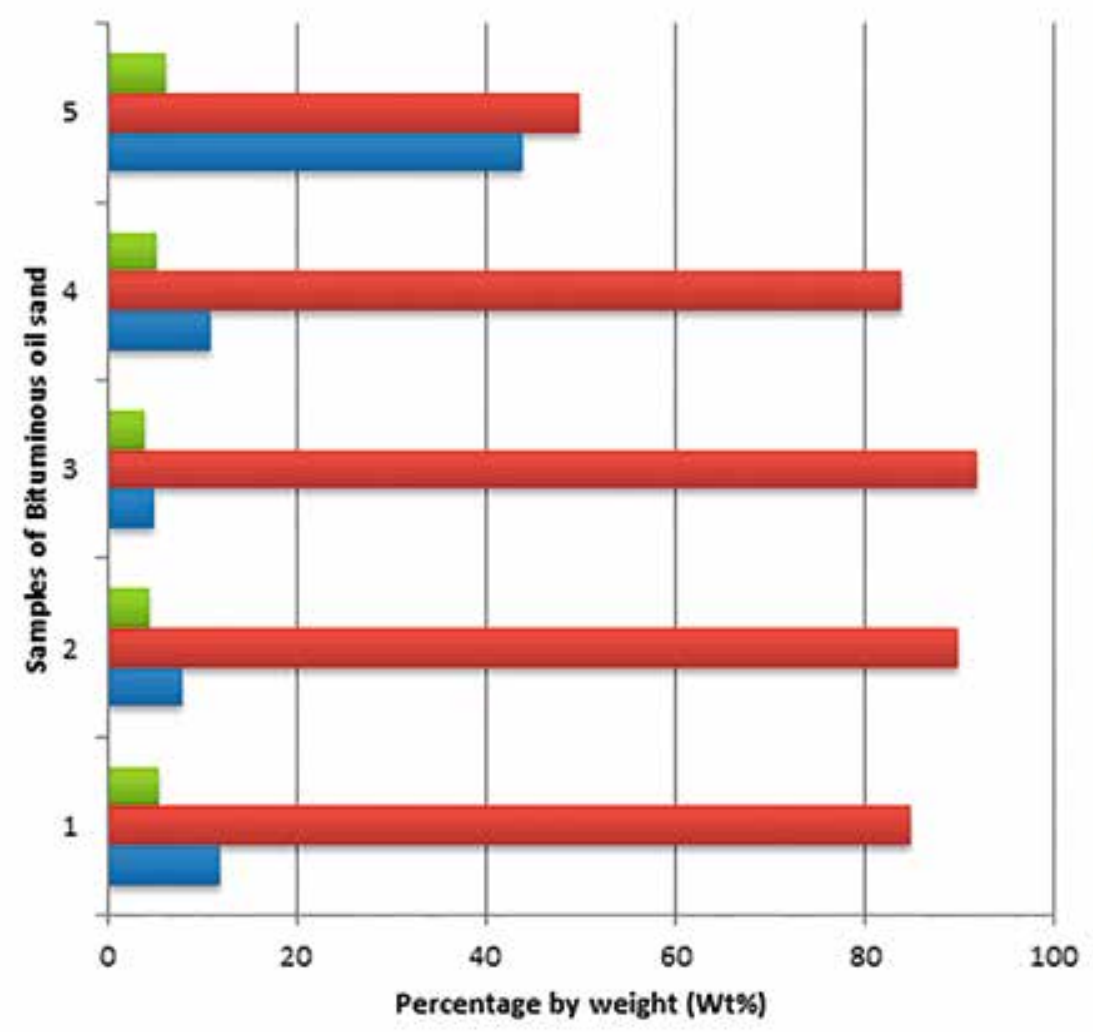

I Wt\% Water

wt\% Mineral Matter

=Wt\% Bitumen

Fig. 2. Graphical analysis of group 2 bituminous oil sand 


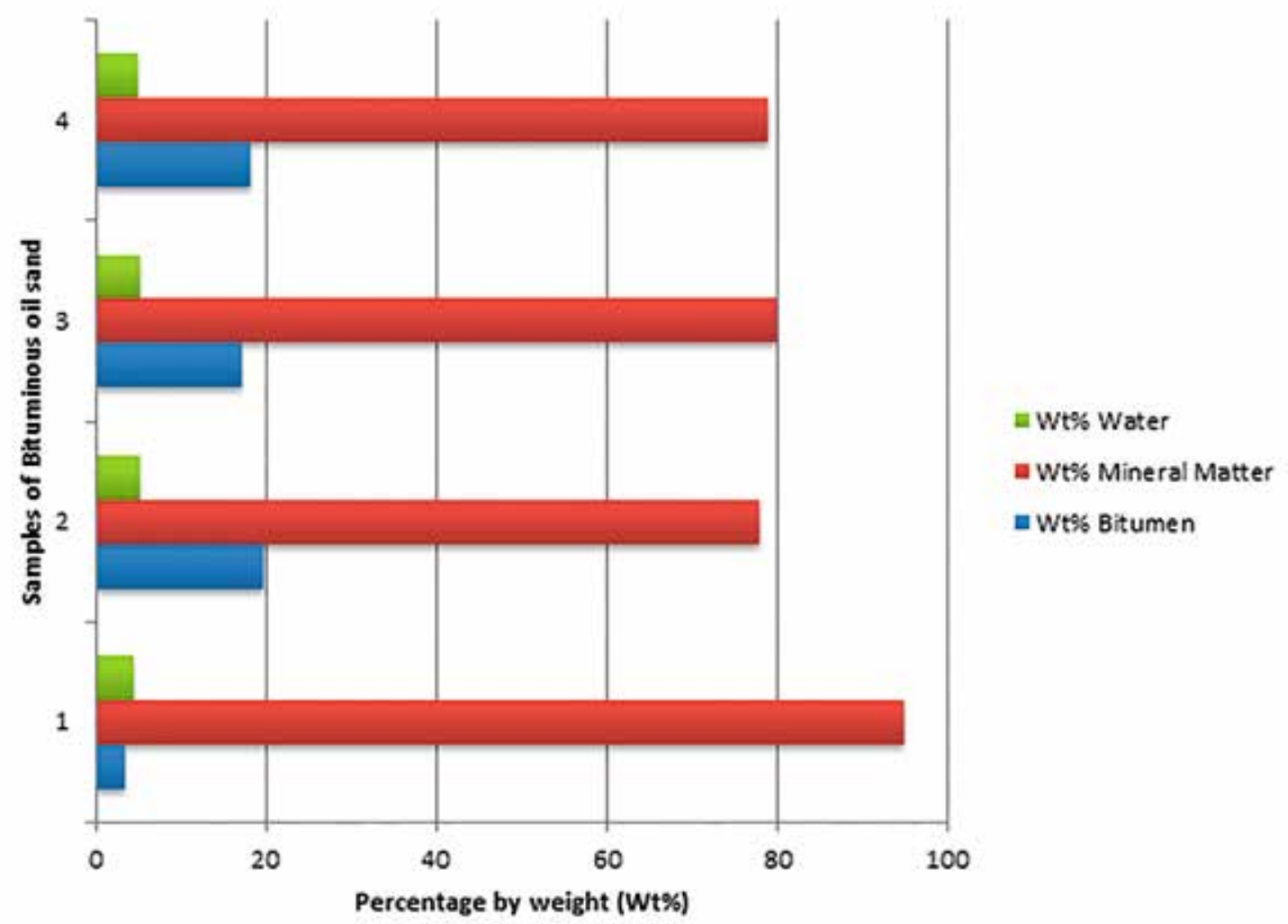

Fig. 3. Graphical analysis of group 3 bituminous oil sand

6.1 Analysis of results and discussion: As shown on the graphical analysis of group 1, 2 and 3 of the bituminous oil sand samples, there is high composition of mineral matter followed by bitumen and water. The composition of water is significantly low in group 1 bituminous oil sand samples compare to group 2 and 3 (Table $1-3$ ).
7. Conclusion: The bituminous oil sand samples are composed basically of bitumen, mineral matter and water. The composition of mineral matter in the oil sand samples are much higher compare to bitumen and water. It is important to note that these three main compositions of the oil sand are economically valuable.

\section{REFERENCES:}

1. Adegoke O.S. Geological Guide to some Nigerian Cretaceous - Recent Localities. 7th African Micropalaeontological Colloquim, Ile - Ife, 1976. P.6.

2. Adegoke O. S. Tar Sand Project Phase II - Estimation of Reserves, Materials Testing and Chemical Analysis. Geological Consultancy Units, University of Ife, Nigeria, 1976. P.10.

3. Adegoke O. S., Omotsola M., Coker S. The Geology of the Nigerian Tar Sands. 5th UNITAR Conference, Caracas . 1991. P. 369-385.

4. Adelu R., Fayose E. Development Prospects for the Bituminous Deposits in Nigeria. 5th UNITAR Conference, Caracas. 1991. P. 509-515.

5. Ademodi B., Dewodu O., Oshonowo T., et al. Recovery of Bitumen from Nigerian Tar Sands - Feed Preparation and Solvent Extraction Studies. 7th Miami International Conference on Alternative Energy Sources. 1985. P.2.
6. Adewusi V.A. Aspect of Tar Sands Development in Nigeria. Energy Sources. 1992. Vol. 14. P.305-315.

7. Adesida A. Geology of the Ore Tar Sands (Maastrichtian - Paleocene). MSc. Thesis, University of Ife. 1980. P.121

8. Nwizug-bee L. K. Economic Importance of the Design, Development and Production of Bitumen from bituminous Sand and Heavy Oil in Nigeria. Scientific Journal of KubSU. 2016. No. 121 (07). P. 144. (In Russian)

9. Nwizug-bee, L. K., Savenok, O. V. Analysis of Natural and Geological Conditions of Occurrence of Deposits with Hard-to-recover Reserves on the Territory of the Federal Republic of Nigeria. Eurasian Scientific Journal. No12. 2015. P. 50-57. (In Russian)

10. Adegoke O.S. Geotechnical Investigation of the Ondo State Bituminous Sands, Geology and Reserves Estimate. Geological Consultancy Unit, University of Ife. 1980. P. 257. 
11. Adegoke O.S., Ibe F.C. The Tarsands and Heavy crude Resources of Nigeria. Proceedings of 2nd Unitar conference. Caracas. Venezuala. 1982. Pp. 8-10.

12. Frazier N. A. et al. Production and processing of US Tar sands: An environmental assessment. 1976. P. 266.

13. Gwynn J. W. Instrumental Analysis of Tars and their correlations in oil impregnated sand stone beds. Unitah and grand countries, Utah. Utah geological and mineral survey, special studies. 1971. Pp. 5-8.

14. JeJe L.K. Aspect of the geomorphology of Nigeria in geography of Nigeria development. 1983. Pp. 5-8.

15. Kadiri M.O. Further desmids from the Ikpoba reservoir: A comparison from elsewhere in Africa. 1993. Pp. 23-35.

16. Adewusi V.A. Aspects of Tarsands developmentin Nigeria. Energy sources. 1992. Vol.14. Pp. 305-315.

17. Ajayi O. Quality of ground water in the Agbabu oil sands area of Ondo State, Nigeria. Journal of African Earth Sciences. 1998. Vol. 27. Pp. 299 - 305.
18. Ako B., Alabi A., Adegoke O., Enu E. Application of resistivity sounding in the exploration of Nigerian Tarsand. Energy exploration and exploitation. 1983. vol. 2. Pp. 155-164.

19. Babalola O. Integrated seismic, geophysical and geological interpretation "Meso-Atlantic" gulf of Guinea continental margin evolution and hydrocarbon potential of the "Cotonou" (Dohomey or Benin) Basin. Ph.D dissertation, University of South Carolina. 1990. Pp. 236.

20. Billman H.G. Offshore stratigraphy and Paleontology of the Dahomey embayment, West Africa. 7th African Micropaleontological Colloquium. 1976. Pp. 29.

21. Coker S. Bitumen saturation and reserve estimates of the Okitipupa oil Sands. Journal of mining and geology. 1988. vol. 24. Pp. 101-110.

22. Ekweozor C., Nwachukwu J. The origin of Tar sands of South western Nigeria. Nigerian Association of Petroleum Explorationists Bulletin. 1989. Vol. 4.

\title{
$\overline{\text { INFORMATION ABOUT AUTHORS / Сведения об авmopax: }}$
}

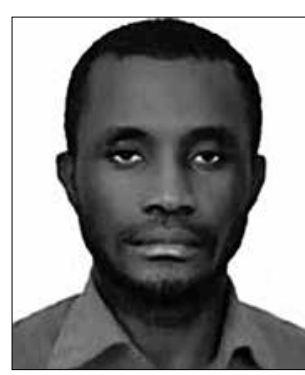

\author{
NWIZUG-BEE Leyii Kluivert \\ Port Harcourt, Rivers State, Nigeria \\ Тел. +7(918)339-51-82, \\ $+7(961) 583-75-96,+7(961) 514-12-98$ \\ E-mail: kluivert_dgreat@mail.ru
}

Department of Petroleum Engineering, Rivers State University of Science and Technology,

НВИЗУГ-БИ Лейи Клюверт,

Кафедра нефтяного дела, Технологический университет, Порт Харкорт, Штат Риверс, Нигерия. E-mail: kluivert_dgreat@mail.ru

\section{МЕСТОРОЖДЕНИЯ ТЯЖЕЛОЙ НЕФТИ И КОМПОЗИЦИОННЫЙ АНАЛИЗ НЕКОТОРЫХ ОБРАЗЦОВ БИТУМИНОЗНОГО НЕФТЯНОГО ПЕСКА В ЮГО-ЗАПАДНОЙ НИГЕРИИ}

\author{
Нвизуг-би Лейи Клюверт \\ Кафедра нефтяного дела, Технологический университет, Порт Харкорт, Штат Риверс, Нигерия. \\ E-mail: kluivert_dgreat@mail.ru
}

DOI: $10.21177 / 1998-4502-2018-10-1-63-68$

Цель: в работе представлен композиционный анализ некоторых образцов битуминозного нефтяного песка и месторождений тяжелой нефти в Юго-Западной Нигерии. Проводится углубленное исследование битумных залежей, верхних латеритных почв, верхних сланцев и известняков, верхних битумных отложений (горизонт X), отложений нижнего гипсового битума (горизонт Y).

Методы: образцы битуминозного нефтяного песка, взятые из различных мест по всему смоляному поясу, были разделены на три группы и проанализированы в лаборатории. Процентное соотношение по весу ( вес, \%) битума, минеральных веществ и воды определяется табл. 1, 2 и 3. Графические иллюстрации в процентах от массы битума, минеральных веществ и воды представлены на рис. 1, 2 и 3.
Результаты: по результатам композиционного анализа некоторых образцов битуминозного нефтяного песка, собранных в различных местах по всему поясу, процентное содержание минерального вещества значительно выше, за ним следуют битум и вода. Минералогический состав классифицируется на глиняные полезные ископаемые, тяжелые минералы и глинистые минералы. Существует три основных типа глин: каолинит, слюда и минералы смешанного слоя. Тяжелые минералы включают лимонит, пирит, кианит и силлиманит, в то время как не глинистые минералы включают полевой шпат, кварц, кальцит и гипс. Пески, богатые кварцем, с небольшим количеством глины, имеют обильный каолинит. 
Вывод: Нигерийские образцы битуминозного нефтяного песка состоят в основном из минерального вещества, за которым следует битум, с меньшим составом воды. Образцы битуминозного нефтяного песка состоят в основном из битума, минерального вещества и воды. Важно отметить, что эти три основных состава нефтяного песка являются экономически ценными.

Ключевые слова: битуминозная нефть, нефтяной песок, композиционный анализ, тяжелая нефть, смоляной пояс, отложения, минералы, в процентах по весу.

References

1. Adegoke O.S. Geological Guide to some Nigerian Cretaceous - Recent Localities. 7th African Micropalaeontological Colloquim, Ile - Ife, 1976. P.6.

2. Adegoke O. S. Tar Sand Project Phase II - Estimation of Reserves, Materials Testing and Chemical Analysis. Geological Consultancy Units, University of Ife. Nigeria. 1976. P.10.

3. Adegoke O. S., Omotsola M., Coker S. The Geology of the Nigerian Tar Sands / 5th UNITAR Conference, Caracas, 1991. Pp. $369-385$.

4. Adelu R., Fayose E. Development Prospects for the Bituminous Deposits in Nigeria / 5th UNITAR Conference, Caracas, 1991. Pp. $509-515$.

5. Ademodi B., Dewodu O., Oshonowo T. et al. Recovery of Bitumen from Nigerian Tar Sands - Feed Preparation and Solvent Extraction Studies / 7th Miami International Conference on Alternative Energy Sources, 1985. Pp. 2.

6. Adewusi V.A. Aspect of Tar Sands Development in Nigeria. Energy Sources. 1992. Vol. 14. Pp. $305-315$.

7. Adesida A. Geology of the Ore Tar Sands (Maastrichtian Paleocene). MSc. Thesis, University of Ife. 1980. P. 121

8. Нвизуг-би Л.К. Экономическое значение проекта, разработка и производство битума из битумного песка и смолы в Нигерии // Научный журнал КубГУ. 2016. №. 121 (07). Р. 144

9. Нвизуг- би Л.К., Савенок О.В. Анализ природных и геологических условий месторождений с труднодоступными запасами на территории Федеральной Республики Нигерия // Евразийский научный журнал. 2015. N12. pp. 50 - 57

10. Adegoke O.S. Geotechnical Investigation of the Ondo State Bituminous Sands,Geology and Reserves Estimate // Geological Consultancy Unit, University of Ife, 1980. P. 257.
11. Adegoke O.S., Ibe F.C. The Tarsands and Heavy crude Resources of Nigeria / Proceedings of 2nd Unitar conference, Caracas, Venezuala. 1982. Pp. $8-10$

12. Frazier N. A et al. Production and processing of US Tar sands: An environmental assessment. I976. P.266.

13. Gwynn J. W. Instrumental Analysis of Tars and their correlations in oil impregnated sand stone beds / Unitah and grand countries, Utah. Utah geological and mineral survey, special studies. 1971. Pp. $5-8$.

14. JeJe L. K. Aspect of the geomorphology of Nigeria in geography of Nigeria development. 1983. Pp. $5-8$.

15. Kadiri M. O. Further desmids from the Ikpoba reservoir: A comparison from elsewhere in Africa. 1993. Pp. 23 - 35.

16. Adewusi V.A. Aspects of Tarsands developmentin Nigeria // Energy sources. 1992. Vol. 14. Pp. 305 - 315.

17. Ajayi O. Quality of ground water in the Agbabu oil sands area of Ondo State, Nigeria // Journal of African Earth Sciences. 1998. Vol. 27. Pp. 299 - 305.

18. Ako B., Alabi A., Adegoke O., Enu E. Application of resistivity sounding in the exploration of Nigerian Tarsand // Energy exploration and exploitation. 1983. Vol. 2. Pp. $155-164$.

19. Babalola O. Integrated seismic, geophysical and geological interpretation "Meso-Atlantic" gulf of Guinea continental margin evolution and hydrocarbon potential of the "Cotonou" (Dohomey or Benin) Basin. PhD dissertation, University of South Carolina.1990. Pp. 236.

20. Billman H.G. Offshore stratigraphy and Paleontology of the Dahomey embayment, West Africa / 7th African Micropaleontological Colloquium. 1976. Pp. 29.

21. Coker S. Bitumen saturation and reserve estimates of the Okitipupa oil Sands // Journal of mining and geology. 1988. Vol. 24. Pp. $101-110$.

22. Ekweozor C., Nwachukwu J. The origin of Tar sands of Southwestern Nigeria // Nigerian Association of Petroleum Explorationists Bulletin. 1989. Vol. 4. Pp. 82-94.

Статья поступила в редакциию 11.10.2017 


\section{ВЛИЯНИЕ ТЕХНОГЕННОЙ ТРАНСФОРМАЦИИ ВОЗДУШНОЙ СРЕДЫ НА УСТОЙЧИВОСТЬ ХВОЙНЫХ ЛЕСОВ КАРАЧАЕВО-ЧЕРКЕСИИ}

1 Дега H.C., 'Онищенко В.В, ${ }^{\text {' }}$ 2Петропавловский Б.С.

\section{Введение}

Карачаево-Черкесия - лесная республика. Около 34\% горной территории покрыто лесом. Естественные леса Тебердинского государственного природного биосферного заповедника (ТГПБЗ) представляют собой феномен биологического и ландшафтного разнообразия их видового состава, популяционных образований и уникальных по ландшафтной структуре лесных сообществ.

Мозаика распространения горных лесов заповедника отражает весь спектр вертикальной зональности на ограниченной территории, которая является зеркальным отображением широтно-поясной дифференциации лесов на обширных пространствах природно-географических зон России. Произрастая спонтанно, в сложных условиях рельефа лесные экосистемы формируют совершенно непредсказуемый состав, вертикальную структуру и лесоводственно-таксационные параметры элементов леса. Отдельные особи и популяции деревьев, поселяясь на валунах, расщелинах скальных обнажений и каменных россыпях, весьма существенно отличаются ростом и развитием от нормальных насаждений равнинных территорий, на которые ориентирован нормативно-справочный материал лесохозяйственной практики.

Исследуя эколого-географические особенности горных лесов Тебердинского заповедника, авторы отмечали специфические черты формирования древостоев - высокую полноту и запас насаждений, сомкнутость полога и количество деревьев на единице площади, не соизмеримые с показателями древостоев равнинных территорий [1-4].

В стесненных условиях сложного рельефа природные леса заповедника особенно чутко испытывают влияние потепления климата. В среднем, по Карачаево-Черкесской Республике за последние 30 лет температура воздуха повысилась на $1.3{ }^{\circ} \mathrm{C}$, количество выпадающих осадков, особенно в летнее время, увеличилось до 178 мм/год [5; 6].

Потепление климата имеет достаточно серьезные последствия. Вопервых, усиливается продвижение верхней границы леса к водоразделам. Миграция деревьев вверх сокращает эколого-географическое пространство, то есть создаются условия для снижения общей популяции взаимосвязанных видов, что приводит к снижению конкурентноспособности отдельных видов из-за генетического и экологического давления. Потепление климата оказывает более сильное воздействие на горные леса, чем на любые другие лесные сообщества, произрастающие на относительно небольших высотах [7].

Горные леса, ослабленные воздействием загрязненного воздуха, становятся более чувствительными к воздействиям комплекса других факторов, особенно погоды (ветер, снег, мороз) и вредных насекомых (личинки моли, еловые жучки, жуки короеды). Весь этот процесс ускоряет деградацию леса. Но даже в относительно стабильных условиях во многих горных районах республики качество лесов ухудшается. Природные лесные экосистемы становятся менее разнообразными из-за медленной повторной колонизации прежде успешно существовавшими здесь видами растений и животных, а также из-за использования монокультур в искусственно восстанавливаемых лесах.

\footnotetext{
${ }^{1}$ Карачаево-Черкесский государственный университет имени У.Д. Алиева, Карачаевск, Россия

*e-mail: ovv333@mail.ru

${ }^{2}$ Ботанический сад-институт Дальневосточного отделения Российской Академии наук, Владивосток,
} Россия
УДК: 502.3.630(470.6) DOI: 10.21177/1998-4502-201810-1-69-76

Усыхание еловых древостоев на горных склонах КарачаевоЧеркесской Республики, которое приобретает прогрессирующий характер, в том числе и на территории Тебердинского государственного биосферного заповедника, становится предметом широких научных дискуссий и объектом различных экспертно-аналитических оценок. Безусловно, доказательной базы причинно-следственных связей до настоящего времени не установлено. Результаты научного исследования НИЛ геоэкологического мониторинга Карачаево-Черкесского государственного университета указывают на увеличение концентрации взвешенных химических соединений в атмосферном воздухе региона, что и является определяющим фактором усыхания ельников. Физиологические особенности ели восточной в горах Кавказа характеризуют ее как наиболее уязвимую из хвойных пород к внешним воздействиям загрязненного атмосфрерного воздуха.

\section{КЛЮЧЕВЫЕ СЛОВА:}

еловый древостой, горные склоны, атмосферный воздух, усыхание, источники загрязнения, аэрозоли, природно-антропогенные явления, кислотные дожди, инверсии, устойчивость хвойных пород

Статья поступила в редакцию 8.11.2017 
Дополнительный ущерб горным лесам КЧР приносят усиливающееся загрязнение воздуха и многочисленные несанкционированные свалки.

Существует множество свидетельств ухудшения горных лесов от атмосферного загрязнения, возросшего в результате выпадения кислотных осадков, фотооксидантов и осадков тяжелых металлов. В горах выпадает большее количество осадков, поэтому они испытывают большие нагрузки от любых химических веществ и частиц из атмосферной влаги [8-10].

За последние годы в естественных лесах Тебердинского заповедника зарегистрировано массовое усыхание ели восточной (Picea orientalis) рис. 1. Отмечено как единичное, так и популяционное ее усыхание в составе сообществ и экосистем. Особенно контрастное распространение усыхающей ели отмечается в верховьях долины реки Теберды, истоки которой находятся в устье двух ущелий при слиянии рек Аманауз и Гоначхир. В этой части Тебердинского заповедника к настоящему времени усохли до $47 \%$ особей ели восточной приспевающей и естественной спелости в возрасте от 80 до 180 лет. Более интенсивно идет усыхание древостоев естественной спелости. Приспевающие ели (80-120 лет) более устойчивы, однако также подвержены усыханию.

Гипотеза основана на очевидном факте загрязнения атмосферного воздуха в тесных ущельях и долинах неуклонно увеличивающимся автотранспортом, экстенсивным рекреационным и традиционным природопользованием.

Целью исследования является установление причинно-следственных связей усыхания ельников в условиях интенсивного освоения горных территорий.

\section{Задачи:}

- сбор экспериментальных и фондовых показателей загрязненности атмосферного воздуха в Карачаево-Черкесской Республике;

- наблюдения и оценка аномальных природноклиматических явлений в среднегорьях региона;

- сопряженный анализ и синтез допустимого влияния загрязняющих воздушную среду ингредиентов на хвойные древостои горных склонов.

Методы исследования. Методологический подход исследования качества воздушного бассейна основан на детальном анализе структуры и сезонной динамике загрязнения по маршрутным постам наблюдения, который проводится Ростехнадзором по КЧР. Центр лабораторного анализа и технических измерений по КЧР и научно-исследовательская лаборатория геоэкологического мониторинга КЧГУ выполняют наблюдения на дополнительных пунктах отбоpa разовых проб в ходе социально-гигиенического мониторинга. Авторы принимали непосредственное участие во всех видах работ, связанных с геоэкологическим мониторингом окружающей среды Карачаево-Черкесской Республики
Перечень загрязняющих веществ, подлежащих контролю, определен на основе сведений о составе и характере выбросов от источников загрязнения в городе и метеорологических условий рассеивания примесей в соответствии с РД 52.04.186-86 «Руководство по контролю загрязнения атмосферы» и ГОСТ 17.2.3.01-86.

Амплитуда абсолютных отметок обследованных участков составляет 440 м (от 1760 м по дну долины до 2200 м вверх по склонам).

Результаты и их обсуждение. На склонах северных разностей румбов этих узких «теснин» произрастают темнохвойные леса из пихты кавказской (Abies Nordmanniana) и ели. Лавинные лотки склонов заселены осиной, березой, рябиной, малиной и породами-пионерами. На пойменных участках распространены отдельные участки сосновых и еловопихтовых древостоев среди основных площадей лиственного леса. Доминируют на склонах Аманауза и Гоначхира ельники, пихтарники и сосняки. В пойме преобладают ольховые ценозы. Все эти типы представляют собой наиболее продуктивные древостои с хорошо выраженным преобладанием эдификаторов.

У подножий склонов, примыкающих к ущельям, отмечаются следы хозяйственной деятельности. На припойменных террасах сохранились каменные строения, свидетельствующие о животноводческой деятельности в прошлом. Наличие полусгнивших пней и отсутствие высокоствольного леса указывает на традиционную форму хозяйствования. Единично произрастающие высоко-возрастные стволы осины, клена высокогорного и сосны свидетельствуют об антропогенном изменении естественных сукцессий в лесах припойменной зоны. Под пологом темнохвойных древостоев затененных склонов сохранились поленницы от пихты кавказской. Почти разложившиеся пни встречаются до отметки 1900 м, на 200 метров выше дна ущелий. Заготовленные сортименты свидетельствуют о вырубке элитных стволов пихты кавказской, вероятно для получения кровельной драни. Нередко на стволах встречаются механические повреждения в виде углубленных затесок, которые наносились с целью определения качества стволовой древесины. Установление характера антропогенных воздействий на отдельные участки в целом спонтанно развивающихся лесных сообществ позволяет объективно характеризовать реальное распределение растительных сообществ в мозаике естественных экологических ниш. Вероятнее всего формирование «чистых ельников» на склонах ущелий происходило в условиях выборочной, приисковой вырубки элитной пихты.

Ель обычно содоминирует с пихтой в роли сопутствующей породы, удачно заполняя пространства, не используемые пихтой. Однако в общем темнохвойном массиве встречаются «острова» с доминированием ели в составах древостоев. Темнохвойные леса 
встречаются до отметки 2300 метров над уровнем моря. Наиболее характерными условиями для них являются нижняя и верхняя части склонов. У подножия склонов приуроченность пихтово-еловых типов леса объясняется устойчивой их структурой, близкой к «климаксовому» состоянию. В верхнем поясе распространения темнохвойные леса сменяются криволесьями, формирующими верхнюю границу леса. В пойменной зоне до отметки 1900 м преобладают ольховые сообщества в разных стадиях сукцессий. В большинстве ольховых типов леса наблюдается тенденция к смене их темнохвойными лесами. Для пихтово-еловых лесов заповедника характерны разновозрастность

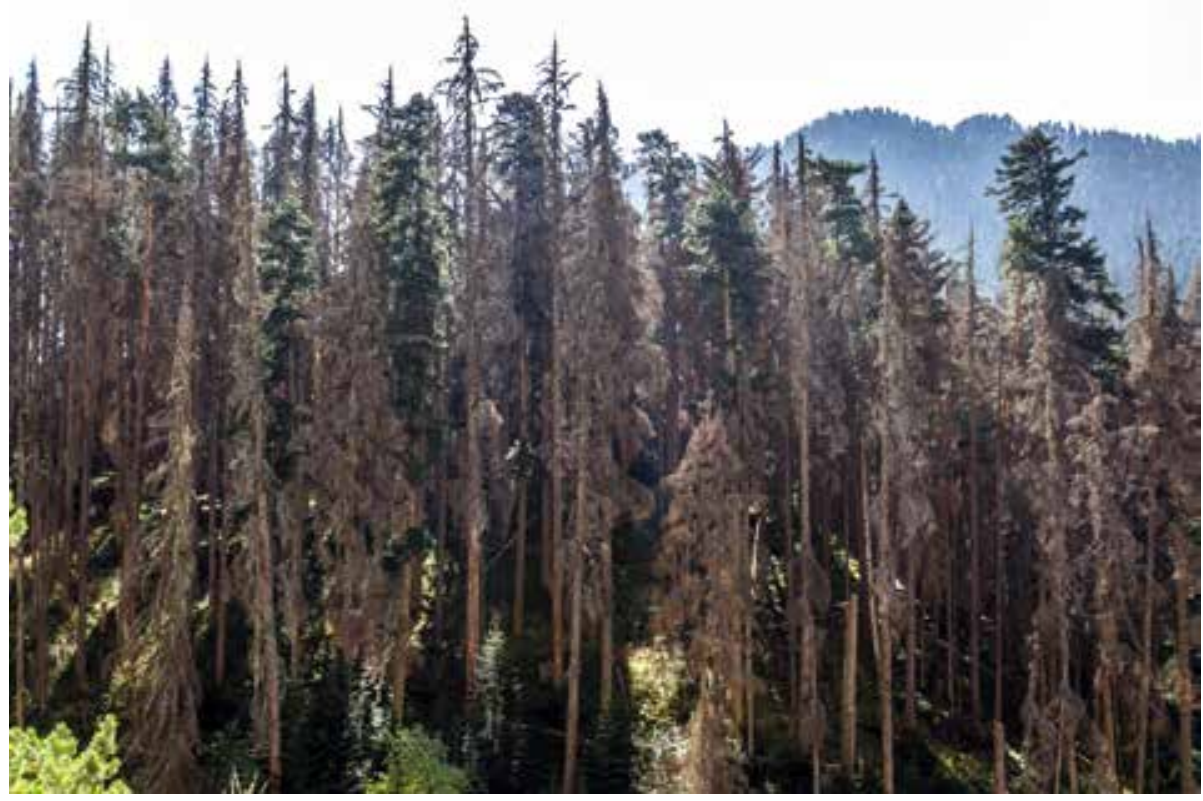

Pис. 1. Горные ельники, усохшие от загрязнения атмосферного воздуха (Ущеелье Гоначхир (ТГПБЗ))

Fig. 1. The mountain fir groves which dried out from pollution of free air (the Gorge Gonachkhir $(T N N B P))$ до IX-X классов; высокий запас древесного яруса, нередко достигающий 2000 м³/га, и повышенные показатели условий произрастания I-II бонитета.

Уникальность этих лесов в их исключительном экосистемном разнообразии, оздоровительных, ландшафтно-формирующих, водорегулирующих и многих других функциях. Поэтому вполне понятны стремления авторов в исследовании причинно-следственных связей в процессе массового усыхания ели. Повышенный интерес вызван также фактом данного явления в условиях заповедного режима. Патологические и другие виды авторитетных комиссий и специалистов пока убедительных объяснений не дали.

Системный геоэкологический мониторинг окружающей природной среды Карачаево-Черкесии на базе НИЛ геоэкологического мониторинга КЧГУ им. У.Д. Алиева позволил предположить, что массовое усыхание ельников в ТГПБЗ происходит в результате достаточно длительного загрязнения атмосферного воздуха в уязвимом пространстве тесных ущелий Тебердинского заповедника и увеличении источников выброса на сопредельных, интенсивно осваиваемых антропогенных территориях региона.

Горные территории в целом принимают большое количество осадков, в отличие от других форм рельефа, и таким образом испытывают большие нагрузки любых химических веществ и частиц из атмосферной влаги.

Растительность гор, включая леса, подвержена прямому осаждению влаги на листву, ветви и стебли, а также поступлению в них влаги из почвы, которая содержит некоторые из этих переносимых по воздуху веществ. В отдельных долинах кислотность осадков увеличилась, они содержат элементарную серу, окись азота, аммиак и тяжелые металлы. Кроме того, в области обволакивающей горы облаками, которые задерживаются в кронах деревьев, этот дополнительный «густой туман», состоящий из загрязняющих металлов, усиливает их воздействие (рис. 1). Важным компонентом становится озон.

Источниками загрязняющих ингредиентов служат выхлопные газы автомашин, уголь и нефтепродукты, сжигаемые на тепловых котельных, промышленные бойлеры предгорных территорий, выбросы производственных предприятий, уголь, древесина или нефтепродукты, используемые для обогрева помещений в домашнем хозяйстве, и сжигание сельскохозяйственных отходов. Количество автомобильного транспорта, в том числе и крупногабаритного, на автотрассе Теберда - Домбай - Гоначхир с 2000 года увеличилось более чем в 5 раз [11].

Источники, как правило, местные, особенно в горных долинах Кубани, Теберде, Большого Зеленчука, Урупа и Большой Лабы, где отмечены участившиеся случаи инверсий гидротермических показателей, туманов, смогов, изморозей и т. д., уменьшают рассеивание атмосферных загрязнителей. Источники также могут находиться за границей (Главным Кавказским хребтом) или в соседних субъектах региона. Многие из этих загрязняющих веществ в атмосфере долговечны и распространяются в ущелья ветровыми потоками. Неблагоприятное воздействие на горные леса загрязняющих веществ, переносимых на большие расстояния по воздуху через государственные и административные границы, становится важным предметом исследований [12].

Так, наблюдаемая над хвойными лесами в летнее время голубоватая дымка представляет собой аэро- 


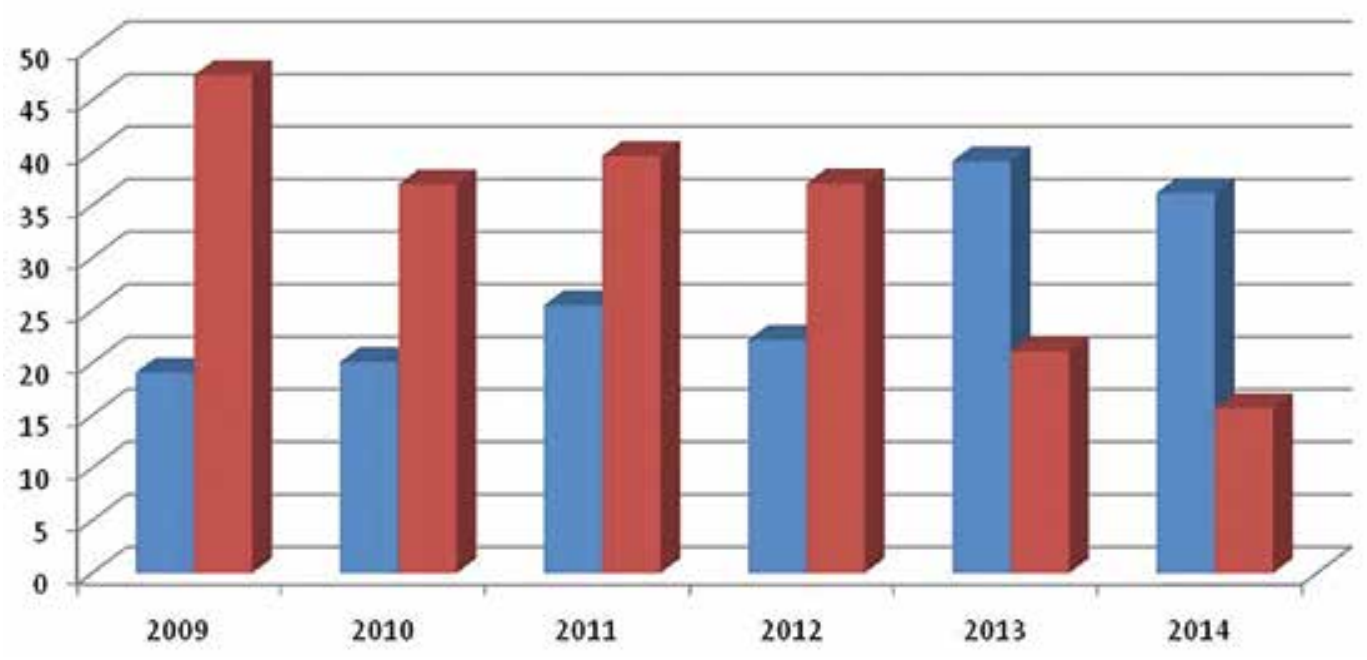

Pис. 2. Динамика основных загрязнителей воздушного бассейна КЧР /

Fig. 2. Dynamics of the main pollutants of the air basin of the Karachay-Cherkess Republic

золь, возникающий в результате фотохимического окисления терпенов. Участившиеся туманы, смоги, изморози, кислотные осадки и инверсии свидетельствуют о локальной концентрации загрязняющих веществ в атмосферном воздухе. За истекший, более чем 15-летний период, валовый выброс загрязняющих веществ в атмосферу КЧР в годовом цикле увеличился более чем в три раза (с 19.2 до 58.1 тыс. т. в год), при этом в 2.4 раза повысилась общая заболеваемость среди населения республики.

Динамика суммарного количества выбросов по КЧР от двух основных загрязнителей (автотранспорта и промышленности) представлена на рис. 2.

Несмотря на увеличение доли выбросов от промышленности в последние годы за многолетний период (с 1999 г.), на долю автотранспорта приходится в среднем $65 \%$ загрязняющих веществ, к основным из которых можно отнести: оксид углерода, оксид азота, ЛОС. Загрязнители атмосферного воздуха от промышленного производства, в среднем составляют около $35 \%$ от общего объема выбросов. В структуре промышленных выбросов преобладают: твердые вещества, оксиды азота, углеводороды (без ЛОС), оксид углерода. Вышеуказанные категории загрязняющих веществ являются определяющими в негативном влиянии как на окружающую среду, так и на здоровье человека.

Наиболее значительные повреждения лесов происходят под воздействием сернистого ангидрида и его производных (триоксид серы, серная кислота). Существенные повреждения вызываются также окислами азота, озона, фтора, хлора, продуктами фотохимического смога и другими веществами. Не редко они воздействуют совместно.

Влияние токсидантов на растения проявляется либо в виде медленных (хронических) отравлений, либо в виде острых поражений типа ожогов. Соответ- ственно гибель лесов также может быть медленной («изреживание» и постепенный распад) либо внезапной (катастрофической). Отмиранию деревьев обычно предшествует скрытый период поражения, который затем быстро проявляется на фоне неблагоприятных метеорологических или других факторов (суровые или необыкновенно теплые зимы, летние засухи, размножение вредителей, антропогенные нагрузки и т.п.) $[9 ; 13]$. Все эти факторы в большей степени проявляются в долинах Карачаево-Черкесии.

Оксиды азота выбрасываются в атмосферу в результате различных процессов горения, в которых азот (N) в воздухе окисляется, превращаясь в оксид азота (NO) с небольшой примесью диоксида азота $\left(\mathrm{NO}_{2}\right)$. При дневном свете $\mathrm{NO}$ легко превращается в $\mathrm{NO}_{2}$ в результате фотохимических реакций с участием углеводородов, присутствующих в воздухе [14]. Эти выбросы, как отмечает автор, могут быть весьма существенными, когда они приходят из сильно удобренных сельскохозяйственных земель и лесов, подверженных воздействию высоких уровней осаждения азотом. Выбросы от транспорта являются главными источниками выбросов оксидов азота. Большие количества оксида азота также выбрасывается химическими заводами, например, в процессе производства удобрений [14]. Производство удобрений, чрезмерное внесение удобрений с азотом и животноводство также являются важными источниками азот содержащих выбросов аммиака $\left(\mathrm{NH}_{3}\right)$.

К загрязнителям воздуха Карачаево-Черкесии относится также большая группа летучих органических соединений (ЛОС), которая состоит из углеводородов и органических атмосферных компонентов, отличающихся от $\mathrm{CO}_{2}$, и оксида углерода (CO). Образуются ЛОС из природных и антропогенных источников. Растения излучают летучие органические соединения биогенного характера, которые включают изопрен, 
спирты, сложные эфиры, простые эфиры и кислоты. Изопрен является наиболее распространенным углеводородом, который излучается наземной растительностью $[15 ; 16]$.

Углекислый газ, метан $\left(\mathrm{CH}_{4}\right)$ и закиси азота $\left(\mathrm{N}_{2} \mathrm{O}\right)$ влияют на патологическое состояние лесов путем воздействия на них в качестве парниковых газов. Все они производятся в результате как природной, так и антропогенной деятельности. Хотя эти газы сами по себе не являются загрязнителями, их избыточное производство в результате человеческой деятельности приводит к загрязнению окружающей среды.

Пожары являются основным источником $\mathrm{SO}_{2}$, аэрозоли серы, черного углерода, тяжелых металлов и органических загрязнителей.

Большинство из указанных выше веществ являются газообразными и действуют на деревья в качестве сухих осадков непосредственно через листву. Некоторые из них ведут к подкислению - при химических реакциях с водой в атмосфере они становятся причиной кислотных осадков. Дождь с кислотностью 5.6, даже при отсутствии подкисляющих загрязнителей воздуха, из-за присутствия углекислого газа $\left(\mathrm{CO}_{2}\right)$ в воздухе образует угольную кислоту $\left(\mathrm{H}_{2} \mathrm{CO}_{3}\right)$.

Лесные биогеоценозы страдают от воздействия кислотных дождей, которые возникают концентрирующимися в воздушной среде оксидами азота и диоксидами серы. Установлено, что хвойные породы деревьев в большей степени подвержены негативному влиянию кислотных дождей, нежели широколиственные. При этом больше всего страдают насаждения вблизи крупных населенных и промышленных центрах [17; $18]$.

Разные древесные породы неодинаково чувствительны к загрязнению атмосферного воздуха. Одни из них более стойки, другие, напротив, очень уязвимы. Это отчасти зависит от того, как долго сохраняются на дереве листья или хвоинки, какова продолжительность их жизни. Например, лиственные деревья с опадающей ежегодно листвой лучше противостоят вредному действию промышленного дыма, чем вечнозеленые хвойные, у которых хвоинки живут несколько лет.

Из всего разнообразия древесно-кустарниковых пород, в силу своих биологической и физиологической восприимчивости, наиболее уязвимой к воздействию атмосферных загрязнителей в Карачаево-Черкесии оказалась ель восточная. По проведенным наблюдениям процесс усыхания ели происходит от подножия склонов к верхней границе распространения, на всех экспозициях. Усыхают в основном особи верхних ярусов в сообществах, или подверженные свободному воздействию перемещающихся воздушных масс. Молодое поколение (подрост), расположенное в непосредственной близости к усохшим деревьям, сохраняет свою жизнеспособность. Деревья ели, прекратившие свои физиологическую деятельность, неза- медлительно заселяются вторичными энтомо-вредителями, что может указывать на достаточно длительный период губительного воздействия негативных факторов, способствующих усыханию. В отличие от других хвойных пород усохшая хвоя ели восточной не задерживается на ветвях и быстро опадает, т.е. особь лишается своего ассимиляционного аппарата, способного к самовосстановлению, что и является причиной усыхания. Наблюдения за другими хвойными породами показывают, что изменившая окраску хвоя сосны, подверженная, воздействию кислотных дождей, долгое время сохраняется на ветвях, восстанавливая свои физиологические функции. Пихта кавказская пока не проявляет видимых признаков воздействия кислотных осадков [19].

Заключение. Знания об отрицательном воздействии на живые организмы, помимо деревьев, очень скудны, но по некоторым признакам можно полагать, что это воздействие чрезвычайно серьезно (например, анализ, проведенный Флоузеком) [20].

Горные леса, ослабленные воздействием загрязненного воздуха, становятся более чувствительными к влиянию комплекса других факторов, особенно погоды (ветер, снег, мороз) и вредных насекомых (личинки моли, еловые жучки, жуки-короеды). Этот процесс ускоряет деградацию леса. Степень повреждения леса усиливается с увеличением высоты над уровнем моря, где загрязняющие вещества концентрируются в осадках, например в тумане или инее. Хвойные виды повреждаются намного сильнее (особенно ель), чем лиственные деревья. В последнее время процесс усыхания ели восточной на территории Тебердинского заповедника приобрел весьма значительный, близкий к катастрофическому характер, причем в возрасте, близком к естественной спелости, основного яруса в древостоях. Молодое поколение при этом сохраняет удовлетворительную жизнеспособность. Ель восточная - очень восприимчива к тепловым и геохимическим эффектам. Подвергаясь внезапному влиянию повышенного тепла и кислотным (аэрозольным) осадкам, в отличие от пихты кавказской и сосны крючковатой, ель не проявляет способности к длительному сохранению хвои, а, следовательно, быстро ее теряет. Ускоренного восстановления физиологических функции у хвои ели восточной, в отличие от сосны крючковатой, не происходит. Ослабленные и усохшие деревья незамедлительно заселяются вторичными вредителями (короедами, лубоедами и другими представителями лесной энтомофауны), возникает реальная опасность развития эпизоотий.

Системы управления лесами необходимо ориентировать на принципы устойчивости. Это означает, что управление должно соответствовать окружающей среде, общественной пользе и быть экономически жизнеспособным. Нужно стремиться сохранять биоразнообразие в генетике на уровне видов и экосистем. 
Будущие планы и системы управления лесами должны концентрироваться, прежде всего, на сохранении богатого естественного разнообразия горных лесов и на экологических функциях, которые они выполняют. Оздоровительные и рекреационные функции использования лесов зависят от этих двух решающих факторов.

Анализ и комплексная оценка структуры и источников выбросов в воздушную среду, физиологические особенности ели восточной, а также наблюдения за аномальными атмосферными явлениями в ущельях и долинах Карачаево-Черкесской Республики априори указывают на тесную связь усыхания еловых древостоев с увеличением концентрации взвешенных химических соединений, снижающих качество атмосферного воздуха.

\section{ЛИТЕРАТУРА:}

1. Онищенко В.В. Горное лесообразование. Особенности, геоэкологический анализ, методы. Germany: LAP LAMBERT Academic Publishing GmbH \& Co. KG Dudweiler Landstr, 2011. $381 \mathrm{c}$.

2. Дега Н.С., Онищенко В.В. К методике исследования экологии лесообразования и устойчивого лесопользования // Карачаево-Черкесская Республика. Устойчивое развитие: опыт, проблемы, перспективы. М.: Институт устойчивого развития Общественной палаты Российской Федерации. Центр экологической политики России, 2013. С. 55 - 62.

3. Friedrich-Karl Holtmeir. Sensitive and response of northern hemisphere altitudinal and polar treelines to environmental change at landscape and local scales. Friedrich-Karl Holtmeir, Gabriele Broll. Global Ecology and Biogeography, 2005. Vol. 14. P. 395.

4. Holtmeie, F.-K. Mountain Timberlines: Ecology, Patchiness and Dynamics. Springer, 2009. 438 p.

5. Онищенко В.В., Салпагаров А.Д., Дега Н.С. Влияние изменения климата на сезонную динамику дендрофлоры Тебердинского заповедника // Проблемы региональной экологии. М., 2006. N 1. С. 42-49.

6. Онищенко В.В., Дега Н.С. Устойчивое развитие Карачаево-Черкесии в условиях современной организации горных экосистем // Устойчивое развитие горных территорий. Владикавказ, 2009. N1. С. 49-54.

7. Хамилтон Л.С., Гилмор Д.А., Касселз Д.С. Горные леса и лесное хозяйство // Горы мира глобальный приоритет. Вклад в Главу 13 повестки дня на XXI век. М.: Издательский дом «НООСФЕРА», 1999. С. 271-299

8. Тихонова И.О., Тарасов В.В., Кручинина Н.Е. Экологический мониторинг атмосферы. М.: Форум: НИЦ ИНФРА-М, 2014. 136 с

9. Ветошкин А.Г., Таранцева К.Р., Ветошкин А.Г.Технология защиты окружающей среды (теоретические основы). М.: НИЦ ИНФРА-М, 2015. 362 с.

10. Онищенко В. В., Дега Н. С., Гербекова Д. Ю. Медико-экологическая парадигма курортно-оздоровительного и рекреационного бассейна реки Теберды Карачаево-Черкесской Республики // Экология человека. Архангельск, 2016. N10. C. 3-9.

11. Дега Н.С., Онищенко В.В., Байчорова Э.М., Узденов У.Б. Моделирование загрязнения атмосферного воздуха на территории Карачаево-Черкесии // Успехи современного естествознания. 2017. N 7. С. 64-70

12. Онищенко В.В., Дега Н.С., Корчагина Н.М. Принципы и перспективы организации интегрированного природопользования в устойчивом развитии Карачаево-Чер- кесии // Известия Дагестанского государственного педагогического университета. Естественные и точные науки. 2017. T. 11. N 2. C. 100-108.

13. Гальперин М.В. Экологические основы природопользования. М.: ИД ФОРУМ: НИЦ ИНФРА-М, 2014. 256 с.

14. Денисов В.В. Экология города. Ростов-н/Д: МарТ, 2008. $832 \mathrm{c}$.

15. Жуков, В. И., Горбунова Л. Н., Севастьянов С. В. Оценка воздействия транспортно-дорожного комплекса на окружающую среду. Красноярск: Сибирский федеральный университет, 2012. $784 \mathrm{c.}$

16. Ясовеев М.Г., Стреха Н.Л.Экологический мониторинг и экологическая экспертиза. М.: НИЦ ИНФРА-М, 2013. 304 c.

17. Добровольский В.В. Основы биогеохимии. М.: Высшая школа, 1998. 189 с.

18. Протасов В.Ф., Молчанов А.В. Экология, здоровье и природопользование в России. М.: Финансы и статистика, $1995.528 \mathrm{c}$.

19. Kapralov, D.S., Shiytov S.G., Moiseev P.A., Fomin V.V.Changes in the Composition, Structure and Altitudinal Distribution of Low Forests at the Upper Limit of Their Growth in the Northern Ural Mountains. Russian Journal of Ecology, 2006. Vol. 37. No 6. Pp. 367-372.

20. Gilmour, D.A. Rearranging trees in the landscape of the middle hills of Nepal. In Arnold, J. E.M. and Dewees, P.A. (eds.), Tree Management in Farmer Strategiers: Responses to Agricultural Intensification. Oxford University Press: London, Pp. 21-42. 


\section{СВЕДЕНИЯ ОБ АВТОРАХ / Information about authors:}

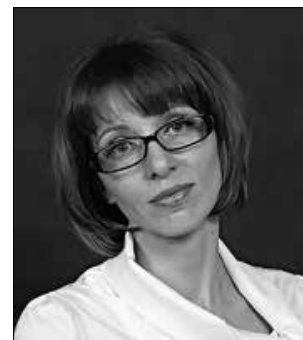

ДЕГА Наталья Сергеевна кандидат географических наук, доцент.

Научно-исследовательская лаборатория геоэкологического мониторинга.

Карачаево-Черкесский государственный университет имени У.Д. Алиева, г. Карачаевск, Россия

E-mail: dega999@mail.ru

Тел.: +7(918)717-82-08

Natalya Sergeevna DEGA - Cand. Geogr. Sc., Associate Prof. Scientific - Research Lab of the Geoecological monitoring.

Karachai-Cherkessk State University after U.D.Aluiev, Karachaevsk, Russia.

E-mail:dega999@mail.ru

Тел.: +7(918)717-82-08

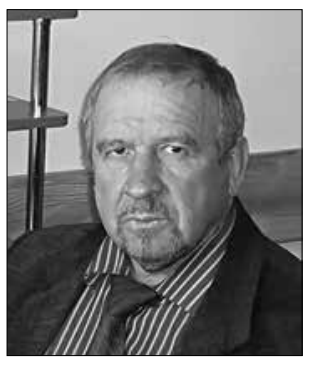

ОНИЩЕНКО Вячеслав Валентинович - доктор географических наук, профессор.

Кафедра экологии и природопользования. Карачаево-Черкесский государственный университет имени У.Д. Алиева, г. Карачаевск, Россия

Тел.: +7(918)713-00-86

E-mail: ovv333@mail.ru

Vyacheslav Valentinovich ONISCHENKO - Dr. Geogr. Sc., Professor. Department of Ecology and Nature Use.

Karachai-Cherkessk State University after U.D.Aluiev

Karachaevsk, Russia.

E-mail:ovv333@mail.ru

Тел.: +7(918)713-00-86

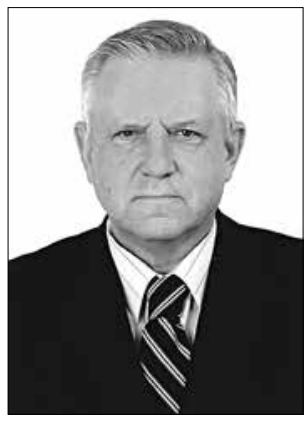

ПЕТРОПАВЛОВСКИЙ Борис Сергеевич - доктор биологических наук, профессор.

Лаборатория экологии растительного покрова. Ботанический сад-институт Дальневосточного отделения Российской Академии наук,

г. Владивосток, Россия

E-mail: petrop5@mail.ru

Boris Sergeevich PETROPAVLOVSKIY - Dr. Biolog. Sc., Professor

Laboratory of Vegetation Cover Ecology. Botanical Garden - Institute of Far East Branch of the Russian Academy of Sciences,

Vladivostok, Russia.

E-mail:petrop5@mail.ru

\section{AIR MEDIUM TECHNOGENIC TRANSFORMATION AFFECT ON THE CONIFEROUS FORESTS OF KARACHAI-CHEKESSIA}

${ }^{1}$ Dega N.S.

'Onischenko V.V.*

${ }^{2}$ Petropavlovskiy B.S.

${ }^{1}$ Karachai-Cherkessk State University after U.D.Aluiev, Karachaevsk, Russia

${ }^{2}$ Botanical Garden - Institute of Far East Branch of the Russian Academy of Sciences, Vladivostok, Russia

*E-mail:ovv333@mail.ru

\section{DOI: $10.21177 / 1998-4502-2018-10-1-69-76$}

Spontaneously developing coniferous forests of the Teberdinsky national natural bio spheric park, in the majority, are in a ripe or over age stage that creates prerequisites of decrease in their resistance to the influence of the external factors - fire danger, environmental, forest pathological susceptibility. In the dark-coniferous forests of the reserve located in the zone of the intensive recreational development for the last five years the very considerable drying of fir-tree forest stands is noted.

Research objective is identification of cause and effect relationship of the forest drying in the conditions of climate warming and intensive operation.

Monitoring of Karachay-Cherkessia air environment quality on the observations route posts by Rostekhnadzor for the KarachaiCherkess Republic is taken as a basis of methodology. The center of the laboratory analysis and technical measurements for the Karachai-Cherkess Republic and research laboratory of the geo environmental monitoring of $\mathrm{KChGU}$ carried out observations on padding points of selection of single tests for the sanitary and epidemiologic monitoring. The data of the hydro meteorological monitoring and the abnormal atmospheric phenomena are created.
The analysis and synthesis of the experimental and share material allowed to establish hypothetically:

- the impurity of free air fluidized chemicals increased more than by 3 times from 2000;

- regional warming of climate and the frequent abnormal atmospheric phenomena (hydrothermal inversions, smogs, fogs, hoarfrost, acid rains ...) confirm the increase in the free air impurity level;

- the main ingredients worsening quality of the air environment are: white damps, sulfurs, nitrogen, aerosols, hydrocarbons and also volatile organic compounds which are formed from the local sources and get into the gorges with the wind streams;

- the majority of the specified substances - gaseous also affect trees as dry settlings, and being acidified by the condensation moisture of air drop out in the form of the acid rains;

- the drying process of fir-trees happens from the bottom of slopes to an upper bound of the growth. Individuals of the top tiers in communities and subject to immediate influence of the airflows dry out, first of all. The younger generation (subbody height) located close to the dried-out trees keeps viability. 
Keywords: fir-tree forest stand, hillsides, free air, prospecting, polluters, aerosols, natural and anthropogenic phenomena, acid rains, inversions, stability of coniferous breeds.

\section{References}

1. Onishhenko V.V. Mountain forest - formation. Features, geoecological analysis, methods. Germany: LAP LAMBERT Academic Publishing GmbH \& Co. KG Dudweiler Landstr, 2011. 381 p (in Russian).

2. Dega N.S., Onishhenko V.V. Ecology research technique forest - formation and steady forest exploitation. Karachay-Cherkess Republic. Sustainable development: experience, problems, prospects. Moscow: Centre of Russian ecological policy. 2013. Pp. 5562 (in Russian).

3. Friedrich-Karl Holtmeir. Sensitive and response of northern hemisphere altitudinal and polar tree lines to environmental change at landscape and local scales. Friedrich-Karl Holtmeir, Gabriele Broll. Global Ecology and Biogeography, 2005. Vol. 14. P. 395.

4. Holtmeie, F.-K. Mountain Timberlines: Ecology, Patchiness and Dynamics. Springer, 2009. 438 p.

5. Onishhenko V.V., Salpagarov A.D., Dega N.S. Influence of climate change on seasonal dynamics dendro floor of the Teberdinsky reserve. Problems of regional ecology. Moscow, 2006. No 1. Pp. 42-49 (in Russian).

6. Onishhenko V.V., Dega N.S. Sustainable development of Karachay-Cherkessia in the conditions of the modern organization of mountain ecosystems. Sustainable development of mountain territories. Vladikavkaz, 2009. No 1. Pp. 49-54 (in Russian).

7. Hamilton L.S., Gilmor D.A., Kasselz D.S. Mountain woods and forestry. Mountains of the world global priority. A contribution to Chapter 13 of the agenda for the 21 st century. Moscow: «NOOSFERA», 1999. Pp. 271-299 (in Russian).

8. Tikhonova I.O., Tarasov V.V., Kruchinina N.E. Geoecological monitoring of the atmosphere. Moscow: Forum: NIC INFRA-M, 2014. 136 p. (in Russian).

9. Vetoshkin A.G., Taranceva K.R., Vetoshkin A.G.) Technology of environment protection (theoretical bases). Moscow: NIC INFRA- $M$, 2015. 362 p. (in Russian).

10. Onishhenko V. V., Dega N. S., Gerbekova D. Ju. Medical - ecological paradigm of resort - recreation development in the ba- sin of the Teberda river (Karachaevo-Cherkessk Republic. Arkhangelsk, 2016. No 10. Pp. 3-9. (in Russian).

11. Dega N.S., Onishhenko V.V., Bajchorova Je.M., Uzdenov U.B. Model operation of air pollution in the territory of KarachayCherkessia. Achievements of the modern natural sciences. 2017. No 7. Pp. 64-70 (in Russian).

12. Onishhenko V.V., Dega N.S., Korchagina N.M. The principles and prospects of the organization of the integrated environmental management in sustainable development of Karachay-Cherkessia. Bulletin of the Dagestan State Pedagogical University. Natural and exact sciences. 2017. Vol. 11. No 2. Pp. 100-108 (in Russian).

13. Galperin M.V. Ecological bases of environmental management. Moscow: ID FORUM: NIC INFRA-M, 2014. 256 p. (in Russian).

14. Denisov V.V. City ecology. Rostov-on-Don: MarT, 2008. 832 p. (in Russian).

15. Zhukov, V. I., Gorbunova L. N., Sevastyanov S. V. Assessment of a transport and road complex impact on the surrounding medium. Krasnojarsk :Sib. Feder. Un., 2012. 784 p. (in Russian).

16. Jasoveev M.G., Streha N. L. Environmental monitoring and environmental assessment. Moscow: NIC INFRA-M, 2013. 304 p. (in Russian).

17. Dobrovolskiy V.V. Fundamentals of biogeochemistry. Moscow: Higher school, 1998. 189 p. (in Russian).

18. Protasov V.F., Molchanov A.V. Ecology, health and environmental management in Russia. Moscow: Finance and statistics, 1995. 528 p. (in Russian).

19. Kapralov, D.S., Shiytov S.G., Moiseev P.A., Fomin V.V.Changes in the composition, structure and altitudinal distribution of low forests at the upper limit of their growth in the Northern Ural Mountains. Russian Journal of Ecology, 2006. Vol. 37. No 6. Pp 367-372.

20. Gilmour, D.A. Rearranging trees in the landscape of the middle hills of Nepal. Arnold, J. E.M. and Dewees, P.A. (eds.), Tree Management in Farmer Strategy: Responses to Agricultural Intensification. Oxford University Press: London. Pp. 2-42.

Article received 08.11.2017 


\section{НЕКОТОРЫЕ ОСОБЕННОСТИ ГИДРОХИМИЧЕСКОГО РЕЖИМА НОВОАФОНСКОЙ ПЕЩЕРЫ (ЗАПАДНЫЙ КАВКАЗ) В КОНТЕКСТЕ СОВРЕМЕННОГО МИНЕРАЛООБРАЗОВАНИЯ И УСЛОВИЙ ПИТАНИЯ КАРСТОВЫХ ВОД}

\author{
1Червяцова О.Я., ${ }^{*}$ \\ "Потапов C.C., \\ Филиппова К.А., \\ ${ }^{3}$ Дбар P.C.
}

\section{Введение}

Новоафонская пещера (Абхазия, Западный Кавказ) заложена в известняках нижнемелового возраста (готерив-баррем**) в осевой части хребта АжАмгва. В пещере имеются постоянные подземные озера, гидродинамически связанные с подземными водами, уровень которых подвержен значительным колебаниям при паводках. Локализация разгрузки карстовых вод пещеры не до конца ясна: по наиболее распространенному мнению, она происходит в источнике (в оклюзе) в долине реки Псырцха [1]. По мнению других исследователей, она происходит в воклюзах р. Мааниквары, а движение подземных вод направлено на юго-запад [2].

Целью настоящей работы является получение дополнительных данных о гидрохимическом режиме источника Псырцха, озёр пещеры и капельных вод, а также изучение некоторых аспектов, связанных с современным минералообразованием.

Гидрохимические исследования выполнены в Южно-Уральском центре коллективного пользования по исследованию минерального сырья Института минералогии УрО РАН, г. Миасс (аттестат аккредитации № ААС.А.00330). Водородный показатель $\mathrm{pH}$, окислительно-восстановительный потенциал $\mathrm{Eh}$ и электропроводность изучались электрохимическим методом (рН-метрмилливольтметр рН-121, кондуктомер НІ933000). Для определения $\mathrm{HCO}_{3}^{-}$, $\mathrm{Cl}^{-}, \mathrm{SO}_{4}^{2-}$ применялись титриметрический, меркурометрический и турбидиметрический методы; $\mathrm{NO}_{2}^{-} \mathrm{NO}_{3}^{-} \mathrm{NH}_{4}^{+}$определялись фотоколориметрическим методом (фотоэлектрический колориметр КФК-2-УХЛ 4.2); $\mathrm{Ca}^{2+}, \mathrm{Mg}^{2+}$, $\mathrm{K}^{+}$, $\mathrm{Na}^{+}$определялись методом атомно-абсорбционной спектрометрии (прибор Perkin-Elmer 3110); микроэлементы определялись методом массспектрометрии с индуктивно связанной плазмой на приборе Agilent 7700x.

Пробы капельных вод (2016-1017 гг.) анализировались полевыми методами "мокрой химии" (ГОСТ 24902), ионный состав воды определялся титрометрическим методом ( $\mathrm{Na}+\mathrm{K}$ расчетным путем). Водородный показатель измерялся на месте с помощью прибора Hanna HI 9125.

Для диагностики минералов использовался дифрактометр ДРОН-2.0, CuKo.

Окислительно-восстановительный потенциал Eh во всех пробах составляет 260-275 мВ, что типично для кислородной слабоокислительной обстановки, благоприятной для миграции $\mathrm{Fe}^{3+}, \mathrm{Mn}^{2+}, \mathrm{Mo}^{6+}, \mathrm{Cu}^{2+}[3]$.

По макрокомпонентному составу все пробы относятся к пресным (минерализация 354.4-238.2 мг/л) гидрокарбонатно-кальциевым водам с нейтральной и слабощелочной реакцией, типичным для карстовых вод. В источнике Псырха, по сравнению с пещерными озёрами, несколько повышено содержание хлора и натрия, что согласуется с данными предыдущих исследований $[1 ; 2]$ и более детально будет обсуждаться ниже.

\footnotetext{
1Заповедник «Шульган-Таш», дер. Иргизлы, Республика Башкортастан, Россия, e-mail: kittary@yandex.ru ${ }^{2}$ Институт минералогии УрО РАН, г. Миасс, Россия

${ }^{3}$ Институт экологии Академии наук Абхазии, г. Сухум

**В литературе говорится только о барремском возрасте вмещающих пород. Однако видовые определения фораминифер, выполненные М.А. Алексеевым (Всероссийский научно-исследовательский геологический институт им. А.П. Карпинского, г. Санкт-Петербург) по полученным авторами статьи электронным микрофотографиям шлифов вмещающих пород из зала Апсны, дают возможность обосновать готеривский возраст для нижней части разреза (неопубликованные данные, 2017).
}

УДК: 551.435 .8

DOI: 10.21177/1998-4502-2018-

10-1-77-90

Приводятся данные

о гидрохимическом

режиме озер и капельных

вод Новоафонской

пещеры. Современный

гидрохимический режим

Новоафонской пещеры

связан с холодными

гидрокарбонатно-

кальциевыми водами,

формирующимися в

химически чистых

карбонатных породах 8

низкогорье. В то же время для расположенного вблизи нее

источника Псырцха с высокой вероятностью можно

сделать вывод о подтоке

глубинных минеральных вод.

Накопление металлов

в озерах пещеры

контролируется локальными

факторами - наличием

коллоидов-концентраторов

и отложением минералов

железа и марганца.

Приводятся результаты

минералогических

исследований

железомарганцевых

минеральных отложений в

озере зала Нартаa.

Наблюдения над химическим

составом капельных вод в

пещере позволяют сделать

вывод, что наиболее

обильные и постоянные

точки капежа имеют

инфильтрационное питание

и способствуют быстрому

отложению кальцита

КЛЮЧЕВЫЕ СЛОВА: гидрохимический режим, минералообразование, карстовые воды,

Новоафонская пещера

Статья поступила в редакцию

23.01.2017 
таблица 1 / Table 1

Физико-химические показатели вод озёр Новоафонской пещеры и источника Псырцха /

Physicochemical parameters of the lakes of the Novoafskaya cave and the source of Psyrtskha

\begin{tabular}{|c|c|c|c|c|c|}
\hline $\begin{array}{c}\text { Показатель / } \\
\text { Indicator }\end{array}$ & \begin{tabular}{|c|} 
Озеро Анатолия \\
СС03 / \\
Anatolia lake \\
CС03 \\
\end{tabular} & $\begin{array}{c}\text { Озеро Провальное } \\
\text { (Голубое) } \\
\text { CC06 / Provalnoe } \\
\text { (Blue) lake CC06 }\end{array}$ & $\begin{array}{c}\text { Озеро Нартаa } \\
\text { СС07 / } \\
\text { Nartaa lake } \\
\text { CC07 }\end{array}$ & $\begin{array}{c}\text { Озеро Сюрприз } \\
\text { СС09 / } \\
\text { Surprise lake } \\
\text { CC09 }\end{array}$ & $\begin{array}{c}\text { Источник Псырцха } \\
\text { СС14 / } \\
\text { The source of } \\
\text { Psyrtskha CC14 }\end{array}$ \\
\hline $\mathrm{t}^{\circ} \mathrm{C}$ & 12.4 & 11.8 & 13.2 & нд & 12.3 \\
\hline $\begin{array}{l}\text { pH на месте/ } \\
\text { pH on a place }\end{array}$ & 7.62 & 7.16 & 7.22 & 6.69 & 7.20 \\
\hline $\begin{array}{c}\text { pН в лаб./ } \\
\text { pH in laboratory }\end{array}$ & 7.55 & 7.45 & 7.50 & 7.55 & 7.40 \\
\hline $\begin{array}{l}\text { Eh, } \mathrm{mB} / \\
E h, m v\end{array}$ & 265 & 270 & 256 & 265 & 270 \\
\hline \multirow[t]{2}{*}{$\begin{array}{c}\gamma, \mathrm{MKCм} / \mathrm{cm} / \\
\gamma, \mu s / \mathrm{cm}\end{array}$} & 183 & 235 & 207 & 253 & 337 \\
\hline & \multicolumn{5}{|c|}{ мг/л / (mg/l) } \\
\hline $\mathrm{HCO}^{3-}$ & 153 & 181 & 157 & 177 & 183 \\
\hline $\mathrm{Cl}^{-}$ & 8.51 & 21.3 & 17.0 & 13.5 & 42.5 \\
\hline $\mathrm{SO}_{4}^{2-}$ & 16.8 & 19.8 & 23.0 & 29.5 & 19.3 \\
\hline $\mathrm{NO} 2$ & 0.069 & 0.037 & 0.071 & 0.036 & 0.009 \\
\hline $\mathrm{NO}^{-}$ & 2.85 & 1.60 & 3.75 & 2.00 & 3.25 \\
\hline $\mathrm{NH}^{4+}$ & 0.10 & 0.15 & $<0.05$ & 0.175 & $<0.05$ \\
\hline $\mathrm{Ca}^{2+}$ & 53.0 & 65.4 & 59.8 & 58.3 & 65.1 \\
\hline $\mathrm{Mg}^{2+}$ & 1.29 & 1.48 & 1.57 & 1.41 & 3.50 \\
\hline $\mathrm{K}+$ & 1.93 & 19.6 & 7.50 & 19.2 & 11.0 \\
\hline $\mathrm{Na}+$ & 1.16 & 1.26 & 0.84 & 1.29 & 26.7 \\
\hline $\begin{array}{c}\text { Общая минера- } \\
\text { лизация / Total } \\
\text { mineralization }\end{array}$ & 238.2 & 311.1 & 271.0 & 302.4 & 354.4 \\
\hline
\end{tabular}

Концентрации микроэлементов, нормированные на кларки для подземных вод зоны гипергенеза по С. Л. Шварцеву [5], приведены на рис. 1а. Содержание большинства металлов не превышает кларковое. Для озёр Провальное, Нартаа и Сюрприз отмечается превышение по иттрию; для источника Псырцха - по стронцию, и общее для всех опробованных пунктов - по барию. Поскольку иттрий и стронций могут входить в кристаллическую решётку кальцита в виде изоморфной примеси, можно предположить связь данных элементов с вмещающими карбонатными породами. В целом, распределение и концентрации элементов близки между собой, однако для пещерных озёр характерно повышение содержания сидеро- и халькофильных элементов (Cr, Mn, Fe, Ti, Ni) по сравнению с источником Псырцха. Наибольшее сходство в распределении микроэлементов отмечается для источника Псырцха и озера Анатолия в зале Анакопия Новоафонской пещеры.

Геохимические спектры лантаноидов, нормированных на североамериканский сланец (NASC), показаны на рис. $1 \mathrm{~b}$. Для всех образцов обнаружено преобладание лёгких РЗЭ, что может объясняться наличием минералов, концентрирующих лёгкие РЗЭ в области питания (таких как полевые шпаты, биотит, глинистые и фосфатные минералы).

Как известно, среди лантаноидов есть те, которые особенно сильно реагируют на изменение геохимической обстановки. Два из них - Cе и $\mathrm{Eu}-$ обладают чувствительностью к редокс-условиям среды, так как у них переменная валентность [5]. Европиевые и цериевые аномалии оценивались по формулам $\mathrm{Eu} / \mathrm{Eu}^{*}=2(\mathrm{Eun}) /(\mathrm{Smn}+\mathrm{Cdn})$ и $\mathrm{Ce} / \mathrm{Ce}^{*}=2(\mathrm{Cen}) /$ $(\mathrm{Lan}+\mathrm{Prn})$, где $\mathrm{n}$ - это концентрация элемента, нормированная на североамериканский сланец (NASC).

Для изученных проб воды характерна ярко выраженная положительная европиевая аномалия $(\mathrm{Eu} / \mathrm{Eu}=3.09-10.56)$. Важнейшим концентратором европия является полевой шпат, который, согласно нашим исследованиям, широко распространён в виде включений во вмещающих известняках. Цериевая аномалия менее выражена. Она отрицательна $(<1)$ для источника Псырцха и озера Анатолия, и положительна для озёр Провальное, Безымянное и Сюрприз.

Соотношение суммы РЗЭ с некоторыми элементамигидролизатами показано на рис. 2. Видно, что для железа, марганца и алюминия наблюдается тесная корреляция. Такая закономерность может объясняться тем, что 
Таблица 2 / Table 2

Микроэлементный состав вод озёр Новоафонской пещеры и источника Псырщха (мкг/л) /

Microelement composition of the lakes of the Novoafonskaya cave and the source of Psyrtskha (mcg/l)

\begin{tabular}{|c|c|c|c|c|c|}
\hline $\begin{array}{c}\text { Элемент/ } \\
\text { Element }\end{array}$ & $\begin{array}{c}\text { Озеро Анатолия } \\
\text { СС03 / } \\
\text { Anatolia lake } \\
\text { CС03 }\end{array}$ & $\begin{array}{c}\text { Озеро Провальное } \\
\text { (Голубое) СС06 / } \\
\text { Provalnoe (Blue) } \\
\text { lake CC06 }\end{array}$ & $\begin{array}{c}\text { Озеро Нартаa } \\
\text { CC07 / } \\
\text { Nartaa lake } \\
\text { CC07 }\end{array}$ & $\begin{array}{c}\text { Озеро Сюр- } \\
\text { приз СС09 / } \\
\text { Surprise lake } \\
\text { CС09 }\end{array}$ & $\begin{array}{c}\text { Источник } \\
\text { Псырџха СС14 / } \\
\text { The source of } \\
\text { Psyrtskha CC14 }\end{array}$ \\
\hline $\mathrm{Li}$ & 0.36 & 0.72 & 0.45 & 0.86 & 4.46 \\
\hline $\mathrm{Be}$ & 0.004 & 0.007 & 0.025 & 0.010 & 0.002 \\
\hline $\mathrm{Al}$ & 22.0 & 77.1 & 233 & 89.9 & 21.3 \\
\hline $\mathrm{Sc}$ & 0.047 & 0.066 & 0.092 & 0.093 & 0.061 \\
\hline $\mathrm{Ti}$ & 0.65 & 2.41 & 4.36 & 1.74 & 0.72 \\
\hline $\mathrm{V}$ & 0.30 & 0.38 & 0.71 & 0.42 & 0.28 \\
\hline $\mathrm{Cr}$ & 0.39 & 1.19 & 0.84 & 0.36 & 1.44 \\
\hline $\mathrm{Mn}$ & 0.85 & 24.2 & 59.7 & 28.0 & 3.27 \\
\hline $\mathrm{Fe}$ & 19.0 & 105 & 284 & 100 & 18.0 \\
\hline Co & 0.21 & 0.40 & 0.70 & 0.40 & 0.27 \\
\hline $\mathrm{Ni}$ & 0.98 & 1.23 & 1.21 & 1.14 & 0.81 \\
\hline $\mathrm{Cu}$ & 1.76 & 0.96 & 0.81 & 0.94 & 1.37 \\
\hline $\mathrm{Zn}$ & 3.72 & 7.21 & 3.26 & 3.58 & 13.1 \\
\hline As & 0.159 & 0.46 & 0.189 & 0.143 & 0.185 \\
\hline $\mathrm{Rb}$ & 0.48 & 0.67 & 0.47 & $\begin{array}{l}0.58 \\
\end{array}$ & 1.18 \\
\hline $\mathrm{Sr}$ & 53.8 & 54.0 & 53.5 & 107 & 277 \\
\hline $\mathrm{Y}$ & 0.116 & 1.64 & 1.37 & 0.99 & 0.122 \\
\hline $\mathrm{Zr}$ & 0.012 & 0.041 & 0.060 & 0.138 & 0.005 \\
\hline $\mathrm{Nb}$ & 0.007 & 0.011 & 0.009 & 0.008 & 0.003 \\
\hline Mo & 0.27 & 0.29 & 0.24 & 0.23 & 0.37 \\
\hline $\mathrm{Cd}$ & 0.169 & 0.044 & 0.037 & 0.151 & 0.133 \\
\hline $\mathrm{Sb}$ & 0.041 & 0.036 & 0.019 & 0.021 & 0.019 \\
\hline $\mathrm{Ba}$ & 105 & 46.7 & 41.6 & 77.6 & 38.0 \\
\hline $\mathrm{Ta}$ & 0.001 & 0.001 & 0.001 & 0.002 & 0.001 \\
\hline $\mathrm{W}$ & 0.018 & 0.026 & 0.005 & 0.004 & 0.007 \\
\hline $\mathrm{Tl}$ & 0.006 & 0.009 & 0.009 & 0.008 & 0.006 \\
\hline $\mathrm{Pb}$ & 0.106 & 0.32 & 0.50 & 0.22 & 0.067 \\
\hline $\mathrm{Bi}$ & 0.003 & 0.005 & 0.002 & 0.007 & 0.001 \\
\hline Th & 0.002 & 0.006 & 0.004 & 0.007 & 0.002 \\
\hline $\mathrm{U}$ & 0.123 & 0.174 & 0.24 & 0.179 & 0.187 \\
\hline \multicolumn{6}{|c|}{ Лантаноиды / Lanthanides } \\
\hline $\mathrm{La}$ & 0.087 & 0.34 & 1.03 & 0.43 & 0.082 \\
\hline $\mathrm{Ce}$ & 0.072 & 0.42 & 1.34 & 0.45 & 0.077 \\
\hline $\operatorname{Pr}$ & 0.018 & 0.23 & 0.25 & 0.26 & 0.015 \\
\hline $\mathrm{Nd}$ & 0.080 & 0.33 & 0.99 & 0.39 & 0.065 \\
\hline $\mathrm{Sm}$ & 0.020 & 0.068 & 0.21 & 0.086 & 0.017 \\
\hline $\mathrm{Eu}$ & 0.020 & 0.075 & 0.067 & 0.032 & 0.008 \\
\hline $\mathrm{Gd}$ & 0.027 & 0.081 & 0.24 & 0.109 & 0.018 \\
\hline $\mathrm{Tb}$ & 0.003 & 0.009 & 0.032 & 0.013 & 0.003 \\
\hline Dy & 0.016 & 0.057 & 0.189 & 0.079 & 0.011 \\
\hline Ho & 0.005 & 0.012 & 0.037 & 0.014 & 0.003 \\
\hline $\mathrm{Er}$ & 0.011 & 0.032 & 0.103 & 0.047 & 0.008 \\
\hline $\mathrm{Tm}$ & 0.001 & 0.004 & 0.013 & 0.005 & 0.001 \\
\hline $\mathrm{Yb}$ & 0.007 & 0.029 & 0.075 & 0.033 & 0.006 \\
\hline $\mathrm{Lu}$ & 0.002 & 0.003 & 0.012 & 0.005 & 0.001 \\
\hline LREE* & 0.325 & 1.553 & 4.112 & 1.747 & 0.283 \\
\hline HREE** & 0.045 & 0.147 & 0.461 & 0.198 & 0.032 \\
\hline $\mathrm{Eu} / \mathrm{Eu}^{* * *}$ & 9.47 & 10.56 & 3.09 & 3.55 & 4.22 \\
\hline $\mathrm{Ce} / \mathrm{Ce} * * * *$ & 0.77 & 1.20 & 1.25 & 1.00 & 0.87 \\
\hline
\end{tabular}

Примечание: * Сумма лёгких лантаноидов; ** Сумма тяжелых лантаноидов;

*** Европиевая аномалия: $\mathrm{Eu} / \mathrm{Eu}^{*}=2\left(\mathrm{Eu}_{\mathrm{n}}\right) /\left(\mathrm{Sm}_{\mathrm{n}}+\mathrm{Cd}_{\mathrm{n}}\right) ; * * *$ Цериевая аномалия: $\mathrm{Ce} / \mathrm{Ce} *=2\left(\mathrm{Ce}_{\mathrm{n}}\right) /\left(\mathrm{La}_{\mathrm{n}}+\mathrm{Pr}_{\mathrm{n}}\right) /$

Note: * Sum of light lanthanides; ** Sum of heavy lanthanides; *** Europium anomaly: Eu/Eu* = 2(Eun)/(Smn +Cdn);

**** Cerium anomaly: $\mathrm{Ce} / \mathrm{C} e^{*}=2(\mathrm{Cen}) /(\mathrm{Lan}+\mathrm{Prn})$ 

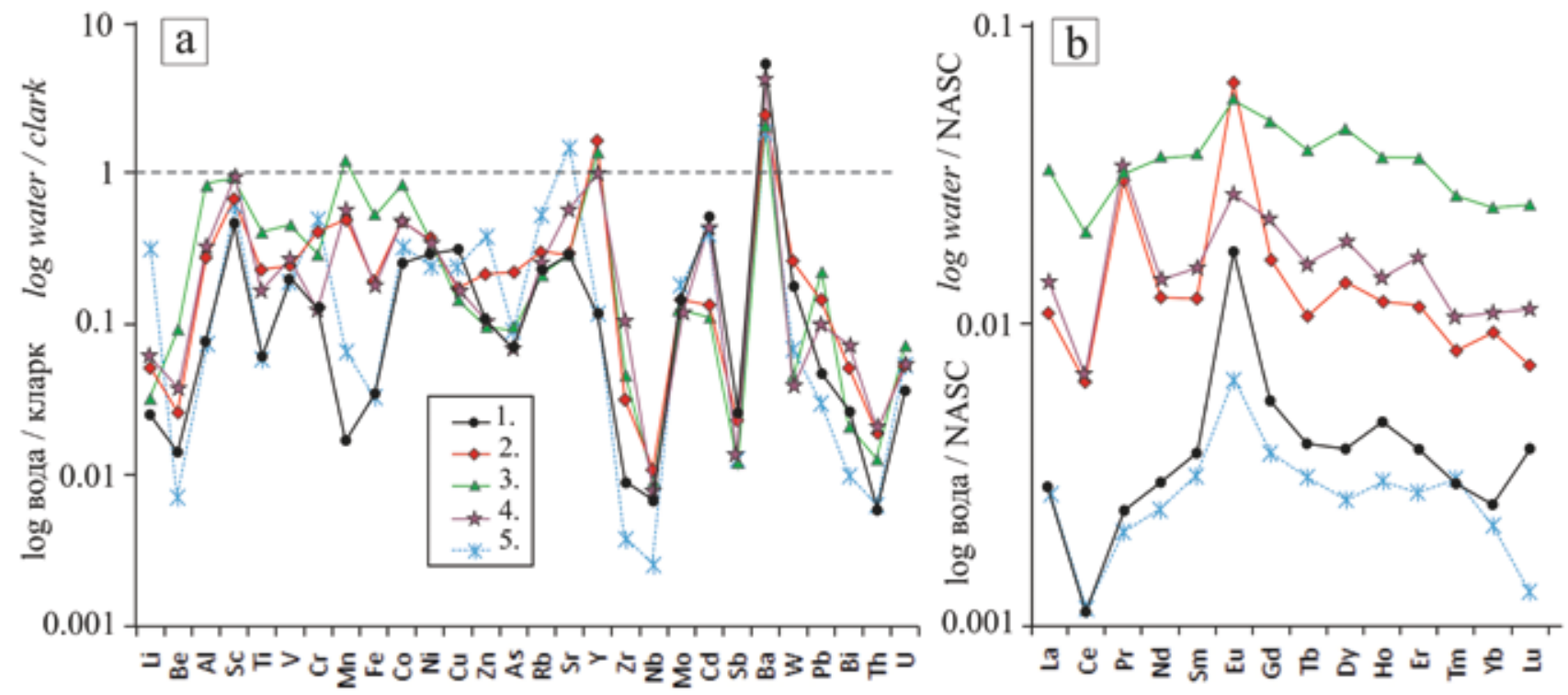

Рис. 1. Геохимические спектры микроэлементов (a) и лантаноидов (b) вод озер Новоафонской пещеры и источника

Псыриха: 1) зал Анакопия, озеро Анатолия; 2) зал Анакопия, озеро Провальное (Голубое); 3) зал Нартаа, озеро Безымянное; 4) озеро в зале Сюрприз; 5) воклюз Псыриха /

Fig. 1. Geochemical spectra of minerals (a) and lanthanides (b) waters of the lakes of the Novoafonskaya cave and the source of Psyrtskha: 1) Anakopia chamber, lake of Anatolia; 2) Anakopia chamber, lake Provalnoe (Blue); 3) Nartaa chamber, lake Nameless; 4) Lake in the Surprise chamber; 5) the source of Psyrtskha
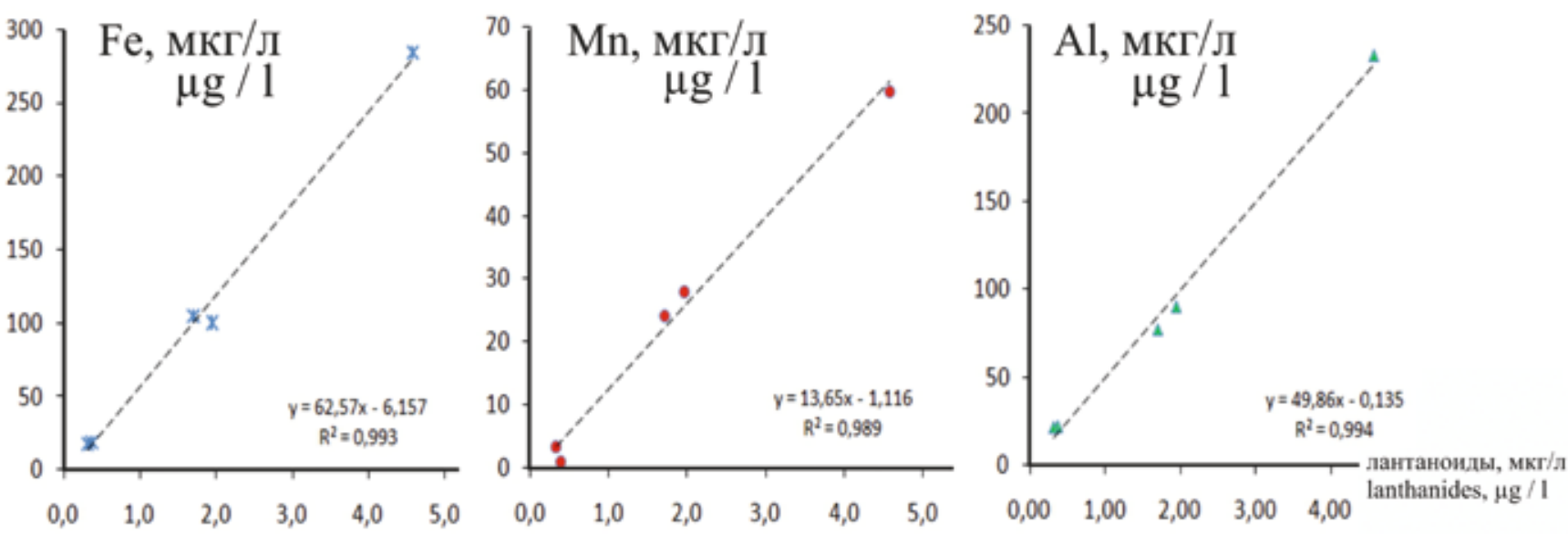

Puc. 2. Соотношение лантаноидов и некоторых элементов-гидролизатов /

Fig. 2. The ratio of lanthanides and some hydrolysates

коллоиды этих металлов являются важнейшими концентраторами-носителями лантаноидов в зоне гипергенеза [5]. Исходя из корреляции с алюминием, также можно предположить, что концентратором металлов выступает ультрадисперсная взвесь глинистых минералов.

Результаты термодинамического расчёта индексов насыщения вод к различным минеральным видам, выполненного в программе PHREEQC Ver. 2 приведены в табл. 3. Для основного породообразующего минерала - кальцита - вода находится в состоянии, близком к равновесию, что связано с длительным временем её нахождения в системе вода - порода, но агрессивна к карбонатам магния и железа, а также к сульфату кальция- гипсу. Расчет прогнозирует воз- можность отложения соединений железа в различной степени окисления: гидроксидов $\mathrm{Fe}(\mathrm{OH})_{3}$ и $\mathrm{FeO}(\mathrm{OH})$, и оксидов $\mathrm{Fe}_{2} \mathrm{O}_{3}$ и $\mathrm{Fe}_{3} \mathrm{O}_{4}$; гидроксидов алюминия $\mathrm{Al}(\mathrm{OH})_{3}$ и $\mathrm{AlO}(\mathrm{OH})$. Пересыщений к марганецсодержащим минералам не обнаружено.

Приведенные расчеты по карбонатам подтверждаются натурными наблюдениями - современное карбонатное минералообразование в озерах пещеры не происходит, также отсутствуют травертины на воклюзе Псырцха. Вместе с тем к подземным озерам приурочены черные минеральные отложения с металлическим блеском, образующие твердые корочки натечного облика на глинистых и карбонатных субстратах толщиной до 2-3 мм (рис. 3a). 
Расчет индексов насыщения к различным минеральным видам /

Таблица 3 / Table 3

Calculation of saturation indices for different mineral species

\begin{tabular}{|c|c|c|c|c|c|}
\hline Минерал / Mineral & $\begin{array}{c}\text { Озеро Анато- } \\
\text { лия СС03 / } \\
\text { Anatolia lake } \\
\text { CC03 } \\
\end{array}$ & $\begin{array}{c}\text { Озеро Провальное (Го- } \\
\text { лубое) СС06 / } \\
\text { Provalnoe (Blue) lake } \\
\text { CC06 } \\
\end{array}$ & $\begin{array}{c}\text { Озеро } \\
\text { Нартаa } \\
\text { CC06 / } \\
\text { Nartaa } \\
\text { lake CCO7 } \\
\end{array}$ & $\begin{array}{c}\text { Озеро Сюр- } \\
\text { приз СС09 / } \\
\text { Surprise lake } \\
\text { CC09 } \\
\end{array}$ & $\begin{array}{c}\text { Источник Псырц- } \\
\text { ха СС14 / } \\
\text { The source of } \\
\text { Psyrtskha CC14 }\end{array}$ \\
\hline $\begin{array}{c}\text { Кальцит / Calcite } \\
\mathrm{CaCO}_{3} \\
\end{array}$ & -0.151 & -0.102 & -0.15 & -0.066 & -0.163 \\
\hline $\begin{array}{c}\text { Сидерит / Siderite } \\
\mathrm{FeCO}_{3}\end{array}$ & -1.68 & -0.873 & -0.487 & -0.9 & -1.66 \\
\hline $\begin{array}{l}\text { Доломит / Dolomite } \\
\mathrm{CaMg}\left(\mathrm{CO}_{3}\right)_{2}\end{array}$ & -1.75 & -1.69 & -1.72 & -1.58 & -1.43 \\
\hline $\begin{array}{l}\text { Гипс / Gypsum } \\
\text { CaSO4xH }{ }_{2} \mathrm{O}\end{array}$ & -2.36 & -2.23 & -2.19 & -2.1 & -2.26 \\
\hline $\mathrm{Fe}(\mathrm{OH})_{3}$ & +1.49 & +2.01 & +2.57 & +2.2 & +1.13 \\
\hline $\mathrm{Fe}(\mathrm{OH})_{2}$ & -6.48 & -5.86 & -5.36 & -5.78 & -6.7 \\
\hline $\mathrm{Al}(\mathrm{OH})_{3}$ & -1.28 & -0.643 & -0.689 & -0.691 & -1.16 \\
\hline $\mathrm{Mn}(\mathrm{OH})_{2}$ & -8.16 & -6.92 & -6.42 & -6.67 & -6.7 \\
\hline $\begin{array}{c}\text { Гётит / Goethite } \\
\text { FeO(OH) }\end{array}$ & +6.9 & +7.42 & +7.97 & +6.61 & +6.53 \\
\hline $\begin{array}{c}\text { Гематит / Hematite } \\
\mathrm{Fe}_{2} \mathrm{O}_{3}\end{array}$ & +15.7 & +16.8 & +17.9 & +17.2 & +15 \\
\hline $\begin{array}{c}\text { Магнетит / Magnetite } \\
\mathrm{Fe}_{3} \mathrm{O}_{4} \\
\end{array}$ & +15.5 & +17.2 & +18.8 & +17.6 & +14.6 \\
\hline $\begin{array}{c}\text { Пиролюзит / Pyrolusite } \\
\mathrm{MnO}_{2}\end{array}$ & -13.4 & -12.4 & -11.8 & -11.9 & -13.4 \\
\hline $\begin{array}{c}\text { Диаспор / Diaspore } \\
\mathrm{AlO}(\mathrm{OH})\end{array}$ & +2.7 & +3.34 & +3.29 & +3.31 & +2.83 \\
\hline $\begin{array}{c}\text { Гиббсит / Gibbsite } \\
\mathrm{Al}(\mathrm{OH})_{3}\end{array}$ & +1.53 & +2.17 & +2.12 & +2.14 & +1.66 \\
\hline
\end{tabular}
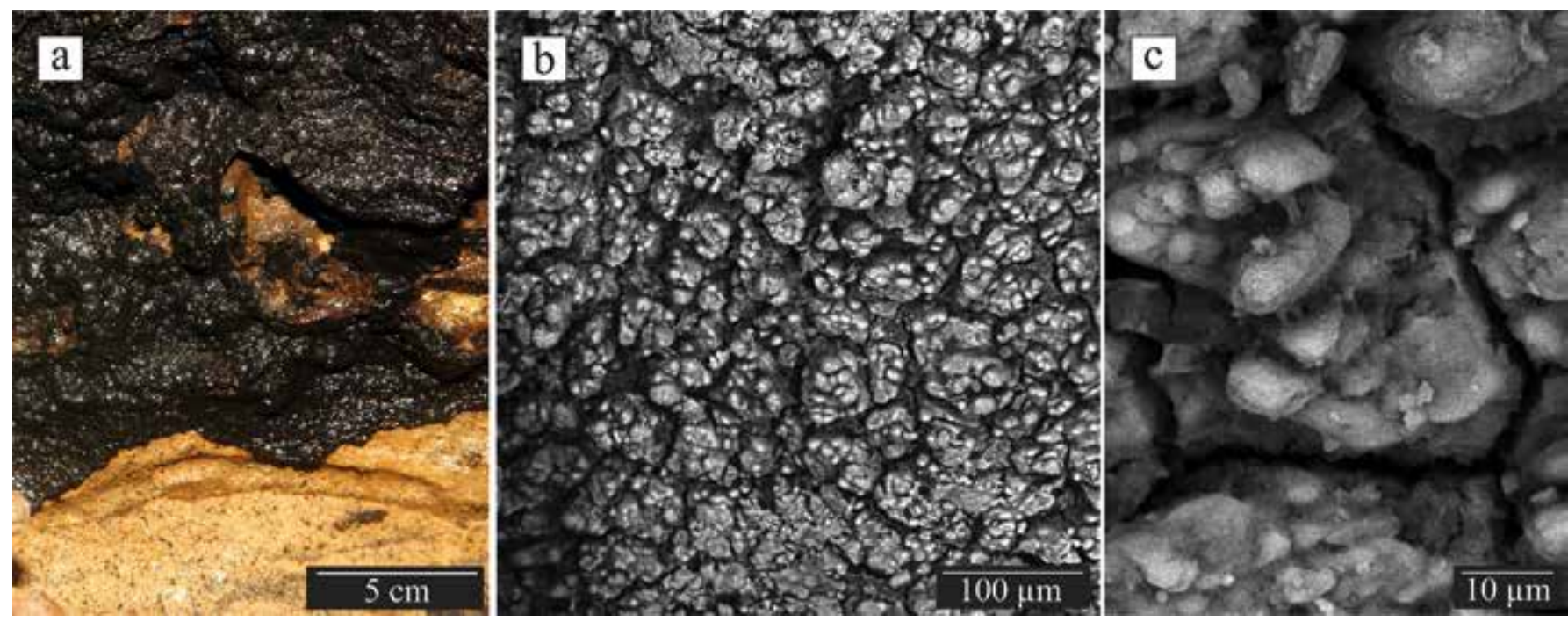

Pис. 3. Железо-марганцевые отложения на глинах на берегу озера в зале Нартаа:

a) натурная макрофотография; $b$, c) электроннье микрофотографии /

Fig. 3. Iron-manganese deposits on the clays on the shore of a lake in Nartaa chamber: a) full-scale macrograph; $b$, c) electronic micrographs 
Отложения представлены почковидными обособлениями метаколлоидной структуры размером 10-50 мкм, преимущественно гидроксидно-марганцевого состава с высоким содержанием железа (см. рис. 3b, с; табл. 4). Почки переплетены между собой пучками нитей субмикронной толщины, скорее всего, представляющими собой микробные маты железо- или марганецокисляющих бактерий, поэтому можно предположить их участие в минералообразовании. Скорее всего, биохимические процессы и формирование агрегатов преимущественно из коллоидных растворов объясняют появление марганцевой минерализации при отсутствии к ней предпосылок по термодинамическим оценкам (см. табл. 3).

Изученные образцы обогащены барием (Ba $0.5-$ 1.3 масс. \%), что согласуется с гидрохимическими данными о концентрировании этого элемента в природных водах. По нашим данным, барит в виде микровключений часто встречается во вторичных карбонатных и сульфатных отложениях пещеры. Также отмечена стабильная примесь кальция (Са 4.1-6.4 масс. \%), никеля (Ni 0.5-1.5 масс. \%), калия (К 0.30.7 масс. \%) - эти элементы, скорее всего, также входят в поглощённый комплекс [5].

По данным рентгенофазового анализа в образце идентифицированы кварц $\mathrm{SiO}_{2}$, иллит $\left(\mathrm{K}_{0.75}\left(\mathrm{H}_{3} \mathrm{O}\right)_{0.25}\right) \mathrm{x}$ $\mathrm{x}(\mathrm{Al}, \mathrm{Mg}, \mathrm{Fe})_{2}(\mathrm{Si}, \mathrm{Al})_{4} \mathrm{O}_{10}\left[(\mathrm{OH})_{2}\right.$ х $\left.\mathrm{H}_{2} \mathrm{O}\right]$, пирит $\mathrm{FeS}_{2}$, превдорутил $\mathrm{Fe}_{2} \mathrm{Ti}_{3} \mathrm{O}_{9}$ и манганотихит $\mathrm{Na}_{6} \mathrm{Mn}_{2}^{2+}\left(\mathrm{CO}_{3}\right)_{4}\left(\mathrm{SO}_{4}\right)$. Вероятно, часть минеральной пробы представлена рентгеноаморфным веществом - ближе не определёнными гидроксидами и/или оксигидроксидами марганца и железа (см. рис. 3).

Железомарганцевые отложения в озёрах тяготеют к поверхности глинистых осадков, что даёт основание предположить гипергенный метасоматоз, в ходе которого коллоидные гидроксиды железа и марганца замещают глинистые минералы [6]. Возможное происхождение отрицательных цериевых аномалий в подземных озёрах, описанных выше - фиксация манганофильного церия из воды в гидроксиды железа и марганца [3].

\section{Гидрохимические особенности инфильтрационных вод и современное карбонатное минералообразование}

Представление о гидрогеохимических процессах в системе "метеорные воды $\rightarrow$ почвенный слой и эпикарстовая зона $\rightarrow$ вадозная зона $\rightarrow$ атмосфера пещеры" помогает в понимании современной активности процессов коррозии и отложения карбонатных минералов [7-10]. В 2016-2017 г. нами был выполнен ряд наблюдений за химическим составом вод капежа в различных частях пещеры, а также вод эпикарстовой зоны, вскрытых шурфами (колодцами) на пещерном массиве (табл. 5).

Для оценки потенциала к кристаллизации кальцита было проведено вычисление равновесных концентраций для «открытой системы» на парциальное давление углекислого газа $\left(\mathrm{pCO}_{2}\right)$ в атмосфере пещеры (рис. 4а). Существует мнение о преимущественно конденсационном питании капельных вод в пещере [11]. Однако наши оценки позволяют допустить такой механизм только для ряда точек капежа, состав которых находится вблизи равновесной линии (поскольку состав конденсатных вод формируется в равновесии с $\mathrm{pCO}_{2}$ в воздухе). Эти точки находятся в залах Махаджиров, на входе в зал Спелеологов, в верхней части зала Апсны (см. рис. 4а). Остальные точки капежа в пещере имеют инфильтрационное питание, на что также указывает близость по минерализации к водам эпикарстовой зоны.

При контакте таких растворов с пещерным воздухом будет происходить разложение гидрокарбоната со смещением равновесия в сторону кристаллизации кальцита. Наибольшие превышения над равновесной линией наблюдаются на натеке «Белая гора» в зале Махаждиров, на подъеме в зал Гиви Смыр, в зале Апсны. Именно на этих участках и наблюдается интенсивный рост натёков.

Оценка скорости роста сталагмитов в зависимости от концентрации углекислого газа в воздухе и содержания $\mathrm{Ca}^{2+}$ в воде (по модели [12]) показана на рис. 4 б. Наибольшая скорость роста (160-220 мкм/год) прогнозируется для точки капежа «Белая гора» в зале Махаджиров, а минимальная (50-100 мкм/год) - в Кораллитовой галерее и в зале Апсны.

На рис. 5 показаны молярные (молекулярные) соотношения между кальцием и магнием в капельных водах, вмещающих известняках (32 определения) и в различных современных карбонатных отложениях пещеры (спелеотемах). Для большинства точек капежа этот показатель ниже, либо близок к вмещающим породам, но для вод Кораллитовой галереи характер-

Таблица 4 / Table 4

Химический состав железомарганцевых отложений из озера Нартаа по данным ЭДС, масс. \% / Chemical composition of ferromanganese deposits from the lake Nartaa according to EMF, mass. \%

\begin{tabular}{|c|c|c|c|c|c|c|c|c|c|c|c|}
\hline $\mathbf{O}$ & $\mathbf{M g}$ & $\mathbf{A l}$ & $\mathbf{S i}$ & $\mathbf{S}$ & $\mathbf{K}$ & $\mathbf{C a}$ & $\mathbf{T i}$ & $\mathbf{M n}$ & $\mathbf{F e}$ & $\mathbf{N i}$ & $\mathbf{B a}$ \\
\hline 19,7 & 0,4 & 4,1 & 3,2 & & 0,3 & 6,4 & & 54,9 & 8,2 & 1,5 & 1,3 \\
\hline 40,0 & 0,8 & 6,5 & 10,5 & & 0,7 & 4,1 & 0,2 & 27,5 & 8,7 & 0,5 & 0,5 \\
\hline 40,6 & 0,4 & 3,7 & 2,3 & 0,67 & & 6,0 & & 38,6 & 6,2 & 0,7 & 0,9 \\
\hline
\end{tabular}


Результаты наблюдений за химическим составом капельных вод в пещере /

Observation results of the chemical composition of drip waters in the cave

\begin{tabular}{|c|c|c|c|c|c|c|c|c|c|c|}
\hline Проба / Sample & Дата / Date & $\mathbf{t}^{\circ} \mathbf{C}$ & pH & $\mathrm{HCO}_{3}^{-}$ & $\mathrm{SO}_{4}{ }^{2}$ & $\mathrm{Cl}^{-}$ & $\mathrm{Ca}_{2}^{+}$ & $\mathbf{M g}_{2}^{+}$ & $\mathbf{N a}^{+}+\mathbf{K}^{+}$ & Мин. / Min. \\
\hline 1 & 2 & 3 & 4 & 5 & 6 & 7 & 8 & 9 & 11 & 12 \\
\hline \multicolumn{11}{|c|}{ Эпикарстовая зона над пещерой (район села Ануква) / Epikarst zone above the cave (in the area of Anukva village) } \\
\hline Шурф $1(\mathrm{~h} \approx 4 \mathrm{~m}) /$ Hole $1(h \approx 4 \mathrm{~m})$ & $\begin{array}{c}\text { авг / } \\
\text { Aug } 17\end{array}$ & 14,5 & 6,61 & 213,5 & 0,8 & 3,56 & 71,1 & 0 & 1,5 & 290,5 \\
\hline $\begin{array}{l}\text { Шурф } 2 \text { (h } \approx 6 \text { м) "Колодец Суш- } \\
\text { ка"/ Hole } 2(h \approx 6 \text { м) "Sushka Well" }\end{array}$ & $\begin{array}{c}\text { авг / } \\
\text { Aug } 17\end{array}$ & 14,4 & 6,55 & 411,75 & 0,8 & 7,12 & 132,3 & 0,62 & 7,2 & 559,8 \\
\hline \multicolumn{11}{|c|}{ Капельные воды в полостях пещеры / Drip waters in the hollows of the cave } \\
\hline $\begin{array}{l}\text { У западной стены з. Анакопия / } \\
\text { Near the Western wall of Anakopia } \\
\text { chamber }\end{array}$ & $\begin{array}{l}\text { май / } \\
\text { May16 }\end{array}$ & 13,1 & 7,81 & 268,4 & 5,4 & 3,6 & 90,2 & 0 & 2,5 & 370,1 \\
\hline $\begin{array}{l}\text { Зал Анакопия, "Натек Череп" / } \\
\text { Anakopia chamber "Skull dropstone" }\end{array}$ & $\begin{array}{c}\text { авг / } \\
\text { Aug } 17\end{array}$ & 11,9 & 7,51 & 137,3 & 0,8 & 12,5 & 46,1 & 0 & 7,3 & 204,0 \\
\hline $\begin{array}{l}\text { Зал Анакопия, рядом с "Черепом" / } \\
\text { Anakopia chamber, near the "Skull" }\end{array}$ & $\begin{array}{c}\text { авг / } \\
\text { Aug } 17\end{array}$ & & 7,71 & 122,0 & 0,8 & 0 & 40,1 & 0 & 0,4 & 163,3 \\
\hline \multirow{2}{*}{$\begin{array}{l}\text { На "Белой горе" зала Махаджиров / } \\
\text { On the "White hill" of Makhajir } \\
\text { chamber }\end{array}$} & $\begin{array}{c}\text { май / } \\
\text { May } 16\end{array}$ & 13,2 & 7,78 & 271,5 & 0,2 & 3,6 & 90,2 & 0 & 1,2 & 366,7 \\
\hline & янв / Jan17 & 13,2 & 7,88 & 213,5 & 0,77 & 7,1 & 67,1 & 1,9 & 4,96 & 295,3 \\
\hline $\begin{array}{l}\text { Кораллитовая галерея / } \\
\text { Corallite gallery }\end{array}$ & $\begin{array}{c}\text { авг / } \\
\text { Aug } 17\end{array}$ & & 7,7 & 186,1 & 0,8 & 8,9 & 64,1 & 1,2 & 0,4 & 261,5 \\
\hline $\begin{array}{l}\text { Перед залом Аюхаа / } \\
\text { In front of Auhua chamber }\end{array}$ & $\begin{array}{c}\text { авг / } \\
\text { Aug } 17\end{array}$ & & 7,54 & 198,3 & 0,8 & 3,56 & 61,1 & 3,1 & 1,5 & 268,4 \\
\hline \multirow{3}{*}{\begin{tabular}{|l|} 
Капеж на входе в з. Спелеологов / \\
Water drip at the entrance to \\
Speleologists chamber
\end{tabular}} & $\begin{array}{l}\text { май / } \\
\text { Мау } 16\end{array}$ & 13,3 & 7,74 & 166,1 & 0,2 & 5,3 & 53,1 & 1,2 & 2,9 & 228,8 \\
\hline & $\begin{array}{c}\text { ЯнB / } \\
\text { Jan } 17 \\
\end{array}$ & 13,5 & 7,53 & 183,0 & 0,00 & 5,3 & 60,1 & 0,0 & 3,44 & 251,8 \\
\hline & $\begin{array}{c}\text { авг / } \\
\text { Aug } 17 \\
\end{array}$ & 14,4 & 7,05 & 137,3 & 0,8 & 12,5 & 46,1 & 0,0 & 7,3 & 204,0 \\
\hline $\begin{array}{l}\text { Капеж на подъеме в з. Гиви Смыр / } \\
\text { Water drip on the rise to Givi Smyr } \\
\text { chamber }\end{array}$ & $\begin{array}{l}\text { май / } \\
\text { Маy16 }\end{array}$ & 13,3 & 7,95 & 265,4 & 0 & 3,6 & 87,2 & 0 & 2,3 & 358,5 \\
\hline $\begin{array}{l}\text { Зал Апсны, "кальцитовая гора" } \\
\text { справа / Apsnyy chamber, "calcite } \\
\text { mountain", right part }\end{array}$ & $\begin{array}{c}\text { авг / } \\
\text { Aug } 17\end{array}$ & & 7,84 & 231,8 & 0,8 & 3,56 & 77,2 & 0,6 & 0,3 & 314,3 \\
\hline $\begin{array}{l}\text { Зал Апсны, "кальцитовая гора" } \\
\text { слева / Apsny chamber, "calcite } \\
\text { mountain", left part }\end{array}$ & $\begin{array}{c}\text { авг / } \\
\text { Aug } 17\end{array}$ & & 7,78 & 259,3 & 0,8 & 3,56 & 86,2 & 0,6 & 0,3 & 350,8 \\
\hline $\begin{array}{l}\text { Зал Апсны, под "каменным водо- } \\
\text { падом" / Apsny chamber, under the } \\
\text { "stone waterfall" }\end{array}$ & $\begin{array}{c}\text { авг / } \\
\text { Aug } 17\end{array}$ & & 7,84 & 183,0 & 0,8 & 7,12 & 60,1 & 0,6 & 3,8 & 255,4 \\
\hline \multirow{2}{*}{$\begin{array}{l}\text { Зал Апсны, ниже "каменного } \\
\text { водопада" / } \\
\text { Apsny chamber, lower the "stone } \\
\text { waterfall" }\end{array}$} & $\begin{array}{c}\text { май / } \\
\text { Мау } 16\end{array}$ & 13,5 & 6,95 & 241,0 & 0 & 2,7 & 80,2 & 0 & 0,6 & 324,5 \\
\hline & $\begin{array}{c}\text { авг / } \\
\text { Aug } 17\end{array}$ & & 7,42 & 204,4 & 0,8 & 5,3 & 70,1 & 0 & 0,4 & 281,0 \\
\hline
\end{tabular}




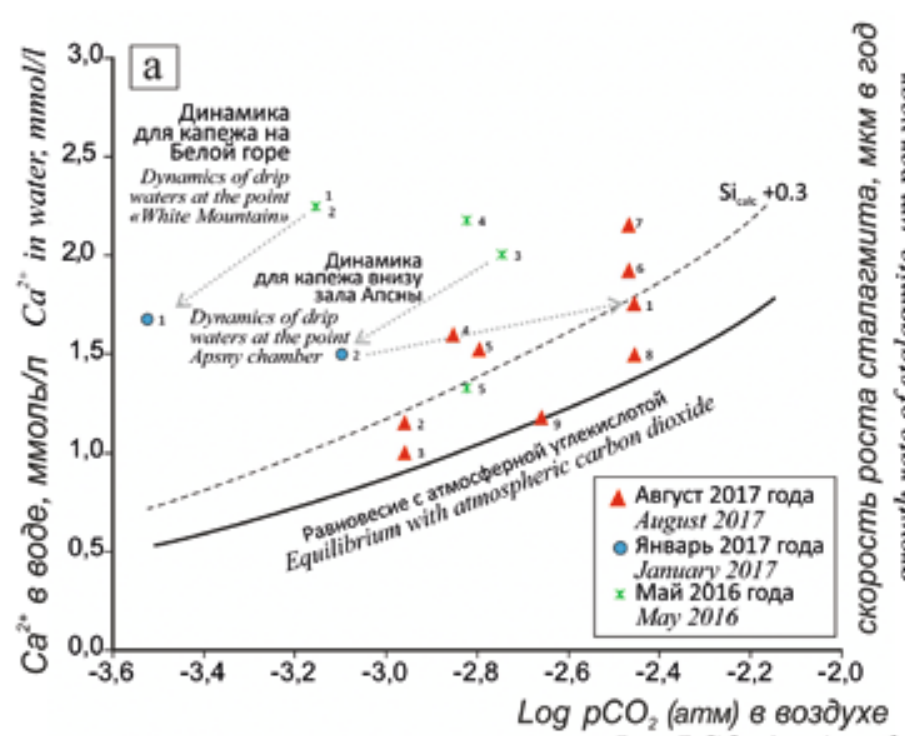

$\log \mathrm{PCO}_{2}(\mathrm{~atm})$ in the air

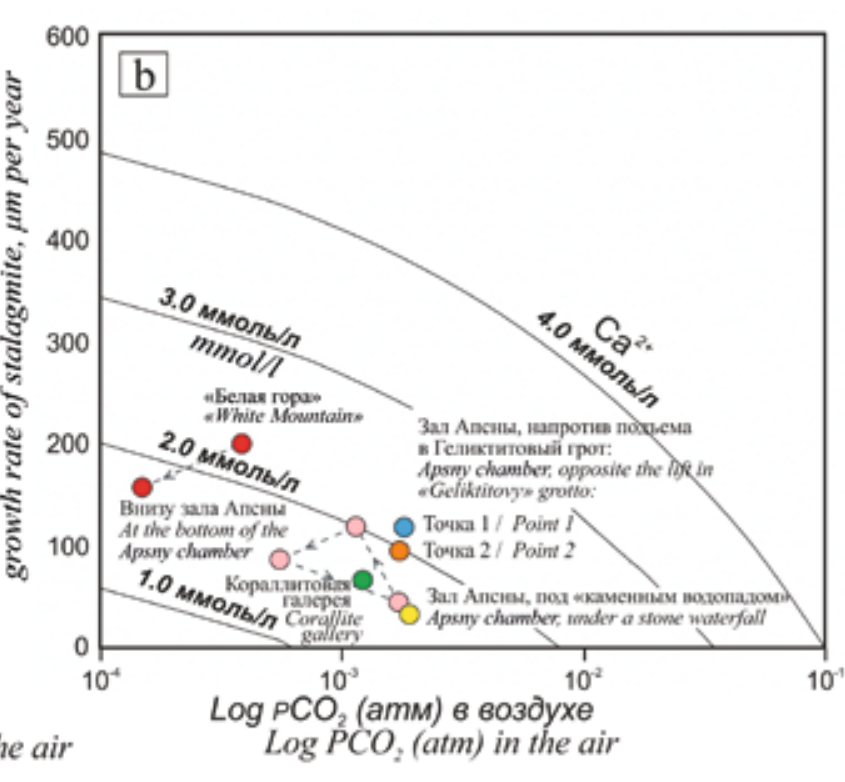

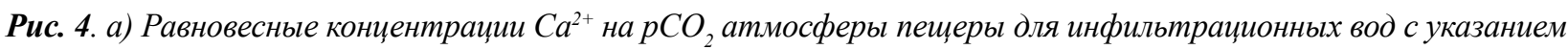
порогового значения $S I_{\text {calc }}+0,3$ (по [13]), до которого происходит дегазация и отложение кальц̧ита.

Точки наблюдения: август 2017: 1) капеж в зале Апсны, наблюдательная точка ниже "каменного водопада"; 2) под натёком "Череп" в зале Махаждиров; 3) рядом с натёком "Череп"; 4) кораллитовая галерея; 5) перед залом Аюхаа, напротив "лунного молока"; 6) Апсны, "кальцитовая гора" справа при входе в зал; 7) Апсны, "кальцитовая гора" слева при входе в зал, напротив входа в Геликтитовый грот; 8) Anсныл, под "каменным водопадом"; 9) на входе в зал Спелеологов;

Январь 2017: 1) капеж на "Белой горе", зал Махаджиров; 2) капеж внизу зала Апснь, наблюдательная точка ниже "каменного водопада"; май 2016 года: 1) капеж на "Белой горе", зал Махаджиров; 2) капеж у западной стены 3.

Анакопия, тупиковое ответвление рядом с натеком "Череп"; 3) капеж в зале Апсны, наблюдательная точка ниже "каменного водопада"; 4) зал Спелеологов, капеж перед подъемом в зал Гиви Смыра; 5) на входе в зал Спелеологов; b) оценочная скорость роста сталагмита при постоянном расходе 1 капля в мин. [12] /

Fig. 4. a) Equilibrium concentration of $\mathrm{Ca} 2+$ on $\mathrm{pCO} 2$ atmosphere of the cave for infiltration water with the indication of a threshold value of SIcalc $+0,3$ (according to [13]), which occurs degassing and deposition of calcite.

Observation points: August 2017: 1) Water drip in the Apsny chamber, observation point lower the "stone waterfall"; 2) Under the "Skull" dropstone in Makhajir chamber; 3) Near the "Skull" dropstone; 4) Corallite gallery; 5) In front of Auhua chamber, opposite to the "moon milk"; 6) Apsny, "calcite mountain", right at the entrance to the chamber; 7) Apsny, "calcite mountain", left at the entrance to the chamber, opposite the entrance to Geliktovy grotto; 8) Apsny chamber, under the "stone waterfall"; 9) At the entrance to Speleologists chamber; January 2017:

1) Water drip on the "White hill", Makhajir chamber; 2) Water drip near the Western wall of Anakopia chamber, dead end near the "Skull" dropstone; 3) Water drip in the Apsny chamber, observation point lower the "stone waterfall"; 4) Speleologists chamber, water drip in front of the rise to Givi Smyr chamber; 5) At the entrance to Speleologists chamber;

b) Estimated growth rate of stalagmite at a constant flow rate of 1 drop per min. [12]

но существенное накопление магния (эти точки отличаются очень малыми расходами капежа, не более 100 мл за сутки).

Увеличение соотношения $\mathrm{Mg} / \mathrm{Ca}$ в инфильтрационных водах до значений, превышающих таковые для вмещающих известняков, может объясняться уже произошедшим осаждением кальцита, в процессе которого преимущественно используются ионы кальция, а остаточный раствор обогащается магнием [14]. Такой процесс возможен при длительном нахождении вод в карстовом массиве и наличии промежуточных полостей, в которых происходит отложение кальцита. В современном быстрорастущем кальците в гурах на Белой горе магний отсутствует, но для спелеотем Кораллитовой галереи, залов Спелеологов и Аюхаа, согласно гидрохимическим особенностям питающих растворов, наблюдается значительное увеличение магнезиальности, вплоть до кристал- лизации гидромагнезита [15]. При этом изученные спелеотемы (кораллиты и антодиты) растут в условиях испарительного насыщения из капиллярных и плёночных вод, что способствует дополнительному концентрированию магния.

\section{К проблеме формирования химического состава карстовых вод пещерного массива и связи с термальными водами глубинной циркуляции}

Аномальные для карстовых вод Западного Кавказа гидрохимические параметры были зафиксированы для источника (воклюза) в долине реки Псырцха, расположенного рядом с пещерой и, по мнению большинства исследователей, связанного с её подземной гидросистемой. Воклюз Псырцха приурочен к той же разломной зоне, что и южные полости пещерной системы, и по высотному уровню находится в 5-6 метрах ниже уровня пещерных озер. Большинство авторов придерживаются мнения, что 


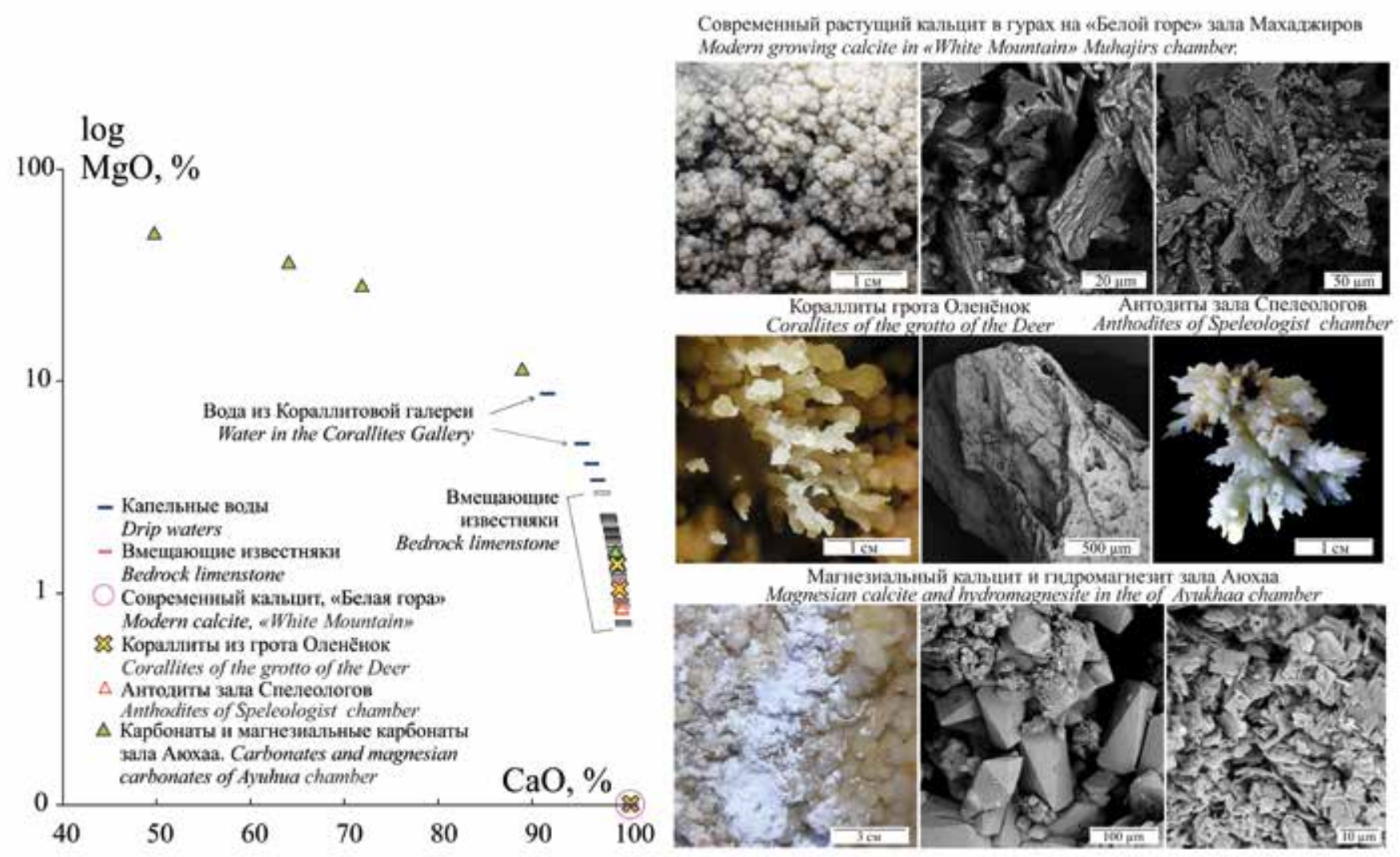

Puс. 5. Молярные соотношения магния и кальция в капельных водах, вмещуающих известняках и некоторьх карбонатньхх спелеотемах /

Fig. 5. The molar ratio of magnesium and calcium in the drip waters with limestone and in some carbonate speleothems

источник Псырцха связан с глубинными минеральными водами, поднимающимися к поверхности по тектоническим нарушениям [1;2]. Минеральные воды этой группы термальные, преимущественно хлоридно-натриевые, реже сульфатно-хлоридно-натриевые, с напорным режимом. Они приурочены к погруженным частям антиклинальных складок в карбонатных породах мелового возраста и распространены вдоль всего побережья. Средняя глубина залегания этого водоносного комплекса составляет 500-600 м [16]. Среди газовых компонентов этих вод наиболее преобладают азот и сероводород, содержание $\mathrm{H}_{2} \mathrm{~S}$ достигает 20-25 мг/л [14].

Диаграммы Пайпера (рис. 6), построенные нами по литературным [16-18] и фондовым [15] материалам, а также архивным данным Абхазского государственного Центра экологического мониторинга и Института экологии АНА (аналитик О.В. Пустоварова), показывают вариации макрокомпонентного состава для источника Псырцха, карстовых вод Новоафонской пещеры и Отапской пещер (приморское низкогорье, нижнемеловые известняки), высокогорных карстовых массивов Хипста и Бзыбь, а также основных проявлений хлоридно-натриевых азотно-сероводородных вод. Воды пещер Новоафонская и Отапская имеют чистый гидрокарбонатно-кальциевый состав. Составы вод, разгружающих высокогорные массивы Хипста и Бзыбь (последний индицируется по источнику Мчишта), варьируют от гидрокарбонатно-кальциевого к гидрокарбонатномагниевому, что связано с наличием доломитов в области питания [20].

Состав вод источника Псырцха резко отличается от карстовых вод зоны активной циркуляции. Химический состав, в зависимости от режима водности, изменяется с гидрокарбонатно-кальциевого в паводок на гидрокарбонатно-хлоридно-кальциево-натриевый - в межень. Результаты сравнения гидрохимического состава вод источника Псырцха и минеральных вод (рис. 6б) согласуются с точкой зрения В.Н. Дублянского [2] об участии последних в питании источника.

Следует отметить, что минеральные воды этой группы имеют довольно пёстрый химический состав, но всё же удается выделить некоторые закономерности. Так, исчезновение сульфатов (при этом доминирующим анионом становится хлорид) отражает степень их биохимического разложения. При этом достоверно снижается и содержание сероводорода - при полной редукции сульфатов в питающем резервуаре он может исчезнуть совсем, и воды приобретают хлоридно-натриевый состав (что, видимо, и наблюдается в отношении современных вод, питающих источник Псырцха). 


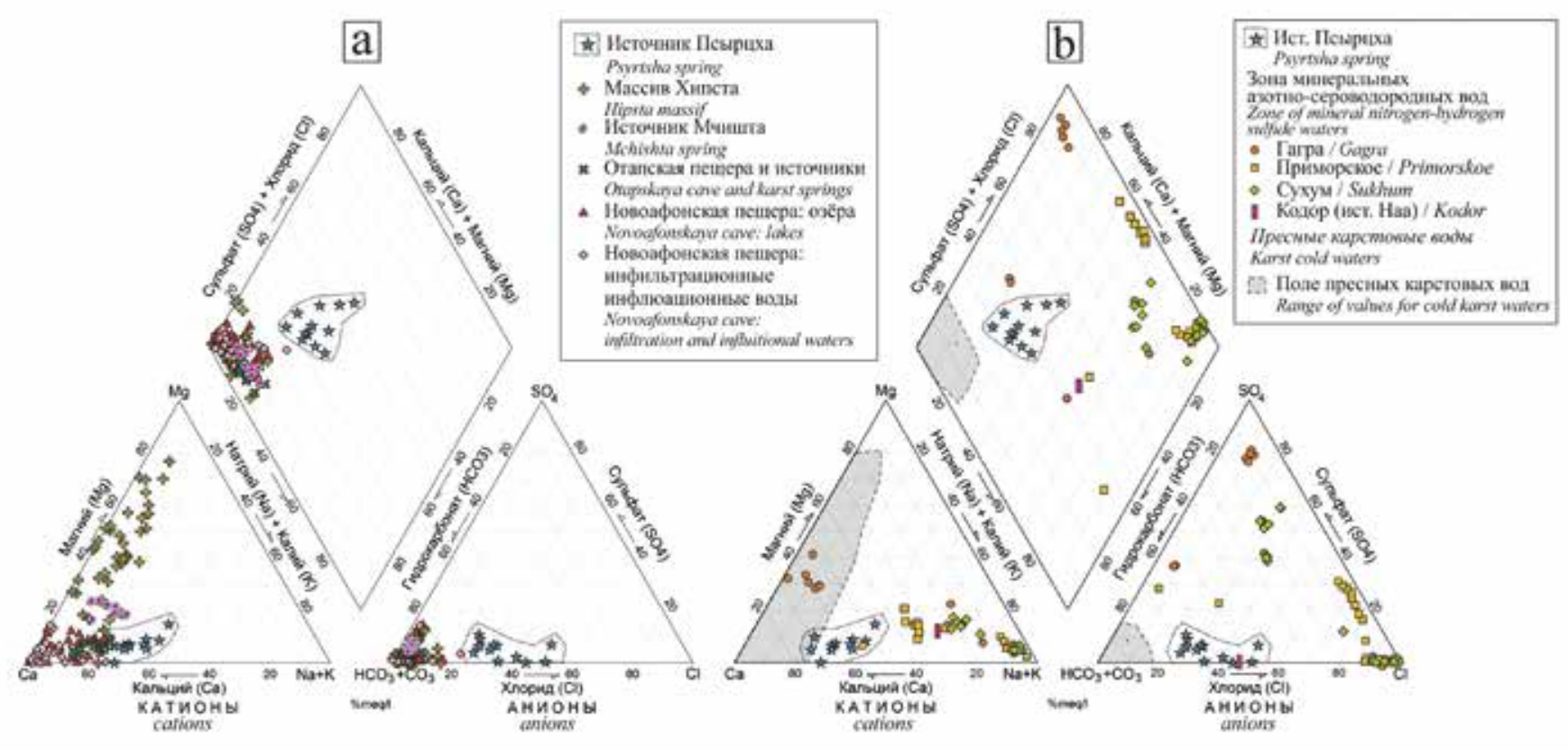

Рис. 6. Химический состав холодных карстовых вод, вод источника Псыриха (а) и минеральных азотно-сероводородных хлоридно-натриевых вод (b) /

Fig. 6. Chemical composition of the cold karst waters, waters of the source of Psyrtskha (a) and mineral nitrogen-hydrogen sulfide sodium chloride waters (b)

\section{Заключение}

Проведённые наблюдения позволяют предположить, что перенос металлов в гидросистеме подземных озёр Новоафонской пещеры происходит совместно с коллоидами железа и марганца и, возможно, с взвесью глинистых минералов. Современное железо-марганцевое минералообразование происходит из коллоидных растворов, с возможной ролью железо- и марганецокисляющих бактерий.

Полученные данные показывают различающийся макрокомпонентный состав, но при этом обнаруживают сходство геохимических спектров микроэлементов и лантаноидов в источнике Псырцха и в озёрах Новоафонской пещеры. Для всех образцов обнаружено преобладание лёгких лантаноидов и выраженная положительная европиевая аномалия. В то же время накопление металлов контролируется локальными факторами - наличием коллоидов-концентраторов, отложением минералов железа и марганца (что делает некорректным прямые сравнения микроэлементного состава для определения гидродинамической связи между различным водопроявлениями).

Наблюдения над химическим составом капельных вод в пещере позволяют сделать вывод, что наиболее обильные и постоянные точки капежа имеют инфильтрационное питание и способствуют быстрому отложению кальцита (160-220 мкм/год в модели, рассчитанной для сталагмитов при расходе 1 капля в минуту [12]). Для ряда точек характерно увеличение молярного соотношения $\mathrm{Mg} / \mathrm{Ca}$ в инфильтрационных водах до значений, превышающих таковые для вме- щающих известняков, что создает предпоссылки к кристаллизации магнезиальных карбонатов.

Проведенные сравнения составов карстовых вод Новоафонской пещеры с различными подземными водопоявлениями низкогорья (Отапская пещера), высокогорных карстовых массивов Хипста и Бзыбь, а также основных проявлений глубинных хлоридно-натриевых азотно-сероводородных вод причерноморской зоны Абхазии позволяют сделать вывод, что современный гидрохимический режим Новоафонской пещеры связан с холодными гидрокарбонатно-кальциевыми водами, формирующимися в химически чистых карбонатных породах в пределах низкогорных массивов. Воды высокогорных карстовых массивов надежно индицируются повышенной магнезиальностью, поэтому их участие в питании пещеры представляется маловероятным. В то же время для расположенного вблизи нее (и приуроченного к той же тектонической структуре, что и южные залы пещеры) источника Псырцха с высокой вероятностью можно сделать вывод о подтоке глубинных минеральных вод. Косвенно об этом могут свидетельствовать и аномальные значения объемной активности радона (4000-20000 Бк/м³) рядом с источником. 
Авторы выражают благодарность Н.В. Паршиной, Л.Г. Удачиной, М.Н. Малярёнок, Н.И. Вализер, Е.Д. Зенович (Институт минералогии УрО РАН), И.И. Мусабирову и С.Н. Сергееву (Институт проблем сверхпластичности металлов РАН) за лабораторные исследования и сотруднику комплекса Новоафонской пещеры В.В. Мархолия за помощь в полевых работах и заместителю директора Абхазского государственного Центра экологического мониторинга О.В. Пустоваровой за предоставленные гидрохимические данные. /

The authors express their gratitude to N.V. Parshina, L.G. Udachina, M.N. Malaryenok, N.I. Valizer, E.D. Zenovich (Institute of Mineralogy Ural Branch of the Russian Academy of Sciences), I.I. Musabirov and S.N. Sergeev (Institute of Problems of Superplasticity of Metals of the Russian Academy of Sciences) for laboratory tests, staff member of the Novoafonskaya cave V.V. Marlokhiu for assistance in field work and Deputy Director of the Abkhaz state Center for Ecological Monitoring O.V. Pustovarova for providing hydrochemical data.

The work is executed at support of the Russian Foundation for Basic Research on the project No. 17-55-40005 Abkh_a "Manifestations of the sulfuric acid speleogenesis in Abkhazia: the morphological, mineralogical and isotope-geochemical aspects".

Работа выполнена при поддержке РФФИ по проекту № 17-55-40005 Абх_а «Проявления сернокислотного спелеогенеза в Абхазии: морфологические, минералогические и изотопно-геохимические аспекты».

\section{ЛИТЕРАТУРА:}

1. Тинтилозов 3. К. Новоафонская пещерная система. Мецниереба, 1983. $151 \mathrm{c.}$

2. Дублянский В. Н., Кинкадзе Т. 3. Гидрогеология карста Альпийской складчатой области СССР. М.: Наука, 1984.127 с.

3. Перельман А. И. Геохимия: учеб. для геол. спец. ВУЗов. 2-е издание., перераб. и доп. М.: Высшая школа, 1989. $528 \mathrm{c}$.

4. Швариев С. Л. Геохимия подземных вод зоны гипергенеза. Геохимия природных вод // Тр. Второго Междунар. симп. Л.: Гидрометеоиздат, 1985. С. 108-113.

5. Водяниикий Ю. Н. Геохимическое фракционирование лантанидов в почвах и горных породах (обзор литературы) // Почвоведение. 2012. N 1. С. 1-13.

6. Юдович Я. Э., Кетрис М. П. Геохимия марганца в процессах гипергенеза: обзор // Междисциплинарный научный и прикладной журнал «Биосфера». 2013. Т. 5. N 1. С. 21-36.

7. Borsato A., Frisia S., Miorandi R. Carbon dioxide concentration in temperate climate caves and parent soils over an altitudinal gradient and its influence on speleothem growth and fabrics // Earth Surf. Process. Landforms 40, 2015. P. 11581170 .

8. Baldini J.U.L., McDermott F., Hoffmann D.L., Richards D.A., Clipson N. Very high-frequency and seasonal cave atmosphere $\mathrm{PCO} 2$ variability: Implications for stalagmite growth and oxygen isotope-based paleoclimate records // Earth and Planetary Science Letters, 2008. N 272 P. 118-129.

9. Kowalczk A.J., Froelich P.N. Cave air ventilation and $\mathrm{CO}_{2}$ outgassing by radon-222 modeling: How fast do caves breathe? // Earth and Planetary Science Letters, 2010. v. 289, P. 209-219.

10. Smith A.C., Wynn P.M., Barker P.A., Leng M.J., Noble S.R., Stott A. Cave monitoring and the potential for palaeoclimate reconstruction from Cueva de Asiul, Cantabria (N. Spain). International Journal of Speleology, 45 (1), Tampa, FL (USA), 2016. P. 1-9 doi.org/10.5038/1827-806X.45.1.1928

11. Кудерина Т.М., Мавлюдов Б.Р., Грабенко Е.А., Экба Я.А. Гидрогеохимическое состояние Новоафонской пещер- ной системы // Геохимия ландшафтов (к 100-летию А.И. Перельмана). Доклады Всероссийской научной конференции, Москва, 18-20 октября 2016 г. Москва, 2016. С. 285-288

12. Dreybrodt W., Processes in Karst Systems - Physics, Chemistry and Geology. Springer, Berlin, New York. 1988. $288 \mathrm{p}$.

13. Spötl C., Fairchild I. J., Tooth A.F. Cave air control on dripwater geochemistry, Obir Caves (Austria): Implications for speleothem deposition in dynamically ventilated caves // Geochimica et Cosmochimica Acta. 2005. Vol. 69. N 10. P. 2451-2468. doi:10.1016/j.gca.2004.12.009

14. Wong C. I., Banner J. L., Musgrove M. Seasonal dripwater $\mathrm{Mg} / \mathrm{Ca}$ and $\mathrm{Sr} / \mathrm{Ca}$ variations driven by cave ventilation: Implications for modeling of speleothem paleoclimate records. Geochimica et Cosmochimica Acta. 2011. V. 75. P. 3514-3529.

15. Червяцова О. Я., Потапов С. С., Паршина Н. В., Дбар P. С. Некоторые особенности карбонатных спелеотем (антодитов и кораллитов) в Новоафонской пещере // Минералогия техногенеза-2017. Миасс: ИМин УрО РАН, 2017. C. 33-41.

16. Гидрогеология СССР. Т. 10: Грузинская ССР. М.: Недра, 1970.

17. Беленький С. М., Лаврешкина Г. П., Дульнева Т. Н. Минеральные воды. М.: Легкая и пищевая промышленность, 1982. $144 \mathrm{c}$.

18. Осия О. В., Кокоша Л. В., Пустоварова О. В., Осия А. О. Природные лечебные факторы Абхазии. Сухум: Дом печати, 2014. $320 \mathrm{c}$.

19. Клименко В., Куканов В., Прокофьев С., Осипова Т., Прокофьев С. Карта распространения основных водоносных комплексов пород на территории Абхазии. Адлерский отдел СКО ПНИИИС. Тема № 13 (16). 1973-1974 гг. Рукопись.

20. Вахрушев Б. А., Дублянский В. Н., Амеличев Г. Н. Карст Бзыбского хребта. Западный Кавказ. М.: РУДН, 2001. $165 \mathrm{c}$. 


\section{СВЕДЕНИЯ ОБ АВТОРАХ / Information about authors:}

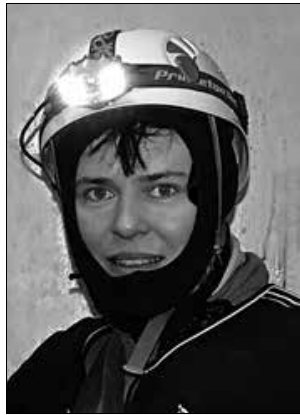

ЧЕРВЯЦОВА Ольга Яковлевна - инженер-исследователь, специалист группы мониторинга пещеры Шульган-Таш (Каповой).

Область научных интересов: карстология, гидрохимия и минералогия пещер, гипогенный спелеогенез, климатология карста. Автор более 50 научных работ.

Государственный природный биосферный заповедник «Шульган-

Таш».

Бурзянский район, дер. Иргизлы, Республика Башкортостан, Россия

E-mail: kittary@yandex.ru

Olga Yakovlevna CHERVYATSOVA - Research Engineer of the State Nature Biosphere Reserve "Shulgan-Tash", Specialist of a cave monitoring group Shulgan-Tash (Kapova).

Research interests: karstology, hydrochemistry and mineralogy caves, Hypogenic speleogenesis, karst climatology.

Author of more than 50 scientific works.

State Nature Biosphere Reserve "Shulgan-Tash", Irgizly village, Republic of Bashkortostan, Russia.

E-mail:kittary@yandex.ru

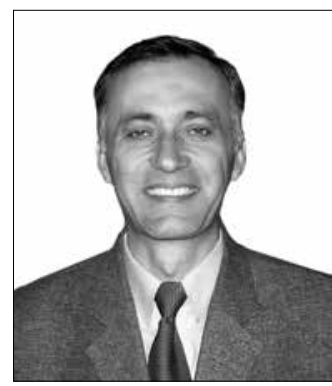

ДБАР Роман Саидович - кандидат биологических наук, директор Института экологии Академии наук Абхазии, зав. кафедрой экологии и морфологии животных Абхазского госуниверситета, и.о. академика-секретаря отделения медико-биологических, сельскохозяйственных наук и наук о Земле Академии наук Абхазии. Автор более 100 работ в журналах, книгах и сборниках научных трудов Зоологического института РАН (г. Санкт-Петербург), Абхазского госуниверситета, монографиях и сборниках академических изданий Абхазии и России.

Институт экологии Академии наук Абхазии (ИЭАНА), г. Сухум, Абхазия

E-mail: romandbar@mail.ru; ieana-abkhazia@mail.ru

Roman Saidovich DBAR - Candidate of Biological Sciences, Director of Institute of Ecology of the Academy of Sciences of Abkhazia, Head of the Department of Ecology and Morphology of animals in Abkhazian State University, Acting Academician-Secretary of Biomedical, Agricultural and Earth Sciences of the Academy of Sciences of Abkhazia.

Author of more than 40 scientific papers in journals, books and collections of scientific works of the Zoological Institute, Russian Academy of Sciences (Saint-Petersburg), Abkhazian State University, monographs and collections of academic publications of Abkhazia and Russia.

Institute of Ecology of the Academy of Sciences of Abkhazia, Sukhum, Republic of Abkhazia.

E-mail:romandbar@mail.ru; ieana-abkhazia@mail.ru

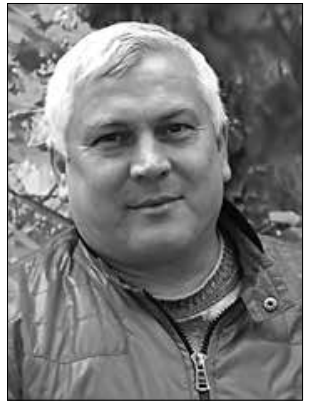

ПОТАПОВ Сергей Сергеевич кандидат геолого-минералогических наук, старший научный сотрудник, руководитель группы минералогии техногенеза лаборатории минералогии техногенеза и геоэкологии Института минералогии УрО РАН, действительный член Российского минералогического общества (РМО) и Уральской академии геологических наук, председатель Ильменского отделения РМО, заслуженный работник науки и образования.

Область научных интересов: минералогия, минералогия техногенеза, биоминералогия, минералогия пещер, физика минералов, геоэкология. Автор более 400 научных работ.

Институт минералогии УрО РАН, территория Ильменского государственного заповедника, Челябинская область, Россия

E-mail: spot@ilmeny.ac.ru

Sergey Sergeevich POTAPOV - Candidate of Geological-Mineralogical Sciences, Senior Researcher, Head of the group of Mineralogy technogenesis in the Laboratory of Geoecology and Technogenesis in Institute of Mineralogy Ural Branch of Russian Academy of Sciences, member of the Russian Mineralogical Society (RMS) and the Ural Academy of Geological Sciences, chairman of the Ilmensky department of RMS, honored worker of science and education.

Research interests: mineralogy, mineralogy technogenesis, biomineralogy and cave mineralogy, physics of minerals, geoecology.

Author of over 400 scientific works.

Institute of Mineralogy, the territory of Ilmen State Reserve, Miass, Russia.

E-mail:spot@ilmeny.ac.ru

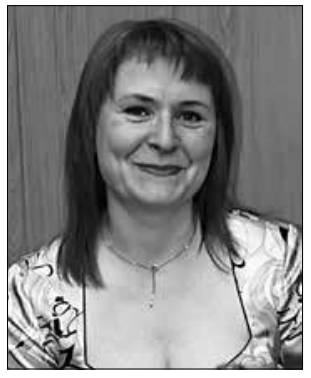

ФИЛИППОВА Ксения Александровна - кандидат геологоминералогических наук, старший научный сотрудник лаборатории минералогии техногенеза и геоэкологии Института минералогии УрО РАН.

Область научных интересов: геохимия, геоэкология. Автор около 50 научных работ.

Институт минералогии УрО РАН, территория Ильменского государственного заповедника, Челябинская область, Россия

E-mail: kseniyafil@yandex.ru

Ksenia Alexandrovna PHILIPPOVA - Candidate of GeologicalMineralogical Sciences, Senior Researcher of the Laboratory of Geoecology and Technogenesis in Institute of Mineralogy Ural Branch of Russian Academy of Sciences.

Research interests: geochemistry, geoecology.

Author of about 50 scientific works.

Institute of Mineralogy, the territory of Ilmen State Reserve, Miass, Russia.

E-mail:kseniyafi@yandex.ru 


\title{
SOME FEATURES OF THE HYDROCHEMICAL REGIME OF THE NOVOAFONSKAYA CAVE (WESTERN CAUCASUS) IN THE CONTEXT OF THE MINERAL FORMATION AND THE GENESIS OF KARST WATER
}

\author{
${ }^{1}$ O. Ya. Cherviatsova* \\ ${ }^{2}$ S.S. Potapov S.S \\ ${ }^{2}$ K.A. Fillipova \\ ${ }^{3}$ R.S. Dbar \\ ${ }^{1}$ State Nature Biosphere Reserve "Shulgan-Tash", Izgirly village, Russia \\ 2 Institute of Mineralogy Ural Branch of the Russian Academy of Sciences, Miass, Russia \\ ${ }^{3}$ Institute of Ecology of the Academy of Sciences of Abkhazia, Sushum, Republic of Abkhazia \\ *e-mail: kittary@yandex.ru
}

\section{DOI: $10.21177 / 1998-4502-2018-10-1-77-90$}

\section{Abstract}

The purpose of this work is to obtain additional data on the hydrochemical regime of lakes and drip waters of the Novoafonskaya cave, as well as to study some aspects related to modern mineral formation.

The obtained data reveal a different macrocomponent composition, but at the same time - the similarity of the geochemical specters of trace elements and lanthanides in the source of Psyrtsha and the lakes of the Novoafonskaya cave. The prevalence of light lanthanides and a pronounced positive europium anomaly is typical for all the samples. At the same time, the accumulation of metals is controlled by local factors - the presence of colloids-concentrators and the deposition of minerals of iron and manganese (which makes incorrect the direct comparison of the trace element composition to determine the hydrodynamic connection between various water manifestations). The results of studies of ferromanganese mineral deposits in the lake of the Nartaa chamber are presented.

Observations on the chemical composition of the drip waters in the cave allow us to conclude that the most abundant and constant drop points have infiltration recharge and contribute to the rapid deposition of calcite. Some points are characterized by an increase in the molar ratio of $\mathrm{Mg} / \mathrm{Ca}$ in infiltration waters to values higher than those for the enclosing limestones, which creates preconditions for the crystallization of magnesian carbonates.

The comparisons of the composition of the karst waters of the Novoafonskaya cave with various underground water occurrences of karst waters in the low-mountainous and highmountainous areas of Abkhazia, as well as the main manifestations of the deep chloride-sodium waters of the Black Sea area of Abkhazia, allow us to conclude that the modern hydrochemical regime of the Novoafonskaya cave is associated with cold $\mathrm{HCO} 3-\mathrm{Ca} 2+$ waters in chemically pure carbonate rocks in low mountains. At the same time, it is possible to conclude with a high probability that there is an inflow of deep mineral waters in the source of Psyrtsha located near the cave.

Keywords: Novoafonsk caves, Karstology, Hydrochemistry and Mineralogy of caves, Climatology of karsts.

\section{References}

1. Tintilozov Z. K. Novoafonskaya cave system. Metsniereba. 1983. P. 151 (in Russian).

2. Dublyansky V. N., Kinkadze, T. Z. Karst Hydrogeology of the Alpine folded region of the USSR. Moscow: Nauka. 1984. P. 127 (in Russian).
3. Perelman A.I. Geochemistry: textbook for Geological special higher educational institutions. 2nd edition, revised and enlarged. Moscow: Higher school. 1989. P. 528 (in Russian).

4. Shvartsev S.L. Geochemistry of groundwater in the hypergenesis zone. Geochemistry of natural waters. Proceedings of the Second International Symposium. Leningrad: Gidrometeoizdat. 1985. Pp. 108-113 (in Russian).

5. Vodyanitsky Yu.N. Geochemical fractionation of lanthanides in soils and rocks (literature review). Soil science. 2012. No. 1. Pp. 1-13 (in Russian).

6. Yudovich Y.E., Ketris M.P. Geochemistry of manganese in supergene processes: a review. Interdisciplinary Scientific and Applied Journal "Biosphere". 2013. Vol.5. No. 1. Pp. 21-36 (in Russian).

7. Borsato A., Frisia S., Miorandi R. Carbon dioxide concentration in temperate climate caves and parent soils over an altitudinal gradient and its influence on speleothem growth and fabrics. Earth Surface Processes and Landforms. 2015. Vol. 40. Pp. 1158-1170.

8. Baldini J.U.L., McDermott F., Hoffmann D.L., Richards D.A., Clipson N. Very high-frequency and seasonal cave atmosphere $\mathrm{PCO} 2$ variability: Implications for stalagmite growth and oxygen isotope-based paleoclimate records. Earth and Planetary Science Letters. 2008. Vol. 272. Pp. 118-129.

9. Kowalczk A.J., Froelich P.N. Cave air ventilation and $\mathrm{CO} 2$ outgassing by radon-222 modeling: How fast do caves breathe? Earth and Planetary Science Letters. 2010. Vol. 289. Pp. 209-219.

10. Smith A.C., Wynn P.M., Barker P.A., Leng M.J., Noble S.R., Stott A. Cave monitoring and the potential for palaeoclimate reconstruction from Cueva de Asiul. Cantabria (N. Spain). International Journal of Speleology. 2016. No. 45 (1). Pp. 1-9. DOI: 10.5038/1827-806X.45.1.1928

11. Kuderina T. M., Mavlyudov B.R., Grabenko E.A., Ekba Y.A. Hydrogeochemical condition of the Novoafonskaya cave system. Geochemistry of landscapes (to the 100th anniversary of A.I. Perelman). Reports of the all-Russian Scientific Conference, 18-20 October 2016. Moscow. Pp. 285-288 (in Russian).

12. Dreybrodt W., Processes in Karst Systems - Physics, Chemistry and Geology. Springer, Berlin, New York. 1988. P. 288.

13. Spötl C., Fairchild I.J., Tooth A.F. Cave air control on dripwater geochemistry, Obir Caves (Austria): Implications for speleothem deposition in dynamically ventilated caves. Geochimica et Cosmochimica Acta. 2005. Vol. 69. No. 10. Pp. 2451-2468. DOI:10.1016/j.gca.2004.12.009 
14. Wong C.I., Banner J.L., Musgrove M. Seasonal dripwater $\mathrm{Mg} / \mathrm{Ca}$ and $\mathrm{Sr} / \mathrm{Ca}$ variations driven by cave ventilation: Implications for modeling of speleothem paleoclimate records. Geochimica et Cosmochimica Acta. 2011.Vol. 75. Pp. 3514-3529.

15. Cherviatsova O.Ya., Potapov S.S, Parshina N.V., Dbar R.S. Some characteristics of carbonate speleothem (antidotes and corallites) in the Novoafonskaya cave. Mineralogy of technogenesis-2017. Miass: Institute of Mineralogy, Ural branch of the Russian Academy of Sciences. 2017. Pp. 33-41 (in Russian).

16. Hydrogeology of the USSR. Vol. 10: Georgian Soviet Socialist Republic. Moscow: Nedra. 1970 (in Russian).

17. Belenky S.M., Lavreshkina G.P., Dulneva T.N. Mineral water. Moscow: Light and food industry. 1982. P. 144 (in Russian).
18. Osiya O.V., Kokosha L.V., Pustovarova O.V., Osiya A.O. Natural healing factors of Abkhazia. Sukhum: Printing House. 2014. P. 320 (in Russian).

19. Klimenko V., Kukanov V., Prokofyev S., Osipova T., Prokofyev S. Map of distribution of main aquifer complexes of rocks on the territory of Abkhazia. Manuscript. Adler Department of The North Caucasian branch of Production and Research Institute engineering survey in construction, theme No. 13 (16). 1973-1974 (in Russian).

20. Vakhrushev B.A., Dublyansky V.N., Amelichev G.N. Karst of Bzyb ridge. Western Caucasus. Moscow: Peoples' Friendship University of Russia. 2001. P. 165 (in Russian).

Article received 23.01.2017 


\section{DYNAMIC PROCESSES AND DEVELOPMENTS IN THE CENTRAL KARAKORAM}

\section{Introduction}

Rural areas are sometimes referred to as "deceleration oases", in which developments seem to be delayed. Particular pronounced forms of rural habitation are high mountain regions, whose inhabitants are often characterized as backward and traditional. In the sense of classical regional development theories, high mountain areas show factors that inhibit development, such as a pronounced relief, a high potential of natural risks, low population and settlement densities or a lean network of traffic and communication infrastructures. According to these aspects, they are often considered as "underdeveloped" areas.

Undeniably, high mountain habitats require special efforts from the inhabitants due to their topographical and ecological features. However, to what extent these development-inhibiting factors are still influential or explanatory today, is to be examined by looking at the astonishing dynamics and development successes in the Central Karakoram of Northern Pakistan, thereby calling into question the theory of the backwardness of mountain societies.

\section{Baltistan - a hopeless case?}

This study refers to the region of Baltistan in the Central Karakoram (see Fig. 1), whose inhabitants speak a Tibetan dialect, Balti, and who mainly belong to the Twelver Shia Islam (Schmidt 2004, 2012). In 1842 Baltistan fell to the Princely State of Jammu \& Kashmir and thus came under the rule of the British Empire. Since the partition of the subcontinent and the first Kashmir war, the region has been under Pakistani administration and is part of what is now the administrative territory of Gilgit-Baltistan.

In the reports of colonial adventurers and explorers, who travelled to Baltistan in the mid-19th century, there were marked attributions of underdevelopment and civilization deficits, coupled with an urge to proselytize and a feeling of undaunted superiority. For example, the Baltis are described as "uncivilized savages" and "wild looking men" (Younghusband 1896: 260) or as "primitive and unintelligent" (Workman \& Workman 1908: 201). As far back as the 1960s, geographer Furrer (1967: 13) wrote: "In the high-altitude settlements in particular, people still live on a Stone Age cultural level." This perception of the backwardness of the societies in the highlands of Baltistan persists until today in the collective memory of a modernizing world. For example, Alok Bansal of the Institute for Defense Studies and Analysis (New Delhi) recently associated the region with stagnation, poverty and backwardness: "Gilgit and Baltistan constitute the most backward areas in the entire South Asia and the region seems to have missed the development bus completely" (Bansal 2008: 93).

A look at the natural conditions and socio-political backgrounds seems to confirm this impression. For instance, the Karakoram has a deficit in resources, the settlements are relatively small, remote and seemingly isolated, the Balti ethnic minority is politically marginalized and the inhabitants, infrastructures and buildings are exposed to a high natural hazard risk. In addition, the large distances between the settlements and to central markets make the transport of people and goods time-consuming and cost-intensive. Assuming that the spatial parameters of density and distance have a significant impact on economic devel-

Institute of Geography, University of Augsburg
${ }^{1}$ Matthias Schmidt

УДK: 551.4 .035

DOI: 10.21177/1998-4502-2018-

10-1-91-96

High mountain areas are often

seen as regions of stagnation

which are characterized

by natural and societal

development constraints.

The Central Karakoram is

such an area in which the

Tibetan speaking Baltis are

confronted with a harsh and

hostile natural environment. In

the sense of classical regional

development theories, high

mountain areas show factors

that inhibit development, such

as a pronounced relief, a high

potential of natural risks, low

population and settlement

densities or a lean network

of traffic and communication

infrastructures. But today the

Central Karakoram stands

out against the widespread

thesis of stagnation and

backwardness as a result of

dynamic developments. Through

creative adaptive processes

of its residents as well as

externally induced measures and programs, natural development

barriers lose their importance

and can sometimes even be

converted into advantages. The

expansion of the transport and

communication infrastructure

and thus the improved

accessibility and networking are important prerequisites for the expansion of individual scopes of action and the unfolding of individual abilities. Multi-local networks, social capital and formal education are becoming increasingly important factors within current livelihood strategies in this high mountain region.

\section{KEYWORDS:}

Development, Modernisation, Discourses, Karakoram, Pakistan

$\overline{\text { Article received 29.10.2017 }}$ 


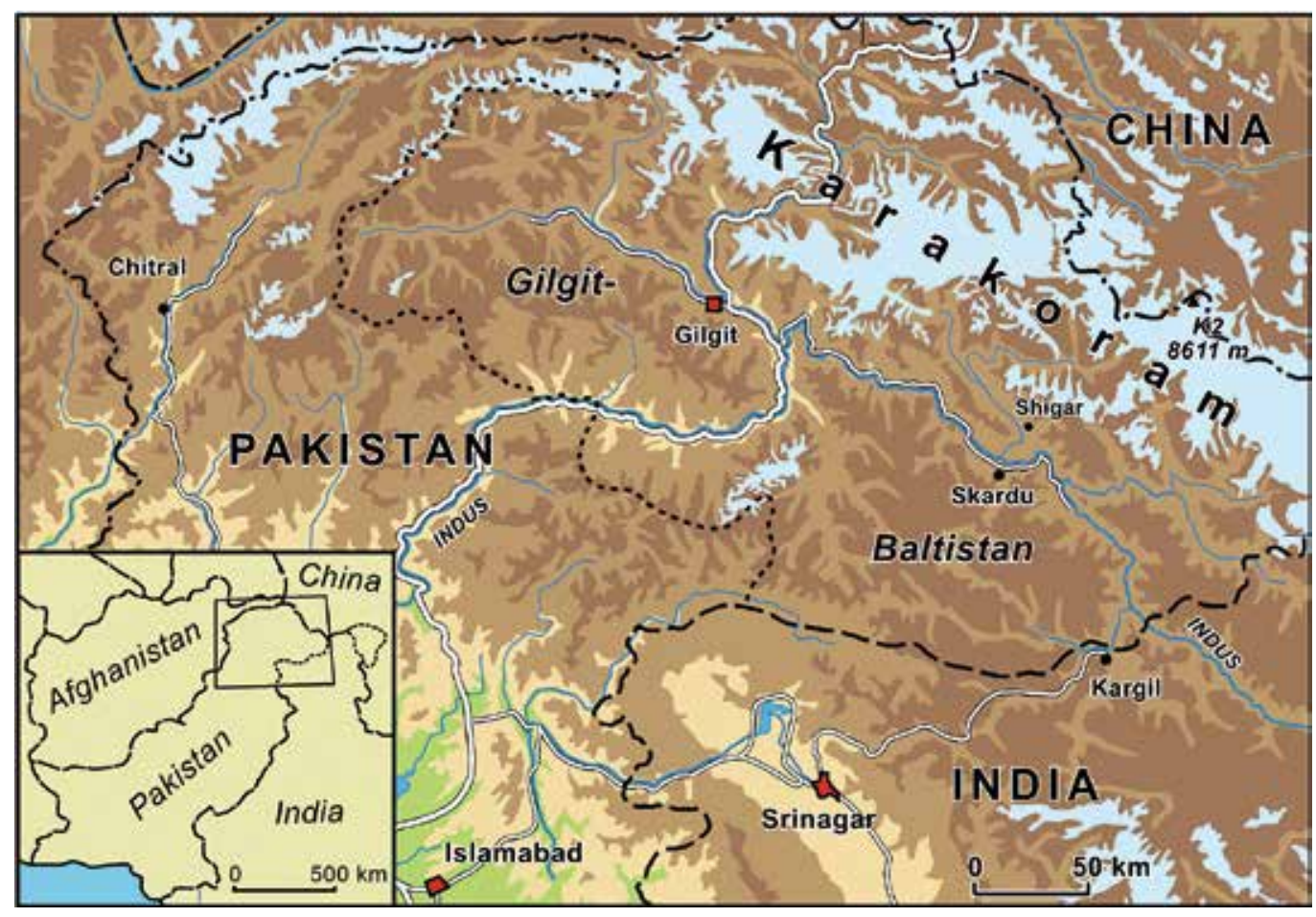

Fig. 1. Study Region Baltistan (Draft: M. Schmidt 2018)

opment (World Bank 2009), the positive developments of the past decades in Baltistan, which is considered to be ecologically disadvantaged, socioeconomically marginalized and politically controversial, are astounding.

\section{Creative adaptations to topographical and ecological challenges}

The basis of local livelihoods is mixed mountain agriculture, a combination of irrigation farming and mobile animal husbandry. This form of agriculture is adapted to the ecological conditions of the Karakoram with its semiarid valleys, short growing seasons and considerable differences by elevation. Over the centuries of adaptation, the Baltis developed elaborate practices for the effective use of the scarce resources soil and water (Schmidt 2004).

In the light of significant population growth, utilisable farmland in particular is a limiting resource. As a result of the practiced inheritance law, which is based on a mixture of Islamic law and local customs, land ownership per household has steadily declined. Thus, the agricultural resources are no longer sufficient to secure the food supply.

One strategy to reduce this supply gap is to grow cash crops, such as apricots, apples or potatoes, which, as seed potatoes, produce relatively high prices in the urban centres of Pakistan. The earned income can be used to purchase the state-subsidized wheat flour. With such a strategy, the difficult agro-ecological conditions are transformed into an advantage. An important precondition for supra-regional marketing is the Karakoram Highway, built in the 1970s, through which the region is connected to the Pakistani lowland all year round. But even this important "lifeline" is interrupted several times a year after heavy precipitation events or earthquakes followed by rock falls, mudflows or avalanches. The relatively extensive construction of roads - almost every settlement in Baltistan is connected to the road network (see Fig. 2) - is mainly a consequence of the strategicmilitary importance of the region in the Kashmir conflict.

External development impulses and modernization

Governmental and non-governmental organizations, such as the Aga Khan Foundation (Fazlur-Rahman 2007), have been providing important development impetus in education, health, agriculture, infrastructure or microcredit for decades. Particularly striking successes can be seen in the education sector (Benz 2014). The literacy rate in the Skardu District increased from 33 per cent in 1998 to 57 per cent in 2013 (Statistical Cell 2013). Meanwhile the advanced school enrolment rate affects not only boys but also girls (see Fig. 3); however, there is still a significant gap between the sexes in higher education.

Concerning infrastructure, in addition to the already mentioned expansion of roads, the water supply has also improved in many places through the installation of water pipe systems. Proportionally, more people have access to clean drinking water in Baltistan than in the rest of the country (World Bank 2010). A measurable consequence of higher levels of education and improved water supply are the lower mortality rates in infants, children and mothers, which are still above the national average (Statistical Cell 2013).

In addition to the population growth, changed living preferences have significantly modified the settlement structures. Increasing urban sprawl is particularly noticeable in larger agglomerations, which often seals valuable 


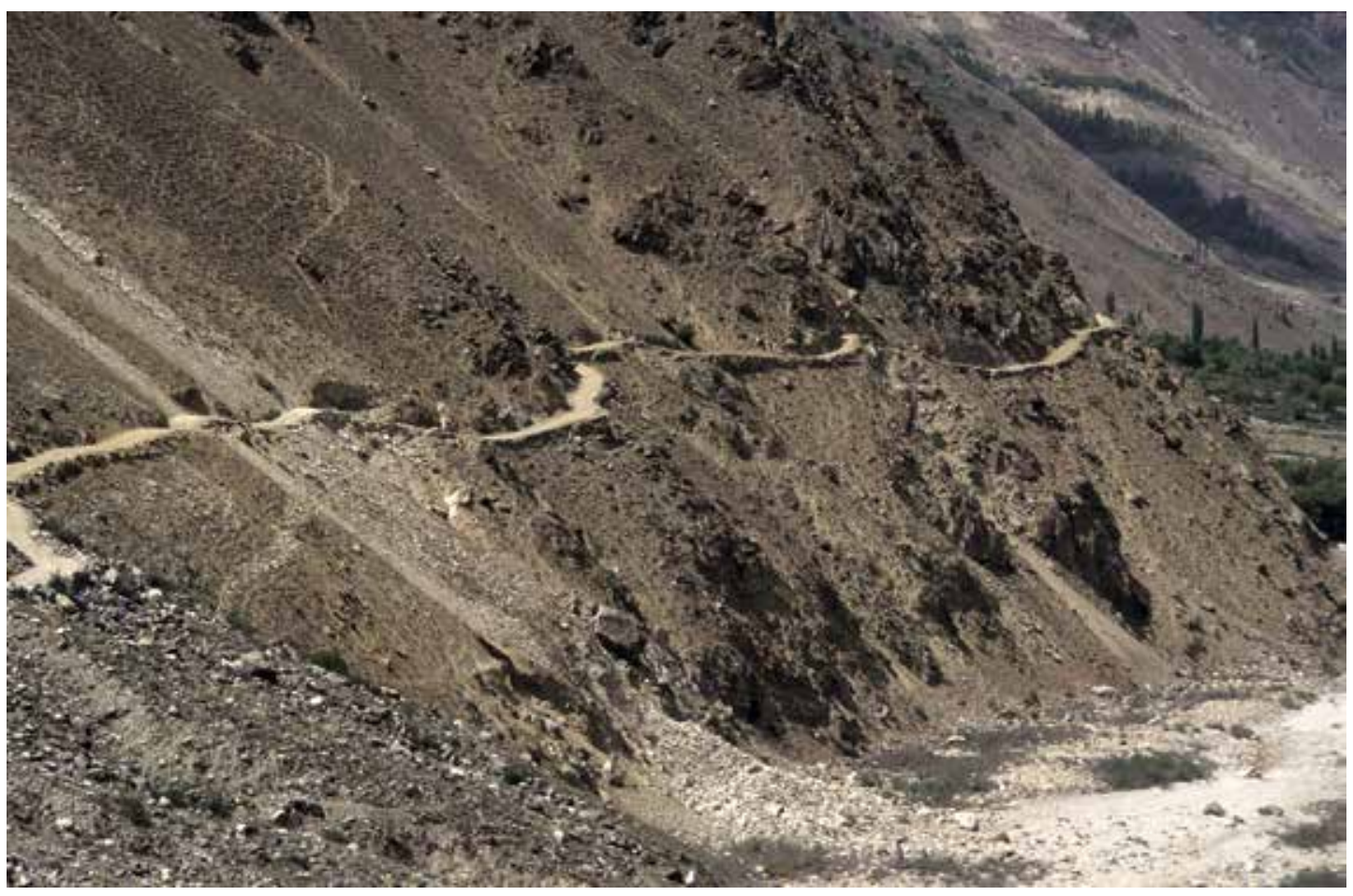

Fig. 2. Road in Basha Valley (Baltistan) (Photo: M. Schmidt)

farmland. In Shigar Proper, about three-quarters of residential buildings are not older than 25 years or have been modernized (Kreutzmann et al. 2008). Traditionally built of stone, clay and wood, and thus relatively earthquakeproof and well isolated, closely built farmhouses with integrated cowsheds have become rare. Single-storey, detached residential buildings are preferred today, which are similar in style to those in the Pakistani lowlands, but are clearly less insulated.

The expansion of electrification is also progressing rapidly, with the result that more and more settlements and residential buildings are being connected to the power grid. This goes hand in hand with the entry of TVs, refrigerators, washing machines and computers. Telecommunications are spreading at a particularly rapid pace: in 1998, there were only 25 landline connections in the entire Shigar Valley that could only be used nationally via a telephone exchange; in Shigar today, thousands of households have at least one mobile phone, that provides low-cost calls worldwide (own surveys). As a concomi-

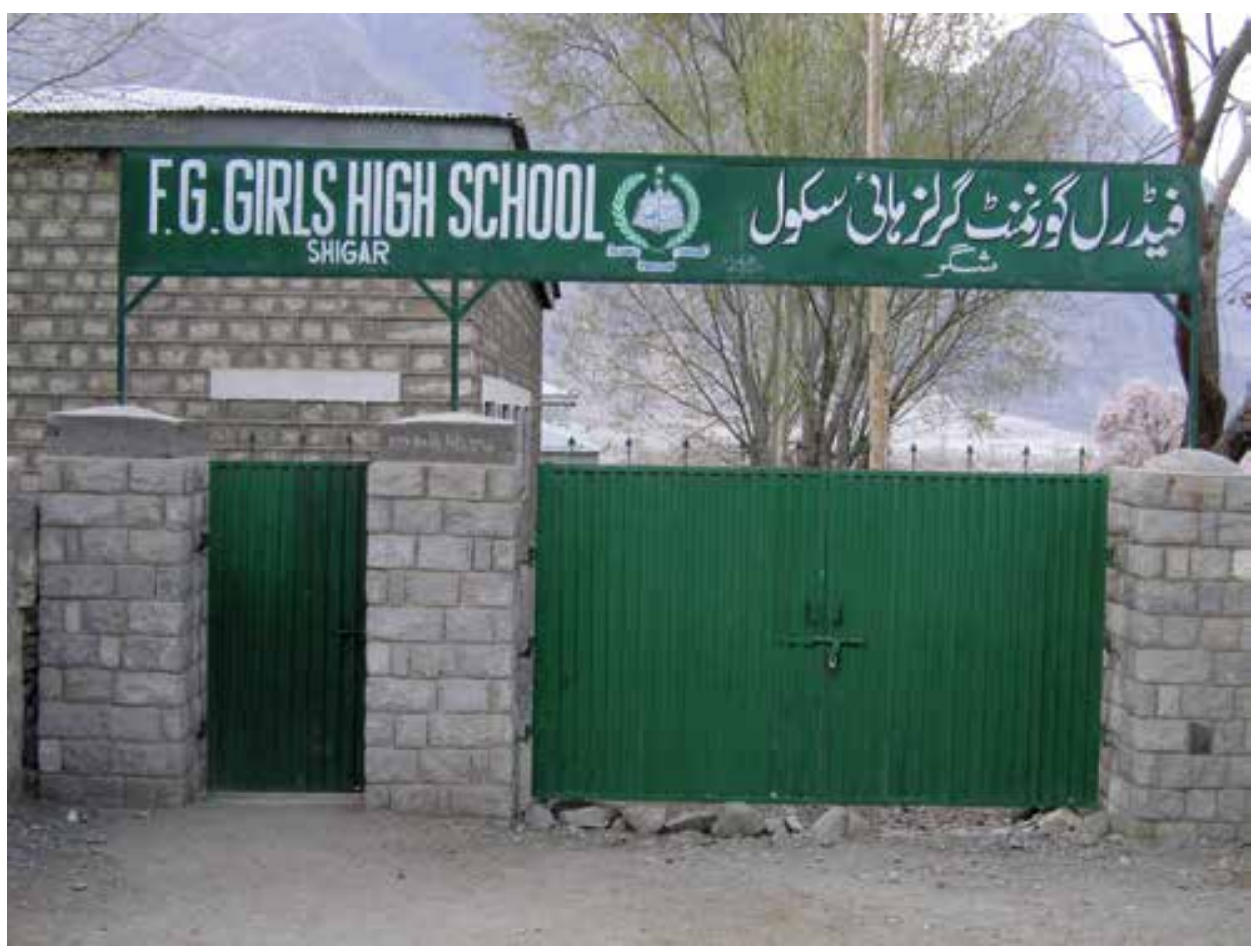

Fig. 3. Girls High School in Shigar Proper (Photo: M. Schmidt) 


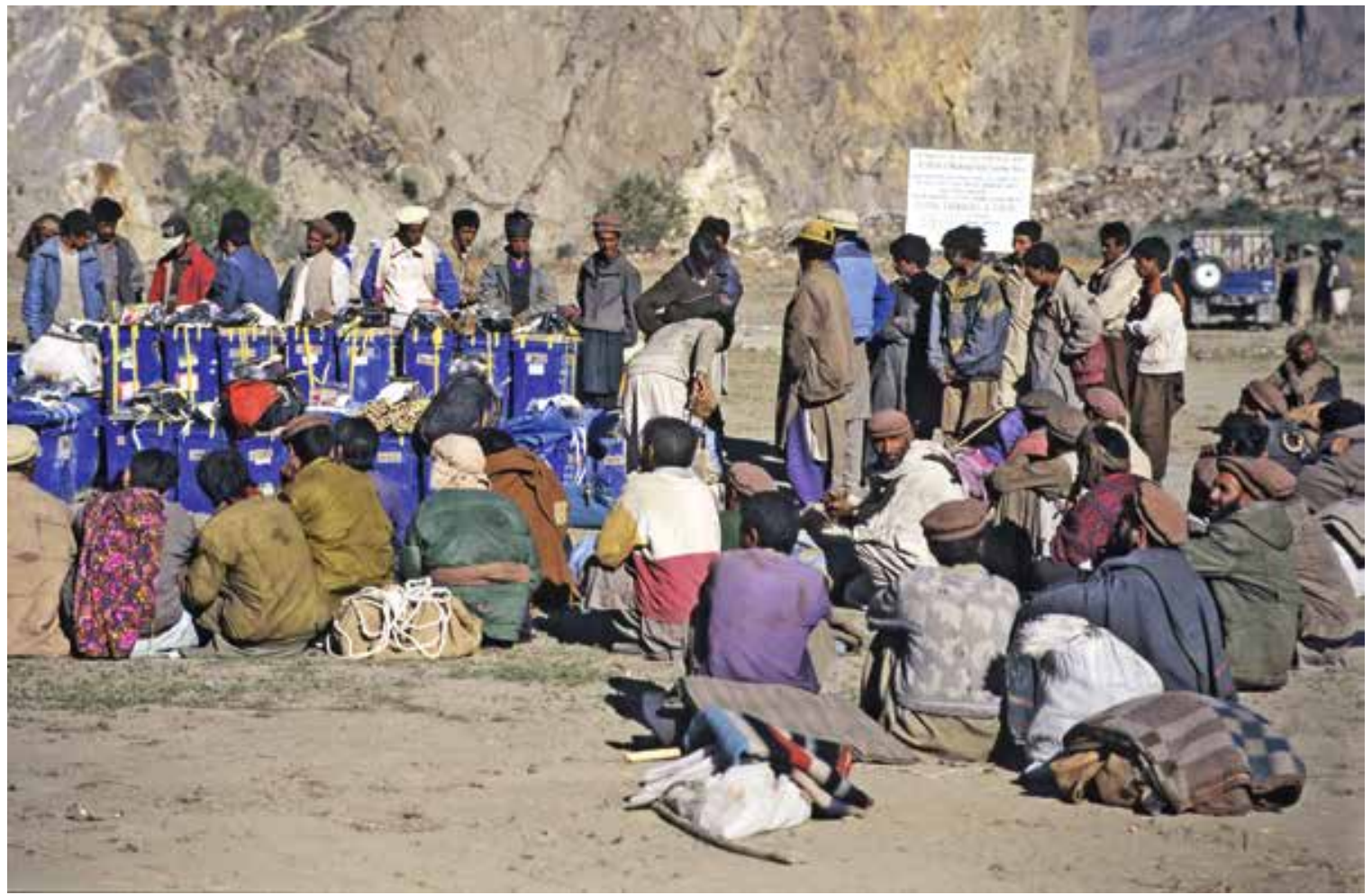

Fig. 4. Porters of a Mountaineering Expedition near Askole (Photo: M. Schmidt)

tant of increased use of electricity and changing living conditions, a not inconsiderable share of income must be used to pay the electricity bills, creating a dependency on regular monetary income.

\section{Region-specific development potential}

The cultural and natural uniqueness of Baltistan offers great tourist potential. Gilgit-Baltistan is advertised as the most spectacular and fascinating region of Pakistan (Pakistan Tourism Development Corporation 2015). In addition to groups and individual travellers, trekking tourists and alpinists from all over the world visit the Karakoram, offering the local population various seasonal employment opportunities, such as mountain guides, porters, cooks or drivers (see Fig. 4). In this way, many young men in Baltistan earn an important extra income during the summer months, which roughly equals the annual salary of a teacher. Tourism is now the most important economic sector in the region after trade, but is fragile and subject to considerable fluctuations due to road blocks, negative reports on Pakistan in the international media or political-military conflicts.

Another more recent source of income is the often extremely dangerous exploration of precious stones and minerals. Amethysts, aquamarines, rubies, topazes, tourmalines and other gems from Baltistan are traded worldwide. But also the removal of marble for customers in urban agglomerations provides as niche production incomes for a few, who are in mining, trade or transportation.

\section{Diversified multi-local livelihoods}

However, the greatest contribution to individual and, indirectly, to regional development is provided by the mobility willingness of the local population. The reduced significance of agriculture, the lack of off-farm employment opportunities, the desire to participate in modernization and the increasing monetization of lifestyles make it necessary to look for employment and income outside the region. Already the service in the army has a certain tradition. Large families send one or more sons to the army, reducing the pressure on limited land resources. With severance payment at the end of the military service, retired soldiers often make productive investments in a vehicle or a shop. Educational and labour migration to urban agglomerations or abroad, especially to the Gulf States, is also widespread today. The remittances support the local livelihoods and are increasingly being invested in the education of children. However, the absence of household members means a higher workload, especially for women. What makes things even more difficult is that traditional ideas about gender-specific division of labour and the strict separation of the spheres of men and women make the pursuit of certain activities almost impossible. For example, field irrigation and pasture services are purely male domains. In the absence of male workers in the household, some jobs can only be carried out with the help of arrangements with friends or paid services (Schmidt 2004).

Today, many of Baltistan's households have nationwide and even global networks and pursue multi-local livelihood strategies. The concomitant build-up of social capital with a large geographical reach increases the chances to participate in global prosperity developments. 
Through these networks and the collected impressions, experiences and knowledge, diffusion of development impulses occurs. This ultimately leads to changes in local lifestyles. Thus, electronic devices become more important as status symbols and the modified architectural styles deliberately express the desired or successful lifestyle changes. However, social transformation also manifests itself in an increasing unwillingness to participate in formerly obligatory communal work such as the maintenance of irrigation canals or the provision of services on mountain pastures.

\section{Conclusion}

The predominantly rural high-altitude Baltistan region stands out against the widespread thesis of stagnation and backwardness as a result of dynamic developments. Through creative adaptive processes of its residents as well as externally induced measures and programs, natural development barriers lose their impor-

\section{$\overline{R E F E R E N C E S:}$}

1. Bansal A. (2008). Gilgit-Baltistan: The Roots of Political Alienation. In: Strategic Analysis 32(1): 81-101.

2. Benz A. (2014). Education for Development in Northern Pakistan: Opportunities and Constraints for Rural Households. Oxford.

3. Fazlur-Rahman (2007). The Role of Aga Khan Rural Support Programme in Rural Development in the Karakorum, Hindu Kush \& Himalayan Region: Examples from the Northern Mountainous Belt of Pakistan. In: Journal of Mountain Science 4(4), S. 331-343.

4. Furrer G. (1967). Siedlungs- und agrargeographische Beobachtungen im Braldotal (Karakorum). In: Zeitschrift für Agrargeschichte und Agrarsoziologie 15: 6-13.

5. Kreutzmann H., Schmidt M., Benz A. (eds.) (2008). The Shigar Microcosm: Socio-economic Investigations in a Karakoram Oasis, Northern Areas of Pakistan. Occasional Papers Geographie 35. Berlin.

6. Pakistan Tourism Development Corporation (2015). Desitinations: About Gilgit-Baltistan. www.tourism.gov.pk/ northern_areas.html (10.03.2015).

7. Robinson W.I. (2002). Remapping Development in Light of Globalisation: From a Territorial to a Social Cartography. In: Third World Quarterly 23(6): 1047-1071. tance and can sometimes even be converted into advantages. The expansion of the transport and communication infrastructure and thus the improved accessibility and networking are important prerequisites for the expansion of individual scopes of action and the unfolding of individual abilities. Multi-local networks, social capital and formal education are becoming increasingly important factors within current livelihood strategies. They open up new opportunities for participation in national and global prosperity development. However, for material and socially disadvantaged groups, these ways of overcoming poverty and underdevelopment are often closed, which can be expected to widen the gap between winners and losers of these processes. From an individual perspective, development increasingly takes place "de-territorialized" (Robinson 2002), since it is usually no longer tied to certain areas, but is the result of functioning networks that can differ significantly between individuals.

8. Schmidt, M. (2004). Boden- und Wasserrecht in Shigar, Baltistan. Autochthone Institutionen der Ressourcennutzung im Zentralen Karakorum. Bonner Geographische Abhandlungen 112. Sankt Augustin.

9. Schmidt M. (2012). (Un)mögliche Entwicklungen im Karakorum Nordpakistans. In: Geographische Rundschau 64(9): 20-27.

10. Statistical Cell (2013). Gilgit-Baltistan at a glance 2013. Planning and Development Department, Govt. of GilgitBaltistan. www.gilgitbaltistan.gov.pk (10.03.2015).

11. Workman F. B., Workman W. H. (1900). In the Ice World of Himalaya: Among the Peaks and Passes of Ladakh, Nubra, Suru and Baltistan. London. (Reprint: New Delhi 1994).

12. World Bank (2009). World Development Report 2009: Reshaping Economic Geography. Washington D.C.

13. World Bank (2010). Pakistan Gilgit-Baltistan Economic Report: Broadening the Transformation. https://openknowledge.worldbank.org/handle/10986/2984 (10.03.2015).

14. Younghusband F. E. (1896). The Heart of a Continent. A Narrative of Travels in Manchuria, Across the Gobi Desert, Through the Himalayas, the Pamirs, and Chitral, 1884-1894. London.

\section{INFORMATION ABOUT AUTHORS / Сведения об авторе:}

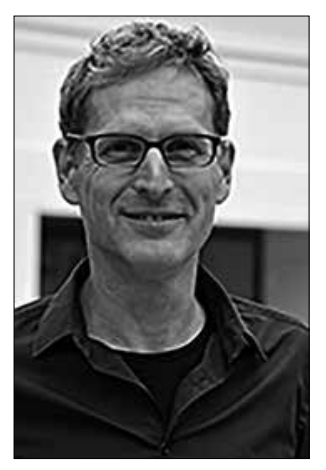

\section{Matthias Schmidt}

Prof. Dr. Institute of Geography, University of Augsburg

Alter Postweg 118, D-86159 Augsburg, Germany

Phone: ++49/821/598-2268

E-mail: schmidt@geo.uni-augsburg.de

www.geo.uni-augsburg.de/lehrstuhl_professur/humgeo/team/schmidt/

Маттиас Шмидт, профессор, доктор.

Институт Географии, Университет Аугсбурга, Германия

Adpec: Alter Postweg 118, D-86159 Augsburg, Germany

Телерон: $++49 / 821 / 598-2268$

Email: schmidt@geo.uni-augsburg.de

www.geo.uni-augsburg.de/lehrstuhl_professur/humgeo/team/schmidt/ 


\section{ДИНАМИЧЕСКИЕ ПРОЦЕССЫ И ПРЕОБРАЗОВАНИЯ В ЦЕНТРАЛЬНОМ КАРАКОРУМЕ}

\section{Маттиас Шмидт}

Институт Географии, Университет Аугсбурга, Германия

E-mail:schmidt@geo.uni-augsburg.de

\section{DOI: $10.21177 / 1998-4502-2018-10-1-91-96$}

Высокогорные районы часто рассматриваются как районы застоя, для которых характерны естественные и социальные ограничения в области развития. Центральный Каракорум - это такая область, в котороq тибетскоговорящие Балты сталкиваются с суровой и враждебной природной средой. В соответствии с классическими теориями регионального развития высокогорные районы характеризуются факторами, препятствующими развитию, такими, как выраженный рельеф, высокий потенциал природных рисков, низкая плотность населения и поселений или слабая сеть транспортных и коммуникационных инфраструктур. Но сегодня Центральный Каракорум выделяется на фоне широко распространенного тезиса о стагнации и отсталости в результате динамичных процессов развития. Благодаря творческим адаптационным процессам своих жителей, а также внешним мерам и программам, барьеры естественного развития теряют свою значимость и иногда даже могут иметь свои преимущества. Расширение транспортной и коммуникационной инфраструктуры и, следовательно, повышение доступности и создание сетей являются важными предпосылками расширения индивидуальных масштабов деятельности и развития индивидуальных способностей. В рамках нынешних стратегий обеспечения средств к существованию в этом высокогорном регионе все более важными факторами становятся местные сети, социальный капитал и формальное образование.

\section{Литература:}

1. Bansal A. (2008). Gilgit-Baltistan: The Roots of Political Alienation // In: Strategic Analysis 32(1): 81-101.

2. Benz A. (2014). Education for Development in Northern Pakistan: Opportunities and Constraints for Rural Households. Oxford.

3. Fazlur-Rahman (2007). The Role of Aga Khan Rural Support Programme in Rural Development in the Karakorum, Hindu Kush \& Himalayan Region: Examples from the Northern Mountainous Belt of Pakistan. // In: Journal of Mountain Science 4(4). Pp. 331-343.
4. Furrer G. (1967). Siedlungs- und agrargeographische Beobachtungen im Braldotal (Karakorum). // In: Zeitschrift für Agrargeschichte und Agrarsoziologie 15: 6-13.

5. Kreutzmann H., Schmidt M., Benz A. (eds.) (2008). The Shigar Microcosm: Socio-economic Investigations in a Karakoram Oasis, Northern Areas of Pakistan. Occasional Papers Geographie 35. Berlin.

6. Pakistan Tourism Development Corporation (2015). Desitinations: About Gilgit-Baltistan. www.tourism.gov.pk/ northern_areas.html (10.03.2015).

7. Robinson W.I. (2002). Remapping Development in Light of Globalisation: From a Territorial to a Social Cartography // In: Third World Quarterly 23(6): 1047-1071.

8. Schmidt, M. (2004). Boden- und Wasserrecht in Shigar, Baltistan. Autochthone Institutionen der Ressourcennutzung im Zentralen Karakorum. Bonner Geographische Abhandlungen 112. Sankt Augustin.

9. Schmidt M. (2012). (Un)mögliche Entwicklungen im Karakorum Nordpakistans // In: Geographische Rundschau. 64(9): 20-27.

10. Statistical Cell (2013). Gilgit-Baltistan at a glance 2013. Planning and Development Department, Govt. of GilgitBaltistan. www.gilgitbaltistan.gov.pk (10.03.2015).

11. Workman F. B., Workman W. H. (1900). In the Ice World of Himalaya: Among the Peaks and Passes of Ladakh, Nubra, Suru and Baltistan. London. (Reprint: New Delhi 1994).

12. World Bank (2009). World Development Report 2009: Reshaping Economic Geography. Washington D.C.

13. World Bank (2010). Pakistan Gilgit-Baltistan Economic Report: Broadening the Transformation. https:/openknowledge.worldbank.org/handle/10986/2984 (10.03.2015).

14. Younghusband F. E. (1896). The Heart of a Continent. A Narrative of Travels in Manchuria, Across the Gobi Desert, Through the Himalayas, the Pamirs, and Chitral, 1884-1894. London.

Статья поступила в редакциию 29.10.2017 


\section{A COMPARATIVE ANALYSIS OF TWO MOUNTAIN RESEARCH COMMUNITIES: INTERDISCIPLINARY AND INTERNATIONAL AGENDAS}

\section{Introduction}

As a social-cultural anthropologist seeking to pursue questions of environmental governance and community agency in Russia, I have become interested in the North Caucasus as a potential region of focus for future fieldwork. The immense ethnic, linguistic, and religious diversity of mountain communities in this region make it highly interesting for anthropological research in general and for examining the variability of outcomes in local ${ }^{1}$ environmental governance in particular. My interest in studying North Caucasian mountain communities situates me within a global scholarly community ${ }^{2}$ on mountain research, as well as within a regional Russian and North Caucasian ${ }^{3}$ scholarly community ${ }^{4}$ on mountain research. It is therefore important to evaluate the research agendas of these scholarly communities with the aim of understanding their disciplinary and regional foci, evaluating what the disciplinary and regional foci say about these scholars' approaches to their regions of study, and identifying where the social sciences as a whole and anthropology in particular can contribute to mountain research in the North Caucasus. In my analysis, I compare two peer-reviewed, open access journals that represent the following two groups of scholars: Mountain Research and Development (MRD), published by the International Mountain Society (IMS) through the Center for Development and Environment at the University of Bern, Switzerland, and Sustainable Development of Mountain Territories (SDMT), published by the North Caucasian Institute of Mining and Metallurgy in Vladikavkaz, the Republic of North Ossetia-Alania. I selected these two journals because they represent the two academic mountain research communities that I wish to examine, and because they offer a succinct and highly comparable format for examining and analyzing research agendas.

\section{Theoretical Background}

The past decades have seen an increase in global changes that adversely affect natural environments and the people dependent upon them for ecosystem services (e.g. food, freshwater, timber, and energy). Academic and policy-oriented initiatives have developed in response to concern over the precarious situations of an increasing number of social and ecological systems. Such initiatives include the growth of research networks and programs dedicated to the study of the environment and sustainable development, and agendas by global organizations such as the United Nations Educational, Scientific, and Cultural Organization program on Man and the Biosphere and the United Nations Sustainable Development Goals (2015). These initiatives have recognized the biodiversity of mountain territories and the significance of these environments for the local and global population 5 .

A growing number of scholars from various disciplines have acknowledged that their own research agendas must reflect the realities of the relationship be-

\footnotetext{
I define "local" more specifically as "municipal".

Otherwise referred to in this paper as the global mountain research community. This global community consists of scholars located in countries around the world and whose research focuses on mountain areas in various regions of the world. What unites the global scholarly community, as discussed later, is a common vision and future research agenda, as well as participation in key mountain research organizations and conferences.

With a few exceptions that include western European scholars from Germany, Switzerland, Austria, and France.

${ }^{4}$ Otherwise referred to in this paper as the regional mountain research community.

As noted, e.g., in goal 51.4 of the United Nations Sustainable Development Goals: "By 2030, ensure the conservation of mountain ecosystems, including their biodiversity, in order to enhance their capacity to provide benefits that are essential for sustainable development”. United Nations 2015.

* Departament of Anthropology. University of Florida. Gainesville. USA.
}

Le Jeune,*

Christine M.

\section{УДК: 622}

DOI: 10.21177/1998-4502-201810-1-97-107

The article discusses the need for scholars to approach research on mountain territories through an interdisciplinary lens that accounts for the dynamic interactions occurring between humans and nature. While the global mountain research community has made strides towards interdisciplinary approaches and international collaboration, the Russian mountain research community has remained largely isolated from these interdisciplinary and international agendas. The article is critical of the persisting natural science bias in Russian mountain research, explains why such a bias is problematic, and offers recommendations for ways forward.

\section{KEYWORDS:}

mountain research, anthropology, social sciences, natural sciences, social-ecological systems, interdisciplinarity, research agendas

$\overline{\text { Article received } 29.10 .2017}$ 
tween humans and the natural environment. This shift reflects a practical argument in favor of interdisciplinary research in that "problems of the world are not organized according to academic disciplines" (Stember 1991, 2). Within sustainability science, a key argument in favor of interdisciplinarity is that "research on complex sustainability problems requires the constructive input from various communities of knowledge to ensure that the essential knowledge from all relevant disciplines and actor groups related to the problem is incorporated" (Lang et al. 2012, 26). In addition to the practical argument, an intellectual argument in favor of interdisciplinary research is that "ideas in any field are enriched by theories, concepts, and methods from other fields" (Stember 1991, 2). The practical and intellectual arguments for interdisciplinarity are captured in the use of the social-ecological systems (SES) framework as a means for examining the dynamic relationships between humans and their natural environments (see Fig. 1 and further discussion of the SES framework below). As its name implies, this framework incorporates the social sciences and the natural sciences to promote an interdisciplinary approach.

The value of this interdisciplinarity is evident in the depth and breadth of research conducted by mountain research scholars using this approach, which result in well-rounded and well-informed analyses. This research includes studies such as Catherine M. Tucker's (2008) examination of dynamic forest landscapes and collective action in La Campa, Honduras, James S. Gardner and Julie Dekens's (2007) work on mountain hazards and the resilience of social-ecological systems in India and China, and Brian K. Hand et al.'s (2018) study of riverscape management in the Columbia River Basin from a socialecological perspective.

In a series of comprehensive studies that highlight the need for interdisciplinary approaches to mountain research in the North Caucasus, Alexey Gunya (2015) first discusses the demise during the Soviet era of scholarly approaches that integrated the study of humans and their natural environment. He explains how a one-sided approach that considers only the human or the natural component can lead scholars to reach incomplete conclusions, and demonstrates in subsequent studies the importance of examining both the social and the ecological systems. Gunya et al. (2016) examine how the social, political, and economic changes brought about by modernization processes affect the local population's relations to land. The authors discuss how multiple state and non-state actors and institutions emerged from the post-Soviet land privatization process, which led the local population to develop new informal rules and networks that it could use to navigate the new institutional and legal landscape. Gunya takes a deeper look at the institutional conditions that accompany development in Jan Koehler et al. (2017). The article takes up Elinor Ostrom's approach to studying the use of common resources by emphasizing the importance of institutions in regulating their use so as to prevent their overuse and degradation (the "tragedy of the commons"). The authors apply Douglass North's (1990) institutions-as-rules approach, whereby institutions are the "rules of the game in a society" (North $1990,3)$ that include both formal rules such as laws and institutions enforced by the state, as well as informal rules that manifest themselves as constraints (e.g. conventions, norms of behavior, and codes of conduct) and are enforced by "members of the relevant group" (Greif and Kingston 2011, 14). The article's detailed analysis shows how in the context of the North Caucasus, informal institutions can play an equally if not more important role than formal institutions. The state should therefore give greater consideration to informal institutions and the potential for hybrid formal and informal institutions if it aims to implement more effective development programs. Finally, Gunya and Miskarova (2017) apply this interdisciplinary thread of SES research to a case study examining the development of the mountainous Elbrus region. The study applies a social-anthropological approach by analyzing the dynamic relationships between the actors, resources, institutions, and landscape in which the resources are used. The authors findings show that a complex and competitive relationship exists between the formal and informal institutions of the state and local community in the Elbrus region, with different implications for land use depending upon the ability of the local community to successfully assert its rights vis-à-vis the state.

\section{Mountain Research Agenda-Setting}

In 2015, scholars from around the world who perform research in mountain regions gathered for the third time in Perth, Scotland. Entitled "Mountains of Our Future Earth: Defining Priorities for Mountain Research", the 2015 conference was one of a series held by the Centre for Mountain Studies every five years and purports to be the "biggest meeting of its kind in mountain research". ${ }^{1}$ One of the main priorities of the Perth I, II, and III Conferences, as the mountain research community has named them, is to analyze current mountain research and emerging issues in this research, identify thematic and regional gaps in this research, and encourage a purposeful research agenda that will close these gaps. The 2015 Perth III Conference evaluated the mountain research community's progress in taking seriously these calls for more deliberate research agendas to fill the identified gaps. In a report synthesizing the outcomes from the Perth III Conference, scholars performed an extensive comparative analysis of abstracts accepted to the 2010 Perth II Conference versus abstracts accepted to the 2015 Perth III Conference, and tracked changes in the thematic and regional focus of these submissions

\footnotetext{
${ }^{1}$ See The Mountain Research Initiative webpage at $<$ http://mri.scnatweb.ch/ en/events/list-of-all-events-2/events-in-2015/mountains-of-our-future-earthconference-2015>. Accessed 25 November 2017.
} 
(Gleeson et al. 2016). While the scholars identified some progress with regard to both regional and thematic gaps, they noted that much work remains to address them: geographically, Europe remained over-represented and Africa, North America, and Latin America under-represented; ${ }^{1}$ thematically, the natural sciences continued to dominate, while social science, resource management, and interdisciplinary contributions continued to lag behind (Ibid., 541 and see Fig. 1 below). The top half of Fig. 1 displays the parts of a simplified representation of mountain social-ecological systems (SES). As discussed above, scholars studying complex mountain landscapes utilize social-ecological systems science to examine issues of global change as they relate to the vulnerability

\footnotetext{
1 Over-represented or under-represented with regard to the number of mountain areas and people living in mountain areas in a certain region, e.g. Asia has $36 \%$ of the world's mountain areas and $53 \%$ of the world's mountain people, but only $19 \%$ of the Perth II abstracts (of a total 433 abstracts) and $30 \%$ of the Perth III abstracts (of a total 446 abstracts) focused on Asia. See Gleeson et al. 2016.
}

of mountain systems and the human communities they support (Alessa et al. 2018). The SES framework was originally developed by Elinor Ostrom as a means for gathering and organizing the findings of scientists across disciplines, with the aim of promoting an interdisciplinary understanding of how to describe and explain these complex systems (Ostrom 2009). In the SES framework pictured in the top half of Fig. 1, the natural sciences are represented in the green bubble on the right entitled ecological systems, while the social science disciplines are represented in the yellow bubble on the left entitled social systems. Ecological and social systems both impact resource use and management (the middle bubble), which incorporates the benefits that humans receive from use of the natural environment (ecosystem services) as well as the human social systems that influence the choices made about this use (decisionmaking). The yellow arrows indicate the impacts of global dynamics on the respective social and ecological systems, and the green arrows in-

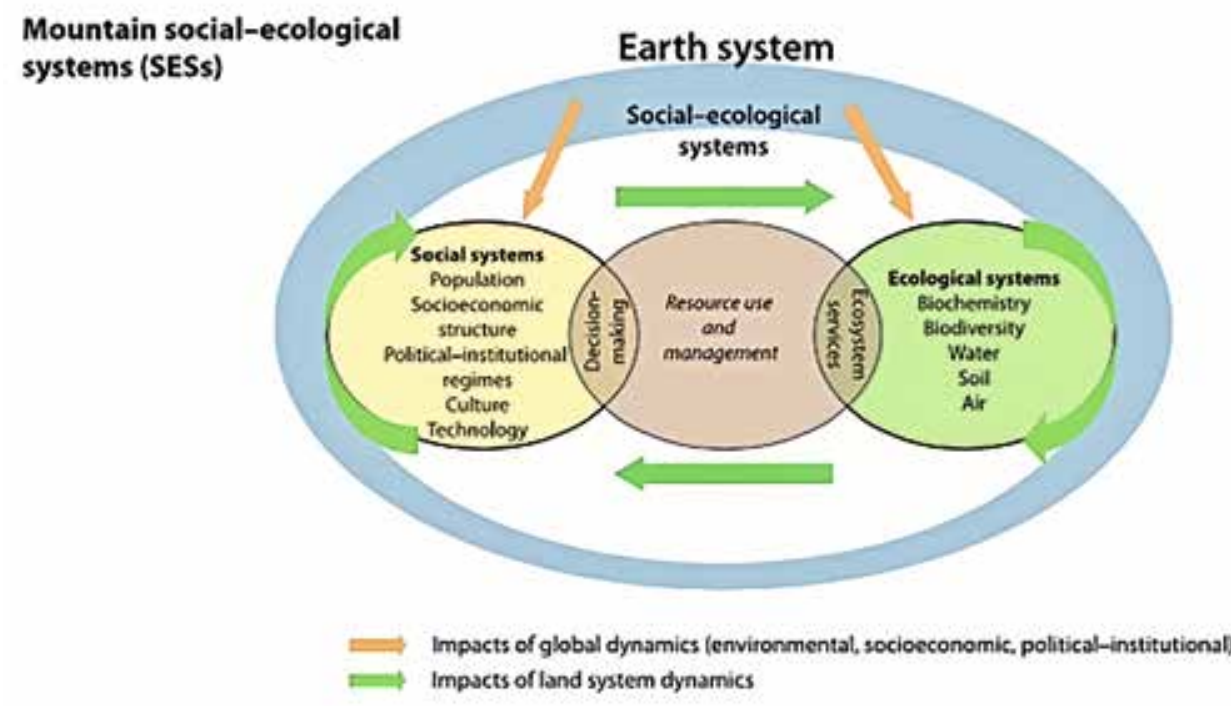

$=$ Impacts of land system dynamics
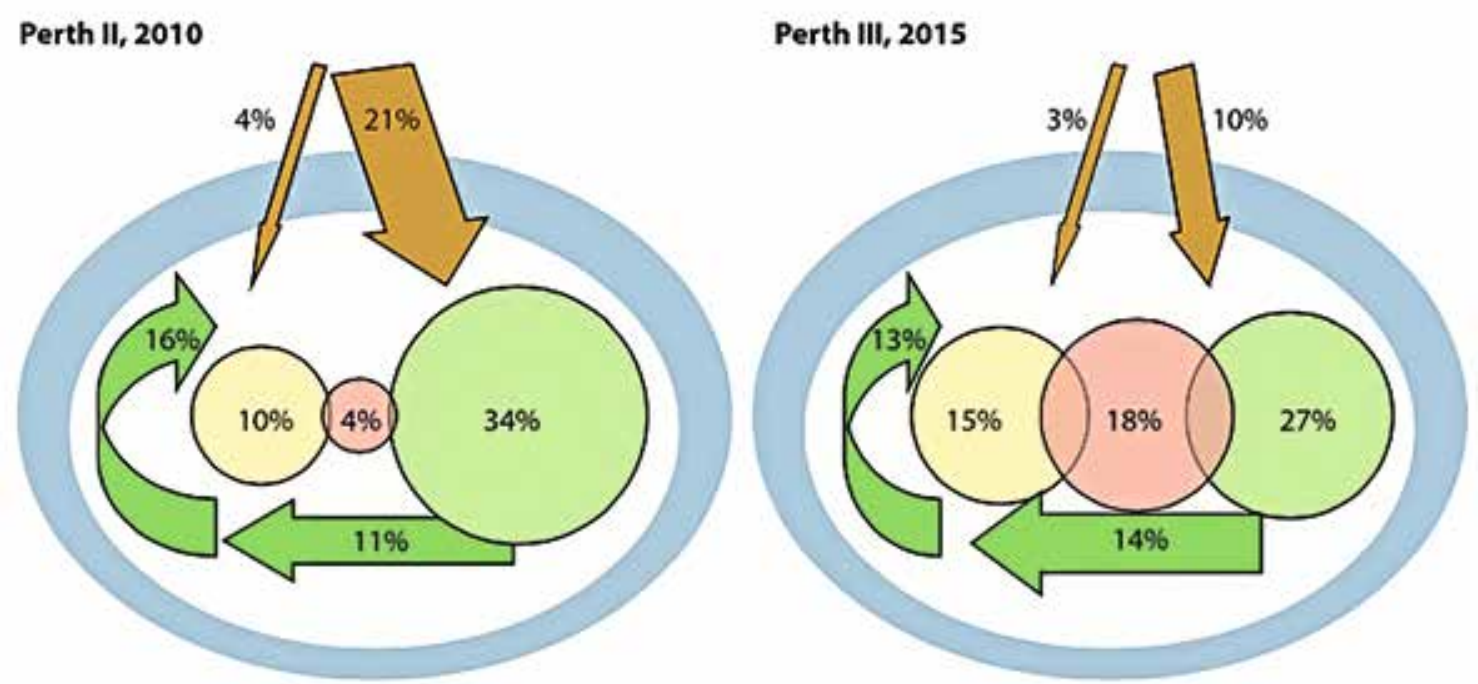

Fig. 1. Changes in common thematic foci from the Perth II and Perth III Conferences (Gleeson et al. 2016, 541.) 
dicate the impacts of land system dynamics on the entire SES framework. The lower half of Fig. 1 displays the thematic emphases and the thematic shifts that occurred in mountain research between 2010 and 2015. During this period, the natural science bias decreased from $34 \%$ to $27 \%$, social science research rose from $10 \%$ to $15 \%$, and research on the interactions between social and ecological systems through resource use and management increased from 4 to $18 \%$ (Fig. 1). Although the scholars who analyzed the outcomes of the Perth III Conference welcomed this shift, they still noted that much work remains to close persisting thematic and regional gaps. To address these shortcomings, the authors recommended that future mountain research (Gleeson et al. 2016, 545): ${ }^{1}$

1. Identify and engage with social and policy scientists to expand from biophysical foci into the social and policy realms.

2. Encourage interdisciplinary collaboration by taking an integrated systems approach that utilizes the mountain social-ecological systems framework (Fig. 1).

With regard to geographical under-representation in research, the authors recommended that mountain research scholars should perform a "rapid review of the literature, in all languages, to obtain a more complete overview of the research output and capacity in these regions" (Ibid.). While Russia technically belongs to the over-represented European geographical category, I argue in this paper that scholars pursuing research on the North Caucasus mountain region have remained primarily an insular and exclusive group, and are thus underrepresented in the global mountain research community. A review of the journal Sustainable Development of Mountain Territories (SDMT) contributes to a more complete understanding of this regional scholarly community's past and current research on the North Caucasus mountain region.

\section{Global and Regional Mountain Research Communities}

In a review ${ }^{2}$ of the mountain research literature and professional organizations dedicated to supporting the global mountain research community, I have identified two organizations that represent the global mountain research community and the regional mountain research community. These include the Mountain Research Initiative (MRI), which organizes the Perth Conferences, and the International Mountain Society

\footnotetext{
${ }^{1}$ Among other recommendations less relevant to the purpose of this paper. ${ }^{2}$ The review included literature such as Ariza et al. 2013, Björnsen et al. 2012, Gleeson et al. 2016, Greenwood 2013, Weingartner and Gunya 2016, Kohler et al. 2015, Messerli 2012, and Schmidt 2017, and journals such as the Journal of Alpine Research, the Journal of Mountain Science, eco.mont Journal on Protected Mountain Areas Research and Management, Mountain Research and Development, and Sustainable Development of Mountain Territories. It also included organizations such as the Mountain Social Ecological Observatory Network (MtnSEON), The Mountain Institute, the Centre for Mountain Studies, the Mountain Research Initiative, the International Center for Integrated Mountain Development, Mountain Partnership, and the Mountain Sentinels Collaborative Network.
}

(IMS), which publishes the journal Mountain Research and Development (MRD). ${ }^{3}$ Both organizations strive to integrate mountain scholars from around the world, and to facilitate collaboration on research across disciplines. ${ }^{4}$

A noticeable overlap exists between scholars who engage not only with the MRI and Perth Conferences, but also with the IMS and MRD: of the 46 total scholars involved with MRD in an editorial or managerial capacity, 37 are also listed in the MRI community and experts database (an $80 \%$ overlap). ${ }^{5}$ And at least $50 \%$ or more of the authors of the Perth II and III Conference synthesis papers $^{6}$ are also editorially or managerially involved with the MRD and listed in the MRI community and experts database. ${ }^{7}$ In contrast, of the 34 total scholars involved with the Russian journal Sustainable Development of Mountain Territories (SDMT) in an editorial or managerial capacity, only 9 are also listed in the MRI community and experts database (a $26 \%$ overlap), and none are authors of the Perth II and III Conference synopsis papers. The lack of overlap correlates with a comparatively low total number (132) of scholars from Russia represented in the MRI community and experts database (see Table 1 below). ${ }^{8}$ These figures indicate that beyond a low level of engagement (132 total scholars) in the larger mountain research community by scholars located in Russia, scholars in Russia who stem from the North Caucasus mountain research community are particularly underrepresented ( 9 of 132 total scholars, or only $6.8 \%$ )

The MRI Europe Program ${ }^{9}$ acknowledges this underrepresentation in its "MRI Europe Vision" statement. The purpose of the organization's "European node for mountain research" is to "bring together researchers who might otherwise never meet and connect scientists from different mountain regions (e.g. Carpathians and Alps)". ${ }^{10}$

\footnotetext{
${ }^{3}$ The IMS's primary function is to publish $M R D$, and a search for the IMS website brings up the $M R D$ website only. The two are synonymous with each other.

${ }^{4}$ As noted in their mission statements: The Mountain Research Initiative "About MRI". <http://mri.scnatweb.ch/en/the-mri/about-mri>. Accessed 25 November 2017; and Mountain Research and Development. "Mission and aims". <http://www.mrd-journal.org/about.asp>. Accessed 25 November 2017.

${ }^{5}$ See The Mountain Research Initiative. "Experts Database and Community". http://mri.scnatweb.ch/en/people/expert-database-who-is-who-in-globalchange-research-in-mountains $>$. Accessed 25 November 2017.

${ }^{6}$ A Perth I synthesis paper was never published.

${ }^{7}$ Gleeson et al. 2016 and Björnsen et al. 2012. Also see The Mountain Research Initiative. "Experts Database and Community". <http://mri. scnatweb.ch/en/people/expert-database-who-is-who-in-global-changeresearch-in-mountains $>$. Accessed 25 November 2017.

${ }^{8}$ The total number of scholars from Russia is 132 , compared to 300 from France, 364 from the United Kingdom, 387 from Germany, 392 from Italy, 429 from Austria, 1,174 from Switzerland, and 1413 from the United States. These numbers refer to the location of scholars listed in the MRI database, not their nationality (although location and nationality are often the same, especially in Russia). I chose to highlight the numbers of scholars in these countries because they represent the regions where scholars are otherwise most engaged in the global mountain research community.

${ }^{9}$ The MRI organizes regional network programs that focus on Europe Africa, Latin America, and the Carpathians.

10 The Mountain Research Initiative. "MRI Europe Vision". <http://mri scnatweb.ch/en/networks/mri-europe/vision>. Accessed 25 November 2017.
} 
The number of scholars listed in the MRI community and experts database according to country

\begin{tabular}{|c|c|}
\hline Country / Страна & Number of Scholars / Количество ученых \\
\hline Russia / Россия & 132 \\
\hline France / Франция & 300 \\
\hline United Kingdom / Великобритания & 364 \\
\hline Germany / Германия & 387 \\
\hline Italy / Италия & 392 \\
\hline Austria / Австрия & 429 \\
\hline Switzerland / Швейцария & 1174 \\
\hline United States / США & 1413 \\
\hline
\end{tabular}

One of the Europe Program's long-term visions is to launch "similar networks in other European eco-regions" - whereby the Caucasus mountain region is listed as one of these eco-regions - with the purpose of "enhancing the overall efficiency and effectiveness of the science network". ${ }^{1}$ Development of a network with scholars from the North Caucasus mountain research community would also contribute to the MRI Europe Program's short-term vision of facilitating "mountain research cooperation between countries and regions", assisting local scientists to "develop regional research strategies", and raising the visibility of high-quality research projects with the aim of attracting funding from institutions such as the European Union. ${ }^{2}$

The MRI Europe Program's vision statement points to an awareness that the global mountain research community has not yet connected to the regional community of scholars engaged in research in the North Caucasus. This regional group consists of a small community of primarily Russian and North Caucasian scholars ${ }^{3}$ whose research focuses on the mountain territory of the North Caucasus. Geographically, this region consists of the Greater Caucasus Mountains, which lies between the Black Sea to the west and the Caspian Sea to the east. I identify the scholars and research foci in this community by analyzing 32 publications in the journal Sustainable Development of Mountain Territories (SDMT) (Устойчивое Развитие Горных Территорий), which has existed since 2009 and is housed at the North Caucasian Institute of Mining and Metallurgy in Vladikavkaz, North Ossetia-Alania. The journal is headed by scholars known in Russia and Western Europe for their research on mountain territories and its publications reflect the research agendas of the regional community of scholars working on the North Caucasus. A map of the geographical locations of SDMT contributors reveals that the majority of authors stem from the North Caucasus,

\footnotetext{
${ }^{1}$ Ibid.

${ }^{2}$ Ibid. Source: Own compilation based on The Mountain Research Initiative. "Experts Database and Community". <http://mri.scnatweb.ch/en/people/ expert-database-who-is-who-in-global-change-research-in-mountains $>$. Accessed 25 November 2017.

${ }^{3}$ Most of these scholars are ethnically Russian or Caucasian, in addition to being based in Russia or the North Caucasus.
}

elsewhere within the Russian Federation, and Eastern Europe (see Fig. 2 below).

Research Questions and Methodology

Based on the lack of integration between the two mountain research communities as discussed above, I perform a comparative analysis of these communities as represented by their respective journals. Mountain Research and Development is closely linked to and representative of scholarly work by the global mountain research community - the same community that is active in the MRI and Perth Conferences. Sustainable Development of Mountain Regions is closely linked to and representative of scholarly work by the regional mountain research community on the North Caucasus.

Given the vision of the global mountain research community to engage with regional mountain scholars and to fill the regional and thematic gaps in research foci, I compare the two journals with particular attention to the regional and thematic differences between them. In doing so, I ask:

- Is there any regional overlap? If so, does the overlap have a particular thematic focus?

- What academic disciplines are most and least represented? Where do the social sciences stand?

- What does a particular thematic focus reveal about the way that the academic community conceptualizes the region of its focus (e.g. borders, nature, people, communities)?

- Where could the regional mountain research community benefit from collaboration with scholars from the global mountain research community and vice versa?

I analyze all 32 issues published between 2009 and 2017 in the journal Sustainable Development of Mountain Regions, which has existed since 2009. For the sake of consistency, I likewise take 2009 as a starting point for analyzing all 37 issues published between 2009 and 2017 in the journal Mountain Research and Development, which has existed since 1981. Both journals publish an average of four issues per year. ${ }^{4}$

\footnotetext{
${ }^{4} S D M T$ occasionally publishes three issues in a given year, and $M R D$
} occasionally publishes five or six issues in a given year. 


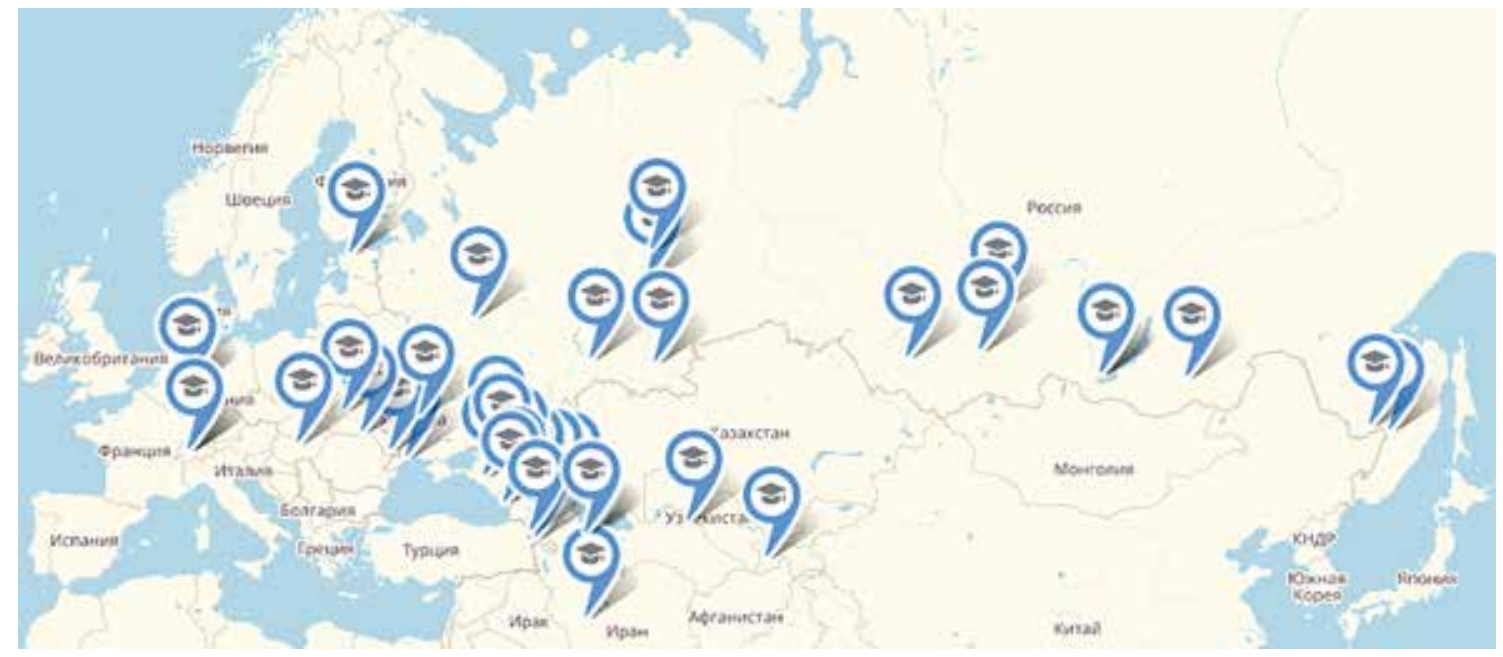

Fig. 2. Geographical Locations of SDMT Authors.

Source: Sustainable Development of Mountain Territories. "The Geography of Authors of the Journal 'Sustainable Development of Mountain Territories". <http://naukagor.ru/en-gb/Geography>. Accessed 25 November 2017.

\section{Mountain Research and Development}

None of the 37 issues published between 2009 and 2017 contained articles that focused on the North Caucasus or Russia. Only two articles published in 2010 and 2016 respectively focused on the mountain regions of Georgia, and another published in 2016 focused on mountainous terrain in the Kyrgyz Republic. Although the articles found in MRD do represent a wealth of regional diversity ${ }^{1}$ in terms of research focus and authorship, I found Russia, the South Caucasus, and Southeast Europe to be one area of regional weakness. MRD is also diverse in terms of authorship. Approximately $70 \%{ }^{2}$ of the articles are coauthored by at least two or more scholars from different institutions located in different countries. Generally, at least one of the co-authors is located at an institution in the country of study. For example, in one article authored by six scholars on the topic of land use in the Himalayas of Eastern Nepal, one of the scholars is based in Nepal, two are based in the United States, one is based in the United Kingdom, and two are based in Switzerland (Garrard et al. 2016). Contributors to MRD articles are affiliated not only with universities and institutions of higher education but also with international bodies such as the United Nations and European Commission, as well as NGOs, research institutes, national associations, and consulting companies.

Although scholars from a variety of disciplines have contributed to MRD, a disparity in representation still exists. Some of the most represented disciplines across all issues include geology, geography, (human) ecology, (geo)botany, biology, forest and water management, forestry, environmental sciences, chemical sciences, soil

\footnotetext{
${ }^{1}$ Including countries such as China, Belgium, United States, United Kingdom, Australia, New Zealand, The Netherlands, Italy, Pakistan, Nepal, Austria, Bhutan, Uganda, Peru, Ethiopia, Germany, Norway, Spain, Czech Republic, Poland, Slovakia, Ukraine, Romania, Switzerland, Thailand, Turkey, Benin, Tajikistan, Afghanistan, India, Mexico, Myanmar, Japan, Ecuador, Guatemala, Philippines, Bolivia, Rwanda, Tibet, and Eritrea.

${ }^{2}$ Based on a calculation of the authorship of all articles published between 2009 and 2017.
}

and water conservation, and agricultural research. Some of the less represented disciplines include economics, anthropology, political science, sociology, history, philosophy, linguistics, religion, and archaeology. Although scholars from the social sciences and humanities make regular and visible contributions to $\mathrm{MRD}$, they remain underrepresented. And despite high levels of co-authorship, most collaboration occurs along disciplinary lines (e.g. geographers collaborating with geographers from other institutions and countries).

Most articles have a regional or country focus and center on issues such as resource management, tourism, species diversity, climate change impacts, hydrology, irrigation, democracy, governance, community livelihoods, protected areas, biodiversity, land reform, and environmental change. Occasionally, articles take a global focus and discuss mountain environments in general on topics such as forest science and forest policy, or climate change adaptation strategies in mountain communities. MRD's issues vary in their format between an "open issue" that touches on a variety of themes, and a "special issue" or "focus issue" 3 that centers on a particular topic such as biodiversity, gender and sustainable development, family farming in mountain regions, and water governance in mountains. Despite existing overrepresentation of certain disciplines, MRD nevertheless maintains diversity in the thematic and regional focus of its articles. In an open issue, it is not uncommon to see articles such as "Regional Assessment of Recharge Elevation of Tap Water Sources Using the Isoscape Approach", "Habitat Ecology of Ophiocordyceps sinensis in Western Nepal", "Albertine Rift Conservation Society Network: A Sustainable Mountain Development Hub for Africa", "Asian Sacred

\footnotetext{
${ }^{3}$ Although both the special issues and the focus issues center on a particular topic, the focus issues tend to have a more practical application than the special issues. For example, the topic of the latest focus issue from August 2017 is "Mountain Forests and the United Nations' Sustainable Development Goals".
} 
Natural Sites: Philosophy and Practice in Protected Areas and Conservation", and "Linking Up the Alps: How Networks of Local Political Actors Build the Pan-Alpine Region". ${ }^{1}$ Such publications demonstrate the thematic and regional diversity that the global mountain research community aims to promote and further expand, as the MRD mission statement also reflects: ${ }^{2}$

The overall mission of Mountain Research and Development is to foster sustainable development in mountains by supporting peer-reviewed interdisciplinary, disciplinary, and transdisciplinary research on mountains, developing scientific capacity, capitalizing on development experiences, promoting policy dialogue, and strengthening networks within the mountain community.

\section{Sustainable Development of Mountain Territories}

In comparison to the $M R D$ mission statement, SDMT "illuminates fundamental and applied regional, national and international research and provides a platform to publish original full papers and related reviews in the following areas: engineering, earth science, economic science in the field of sustainable development of mountain territories". ${ }^{3}$ As this statement indicates, contributors to $S D M T$ stem largely from engineering, technical, and natural science disciplines, which results in research and publications focused largely on geoenvironmental and engineering aspects of mountainous terrain that discuss the ability to exploit the natural resources found in this terrain and to build man-made infrastructures upon it. Outlier articles include research by scholars in medicine, economics, tourism studies, human geography, anthropology, political science, sociology, history, philosophy, linguistics, religion, and archaeology.

Unlike $M R D, S D M T$ has a dominant regional focus on the North Caucasus. SDMT began bilingual EnglishRussian publication with Volume 7, Number 1 in 2015, ${ }^{4}$ and since then the journal has published a handful of publications on regions other than the North Caucasus, such as the European Alps or the Ukrainian Carpathians. A slight amount of regional overlap between the two journals does exist within this handful of articles focused on regions other than the North Caucasus, but where this regional overlap does exist there is little to no thematic overlap. Such a small number of overlapping articles

\footnotetext{
These articles were published in the May 2017, Volume 37 Open Issue of MRD.

${ }^{2}$ Mountain Research and Development. "Mission and aims". <http://www. mrd-journal.org/about.asp>. Accessed 25 November 2017.

3 Sustainable Development of Mountain Territories. "Editorial policy". $<$ http://naukagor.ru/en-gb/about/structuremagazine $>$. Accessed 25 November 2017.

${ }^{4}$ I would assume but need to verify that bilingual publication began in an effort to increase the international visibility and reach of SDMT. The bilingual format includes a cover page and table of contents in both Russian and English, and an English or Russian abstract of each article, depending on the language of the original article (e.g. if the article is written in Russian, the abstract is written in English and vice versa).
}

are ultimately insignificant and provide too little data to draw any conclusions about similarities and differences in regional and thematic approaches.

Given the insular nature of the regional mountain research community as evident by its lack of overlap with $M R D$ and its low level of engagement with the global mountain research community through the MRI and the Perth Conferences, I now take a closer look at the thematic foci of the articles published in SDMT and examine what these research agendas reveal about the way that this regional academic community conceptualizes the North Caucasus with regard to its borders, natural environment, people, and communities.

As discussed above, the SDMT's thematic foci revolve much more around the natural, technical, and engineering sciences than the thematic foci of the $M R D$, which - while still prone to unequally representing certain academic disciplines - are comparatively more balanced and representative of a number of disciplinary approaches. A common theme across SDMT issues is the question of how scientific knowledge of geological and geographical phenomenon can be utilized to exploit the natural mountain environment for human use. The authors often use economic development to justify this exploitation, which includes the following forms: extraction of mineral and other natural resources, ${ }^{5}$ installation of man-made infrastructures, and exploitation of the nature for the purposes of tourism and recreation.

Articles in SDMT often do not make note of internal borders within the North Caucasus. Again, this is related to the fact that SDMT's contributing scholars stem primarily from the engineering, technical, and natural science disciplines. Scholars from these disciplines often do not delineate the internal regional borders of the North Caucasus or consider the social, political, and historical factors that contributed to the formation of these borders. Instead, the maps display the entire region as one and delineate it only according to the geological, technical, or other phenomenon under examination. An example of this type of delineation and appears in an article co-authored by physical geologists on the topic of "Geochemical fields of rocks and soils of the Greater Caucasus: An evolutionary approach and research methods" (Degtyareva et al. 2017).

In contrast, scholars who publish in SDMT from underrepresented disciplines including economics, anthropology, political science, sociology, history, philosophy, linguistics, religion, and archaeology more readily acknowledge regional, ethnic, and linguistic borders in their publications. An example of this attention to internal borders appears in an article published by an economist on the topic of "Mountain Territories of the Republic of Dagestan: Economic Potential and Development Institutions" (Askerov 2016). A focus on

\footnotetext{
${ }^{5}$ Such as mining, oil extraction, and freshwater extraction.
} 
the mountainous territory while ignoring regional borders is problematic in this region, which has a long history of interethnic tensions and territorial disputes. Such a history grants great importance to the borders existing within the region and these should not be swept aside, regardless of how irrelevant the scholar deems attention to these borders to be for her research.

\section{Conclusion}

The above discussion of scholarly contributions to SDMT highlights an ongoing imbalance in contributions across disciplines. To break away from this approach, the regional mountain research community could benefit immensely from contributions and interdisciplinary collaboration with scholars from the social sciences and humanities. Scholarship from these disciplines would reinsert the human-environmental relationship into the equation. Currently, none of the articles that focus on the various forms of exploitation discussed above reflect deeply on how communities might be affected by these plans. What benefits and drawbacks will the extraction of mineral and other natural resources, the installation of man-made infrastructures, or the exploitation of nature for the purposes of tourism and recreation have for communities and individuals living in the areas where such plans will be carried out? How will their environment be altered in the process? Who is implementing and carrying these plans out (e.g. the Russian state, a private stakeholder, or a joint public-private stakeholder), and how will any conflicts that arise between the actors pursuing these plans and the communities affected by them be mediated? Anthropology is particularly well suited to engage with these questions at the local level by use of ethnographic field methods and through its holistic approach to understanding the human condition.

This analysis also reveals the need for greater engagementwith theglobalmountain researchcommunity. Such collaboration would prove advantageous for both. The regional mountain research community would benefit from collaboration with global mountain research scholars from the humanities and social sciences if it

\section{REFERENCES:}

1. Alessa Lilian, Andrew Kliskey, James Gosz, David Griffith and Amber Ziegler. 2018. MtnSEON and Social-Ecological Systems Science in Complex Mountain Landscapes. Frontiers in Ecology and the Environment 16(S1): S4-S10. DOI: $10.1002 /$ fee. 1753 .

2. Askerov N.S. 2016. Mountain Territories of the Republic of Dagestan: Economic Potential and Development Institutions. Sustainable Development of Mountain Territories, 8(4), 338-347. DOI: 10.21177/1998-4502-2016- 8-4-338-347 (in Russian).

3. Björnsen Gurung, Astrid, Susanne Wymann von Dach, Martin F. Price, R. Aspinell, Jörg Balsiger, Jill S. Baron, seeks to fill its disciplinary and thematic void, while the global mountain research community would benefit from collaboration with scholars who work on a region that is greatly underrepresented in the global mountain research community, thus helping the global mountain research community to fill this regional void.

Much further research remains that could not be addressed within the space allotted in this paper. First, a larger and more detailed data set of the scholars publishing in each journal that tracks each scholar's engagement in the global mountain research community would provide greater insight into current collaboration. This paper only tracked the engagement of scholars that serve on each journal's managerial and editorial boards. Second, deeper research should be conducted to identify informal crossdisciplinary and cross-regional collaboration occurring at the bilateral level, for example between scholars from specific universities and countries. A great deal of collaboration may already exist at this level between the two research communities, which is simply not apparent in a database or elsewhere. Third, further research is required to clarify the following questions: Does the MRI community and experts database contain accurate information, or is it outdated? Why did the SDMT begin publication in 2009? Fourth, given that $M R D$ is housed at the Center for Development and Environment at the University of Bern in Switzerland, and that the SDMT is housed at the North Caucasian Institute of Mining and Metallurgy in Vladikavkaz, the Republic of North Ossetia-Alania, it would be interesting to examine how each journal's home institution has or has not influenced its geographical and thematic foci. Fifth and finally, despite some linkage between Russian mountain scholars and the international mountain research community, the relationship remains weak. What are the reasons for this, and what factors can contribute to forging a stronger regional and global relationship? Identifying these points is a crucial step towards understanding how to more effectively develop long-lasting international and interdisciplinary connections in the future.

Eklabya Sharma, G. Greenwood, Thomas Kohler. 2012 Global Change and the World's Mountains-Research Needs and Emerging Themes for Sustainable Development. Mountain Research and Development 32(S1):S47-S54. DOI: http:// dx.doi.org/10.1659/MRD-JOURNAL-D-11-00084.S1.

4. Degtyareva T. V., V. A. Shalnev, and A. V. Lysenko. 2017. Geochemical fields of rocks and soils of the Greater Caucasus: An evolutionary approach and research methods. Sustainable Development of Mountain Territories, 9(3), 219-232. DOI: 10.21177/1998-4502-2017-9-3-219-232 (in Russian).

5. Gardner, James S. and Julie Dekens. 2007. Mountain Hazards and the Resilience of Social-Ecological Systems: Les- 
sons Learned in India and Canada. Natural Hazards 41:317336. DOI: $10.1007 / \mathrm{s} 11069-006-9038-5$.

6. Garrard Rodney, Thomas Kohler, Martin F. Price, Alton C. Byers, Ang Rita Sherpa, and Gyanu Raja Maharjan. 2016. Land Use and Land Cover Change in Sagarmatha National Park, a World Heritage Site in the Himalayas of Eastern Nepal. Mountain Research and Development, 36(3):299-310. DOI: https://doi.org/10.1659/MRD-JOURNAL-D-15-00005.1.

7. Gleeson Erin H., Susanne Wymann von Dach, Courtney G. Flint, Gregory B. Greenwood, Martin F. Price, Jörg Balsiger, Anne Nolin, and Veerle Vanacker. 2016. Mountains of our Future Earth: Defining Priorities for Mountain ResearchA Synthesis From the 2015 Perth Conference. Mountain Research and Development, 36(4):537-548. DOI: https://doi. org/10.1659/MRD-JOURNAL-D-16-00094.1.

8. Greenwood Gregory B. 2013. Mountain Research Initiative Seeks to Break New Ground in Second Decade. Mountain Research and Development 33(4):473-476. DOI: https://doi. org/10.1659/MRD-JOURNAL-D-13-00094.1.

9. Greif Avner and Christopher Kingston. 2011. Institutions: Rules or Equilibria? In: Schofield, Norman and Gonzalo Caballero, eds. Political Economy of Institutions, Democracy and Voting. New York: Springer.

10. Gunya Alexey N. 2015. Socially-Oriented Concepts and Approaches in the Caucasus Mountain Research and Sustainable Development. Sustainable Development of Mountain Territories 3(25):15-22 (in Russian).

11. Gunya Alexey N., Gayrabekov Y.T., Karaev Y.I. , and Chechenov A.M. 2016. Modernization in the North Caucasus: How Do Modern Social-Economic and Political Changes Affect the Life of the Local Population? Sustainable Developent of Mountain Territories 8(4):356-386. DOI: 10.21177/19984502-2016-8-4-312-322 (in Russian).

12. Gunya Andrey N. and Miskarova R. 2017. Socio-Anthropological Approach to the Assessment of the Development of the Mountainous Area: An Example of the Elbrus Region. Proceedings of the VGI. 2017. Vol. 100. Pp. 167-172 (in Russian).

13. Hand Brian K., Courtney G. Flint, Chris A. Frissell, Clint C. Muhlfeld, Shawn P. Devlin, Brian P. Kennedy, Robert L. Crabtree, W. Arthur McKee, Gordon Luikart, and Jack A. Stanford. 2018. A Social-Ecological Perspective for Riverscape Management in the Columbia River Basin. Frontiers in Ecology and the Environment 16(S1):S23-S33. DOI: 10.1002/fee. 1752 .

14. Koehler Jan, Alexey Gunya, Tenov T., and Chechenov A. 2017. An Institutionally-Oriented Study of the Problems of Sustainable Mountain Development. Sustainable Development of Mountain Territories 9(2):152-162. DOI: 10.21177/19984502-2017-9-2-152-162 (in Russian).

15. Kohler Thomas, Jörg Balsiger, Gilles Rudaz, Bernard Debarbieux, J. Pratt, D. Maselli. 2012. Green Economy and Institutions for Sustainable Mountain Development: From Rio 1992 to Rio 2012 and Beyond. Bern, Switzerland: Centre for Development and Environment, Swiss Agency for Development and Cooperation, University of Geneva, and Geographica Bernensia.

16. Lang Daniel J., Arnim Wiek, Matthias Bergmann, Michael Stauffacher, Pim Martens, Peter Moll, Mark Swilling, Christopher J. Thomas. 2012. Transdisciplinary Research in Sustainability Science: Practice, Principles, and Challenges.
Sustainability Science 7(S1):25-43. DOI: 10.1007/s11625011-0149-x.

17. Messerli, Bruno. 2012. Global change and the World's Mountains. Where Are We Coming From, and Where Are We Going To? Mountain Research and Development 32(S1):S55S63. DOI: https://doi.org/10.1659/MRD-JOURNALD-11-00118.S1. Accessed 02 November 2017.

18. Mountain Research and Development. Selected publications from 2009-2017. URL: http://www.bioone.org/loi/ mred. Accessed 11 November 2017.

19. North, Douglass. 1990. Institutions, Institutional Change and Economic Performance. Cambridge, UK: Cambridge University Press.

20. Ostrom, Elinor. 2009. A general framework for analyzing sustainability of social- ecological systems. Science 325(5939):419-422. DOI: 10.1126/science.1172133.

21. Schmidt, Matthias. 2017. Human Geography of PostSocialist Mountain Regions. Journal of Alpine Research 105(1):1-7. URL: http://rga.revues.org/3573. Accessed 25 November 2017.

22. Stember, Marilyn. 1991. Presidential Address Advancing the Social Sciences Through the Interdisciplinary Exercise. The Social Science Journal 28(1):1-14.

23. Sustainable Development of Mountain Territories. Selected publications from 2009-2017. URL: http://naukagor.ru/ en-gb/about/allissues. Accessed 23 November 2017.

24. Tucker, Catherine M., ed. 2012. Nature, Science, and Religion: Intersections Shaping Society and the Environment. Santa Fe, NM: School for Advanced Research Press.

25. Tucker, Catherine M. 2008. Changing Forests. Collective Action, Common Property, and Coffee in Honduras. New York: Springer.

26. United Nations General Assembly. 2015. Transforming Our World: The 2030 Agenda for Sustainable Development. Resolution adopted by the General Assembly on 25 September 2015. URL: http://www.un.org/ga/search/view_doc. asp?symbol=A/RES/70/1\&Lang=E. Accessed 02 November 2017.

27. Weingartner, Rolf and Alexey Gunya. 2016. The Value of Mountains and the Need for Active Participation in the International Mountain Programmes. Sustainable Development of Mountain Territories 2(8):120-126. DOI: 10.21177/19984502-2016-8-2-120-126. 


\title{
СВЕДЕНИЯ ОБ АВТОРАХ / Information about authors:
}

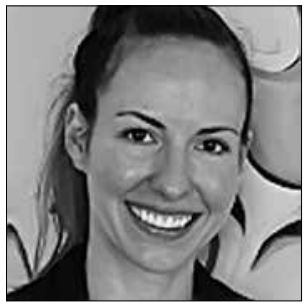

Le Jeune, Christine Marie - M.A., currently a Ph.D. candidate in anthropology at the University of Florida.

Address: Gainesville, Florida, 32611, United States

E-mail: cmlejeune@ufl.edu

Ле Жен, Кристин Мари - М.А., докторант по антропологии в Университете Флориды.

Адрес: Гейнсвилль, Флорида, 32611, США

E-mail: cmlejeune@ufl.edu

\section{СРАВНИТЕЛЬНЫЙ АНАЛИЗ ДВУХ ГОРНЫХ ИССЛЕДОВАТЕЛЬСКИХ СООБЩЕСТВ: МЕЖДИСЦИПЛИНАРНЫЕ И МЕЖДУНАРОДНЫЕ ПОВЕСТКИ ДНЯ}

\author{
Ле Жен, Кристин М. \\ Факультет антропологии, Университет Флориды, Гейнсвилл, США
}

\section{DOI: $10.21177 / 1998-4502-2018-10-1-97-107$}

Чтобы понять, как антропология может способствовать горным исследованиям на Северном Кавказе, в статье анализируются научно-исследовательские программы регионального российского горного научно-исследовательского сообщества и более крупного глобального сообщества горных исследований. Для проведения этого анализа в статье определены два рецензируемых журнала открытого доступа, которые представляют эти две группы ученых: «Горные исследования и разработки и устойчивое развитие горных территорий». Сравнение горных исследований, представленных в этих журналах, предлагает сжатый и сопоставимый формат для изучения и анализа исследовательских программ. В статье впервые обсуждается методологический переход к большей междисциплинарности в рамках глобального сообщества горных исследований. Этот сдвиг произошел, когда ученые, изучающие сложные горные ландшафты, поняли, что для изучения вопросов глобальных изменений необходимо изучать как человеческие, так и природные элементы, которые взаимодействуют и влияют друг на друга в динамичных социально-экологических отношениях.

Затем в статье рассматривается степень, в которой каждое исследовательское сообщество проводит междисциплинарную исследовательскую программу и международное научное сотрудничество. Анализ участия в международных и междисциплинарных сетях и журналах горных исследований показывает, что российские ученые имеют низкий уровень участия. Кроме того, публикации этих ученых сосредоточены прежде всего на естественных, технических и инженерных науках, практически не имеющих сотрудничества со стороны социальных наук. Статья завершается замечаниями о том, как неспособность учитывать социальные элементы может быть проблематичной и рекомендациями для первых шагов по более эффективному развитию долгосрочных международных и междисциплинарных связей в будущем. Вывод также ставит вопросы для будущих исследований, которые не могут быть рассмотрены в рамках статьи.

Ключевые слова: горные исследования, антропология, социальные науки, естественные науки, социально-экологические системы, междисциплинарность, программа исследований

\section{Литература}

1. Alessa Lilian, Andrew Kliskey, James Gosz, David Griffith, Amber Ziegler. 2018. MtnSEON and Social-Ecological Systems Science in Complex Mountain Landscapes // Frontiers in Ecology and the Environment 16(S1):S4-S10. DOI: $10.1002 /$ fee. 1753 .

2. Аскеров Н. С. Горные территории Республики Дагестан: экономический потенциал и институты развития // Устойчивое развитие горных территорий. 2016. T. 8(4). C. 338-347. DOI: 10.21177/1998-4502-20168-4-338-347

3. Björnsen Gurung, Astrid, Susanne Wymann von Dach, Martin F. Price, R. Aspinell, Jörg Balsiger, Jill S. Baron, Eklabya Sharma, G. Greenwood, Thomas Kohler. 2012. "Global Change and the World's Mountains-Research Needs and Emerging Themes for Sustainable Development". Mountain Research and Development 32(S1):S47-S54. DOI: http://dx.doi.org/10.1659/MRD-JOURNAL-D-11-00084.S1.

4. Дегтярева Т.В., Шальнев В.А., Лысенко А.В. Геохимические поля скал и почв Большого Кавказа: эволюционный подход и методы исследования // Устойчивое развитие горных территорий. 2017. Т. 9(3). C. 219-232. DOI: 10.21177/1998-4502-2017-9-3-219-232

5. Gardner, James S. and Julie Dekens. 2007. "Mountain Hazards and the Resilience of Social-Ecological Systems: Lessons Learned in India and Canada". Natural Hazards 41: 317-336. DOI: 10.1007/s11069-006-9038-5.

6. Garrard Rodney, Thomas Kohler, Martin F. Price, Alton C. Byers, Ang Rita Sherpa, and Gyanu Raja Maharjan. 2016. "Land Use and Land Cover Change in Sagarmatha National Park, a World Heritage Site in the Himalayas of Eastern Nepal". Mountain Research and Development, 36(3):299-310. DOI: https://doi.org/10.1659/MRD-JOURNAL-D-15-00005.1.

7. Gleeson, Erin H., Susanne Wymann von Dach, Courtney G. Flint, Gregory B. Greenwood, Martin F. Price, Jörg Balsiger, Anne Nolin, and Veerle Vanacker. 2016. "Mountains of our Future Earth: Defining Priorities for Mountain Research-A Synthesis From the 2015 Perth Conference". Mountain Research and Development, 36(4): 537-548. DOI: https://doi.org/10.1659/MRD-JOURNAL-D-16-00094.1.

8. Greenwood, Gregory B. 2013. "Mountain Research 
Initiative Seeks to Break New Ground in Second Decade". Mountain Research and Development 33(4):473-476. DOI: https://doi.org/10.1659/MRD-JOURNAL-D-13-00094.1.

9. Greif, Avner and Christopher Kingston. 2011. "Institutions: Rules or Equilibria?". In: Schofield, Norman and Gonzalo Caballero, eds. Political Economy of Institutions, Democracy and Voting. New York: Springer.

10. Гуня А.Н. Социально ориентированные понятия и подходы при исследовании гор Кавказа и устойчивое развитие // Устойчивое развитие горных территорий. 2015. T. 3(25). C.15-22.

11. Гуня А.Н., Гайрабеков Ю.Т., Караев Ю.И., Чеченов А.М. Модернизация на Северном Кавказе: как современные социально-экономические и политические изменения влияют на жизнь местного населения? // Устойчивое развитие горных территорий. 2016. Т. 8(4). С. 356-386. DOI: 10.21177/1998-4502-2016-8-4-312-

12. Гуня А.Н., Мискарова Р. Социо-антропологический подход к оценке развития горных территорий: на примере региона Эльбруса: Материалы ВГИ. 2017. Вып. 100. С. 167-172

13. Hand, Brian K., Courtney G. Flint, Chris A. Frissell, Clint C. Muhlfeld, Shawn P. Devlin, Brian P. Kennedy, Robert L. Crabtree, W. Arthur McKee, Gordon Luikart, and Jack A. Stanford. 2018. "A Social-Ecological Perspective for Riverscape Management in the Columbia River Basin". Frontiers in Ecology and the Environment 16(S1):S23-S33. DOI: 10.1002/fee. 1752 .

14. Кехлер Ян, Гуня А., Тенов Т. и Чеченов А. " Институционно-ориентированное изучение проблем устойчивого развития горных территорий" // Устойчивое развитие горных территорий. 2017. Т. 9(2). С.152-162. DOI: $10.21177 / 1998-4502-2017-9-2-152-162$

15. Kohler, Thomas, Jörg Balsiger, Gilles Rudaz, Bernard Debarbieux, J. Pratt, D. Maselli. 2012. "Green Economy and Institutions for Sustainable Mountain Development: From Rio 1992 to Rio 2012 and Beyond”. Bern, Switzerland: Centre for Development and Environment, Swiss Agency for Development and Cooperation, University of Geneva, and Geographica Bernensia.

16. Lang, Daniel J., Arnim Wiek, Matthias Bergmann, Michael Stauffacher, Pim Martens, Peter Moll, Mark Swilling, Christopher J. Thomas. 2012. "Transdisciplinary Research in Sustainability Science: Practice, Principles, and Challenges". Sustainability Science 7(S1):25-43. DOI: 10.1007/s11625-011-0149-x.
17. Messerli, Bruno. 2012. "Global change and the World's Mountains. Where Are We Coming From, and Where Are We Going To?". Mountain Research and Development 32(S1):S55-S63. DOI: https://doi.org/10.1659/ MRD-JOURNAL-D-11-00118.S1. Accessed 02 November 2017.

18. Mountain Research and Development. Selected publications from 2009-2017. URL: http://www.bioone.org/loi/ mred. Accessed 11 November 2017.

19. North, Douglass. 1990. Institutions, Institutional Change and Economic Performance. Cambridge, UK: Cambridge University Press.

20. Ostrom, Elinor. 2009. "A general framework for analyzing sustainability of social- ecological systems". Science 325(5939):419-422. DOI: 10.1126/science.1172133.

21. Schmidt, Matthias. 2017. "Human Geography of Post-Socialist Mountain Regions". Journal of Alpine Research 105(1):1-7. URL: http://rga.revues.org/3573. Accessed 25 November 2017.

22. Stember, Marilyn. 1991. "Presidential Address Advancing the Social Sciences Through the Interdisciplinary Exercise". The Social Science Journal 28(1):1-14.

23. Sustainable Development of Mountain Territories. Selected publications from 2009-2017. URL: http://naukagor. ru/en-gb/about/allissues. Accessed 23 November 2017.

24. Tucker, Catherine M., ed. 2012. Nature, Science, and Religion: Intersections Shaping Society and the Environment. Santa Fe, NM: School for Advanced Research Press.

25. Tucker, Catherine M. 2008. Changing Forests. Collective Action, Common Property, and Coffee in Honduras. New York: Springer.

26. United Nations General Assembly. 2015. "Transforming Our World: The 2030 Agenda for Sustainable Development". Resolution adopted by the General Assembly on 25 September 2015. URL: http://www.un.org/ga/search/ view_doc.asp?symbol=A/RES/70/1\&Lang=E. Accessed 02 November 2017.

27. Weingartner, Rolf and Alexey Gunya. 2016. "The Value of Mountains and the Need for Active Participation in the International Mountain Programmes". Sustainable Development of Mountain Territories 2(8):120-126. DOI: 10.21177/1998-4502-2016-8-2-120-126.

Article recived 29.10.2017 


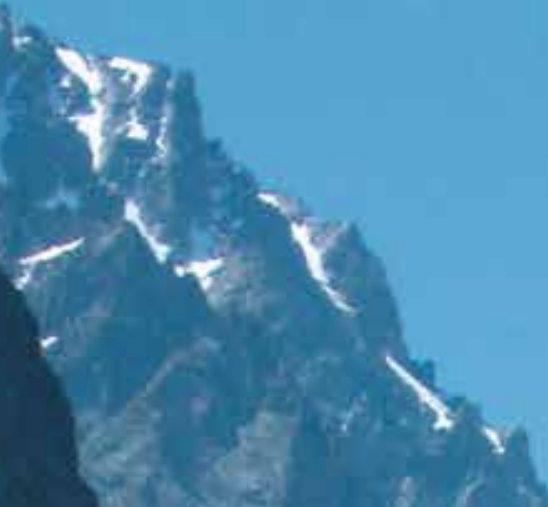

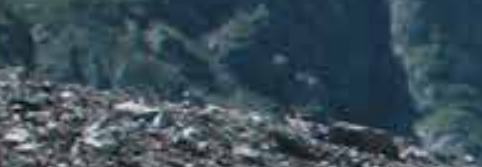

W.

S.

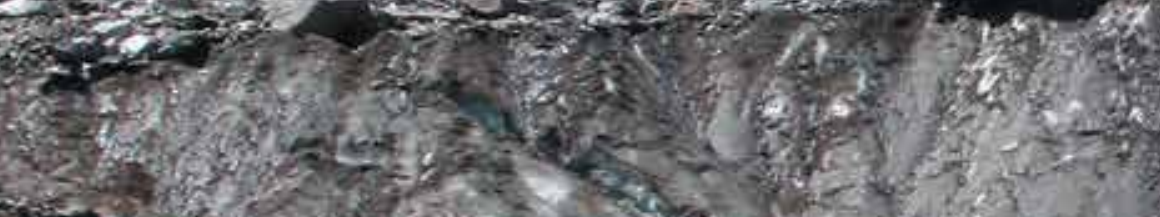

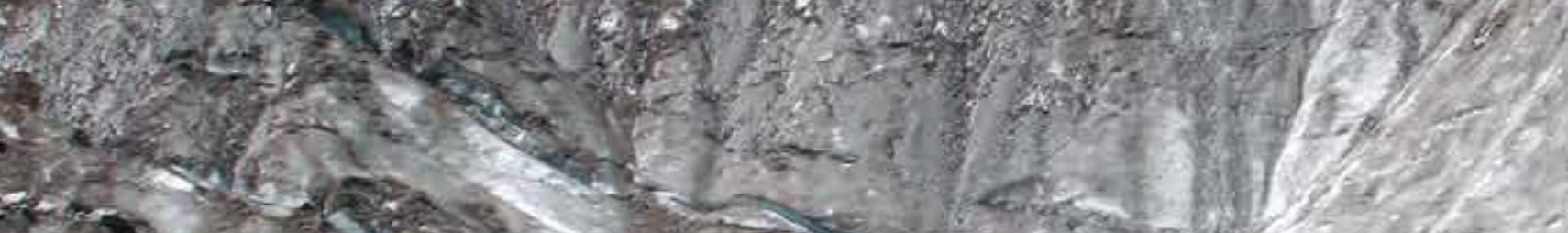

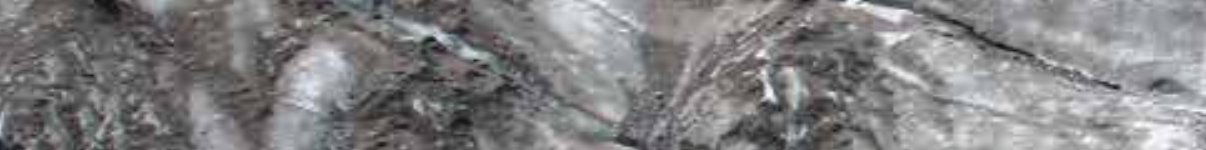

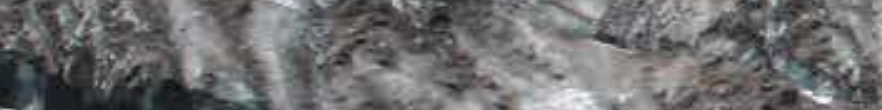
is.

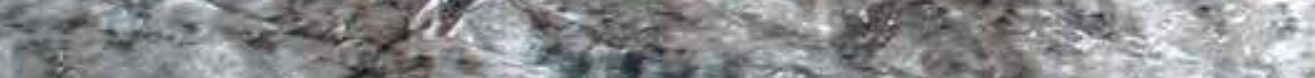
is

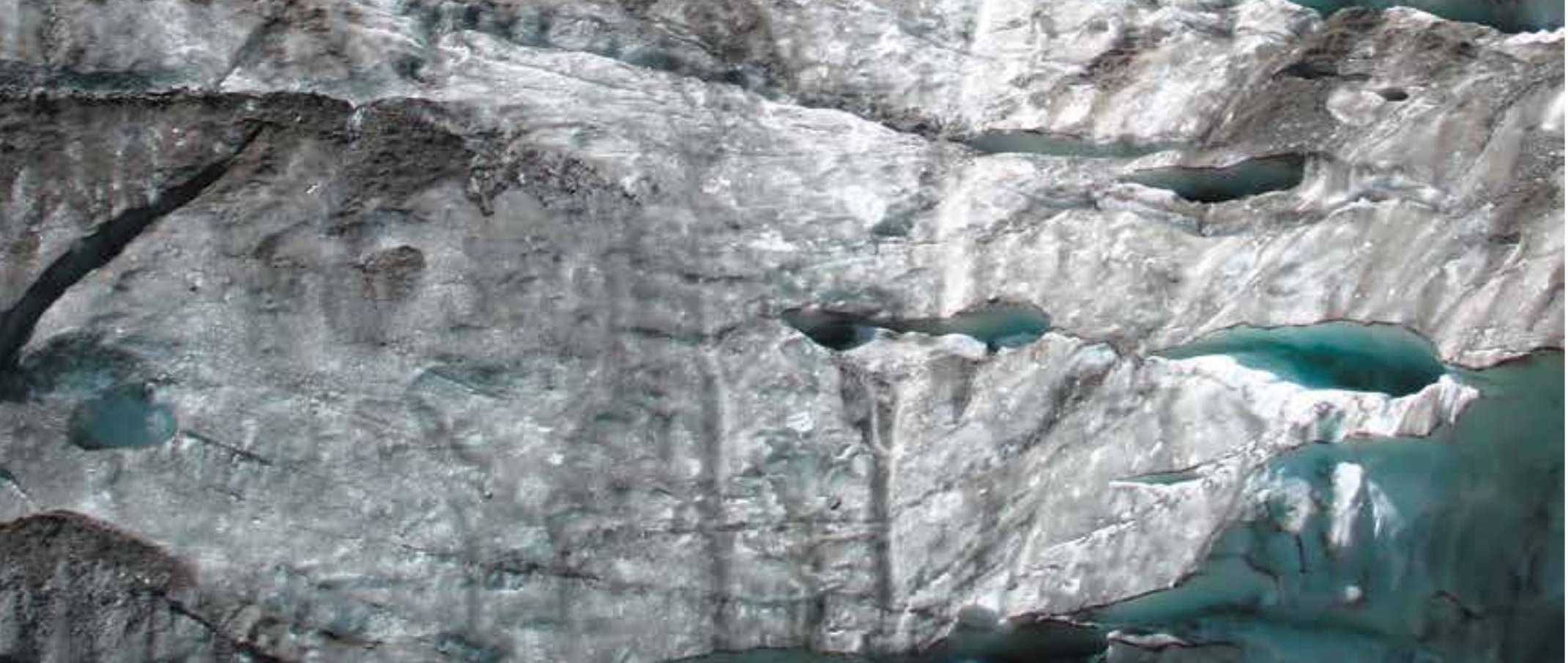

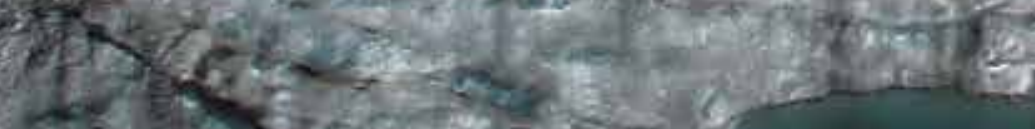




\title{
ТЕХНИЧЕСКИЕ НАУКИ
}

\author{
ENGINEERING
}

Если бы я захотел читать, ещее не зная букв, это было бы бессмыслицей.

Точно так же, если бы я захотел судить о явлениях природы,

не имея никакого представления о началах вещей, это было бы такой же бессмыслицей.

Михаил ЛОМОНОСОВ

\section{ОСНОВА УСТОЙЧИВОГО РАЗВИТИЯ РСО-АЛАНИЯ - ГОРНОДОБЫВАЮЩАЯ ОТРАСЛЬ}

История промышленной разработки Садонских месторождений насчитывает почти 200 лет. Все это время рудовмещающие породы сохраняли от обрушения путем оставления рудных целиков, частичное извлечение которых сопровождалось примешиванием пустых пород к руде или разубоживанием руд [1-3].

При обогащении руд из горной массы извлекалась только часть пород, а остальная часть вместе с рудными частицами составляла «хвосты», которые со временем превратились в техногенные месторождения.

Со временем на Садонских рудниках накопилось около 7 млн. т хвостов, которые стали постоянно действующим реактором химических процессов заражения окружающей среды не только региона РСО-Алания, но и прилегающих регионов Кавказа, Юга России и Каспия.

Попытки изменить технологию разработки месторождений, в том числе, и переработки хвостов, сдерживаются не только экономическими соображениями, но и неспособностью традиционных технологий обогащения, которые извлекают только целевые для данного месторождения металлы, а остальные отправляются в хвосты.

Проблема безотходной и ресурсосберегающей разработки может быть решена с использованием новых технологий добычи и переработки, сущность которых сводится к следующим положениям:

- добыча богатых руд традиционными технологиями с отправкой на заводскую переработку и закладка пустот твердеющими смесями;

-выщелачивание металлов из бедных руд без извлечения их на земную поверхность и использованием хвостов для поддержания породного массива;

-переработка уже накопленных хвостов с превращением их в товарную продукцию после извлечения металлов и солей технологиями, основанными на механохимической активации с изменением свойств.

Горнодобывающее направление промышленности Осетии когда-то ускорило вхождение ее в семью народов России и всегда определяло ее экономическое состояние. Причиной кризиса горной отрасли послужило то, что

\footnotetext{
${ }^{1}$ Донецкий национальный технический университет, г. Донецк, Донецкая Народная Республика,

*e-mail: borshevskiy@gmail.com

${ }^{2}$ Национальный технический университет, г. Кривой Рог, Украина

${ }^{3}$ Университет горного дела и геологии "Св. Иван Рильский”, г. София, Болгария

${ }^{4}$ Китайский геологический университет, г. Пекин, Китай
}

\author{
'Борщевский С.В., ${ }^{*}$ \\ ${ }^{2}$ Моргун B.C., \\ ${ }^{3}$ Тотев Л., \\ 4Чжун Чан
}

УДК: 504.55.054:622(470.6) DOI: 10.21177/1998-4502-2018-101-109-116

Приведено обоснование необходимости разработки рамочных условий рентабельного производства, которые могут быть положены в основу оздоровления экономики региона, путем обоснования эколого-экономической эффективности технологий охраны окружающей среды посредством утилизации хвостов добычи и переработки руд.

Доказательства включают в себя обобщение и критический анализ публикаций, результаты технологических и экономических исследований, экспертную оценку и научное прогнозирование перспектив развития.

Показано, что снову оздоровления экономики может составить комбинированная технология разработки месторождений с рациональным сочетанием элементов традиционной технологии и новых технологий выщелачивания. Экономика горного производства может быть улучшена созданием смежных производств товарной продукции после извлечения металлов из хвостов выщелачивания руд.

\section{КЛЮЧЕВЫЕ СЛОВА:}

горная отрасль, добыча металлов, технология выщелачивания, регион, конверсия

Статья поступила в редакцию 02.06.2017 
стратегические металлы добывали с дотированием государством, не утруждая себя радикальной модернизацией технологий.

Уменьшить техногенную нагрузку хвостов обогащения на окружающую среду с получением экономического эффекта можно утилизацией хвостов. Но использовать хвосты, например, в строительной индустрии нельзя из-за остаточного содержания в них металлов и серы.

Извлечение целевых компонентов из хвостов нуждается в обосновании технологической возможности и экономической целесообразности с учетом экологических аспектов и рыночных отношений.

Целью исследования экономических и экологических аспектов рассматриваемого направления явля- ется обоснование эколого-экономической эффективности технологий охраны окружающей среды путем утилизации хвостов добычи и переработки руд нетрадиционными методами на основе выщелачивания.

Теоретическое обоснование природоохранности технологий утилизации отходов обогащения достигается решением задач:

- исследование путей устранения опасности окружающей среде;

- анализ возможности использования отходов для строительства;

- установление эквивалентности вяжущих при утилизации отходов;

- исследование параметров природного выщелачивания хвостов;

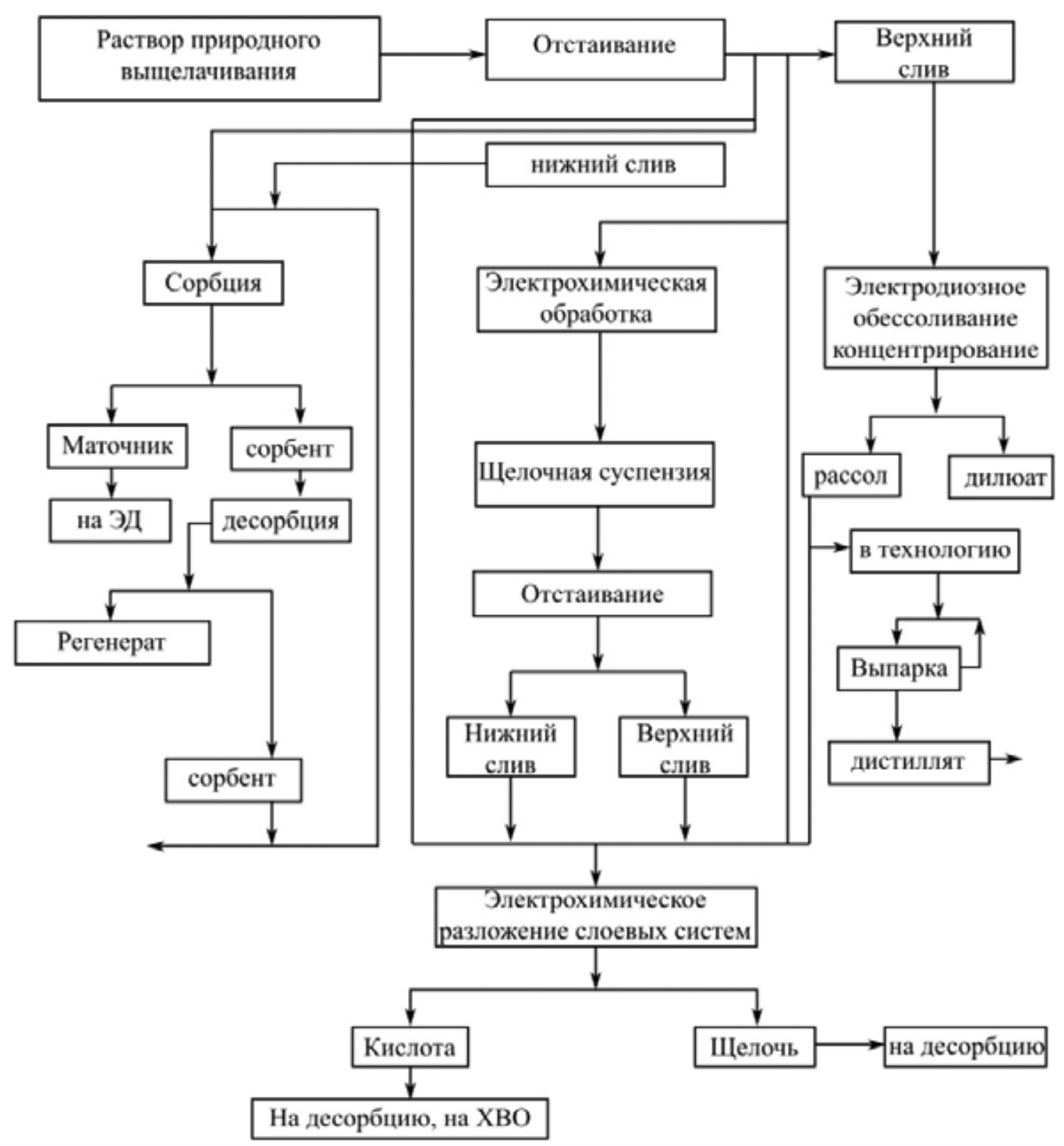

Рис. 1. Схема электрохимического извлечения металлов из раствора /

Fig.1. Scheme of electrochemical extraction of metals from solution 
- разработка эффективных технологий утилизации хвостов.

Для решения поставленных задач используют комплексную методику, основу которой составляют анализ существующего положения, исследование эколого-экономических аспектов утилизации хвостов, прогноз и экспертная оценка.

Создание безотходных технологий утилизацией промежуточных продуктов добычи сталкивается с трудностями. Так, мелкая фракция хвостов обогащения пригодна для строительства в виде щебня и песка, в том числе, для изготовления твердеющих смесей при закладке пустот. Крупная фракция пригодна для использования в виде щебня и гравия. Но использовать содержащие металлы хвосты не только не выгодно экономически, но и опасно. Поэтому успех данного направления зависит от освоения технологии выщелачивания.

На территории Республики Северная Осетия-Алания хранится до 10 млн. тонн хвостов обогащения и металлургического передела 1-4 классов опасности. Проблема накопления отходов минералов соседствует с другой проблемой: дефицитом строительных материалов. Поэтому наличие технологически подготовленного сырья, которое можно утилизировать для строительства, привлекает внимание. Это относится к хвостам обогащения Мизурской обогатительной фабрики, откуда строительные материалы можно легко доставлять на объекты Северной и Южной Осетии, благоустраиваемые в рамках программы "Горы Осетии".

Эксплуатация Садона была начата в 1863 г. За время эксплуатации месторождения потери металлов в добытой руде составили $20 \%$, а разубоживание руды породой - 40\% [4-6]. Кондиции на металл уменьшились за это время на 2 порядка. Повторная разработка месторождения - одна из первых в горной практике СССР была начата в 1942 г. и продолжалась в виде основной деятельности вплоть до полной остановки производства после изменения стратегии производства в 1990 г.

Уменьшение содержания металлов в балансовых рудах и вовлечение в обогащение упорных металлоносных минералов снизило извлечение металла из руд и способствовало росту объемов хвостохранилища, поэтому в свое время возникла проблема строительства второй очереди хвостохранилища для Садонских рудников. Хвостохранилище вблизи реки Ардон не может предотвращать попадание продуктов обогащения в окружающую среду и является предметом проектов его ликвидации.

Теория и практика использования отходов производства разработана трудами академиков Агошкова М.И., Котенко Е.А., Ломоносова Г.Г., Цыгалова М.Н., Шестакова В.А., Остроушко И.А. и многих других [7-9].

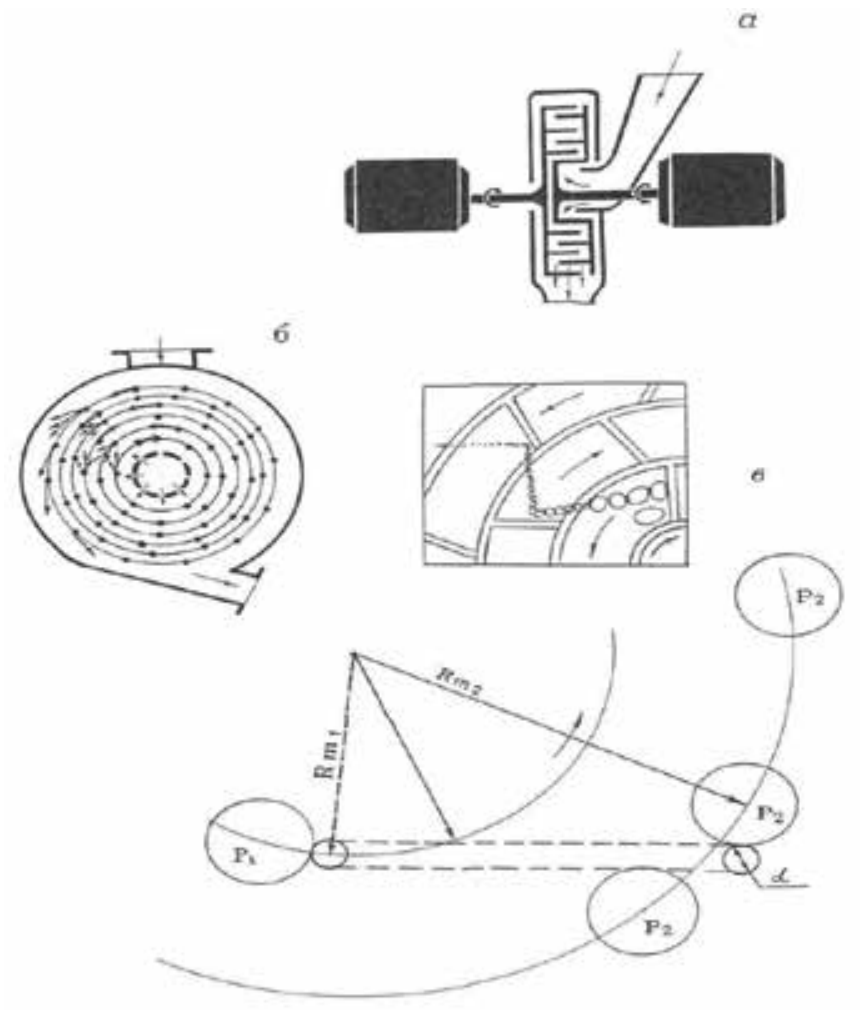

Pис. 2. Схема и принцип работь дезинтеграторной установки: $а$ - схема; б-движение частии в рабочем органе; в-рабочая схема: $P_{1}, P_{2}-$ расстояния между иентрами двух соседних пальцев круга; $R_{m 1}, R_{m 2}-$ радиусы

круга пальцев; $\alpha$-размер частицы обрабатываемого материала /

Fig. 2. Scheme and principle of operation of the disintegrator installation: $a$-scheme; $b$-the movement of particles in the working body; $C$-working scheme: $P_{1}, P_{2}$-the distance between the centers of two adjacent fingers of the circle; $R_{m}, R_{m 2}$-the radius of the finger circle; $\alpha$ - the particle size of the material to be treated

Анализ направлений использования хвостов показывает, что объем их утилизации пока еще мал, при этом основное препятствие для утилизации - низкая активность и остаточное содержание металлов. Большинство хвостов утилизируется без извлечения металлов, что является паллиативным решением.

Теория выщелачивания руд была разработана во второй половине прошлого века. С тех пор она получила развитие при добыче наиболее легко вскрываемых руд золота, урана, меди и других металлов [10-12].

При замене стандартного вяжущего - цемента - активными фракциями хвостов обогащения оптимальное сочетание заполнителя, цемента и добавок находится по критерию прочности при расходе портландцемента с добавкой гранулированных шлаков.

Наиболее трудны для утилизации упорные и многокомпонентные хвосты обогащения. Нами переработано по $1 \mathrm{~m}^{3}$ хвостов каждой из обогатительных фабрик. Из растворов последовательно цинковой пылью и кальцинированной содой осаждали медь, железо, свинец, цинк. 


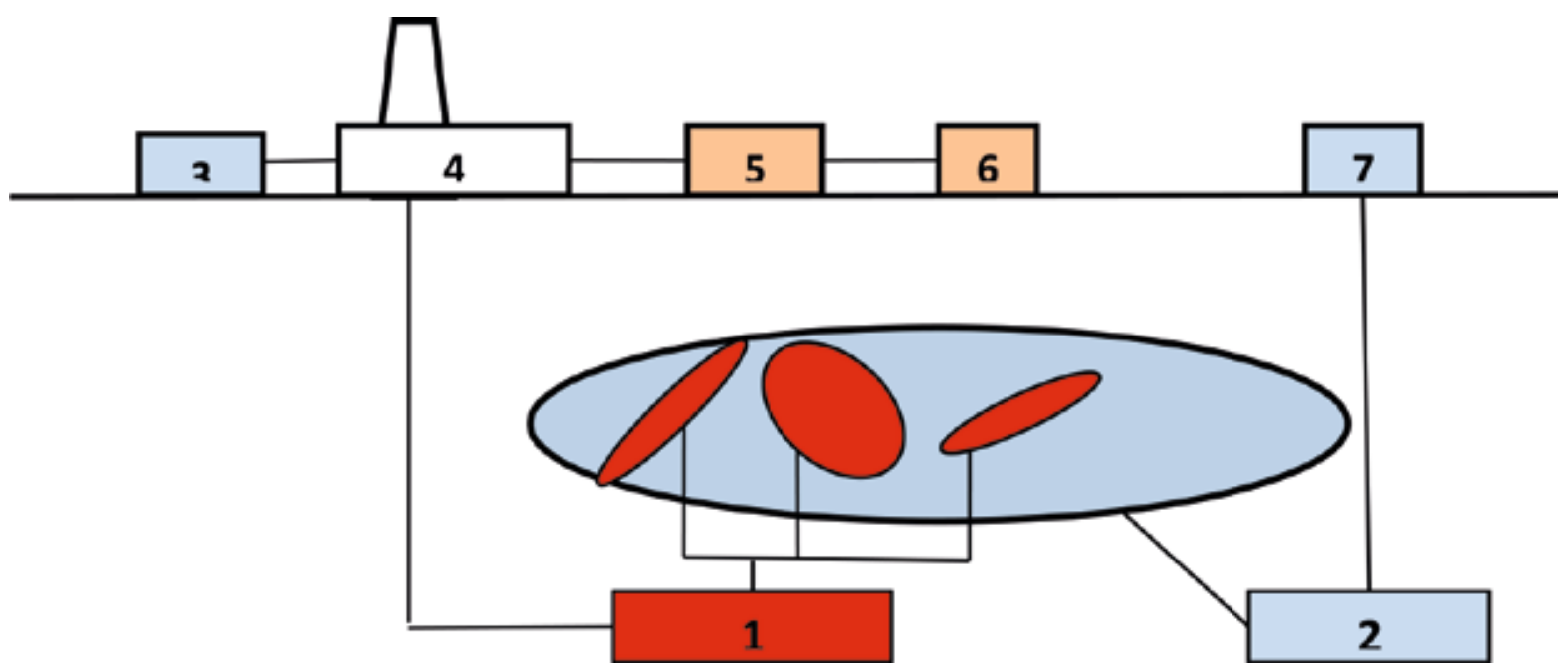

Рис.3. Комбинированная разработка месторождения: 1 - богатые руды; 2 - бедные руды; 3 - куча выщелачивания; 4 рудо-контрольная станщия; 5 - обогатительная станщия; 6-закладочньй комплекс; 7 - цех приготовления растворов реагентов /

Fig. 3. A combined field development: 1 - rich ore; 2 - copper ore; 3 - heap leaching; 4 - rotocontrol station; 5 - processing station; 6 stowing facility; 7 - plant the preparation of solutions of reagents

Соляной кислотой за 60 мин. в раствор переведено: цинка - 100 г, свинца - 30 г, меди - 60 г, железа - 116 г или соответственно - 45, 26, 38 и $12 \%$ исходного металла.

Рабочий орган установки циркуляционно-порционного типа -электродиализатор из пакетов, анионитовых мембран генерирует анолит с $\mathrm{pH} 2$ и окислительно-восстановительным потенциалом 1100-1200 м3, который аналогичен растворам кислот, а католит с $\mathrm{pH}$ 11,4 - растворам щелочей (рис.1).

Эффективность активации оценивается по изменению прочности бетона. Бетон с прежним соотношением вяжущих и заполнителей, в возрасте 28 дней имел прочность уже 2,7 МПа. Эффект приращения активности достиг $20 \%$ по сравнению с базовым значением.

Дезинтегратор представляет собой установку, на станине которой смонтированы двигатели роторов. В корзине дезинтегратора происходит активация процесса выщелачивания металлосодержащих минералов (рис.2).

Установлено, что бетон с заполнителем из хвостов обогащения удовлетворяет строительным требованиям, а хвосты могут служить заполнителем при изготовлении бетонов марки 100 и выше.

Для погашения большинства пустот Садонских месторождений пригодны твердеющие смеси прочностью 0,5-1,5 МПа, причем увеличение прочности смесей оценивается коэффициентом 1,15-1,25.

При одинаковом соотношении и качестве компонентов твердеющей смеси ее прочность при комплексной активации увеличивается на 30-40\%.

Активация хвостов обогащения анолитом электрохимической обработки обеспечивает извлечение до $60 \%$ остаточных металлов, что позволяет использовать хвосты при изготовлении бетонов и твердеющих смесей [13-16].

Природоохранной схемой утилизации является комбинирование традиционных технологий подготовки сырья, технологий активации в быстроходных аппаратах и технологий выщелачивания металлов (рис.3).

Радикальное сокращение объемов хвостов в хранилищах обеспечивается при их выщелачивании в активаторах с извлечением до $60 \%$ металлов и солей, что позволяет использовать вторичные хвосты для изготовления твердеющих смесей прочностью до 1,5 МПа при эквивалентности 4 кг активированных хвостов и 1 кг цемента.

Эффективность технологий утилизации хвостов определяется решением математической модели поражения окружающей среды по экономическому критерию, который зависит от корректности технологий добычи и переработки [17-20].

В ходе исследования установлены адекватные закономерности управляемого технологического выщелачивания хвостов с корреляцией между крупностью хвостов, скоростью выщелачивания и периодичностью процессов вскрытия элементарного куска.

Получены закономерности использования вторичных хвостов для изготовления твердеющих смесей прочностью до 1,5 МПа с использованием феномена эквивалентности активированных хвостов и цемента.

Установлены закономерные связи между экологией горнопромышленного региона и техническим уровнем горного производства и разработан механизм регулирования этих отношений.

Практическая ценность выполняемых для реализации концепции работ состоит в следующем: 
1

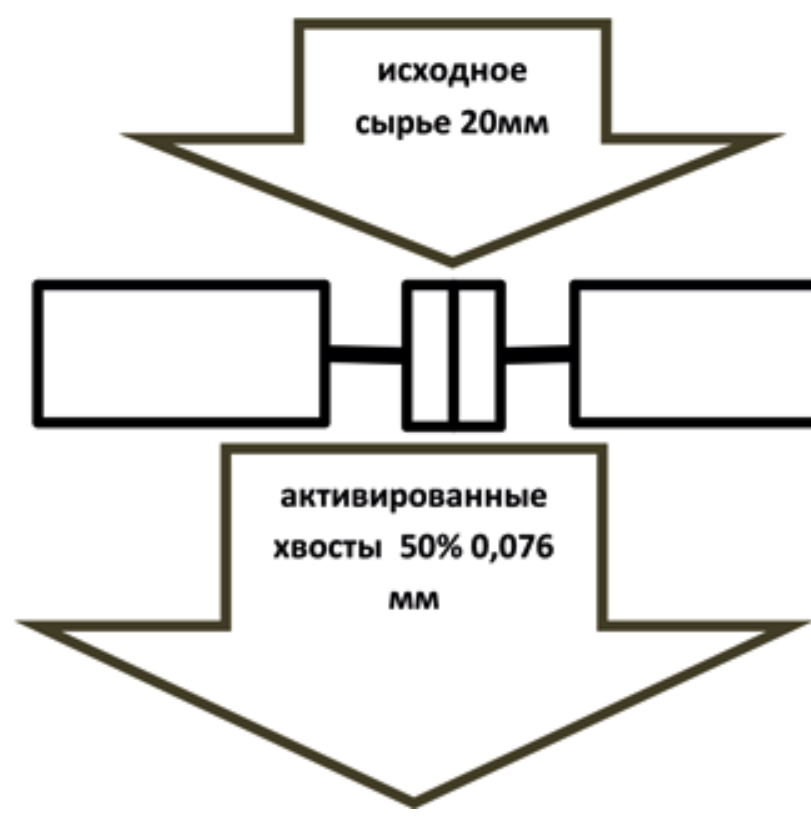

2

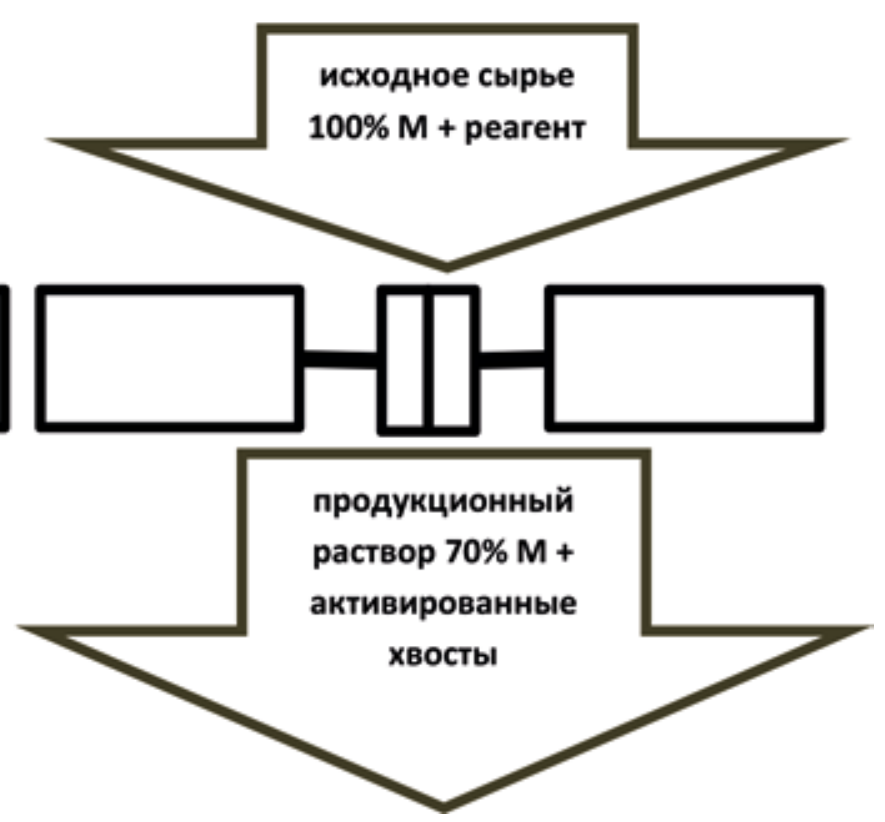

Pис.4. Функиии дезинтеграторов: 1 - для приготовления бетонных смесей; 2 - для извлечения металлов и приготовления бетонных смесей /

Fig.4. Functions of disintegrators: 1-for the preparation of concrete mixtures; 2 -for the extraction of metals and the preparation of concrete mixtures

- предложены нетрадиционные процессы выщелачивания хвостов путем вовлечения их в производство;

- обоснована методика определения параметров комбинированной механохимической активации, повышающих прочность твердеющих смесей на основе хвостов;

- разработана методика определения экономической эффективности вовлечения хвостов в производство.

Участок подготовки отходов к утилизации хвостов обогащения отличается от известных комплексом для приготовления бетонов и смесей, включая активаторы. Он может быть построен и оборудован механизмами, которые выпускаются серийно или изготавливаются собственными силами.

Дезинтегратор. Материал доставляется на верхнюю отметку, проходит сито с отверстиями 20 мм и попадает в установку. Продукты измельчения направляются в технологическую цепь.

Функции дезинтегратора при утилизации хвостов обогащения для приготовления твердеющих смесей даны на рис.4.

Установка электрохимической активации. Для приготовления анолита при комбинированной активации хвостов используют промышленные установки.

Оптимальной схемой утилизации является вариант с активацией компонентов смесей на основе комбинирования традиционных технологий подготовки сырья, технологий механической активации в бы- строходных аппаратах типа дезинтегратор и электрохимических технологий перевода металлов в раствор и извлечения их из раствора.

Комплекс по переработке хвостов моет быть построен на промплощадке Мизурской обогатительной фабрики. Он включает в свой состав дробильно-сортировочное отделение, цех по извлечению металлов в раствор и из раствора и закладочный комплекс в рамках единой транспортно-коммуникационной сети.

Ориентировочный объем строительства из условия годовой мощности предприятия 200 тыс. т: $20 \times 10 \times 10$ м в трех уровнях.

Использование рекомендованной технологии обеспечивает разработку запасов месторождений Садонской группы с минимизацией угрозы для окружающей среды на принципах ресурсосбережения и безотходности.

Освоение в перспективе комбинированной технологии добычи с из-влечением на поверхность и заводской переработкой богатых руд и выщелачиванием под землей и в кучах на поверхности бедных руд позволит сократить выход хвостов на $30-40 \%$, которые будут перерабатываться по предложенной схеме. В течение 15-20 лет можно переработать накопленные хвосты в районе с. Унал.

Вторичные хвосты переработки, отвечая требованиям ПДК, упрочняют базу строительной индустрии Северной и Южной Осетии, обеспечивая дешевыми инертными заполнителями. 
Продукты переработки хвостов обогащения представляют собой ценный товар, реализация которого облегчает финансовое состояние основного производства.

Долгосрочный эффект проявляется в возможности эксплуатации месторождений без строительства второй очереди хвостохранилищ, получении новых финансовых потоков и радикальном оздоровлении окружающей среды не только РСО-Алания, но и других регионов Северного Кавказа и Юга России.

\section{Выводы}

1. Региональные проблемы Республики РСО-Алания не могут быть решены без использования при-

\section{ЛИТЕРАТУРА:}

1. Голик В.И., Дребенштедт К, Разоренов Ю.И. Оценка эффективности комбинирования технологий добычи металлов // Устойчивое развитие горных территорий. 2015. N 1 (23). C. 5-10.

2. Дмитрак Ю.В., Камнев Е.Н. АО "Ведущий проектноизыскательский и научно-исследовательский институт промышленной технологии" - путь длиной в 65 лет // Горный журнал. 2016. N 3. С. 6-12.

3. Габараев О.3., Сабанов Н.А., Логачев А.В., Петрова О.В., Ногаев А.Х. Технологии управления состоянием массива при отработке подработанных вкрапленных руд. МГГУ. ГИАБ. 2008. N 2. С. 63-69.

4. Цирихова Э.М. Анализ сырьевой базы Садонского комбината / Сб. тр. к 150-летию Садонского ГОК. Владикавказ: Ир, 1993. С. 17-22.

5. Шелкунова Т.Г. Оценка инновационного развития горнодобывающего предприятия на основе производственной функции и ее отраслевое применение // Известия вузов. Северо-Кавказский регион. Технические науки. 2006. N 8. C. $188-190$.

6. Шелкунова Т.Г. Экономическое обоснование разработки забалансовых руд / Научные труды аспирантов, соискателей и преподавателей экономического факультета «Современные проблемы рыночного реформирования экономики». Владикавказ. 2005. С.45-52.

7. Остроушко И.А. Изыскание и внедрение способов извлечения металлов, оставленных в отработанных пространствах рудников // Отчет о НИР. Орджоникидзе, фонды СКГМИ. 1975. 137 с.

8. Шестаков В.А., Разоренов Ю.И., Габараев О.3. Управление качеством продукции на горных предприятиях. Новочеркасск, 2001. 262 с.

9. Muller N. Z., Mendelsohn R., Nordhaus W. Environmental Accounting for Pollution in the United States Economy // American Economic Review. 2011. Vol. 101. No. 5. Pp. $1649-1675$.

10. Шестаков В.А., Венедиктов А.А., Литовченко Т.В. Экономико-экологическая оценка физико-химической геотехнологии // Горный информационно-аналитический бюллетень. 2001. N 9. С. 217-219. родных минеральных ресурсов, в первую очередь, металлических месторождений.

2. Возрождение былого потенциала рентабельного производства металлов возможно на основе комбинирования традиционной технологии и новых технологий подземного, кучного и механохимического выщелачивания.

3. Экономика горного производства может быть улучшена производством товарной продукции из хвостов выщелачивания руд.

4. Основу устойчивого развития РСО-Алания должна составлять не рекреационная деятельность, а технологически модернизированная горнодобывающая отрасль, имеющая все возможности развития.

11. Логачев А.В. Производство золота при поэтапной разработке месторождений. Цветная металлургия. 2011. N 12. C. 31-34.

12. Sinclair L., Thompson J. In situ leaching of copper: Challenges and future pro spects // Hydrometallurgy. 2015. T.157. Pp. 306-324.

13. Голик В.И., Комащенко В.И., Качурин Н.М. Концепция комбинирования технологий разработки рудных месторождений // Известия Тульского государственного университета. Науки о Земле. 2015. N 4. С. 76-88.

14. Karimi N. S., Atashpanjeh A., Mollaei F. M. R. Design considerations of heap leaching at the sarcheshmeh copper open pit mine // International Mining Congress of Turkey. IMCET. 2001. Pp. 513-516.

15. Randolf E., Miller Sh., Miller G. Minimizing acid consumption in mixed oxide/supergene and sulfide heap leach // Proceedings of the 3rd International Conference on Heap Leach Solution.Lima. 2015. Pp. 36-44.

16. Doifode S. K., Matani A. G. Effective Industrial Waste Utilization Technologies towards Cleaner Environment // International Journal of Chemical and Physical Sciences. 2015. Vol. 4. Special Issue. NCSC. Pp. 536-540.

17. Хетагурова Т.Г. Экономическая целесообразность повторной отработки месторождений // Сборник науч. тр. аспирантов СКГТУ. Владикавказ: Терек. 2000. С. 321 325.

18. Каплунов Д. Р., Рыльникова М. В., Радченко Д. Н. Научно-методические основы проектирования экологически сбалансированного цикла комплексного освоения и сохранения недр Земли // Горный информационно-аналитический бюллетень. 2015. N 4 (специальный выпуск N 15). C. 5-11.

19. Ермишина Е. Б. Пути диверсификации в экономической системе РСО-Алания / Е. Б. Ермишина // Вестник Адыгейского государственного университета. Серия Экономика. 2011. Вып. 1. C. $95-100$

20. De Oliveira D. M., Sobral L. G. S., Olson G. J., Olson S. B. Acid leaching of a copper ore by sulphur-oxidizing microorganisms // Hydrometallurgy. 2014. Vol.147-148. Pp.223-227. 


\title{
СВЕДЕНИЯ ОБ АВТОРАХ / Information about authors:
}

БОРЩЕВСКИЙ Сергей Васильевич - доктор технических наук, профессор, декан горного факультета Донецкого национального технического университета.

Донецкая Народная Республика, г. Донецк,

e-mail: borshevskiy@gmail.com

Sergey Vasilievich BORSCHEVSKI - Dr. Tech. Sc., Professor, Dean of the Mining Faculty.National Technical University, Donetsk, DNR, e-mail: borshevskiy@gmail.com

МОРКУН Владимир Станиславович - доктор технических наук, профессор, проректор национального технического университета, г. Кривой Рог, Украина

e-mail: morkunv@gmail.com

Vladimir Stanislavovich MORKUN - Dr. Tech. Sc., Professor, Vice Rector of the National Technical University, Krivoy Rog, Ukraine e-mail:morkunv@gmail.com
ТОТЕВ Любен - доктор технических наук, профессор. Университет горного дела и геологии " Св. Иван Рильский”, г. София, Болгария

e-mail: rector@mgu.bg

TOTEV Lyuben, Dr. Tech. Sc,. Professor, University of Mining and Geology "St. Ivan Rilskiy", Sofia, Bulgaria,e-mail: rector@mgu. bg

чЖУН Чан - доктор геолого-минералогических наук, зав. лабораторией.

Китайский геологический университет, г. Пекин, Китай

CHYUN Chan - Doctor of Geological and Mineralogical Sciences, Head of Laboratory. Chinese Geological University, Beijing, China

\section{THE BASIS OF THE SUSTAINABLE DEVELOPMENT OF NORTH OSSETIA-ALANIA - MININGINDUSTRY}

\author{
${ }^{1}$ Borschevski S.V.,* \\ ${ }^{2}$ Morkun V.S., \\ ${ }^{3}$ Totev Lyuben, \\ ${ }^{4}$ Chyun Chan \\ ${ }^{1}$ Donetsk National Technical University,DNR, Donetsk,borshevskiy@gmail.com \\ ${ }^{2}$ National Technical University, Krivoy Rog, Ukraine \\ ${ }^{3}$ University of mining and geology "St. Ivan Rilskiy", Sofia, Bulgaria \\ ${ }^{4}$ Chinese geological University, Beijing, China
}

\section{DOI: $10.21177 / 1998-4502-2018-10-1-109-116$}

The purpose of the article is to substantiate the need to develop the framework conditions for self-cost production, which can be the basis economy betterment in the region, by justifying the ecological and economic efficiency of environmental protection technologies through the utilization of tailings production and ore processing.

Methods. Evidence includes generalization and critical analysis of publications, results of technological and economic research, expert evaluation and scientific forecasting of development prospects.

Results. The information about the history of industrial development of Sadon deposits and the problem of accumulation of ore processing tailings, which became a source of chemical contamination of the environment. The problem of waste accumulation is characterized. The concept of non-waste and resource-saving development of fields using new technologies is described. A reference is given to the theory and practice of using production waste with detailing the direction of extraction of metals by leaching the tailings of enrichment. The principle of operation of the disintegrator with the activation of the process of leaching of metal-containing minerals is described. The direction of combination of traditional technologies of preparation of raw materials, technologies of activation in high-speed devices and technologies of leaching of metals is detailed. Natural connections between the ecology of the mining region and the technical level of mining production are established. It is shown that the effect of the concept implementation is manifested in the extension of the field life, obtaining new financial flows and radical improvement of the environment.

Summary. The basis of economy betterment could be combined technology of field development with rational combination of elements of traditional and new leaching technologis. Economics of mining can be improved creating the adjacent marketable products after metalls extraction from the tailings.

Keywords: mining industry, metal mining, leaching technology, region, conversion.

\section{References}

1. Golik V. I., Drebenshtedt To, Razorenov Yu. I. Assessment of the effectiveness of a combination of technologies for extraction of metals. Sustainable development of mountain territories. 2015. No 1 (23). Pp. 5-10.

2. Dmitrak Yu. V., Kamnev E. N. Leading design and survey research Institute of industrial technology-a path of 65 years. Mining journal. 2016. No 3. Pp. 6-12.

3. Gabaraev O. Z., Sabans N. A. Logachev V. A., Petrova O. V. Nagoyev A. H. Management technology state of the array when working out underworked disseminated ore. Moscow State Mining University. MINING. 2008. No 2. Pp. 63-69.

4. Chirikova E. M. Analysis of raw materials of plant 
Zadonskogo. Proceedings of the 150th anniversary of Zadonskogo mine. Vladikavkaz, IR, 1993. Pp. 17-22.

5. Shelkunova T. G. Assessment of innovative development of the mining enterprise based on production functions and industrial applications. Izvestiya vuzov. North Caucasian region. Technical science. 2006. No 8. Pp. 188190.

6. Shelkunova T. G. Economic justification of development of off-balance ores. Modern problems of market reforming of economy. Scientific works of graduate students, applicants and teachers of economic faculty. Vladikavkaz. 2005. Pp. 45-52.

7. Ostroushko I. A. Research and implementation of methods of extraction of metals left in the waste areas of mines. Report on research. Ordzhonikidze, NCIMM funds. 1975. P. 137.

8. Shestakov V. A., Razorenov Yu. I., Gabaraev O. Z. Product quality management at mining enterprises. Novocherkassk, 2001.P. 262.

9. Muller N. Z., Mendelsohn R., Nordhaus W. Environmental Accounting for Pollution in the United States Economy. American Economic Review. 2011. Vol. 101. No. 5. Pp. 1649-1675.

10. Shestakov V. A., Venediktov A. A., Litovchenko T. V. Economic and environmental assessment of physical and chemical geo-technology. Mining information and analytical Bulletin. 2001. N 9. Pp. 217-219.

11. Logachev V. A. Gold production in the phased field development. Nonferrous metallurgy. 2011. No12. Pp. 3134.

12. Sinclair L., Thompson J. In situ leaching of copper: Challenges and future prospects. Hydrometallurgy. 2015. Vol.157. Pp. 306-324.
13. Golik V. I., Komashchenko V. I., Kachurin N. Mmm. The concept of combining technologies of ore deposits development. Bulletin of Tula State University. Earth Science. 2015. No 4. Pp. 76-88.

14. Karimi N. S., Atashpanjeh A., Mollaei F. M. R. Design considerations of heap leaching at the Sarcheshmeh copper open pit mine. International Mining Congress of Turkey. IMCET. 2001. Pp. 513-516.

15. Randolf E., Miller Sh., Miller G. Minimizing acid consumption in mixed oxide/supergene and sulfide heap leach. Proceedings of the 3rd International Conference on Heap Leach Solution. Lima. 2015. Pp. 36-44.

16. Doifode S. K., Matani A. G. Effective Industrial Waste Utilization Technologies towards Cleaner Environment. International Journal of Chemical and Physical Sciences. 2015. Vol. 4. Special Issue. NCSC. Pp. 536-540.

17. Khetagurova T. G. Economic feasibility of re-mining. Collection of scientific works of graduate students NCIMM. Vladikavkaz, Terek. 2000. Pp. $321-325$.

18. Kaplunov D. R., Rylnikova M. V., Radchenko D. N. Scientific-methodical bases of designing ecologically balanced cycle of complex development of bowels of the Earth. Mining information-analytical Bulletin. 2015. No 4 (special edition N 15). Pp. 5-11.

19. E. B. Ermishina Ways of diversification in the economic system of North Ossetia-Alania. Bulletin of Adyghe State University. Economy Series. 2011. Issue. 1. Pp. 95-100.

20. De Oliveira D. M., Sobral L. G. S., Olson G. J., Olson S. B. Acid leaching of copper ore by sulphur-oxidizing microorganisms. Hydrometallurgy. 2014. Vol.147-148. Pp.223-227.

Article received 02.06.2017 


\section{ESTIMATION OF THE RELIABILITY OF THE VENTILATION CONTROL SYSTEM AT THE MINING SITES}

Relevance. The intensification of mining operations in the underground mode, the increase in the depth of development and the associated complication of the ventilation network of modern mines, the increase in gas evolution, dust generation, heat generation and the uneven distribution of these in time and space require the solution of the issues of further improving the ventilation of mine workings in order to improve the safe conditions and productivity labor [1-5].

The solution of the problem of further increasing the efficiency of ventilation can be achieved by rational and timely redistribution of the air supplied to the mine, i.e. on the basis of management of ventilation of mines. Managing the ventilation of mines will improve working conditions, improve safety techniques, increase extraction of minerals and reduce energy costs for ventilation.

With the set goal and tasks, we will investigate the problems of further increasing the efficiency of the technical system of the mining complex, develop an integrated system, assess the reliability of the ventilation control system, and mine and mine mining sites in mountainous areas [3-12].

The mine 18 is presented on Figure 1 (Rostov Region, Russia).

Formulation of the problem. The breakdown into components of limited complexity arise in connection with the layout of the control system (CS) in structural units, limited in volume and in the number of external links. Since the volume of the structural unit is practically limited, in each block, when assembling the circuit, only a plurality of such elements can be placed, the total volume of which does not exceed the capacity of the block. In addition, the building blocks are connected to each other with a different number of connections. This imposes a restriction on the number of external links of each block with elements of other blocks. The formally considered problem reduces to splitting a specially introduced graph, which is a suitable model of the scheme under consideration to subgraphs of bounded complexity [6-11; 17].

The mining site of the longwall 31 is presented on Figure 2.

Development of an integrated system. We begin by describing a specific variant of the algorithm $G 3$ enumerating in the graph $F$ all possible $q$-compatible subsets of the given set of vertices $Q \in V_{0}$ that are unions of some maximal dense subsets of $Q$ and containing a given vertex $V_{0} \in Q$. The algorithm works in the proposed variant in the construction of the graph of the $F *$ result successive contraction in the graph $F$ of each maximal dense subset $A \in Q$ to some one vertex $v_{A}$ such that different such subsets contract to different vertices in the enumeration in graph $F$ * of all $q$-compatible subsets of some set $Q *$ containing some vertex $V_{o}^{*}$, and in the replacement of each such subset $B$ by the union of maximal dense subsets of $Q_{v}{ }^{*} \subset$ $Q$, contracted by the construction of $F^{*}$ to the vertices $v^{*} \in B$. The set $Q *$ here consists of all those vertices in the graph $F *$ to which the different maximal dense subsets of $Q$ (including the one-element subsets) contract, and the vertex in $F *$, to which a subset containing vo is contracted. The enumeration of q-compatible subsets of $Q *$ containing the vertex $V_{o}^{*}$ is trivial-by successively (in order of increasing cardinality) enumeration of all subsets of $Q *$ containing $v^{*} \in B$ and selecting

${ }^{1}$ Department of Geoscience-National Taiwan University IGS-Vietnam Academic of Science and Technology

${ }^{2}$ North-Caucasian Institute of mining and metallurgy (State Technological University), Vladikavkaz, Russia
${ }^{1}$ Tran Viet Anh., 2Klyuev R.V., ${ }^{2}$ Bosikov I.I., * ${ }^{2}$ Tsidaev B.S.
УДК: 622:577.4 DOI: $10.21177 / 1998-4502-2018-$ 10-1-117-124

The article describes research conducted by authors at mining enterprises in Russia and Kazakhstan.

The purpose of the research is to develop an integrated system for assessing the reliability of the ventilation management system at mining sites in mountainous areas.

The research objectives: - to make the layout of the ventilation control system into structural units;

- to establish the properties of dense sets with the help of which it is necessary to prove the conditions for the implementation of the enumeration algorithm and the reduction operation.

The tasks are solved on the basis of a comprehensive study of the increasing efficiency problems of the technical system of the mining complex. For this purpose, an integrated system for the reliability assessment of a ventilation management system at mines mining areas is being developed.

Results of the research. An integrated system for assessing the reliability of the ventilation control system at mining sites was developed. An algorithm based on the construction of a graph is developed. The result of successive contraction in the graph of each maximal dense subset to some one vertex is that different subsets are contracted to different vertices. The obtained algorithms can be successfully applied for a complete analysis of the stability of the jets of individual independent ventilation areas and small mines. More extensive use of the criteria and algorithms developed in the integrated system is possible after simplifying the schemes for the proposed methods

KEYWORDS:

algorithm, graph, decomposition, reliability assessment, ventilation system, efficiency, functioning, compatible subsets

Статья поступила в редакцию 21.03.2017 


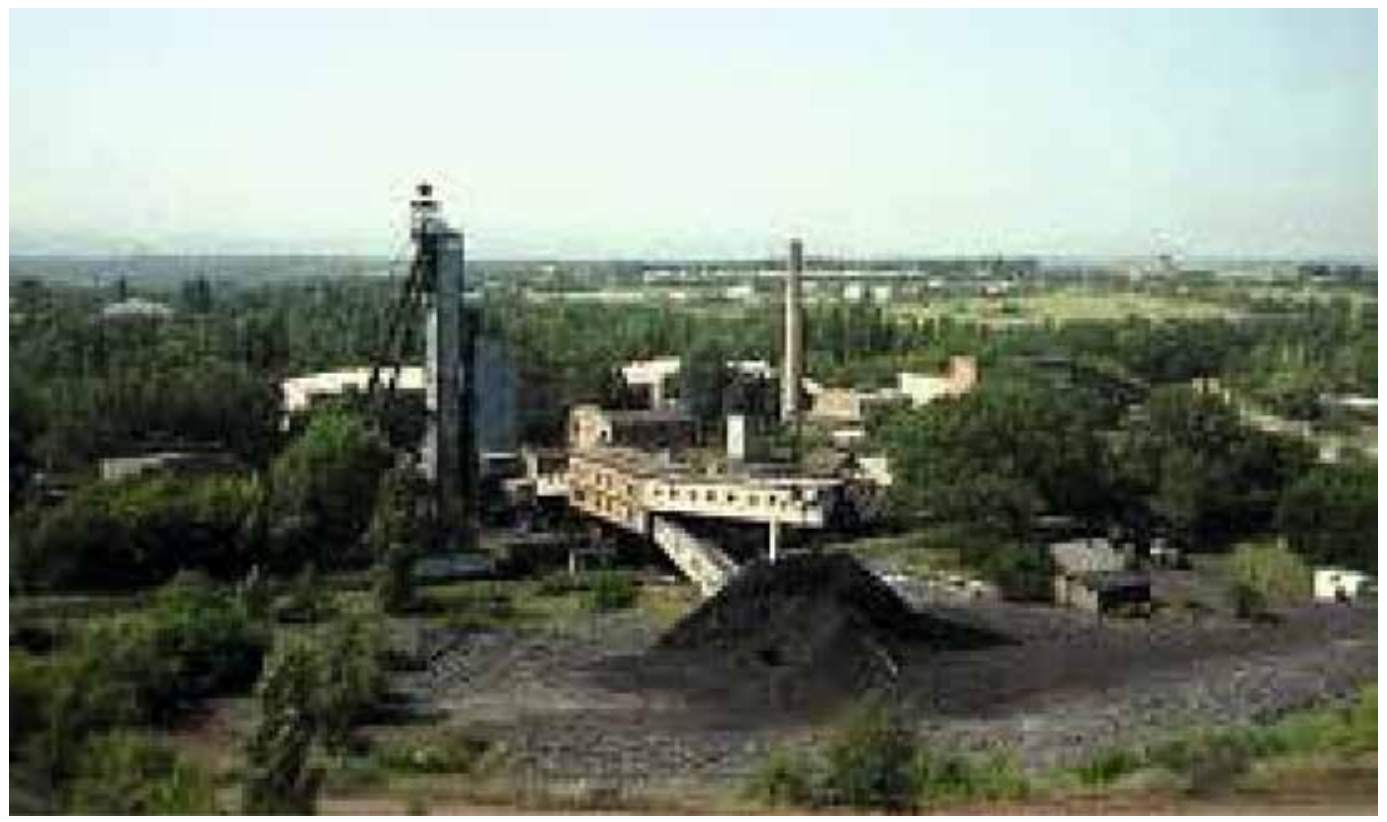

Fig. 1. The mine 18 (Rostov Region, Russia)

among them those subsets that are $q$-compatible in $F^{*}$. The construction of the graph $F^{*}$, the set $Q$, and the vertex $v_{0}^{*}$ is carried out simultaneously with the construction in $F$ of maximal dense subsets of $Q$ by means of the following simple algorithm $G 4$, which follows from the properties of the disjointness and connectivity of such subsets and the density conditions for the union of dense sets $[13 ; 14 ; 16 ; 18]$.

\section{Algorithm G4}

$F^{*}:=F, Q^{*}:=\left\{v^{*}: v_{0} \in Q\right\}, v_{0}^{*}:=v_{0}, Q_{v}^{*}:=\{v\}$ for each vertex $v_{0} \in Q$.

1. $l:=1$.

2. If the $l \geq\left|Q^{*}\right|$, then n. 5; otherwise $l:=l+1$.

3. We select in $Q^{*}$ another subset $A$ of cardinality $f$ connected in $F^{*}$ and satisfies $\S 4$; on the exhaustion of all such $A \subseteq Q^{*}$ a return is made to point 2 .

4. If in the column $F \exists A_{j} \in A\left(q\left(A_{j}\right)<q(A)\right)$, then subsection 3; otherwise the set $A$ contracts in $F$ to some vertex $V_{A}$ that is accepted in the case $v_{0}{ }^{*} \in A$ with $v_{0}^{*}$ in the new box $F^{*}, Q^{*}:=\left(Q^{*}-A\right) \cup\left\{V_{A}\right\}, Q_{v A}:=U Q_{v}$ and $v^{*} \in A$ the transition to p. 1 is carried out.

End: the resulting graph $F^{*}$, array $Q^{*}$, superlative $v_{0}{ }^{*}$ and subsets $Q_{v}{ }^{*} \subseteq Q$, contracted to the vertices $v^{*} \in Q^{*}$ and representing all possible maximal dense subsets of $Q$ form the result of the operation of the algorithm.

The contraction of the subset $A \subseteq V_{o}$ to one vertex, which appears in the description of the algorithm, consists in identifying, among themselves, all vertices in $A$. Formally, the result of this operation is achieved by the following sequence of actions:

1) all vertices of the set $A$ are removed from the set of vertices of the graph under consideration;

2) a new vertex $v_{A}$ with a weight equal to the sum of the weights of the removed vertices is added to the remaining vertices of the graph, in this case we say that $A$ contracts to $v_{A}$;

3 ) from the set of edges of the graph all edges incident to vertices in $A$ and not incident to vertices outside of $A$ are deleted;

4) in the remaining edges of the graph, each vertex of $A$ is replaced by the vertex $V_{A}$ without changing the weights of the edges;

5) of all identical edges possible as a result of the indicated substitution, one edge with a weight equal to the sum of the weights of the edges being replaced is preserved. In addition, it is permitted (with a view to simplifying the graph's image) to delete any node node incident to no more than two edges, together with the edges incident to it. Moreover, if the removed vertex is incident to edges of the form $\mathrm{kl}$ and $\mathrm{km}$, then a new edge $l \mathrm{~m}$ with weight $l$ is introduced into the graph or the weight of the existing edge $1 \mathrm{~m}$ increases by $l$. This simplification, obviously, does not affect the final result of the solution of the problem under consideration [17-21].

Let's illustrate the work of the algorithm by points, for example, the graph $F$, shown in Figure 3, with the set of element vertices $V_{o}=\{1,2, \ldots, 12\}$. Weights of edges, other than 1, are shown on the graph by the numbers of the corresponding edges.

Let $Q=\{1,5,8,9,10,11,12\}, q=7$ and $V_{0}=1$.

$0 . \mathrm{F}^{*}:=\mathrm{F}, Q^{*}:=\left\{1^{*}, 5^{*}, 8^{*}, 9^{*}, 10^{*}, 11^{*}, 12^{*}\right\}, v_{0}^{*}:=1, Q_{1^{*}}:=\{1\}, Q_{5^{*}}:=\{5\}$, 
$Q_{8 *}:=\{8\}, \ldots, Q_{12 *}:=\{12\}$.

1-2. $l:=2$.

3-4. As a result of a successive search of connected in $F *$ subsets of cardinality 2 , there is a subset $A=$ $=\left\{11^{*}, 12^{*}\right\}$, which contracts in $F *$ to the vertex $v_{A}=$ $=(8,9,10)^{*}$, after which $Q^{*}:-\left\{1^{*}, 5^{*}, 8^{*}, 9^{*},(10)^{*},(11\right.$, $\left.12)^{*}\right\}, Q_{V A}:=\{U, 12\}$

$1-2 . l:=2$.

3-4. There is no dense subset $Q *$ of cardinality 2 .

2. $l:=3$.

3-4. There is a set $A=\left\{8^{*}, 9^{*}, 10^{*}\right\}$, which contracts to the vertex $v_{A}=(8,9,10) *$; as a result of $Q^{*}:=$ $=\left\{1^{*}, 5^{*},(8,9,10)^{*},(11,12)^{*}\right\}, Q_{V A}:=\{8,9,10\}$.

5. As a result of the search of subsets of $Q *$ of cardinality 2,3 and 4, there is no subset $A \subseteq Q^{*}$ with a property that satisfies the contraction condition, therefore:

6 . The result of the algorithm is the set $Q^{*}:=[1 *$, $5 *,(8,9,10) *,(11,12) *\}$, the subsets $Q_{i}^{*}=\{1\} Q_{5^{*}}=\{5\}$ $Q_{(8,9,10)^{*}}=\{8,9,10\}$ and $Q_{(11,12)^{*}}=\{11,12\}$, representing all

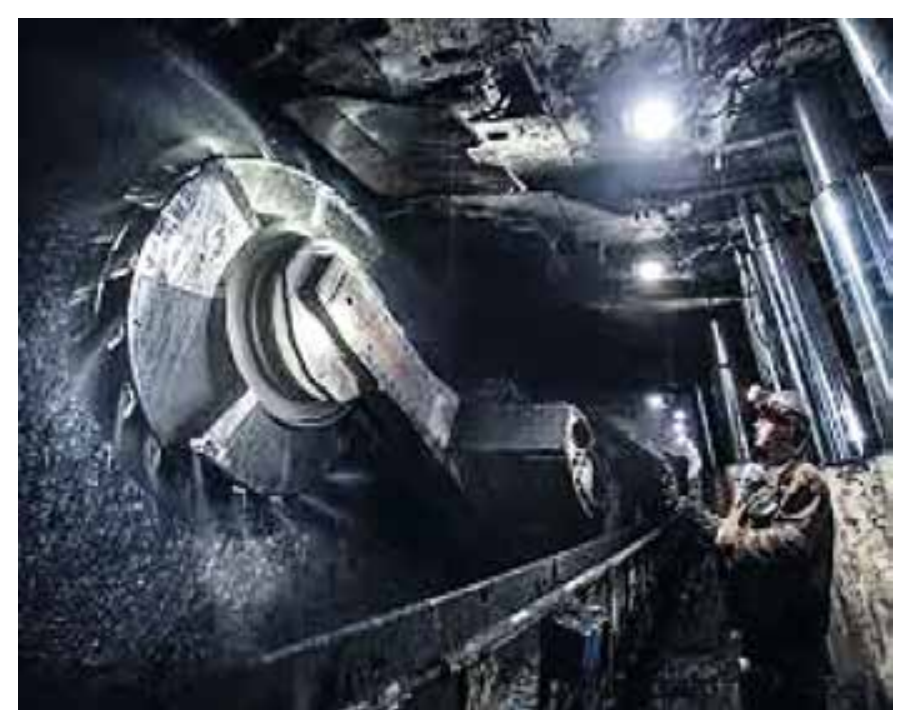

Fig. 2. Mining in the longwall 31 (Karaganda coal basin, Kazakhstan) possible maximal dense subsets of $Q, V_{o}^{*}=1$ and the graph $F *$ shown in Figure 3.

7. Enumerating subsets of $Q *$ containing $v_{0}{ }^{*}=l$, checking them for $q$-compatibility (for $q=7$ ) and replacing each such subset by a union of the elements entering into it, we obtain the set $G 3(Q)=\{\{1\},\{1,8,9,10\},\{1,11,12\},\{1$, $5\}$ \}. The vertices $i$ and $j$ of the graph $F_{o}$ are said to be quasi-adjacent in $F$ if they are adjacent in $F_{o}$ or there is a vertex in $V-V_{0}$ that is adjacent to vertex $i$ and vertex $j$ and is not adjacent to any other vertex. We introduce the following notation for certain subsets of element vertices in any graph $H$ obtained from the graph $F$ by contracting to single vertices of certain subsets of vertices in $V_{o}$ :

$B=\{i: q(i)>q\}$;

$B_{j}=\left\{j: i\right.$ and $j$ are quasisim- essent in $\left.H \wedge w_{i}+w_{j}<w \mu q(i)>q(i, j)\right\}$;

$B^{\prime}=\{i: i \in B \wedge B, \neq \varnothing\} ; B_{i}^{\prime}=\left\{j: j \in B_{i} \wedge q(i j) \leq q\right\}$

Let the set $D=\left\{\{i, j\}: q(i, j) \leq q \wedge w_{i}+w_{j} \leq w\right\}$, then the algorithm G3 for constructing the initial partition $R_{0}$ of the set $V_{0}$ into $(q, w)$ - compatible subsets is formulated as follows way [16-19].

\section{Algorithm G3}

$0 . R_{o}:=\varnothing, W:=G$

1. If $B=\varnothing$, then item 3; otherwise, if $B^{\prime}=\varnothing$, then item 4 , otherwise, select a vertex $i \in B^{\prime}$ with the largest $q(i)$ and for it the vertex $j B^{\prime}$ with the smallest sum $\left(w_{i}+w_{j}\right)$ if $B_{i}{ }^{\prime}=\varnothing$, or the vertex $j \in B_{i}$ with the smallest $q(i, j)$, if $B_{i}{ }^{\prime}=\varnothing$.

2. The set $\{i, j\}$ contracts to one vertex, the resulting graph is taken as $W$ and p. 1 is satisfied again.

3. If $D \neq \varnothing$, then some of the sets $\{i, j\} \in D$ contracts to a single vertex, the resulting graph is taken for $W$, and $\S 3$ is again applied to it, otherwise all those subsets of vertices in $F_{o}$ that eventually turned out to be bounded to the vertices of the graph $W$, and also the one-element subsets of all other vertices of the graph $F$ that are not involved in the contraction are declared classes of the partition $R_{0}$.

4. End: $R$ is the result of the algorithm $G 3$.

The answer $R_{o}=\varnothing$ means that the given algorithm can not (due to the locality of its character) find a partition of the set $V_{o}$ into $(q, w)$ - compatible subsets or there is no such partition at all.

Note that, in view of assertion 5, the inequality $q(i)>q(i, j)$ for $i, j \in V_{0}$ is possible only if the vertices $i$ and $j$ are quasisimis - sive in the graph $F$. This explains the selection rule $j$ for $i$ in $\S 1$ of the algorithm $\mathrm{c}$ the goal of contracting the pair $\{i, j\}$ to one vertex.

Let us demonstrate the work of this algorithm on points by the example of the graph depicted in Figure 3 for $q=7$ and $w=12$. We calculate the previously required quantities: $q(a)=7, q(c)=8, q(d)=9, q(g)=9, q(h)=6$, $q(c, d)=6, q(c, h)=10, q(e)=6, q(e, g)=8, q(g, h)=8$.

$0 . B=\{c, d, g\} \neq \varnothing, B_{c}=\{d\}, B_{d}=\{c\}, B_{g}=\{e\}, B^{\prime}=\left\{c^{*}, d, g\right\} \neq \varnothing$. The vertices $i=d$ and $j=c$ are selected.

2. The set $\{c, d\}$ contracts to one vertex $v_{c d}$. The result of the contraction is shown in Fig. 3 ,a. In this graph, $q\left(v_{c d}\right)=6, q\left(g, v_{c d} j\right)=l 3$.

$0 . B=\{g\} \neq \varnothing, B_{g}=\{e\}, B^{\prime}=\{g\} \neq \varnothing$. The vertices are selected $i=g$ и $j=e$.

1. The set $\{e, g\}$ contracts to one vertex $v_{e g}$; The result of the contraction is shown in Figure 5,c. In this graph, $q\left(v_{e g}\right)=8, q\left(a, v_{e g}\right)=8, q\left(v_{c d}, v_{e g}\right)=12, q\left(h, v_{e g}\right)=7$.

1. $B=\left\{v_{e g}\right\}, B_{v e g}=\{h\}, B^{\prime}=\left\{v_{e g}\right\} \neq \varnothing$. The vertices $i=v_{e g}, j=h$ are chosen. 
2. The set $\left\{h, v_{e g}\right\}$ contracts to one vertex $v_{e g h}$; The result of the contraction is shown in Fig. 5,c. In this graph, $q(x) \leq q$ for each $x$ and $q\left(a, v_{e g h}\right)=6$.

1. $B \neq \varnothing$.

2. $W=\left\{\left\{a, v_{e g h}\right\}\right\} \neq \varnothing$ and the set $\left\{a, v_{e g h}\right\}$ contracts to one vertex $v_{a e g h}$, the contraction result is shown in Figure 5,d. In this graph, $W=0$

3. The result of the algorithm is the partition $R_{0}=\{\{c$, $d\},\{a, e, g, h\}\}$. Below we describe another algorithm $G 4$ for constructing the initial partition Ro of the set $V_{o}$ in the graph $F$ into $(q, w)$ - compatible subsets, which in some cases delivers a more accurate solution [15-18].

\section{Algorithm G4}

Let $X^{(l)}=V$, then the step $i(i \geq 1)$ of the algorithm is as follows. We choose some vertex $y_{o} \in X^{(i)}$; We construct two maximal $(q, w)$ - compliant subsets $X_{i l} X_{i 2}-X^{(i)}$, containing the selected vertex $y_{0}$; a subset with the greatest sum of weights of vertices in it is taken as the class $X_{\mathrm{i}}$ of the required decomposition $R_{o}$; the set $X^{1 l+l)}=X^{(i)}-X_{i}$; is computed; if it is not empty, step $i+1$ is performed; otherwise the partition $R_{o}$ is constructed. The subsets $X_{i 1}$ and $X_{i 2}$ are constructed using the following two algorithms $R 1$ and $R 2$, respectively. The algorithm $R 1$ for any set $Y$ $\subseteq V_{0}$ and a given vertex $y_{0} \in Y$ first constructs the maximal $w$-compatible subset of $A$ containing $y_{o}$, which is typed consecutively by including in its original subset $A=\left\{y_{0}\right\}$ (for the time being this) each vertex $j \in Y$ - $A$, for which $w_{j}+w(A)<w$ and the number $q(A \cup\{j\})$ has the smallest value. Then, by permutation of pairs of quasiperactive vertices, one of which belongs to $\mathrm{A}$ and is not equal to $y_{o}$, and the other is contained in $Y$ - $A$, the greatest possible decrease of $q(A)$ is made. If as a result of such permutations $q(A)>q$ and $A \neq\left\{y_{0}\right\}$, then by successive elimination from $A$ each time of such a vertex $j \neq y_{o}$, for which $q(A-\{j\})$ is minimal, the inequality $q(A) \leq q$. Then, if possible, the extension of the resulting $(q, w)$ incompatible set $Z$ by including some elements of $Y-A$ into it [18-21].

The algorithm $R 2$ differs from the algorithm $R 1$ only in the way of constructing the original w-compatible set $A$, while the remaining actions in it coincide with the actions of the algorithm $R 1$. By definition, let $S_{Y}^{0}\left(y_{o}\right)=\left\{y_{o}\right\}$ and for any positive integer $1 S_{Y}^{l}\left(y_{\partial}\right)=S_{Y}^{l}\left(S^{i-1}{ }_{Y}\left(y_{0}\right)\right)$, where $S_{Y}^{l}(Z)$ for any $Z \subseteq Y$ is the set of all vertices in $Y$, quasi-adjacent vertices in $Z$. Then for the initial w-compatible set $A$ in the algorithm $R 2$ we take a set obtained from $B=S_{Y}^{l}\left(y_{0}\right)$ for $l=$ ] $\mathrm{w} / \mathrm{w}_{\mathrm{y} 0}$ [ by successively excluding from each vertex $j$ different from $y_{0}$ and minimizing the value $q(B-\{j\})$, which terminates when the inequality $w(B) \leq w$ is satisfied [15-18].

In addition to the above notation, the description of algorithms uses the following: $Y_{W}^{*}(A)=\{i: i \in Y-A \wedge w(A)+$ $\left.+w_{i} \leq w\right)$.

\section{Algorithm R1}

0 . $R:=\left\{y_{0}\right\}$.

1. If $Y_{w}^{*}(A) \neq \varnothing$, then subsection 2 , otherwise a certain vertex $a \in Y_{W}{ }^{*}(A)$ with the smallest value $q(A \cup\{a\})$, $A:=A \cup\{a\}$ and p. 1 is satisfied again.

2 . We choose (if possible) some pair of quasimexes in $F$ of vertices $i \in A$ and $j \in Y-A, i \neq y_{o}$ such that $w(A)$ $-w_{i}+w_{j} \leq w \wedge q(A \cup\{j\}\{i\})<q(A), A:=A \cup\{j\}-\{i\}$ and subsection 2 are satisfied again; If there are no such $i$ and $j$, then the next action of this algorithm is performed.

3. If $q(A)<q$, then subsection 4; otherwise, for $A \neq\left\{y_{0}\right\}$ there is a vertex $b \in A, t \neq y_{o^{\prime}}$, with the smallest value $q(A-\{b\}), A:=A-\{b\}$, and again $\S 3$; if $A=\left\{y_{o}\right\}$, then $A:=\varnothing$ and p. 5.

4. A vertex $i \in Y_{W}^{*}(A)$ with the property $q(A \cup\{i\}) \leq q$, $A:=A \cup\{i\}$ is found and the point 4 is repeated again; if

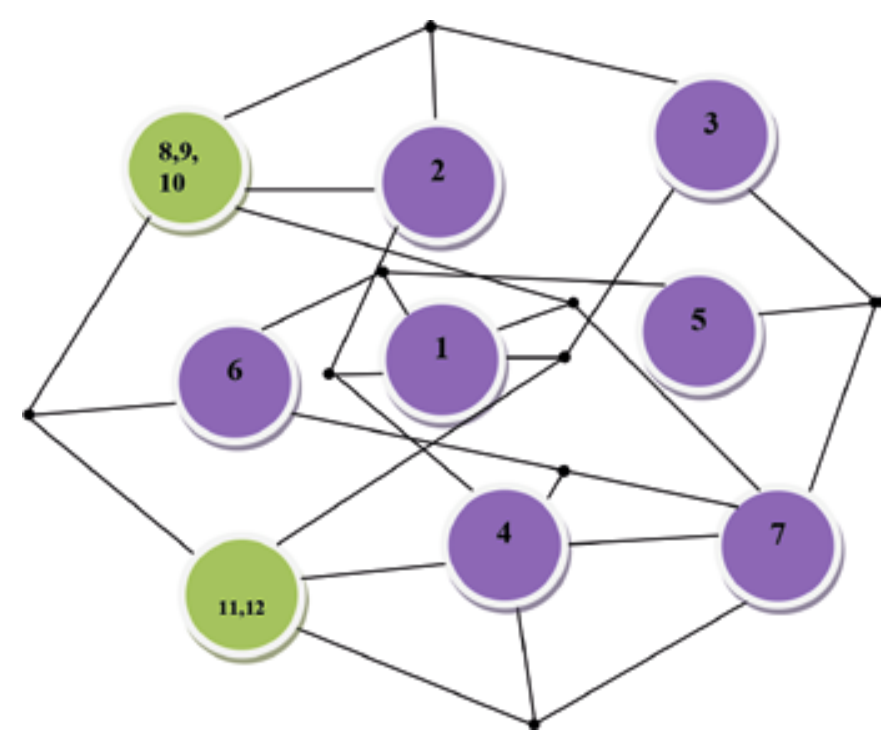

Fig. 4. The result of the algorithm 


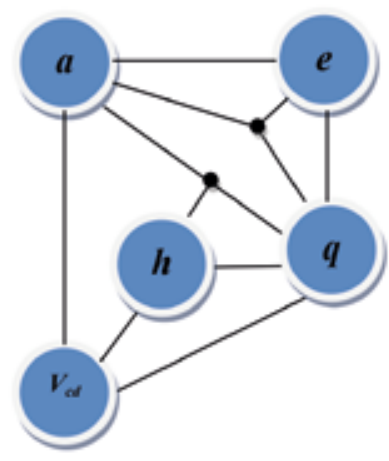

a)

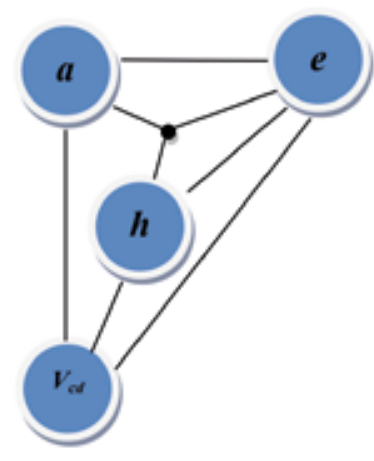

b)

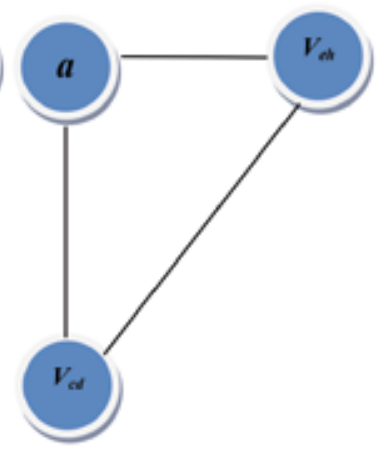

c)

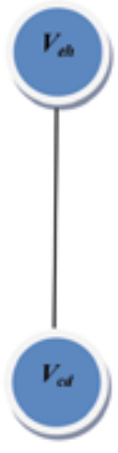

d)

Fig. 5. Stretching to one vertex

there does not exist such a vertex $i$, we perform step 5 .

The end; $A$ is a ( $q$ and $w$ - compatible subset of $Y$ containing the vertex $y_{o}$; the result of $\mathrm{A} \neq$ means that the given algorithm can not construct $(q, w)$ - the compatible subset of $Y$ containing $\mathrm{y}_{\mathrm{o}}$, or there is no such subset at all [15-18].

Algorithm $R 2$ differs from algorithm $R 1$ only in items 0 and 1 , the rest of the actions in it coincide with the actions of the algorithm $R 1$.

\section{Algorithm $\boldsymbol{A 2}$}

$0 . \quad \mathrm{t}:=] \mathrm{w} / \mathrm{w}_{\mathrm{yo}}\left[, \mathrm{A}:=\mathrm{S}_{\mathrm{y}}^{\prime}\left(y_{0}\right)\right.$.

1. If $w(A) \leq w$, then subsection 2 , otherwise the vertex of $y \in A, y \neq y_{o}$ with the minimal value of $q(A-\{y\})$, $A:=A-\{y\}$ is chosen and again one of the points 1 .

2. 2-5. We will implement $2-5$ of the algorithm $R 1$

Conclusion. Based on the studies carried out, the fol- lowing conclusions can be drawn:

- Partitioning into components of limited complexity with the layout of the control system by venting the mining section into structural units, limited in volume and number of external links;

- the condition for the implementation of the enumeration algorithm and the reduction operation with the help of properties of dense sets is proved;

- An algorithm for enumerating compatible subsets is developed, enumerating in the graph all possible compatible subsets of a given set of vertices. The operation of the algorithm in the proposed variant is expressed in the construction of a graph of the result of successive contraction in the graph of each maximal dense subset to some one vertex so that different such subsets contract to different vertices.

\section{REFERENCES:}

1. Bosikov I.I., Klyuev R.V., Kelekhsaev V. B. Method for determining of the ventilation object transfer function according to normal operation (by the example of mining and processing complex). Industrial Engineering. Applications and Manufacturing (ICIEAM). 2017 International Conference. 2017. Pp. 1-5. DOI: 10.1109/ICIEAM.2017.8076113.

2. Moiseev N.N. Mathematical problems of system analysis. Moscow, Nauka, 1981. 488 p.

3. Rykov A.S. Models and methods of system analysis: decision making and optimization. Moscow. MISIS. 2005. 352 p.

4. Benardos A., Athanasiadis I., Katsoulakos N. Modern earth sheltered constructions: a paradigm of green engineering. Tunnelling and Underground Space Technology. 2014. Vol. 41. Pp. 46-52.

5. L. He, Y. Song, S. Z. Dai, K. Durbak. Quantitative research on the capacity of urban underground space. Tunnelling and Underground Space Technology. 2012. Vol. 32. Pp. 168179.

6. Wang G., Li R., Carranza E. J. M., Yang F. 3D geological modeling for prediction of subsurface Mo targets in the Luanchuan district, China. Ore Geology Reviews. 2015. Vol. 1. Pp. 592-610.
7. Saaty T. L., Vargas L. C. Inconsistency and rank preservation. J. of Mathematical Psychology. vol. 28. No 2. Pp. 205241. 1984, June.

8. Pismenny A., Chaadaev A., Akishev A., Bondarenko I., Babaskin S. Innovative technologies at open-cast mining of diamond deposites. Innovations and Nanotechnologies of Russia. 2012. No. 1(2). Pp. 38-39.

9. Najafi B. A., Saeedi G. R., M. A. E. Farsangi Risk analysis and prediction of out-of-seam dilution in longwall mining. International Journal of Rock Mechanics and Mining Sciences. 2014. Vol. 70. Pp. 115-122.

10. Trubetskoy K. N., Kaplunov D. R., Rylnikova M. V., Radchenko D. N. New approaches to designing resource-reproducing technologies for comprehensive extraction of ores. Journal of Mining Science. 2011. Vol. 47. No. 3. Pp. 317-323.

11. Sbárbaro D., René del Villar. Advanced Control and Supervision of Mineral Processing Plants. London : Springer, $2010.310 \mathrm{p}$.

12. Remes A. Advanced Process Monitoring and Control Methods in Mineral Processing Applications. Espoo: Aalto University, 2012. $76 \mathrm{p}$.

13. Belov P. G. System analysis and modeling of hazard- 
ous processes in the technosphere. Moscow. Publishing Center "Academy", 512 p. 2003.

14. Spitsnadel V. N. Theory and practice of optimal decision making. SPb: Publishing house "Business press". 394 p. 2002.

15. Jørgensen S.E. A eutrophication model for a lake. $J$. Ecol. Model. vol. 2. Pp.147-165. 1976.

16. Youn R.B., Klyuev R.V., Bosikov I.I., Dzeranov B.V. The petroleum potential estimation of The North Caucasus and Kazakhstan territories with the help of the structuralgeodynamic prerequisites. Sustainable development of mountain territories. 2017. T. 9. No. 2 (32).Pp. 172-178. DOI: 10.21177/1998-4502-2017-9-2-172-178.

17. Puchkov L. A. Aerodynamics of underground workings. Publishing house of Moscow state mining University. 1993. $266 \mathrm{p}$.
18. Savelyev MV, Engibaryan IA, Eremenko AS, Alikov A.Yu. Calculation of upper and lower reliability estimates of complex technical systems with a variable structure. (Estimations) Certificate of official registration of the computer program No. 2006613810 RF. - No. 2006612791. - Declared. 14.08.2006. Registered users. in the register of computer programs 03.11.2006.

19. Dorigo M., Gambardella L. M. Ant Colony System: A Cooperative Learning Approach to the Traveling Salesman Problem. IEEE Transactions on Evolutionary Computation. 1997. Vol. 1, 1. Pp. 53-66.

20. Karpenko A. P. Modern algorithms of search engine optimization. Algorithms inspired by nature. Moscow. Izd-vo MGTU by N. Uh. Bauman, 2014. 446 p.

21. Kremer N. Sh. Probability theory and mathematical statistics. Moscow. UNITEDONE, 2004. 57 p.

\section{СВЕДЕНИЯ ОБ АВТОРАХ / Information about authors:}

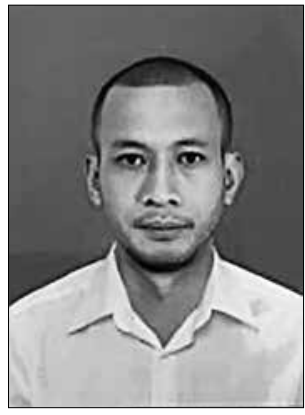

ТРАН ВИЕТ АН - доктор геолого-минералогических наук, главный научный сотрудник Института геологии, наук о Земле Академии наук и технологий Вьетнама.

Область исследований: геохимия.

Округ Донг Да, г. Ханой, Вьетнам.

E-mail: vietanh8177@gmail.com

TRAN VIET ANH - Doctor of Geological and Mineralogical Sciences, Chief Researcher of the Institute of Geology and Earth Sciences.

Research interests: Geochemistry.

Vietnam Academy of Science and Technology, Hanoi, Vietnam.

E-mail:vietanh8177@gmail.com

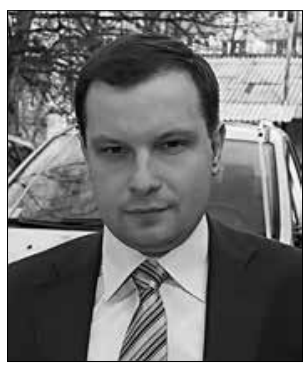

КЛЮЕВ Роман Владимирович доктор технических наук, профессор; зав. кафедрой «Электроснабжение промышленных предприятий».

Северо-Кавказский горно-металлургический институт (государственный технологический университет), г. Владикавказ, Россия

Тел.: +7(8672)-40-73-71 (раб.);

+7 (918)707-39-25 (моб.).

E-mail: kluev-roman@rambler.ru

Roman Vladimirovich KLYUEV - Doctor of Technical Sciences, Head of the Department of Electrical Supply of Industrial Enterprises. North Caucasian Institute of Mining and Metallurgy (State Technological University), Vladikavkaz, Russia.

Tel.: +7 (918) 707-39-25 (mobile); +7(8672) 40-73-71 (work);

E-mail:kluev-roman@rambler.ru

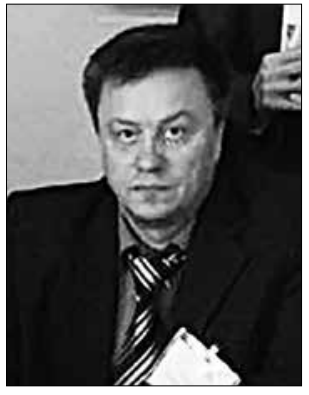

БОСИКОВ Игорь Иванович кандидат технических наук, доцент; доцент кафедры «Прикладная геология».

Научные интересы: математическое моделирование в геоэкологии.

Северо-Кавказский горно-металлургический институт (государственный технологический университет), г. Владикавказ, Россия

Igor Ivanovich BOSIKOV - Candidate of Technical Sciences, Associate Professor.

Research interests: mathematical modeling in Geoecology.

North Caucasian Institute of Mining and Metallurgy (State Technological University), Vladikavkaz, Russia.

E-mail: igor.boss.777@mail.ru

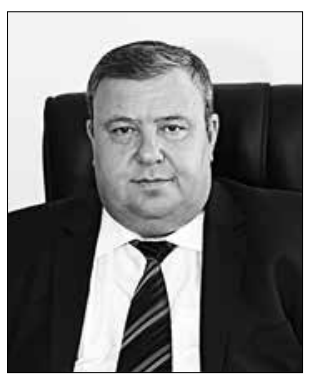

ЦИДАЕВ Батраз Саламович кандидат технических наук, первый проректор-проректор по стратегическому развитию.

Область исследований: горное и нефтегазовое дело.

Северо-Кавказский горно-металлургический институт (государственный технологический университет), г. Владикавказ, Россия

Тел.: +7 (8672) 407-103

Batraz Salamovich TSIDAEV - Candidate of Technical Sciences, first Vice Rector - Vice Rector for Strategic Development.

Research interests: Mining, Oil and Gas Engineering.

North Caucasian Institute of Mining and Metallurgy (State Technological University), Vladikavkaz, Russia.

Tel: +7 (8672) 40-71-03 


\section{ОЦЕНКА НАДЕЖНОСТИ СИСТЕМЫ УПРАВЛЕНИЯ ВЕНТИЛЯЦИЕЙ НА ГОРНОДОБЫВАЮЩИХ ОБЪЕКТАХ}

${ }^{1}$ Тран Виет Ан

${ }^{2}$ Р.В. Клюев

${ }^{2}$ И.И. Босиков*

${ }^{2}$ Б.С. Цидаев

${ }^{1}$ Академия наук и технологий Вьетнама, г. Ханой, Вьетнам

${ }^{2}$ Северо-Кавказский горно-металлургический институт (государственный технологический университет), Владикавказ, Россия

*E-mail: igor.boss.777@mail.ru

\section{DOI: $10.21177 / 1998-4502-2018-10-1-117-124$}

В настоящее время отсутствуют не только практические, но и теоретические методы расчета эффективности функционирования систем, которые могут изменяться случайным образом через короткие интервалы времени. Изменение выполняемых системой функций всегда приводит к изменению ее структуры.

Существующие методы не обеспечивают возможность расчета надежности современных систем, обладающих большим количеством состояний и сложными связями между ними. Практически не рассматривался вопрос моделирования собственного времени жизни сложной системы, когда ее элементы работают не одновременно. Подобная картина имеет место и в отношении динамично изменяющейся границы между отказовыми и работоспособными составляющими. Задачи такого уровня сложности в теории надежности недостаточно изучены. Решение перечисленного круга проблем чрезвычайно актуально в настоящее время.

В статье описываются исследования проводимые авторами на горнодобывающих предприятиях Северного Кавказа и Казахстана.

Цель исследований - оценка надежности системы управления вентиляцией на добычных участках шахт и рудников в условиях горных территорий.

Задачи исследований:

- произвести компоновку схемы управляющей системы вентиляции в конструктивные блоки;

- установить свойства плотных множеств, с помощью которых необходимо доказать условия реализации алгоритма перечисления и операции сокращения.

Поставленные задачи решаются на основе комплексного исследования проблем повышения эффективности технической системы горнодобывающего комплекса. Для этого разрабатывается интегрированная система оценки надежности системы управления вентиляцией на добычных участках шахт и рудников в условиях горных территорий.

Результаты исследований. Разработана интегрированная система оценки надежности системы управления вентиляцией, на добычных участках шахт и рудников. Разработан алгоритм, основанный на построении графа. Результат последовательного стягивания в графе каждого максимального плотного подмножества к некоторой одной вершине заключается в том, что разные подмножества стягиваются к разным вершинам. Полученные алгоритмы могут успешно применяться при полном анализе устойчивости струй отдельных независимых вентиляционных участков и небольших шахт. Более широкое использование разработанных в интегрированной системе критериев и алгоритмов возможно после упрощения схем по предлагаемым методам.

Ключевые слова: алгоритм, график, декомпозиция, оценка надежности, система вентиляции, эффективность, функционирование, совместимые подмножества

\section{Литература}

1. Bosikov I.I., Klyuev R.V., Kelekhsaev V. B. Method for determining of the ventilation object transfer function according to normal operation (by the example of mining and processing complex). Industrial Engineering, Applications and Manufacturing (ICIEAM), 2017 International Conference. 2017. Pp. 1-5. DOI: 10.1109/ICIEAM.2017.8076113.

2. Моисеев Н. Н. Математические проблемы системного анализа. Москва: Наука, 1981. С. 488

3. Рыков А. С. Модели и методы системного анализа: принятие решений и оптимизация. Москва: Национальный университет науки и техники (МИСиС), 2005. С. 352

4. Benardos A., Athanasiadis I., Katsoulakos N. Modern earth sheltered constructions: a paradigm of green engineering// Tunnelling and Underground Space Technology. 2014. Vol. 41. Pp. 46-52.

5. L. He, Y. Song, S. Z. Dai, K. Durbak. Quantitative research on the capacity of urban underground space // Tunnelling and Underground Space Technology. 2012. Vol. 32. Pp. 168-179.

6. Wang G., Li R., Carranza E. J. M., Yang F. 3D geological modeling for prediction of subsurface Mo targets in the Luanchuan district, China. // Ore Geology Reviews. 2015. Vol. 71. Pp. 592-610.

7. Saaty T.L., Vargas L.C. Inconsistency and rank preservation. // Journal of Mathematical Psychology. 1984. Vol. 28, No 2. Pp. 205-241.

8. Письменный А., Чаадаев А., Акишев А., Бондаренко И., Бабаскин С. Инновационные технологии при открытой добыче алмазов на месторождениях // Инновации и нанотехнологии России. 2012. № 1 (2). С. 38-39

9. Najafi B.A., Saeedi G.R., Farsangi M.A.E. Risk analysis and prediction of out-of-seam dilution in longwall mining // International Journal of Rock Mechanics and Mining Sciences. 2014. Vol. 70. Pp. 115-122.

10. Трубецкой К. Н., Каплунов Д. р., Рыльникова М. В., Радченко Д. Н. Новые подходы к проектированию ресурсо-воспроизводящих технологий комплексного извлечения руд // Журнал горной науки. 2011. Т 47, N 3. C. $317-323$ 
11. Sbárbaro D., René del Villar. Advanced Control and Supervision of Mineral Processing Plants. London: Springer. 2010. P. 310.

12. Remes A. Advanced Process Monitoring and Control Methods in Mineral Processing Applications. Espoo: Aalto University. 2012. P. 76.

13. Белов П. Г. Системный анализ и моделирование опасных процессов в техносфере. Москва: Издательский Центр "Академия". 2003. С. 512

14. Шпицнадель В. Н. Теория и практика принятия оптимальных решений. Санкт-Петербург: Издательство "Деловая пресса". 2002. С. 394

15. Jørgensen S.E. A eutrophication model for a lake // Journal of Ecological Modelling. 1976.Vol. 2. Pp.147-165.

16. Юн Р. Б., Клюев Р.В., Босиков И. И., Дзеранов Б. В. Оценка запасов нефти на территориях Северного Кавказа и Казахстана с помощью структурно-геодинамических предпосылок // Устойчивое развитие горных территорий. 2017. Т. 9, N 2 (32). C. 172-178 . DOI: 10.21177 / 1998-4502-2017-9-2-172-178.

17. Пучков Л. А. Аэродинамика подземных вырабо- ток. М.: Издательство Московского государственного горного университета, 1993. С. 266.

18. Савельев М. В., Енгибарян И. А., Еременко А. С., Аликов А. Ю. Расчет оценок верхней и нижней надежности сложных технических систем с переменной структурой. Свидетельство об официальной регистрации программы для ЭВМ № 2006613810 РФ. Номер 2006612791. Объявленный. 14.08.2006. Зарегистрированный пользователь в реестре программ для ЭВМ 03.11.2006.

19. Dorigo M., Gambardella L. M. Ant Colony System: A Cooperative Learning Approach to the Traveling Salesman Problem // IEEE Transactions on Evolutionary Computation. 1997. Vol. 1. No. 1. Pp. 53-66.

20. Карпенко А. П. Современные алгоритмы поисковой оптимизации. Алгоритмы, вдохновленные природой. Москва: Издательство Московского государственного технического университета имени Баумана. 2014. С. 446

21. Кремер Н. Ш. Теория вероятности и математическая статистика. Москва: UNITEDONE, 2004. С. 57.

Artide received 21.03.2017 


\section{ПЕРСПЕКТИВЫ ДИВЕРСИФИКАЦИИ ТЕХНОЛОГИИ ДОБЫЧИ МЕТАЛЛОВ В РСО-АЛАНИЯ}

\author{
${ }^{1}$ Дребенштедт К., \\ 2Голик В. И., ${ }^{*}$ \\ Дмитрак Ю. В.
}

\section{Введение}

Республика Северная Осетия-Алания располагает мощным горно-промышленным потенциалом (рис.1).

Добыча и переработка минерального сырья всегда была основной деятельностью населяющих регион народов. В новейшей истории градообразующим предприятием Северной Осетии был Садонский свинцово-цинковый комбинат (ССЦК). Северная Осетия обеспечивала потребности в металлах с первых лет вхождения в семью народов сначала России, а затем СССР. Было время, когда Осетия удовлетворяла потребности России и СССР в свинце полностью и в цинке на $2 / 3$.

В результате экономической реформы 90-х годов ССЦК, как и большинство дотационных предприятий, практически прекратил добычу руды, не в силах конкурировать на рынке металлов в силу особенностей своего развития, как стратегического объекта. Восстановление экономического потенциала горнодобывающей является одной из приоритетных проблем развития и укрепления депрессивной экономики Северной Осетии [1-3].

Практика горного производства свидетельствует, что часть добывающих предприятий находит выход из сложившейся ситуации в диверсификации технологий добычи и переработки руд. Одним из реальных направлений оживления производства является комбинирование технологий извлечения металлов с использованием методов выщелачивания в блоках, кучах и дезинтеграторах. Пионерные исследования этого направления обнаружили их перспективность в условиях происшедших изменений состояния минерально-сырьевой базы региона.

\section{Анализ последних исследований и публикаций}

Проблемы совершенствования и развития технологий разработки Садонских месторождений всегда были приоритетными для ученых Северного Кавказа [4-6].

Ученый с мировым именем, профессор СКГМИ Остроушко И.А. не только доказал возможность и целесообразность извлечения металлов из некондиционных для традиционных технологий руд и шахтных стоков, но и обеспечил научное сопровождение проектирования, а затем и строительства первого в мировой практике подземного рудника для добычи балансовых руд. Уникальное предприятие не получило развития, потому что не был решен вопрос переработки нового для завода «Электроцинк» вида концентрата.

Голик В.И. и Кондратьев Ю.И. многофакторными исследованиями в рамках Федеральной программы доказали, что сокращение запасов руд с промышленным содержанием металлов может быть компенсировано освоением запасов бедного по содержанию металлов сырья альтернативной традиционным способам технологией добычи полезных ископаемых с активацией процессов выщелачивания путем механохимического воздействия в дезинтеграторе.

\footnotetext{
${ }^{1}$ Технический Университет Горная Академия, г. Фрайберг, Германия

${ }^{2}$ Северо-Кавказский горно-металлургический институт (государственный технологический университет), г. Владикавказ, Россия
}

\section{УДК: 504.55.054:622(470.6) DOI: 10.21177/1998-4502-2018- 10-1-125-131}

Рассмотрена проблема восстановления горной отрасли РСО-Алания путем диверсификации производства в ходе комбинирования традиционных и нетрадиционных технологий добычи и переработки руд. Использован комплексный метод исследований оm анализа опыта разработки месторождения до оценки нетрадиционных технологий добычи металлов из некондиционного сырья. Систематизирован опыт выщелачивания балансовых руд и хвостов обогащения. Определен объем сырьевой базы для технологий выщелачивания. Дана оценка перспектив добычи металлов с использованием традиционных технологий. Сделан вывод о

возможности использования нетрадиционных технологий получения металлов из некондиционного сырья.

КЛЮЧЕВЫЕ СЛОВА: диверсификация, технология, добыча, переработка, руда, выщелачивание, месторождение, Садон, комбинирование, экономика.

Статья поступила в редакцию 22.09.2017 
Исследованиями доказана возможность при сегодняшней минерально-сырьевой базе увеличить показатели предприятия не на проценты, а в разы. В СКГМИ разработаны технологии извлечения металлов из хвостов переработки упорных сульфидных свинец- и цинксодержащих руд и из растворов полезных компонентов из шахтных стоков с очисткой от солей и металлов до предельно-допустимых концентраций.

Все известные ранее технологии уменьшают потери металла, но не делают процесс извлечения металлов безотходным [7-9].

Сокращение запасов руд с промышленным содержанием цветных металлов делает необходимым поиск технологий рентабельной переработки бедных забалансовых руд и отходов первичного обогащения. Альтернативными способами их переработки являются виды выщелачивания, в том числе, применяемое для преодоления кольматации со снижением темпов фильтрации раствора сквозь материал агитационное.

В горной практике получают раз-

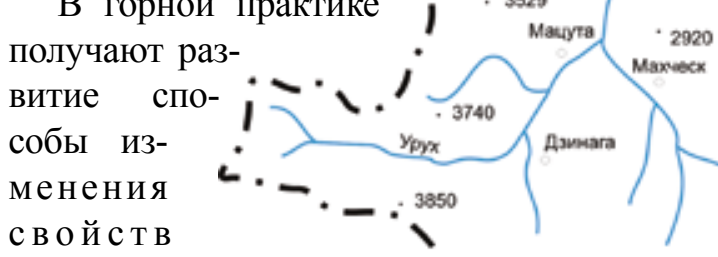
с в ой с т в минералов в аппара- ' $\mathbf{i}^{3800}$ тах путем приложения высокой механической энергии [10-12] (рис. 2).

Учеными Юга России технология изменения свойств мине-

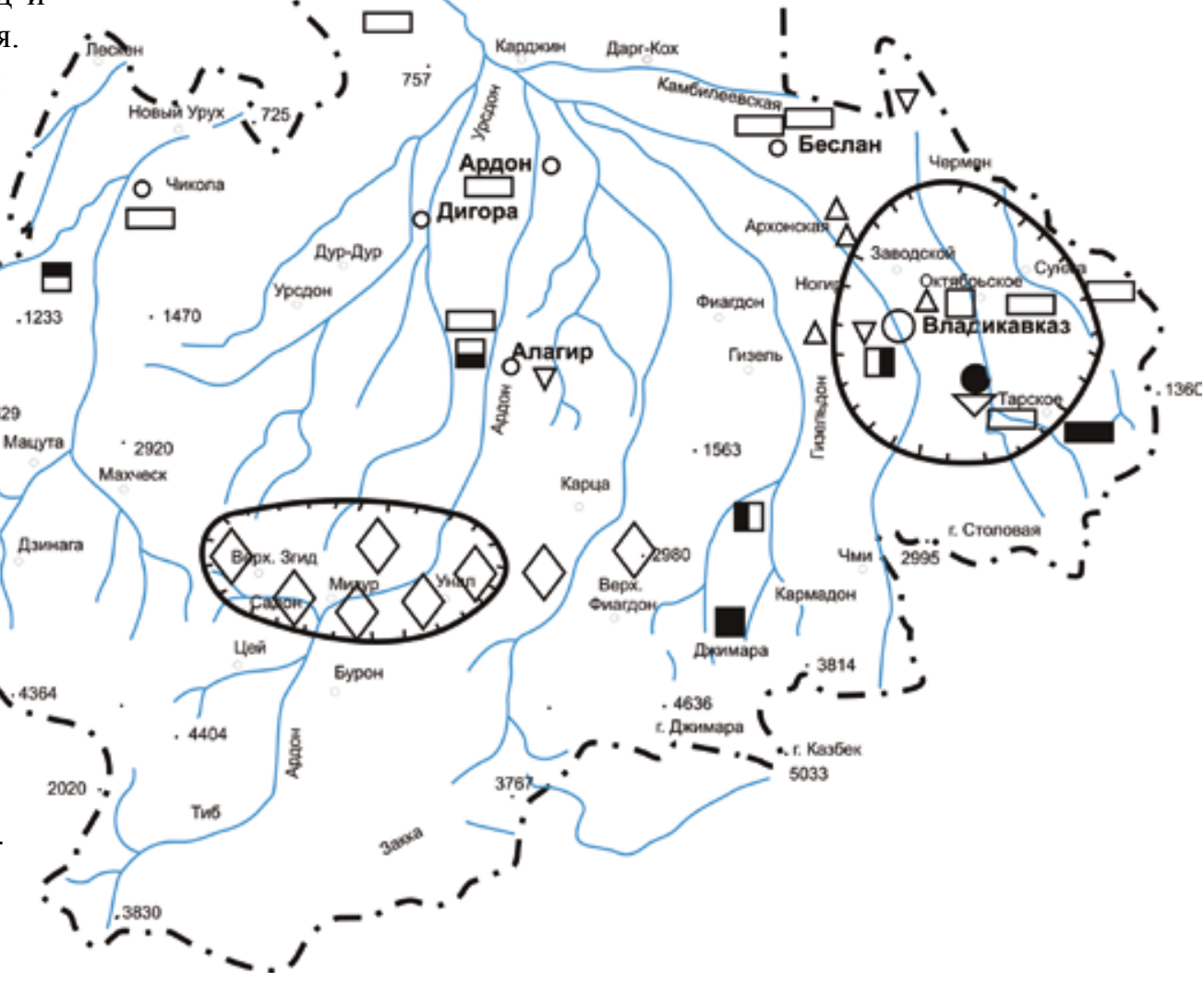

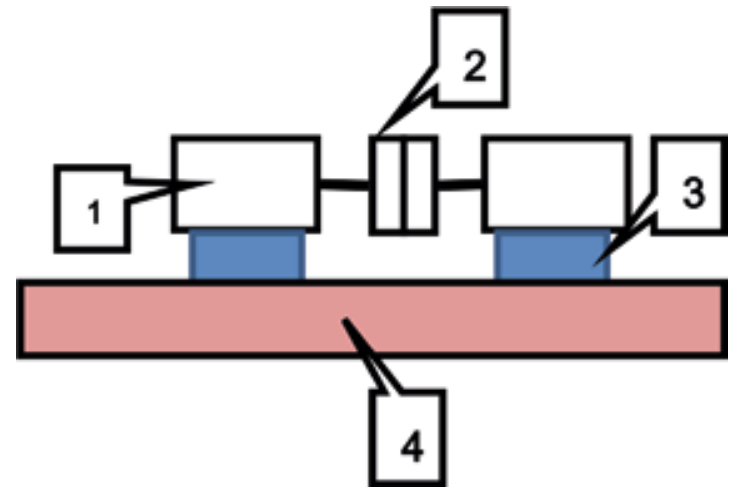

Pис. 2. Схема механической активации минералов в дезинтеграторе: 1 - электродвигатель; 2 - рабочая корзина; 3 - виброгасящая основа; 4 -основание

Fig. 2. Scheme of mechanical activation of minerals in the disintegrator: 1 -motor; 2 -working basket; 3 -vibration damping base; 4 -base

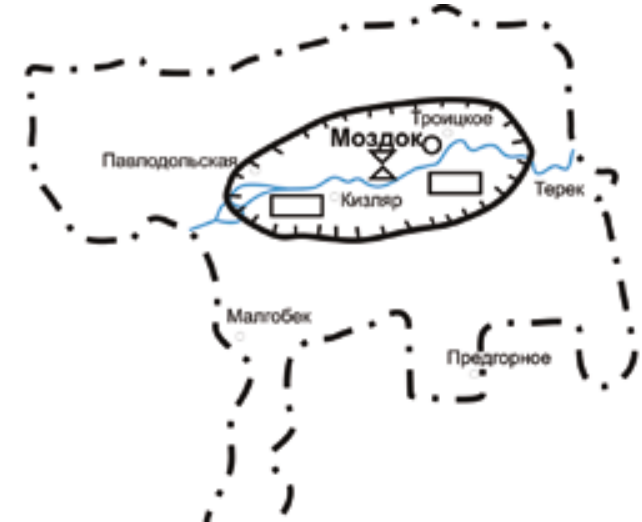


няются управляемой переработкой растворов в рамках замкнутой и контролируемой на каждом этапе системы.

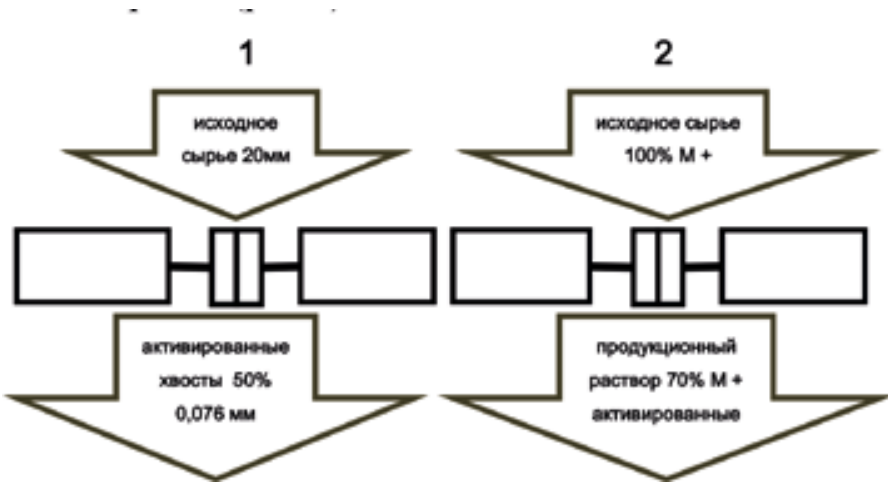

Puc. 3. Аспекты повышения активности минералов в дезинтеграторе:1 - активачия механической энергией;

2 - активация одновременно механической и химической энергией /

Fig. 3. Aspects of minerals activity increase in the disintegrator: 1 -activation of mechanical energy; 2 - activation of both mechanical and chemical energy

В результате увеличивается количество извлекаемых металлов, увеличивается объем сырья для строительной индустрии и устраняется опасность для окружающей среды региона [13-15].

\section{Цель исследования}

В условиях ССЦК исчерпание запасов балансовых руд лишает перспективы модернизацию производства на основе традиционных технологий. Анализом состояния горных предприятий и региона и аналогичных предприятий мира и России установлено, что реальным направлением развития является диверсификация производства путем комбинирования традиционных и нетрадиционных технологий добычи и переработки руд. Реанимация одного из флагманов цветной металлургии в прошлом позволит оживить экономику депрессивного региона [16-18].

В отработанных рудных телах Садонских месторождений в виде эксплуатационных потерь, целиков и во вмещающих породах оставлены объемы минерального сырья, сравнимые с объемом добытых руд. В последние годы Садонские рудники добыли около 1 миллиона тонн такой руды, оставив в недрах столько же.

Целью исследования является восстановление экономического состояния горной отрасли РСО-Алания путем диверсификации технологий его месторождений. Инструментом достижения цели является извлечение металлов из ранее считавшегося некондиционным сырья.

\section{Основной раздел}

На Северном Кавказе известно около 600 металлических месторождений и рудопроявлений, которые для традиционных технологий добычи и переработки непригодны, а для новых технологий экономически привлекательны, например, Какадур-Ханикомское месторождение.
Технологическая возможность химического извлечения металлов из Садонских руд доказана не однократно и только несогласованность действий между участниками освоения новой технологии не позволила развить достигнутый успех. В 1974 г. ССЦК получил концентрат выщелачивания, содержащий 15 \% цинка и другие металлы, для переработки которого металлургический завод не построил технологической линии.

На Фиагдонском месторождении путем осаждения содой и цинковой пылью из шахтных вод за 48 суток получено 32 т цинкового концентрата с влажностью 65-78 \% и содержанием, \%: цинка - до 30, никеля - 6, железа - 6, свинца - до 0,54, меди - до 0,15 , кадмия - 0,021. В сбрасываемых в гидросферу водах концентрация цинка снижена до 0,01-0,1 мг/л, свинца - 0,10,15 мг/л [5].

В свою очередь на Архонском руднике за 51 сутки таким же способом осаждено 40 т цинкового концентрата влажностью 65-78\% с содержанием, \%: цинка до 25 , железа - 6,0, свинца - 0,3-0,5, меди -0,15-0,28, кадмия - 0,054, кобальта - 0,08, никеля - 0,075 (рис. 4).

В случае реализации идеи И.А. Остроушко о добыче и переработке некондиционного для традиционных технологий сырья можно было добывать до 2500 т цинка в год с меньшими затратами, что могло бы сделать продукцию предприятий конкурентоспособной.

Возможности геотехнологических методов добычи металлов подтверждаются феноменом природного выщелачивания с растворением и выносом металлов. В процессах выщелачивания металлы переводятся в мобильное состояние не только технологически, но и природой, поэтому экономическая эффективность их извлечения становится приемлемой для экономики предприятия, а с учетом снижения затрат на поддержание экологии увеличивается [6].

В условиях Садонских месторождений в процесс добычи металлов могут быть вовлечены металлосодержащие ресурсы с содержанием металлов $1 \%$.

В настоящее время Садонское месторождение представляет собой реактор объемом около 2,5 млн. м ${ }^{3}$, в котором шахтными водами и шахтной атмосферой выщелачивается около 4 млн. тонн руд, содержащих более 5000 тыс. тонн свинца и цинка. С учетом раскрытия трещин во вмещающих породах объем реактора увеличивается еще на 0,5 млн. ${ }^{3}$, достигая 3 млн. м $^{3}$.

Подсчет запасов с критическим пределом в виде суммарного содержания свинца и цинка 0,5 \% показывает, что количество потерянных в недрах Садонских месторождений руд содержанием свинца и цинка соответственно 2,6 и 3,6\% составляет 2 млн. тонн, а вместе с вкрапленными рудами в боковых породах достигает 30 млн. тонн.

Сегодняшние планы возрождения потенциала ССЦК связаны с добычей 200 тыс.т/г. руды традиционными методами на флангах и глубоких горизонтах 


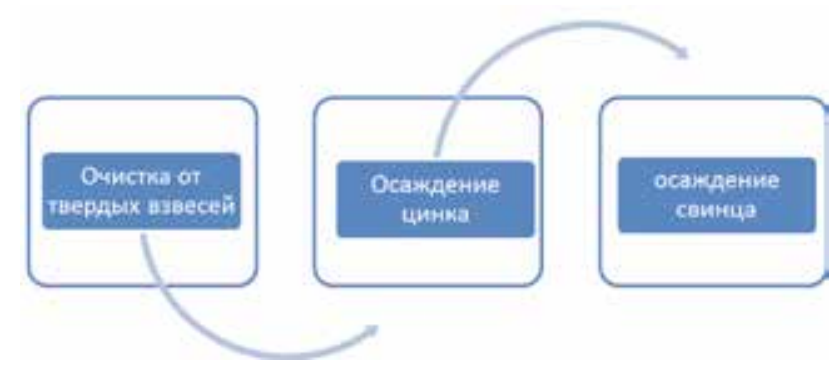

Рис. 4. Технологическая схема осаждения металлов из шахтных стоков /

Fig.4. Technological scheme of metals deposition from mine effluents

Згидского, Садонского и Архонского месторождений и при освоении нового Джимидонского месторождения.

Перспективы безотходной переработки некондиционных руд открывают результаты исследования вариантов извлечения металлов из хвостов Мизурской обогатительной фабрики и руд Архонского месторождения с механоактивацией в дезинтеграторе:

- выщелачивание хвостов или руды в дезинтеграторе;

- агитационное выщелачивание активированных хвостов и руды предварительно активированных в дезинтеграторе;

- многократное выщелачивание хвостов и руды в дезинтеграторе.

Анализ результатов экспериментов и описывающих их уравнений регрессии позволяет характеризовать механизм и полноту извлечения металлов из некондиционного сырья.

Извлечение металлов в раствор практически совпадает при агитационном выщелачивании, агитационном выщелачивании после активации в дезинтеграторе и при выщелачивании с многократной активацией дезинтеграторе.

В то же время при агитационном выщелачивании минералов, предварительно активированных в сухом состоянии, или при выщелачивании одновременно с активацией при однократном пропускании через дезинтегратор в раствор переходит меньшее количество металлов.

Извлечение металлов в раствор практически одинаково и при многократной активации в дезинтеграторе, и при простом агитационном выщелачивании и при агитационном выщелачивании после активации и выщелачивания в дезинтеграторе.

Вместе с тем время агитационного выщелачивания более чем на два порядка больше времени обработки испытываемых материалов в дезинтеграторе. Можно утверждать, что выщелачивание пульпы хвостов или руды при многократной активации с выщелачиванием в дезинтеграторе более эффективно, чем простое агитационное выщелачивание [19].

В самое последнее время исследования по извлечению металлов продолжены на хвостах переработки Донбасских углей и железистых кварцитов Лебе- динского месторождения КМА. Сходимость результатов выщелачивания минералов в дезинтеграторе подтверждает корректность исследований и новой технологии.

Минералами-окислителями в рудах Садонских являются пирит и пирротин, ускоряющие окисление рудных минералов кислородом воздуха. На поверхности сульфидных руд происходят вертикальные перемещения. При окислении пирита выделяется 3400 ккал/кг тепла, которое сначала способствует выщелачиванию, но затем выделяющиеся пары затрудняют проникновение кислорода в раствор.

При окислении в присутствии воды выделяется одна молекула $\mathrm{H}_{2} \mathrm{SO}_{4}, 7$ молекул закисного сернокислого железа. Одна молекула пирротина компенсирует недостаток закисного железа у 5 молекул пирита, поэтому для выщелачивания оптимально соотношение пирита и пирротина 1:5.

Пирротин окисляется быстрее пирита, выделяя тепло. Пирротина в рудах около $2 \%$, с ним связано около $6 \%$ серы, а остальная сера связана с пиритом. При окислении его выделяется около 100 г серной кислоты, из которой 90 г нейтрализуется карбонатами, которых в рудах содержится около $5 \%$.

В границах Садонского месторождения выделяются два типа оруденения: полиметаллическое и пирротиновое. В полиметаллическом месторождении пирита не более $20 \%$, пирротина и марказита до $10 \%$, а в пирротиновом месторождении пирита 10-20\%, пирротина более $20 \%$, а марказита мало.

Для месторождений характерна замена пирротиновой минерализации пиритовой с удалением от крупных разломов. В рудах наблюдается снижение пирротина с увеличением пирита в направлениях от периферии к центру и снизу вверх.

Верхняя часть месторождения содержит большее количество пирита, и процессы окисления протекают в ней активнее примерно в 3 раза.

Совместное действие минералогических факторов способствует активному извлечению металлов в раствор в присутствии пирита в верхней части месторождения и пассивное в присутствии пирротина в нижней части.

Лучшие перспективы выщелачивания руд имеют верхние части участков Ход, Центральный и Кирова. Несколько хуже условия вскрытия сульфидов для остальной части указанных участков и участка Новая зона. Неудовлетворительно обеспечены кислотами участок Артем, нижние части участков Центральный, Кирова, Новая зона и участок Вторая рудная зона.

Присутствие пирита, марказита и марматита с тонким взаимным прорастанием минералов способствует продолжению физических и химических процессов природного выщелачивания в недрах и на земной поверхности. 
Проблема вовлечения в производство некондиционных минеральных ресурсов становится все более актуальной по мере исчерпания запасов действующих месторождений [20].

\section{Заключение}

Возможности выживания депрессивных горнодобывающих предприятий могут быть улучшены путем повышения объемов добычи минерального сырья за счет использования нетрадиционных технологий с выщелачиванием при комбинировании с традиционными способами добычи руд.

Освоение инновационных технологий освоения некондиционных запасов месторождений методами выщелачивания является возможностью увеличить экономический потенциал региона.

Горнодобывающие предприятия РСО-Алания располагают приоритетом в освоении технологий с выщелачиванием, обладают инфраструктурой и кадрами для реализации новых технологий.

В статье представлены результаты исследований, выполненных по программе Erasmus + 574061-EPP-1-2016-1DE-EPPKA2-CBHE-JP "Modernization of geological education in Russian and Vietnamese universities".

\section{ЛИТЕРАТУРА:}

1. Комащенко В.И. Эколого-экономическая целесообразность утилизации горнопромышленных отходов с целью их переработки // Известия Тульского государственного университета. Науки о Земле. 2015. N 4. С. 23-30.

2. Каплунов Д.Р., Рыльникова М.В., Радченко Д.Н. Реализация концепции устойчивого развития горных территорий - базис расширения минерально -сырьевого комплекса России // Устойчивое развитие горных территорий. Владикавказ. 2015. N3. C.46-50.

3. Комащенко В.И. Разработка взрывной технологии, снижающей вредное воздействие на окружающую среду // Известия Тульского государственного университета. Науки о Земле. 2016. N 1. C. $34-43$.

4. Босиков И.И., Клюев Р.В. Методы системного анализа природно-промышленной системы горно-металлургического комплекса. Владикавказ, 2015. 124 с.

5. Кондратьев Ю.И., Кондратьева И.Ю., Мирецкий А.В., Малиева 3.В. Выщелачивание полиметаллических руд сернокислотно-хлоридными растворами с добавкой некоторых реагентов // Известия высших учебных заведений. Цветная металлургия. 2006. N 4. С. 34-37.

6. Акоева И.В. Совершенствование методических основ оценки эффективности инвестиционных проектов - необходимое условие реализации целевых программ на Юге России // Устойчивое развитие горных территорий. 2012. N3. C.43-45.

7. Евдокимов С.И., Евдокимов В.С. Повышение извлечения золота на основе совместной переработки руды и отходов // Физико-технические проблемы разработки полезных ископаемых. 2017. N2. C. 160-169.

8. Evdokimov S.I., Evdokimov V.S. Metal recovery from old tailings // Journal of Mining Science. 2015. T. 50. N 4. Pp. 800-806.

9. Jarvie-Eggart M. E. Responsible Mining: Case Studies in Managing Social \& Environmental Risks in the Developed World. Englewood, Colorado: Society for Mining, Metallurgy and Exploration. 2015. 804 p.

10. Golik V., Komashchenko V., Morkun V., Burdzieva O. Metal extraction in the case of non-waste disposal of enrichment tailings // Metallurgical and Mining Industry. 2015. No.10. Pp. 213-217.

11. Golik V.I., Efremenkov A.V. Phisicochemikal processes of metal in the disintegrator. All-Russia scientic and practical conference on materials treatment. Bristol. IOP Publishing Ltd. 2016. P. 12038-12042.

12. Прогрессивные методы обогащения и комплексной переработки природного и техногенного минерального сырья (Плаксинские чтения-2014): Материалы междунар. совещ., 16-19 сентября 2014 г. / Под общ. ред. В. А. Чантурия. Алматы: АО «Центр наук о Земле, металлургии и обогащения», 2014. 624 c.

13. Onica I. Environmental Mining Impact. Universitas Publishing House, Petroşani, 2001. Pp. 173-198. (in Romanian).

14. Hu Zhenqi, Wang Peijun and Li Jing. Ecological Restoration of Abandoned Mine Land in China // Journal of Resources and Ecology. 2012. 3(4). Pp. 289-296.

15. Версилов С.О., Фролов А.В., Версилова Е.С., Дремов В.И. Оптимизация литологической системы горнообогатительного комбината «подземный рудник - хвостохранилище» // ГИАБ. 2013. N3. C.67-72.

16. Бабкин В. В., Успенский Д. Д. Новая стратегия. Химия-2030. Высокие переделы сырья. Кластеризация. Химизация индустрии РФ. М.: Лика, 2015. 222 с.

17. Dodson J.R., Hunt A.J., Parker H.L., Yang Y., Clark J.H. Element sustainability: Towards the total recovery of scarce metals // Chem. Eng. Process. 2012. 51. Pp. 69-78.

18. Prior T., Giurco D., Mudd G., Mason L., Behrisch J. Resource depletion, peak minerals and the implications for sustainable resource management. Glob. Environ. Chang. 2012. 22. Рp. 577-587.

19. Хулелидзе К.К., Кондратьев Ю.И., Бетрозов 3.С., Заалишвили В.Б. Оценка коренных и техногенных месторождений РСО-Алания как возможных объектов применения технологии подземного и кучного выщелачивания // Устойчивое развитие горных территорий. 2016. N1. C. 46-49.

20. Sinclair L., Thompson J. In situ leaching of copper: Challenges and future prospects // Hydrometallurgy. 2015. T. 157. Pp. 306-324. 


\title{
СВЕДЕНИЯ ОБ АВТОРАХ / Information about authors:
}

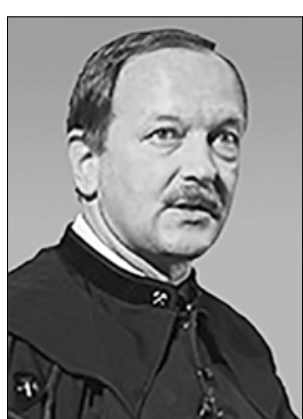

ДРЕБЕНШТЕДТ Карстен -

кандидат технических наук, профессор, директор института горного дела и специального подземного строительства технического университета Фрайбергская горная академия, Германия.

Область научных интересов: совершенствование технологии открытых горных работ.

Автор 395 научных трудов.

Karsten DREBENSHTEDT - Candidate of Technical Sciences, Professor, Director of the Institute of Mining and Special Underground Engineering at Freiberg University of Mining and Technology.

Research interests: improvement of surface mining technology.

Author of 395 scientific publications.

Freiberg University of Mining and Technology, Freiberg, Germany.

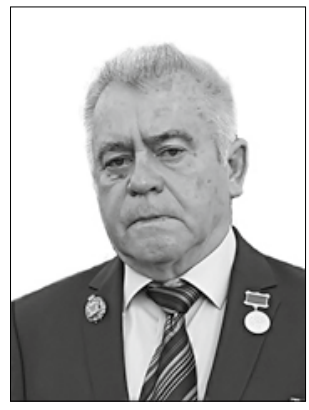

ГОЛИК Владимир Иванович доктор технических наук, професcop, профессор кафедры "Технология разработки месторождений"; заслуженный деятель науки Российской Федерации.

Научные интересы: способы добычи металлов выщелачиванием, утилизация отходов добычи и переработки минералов с активацией

компонентов.

Автор более 1000 печатных трудов, 55 учебников, учебных пособий и монографий, 35 патентов.

Северо-Кавказский горно-металлургический институт (государственный технологический университет), 362021 , г. Владикавказ, РСО-Алания, Россия.

e-mail: v.i.golik@mail.ru

Vladimir Ivanovich GOLIK - Doctor of Technical Sciences, Professor, Professor of the Department "Development of Mineral Deposits"; Honored Scientist of the Russian Federation.

Research interests: methods of extraction of metals by leaching, recycling of waste extraction and processing of minerals with the activation of components. Author of more than 1000 publications, 55 textbooks, manuals and monographs, 35 patents. NorthCaucasian Institute of Mining and Metallurgy (State Technological University), Vladikavkaz, Russia.

e-mail:v.i.golik@mail.ru

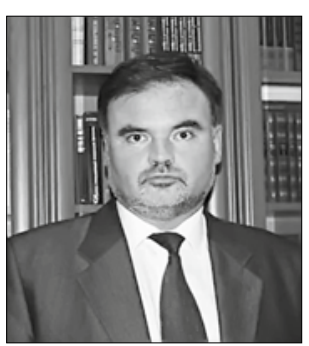

ДМИТРАК Юрий Витальевич доктор технических наук, профессор, исполняющий обязанности ректора.

Направления научной деятельности: разработка и проектирование комплексов оборудования для тонкого и сверхтонкого измельчения горных пород; исследование динамики мелющей загрузки в мельницах различных типов; создание устройств для непосредственного измерения ударных импульсов в помольных камерах мельниц.

Автор более 71 научных и учебно-методических работ, в том числе 13 учебных пособий с грифом УМО, а также 8 авторских свидетельств и патентов РФ на изобретения.

Северо-Кавказский горно-металлургический институт (государственный технологический университет).

362021, г. Владикавказ, Россия

Тел.: +7(8672) 40-71-00 (служ.)

E-mail: rector@skgmi-gtu.ru

Yuri Vitalyevich DMITRAK - Doctor of Technical Sciences, Professor, acting Rector.

Research interests: development and design of complex equipment for fine and ultrafine grinding of rocks; study of dynamics of the grinding load in mills of various types; creation of devices for direct measurement of shock pulses in the grinding chambers of mills.

Author of 71 scientific and educational works, including 13 textbooks stamped by Academic Methodological Association, 8 author's certificates and Russian Federation patents for inventions.

North Caucasian Institute of Mining and Metallurgy (State Technological University), Vladikavkaz, Russia.

Tel. +7 (8672) 40-71-00

E-mail: rector@skgmi-gtu.ru

\section{THE PROSPECTS OF DIVERSIFICATION OF TECHNOLOGY OF EXTRACTION OF METALS IN REPUBLIC OF NORTH OSETIA-ALANIYA}

\author{
${ }^{1} \mathrm{~K}$. Drebenshtedt \\ ${ }^{2}$ V. I. Golik* \\ ${ }^{2}$ Yu. V. Dmitrak \\ ${ }^{1}$ Institute of mining TU Mountain Academy Freiberg, Germany \\ ${ }^{2}$ North Caucasian Institute of Mining and Metallurgy (State Technological University), Vladikavkaz, Russia
}

DOI: $10.21177 / 1998-4502-2018-10-1-125-131$

Introduction. The mining region RSO-Alania looks for ways of recovery of the mountain industry which is in the protracted crisis condition after the managing system change in Russia. In similar conditions in case of exhaustion of the majority of inventories of balance sheet ores the real direction of development is production diversification, in this 
case, by a combination of traditional and nonconventional technologies of production and conversion of ores.

Materials and methods. For the purpose of the potential recovery of one of the non-ferrous metallurgy leaders the complex method of researches including stages from the mining experience analysis to assessment of nonconventional technologies of metals production from substandard raw materials is used.

Results. Experience of balance sheet ores leaching first in the world practice of underground mine built for this purpose in Sadon ore node is systematized and used. The potential amount of raw materials source for leaching technologies is determined. An assessment of metals production prospects with the use of traditional technologies is given. An assessment of a potential object of leaching is given. The conclusion is drawn on the possibility of earlier subsidized mining entities survival when using nonconventional technologies by a combination of the traditional and innovative methods of ores production. This conclusion is confirmed with researches in case of metals production from other ores and coals.

Discussion. Diversification of the mountain entities and complex use of resources in conditions of RSO-Alania is more effective in comparison with the construction of the new mountain entities because of the available business assets and inventories use. The new direction of the mining entities survival due to nonconventional technologies use in case of the technologies combination on the economic basis is the real direction of the depressive region budget replenishment .

Keywords: diversification, technology, production, conversion, ore, leaching, field, Sadon, combination, economy.

\section{Referensces}

1. Komashenko, V. I. Ecological and economic feasibility of disposal of mining waste with the purpose of their processing. Proceedings of the Tula state University. Earth science. 2015. N 4. Pp. 23-30.

2. Kaplunov D. R., Ryl'nikova M. V., Radchenko D. N. The implementation of the concept of sustainable development of mountain territories is the basis of the extension of the mineral resource complex of Russia. Sustainable development of mountain areas. Vladikavkaz. 2015. No 3. Pp. 46-50.

3. Komashenko, V. I. Development of technology to reduce the harmful effects on the environment. Izvestia of the Tula state University. earth science. 2016. No 1. Pp. 34-43.

4. Bosikov I. I., Klyuev R. V. Methods of system analysis of natural and industrial system of mining and metallurgical complex. Vladikavkaz, 2015. 124 p.

5. Kondrat'ev, Y. I., Kondratyeva I. Y. Miretskiy, A. V., Z. V. Maleeva Leaching of polymetallic ores with sulfuric acid-chloride solutions with addition of some reagents. proceedings of higher educational institutions. Nonferrous metallurgy. 2006. No 4. Pp. 34-37.

6. Akoeva I. V. Improvement of the methodological basis for evaluating the effectiveness of investment projects - a necessary condition for the implementation of targeted programs in the South of Russia. Sustainable development of mountain territories. 2012. No3. Pp. 43-45.
7. Evdokimov S. I., Evdokimov V. S. Increase of gold extraction on the basis of joint ore and waste processing. Physico-technical problems of mineral development. 2017. N2. Pp. 160-169.

8. Evdokimov S.I., Evdokimov V.S. Metal recovery from old tailings. Journal of Mining Science. 2015. T. 50. No 4. Pp. 800-806.

9. Jarvie-Eggart M. E. Responsible Mining: Case Studies in Managing Social \& Environmental Risks in the Developed World. Englewood, Colorado: Society for Mining, Metallurgy and Exploration. 2015. 804 p.

10. Golik Vladimir, KomashchenkoVitaly, Morkun Vladimir, Burdzieva Olga. Metal extraction in the case of non-waste disposal of enrichment tailings. Metallurgical and Mining Industry. 2015. No.10. Pp. 213-217.

11. Golik V.I., Efremenkov A.V. Phisicochemikal processes of metal in the disintegrator. All-Russia scientic and practical conference on materials treatment .Bristol. IOP Publishing Ltd. 2016. Pp. 12038-12042.

12. Progressive methods of enrichment and complex processing of natural and man-made mineral raw materials (Plaksin readings-2014): international Materials. the meeting. On 16-19 September 2014 / under the General editorship of V. A. Chanturia. Almaty: JSC "Center of Sciences about Earth, metallurgy and enrichment", 2014. 624 p.

13. Onica I. Environmental Mining Impact. Universitas Publishing House, Petroşani, 2001. Pp. 173-198. (in Romanian).

14. Hu Zhenqi, Wang Peijun and Li Jing. Ecological Restoration of Abandoned Mine Land in China. Journal of Resources and Ecology. 2012. 3(4). Pp. 289-296.

15. Versilov S. O., Frolov A.V., Versilov, E. S., Dremov V. I. Optimization of lithologic mining and processing plant "underground mine - tailings", GORN. 2013. No3. Pp. 6772.

16. Babkin, V. V., Uspensky D. D. A new strategy. Chemistry-2030. High recycling of raw materials. Clustering. Chemical industry. Moscow. Lika. 2015. 222 p.

17. Dodson J.R., Hunt A.J., Parker H.L., Yang Y., Clark J.H. Element sustainability: Towards the total recovery of scarce metals. Chem. Eng. Process. 2012. 51. Pp. 69-78.

18. Prior T., Giurco D., Mudd G., Mason L., Behrisch J. Resource depletion, peak minerals and the implications for sustainable resource management. Glob.Environ. Chang. 2012. 22. Pp. 577-587.

19. Khulelidze, K. K., Kondrat'ev, Y. I., Petrosov Z. S., Zaalishvili V. B. Evaluation of indigenous and man-made deposits of North Ossetia-Alania as possible objects of application of technology of underground and heap leaching. Sustainable development of mountain territories. 2016. No1. Pp. 46-49.

20. Sinclair L., Thompson J. In situ leaching of copper: Challenges and future prospects. Hydrometallurgy. 2015. T.157. Pp. 306-324.

Article received 22.09.2017 
1Евдокимов С.И., 2Ли И, ${ }^{3}$ Герасименко Т.E.

\section{УСТОЙЧИВОЕ РАЗВИТИЕ ГОРНЫХ ТЕРРИТОРИЙ: ИНВЕСТИЦИОННАЯ ПРИВЛЕКАТЕЛЬНОСТЬ ТЕХНОГЕННЫХ ЗАПАСОВ ЗОЛОТА}

\section{Введение}

Техногенные ресурсы занимают в структуре запасов золота в России от 7 до $12 \%$ [1; 2]. Вовлечение их в хозяйственный оборот может быть актуальным направлением устойчивого развития минерально-сырьевой базы страны [3-5]. Известен зарубежный опыт освоения ресурсного потенциала малообъемных месторождений техногенного происхождения [6-13].

Вовлечение в производственный цикл отходов россыпной золотодобычи малыми горными предприятиями является условием устойчивого развития территорий: увеличиваются платежи в бюджеты разного уровня от лицензирования недр и налогообложения производственной деятельности и занятость населения [14-21] при одновременном снижении нагрузки на окружающую среду [22; 23]. Решение задачи экономически выгодной эксплуатации нераспределенных среди недропользователей малообъемных объектов (с балансовыми запасамив регионах Сибири и Дальнего Востока более 1,2 тыс. т на 100 участках, что составляет 38 \% запасов золота категорий $\mathrm{BC}_{1}$ и 20 \% по категории $\mathrm{C}_{2}$ ) позволит получить прирост добычи золота в ближайшие 10-20 лет на 20-30 т ежегодно [24].

\section{Постановка задачи}

Объектом исследования являются техногенные минеральные ресурсы отходы россыпной золотодобычи.

Цель работы - разработка технологии переработки техногенных россыпей золота малыми горными предприятиями с использованием физико-механических и физико-химических процессов, обеспечивающей получением эффекта, основанного на снижении суммарных капитальных, эксплуатационных и организационных затрат, за счет глубокой доводки золотосодержащих концентратов до высоколиквидной товарной продукции.

Аффинажный завод может принять от предприятия бедные концентраты, но плата за их аффинаж настолько высока, что делает их производство мало- и даже нерентабельным.Так, цена аффинажа концентрата, содержащего 1-2 \% $\mathrm{Au}$, равна стоимости 4,4 \% находящегося в нем золота (аффинаж, транспорт и страховка - \$US0,29 за 1 г Аu) при извлечении $85 \% \mathrm{Au}$; цена аффинажа 2-10 \%-го концентрата тоже 4,4\%, но извлечение $\mathrm{Au}-95$ \%. Следовательно, при производстве бедных концентратов предприятие теряет до 20 \% химически чистого золота.

Для крупных вертикально интегрированных холдингов освоение небольших по запасам месторождений (а также доработка старых после достижения определенных технологических и экономических границ) в условиях несовершенства налоговой системы, резких изменений конъюнктуры и цен на мировых рынках металлов становится экономически нецелесообразной: инвестиции не окупаются в сколько-нибудь приемлемые сроки (удельные капитальные вложения в строительство стационарной золотоизвлекательной фабрики (ЗИФ) достигают \$US43-50 на 1 т годовой переработки, себестоимость обогащения 1 т руды составляет \$US13-15), инвестиционные циклы длительные (5-15 лет),

${ }^{1}$ Научно-производственное предприятие "ГЕОС», Владикавказ, Россия

${ }^{2}$ Акционерное общество "Научно-техническая фирма "Аньтай", Пекин, Китай

${ }^{3}$ Северо-Кавказский горно-металлургический институт (государственный технологический университет), Владикавказ, Россия 
рентабельность производства низкая (0-10 \%). Это означает, что в цепи "спрос-предложение" свойство инвестиционного товара имеют малообъемные техногенные объекты, осваиваемые предприятиями малого бизнеса. Эффективность работы малых горных предприятий определяется гибкостью управления и оперативностью реагирования на изменение внешних институциональных и фискально-экономических факторов, небольшие сроки оценки количества и качества запасов, существенно меньшие капиталовложения при быстром вводе в эксплуатацию производственных мощностей, несложная организация работы (вахтовым методом с сезонным режимом работы).

Значимыми доводами в пользу освоения небольших месторождений малыми предприятиями выступают такие аргументы, как: использование местного населения на производстве; скромные требования к инфраструктуре; привлекательность для иностранных компаний с целью создания совместных предприятий, что приводит к сокращению размера необходимых капитальных вложений и времени для организации производства.

Применение мобильных обогатительных комплексов (МОК-технологий) и сезонного режима работы (120-160 дней в год по 12 часов в сутки) позволяет изменить в смете затрат отношение стоимости оборудования к стоимости строительно-монтажных работ (СМР). Если при строительстве ЗИФ это отношение составляет $1: 4$, то при переходе на МОКтехнологиионо изменяется на $1: 3$, т.е. позволяет на $25 \%$ уменьшить размер инвестиций. Если срок ввода в эксплуатацию мобильных (сборно-разборных) установок на основе МОК-технологий не превышает 1 года (МОК производительностью 15 т/ч стоимостью \$US 2-3 млн. обслуживает 7 человек в смену), то строительство ЗИФ требует 4-5 лет [25].

Сдерживающим фактором освоения техногенных месторождений является вытекающий из необходимости соблюдения нормального амортизационного срока существования ЗИФ (норма амортизации 14-15 \%) небольшой объем производства продукции, часто недостаточный для окупаемости капитальных вложений и эксплуатационных затрат.

Теоретическая база

Новые возможности для получения в условиях малого горного предприятия товарной продукции с высокой добавленной стоимостью в виде шлихового золота, переплавляемого на слитки сплава Доре, появились с развитием технологии магнитожидкостной сепарации [26]. Наиболее эффективным ее вариантом является сепарация в несмешивающихся разноплотных магнитных жидкостях [27], когда в рабочих зонах аппаратов движущей силой в сепарационном массопереносе является линейное натяжение $\chi$.

Введение представления о линейном натяжении $\chi$ двумерного давления (или натяжения) $\sigma_{\chi}$ при искривлении линии трехфазного контакта подобно тому, как представление о поверхностном натяжении связано с возникновением капиллярного давления $P_{\sigma}$, когда поверхность раздела двух фаз искривлена.

На точки $a$ и $b$, расположенные симметрично около пересечении нормали $N$ с линией трехфазного контакта с радиусом $r$, действует натяжение $\chi$ по касательной к этим точкам (рис. 1.)

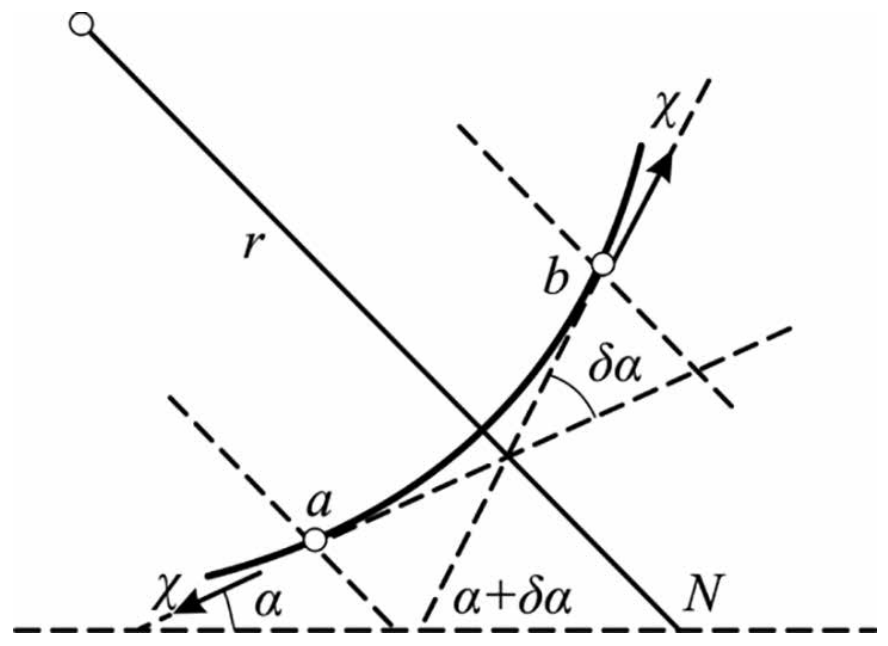

Puc. 1. Схема трехфазного контакта/

Fig 1. Diagram of the three-phase contact

Это натяжение образует силу $2 \chi \sin \frac{\delta a}{2}$ в направлении, параллельном $N$. Тогда на единицу длины дуги $a b$ действует сила $\frac{2 \chi}{a b} \sin \frac{\delta a}{2}$. Двумерное давление (натяжение) для точки пересечения с $N$ получим при $a b \rightarrow 0$.

$$
\sigma_{\chi}=\lim _{a b \rightarrow 0} \frac{2 \chi \sin \frac{\delta a}{2}}{\underset{a b}{\cup}}=\chi \lim _{a b \rightarrow 0} \frac{\delta a}{\breve{a b}}=\chi K_{L}=\frac{\chi}{r},
$$
поскольку $\lim \frac{\delta a}{\breve{v}}$ при $a b \rightarrow 0$ равен кривизне линии
$K_{L}=1 / r$ в этой точке.

Возникновение контакта между жидкими или жидкой и твердой фазами сопряжено с некоторым энергетическим барьером, обусловленным действием линейного натяжения, если оно положительно. Рассмотрим в качестве примера (рис.2) соединение твердой частицы с жидкой границей раздела («жидкость-жидкость» или «жидкость-газ»).

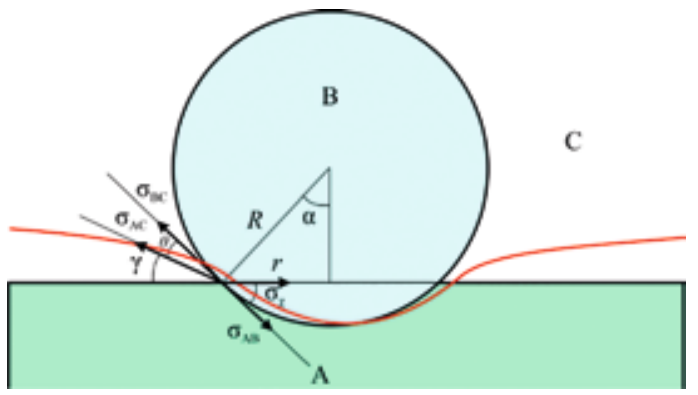

Puc. 2. Схема профиля твердой сферической частицуы на поверхности жидкой капли /

Fig. 2. Scheme of profile of a solid spherical particle on the surface of a liquid drop 
Для этого случая выражение (1) можно записать в виде [28]:

$$
G=2 \pi R \sigma_{1} \sin ^{2} \alpha
$$

где эффективное натяжение равно:

$$
\sigma_{1}=\sigma+\frac{\chi}{R}\left(\frac{1}{\sin \alpha}-\frac{1}{\sin \alpha_{c r}}\right) \cos \alpha
$$

где $\alpha_{\text {сr }}-$ угол, при котором радиус периметра смачивания $r$ соответствует последней возможности компенсации натяжения вдоль поверхности сферы при обращении краевого угла смачивания $\theta$ в нуль.

Таким образом, система ведет себя так, как если бы натяжение жидкости было повышено на компоненту $\Delta \sigma_{\chi} \cos \alpha$.

С уменьшением радиуса периметра смачивания $r$ двумерное давление (или натяжение) $\Delta \sigma_{\chi}=1 / r$ увеличивается и становится силовым и энергетическим барьером, препятствующим закреплению мелких частиц на межфазной границе, и причиной их эффективного извлечения в тяжелую фракцию МЖ-сепарации.

\section{Полученные результаты}

Разработана технология извлечения из техногенной россыпи золотосодержащего концентрата (рис.3). Извлечение золота из песков техногенной россыпи ( $\alpha=300$ мг/м ${ }^{3}$ золота) левой террасы $\mathrm{p}$. Харга ниже руч. Нижние Ингагли (Амурская обл.) в концентрат $\left(\beta=374\right.$ г $\left./ \mathrm{M}^{3} \mathrm{Au}, \varepsilon=90,0 \% \mathrm{Au}\right)$ выполнено в условиях малого горного предприятия (ГГП «Амурзолотораведка»), а его доводка - в лабораторных условиях. Технология от известных отличается способом доводки золотосодержащего концентрата до продукта, соответствующего требованиям аффинажа золота.
Доводка начинается с удаления из концентрата сульфидов мышьяка, сурьмы и свинца методом вакуум-термической сублимации [29]. Одновременно происходит термодеструкция пирита до магнитного пирротина, который выделяют из кека после дезинтеграции. Из немагнитной фракции золото экстрагируют в расплавленный свинец, механически перемешивая шихту, составленную из золотосодержащего материала, свинца и едкого натра, по методике, описанной в [30]. Мелкий свинец из щелочного плава выделяют методом магнитожидкостной сепарации с бислойной средой разделения после диспергирования. Свинцовый сплав обессвинцовывают вакуумтермической сублимацией. Вакуум-термические пироселекции выполняют в одном и том же реакторе, а диспергацию кеков и щелочного плава - на одном дезинтеграторе.

Выполнено сравнение технико-экономической эффективности двух технологий (табл.1) - существующей (автоклавное вскрытие $\rightarrow$ цианирование) и разработанной в проекте (рис. 3).

Выявлено, что применение разработанной технологии доводки золотосодержащих концентратов до лигатурного металла в сравнении с существующей гидрометаллургической технологией позволяет снизить затраты на процесс (табл.2).

Оценка эффективности инвестиций дала следующие величины показателей экономической эффективности:

1) чистый дисконтированный доход NPV $=40425,20$ тыс. руб.;

2) внутренняя норма доходности IRR $=21,2607 \%$;

3) коэффициент дисконтированной стоимости $\mathrm{PVR}=1,12$;

Таблица 1 / Table 1

\begin{tabular}{|c|c|c|c|c|}
\hline \multirow[b]{2}{*}{$\begin{array}{l}\text { № } \\
\text { п/II }\end{array}$} & \multirow[b]{2}{*}{ Показатель / Index } & \multirow[b]{2}{*}{$\begin{array}{l}\text { Ед. измерения } \\
\text { Index.measurement }\end{array}$} & \multicolumn{2}{|c|}{ Технология / Technology } \\
\hline & & & $\begin{array}{c}\text { разработан- } \\
\text { ная в проекте / } \\
\text { developed in the } \\
\text { project }\end{array}$ & $\begin{array}{l}\text { существующая } \\
\text { в практике / } \\
\text { existing in practice }\end{array}$ \\
\hline 1. & \multicolumn{4}{|c|}{ Капитальные затраты / Capital expenditure } \\
\hline 1.1 & $\begin{array}{l}\text { на технологическое оборудование / } \\
\text { on technological }\end{array}$ & руб./T/ rbl/t & 141,9 & 218,3 \\
\hline 1.2 & $\begin{array}{l}\text { на строительство зданий и сооружений / for the } \\
\text { construction of buildings and structures }\end{array}$ & руб./T/rbl/t & 50,6 & 54,6 \\
\hline 2. & $\begin{array}{c}\text { Эксплуатационные расходы (с учетом амортиза- } \\
\text { ционных отчислений) / } \\
\text { Operating expenses (including depreciation) } \\
\end{array}$ & руб./T/ rbl/t & 4023,4 & 5418,4 \\
\hline 3. & Расход электроэнергии / Power consumption & кBт/т kwt/t & 3,69 & 5,61 \\
\hline 4. & $\begin{array}{c}\text { Расход материалов и реагентов / } \\
\text { The consumption of materials and reagents }\end{array}$ & руб./т/rbl/t & 2,50 & 3,09 \\
\hline 5. & Оплата труда персонала / The salaries of the staff & руб./т / rbl/t & 4,76 & 4,76 \\
\hline
\end{tabular}

Технико-экономические показатели / Technical and economic indicators 


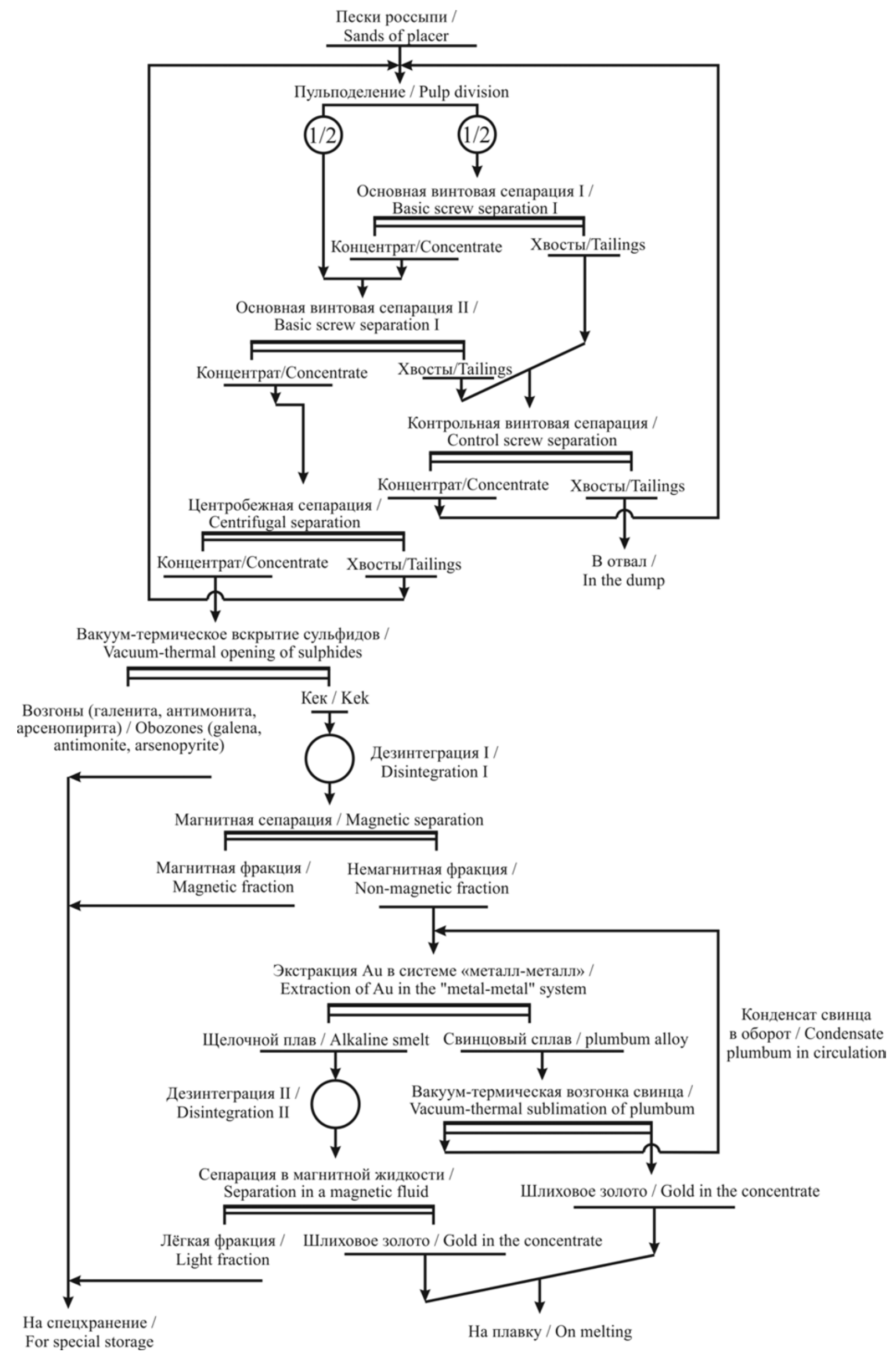

Pис. 3. Технологическая схема переработки песков техногенной россыпи /

Fig. 3. Technological scheme of man-made placer sands processing 
Таблица 2 / Table 2

Сравнение технико-экономических показателей / Comparison of technical and economic indicators

\begin{tabular}{|c|c|c|}
\hline $\begin{array}{c}\text { № } \\
\text { п/п }\end{array}$ & Показатель / Index & $\begin{array}{c}\text { Достигнутое снижение показа- } \\
\text { теля, } \% \text { / } \\
\text { Achieved decline in the indicator }\end{array}$ \\
\hline 1. & Удельные капитальные затраты: / Unit capital costs: \\
\hline 1.1 & на технологическое оборудование / on technological equipment & 35,0 \\
\hline 1.2 & $\begin{array}{c}\text { на строительство зданий и сооружений / for the construction of buildings and } \\
\text { structures }\end{array}$ & 2,3 \\
\hline 2. & Эксплуатационные расходы (с учетом амортизационных отчислений) / \\
\hline 3. & Орегаting ехреnses (including depreciation) & 25,7 \\
\hline 4. & Расход электроэнергии /Power consumption & 34,2 \\
\hline 5. & Расход материалов и реагентов / The consumption of materials and reagents & 19,1 \\
\hline
\end{tabular}

Расчёт налогов и платежей при отработке техногенной россыпи /

Таблица 3 / Table 1 Calculation of taxes and payments for working off man-made placers

\begin{tabular}{|c|c|c|c|}
\hline № & Показатель / Index & $\begin{array}{c}\text { Единицы измере- } \\
\text { ния / } \\
\text { Index. measurement }\end{array}$ & $\begin{array}{c}\text { Величина показате- } \\
\text { ля / The value of the } \\
\text { index }\end{array}$ \\
\hline 1 & $\begin{array}{c}\text { Годовая выручка от реализации товарной продукции / } \\
\text { Annual revenue from sales of commercial products }\end{array}$ & тыс. руб. / th. $r b l$ & 312490,52 \\
\hline 2 & Производственные фонды всего / Production assets total & тыс. руб. / th. rbl & 377983,64 \\
\hline 2.1 & Капитальные затраты / Capital expenditure & тыс. руб. / th. rbl & 342182,50 \\
\hline 2.2 & $\begin{array}{c}\text { Оборотные средства (20\% от эксплуатационных затрат) / } \\
\text { Working capital (20\% of operating costs) }\end{array}$ & тыс. руб. / th. rbl & 35801,14 \\
\hline 3 & Годовые эксплуатационные затраты / Annual operating costs & тыс. руб. / th. rbl & 179005,68 \\
\hline 4 & Налоги в себестоимости всего / Taxes in the cost of all & тыс. руб. / th. rbl & 18749,43 \\
\hline 4.1 & $\begin{array}{l}\text { в том числе на добычу (6\% от п.1) / } \\
\text { Including extraction (6\% of claim 1) }\end{array}$ & тыс. руб. / th. $r b l$ & 18749,43 \\
\hline 5 & $\begin{array}{l}\text { Сумма годовых затрат с налогом / } \\
\text { The amount of the annual cost of tax }\end{array}$ & тыс. руб. / th. rbl & 197755,11 \\
\hline 6 & Валовая выручка / Gross proceeds & тыс. руб. / th. rbl & 114735,41 \\
\hline 7 & Налоги от валовой выручки / Taxes on gross revenue & тыс. руб. / th. $r b l$ & 8315,64 \\
\hline 7.1 & $\begin{array}{c}\text { в т.ч. налог на имущество (2,2\% от п.2) / } \\
t . h . \text { property tax (2.2\% of claim } 2)\end{array}$ & тыс. руб. / th. $r b l$ & 8315,64 \\
\hline 8 & Налоговая прибыль / Tax profit & тыс. руб. / th. $r b l$ & 106419,77 \\
\hline 9 & Налог на прибыль (20\% от п.8) / Income tax (20\% from $n .8)$ & тыс. руб. / th. rbl. & 21283,95 \\
\hline 10 & Чистая прибыль / Net profit & тыс. руб. / th. rbl & 85135,82 \\
\hline 11 & $\begin{array}{l}\text { Сумма годовых затрат с учетом всех налогов / } \\
\text { The sum of the annual cost, including all taxes }\end{array}$ & тыс. руб. / th. rbl & 206070,75 \\
\hline
\end{tabular}

4) общий показатель возврата ORR = 11,81\%;

5) коэффициент рентабельности инвестиционного проекта ARR = 24,88 \%;

6) дисконтированный период окупаемости капитала инвестора DPP $=8$ лет (рис.4).

Экономическую эффективность отработки техногенной россыпи в целом характеризуют данные табл. 3.

\section{Заключение}

Горный бизнес относится к фондоемкой сфере промышленного производства, повышение эффек- тивности и конкурентоспособности которой возможно на основе увеличения количества малых горных предприятий. Предприятия малого горного бизнеса могут стать связующим звеном между сбалансированным развитием региональных производств и занятостью населения, т.е. устойчивого развития территорий. Перспективным направлением развития малого горного бизнеса является вовлечение в хозяйственный оборот отходов россыпной золотодобычи. В статье приведена технология (основанная на инно- 


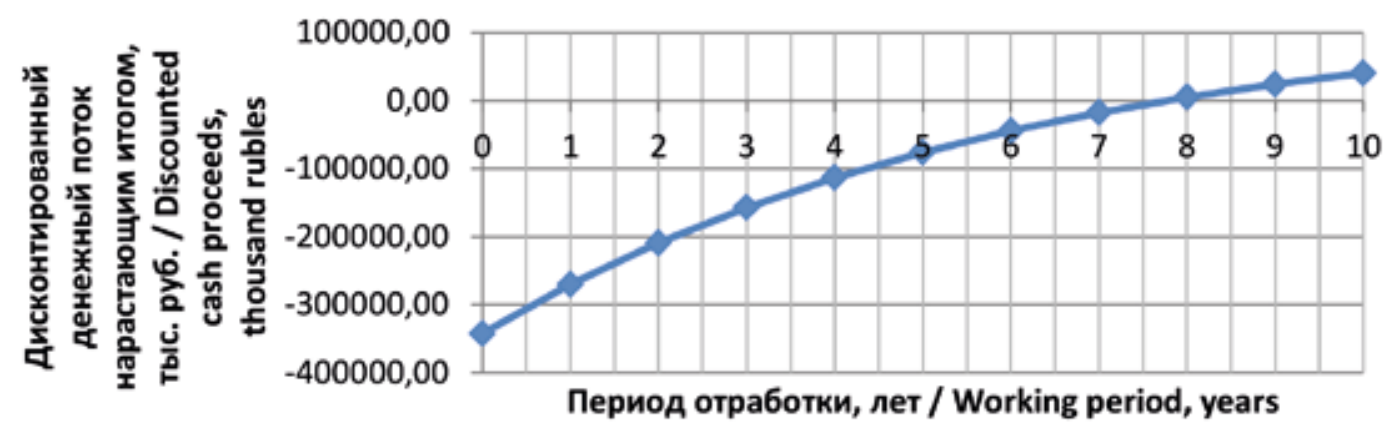

Pис. 4. Денежный поток и период окупаемости капиталовложений при индивидуальной разработке техногенной poccbinu /

Fig 4. Cash flow and return on investment period in the individual development of man-made placer

вационных процессах), обеспечивающая получение в условиях малого горного предприятия товарной продукции с высокой добавленной стоимостью и ликвидностью - подготовленного к плавке на сплав Доре шлихового золота. Приведены показатели экономической эффективности проекта.

\section{КРИТЕРИИ АВТОРСТВА / Contribution:}

Евдокимов С.И. - автор, в значительной степени, участвовавший в написании работы, в ее концепции / Evdokimov S. I. - the author, who largely participated in the writing of the work, in its concept; Ли И - автор, участвующий в сборе информации и научном дизайне / Ли И - the author involved in information gathering and scientific design; Герасименко Т.Е. - автор, корректирующий рукопись до подачи в редакцию, который несёт ответственность при обнаружении плагиата или других неэтических проблем / Gerasimenko T.E. - the author correcting the manuscript before submission to the editorial office, which is responsible for detecting plagiarism or other unethical problems.

\section{КОНФЛИКТ ИНТЕРЕСОВ / Conflict of interest:}

Авторы заявляют об отсутствии конфликта интересов / The authors declare no conflict of interest

\section{ЛИТЕРАТУРА:}

1. Крюков В.А., Силкин В.Ю., Токарев А.Н., Шмат В.В. Минерально-сырьевой комплекс России: реализация преимуществ и возможностей развития // Минеральные ресурсы России: экономика и управление. 2011. № 5. С. 28-37.

2. Пашкевич Н.В., Исеева Л.И., Федченко А.А. Россия на мировых рынках минерального сырья // Записки Горного института. 2014. № 208. С. 60-64.

3. Литвинцев В.С. Проблемы рационального освоения техногенных россыпных месторождений благородных металлов // Физико-технические проблемы разработки полезных ископаемых. 2015. № 1. С. 97-105.

4. Литвинцев В.С., Серый Р.С., Банщикова Т.С., Сас П.П. Проблемы оценки и освоения техногенных образований золотосодержащих россыпей Приамурья // Физикотехнические проблемы разработки полезных ископаемых. 2016. No 2. C. 72-79.

5. Литвинцев В.С. О ресурсном потенциале техногенных золотороссыпных месторождений // Физико-технические проблемы разработки полезных ископаемых. 2013. № 1. C. $118-126$.

6. Zhang Z., Li J., Huang H., Zhou L., Xiong T. High efficiency iron removal from quartz sand using phosphoric acid // International Journal of Mineral Processing. 2012. Vol. 114117. Pp. 80-92.

7. Ali M.A.M., Yang Y.-S. A study of some Egyption carbonate rocks for the building construction industry // Interna- tional Journal of Mining Science and Technology. 2014. Vol. 24. No. 4. Pp. 467-470.

8. Yi Z., Sun H., Wei X., Li C. Iron ore tailings used for the preparation of cementious material by compound thermal activation //International Journal of Minerals, Metallurgy and Materials. 2009. Vol. 16. No. 3. Pp. 355-358.

9. Chen Wang, David Harbottle, Qingxia Liu, Zhenghe Xu. Current state of fine mineral tailings treatment: A critical review on theory and practice //Mineral Engineering. 2014. Vol. 58. Pp. 113-131.

10. Huang Hongjun, Zhu Haifeng, Hu Yuehua. Hydrophobic surface of copper from converter slag in the flotation system // Int. J. Mining Sci. and Technol. 2013. Vol. 23. No. 4. Pp. 613-617.

11. Tripathy S.K., Ramamurthy Y., Singh V. Recovery of chromite values from plan tailings by gravity concentration // Journal of Minerals and Materials characterization and engineering. 2011. Vol. 10. No. 1. Pp. 13-25.

12. Ayeni F.A., Madugu I.A., Sukop P., Ibitoye S.A., Adeleke A.A. Abdulwahab M. Secondary Recovery of columbite from tailing dump in Nigerian Jos Mines Field // Journal of Minerals and Materials characterization and engineering. 2012. Vol. 11. No. 6. Pp. 587-595.

13. Praes P.E., de Albuguergue R.O., Lus A.F.O. Recovery of iron ore tailings by column flotation // Journal of Minerals and Materials characterization and engineering. 2013. Vol. 1. No. 5, Pp. 212-216. 
14. Kiventera J., Golek L., Vliniemi J., Ferreira V., Deja J., Llikainen M. Utilization of sulphidic tailings from gold mine as a raw material in geopolymerization // International Journal of Mineral Processing. 2016. Vol. 149. Pp. 104-110.

15. Roy S., Datta S. Flotation of copper sulphide from copper smelter slag using multiple collectors and their mixtures // International Journal of Mineral Processing. 2015. Vol. 143. Pp. 43-49.

16. Anastassakis G., Bevilacqua R., De Lorenzi L. Recovery of residual copper from low-content tailings derived from waste electrical cable treatment // International Journal of Mineral Processing. 2015. Vol. 143. Pp. 105-111.

17. Khaldoun A., Ouadif L., Baba K., Bahi L. Valorization of mining, waste and tailings through paste backfilling solution, limiter operation, Morocco // International Journal of Mining Science and Technology. 2016. Vol. 26. No. 3. Pp. 51-56.

18. Seo B., Kim S. Cobalt extraction from tungsten carbide-cobalt (WC-Co) hard metal scraps using malic acid // International Journal of Mineral Processing. 2016. Vol. 151. Pp. 1-7.

19. Da Costa A.J., Matos J.F., Bernardes A.M., Muller I.L. Benefication of cobalt, copper and aluminum from wasted lithium-ion batteries by mechanical processing // International Journal of Mineral Processing. 2015. Vol. 145. Pp. 77-82.

20. Nam K.S., Jung B.H., An J.W., Ha T.J., Tran T., Kim M.J. Use of chloride-hypochlorite leachants to recover gold from tailings // International Journal of Mineral Processing. 2008. Issues 1-4. Vol. 86. Pp. 131-140.

21. L. Valderrama, J. Rubio. Unconventional column flotation of low-grade gold fine particles from tailings // International Journal of Mineral Processing. 2008. Issues 1-4. Vol. 86. Pp. $75-84$.

22. Kashinath Pal, Harsha Vardhan, Mangalpady Aruna. Investigation of contaminant transport in groundwater from the tailings pond of uranium mine: a case study // International Journal of Mining and Mineral Engineering. 2010. Vol. 2. No. 4. Pp. 290-309.
23. G.W. Poling. Mining/milling processes and tailings generation // Marine Georesources \& Geotechnology. 1995. Vol. 13 (1-2). Pp. 19-31.

24. Samsonov N.Y. Development of small gold deposits with modular processing plant: cost evaluations of individual and grouped mines // Socio-economic space of Russia: innovation and modernity : collection of articles All-Russian scientific-practical conf. of young scientists. 10-12 Nov. $2010 /$ Ed. by V.M. Gilmundinov, A.A. Goryushkin, I.O. Semykina. Novosibirsk : Inst. of econ. and industrial engineering Siberian branch of RAS, 2011. Pp. 40-49.

25. Фролов О.М. Малые горные предприятия в си системе горнодобывающей промышленности. Дис. ... канд. эконом. наук. СПб.: Северо-Западный государственный заочный технический университет, 2004. 218 с.

26. Евдокимов С.И., Евдокимов В.С. Повышение извлечения золота на основе совместной переработки руды и отходов // Физико-технические проблемы разработки полезных ископаемых. 2017. N 2. C. 160-169.

27. Evdokimov V.S., Evdokimov S.I. Application of Immiscible Magnetic Liquids of Different Densities as the Separation Medium for Magnetic Liquid Separation // Russian Journal of Non-Ferrous Metals. 2017.Vol. 58. No. 3. Pp. 181-187.

28. Шелудко А., Тошев Б.В., Платиканов Д. О механике и термодинамике систем с линией трехфазного контакта. В кн.: Современная теория капиллярности: к 100-летию теории капиллярности Гиббса / Под. ред. А.И. Русанова, Ф.Ч. Гудрича. Л.: Химия, 1980. С. 274-299.

29. Евдокимов С.И., Троценко И.Г., Евдокимов В.С. Доводка золотосодержащих концентратов в условиях малого горного предприятия. Часть II: Исследовательские испытания реактора для вакуум-термической пироселекции золотосодержащих концентратов // Цветная металлургия. 2016. N 5. C. 53-59.

30. Chekushin V.S., Oleinikova N.V., Tychenko A.I. The extraction of gold from sulfide concentrates into molten lead // Russian Journal of Non-Ferrous. 2008. Vol. 49. N 3. P. 340-346.

\section{СВЕДЕНИЯ ОБ АВТОРАХ / Information about authors:}

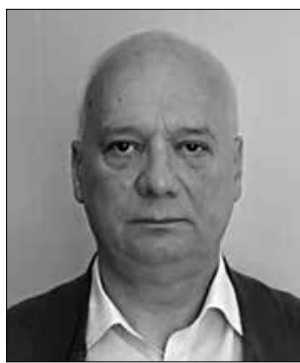

ЕВДОКИМОВ Сергей Ивано-

вич - кандидат технических наук; технический директор.

Научно-производственное предприятие «ГЕОС», Владикавказ, Россия 362021 , г. Владикавказ, РСО-Алания, Россия

Тел.: +7(8672)40-73-34 (служ.); +7(928)486-39-47 (моб.).

E-mail: eva-ser@mail.ru (Для переписки).

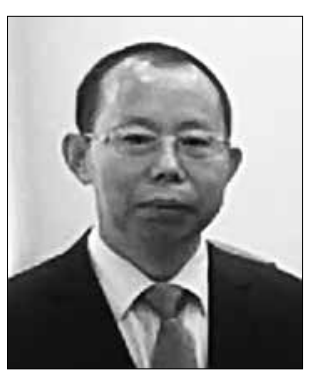

ЛИ И - профессор, специалист АО Научно-техническая фирма «Аньтай».

Китай, г. Пекин.

E-mail: zy1937@163.com

Li I-Professor, Research Officer of JSC Scientific and Technical Firm "Anthai".

China, Beijing.

E-mail: zyl937@163.com

Sergey Ivanovich EVDOKIMOV-Cand. Sci. (Tech.),

Scientific-Production Enterprise "GEOS".

362021, Russia, Vladikavkaz

Tel.: +7(8672)40-73-34 (служ.); +7(928)486-39-47 (mоb). 


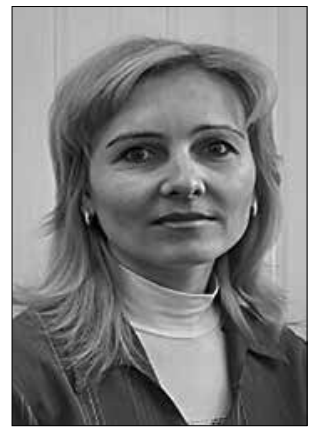

ГЕРАСИМЕНКО Татьяна Евгеньевна - кандидат технических наук, начальник отдела интеллектуальной собственности.

Северо-Кавказский горно-металлургический институт (государственный технологический университет).

362021, РСО-Алания, г. Владикавказ, Россия

Тел.: +7(8672)40-71-64.

E-mail: gerasimenko_74@mail.ru

Tatyana Evgenyevna GERASIMENKO - Cand. Tech. Sci., Head of Intellectual Property Department of the North Caucasian Institute of Mining and Metallurgy (State Technological University).

E-mail: gerasimenko_74@mail.ru

362021, Vladikavkaz, Russia,

\title{
SUSTAINABLE DEVELOPMENT OF MOUNTAIN TERRITORIES: INVESTMENT INTERESTS OF TECHNOGENIC GOLD STOCKS
}

\author{
${ }^{1}$ S.I. Evdokimov, * \\ ${ }^{2} \mathrm{Li}$ I., \\ ${ }^{1}$ T.E. Gerasimenko \\ ${ }^{1}$ Scientific-production enterprise “GEOS”, Vladikavkaz, Russia,e-mail: eva-ser@mail.ru \\ ${ }^{2}$ Officer of JSC "Scientific and Technical Firm" An thai ". China, Beijing. \\ ${ }^{3}$ North Caucasian Institute of Mining and Metallurgy (State technological university), Vladikavkaz, Russia
}

DOI: $10.21177 / 1998-4502-2018-10-1-132-140$

Enterprises of small mining business can become an effective mechanism for the increasing the sustainability of the territories development which determines the relevance of the work that can be used to draw up the program of enterprise investment development.

The aim of the work is to develop technology for processing technogenic gold placers by small mining enterprises using physical-mechanical and physicochemical processes which provides an effect based on the total capital reduction, operational and organizational costs due to deep refinement of gold-containing concentrates to highly liquid commercial products.

Finishing begins with the removal of arsenic, antimony and lead sulfides from the concentrate by vacuum-thermal sublimation. Simultaneously thermal destruction of pyrite occurs to magnetic pyrrhotite, which is isolated from the cake after disintegration. From the non-magnetic fraction, gold is extracted into molten lead, mechanically mixing the charge, composed of gold-bearing material, lead and sodium hydroxide. The fine lead from the alkaline melt is isolated by the method of magneto-liquid separation with a bilayer separation medium after dispersion. The lead alloy is lead-free by vacuum-thermal sublimation.

Scientific novelty is the introduction of the linear tension concept in the mechanics of three-phase contact. When separating in the bilayer separation medium, the equilibrium condition of the particle on the plane surface written according to Young's law and Neumann's rule, must be supplemented by the linear tension of the curved interphase surface. The linear tension is a force and energy barrier that prevents the fixation of fine particles of noble metals at the interphase boundary and the reason for their effective extraction into the heavy fraction.

Indicators of the project economic efficiency are presented.
Keywords: gold-containing concentrate, fine-tuning, vacuum-thermal sublimation, disintegration, gold extraction into lead, magnetic-liquid separation, economic efficiency.

\section{References}

1. Kryukov V.A., Silkin V.Yu., Tokarev A.N., Shmat V.V. Mineral and raw materials complex of Russia: realization of pre-property and development opportunities. Mineral resources of Russia: economy and management. 2011. N 5. Pp. 28-37.

2. Pashkevich N.V., Iseyeva L.I., Fedchenko A.A. Russia in the world markets of mineral raw materials. Proceedings of Mining Institute. 2014. N 208. Pp. 60-64.

3. Litvintsev V.S. Problems of rational development of man-made fertile deposits of precious metals. Physical - Technical problems of minerals mining. 2015. No 1. Pp. 97-105.

4. Litvintsev V.S., Seryy R.S., Banshchikova T.S., Sas P.P. Problems of assessment and development of technogenic formations of gold-bearing placers of the Amur region . Physical - Technical problems of minerals mining. 2016. No 2. Pp. 72-79.

5. Litvintsev V.S. On the resource potential of technogenic gold-sulphide deposits. Physical - Technical problems of minerals mining. 2013. No 1. Pp. 118-126.

6. Zhang Z., Li J., Huang H., Zhou L., Xiong T. High efficiency iron removal from quartz sand using phosphoric acid. International Journal of Mineral Processing. 2012. Vol. 114 117. Pp. 80-92.

7. Ali M.A.M., Yang Y.-S. A study of some Egyptian carbonate rocks for the building construction industry. International Journal of Mining Science and Technology. 2014. Vol. 4. No. 4. Pp. 467-470.

8. Yi Z., Sun H., Wei X., Li C. Iron ore tailings used for the preparation of cement material by compound thermal activation. International Journal of Minerals, Metallurgy and Materials. 2009. Vol. 16. No. 3. Pp. 355-358. 
9. Chen Wang, David Harbottle, Qingxia Liu, Zhenghe $\mathrm{Xu}$. Current state of fine mineral tailings treatment: A critical review on theory and practice. Mineral Engineering. 2014. Vol. 58. Pp. 113-131.

10. Huang Hongjun, Zhu Haifeng, Hu Yuehua. Hydrophobic surface of copper from converter slag in the flotation system . Int. J. Mining Sci. and Technol. 2013. Vol. 23, No. 4. Pp. 613-617.

11. Tripathy S.K., Ramamurthy Y., Singh V. Recovery of chromite values from plan tailings by gravity concentration. Journal of Minerals and Materials characterization and engineering. 2011. Vol. 10, No. 1. Pp. 13-25.

12. Ayeni F.A., Madugu I.A., Sukop P., Ibitoye S.A., Adeleke A.A. Abdulwahab M. Secondary Recovery of columbite from tailing dump in Nigerian Jos Mines Field. Journal of Minerals and Materials characterization and engineering. 2012. Vol. 11, No. 6. Pp. 587-595.

13. Praes P.E., de Albuguergue R.O., Lus A.F.O. Recovery of iron ore tailings by column flotation. Journal of Minerals and Materials characterization and engineering. 2013. Vol. 1. No. 5. Pp. 212-216.

14. Kiventera J., Golek L., Vliniemi J., Ferreira V., Deja J., Llikainen M. Utilization of sulphidic tailings from gold mine as a raw material in geopolymerization. International Journal of Mineral Processing. 2016. Vol. 149. Pp. 104-110.

15. Roy S., Datta S. Flotation of copper sulphide from copper smelter slag using multiple collectors and their mixtures. International Journal of Mineral Processing. 2015. Vol. 143. Pp. 43-49.

16. Anastassakis G., Bevilacqua R., De Lorenzi L. Recovery of residual copper from low-content tailings derived from waste electrical cable treatment. International Journal of Mineral Processing. 2015. Vol. 143. Pp. 105-111.

17. Khaldoun A., Ouadif L., Baba K., Bahi L. Valorization of mining, waste and tailings through paste backfilling solution. International Journal of Mining Science and Technology. 2016. Vol. 26. No. 3. Pp. 51-56.

18. Seo B., Kim S. Cobalt extraction from tungsten carbidecobalt (WC-Co) hard metal scraps using malice acid. International Journal of Mineral Processing. 2016. Vol. 151. Pp. 1-7.

19. Da Costa A.J., Matos J.F., Bernardes A.M., Muller I.L. Benefaction of cobalt, copper and aluminum from wasted lithium-ion batteries by mechanical processing. International Journal of Mineral Processing. 2015. Vol. 145. Pp. 77-82.

20. K.S. Nam, B.H. Jung, J.W. An, T.J. Ha, T. Tran, M.J. $\mathrm{Kim}$. Use of chloride-hypochlorite leachants to recover gold from tailings. International Journal of Mineral Processing. 2008. Issues 1-4, Vol. 86. Pp. 131-140.
21. L. Valderrama, J. Rubio. Unconventional column flotation of low-grade gold fine particles from tailings. International Journal of Mineral Processing. 2008. Issues 1-4. Vol. 86. Pp. $75-84$.

22. Kashinath Pal, HarshaVardhan, Mangalpady Aruna. Investigation of contaminant transport in groundwater from the tailings pond of uranium mine: a case study. International Journal of Mining and Mineral Engineering. 2010. Vol. 2, No. 4. Pp. 290-309.

23. G.W. Poling. Mining/milling processes and tailings generation. Marine Georesources\&Geotechnology. 1995. Vol. 13 (1-2). Pp. 19-31.

24. Samsonov N.Y. Development of small gold deposits with modular processing plant: cost evaluations of individual and grouped mines. Socio-economic space of Russia: innovation and modernity: collection of articles All-Russian scientific-practical conf. of young scientists. 10-12 Nov. 2010 / ed. by V.M. Gilmundinov, A.A. Goryushkin, I.O. Semykina. Novosibirsk: Inst. of Econ. and Industrial engineering. Siberian branch of RAS, 2011. Pp. 40-49.

25. Frolov O.M. Small mining enterprises in the system of mining industry. Author's abstract. Dis of. ... Cand. Economy. Sciences. St. Petersburg: St. Petersburg State Institute of Economics and Finance. 2004. 19 p.

26. Yevdokimov S.I., Yevdokimov V.S. Increase of gold extraction based on joint processing of ore and wastes. Physical-Technical problems of minerals mining. 2017. No 2. Pp. 160-169.

27. Evdokimov V.S., Evdokimov S.I. Application of Immiscible Magnetic Liquids of Different Densities as the Separation Medium for Magnetic Liquid Separation. Russian Journal of Non-Ferrous Metals.2017. Vol. 58. No. 3. Pp. 181-187.

28. Sheludko A., Toshev B.V., Platikanov D. On mechanics and thermodynamics of systems with a three-phase contact line. Modern theory of capillarity. Chimiya. 1980. Pp. 274-299.

29. Yevdokimov S.I., Trotsenko I.G., Yevdokimov V.S. Finishing gold-bearing concentrates in the conditions of a small mining enterprise. Part II: Investigation tests of the reactor for vacuum-thermal pyro-selection of gold-containing concentrates. Tsvetnaya metallurgiya. 2016. No 5. Pp. 53-59.

30. ChekushinV.S., Oleinikova N.V., Tychenko A.I. The extraction of gold from sulfide concentrates into mol-ten lead. Russian Journal of Non-Ferrous Metals. 2008. Vol. 49. No 3. Pp. 340-346.

Article received 25.09.2017 


\section{ВОЗДЕЙСТВИЕ СТОКОВ С ПОРОДНЫХ ОТВАЛОВ ШАХТ УГОЛЬНОГО БАССЕЙНА НА ПОЧВЫ ПРИЛЕГАЮЩИХ ТЕРРИТОРИЙ}

\author{
Грязев М.В., \\ Качурин Н.M*, \\ Стась Г.В.
}

\section{Введение}

В последние годы в мире растет значение угля как источника энергии и ожидается, что в перспективе такая тенденция сохранится. Согласно прогнозу «Energy Information Administration», к 2030 г. доля угля в мировом потреблении энергоносителей составит около $28 \%$, а в производстве электроэнергии - примерно 45\% (например, в 2004 г. - 43\%). В настоящее время уголь имеет ценовые преимущества перед нефтью и природным газом. Несмотря на возрастающие транспортные издержки, аналитики называют уголь «конкурентоспособным энергоносителем будущего». Долгосрочная программа развития угольной промышленности России также нацелена на реализацию потенциальных конкурентных преимуществ российских угольных компаний и переход к инновационному социально ориентированному типу экономического развития страны. Прогнозный диапазон рациональных объемов добычи угля в 2030 г. должен составить 380 - 430 млн. т. При этом научные исследования, связанные с экологической оценкой реструктуризации и диверсификации угольной промышленности, позволят реформировать экономику страны во многих промышленных отраслях на собственной природно-ресурсной базе.

$\mathrm{B}$ соответствии с программой реструктуризации и общей стратегией развития угольной промышленности России предусматривается превращение ее в устойчиво функционирующую и рентабельную отрасль. В результате осуществляемой реструктуризации угольной промышленности России и ликвидации нерентабельных угледобывающих предприятий произошла ликвидация ряда шахт Кузбасса и Восточного Донбасса, а также полная ликвидация угольных шахт и разрезов Подмосковного угольного бассейна. Но весьма ощутимые масштабы воздействия на атмосферу и гидросферу, а также техногенная активизация геохимического переноса на территориях этих регионов сохраняются. Особую остроту приобретают проблемы, связанные с экологическими последствиями, обусловленными, воздействием породных отвалов угольных шахт горнопромышленных регионов.

Проекты проведения работ по экологической реабилитации нарушенных территорий, предусмотренные проектами ликвидации шахт, и обеспечивающие приведение территорий промышленных площадок ликвидируемых шахт в экологически безопасное состояние, как правило, не содержат действенных технических мероприятий по локализации воздействия отвалов на окружающую среду. В лучшем случае, все сводится к мониторингу этих воздействий. Однако существующие методы оценки воздействия отвалов шахт на окружающую среду требуют более глубокого научного обоснование для реализации эффективных алгоритмов экологического мониторинга.

\section{Материал и методы исследования}

Физико-химические свойства породной массы отвалов шахт Подмосковного угольного бассейна. В Тульской области основным полезным ископаемым до недавнего времени был бурый уголь, добыча которого началась в 1853 году. За это время в области добыто более 1 млрд 200 млн т угля. В Подмосковном бассейне суммарная площадь, в той или иной мере подвер-

Тульский государственный университет, Тула, Российская Федерация, e-mail: ecology_tsu_tula@mail.ru
УДК: 622.27

DOI: 10.21177/1998-4502-201810-1-141-148

Приведена обобщенная геоэкологическая модель породного отвала, которая является основой физических моделей процессов миграции загрязнителей и их математического описания. Показано, что интенсивность процессов массообмена породного отвала с окружающей средой во многом определяется геоэкологическими и геотехнологическими периодами существования породного отвала на промплощадке шахты. При этом ликвидация шахты не означает ликвидации отвала u, он как источник жидких стоков может действовать в течение многих лет. Предложена математическая модель вертикальной миграции загрязнителя в почву на основе одномерного уравнения конвективной дифффузии с учетом кинетики сорбции загрязнителя твердой фазой почв и подстилающих и nopod.

\section{КЛЮЧЕВЫЕ СЛОВА:}

породный отвал, ликвидированная шахта, угольный бассейн, загрязнитель, почва, фильтрация, математическая модель.

Статья поступила в редакцию 08.01.2017 
женная техногенному воздействию, связанному с разработкой месторождений угля, составляет около $12 \%$ от общей территории области. Закрытие шахт на территории Тульской области создало экологические проблемы [1 - 6]. Продолжается отрицательное воздействие породных отвалов ликвидированных угольных шахт на все составляющие окружающей среды и в настоящее время. На дневной поверхности размещено в виде различных отходов угольной промышленности более 250 млн. т горных пород. В настоящее время подавляющая часть породной массы в Подмосковном бассейне сосредоточена в терриконах шахт емкостью 300 - 600 тыс. тонн, построенных в 40-е годы прошлого века. В хребтовых породных отвалах, образованных на более современных шахтах, находится до 900 тыс. тонн пород [7 - 10]. Породные отвалы угольных шахт являются комплексным источником загрязнения окружающей среды. На рис. 1. приведена обобщенная геоэкологическая модель породного отвала.

Разработанная геоэкологическая модель является основой физических моделей процессов миграции загрязнителей и их математического описания. Очевидно, что интенсивность процессов массообмена породного отвала с окружающей средой во многом определяется геоэкологическими и геотехнологиче- скими периодами существования породного отвала на промплощадке шахты. При этом ликвидация шахты не означает ликвидации отвала и, он, как источник жидких стоков, может действовать в течение многих лет [11-14].

Породные отвалы формируются из разнородной горной массы, в которой вследствие её измельчения и перемешивания в присутствии кислорода воздуха активизируются физико-химические процессы. Указанные процессы являются основным фактором, определяющим как направленность, так и интенсивность воздействия отвала на окружающую среду. Содержание тяжелых металлов и пределы изменения $\mathrm{pH}$ как в ювенильной породной массе, так и в породной массе терриконов, отсыпка которых завершена на протяжении последних 70 лет, показаны на рис. 2.

Проведены исследования проб породной массы представляющих все типы и размеры отвалов, отсыпанных в различные периоды и расположенных в разных частях Подмосковного угольного бассейна. Отбор проб производился на различных уровнях по периметру отвала с шагом сетки равным 50 м.

Приведенные данные свидетельствуют о высокой кислотности породной массы, которая предопределяет подвижность содержащихся в ней тяжелых металлов. Следовательно, основная часть вертикальной мигра-

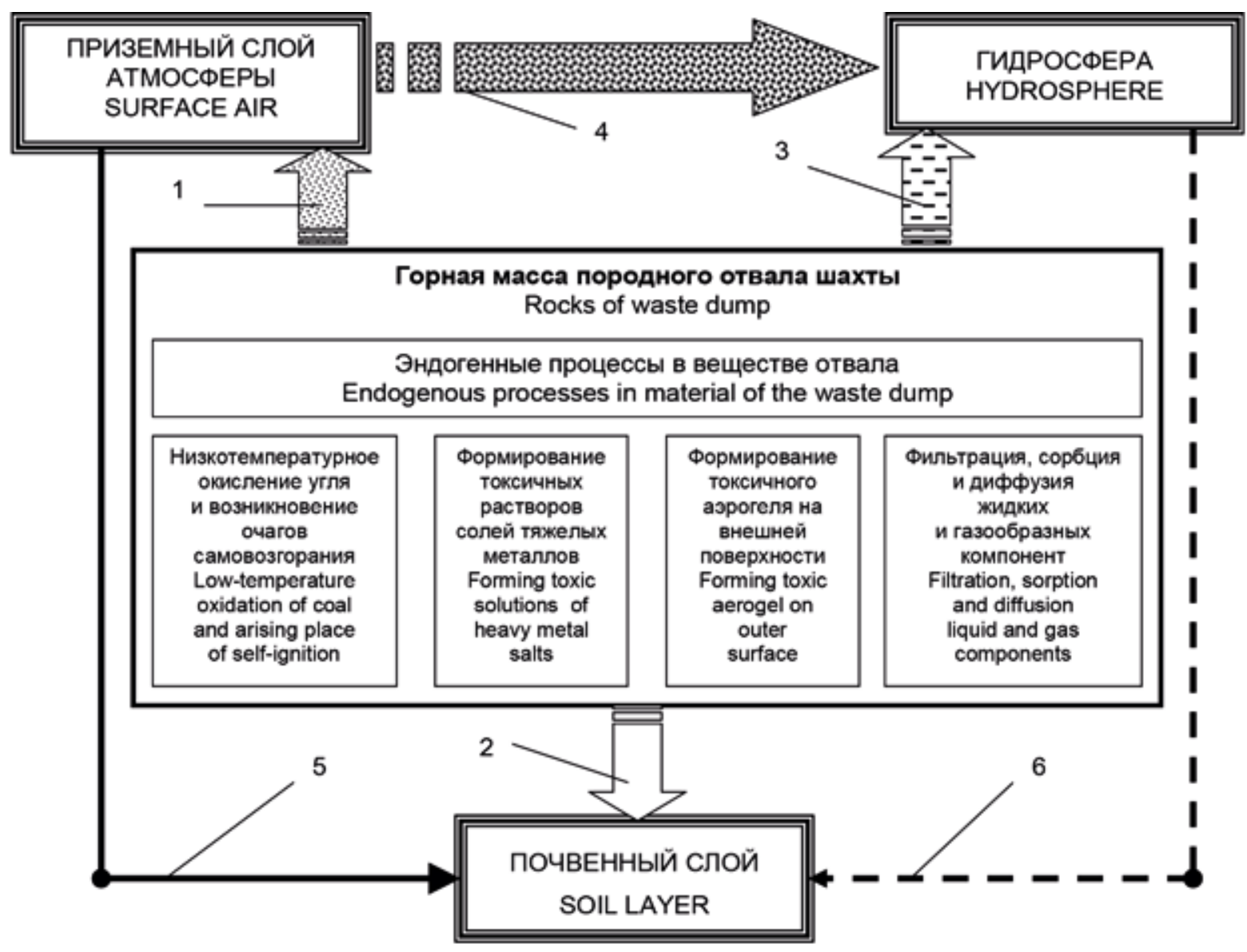

Рис. 1. Геоэкологическая модель породного отвала / Fig. 1. Geoecological model of rock blade 


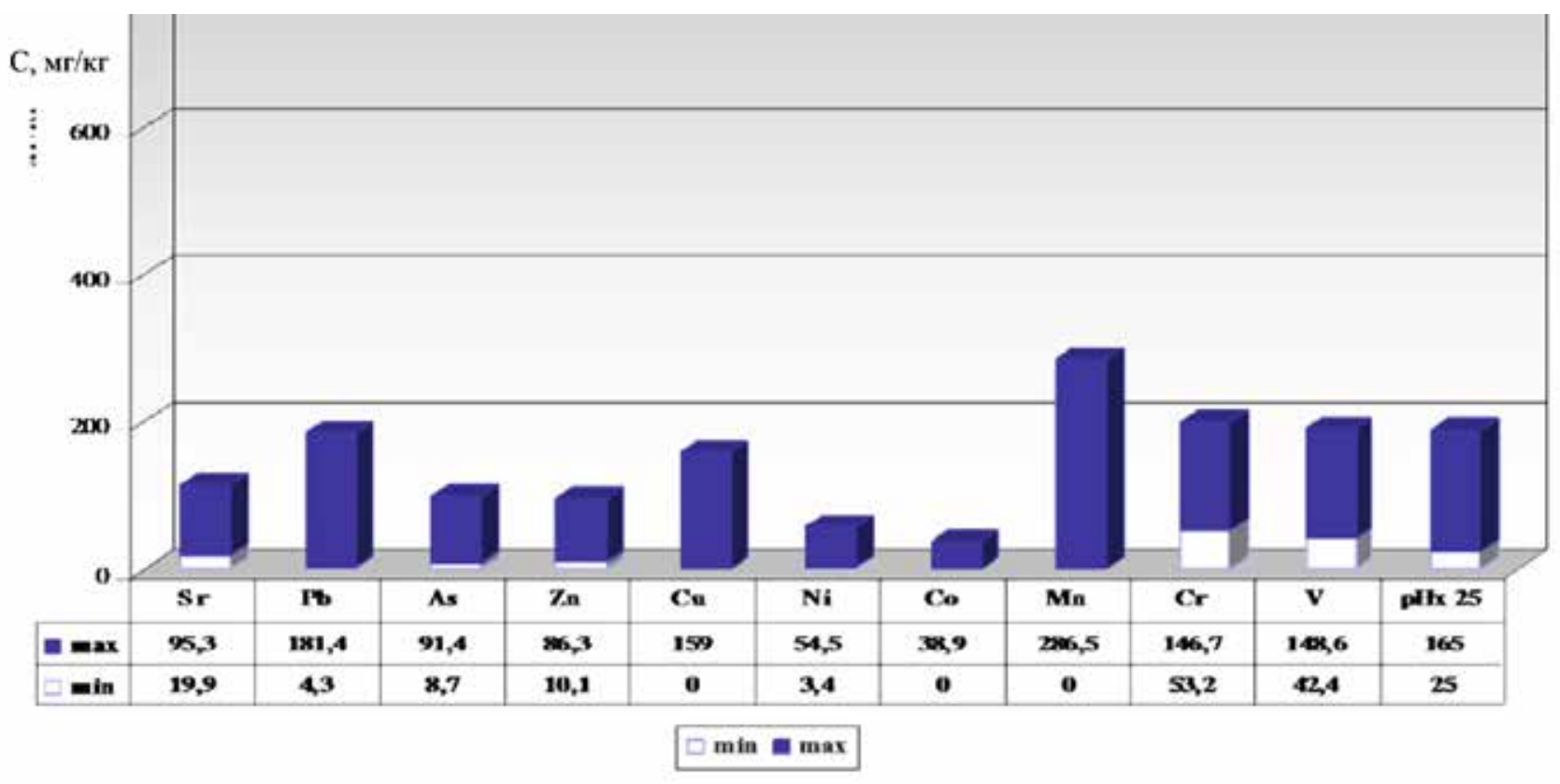

Pис. 2. Концентрация металлов в породных отвалах /

Fig. 2. The Concentration of metals in waste dumps

ции кислотных стоков происходит посредством их фильтрации, при которой интенсивность процесса помимо фильтрационных характеристик грунта существенно определяется временем контакта стоков с подстилающей поверхностью. Следовательно, для прогнозирования изменения кислотности прилегающих к отвалу почв, необходимо исследование процессов формирования кислотных стоков.

Миграция токсичных компонентов в почву и подстилающцие породы с отвалов угольных шахт. В силу многообразия горнотехнических, технологических и других условий формирования и трансформации породных отвалов поступление стоков на прилегающие территории происходит вследствие стекания обогащенных серной и угольной кислотами атмосферных осадков. Происходит растекание и инфильтрация стоков на горизонтальных участках рельефа, а также скапливания стоков в низинах. При этом независимо от путей миграции стоков, их распространение вызывает изменение кислотно-щелочных и окислительно-восстановительных условий в почвах (в значительной степени определяемых их буферной емкостью), приводящее к протеканию разнообразных химических реакций, в частности, приводящих к увеличению лабильности токсичных веществ [15 - 18].

Таким образом, для обеспечения безопасности населения, проживающего на прилегающих к породным отвалам территориях, и предотвращения деградации почв необходимо прогнозировать масштабы и интенсивность загрязнения окружающей среды токсичными веществами [19-20].

Загрязнение окружающей среды породными отвалами включает вертикальную миграцию фильтрата породного отвала в почву его основания, растекание стоков атмосферных осадков с поверхности отвала на прилегающих территориях и впитывание их в почвы, а также перенос грунтовыми водами веществ, экстрагируемых из почвы кислотными стоками.

Вертикальная миграция загрязнителя в почву и далее в подстилающие породы удовлетворительно описывается одномерным уравнением конвективной диффузии с учетом кинетики сорбции загрязнителя твердой фазой почв и подстилающих и пород. В данном случае целесообразно рассматривать полубесконечное пространство. Уравнение миграции загрязнителя имеет следующий вид:

$$
\frac{\partial c}{\partial t}+w \frac{\partial c}{\partial z}=D_{s} \frac{\partial^{2} c}{\partial z^{2}}-K c
$$

где $c(z, t)$ - концентрация загрязнителя в горных породах; $w$ - средняя скорость фильтрации почвенного раствора; $D_{S}-$ коэффициент диффузии; $K$ - константа скорости сорбции загрязнителя горными породами.

Начальные и граничные условия:

$$
c(z, 0)=c_{0}=\text { const }, c(0, t)=c_{b}=\text { const }, \lim _{z \rightarrow \infty} c \neq \infty .
$$

Решение уравнения (1) для условий (2) получено в виде: 


$$
\begin{gathered}
c(z, t)=c_{0} \exp (-K t)+0,5 \exp (0,5 \alpha z)\left\langle c_{b}[\exp (-\sqrt{A B}) \operatorname{erfc}(0,5 \sqrt{A / t}-\sqrt{B t})+\right. \\
+\exp (\sqrt{A B}) \operatorname{erfc}(0,5 \sqrt{A / t}+\sqrt{B t})]-c_{0} \exp (-A t)\{\exp [-\sqrt{A(B-K)}] \times \\
\quad \times \operatorname{erfc}[0,5 \sqrt{A / t}-\sqrt{(B-K) t}]+\exp [\sqrt{A(B-K)}] \times \\
\times \operatorname{erfc}[0,5 \sqrt{A / t}+\sqrt{(B-K) t}]\}\rangle, \\
\text { где } A=z^{2} / D_{s} ; B=0,25 D_{s}\left(w^{2} / D_{s}^{2}+4 K / D_{s}\right) .
\end{gathered}
$$

Следует отметить, что зависимость вертикального распределения концентрации загрязнителя, определяемая по формуле (3), имеет общий вид. В определенных условиях зависимость (3) можно упростить.

\section{Полученные результаты и их обсуждение}

Выбросы с породных отвалов имеющие низкий уровень $\mathrm{pH}$, попадая на прилегающие территории, разрушают плодородие почв, вследствие чего вокруг отвала формируется техногенная пустыня (рис. 3). Происходит нарушение равновесия окружающей среды [15-19].

Исследования профилей грунта вдоль русла стока, в различных точках техногенной пустыни и на незакисленных (фоновых) участках прилегающих к отвалам территорий показали тесную связь подвижности педогенного марганца и уровня $\mathrm{pH}$ почв. При этом снижение $\mathrm{pH}$ почв до 4 единиц приводит к образованию в 1 м $^{3}$ грунта подвижного марганца, достаточного для сверхнормативного загрязнения 20 тыс. м $^{3}$ поверхностных вод.

Таким образом, вследствие огромной разницы ПДК марганца для почв и водных объектов, даже относи- тельно небольшое подкисление почв может привести к катастрофическому загрязнению водных объектов.

Данный факт подтверждается 30 кратным превышением ПДК для поверхностных вод на расстоянии 300 м от террикона отработанной шахты «Жданковская». В то же время при анализах проб родниковой воды, отобранных за водоразделом на расстоянии в 1,5 км от террикона, марганец не обнаружен даже в следовых количествах. Из приведенных результатов следует, что в настоящее время одними из основных факторов, оказывающих дестабилизирующее влияние на состояние окружающей среды, является фильтрация загрязняющих веществ из тела отвала в водоносные горизонты. При этом осуществляется вынос раствора серной кислоты атмосферными осадками с отвала на прилегающие территории. Серная кислота накапливается в поверхностном слое породной массы вследствие низкотемпературного окисления веществ, содержащих серу и входящих в состав породной массы.

Использование зависимости (3) позволяет рассчитать вертикальный профиль концентраций загрязнителя в почве и подстилающих породах в зоне

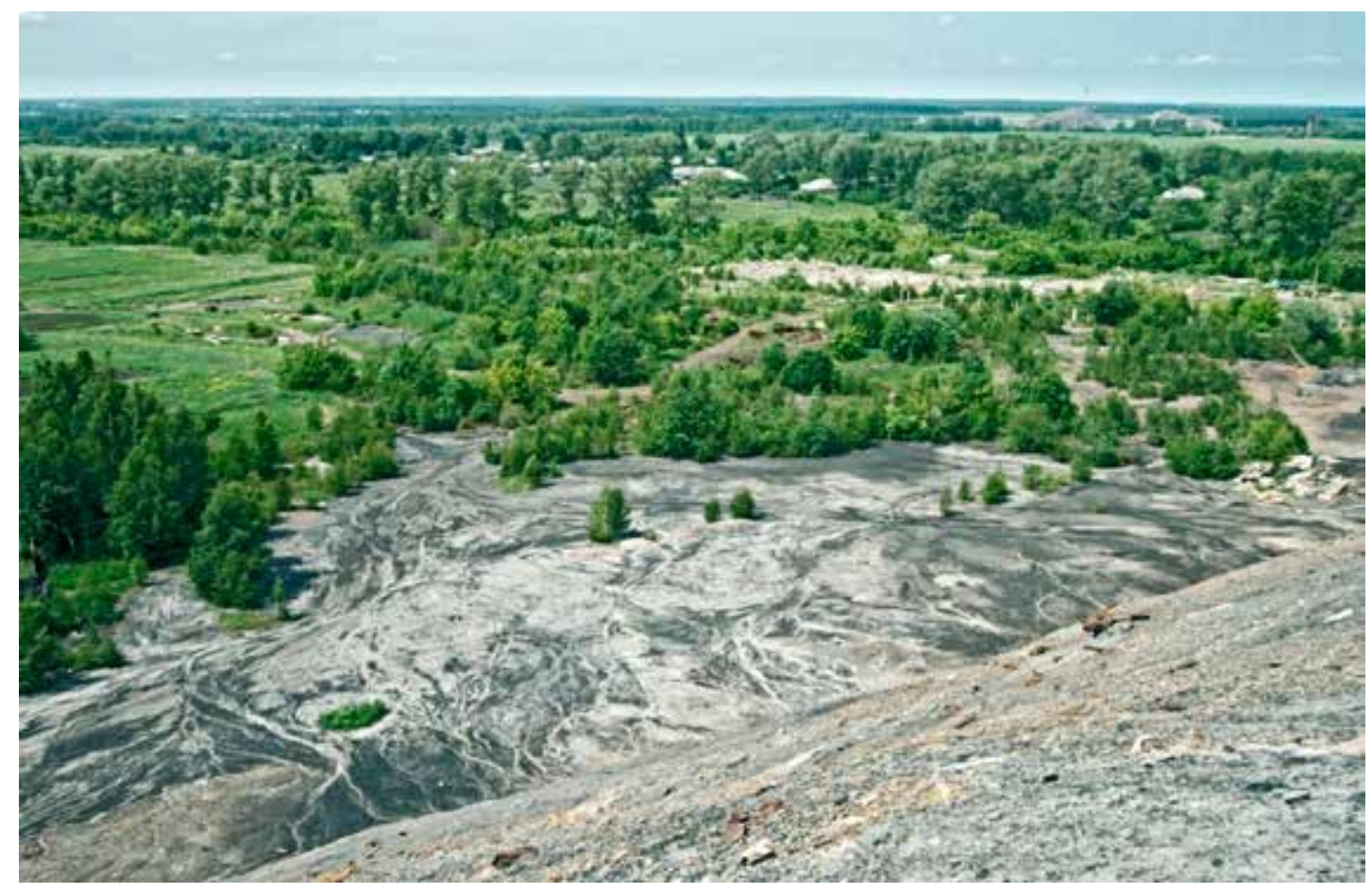

Рис. 3. Техногенная пустыня террикона отработанной шахты на территории Тульской области / Fig. 3. A man-made desert of the waste heap of the mine on the territory of Tula region 


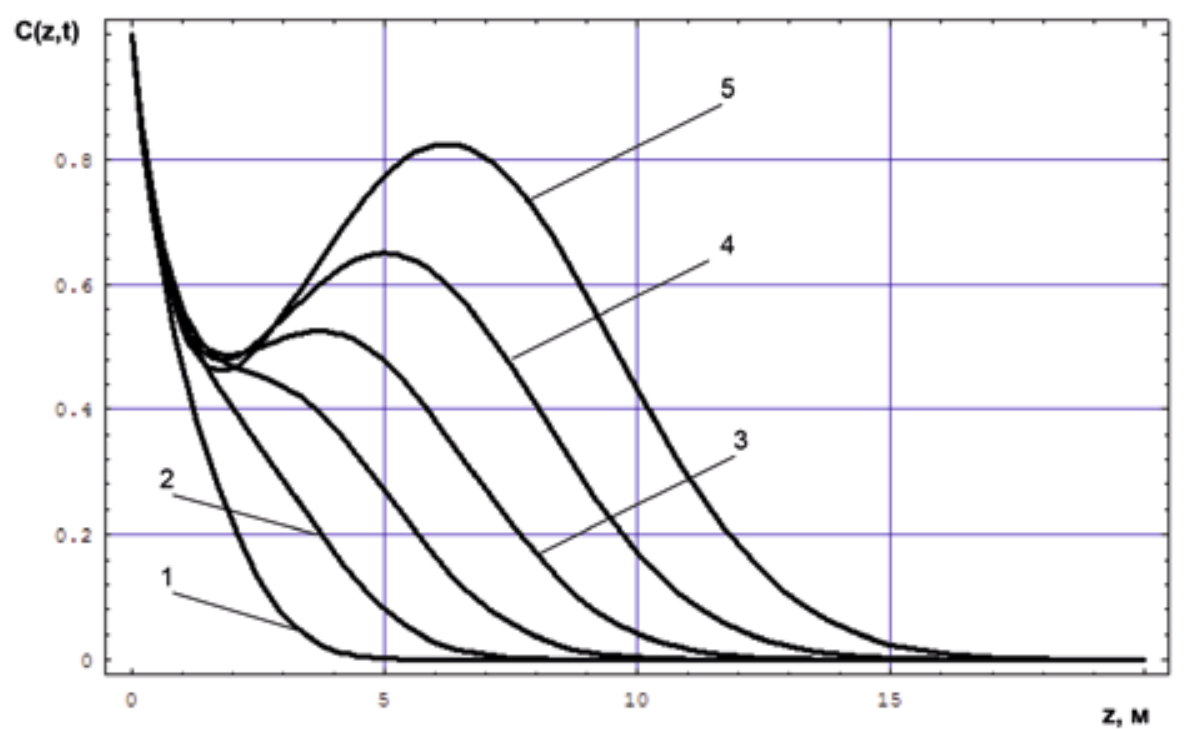

Рис. 4. Вертикальный профиль концентраций загрязнителя в почве и подстилающих породах в зоне действия породного отвала: $C(z, t)=c(z, t) / c ; 1-t=1 \mathrm{cym} . ; 2-t=2 \mathrm{cym} . ; 3-t=3 \mathrm{cym} . ; 4-t=4 \mathrm{cym} . ; 5-t=5 \mathrm{cym} .1$

Fig. 4. Vertical profile of pollutant concentrations in soil and underlying rocks in the rock dump zone: $C(z, t)=c(z, t) / c b ; 1-t=1$ day.; $2-t=2$ days.; $3-t=3$ days.; $4-t=4$ days.; $5-t=5$ days.

действия породного отвала для любого вида загрязнителя. В частном случае, когда $c_{0}=0$, зависимость (3) записать следующим образом:

$$
\begin{gathered}
c(z, t)=0,5 c_{b} \exp (0,5 \alpha z)\left[\exp \left(-f_{1} z\right) \operatorname{erfc}\left(0,5 \mathrm{z} / \sqrt{D_{s} t}-\sqrt{B t}\right)+\right. \\
\left.\left.+\exp \left(f_{1} z\right) \operatorname{erfc}\left(0,5 \mathrm{z} / \sqrt{D_{s} t}+\sqrt{B t}\right)\right]+\exp (\sqrt{A B}) \operatorname{erfc}(0,5 \sqrt{A / t}+\sqrt{B t})\right], \\
\text { где } f_{1}=0,5 \sqrt{w^{2} / D_{s}^{2}+4 K / D_{s}} .
\end{gathered}
$$

Вычислительные эксперименты проведены с использованием зависимости (3). Результаты вычислительного эксперимента представлены на рис. 4.

Результаты вычислительного эксперимента показывают, что миграция токсичных компонентов жидких стоков с поверхности отвала приводит к интенсивному загрязнению почвы и подстилающих пород. При этом профиль концентрации имеет волнообразный характер с точкой максимума, обусловленной в данный момент времени в конкретной точке рассматриваемого пространства равенством скоростей процесса конвективно-диффузионного переноса и сорбции.

\section{Выводы}

Обобщение результатов натурных наблюдений, лабораторных экспериментов и математического моделирования позволили сделать следующие выводы:

1. Для оценки влияния породных отвалов угольных шахт на состояние окружающей среды необходимо на основе топографических данных определить площадь бассейна стока и основные пути поступления поллютантов на территории, прилегающие к отвалу.

2. Химически активные водорастворимые соединения, образующиеся при фильтрации атмосферных осадков через тело отвала, могут скапливаться в образовавшейся под ним глинистой непроницаемой мульде, а в периоды интенсивных атмосферных осадков и снеготаяния, переполняя эту линзу, попадать в окружающие отвал почвы и распространяться с грунтовыми водами.

3. Наиболее значительно процесс закисления почвы проявляется в поверхностных горизонтах, хотя тенденция к снижению $\mathrm{pH}$ прослеживается до глубины в несколько десятков сантиметров. Плодородие почв в основном определяется значением таких агрохимических показателей как $\mathrm{pH}$, подвижные соединения фосфора и калия.

4. Миграция токсичных компонентов жидких стоков с поверхности отвала приводит к интенсивному загрязнению почвы и подстилающих пород. При этом профиль концентрации имеет волнообразный характер с точкой максимума, обусловленной в данный момент времени в конкретной точке рассматриваемого пространства равенством скоростей процессов конвективно-диффузионного переноса и сорбции. 


\section{КРИТЕРИИ АВТОРСТВА / Contribution:}

Грязев М.В. - обосновал физическую модель диффузионной миграции загрязнителей в почвенный слой, разработал математическую модель диффузионного процесса; Качурин Н.М. - проводил натурные и лабораторные исследования, написал рукопись и несет ответственность за плагиат; Стась Г.В. - проводила обработку результатов натурных и лабораторных исследований, провела серию вычислительных экспериментов / Griyzev M. V. - substantiated physical model of diffusion migrating pollutants into soil seam and created mathematical model of diffusion process; Kachurin $\mathbf{N}$. M. - investigated field observation and laboratory researches, wrote manuscript, and he responds by plagiarism; Stas $\boldsymbol{G}$. $\boldsymbol{V}$ - treated data of field observation and laboratory researches and real-ized calculated experiment.

\section{КОНФЛИКТ ИНТЕРЕСОВ / Conflict of interest:}

Авторы заявляют об отсутствии конфликта интересов / The authors declare no conflict of interest.

\section{ЛИТЕРАТУРА:}

1. Экологические последствия закрытия угольных шахт Кузбасса по газодинамическому фактору и опасности эндогенных пожаров на отвалах / Н.М. Качурин, С.А. Воробьев, Я.В. Чистяков, Л.Л. Рыбак // Экология и промышленность России. 2015. N4. С. 54-58.

2. Качурин Н. М., Ефимов В. И., Воробьев С. А. Методика прогнозирования экологических последствий подземной добычи угля в России // Горный журнал. 2014. N9. C. $138-142$.

3. Брикеты из отходов обогатительных фабрик / В.И. Ефимов, С.И. Митичкин, В.Л. Рыбак, Л. Л. Рыбак // Перспективы инновационного развития угольных регионов России. Сб. трудов IV Международной научно-практической конференции // Прокопьевск. КузГТУ. 2014. С. 17-19.

4. Голик В.И., Комащенко В.И., Страданченко С.Г., Масленников С.А. Повышение полноты использования недр путем глубокой утилизации отходов обогащения угля // Горный журнал. 2012. N 9. С. 91- 95.

5. Dubilski J. Sustainable Development of Mining Mineral Resources // J. Sustain. Min. 2013. N 1. Pp. 1-6.

6. Голик В.И., Комащенко В.И. Отходы обогащения железистых кварцитов как сырье для доизвлечения металлов и использования в качестве закладочных смесей // Горный журнал. 2017. N 3. C. 43-47. DOI 10.17580/GZH.2017.03.08.

7. Harris J. M., Roach B. Environmental and Natural Resource Economics//A Contemporary Approach. M. E. Sharpe, Inc., Armonk, New York, 2013. Pp. 67-85.

8. Потокина М.В. Способ брикетирования илов и шламов сточных вод // Проблемы геологии и освоения недр: труды XIV международного симпозиума имени академика М.А. Усова студентов и молодых ученых. - Томск: Изд-во Томского политехнического университета, 2010. 694 с.

9. Потокина М.В. Анализ существующих методов утилизации шламов, илов и осадков сточных вод // Инновации молодых: сб. науч. тр.: посвящ. 65-летию Победы в Великой Отечественной войне и 15-летию Новокузнецкого института (филиала) Кемеровского государственного университета.- Новокузнецк: РИО НФИ «КемГУ», 2010. $250 \mathrm{c}$.
10. Грязев М.В., Качурин Н.М., Стась Г.В. Аэрогазодинамические процессы и аэрологическая безопасность при подземной добыче полезных ископаемых: монография. Тула: Изд-во Тульского государственного университета, 2018. 266 c.

11. Левкин Н.Д., Комиссаров М.С., Рыбак В.Л. Защита территорий от загрязнения стоками полигонов твердых отходов // Безопасность жизнедеятельности. 2012. N 12. С. $48-50$.

12. Алехин В.И., Мигуля П.С., Проскурня Ю.А. Минералого-петрографи-ческие и эколого-геохимические особенности пород терриконов Донбасса (на примере Донецко-Макеевского промышленного района) // Сборник научных трудов НГА Украины. - Днепропетровск, 1998. T. 5. N3. C. 35-39.

13. Голынская Ф.А. Методика исследования самовозгорания углей в пластах / Межвуз. научн. тематич. сборник «Геология угольных месторождений». - Екатеринбург, 2001. C. 268-270.

14. Зборщик М.П., Осокин В.В. Предотвращение самовозгорания горных пород. К.: Тєхника, 1990. 176 с.

15. Леонов П.А., Сурначев Б.А. Породные отвалы угольных шахт. М.: Недра, 1970. 112 с.

16. Мигуля П.С. Забытая экологическая катастрофа // Газета «Донецкий политехник», 1998. 4. С. 5.

17. Панов Б.С., Шевченко О.А., Проскурня Ю.А. и др. К геоэкологии Донбасса // Проблемы экологии. Донецк: ДонГТУ, 1999. N 1. С. 17-26.

18. Панов Б.С., Проскурня Ю.А. О техногенной минерализации породных отвалов угольных шахт Донбасса // Межвуз. научн. тематич. сб. «Геология угольных месторождений». Екатеринбург, 1999. С. 241-249.

19. Шахта-пласт. Российская угольная энциклопедия. Москва-Санкт-Петербург, 2007. 418 с.

20. C. Ozgen Karacan. Modeling and analysis of gas capture from sealed section of abandoned coal mines // International Journal of Coal Geology. Issue 138. 2015. Pp. 30 - 40. 


\title{
$\overline{С В Е Д Е Н И Я ~ О Б ~ А В Т О Р А Х ~ / ~ I n f o r m a t i o n ~ a b o u t ~ a u t h o r s: ~}$
}

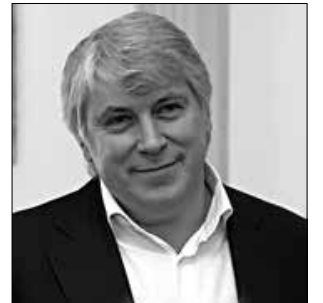

ГРЯЗЕВ Михаил Васильевич доктор технических наук, профессор, ректор, Тульский государственный университет, г. Тула, Россия.

T.: +7(4872)35-21-55

e-mail: ecology_tsu_tula@mail.ru

Mikhail Vasilievich GRYAZEV - Doctor of Tech. Sciences, Professor, Rector, Tula State University, Tula, Russia,

$T .:+7(4872) 35-21-55$

e-mail:ecology_tsu_tula@mail.ru

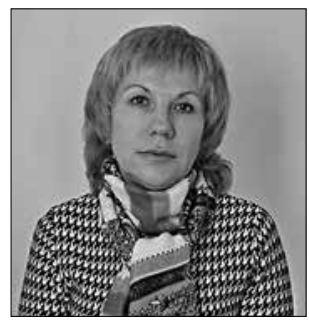

СТАСЬ Галина Викторовна кандидат технических наук, доцент, Тульский государственный университет, Тула, Россия,

T.: +7(4872)35-20-55

e-mail: galina_stas@mail.ru

Galina Viktorovna STAS - Candidate of Technical Science, Associate Prof., Tula State University, Tula, Russia,

T.: +7(4872)35-20-55

e-mail:galina_stas@mail.ru.

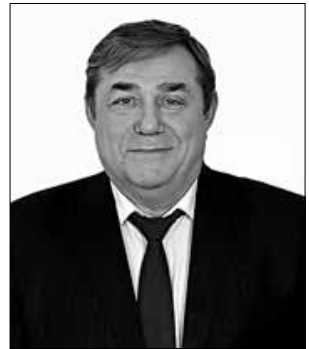

КАЧУРИН Николай Михайлович - доктор технических наук, профессор, заведующий кафедрой, Тульский государственный университет, г. Тула, Россия,

T.: +7(4872)35-21-55

e-mail: ecology@tsu.tula.ru

Nikolai Mikhailovich KACHURIN Doctor of Tech. Sciences, Professor, Chief of Department, Tula State University, Tula, Russia

T.: +7(4872)35-21-55

e-mail: ecology_tsu_tula@mail.ru

\section{INFLUENCING SLUDGE LIQUOR FROM WASTE DUMPS OF MOSCOW COAL BASIN MINES UPON SOILS OF ADJACENT TERRITORIES}

\author{
M.V. Griyzev, \\ N.M. Kachurin,* \\ G.V. Stas \\ Tula State University, Tula City, Russia \\ *e-mail: ecology_tsu_tula@mail.ru
}

\section{DOI: $10.21177 / 1998-4502-2018-10-1-141-148$}

Basic mineral wealth was brown coal deposits of Moscow Coal Basin in Tula Region until recently. Mining brown coal deposits of Moscow Coal Basin was begun since 1853. More than 1 milliard and 200 million tons of coal were mined that time. Summarized area which somehow or other undergoing anthropogenic influencing connected with mining coal deposits is equal about $12 \%$ from common territory of the region. Liquidating mines in the territory of Tula Region created environmental problems. Negative influencing liquidated waste dumps continue upon all components of environment until our time. There are more than 250 million tons of rocks on the earth surface of different forms of mining industry wastes. Integrated environmental model of waste dump is proposed which can be basis of physical models for migrating pollutants processes and their mathematical description. It's shown that intensity of mass exchange processes between the waste dump and environment as a rule is identified by environmental and geotechnological periods of waste dump existing on surface industrial area of a mine. Under such conditions liquidating the mine doesn't signify liquidating the waste dump and the one can function as sludge liquor source during a lot of years. Mathematical model of vertical migration a pollutant into soil on base of onedimensional equation of convective diffusion with taking into account sorption kinetic of the pollutant by solid phase of soil and rocks is proposed. Calculating experiments were realized and it's established that migrating toxic sludge liquor from waste dump surface result in polluting soil and underlying rocks. Vertical concentration profile has wave-like nature with point of maximum which stipulating velocities balance of convectivediffusion transfer and sorption processes at the moment of time in concrete point of considering space.

Keywords: waste dump, liquidated mine, Coal Basin, pollutant, soil, filtration, mathematical model.

\section{References:}

1. Экологические последствия закрытия угольных шахт Кузбасса по газодинамическому фактору и опасности эндогенных пожаров на отвалах / Н.М. Качурин, С.А. Воробьев, Я.В. Чистяков, Л.Л. Рыбак // Экология и промышленность России. 2015. N4. С. 54-58.

2. Качурин Н. М., Ефимов В. И., Воробьев С. А. Методика прогнозирования экологических последствий подземной добычи угля в России // Горный журнал. 2014. N9. C. $138-142$.

3. Брикеты из отходов обогатительных фабрик / В.И. Ефимов, С.И. Митичкин, В.Л. Рыбак, Л. Л. Рыбак // Перспективы инновационного развития угольных регионов России. Сб. трудов IV Международной научно-практической конференции // Прокопьевск. КузГТУ. 2014. С. 17-19.

4. Голик В.И., Комащенко В.И., Страданченко С.Г., Масленников С.А. Повышение полноты использования недр путем глубокой утилизации отходов обогащения угля // Горный журнал. 2012. N 9. С. 91- 95. 
5. Dubilski J. Sustainable Development of Mining Mineral Resources // J. Sustain. Min. 2013. N 1. P. 1-6.

6. Голик В.И., Комащенко В.И. Отходы обогащения железистых кварцитов как сырье для доизвлечения металлов и использования в качестве закладочных смесей // Горный журнал. 2017. N 3. C. 43-47. DOI 10.17580/ GZH.2017.03.08.

7. Harris J. M., Roach B. Environmental and Natural Resource Economics//A Contemporary Approach. M. E. Sharpe, Inc., Armonk, New York, 2013. Pp.67-85.

8. Потокина М.В. Способ брикетирования илов и шламов сточных вод // Проблемы геологии и освоения недр: труды XIV международного симпозиума имени академика М.А. Усова студентов и молодых ученых. Томск: Изд-во Томского политехнического университета, 2010. 694 c.

9. Потокина М.В. Анализ существующих методов утилизации шламов, илов и осадков сточных вод // Инновации молодых: сб. науч. тр.: посвящ. 65-летию Победы в Великой Отечественной войне и 15-летию Новокузнецкого института (филиала) Кемеровского государственного университета.- Новокузнецк: РИО НФИ «КемГУ», 2010. $250 \mathrm{c}$.

10. Грязев М.В., Качурин Н.М., Стась Г.В. Аэрогазодинамические процессы и аэрологическая безопасность при подземной добыче полезных ископаемых: монография. Тула: Изд-во Тульского государственного университета, 2018. 266 с.

11. Левкин Н.Д., Комиссаров М.С., Рыбак В.Л. Защита территорий от загрязнения стоками полигонов твердых отходов // Безопасность жизнедеятельности. 2012. N 12. C. $48-50$.
12. Алехин В.И., Мигуля П.С., Проскурня Ю.А. Минералого-петрографи-ческие и эколого-геохимические особенности пород терриконов Донбасса (на примере Донецко-Макеевского промышленного района) // Сборник научных трудов НГА Украины. - Днепропетровск, 1998. T. 5. N3. C. 35-39.

13. Голынская Ф.А. Методика исследования самовозгорания углей в пластах / Межвуз. научн. тематич. сборник «Геология угольных месторождений». - Екатеринбург, 2001. С. 268-270.

14. Зборщик М.П., Осокин В.В. Предотвращение самовозгорания горных пород. К.: Тєхника, 1990. 176 с.

15. Леонов П.А., Сурначев Б.А. Породные отвалы угольных шахт. М.: Недра, 1970. 112 с.

16. Мигуля П.С. Забытая экологическая катастрофа // Газета «Донецкий политехник», 1998. 4. С. 5.

17. Панов Б.С., Шевченко О.А., Проскурня Ю.А. и др. К геоэкологии Донбасса // Проблемы экологии. Донецк: ДонГТУ, 1999. N 1. С. 17-26.

18. Панов Б.С., Проскурня Ю.А. О техногенной минерализации породных отвалов угольных шахт Донбасса // Межвуз. научн. тематич. сб. «Геология угольных месторождений». Екатеринбург, 1999. С. 241-249.

19. Шахта-пласт. Российская угольная энциклопедия. Москва-Санкт-Петербург, 2007. 418 с.

20. C. Ozgen Karacan. Modeling and analysis of gas capture from sealed section of abandoned coal mines // International Journal of Coal Geology. Issue 138. 2015. Pp. 30 - 40.

Article received 08.01.2018 


\section{ОБОЗРЕНИЕ}

REVIEW

Мера жнизни не в ее длительности, а в том, как вы ее использовали.

М. МОНТЕНЬ

\section{ОСОБЕННОСТИ РЕАЛИЗАЦИИ ПРОЕКТА ЕRASMUS+ В ГОРНЫХ ВУЗАХ}

$\mathrm{T}^{\mathrm{s}}$ енденции мирового экономического развития требуют расширения сфер международного взаимодействия на уровне государств, регионов, а также в отдельных отраслях промышленности и производства. Реализации такого сотрудничества довольно многогранны: совместное производства, консультации, стажировки, обучение и переподготовка персонала и др.

Синергия такого сотрудничества очевидна как для РФ, так и для зарубежных партнеров: создание инновационной экономики, технологическое развитие, развитие научно-исследовательской деятельности, расширение рынков сбыта, продвижение российских товаров и услуг, не имеющих аналогов за рубежом.

Международный образовательный проект Erasmus+ по программе «Mодернизация геологического образования в российских и вьетнамских университетах (МИНЕРАЛ)» реализуется в рамках Болонского процесса [1-5] (Geology; economy; Others (58:34:8), Single degree (120 ECTS credits, 2 years)).

Для успешного сотрудничества ВУЗов-партнеров необходимо:

-повысить академическую мобильность студентов и ППС,

-получить практический опыт работы в условиях глобализации экономики РФ и экономики ЕС;

-обеспечить совместимость ООП, взаимное признание дипломов об образовании и возможность продолжить обучение в РФ и в ЕС;

-внедрить наиболее эффективные инновационные технологии в образовании и промышленности странами-партнерами;

-расширить неформальное общение студентов [6-7] РФ и ЕС, которое позволит лучше понять друг друга и преодолеть имеющиеся у каждой стороны предрассудки и стереотипы.

B рамках проекта Erasmus+ была достигнута договоренность о начале разработки совместного учебного плана магистратуры «Производственный менеджмент в области геологии нефти и газа» с последующим признанием дипломов равнозначными в странах-партнерах с набором групп в Германии, Италии, Австрии, Вьетнаме и России.

Участие СКГМИ (ГТУ), как одного из партнеров проекта, позволяет ре-

\footnotetext{
${ }^{1}$ Северо-Кавказский горно-металлургический институт (государственный технологический университет), Владикавказ, Российская Федерация

*e-mail:katya_sea@mail.ru
}

${ }^{1}$ Габараев О. 3., ${ }^{1}$ Соколова Е. А.*, 'Баликоева М. И.

УДК: 658.5, 007, 65.01 DOI: 10.21171/1998-4502-201810-1-149-396

Описан международный образовательный проект Erasmus+. Раскрыта цель создания магистерской программы в рамках проекта, учебнометодическое обеспечение образовательного процесса с применением новейших систем мультимедийного оборудования для обучения. Описаны особенности образовательных технологий. Дана характеристика учебного плана согласно Европейским стандартам. Раскрыты инновационная методика и преимущества образовательного проекта Erasmus+.

\section{КЛЮЧЕВЫЕ СЛОВА:}

Erasmus, образовательный проект, магистерская программа, инновации, Европейский стандарт образования.

Статья поступила в редакцию 02.06.2017 
шить задачу, которая поставлена сегодня перед российской системой образования - усиление позиций РФ на мировом рынке образовательных услуг [8]. Следовательно, работа в данном направлении и привлечение иностранных студентов на сегодняшний день является стратегически важным и приоритетным направлением в образовании.

Согласно Партнерскому соглашению 20162974/001-001, заключенному между странами-участниками программы Erasmus+ и странами-партнерами, в перспективе планируется реализация программ двойных дипломов, которая предусматривает одновременное обучение студентов в российских и зарубежных вузах с перспективой получения как российского, так и зарубежного диплома о присуждении степени магистра.

Однако с учетом требования Исполнительного агентства по образованию, культуре и аудиовизуальным средствам ЕC (ЕАCEA) реализация программ по основным специальным дисциплинам осуществляется на английском языке, что влечет за собой определенные сложности [9].

Для облегчения восприятия материала по техническим дисциплинам желательно:

- обеспечить все лекции демонстрационными материалами (презентациями) для облегчения восприятия информации, которую сложно уловить на слух; внедрить интерактивную форму урока (вопросы, персональный вариант задания и т.д.);

- реализовать возможность тестирования для опре- деления уровня восприятия материала и возможности оценить уровень качества подачи материала.

Одним из ключевых мероприятий проекта является организация «зимней школы» - проведение онлайн-лекции для популяризации и повышения интереса к геологии. Разработка курса лекций Зимней Школы «Юный геолог» потребует от преподавателя значительных усилий, при этом необходимо подчеркнуть, что использование материалов Зимней школы в последующем сократит время на подготовку к лекциям и позволит организовать рабочее время по читаемым дисциплинам с большей эффективностью по сравнению с традиционной системой преподавания. Преимущества от использования электронного курса для студентов тоже очевидны:

- обучающийся будет иметь возможность свободного доступа к материалам в удобное ему время;

- обучающийся сможет самостоятельно разрабатывать план изучения материала, согласно установленным срокам и собственной загруженности и работоспособности.

Очевидно, что наличие иностранных студентов представляет собой сложный процесс для любой организации как в РФ, так и в ЕС. Необходимо привлечение высококвалифицированных кадров, которые смогут тщательно планировать курс дисциплины исходя из прогнозирования возможных способностей обучающегося (языковой уровень, национальные особенности, особенности учебной деятельности в зависимости от региона и др.).

*В статье представлены результаты исследований, выполненных по программе Еrasmus + 574061-EPP-1-2016-1DE-EPPKA2-CBHE-JP "Modernization of geological education in Russian and Vietnamese universities

\section{ЛИТЕРАТУРА:}

1. О мерах по реализации государственной политики в области образования и науки: Указ Президента РФ от 07.05.2012 г. № 59: [Электронный ресурс]. URL http://www. garant.ru

2. Концепция долгосрочного социально-экономического развития Российской Федерации на период до 2020 года: [Электронный pecypc]. URL http://economy.gov.ru/minec/ activity/sections/strategicPlanning/concept (дата обращения 22.01.2018).

3. Вагин В.С., Соколова Е.А. Разработка программных продуктов по индивидуальным планам ППС как одно из направлений повышения эффективности работы системы менеджмента качества образования в ВУЗе // Устойчивое развитие горных территорий. 2011. 3(8). С.100-103.

4. Аксенов А.А., Соколова Е.А. Совершенствование методических аспектов разработки индивидуального плана преподавателя как элемента системы «Эффективного контракта» // Научное обозрение. 2013. 11. С.314-318.

5. Чевела О.В. Сопоставительно-ориентированная методика в преподавании РКИ // Материалы Всероссийской научно-практической конференции «Сопоставительная филология и полилингвизм». Казань: РИЦ «Школа», 2002. C. $145-146$.
6. Dooge J. Engineering training and education. Dublin: Collins Press, 2007.

7. Lorin W. Anderson., David Krathwohl. A taxonomy for learning, teaching, and assessing: a revision of Bloom's taxonomy of educational objectives New York. Longman, 2001.

8. Johri A. and Olds B. M. Situated Engineering Learning: Bridging Engineering Education Research and the Learning Sciences // Journal of Engineering Education. Washington DC, 2011. 1. Pp. 151-185.

9. The framework of qualifications for the European Higher Education Area: EHEA May 2005 Retrieved 18 March 2016. 


\title{
СВЕДЕНИЯ ОБ АВТОРАХ / Information about authors:
}

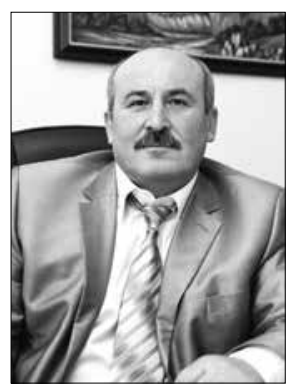

ГАБАРАЕВ Олег Знаурович доктор технических наук, профессор, заведующий кафедрой «Горное дело». Северо-Кавказский горно-металлургический институт (государственный технологический университет),

362021 , г. Владикавказ, Россия

Тел.: +7 (8672) 40-73-13 (служ.)

e-mail: gabar@skgmi-gtu.ru

Oleg Znaurovich GABARAEV - Doctor of Technical Sciences, Professor, Head of "Mining" Department. North-Caucasian Institute of Mining and Metallurgy (State Technological University), 362021, Vladikavkaz, Russia

Tel.: +7 (8672) 40-73-13

e-mail:gabar@skgmi-gtu.ru

БАЛИКОЕВА Марта Ибрагимовна - доцент кафедры «Иностранных языков», Северо-Кавказский горнометаллургический институт (государственный технологический университет), 362021, г. Владикавказ, Россия

Тел. +7 (8672) 407-480

e-mail: martabalikoti@gmail.com

Marta Ibragimovna BALIKOEVA - Associate Professor of the Department of "Foreign languages", North-Caucasian Institute of Mining and Metallurgy (State Technological University), 362021, Vladikavkaz, Russia

Tel.: +7 (8672) 407-480

e-mail:martabalikoti@gmail.com

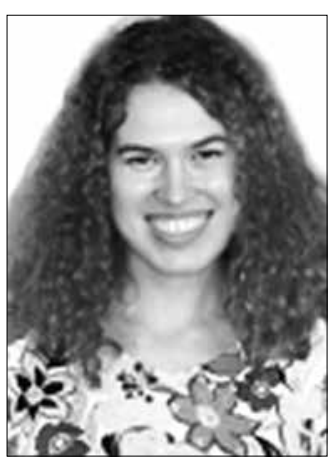

СОКОЛОВА Екатерина Андреевна* - доцент кафедры «Автоматизированной обработки информации», Северо-Кавказский горно-металлургический институт (государственный технологический университет).

362021 , г. Владикавказ, Россия

Тел.: +7 (8672) 407-518

e-mail: katya_sea@mail.ru

Ekaterina Andreyevna SOKOLOVA

- Associate Professor of the Department of "Automated Data Processing”, North-Caucasian Institute of Mining and Metallurgy (State Technological University), 362021. Vladikavkaz, Russia Tel.: +7 (8672) 407-518

e-mail:katya_sea@mail.ru

\section{ERASMUS+ PROJECT IMPLEMENTATION IN MINING UNIVERSITIES}

\author{
Gabaraev O.Z.,* \\ Sokolova E.A., \\ Balikoeva M.I. \\ North Caucasian Institute of Mining and Metallurgy (State Technological University), Vladikavkaz, Russia \\ *e-mail: gabar@skgmi-gtu.ru
}

DOI: $10.21177 / 1998-4502-2018-10-1-149-152$

Purpose: For the past decades the specialists training in geology has been declining significantly and as a result the foreign companies are starting to play a bigger role in resource exploration in Russia. This situation gave rise to the necessity of improving higher education in the field of geology. The purpose of the article is to describe the international educational project funded by Erasmus ${ }^{+}$, to investigate the new master program under the project and to substantiate the new multimedia -based teaching methodology. The new curriculum developed according to European educational standards is described. The article also elaborates on the innovative methods and benefits of the educational project Erasmus+.

Methods: The methodology of research is based on comparing European, Russian and Vietnamese education systems for harmonization the curriculum for Master programs in petroleum geology.

Results: One of the key tendencies in economy is strengthening international cooperation which requires revi- sion of modern educational standards and internalization of educational programs. Erasmus + foundation provides opportunities for promoting mobility of both students and academic staff and for elaborating unique curriculums under the Bologna process recommendations in countries outside European Union. The project "Modernization of geological education in Russian and Vietnamese Universities" (MINERAL) involves academic mobility for sharing practical knowledge in geological education, introduction of innovative teaching methods and recognition of diplomas in partner countries. North-Caucasian Institute will be the basis for signing a letter of intention for double-degree diplomas. However the most serious problem for project partners is that the master program should be implemented in English. To motivate students an online school "Young Geologist" is planned with basic lectures by leading professors from partner and program countries (Germany, Italy and Austria) in English.

Conclusion: To promote geological education in mining universities in accordance with European standards it is 
crucial to attract highly-qualified professionals, improve language learning and employ on-line educational platforms in collaboration with European universities, which can be achieved under the Erasmus + projects.

Keywords: Erasmus ${ }^{+}$, educational project, master program, innovations, European educational standards.

\section{References}

1. On the implementation of state policy in education and science: Decree № 59 of the President of the RF dated May 7 2012: [ E-resource] URL http://www.garant.ru

2. The concept of long-term social-economic development of Russia till 2020: [ E-resource]. URL http://economy.gov.ru/ minec/activity/sections/strategicPlanning/ concept Reference date 22.01.2018.

3. Vagin V.S., Sokolova E.A. Development of software for academic staff individual plans as means of increasing the efficiency of higher education quality system management. Sustainable development of mountain territories. 2011. 3(8). Pp. 100-103.

4. Aksenov A.A., Sokolova E.A. Improvement of methodology for developing teacher's individual plans as an element of the "Performance-based contract of employment". Scientific review. 2013. 11. Pp. 314-318.
5. Chevela O.V. Contrastive-comparative methods in teaching Russian as a foreign language. All-Russia sciencepractical conference proceedings " Comparative philology and multilingualism. Kazan: RIC «Shcool», 2002. Pp. 145-146.

6. Dooge J. Engineering training and education. Dublin // Collins Press. 2007.

7. Lorin W. Anderson., David Krathwohl. A taxonomy for learning, teaching, and assessing : a revision of Bloom's taxonomy of educational objectives New York. Longman, 2001.

8. Johri A. and Olds B. M. Situated Engineering Learning: Bridging Engineering Education Research and the Learning Sciences. Journal of Engineering Education. Washington DC, 2011. Pp. 151-185.

9. The framework of qualifications for the European Higher Education Area: EHEA May 2005. Retrieved 18 March 2016.The concept of long-term social-economic development of Russia till 2020: [ E-resource]. URL http:// economy.gov.ru/minec/activity/sections/strategicPlanning/ concept Reference date 22.01.2018.

Article received 02.06.2017 


\section{ГЛУБОКОУВАЖАЕМЫЕ КОЛЛЕГИ!}

В соответствии с Заключением Президиума ВАК Минобрнауки РФ от 19.12.2014 2. №47/307 с 2015 года статьи для публикации в журнале «Устойчивое развитие горных территорий» принимаются по следующим отраслям и группам наук:

25.00.00 Науки о Земле (вся отрасль наук о Земле);

05.00.00 Технические науки (три группы из отрасли):

05.05.00 Транспортное, горное и строительное машиностроение,

05.13.00 Информатика, вычислительная техника и управление,

05.14.00 Энергетика;

08.00.00 Экономические науки (вся отрасль экономических наук).

В соответствии с градацией наук, принятой в международных системах цитирования Scopus и Web of Science, статьи для публикации в журнале «Устойчивое развитие горных территорий» принимаются по следующим отраслям и группам наук:

1. Engineering (технические науки);

2. Earth and Planetary Sciences (науки о Земле и планетарные науки);

3. Environmental Science (наука об окружающей среде).

В журнале «Устойчивое развитие горных территорий» печатаются:

- статьи с изложением новых научных результатов, объемом не более 10 машинописных страниц, включая иллюстрации и таблицы;

- краткие сообщения, содержащие информацию о важных результатах предварительных исследований, объемом 3-5 страниц (эти материалы впоследствии могут использоваться в тексте полной статьи);

- обзоры печатных работ по актуальным проблемам устойчивого развития горных территорий, объемом 20-25 страниц по заказу редакции.

К опубликованию также принимаются платные рекламные сообщения о новых материалах, технологиях, приборах и аппаратуре, соответствующие тематике журнала.

Все работы должны соответствовать тематике журнала. Предоставленные рукописи проходят этапы предварительного и итогового рецензирования, и в случае необходимости, направляются авторам на исправление и доработку. Рукописи в журнале публикуются на русском либо английском языках, аннотации на русском и английском языках.

Журнал публикует исключительно оригинальные статьи. Автор несет полную ответственность за соблюдение этого требования. Рукописи, не принятые к опубликованию, авторам не возвращаются. Редакция также не возвращает присылаемые материалы.

Редакция оставляет за собой право производить сокращение и редакторскую правку текста статьи. Исправления в тексте и иллюстрациях авторы могут вносить только на стадии подготовки статьи к набору. Корректура авторам для просмотра не высылается.

Несоблюдение правил оформления рукописи приведет к отклонению статьи.

Публикация бесплатна для авторов статей, написанных по заказу редакции, и для аспирантов.

За сведения в рекламных материалах редакция ответственности не несет.

Перепечатка допускается только с разрешения редакции и с обязательной ссылкой на журнал «Устойчивое развитие горных территорий».

\section{Инструкция для авторов}

В редакцию необходимо предоставить следующие материалы:

- статья (структуру и правила оформления смотри ниже); представляется как в бумажном (2 экз.), так и в электронном виде. Второй экземпляр обязательно подписывается авторами;

- на отдельном листе: сведения об авторах, содержащие фамилию, имя, отчество, ученую степень, звание, название организации, служебный и домашний адрес и телефоны, e-mail (если есть) и указание, с кем из авторов предпочтительнее вести переписку;

- направление от организации, если предоставляемые материалы являются результатом работы, выполненной в этой организации; в направлении следует указать название рубрики журнала;
- экспертное заключение или другой документ, разрешающий опубликование в открытой печати, утвержденные руководителем организации и заверенные гербовой печатью (представляют только авторы из России);

- компакт-диск, содержащий обязательный пакет электронных файлов (подробные инструкции приведены ниже);

- рекомендации для переводчика, включающие научные термины, ключевые слова, сокращения, фамилии и т. п. (если предполагается издание переводного варианта за рубежом)

\section{Правила оформления статьи}

На первой странице должны быть указаны: УДК; название статьи на русском языке (прописными буквами, без кавычек, переносы не допускаются, точка в конце не ставится, подчеркивание не используется), кегль 14 полужирный, выравнивание по центру; инициалы и фамилии авторов (кегль 
12 полужирный курсив, выравнивание по правому краю), название учреждения, город, страна представляющих рукопись для опубликования.

Текст статьи набирается шрифтом Times New Roman размером 14 пт через одинарный интервал, выравнивание по формату. Подзаголовок - шрифт курсивный, выравнивание по левому краю. При написании статьи используются общепринятые термины, единицы измерения и условные обозначения, единообразные по всей статье. Расшифровка всех используемых авторами обозначений дается при первом употреблении в тексте. Буквы латинского алфавита набираются курсивом, буквы греческого алфавита - прямым шрифтом. Математические символы $\mathrm{lim}, \mathrm{lg}, \mathrm{ln}$, arg, const, $\sin , \cos , \min , \max$ и т.д. набираются прямым шрифтом. Символ не должен сливаться с надсимвольным элементом в химических элементах $\left(\mathrm{H}_{2} \mathrm{O}\right)$ и единицах измерений $(\mathrm{MBT} /$ $\mathrm{cm}^{2}$ ) - прямым (обычным) шрифтом. Не следует смешивать одинаковые по написанию буквы латинского, греческого и русского алфавитов, использовать собственные макросы. Буквы $I$ и $J$, и и v, e и $l, h$ и $n, q$ и $g, V$ и $U, O$ (буква) и 0 (нуль) должны различаться по начертанию.

Между цифровым значением величины и ее размерностью следует ставить знак неразрывного пробела. Переносы в словах либо не употреблять, либо пользоваться командой «расстановка переносов». Не использовать в тексте для форматирования знаки пробела. Различать дефис «-», знак минус «-» и тире «-».

Формулы создаются с помощью встроенного редактора формул Microsoft Equation с нумерацией в круглых скобках - (2), выравниваются по правому краю, расшифровка всех обозначений (букв) в формулах дается в порядке упоминания в формуле. Формулы должны быть аккуратно набраны на компьютере. Во избежание недоразумений и ошибок редакция рекомендует авторам использовать в формулах буквы латинского, греческого и других (не русских) алфавитов; при наборе формул необходимо соблюсти размеры по умолчанию. Следует учитывать, что при верстке формулы должны помещаться на половине страницы (8 cм). Большие формулы необходимо будет разбивать на отдельные фрагменты. Фрагменты формул по возможности должны быть независимы (при использовании формульного редактора каждая строка - отдельный объект). Нумерацию и по возможности знаки препинания следует ставить отдельно от формул обычным текстом. Нумеровать следует только те формулы, на которые есть ссылки в тексте.

Таблицы, рисунки, фотографии размещаются внутри текста и имеют сквозную нумерацию по статье (не по разделам!) и собственные заголовки. Названия всех рисунков, фотографий и таблиц приводятся на русском языке 11 кеглем, курсивом. Нумерация обозначений на рисунках дается по порядку номеров по часовой стрелке или сверху вниз. Рисунки необходимо выполнять в компьютерном виде, желательно в программе Word 97, Corel Draw (до 13 версии) по следующим правилам: ширина рисунка не более $8 \mathrm{cm;} \mathrm{толщина} \mathrm{ли-}$ ний: основных - 1 пт, вспомогательных - 0,5 пт; для обозначений в поле рисунка использовать шрифт Times New Roman размером - 9 пт. Рисунки с большим количеством деталей (сложные схемы, графики) размещаются на всю ширину страницы (16,5 см). Векторные рисунки записываются в от- дельные файлы документов. Фотоснимки должны быть контрастными и выполненными на матовой бумаге. Отсканированные фотографии записываются в файлы в формате TIFF, JPEG. Сканировать изображение следует с разрешением 300 dpi для контрастных черно-белых рисунков и $600 \mathrm{dpi}-$ для полутоновых. Цветные иллюстрации допускаются по согласованию с редакцией.

Обозначения, термины, иллюстративный материал, список литературы должны соответствовать действующим ГОСТ.

Библиографические ссылки в списке литературы нумеруются в той последовательности, в какой упоминаются в тексте. Описание литературных источников по ГОСТ 7.0.5-2008.

\section{Приложения к статье}

1. Аннотация (на отдельной странице - не более 100 слов). В ней не рекомендуется использовать формулы и ссылки на литературу. Если рукопись подается на русском языке, то аннотация должна быть продублирована на английском с указанием названия статьи, фамилий и инициалов авторов на этих языках. Если рукопись подается на английском языке, необходимо привести также аннотацию на русском. Аннотация печатается шрифтом Times New Roman (12 кегль) в одном файле в следующем порядке: название статьи, авторы, наименование организации, текст аннотации на русском языке; далее, через 2 строки, в той же последовательности на английском языке. Аннотация также публикуется на сайте журнала www.naukagor.ru. (на русском и английском языках).

2. Сведения об авторах на русском и английском языках печатается шрифтом Times New Roman (10 кегль) и должно содержать следующую информацию: должность, научное звание, ученая степень, награды и научные премии, круг научных интересов, количество публикаций, место работы, e-mail, номер телефона.

3. Фотографии авторов для резюме в формате TIFF или JPEG (300 dpi).

4. Реферат статьи (от 300 слов). Параметры страницы: формат A4 (210х297 мм); межстрочный интервал полуторный; шрифт Times New Roman (12 кегль) в одном файле в следующем порядке: наименование статьи, авторы, наименование организации, реферат на русском языке; далее, через 2 строки, в той же последовательности - на английском языке.

5. Электронная версия статьи представляется в редакцию на CD-R-диске или по электронной почте. Запись файлов выполняется в текстовом редакторе Microsoft Word (расширения .doc или .rtf), для набора формул применять редактор Equation 3.0.

Должны присутствовать следующие файлы:

- основной, содержащий текст статьи, включая формулы, таблицы, рисунки, подрисуночные подписи, список литературы, аннотация и ключевые слова на русском и английском языках;

- содержащий только иллюстрации, которые должны быть именованы таким образом, чтобы было понятно, к какой статье они принадлежат и каким по номеру рисунком статьи они являются. Каждый файл должен содержать один рисунок.

Электронная и бумажная версии статьи должны быть абсолютно идентичны.

Если авторы не могут полностью или частично удовлетворить требования по оформлению рукописи на диске, им необходимо проконсультироваться в редакции. 


\section{Адрес редакции:}

Россия, РСО-Алания, 362021, Владикавказ, ул. Николаева, 44. Северо-Кавказский горно-металлургический институт (государственный технологический университет).

Редакция журнала «Устойчивое развитие горных территорий».

Тел.: 8(8672) 40-73-60; 8(8672) 40-72-28 (служ.),+7(918)707-39-25 (моб.). E-mail: editor@naukagor.ru.

\section{DEAR COLLEAGUES!}

In accordance with the Conclusion of the Presidium of the Higher Attestation Commission of the Ministry of Education and Science of the Russian Federation from 12.19.2014 №47/307 from 2015 articles for publication in the journal "Sustainable Development of Mountain Territories" are accepted for the following Industries and groups of Sciences:

25.00.00 Earth Sciences (all branches of the Earth Sciences);

05.00.00 Engineering Sciences (three groups of industries):

05.05.00 Transport, Mountain and Building Mechanical Engineering,

05.13.00 Computer Sciences, Computer facilities and Management,

05.14.00 Energetics;

08.00.00 Economic sciences (all branches of Economic Sciences).

According to the gradation of Sciences accepted in international citation systems Scopus and Web of Science articles for publication in the journal "Sustainable development of mountain territories" are accepted by the following branches and groups of Sciences:

1. Engineering;

2. Earth and Planetary Sciences;

3. Environmental Science.

The journal «Sustainable Development of the Mountain Territories» publishes:

- articles interpreting the new scientific- research results of volume not more than 10 type written pages including illustrations and tables;

- brief messages containing information on the important results of the preliminary research of volume 3-5 pages (these materials can be used in the full article text);

- reviews of the typewritten articles on the actual problems of the sustainable development of the mountain territories, volume 20-25 pages by the editor's order, also the paid advertisements concerning new materials, devices and equipment in terms of the journal theme are accepted to the publication.

All papers must correspond to the journal theme.

The presented manuscripts pass the preliminary and total reading stages and if necessary are sent back to the authors for the correction and finishing.

The manuscripts are published in Russian and in English, the abstracts in Russian and in English as well.

The journal publishes only the original articles. The author is fully responsible for the requirement.

The manuscripts are not returned to the authors in case of being rejected in publication. The editor has a right to make reductions and corrections of the article text. All corrections in the text and figures can be done by the authors only at the stage of the typesetting preparations. The correction isn't sent to the authors for revision.

The infringement of the manuscript lay-out rules will lead to the publication delay or the article rejection.

The publication is free of charge for the authors, the fees aren't paid.

The authors (or the author) of each article having been published in the regular number of the journal have the right to get the authors' copies or their articles from the editorship.

The editorship isn't responsible for the advertisement information.

Reprinting is allowed only with the editorship permission with the obligatory references to the journal «Sustainable Development of the Mountain Territories»».

\section{INSTRUCTIONS FOR THE AUTHORS}

The following materials should be presented to the editorial office:

- an article, both in paper ( 2 copies) and in the electronic version. The second copy must be signed by the authors;

- a separate sheet with the information: about the authors (surname, name, patronymic name, scientific degree, rank, name of the organization, office and home address and telephone number, E-mail (if exists) and the reference to the author to contact with;

- a confirmation from the organization in case the presented materials are the result of the work carried out in that organization; the journal heading should be pointed out in the confirmation;
- an expert conclusion or any other document allowing the publication in the open press confirmed by the organization head and proved with the stamped seal; the expert conclusion is presented only by the authors from Russia;

- CD or a diskette with the files containing an obligatory set of the electronic files;

- recommendations for the translation including scientific terms, key words, cuttings, surnames, etc. (if the translated version is supposed to be published abroad).

\section{THE ARTICLE LAY-OUT RULES}

The following information should be pointed out on the first page: the article heading in Russian (in capital letters, without quotation marks, without division of a word, without a full stop at the end, underlining isn't used), point 14 semi bold, centre 
aligning; the authors surnames (point 12 semi bold type, the right-edge aligning), the organization name, town, country, a person responsible for the manuscript publication.

The article text is typed in Times New Roman (14 pt) through an ordinary interval aligning along the format. A subtitle is typed in italics, aligning along the left edge. The common terms, measurement units and conventional symbols similar for the whole article are used. The decoding of all symbols is given for the first text use. The Latin alphabet letters are typed in the italics while the Greek and Latin letters in the straight type. The mathematical symbols lim, lg, ln, arg, const, sin, cos, min, max, etc. are typed in the straight type. The symbol shouldn't coincide with the over symbol element in the chemical elements $\left(\mathrm{H}_{2} \mathrm{O}\right)$ and measurement units $(\mathrm{MBt} / \mathrm{cmI})$ and must be of the straight (ordinary) type. You shouldn't mix similar written letters of the Latin, Greek and Russian alphabets and should use the proper macros. The letters L and J, e and I, h and n, q and g, V and U, O (letter) and 0 (zero) must differ in inscribing.

There must be a sign of the continuous gap between a value figure meaning and its dimension. The hyphens are not used otherwise the command «hyphens arrangement», the gap signs also mustn't be used in the text for the lay-out and a hyphen «-»), a minus sign «-», and a dash «-» should be differentiated.

The formulas are designed with the help of the built-in formulas processor (Microsoft Equation), the enumeration being done in the round brackets (2), aligned along the right edge; the decoding of all signs (letters) in the formulas is given in the order of the formula reference. The formulas should be typed on computer. To avoid the errors and misunderstandings, the editorial staff recommends the authors to use the Latin, Greek and other (not Russian) alphabet letters in the formulas and to keep to the omission sizes while the formulas printing. One should account that during the page-making the formulas must be placed on the half of the page $(8 \mathrm{sm})$, the big formulas being split into the separate fragments. If possible, the fragments must be independent; each line is a separate object. The enumeration and stops should be put into an ordinary text separately from the formulas. Only the formulas having the text references should be numerated.

The tables, pictures and photos are placed inside the text and must have a through numeration along the text (not by the sections!) and their own headings. The titles of all tables, pictures and photos are presented in Russian (11 point, italics). The numeration of the picture symbols is given in clockwise order or from up to down. The pictures should be done in the computer form, preferably in Word 97 program using the following rules: a picture width - not more than $8 \mathrm{sm}$, a line thickness: the main $-1 \mathrm{pt}$, auxiliary $-0,5 \mathrm{pt}$; for the symbols in the picture area - «Times New Roman» type of 9 pt must be used.

The pictures with the great amount of details (complex schemes, graphs) are placed on the whole page width $(16,5 \mathrm{sm})$. The vector pictures are written into the separate documentary files. The photo pictures must be contrast and performed on the mat paper. The scanned photos are written into the files of TIFF, JPEG format. To scan the image one should use the resolution of $300 \mathrm{dpi}$ for the contrast black-white pictures and $600 \mathrm{dpi}$ for semitone ones. The colour illustrations are admitted on the editorial is agreement.

All symbols, terms and illustrations should correspond to the operative standards.
The literature sources should be numerated in the order of the text reference (not in the alphabetic order). The literature sources list is given as a total list at the end of the article. The list is composed according to the references consequence in the text. References should be designed according to GOST 7. 1-84. All references to the literature sources are applied in the square brackets [3].

\section{SUPPLEMENTS TO THE ARTICLE}

1. Abstract (on a separate page - not more than 100 words), without formulas and literature references. In case a manuscript is presented in Russian, the abstract should be repeated in English with the article heading, surnames and names in this language. In case a manuscript is presented in English, the Russian variant must be supplied. The abstracts are typed in Times New Roman (12 point) in one file in the following order: the article heading, the authors, the name of the organization, the abstract text in Russian with the further information in 2 lines in the same sequence in English. The abstracts are also published in the journal site www. naukagor.ru (in Russian and in English).

2. Resume in Russian and English is typed in Times New Roman (10 point) and must contain the following information: a place of work, a post, a scientific rank, degree, awards and scientific grants, professional experience, the main sphere of the scientific interests, the number of the publications for each author.

3. The authors' photographs for the resume should be done in TIFF or JPEG format.

4. The essay text (one page) for the publication in the essay journals. The page parameters: A4 $(210 \times 297 \mathrm{~mm})$ format; interline interval - one and a half; Times New Roman (12 point) type in one file in the following order: the article heading, the authors, the organization name, an essay in Russian, then in 2 lines in English.

5. The electronic version of the article.

To reduce the material preparation time for the publication and to avoid errors during typing, the materials should be presented on the CD-R disks. The files are written in the word processor Microsoft Word (doc or rtf), the formulas being printed with Equation 3.0. The author's name should be pointed out in the file title. Several file copies are preferable.

The following files are to be present on the diskette:

- the main file containing the article text, formulas, tables, pictures, under picture signatures, reference list, abstracts in Russian and English;

- the file containing only the illustrations for to the exact articles or pictures. Each file must have one picture.

The electronic and paper versions should be identical.

In case the authors fail to meet the requirements on the manuscript design on the disk, they should consult the editorials.

The editorial office address: 44 Nikolaev Str., Vladikavkaz, North Ossetia-Alania, Russia, 362021, The North Caucasian Institute of Mining and Metallurgy (The State Technological University), the Editorials of the journal «Sustainable Development of Mountain Territories».

Phone: 8(8672) 40-75-75;

+7(8672) 40-73-60, +7(918)707-39-25 (mob.).

E-mail: editor@naukagor.ru. 

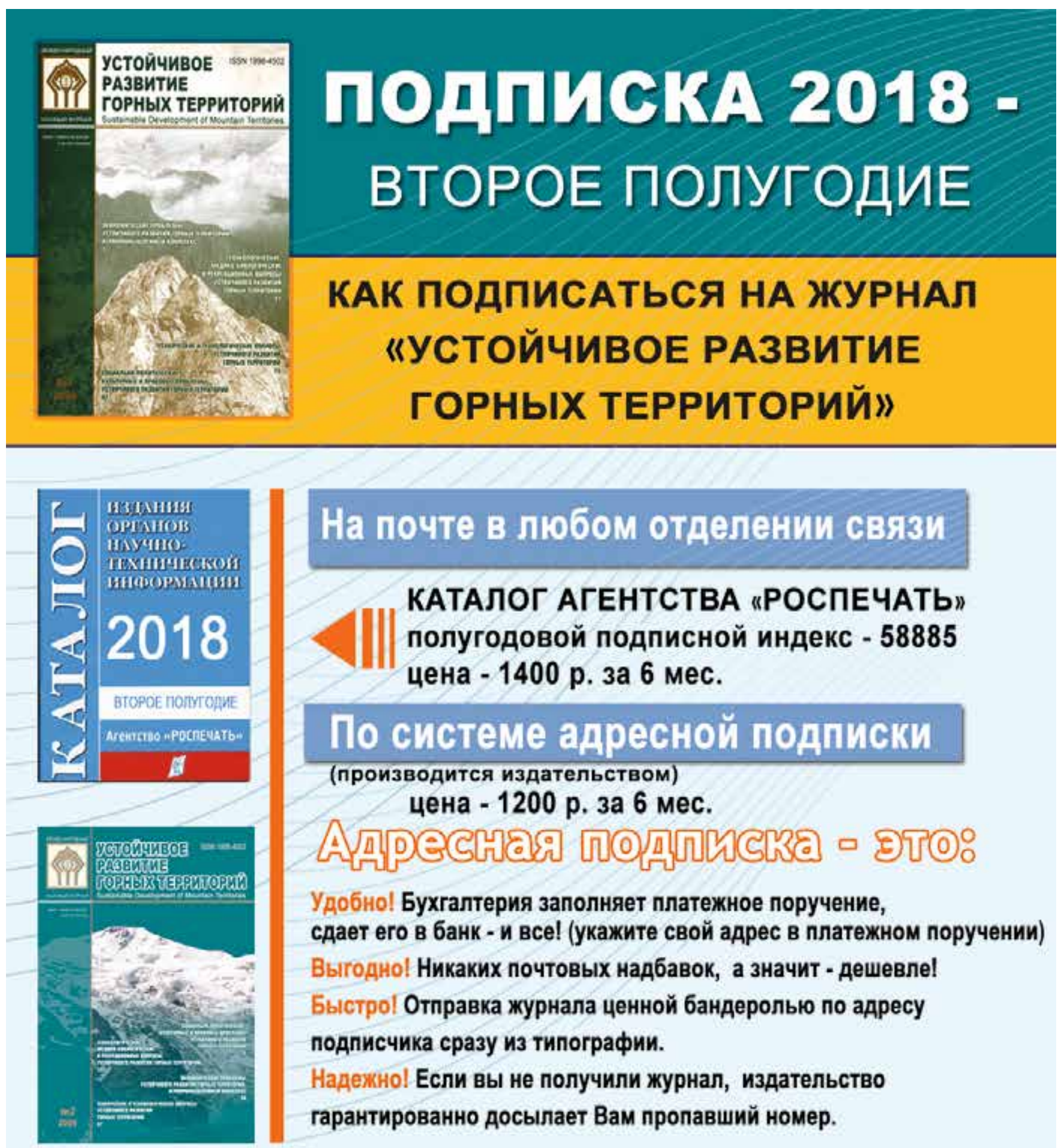

КАТАЛОГ АГЕНТСТВА "РОСПЕЧАТЬ" полугодовой подписной индекс - 58885 цена - 1400 р. 3 а 6 мес.

\section{I0 системе алресноЙ подписки (производится издательством)} цена - 1200 р. 3 а 6 мес. A.

Удобно! Бухгалтерия заполняет платежное поручение, сдает его в банк - и все! (укажите свой адрес в платежном поручении) Выгодно! Никаких почтовых надбавок, а значит - дешевле! БыстроI Отправка журнала ценной бандеролью по адресу подписчика сразу из типографии.

Надежно! Если вы не получили журнал, издательство гарантированно досылает Вам пропавший номер.
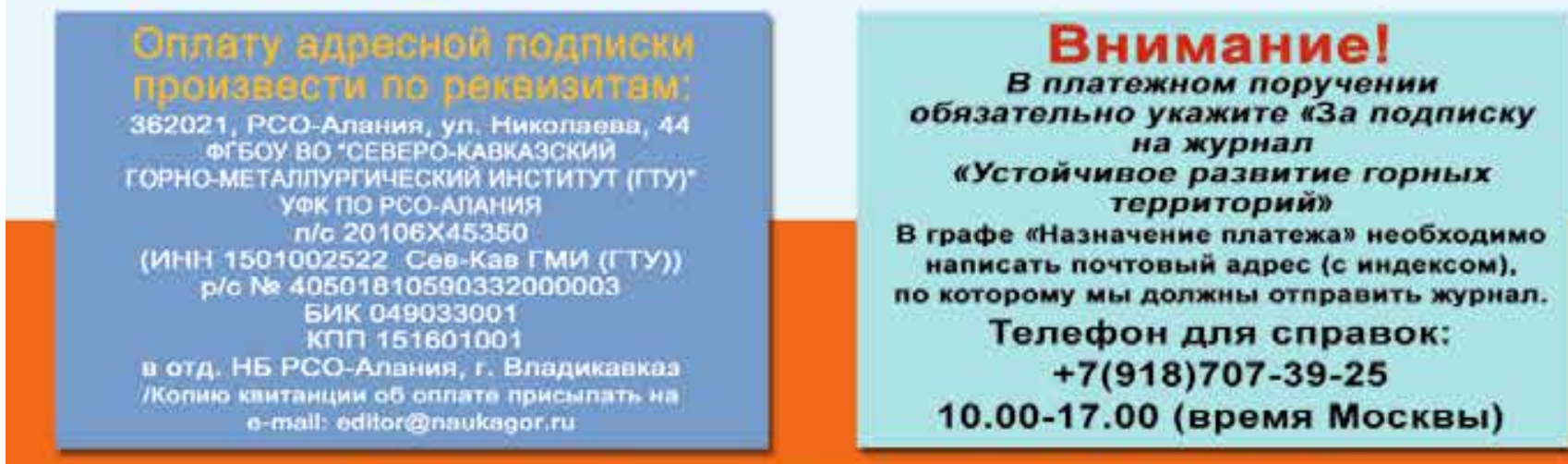

Стоимость адресной подписки для любоб региона PФ НАС не облагается стоимость доставки включена. 


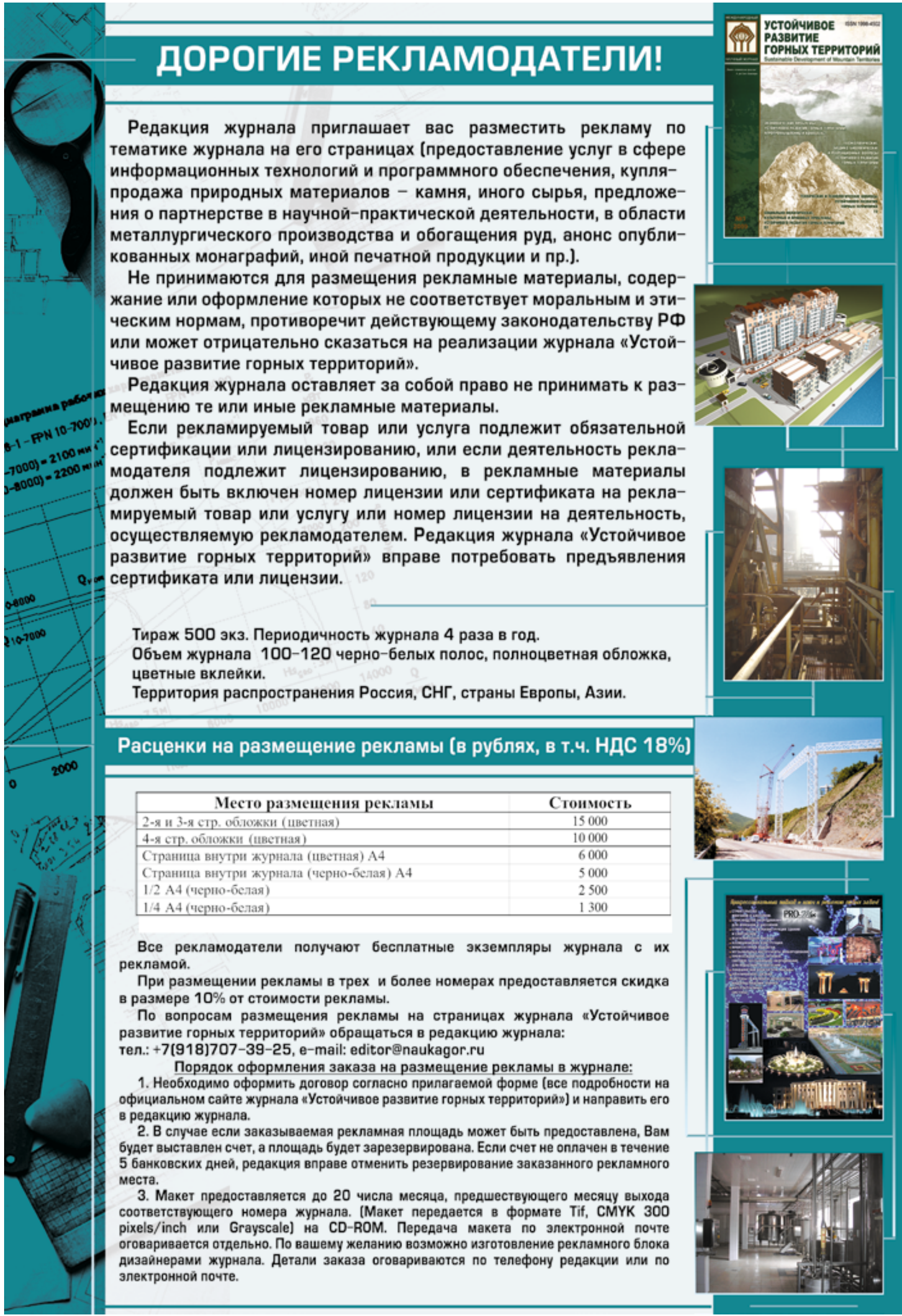



